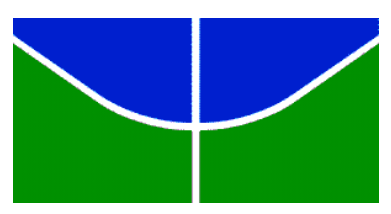

Universidade de Brasília

Instituto de Ciências Humanas

Programa de Pós-Graduação em História

Área de Concentração: História Cultural

Linha de Pesquisa: Identidades, Tradições, Processos

Tese de Doutorado

Orientadora: Prof ${ }^{\mathrm{a}}$ DráEleonora Zicari Costa de Brito

\title{
"O negro é a soma de todas as cores" \\ A construção da africanidade na trajetória e obra de Gilberto Gil (1942-2008)
}

Débora Dutra Fantini

Brasília, 2016 


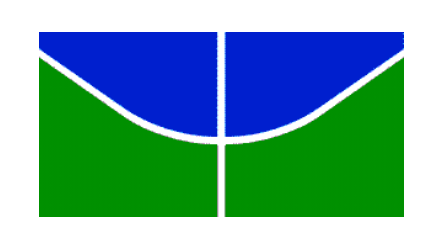

\section{Universidade de Brasília}

\section{"O negro é a soma de todas as cores"}

A construção da africanidade na trajetória e obra de Gilberto Gil (1942-2008)

Tese apresentada ao Programa de Pós-Graduação em História da Universidade de Brasília, na área de Concentração de História Cultural, como requisito à obtenção do título de Doutora em História.

Orientadora: $\operatorname{Prof}^{\mathrm{a}} \mathrm{Dr}^{\mathrm{a}}$ Eleonora Zicari Costa de Brito

Débora Dutra Fantini

Brasília, 2016 


\section{Banca examinadora}

Prof ${ }^{a}$. Dra. Eleonora Zicari Costa de Brito (UnB - Orientadora)

Prof $^{a}$. Dra. Maria Thereza Ferraz Negrão de Mello (UnB)

Prof. Dr. Anderson Ribeiro Oliva (UnB)

Prof. Dr. Marcelo Gustavo Costa de Brito (UEG/Formosa)

Prof. Dr. Leandro Santos Bulhões de Jesus (UniCEUB/UnB) 
À fé, que nunca costuma faiá... 


\section{Agradecimentos}

Primeiramente gostaria de agradecer à minha musa inspiradora maior, minha mãe. Além de minha terapeuta personalizada, me apoia com um colo que só as mães sabem dar. Ao Kuka, por me possibilitar constantemente abrir as portas da percepção.

Gostaria de agradecer especialmente à Elê, que não só acreditou nesse projeto como aceitou me orientar. Além de excelente professora, Eleonora é dessas pessoas que te ensinam várias coisas em todas as "horinhas de descuido", numa companhia pra lá de divertida. E, acima de tudo, por suas preciosas sugestões.

Agradeço enormemente aos apontamentos de Thereza Negrão e Selma Pantoja, realizados no momento da qualificação. As sugestões e a leitura acurada de ambas muito contribuíram para o desenvolvimento da tese.

Aos amigos que ganhei em Brasília, que tornaram minha estadia mais feliz! Leidiane, Rafael, Leandro(s), Valeska, Kênia, Nancy, Silvio, Marcelo e Guilherme, valeu! Além dos anjos, como Renata e Pedro Ivo, que sempre costumam pitar por aí...

Um agradecimento especial à família Pacheco, além de Carlos, é claro! Bia, Mayara e Douglas, a companhia de vocês acalma e alegra! E, dentre os Pachecos, está Mateus. A você, meu mais que obrigado, além das afinidades e da nossa profundidade pisciana, ahhh quantos ais... Obrigado por sempre doar palavras tão amáveis e sábias!

Gostaria de agradecer a duas figuras das antigas e de muitos futuros ainda! Cynthia e Marcus, vocês são demais! Obrigado por nos receberem tão mineiramente nas terras do além-mar e nos proporcionar experimentar a melhor viagem das nossas vidas!

Ao camarada Vladmir Cerqueira, amigo dessa vida e de outras!Agradeço não só pela análise musical da tese, mas por passar boas horas das nossas vidas conversando como se não houvesse amanhã. Obrigado também por nos trazer Mariana e Melinda!

Agradeço ao Pedrito, o Belchior! Não só por ser aquele mega-amigo desde os tempos da faculdade, mas por ser também um leitor crítico desta tese. Obrigado pelos apontamentos de um super nerd historiador! 
À Capes, pelo maravilhoso apoio financeiro que me deu sustento nesses quatro anos de pesquisa.

E por último, mas não menos importante, André! Agradeço por ser meu companheiro, meu malungo! Obrigado por sempre me questionar e ser parceiro de elucubrações constantes! Obrigado por seu meu sous chef e ao mesmo tempo experimentar e criticar meus pratos. Obrigado por se tornar meu parceiro no mundo dos vinhos! Obrigado por existir, meu amor! E que essa jornada siga vida a fora com muita Billie Holiday na vitrola... 


\section{Resumo}

Este trabalho busca seguir as múltiplas veredas da construção de uma africanidade na trajetória do artista e político Gilberto Gil. Abordarei as mudanças ocorridas ao longo de sua caminhada e que tangenciam sua ligação com certa representação de africanidade, que vão do "embranquecimento" social à afirmação da negritude. Saliento a importância de se estudar o artista não como um indivíduo isolado, mas como sujeito envolvido nos múltiplos processos de construção de identidades e memórias sobre a presença do negro na formação da sociedade brasileira. O intuito é contribuir de maneira mais ampla para a compreensão da tradução que o Brasil fez da África, no bojo da cultura da diáspora. A trajetória de Gil é o fio da meada para a interpretação das múltiplas temporalidades presentes em sua carreira artística e política - sem, contudo, cair na armadilha da biografia linear, um tanto previsível e excessivamente coerente, própria das narrativas cujo olhar retrospectivo ajusta arestas, contradições e ambiguidades. O primeiro capítulo aborda a infância, a juventude e a participação de Gil no movimento tropicalista, até o exílio em Londres, em 1969. O segundo capítulo explora aspectos poético-musicais de Gil e sua trajetória entre o exílio e a década de 1980. Por fim, o marco cronológico do terceiro capítulo é a incursão do compositor na política, a partir de1987, e sua atuação no Ministério da Cultura, entre 2003 e 2008, em uma análise que contempla a articulação entre poética e política na trajetória do artista.

Palavras-chave: Gilberto Gil, Africanidade, Negritude, Cultura, Política. 


\begin{abstract}
This work seeks to follow multiple paths of building an Africanity in the trajectory of the artist and politician Gilberto Gil. I will discuss the changes throughout his walk and his connections with certain representation of Africanity, ranging from "graying" social to the affirmation of blackness. It is importance to study the artist not as an isolated individual, but as a subject involved in multiple identity construction processes and memories about the presence of the black people in the formation of Brazilian society. The aim is to contribute more broadly to understand the translation that Brazil has made on Africa in the Diaspora culture bulge. Gil's trajectory is the thread for the interpretation of multiple temporalities, which are present in his artistic career and politics - without, however, falling in the linear biography trap, somewhat predictable and overly consistent, own narratives whose retrospective look set edges, contradictions and ambiguities. The first chapter deals with childhood, youth and the participation of Gil in the Tropicalia movement, until his exile in London in 1969. The second chapter explores poetic-musical aspects of Gil and his career between exile and the 1980s. Finally, the chronological framework of the third chapter is the composer's foray into politics, from 1987, and its activities in the Ministry of Culture between 2003 and 2008 in an analysis that considers the relationship between poetics and politics in the artist's career.
\end{abstract}

Keywords: Gilberto Gil, Africanity, Blackness, Culture, Policy. 


\section{Índice}

Introdução

01

Capítulo 1 - "Régua e compasso": Ituaçu, Salvador e São Paulo na trajetória de Gil 16

- Ituaçu, o sertão

- Salvador: "Na Bahia que é meu lugar"

- São Paulo

- O Fino da bossa e Arena conta Bahia

64

- LP Louvação e a viagem a Recife

1.3.3- A passeata contra as guitarras elétricas

1.3.4 - Os festivais

1.4 - O tropicalismo

Capítulo 2 - A construção de uma africanidade na trajetória e obra de Gilberto Gil 107

- O pré-exílio 108

- O exílio 114

- Back in Bahia: o retorno do exílio 139

- Filhos de Gandhy 146

- Gil Jorge Ogum Xangô 160 
- A trilogia "Re"

- Refazenda

- Refavela

- Realce

- Os Doces Bárbaros 204

- A viagem de Gil à África 209

- As tensões entre Gil e o movimento negro brasileiro 214

$\begin{array}{ll}\text { - Ecos de África } & 225\end{array}$

- Movimento Figa Brasil 265

- Caso Zelberto Zel 270

3. 4 - O livro O poético e o político 275

3.5 - Gil vereador (1989-1992) 283

- Pierre Verger: mensageiro entre dois mundos 287

- O Ministério da Cultura 293

$\begin{array}{ll}\text { - Um ministro entre muitas culturas } & 301\end{array}$

3. 9 - A renascença africana 305

$\begin{array}{ll}\text { - Ministro tropicalista } & 310\end{array}$

- Ministro da diáspora 316 
Considerações finais

Corpus documental

Bibliografia 


\section{Introdução}

Há tempos sou uma curiosa quando o assunto é cultura brasileira, e especialmente curiosa quando a África é chamada a fazer parte desse cenário. ${ }^{1}$ Nem sempre a resultante desse amálgama é exuberante, como aparentemente possa parecer, haja visto boa parte dos simbolismos conectados à África serem elaborados e vivenciados através de celebrações festivas, ditados quase sempre por música e dança; muitas vezes essas vozes também clamam por um maior reconhecimento de suas necessidades, fazendo eco tanto ao passado quanto ao futuro. Essas identidades culturais se transformam constantemente no "jogo" da história, da cultura e do poder. Vêm, daí, pistas para muitas indagações, algumas das quais se fazem desenrolar nesta tese.

A intenção é investigar como a representação das africanidades foi elaborada por Gilberto Gil, cruzando dados de sua trajetória biográfica $^{2}$, sua discografia e uma série de outras fontes. ${ }^{3}$ Entendo as africanidades como representações que ressignificam práticas culturais africanas, e a negritude, como um processo de identificação ideológica de valorização da cultura negra. Quando nos referimos à cultura negra, a complexidade se torna ainda maior, já que de 1520 a 1870 várias regiões da África forneceram pessoas para a América, e, em cada lugar onde desembarcaram, na condição de cativos, eles criaram significações próprias para seus antigos costumes. Vale salientar que, por se tratar de um imenso continente, não é tarefa das mais fáceis identificar traços cultura is africanos. Além desse aspecto, as imagens referentes à África repetiram, ao longo dos séculos, quase sempre sem maiores inovações, representações herdadas de gerações quase sempre informadas por percepções preconceituosas, e constantemente reforçadas

\footnotetext{
${ }^{1}$ Comecei a me interessar pelo universo da cultura afro-brasileira por volta dos meus 15 anos de idade, quando comecei a frequentar um curso de capoeira "regional" e já era encantada pelas músicas do Olodum, Daniela Mercury, João Gilberto e também pelas caribenhas. Tempos depois, já na universidade, nos primeiros semestres do curso de História, conhecium rapaz que tempos depois se tornaria meu marido. Fui monitora de uma oficina de percussão que ele ministrou, oferecida pelo projeto Malungo: diálogos entre saberes acadêmicos e populares (Departamento de Ciências Sociais, Políticas e Jurídicas da Universidade Federal de São João del-Rei). André, que já era percus sionis ta no período dessas oficinas, tornou-se também etnomusicólogo, tendo como base de suas pesquisas acadêmicas a rítmica brasileira, com ênfase nas africanidades. Há mais de dez anos divido com ele a paixão pelos temas: África, cultura popular e música, frequentando e pesquisando maracatus, congados, candomblés, umbandas, cirandas e sambas.

${ }^{2}$ Analisada através da perspectiva de BOURDIEU, Pierre. A ilusão biográfica. In: AMADO, Janaína; MORAES, Marieta de (Org.). Usos \& Abusos da história oral. Rio de Janeiro: Editora da Fundação Getúlio Vargas, 1996; GINZBURG, Carlo. O Queijo e os Vermes: o cotidiano e as ideias de um moleiro perseguido pela Inquisição. São Paulo: Cia. das Letras, 1987, entre outros.

${ }^{3}$ Entrevistas, DVDs, filmes produzidos por Gil e outros que tiveram sua participação, músicas, livros escritos por Gil, livros sobre o Gil, depoimento ao Museu da Imagem e do Som, periódicos, dentre outras.
} 
ou renovadas pelo contato transatlântico. A contribuição africana no Brasil é um amálgama de distintas tradições de diversas nações africanas. Somam-se a esse fato as constantes reelaborações às quais esses costumes foram sendo submetidos ao longo de mais de três séculos.

Ao me concentrar em uma biografia, procuro estabelecer os elementos e as mudanças significativas que demarcaram as estratégias artísticas de Gilberto Gil, atentando especialmente para as sensibilidades ${ }^{4}$ e para as práticas sociais e políticas que atravessaram esse percurso, cruzando ao mesmo tempo informações empíricas e teóricas, a fim de compreender a dinâmica de uma história mais global através de uma perspectiva biográfica.

A escolha por tomar como objeto a trajetória de um artista não pode ser vista como contraditória à preocupação com o social. O que ocorre é a opção por uma abordagem que entende ser possível acompanharmos o fio de um destino particular - o de Gil - e, com ele, a multiplicidade dos espaços e dos tempos que o atravessam, assim como a meada das relações nas quais essa história pessoal se inscreve. Logo, não se perde de vista que essa proposta busca igualmente a compreensão de uma experiência coletiva. ${ }^{5}$

Escolher estudar um artista, como quaisquer outros sujeitos, contribui para que se compreenda melhor a relação entre agentes históricos individuais e processos históricos coletivos. Não existe um contexto que independa de sujeitos, e o estudo de casos específicos é importante, uma vez que eles atuam e modificam a realidade em que estão inseridos. Esse tipo de proposta possibilita, ainda, compreendermos melhor a relação da arte com o mercado e, também, o modo como se dá o diálogo entre elementos da tradição com outros de modernidade e, principalmente, como o negro participou dessa elaboração.

\footnotetext{
${ }^{4}$ As sensibilidades serão aqui compreendidas enquanto "modos de percepção e tradução da experiência humana no mundo, onde o mundo sensívelé talvez difícil de ser quantificado, mas é fundamental que seja avaliado pela História Cultural. Ele incide justo sobre as formas de valorizar, classificar o mundo ou de reagir diante de determinadas situações e personagens sociais. Em suma, as sensibilidades estão presentes na formulação imaginária do mundo que os homens produzem em todos os tempos. Pensar nas sensibilidades, no caso, é não apenas mergulhar no estudo do indivíduo e da subjetividade, das trajetórias de vida, enfim. É também lidar com a vida privada e com todas as nuances e formas de exteriorizar - ou esconder - os sentimentos". In: PESA VENTO, Sandra Jatahy, op. cit., p. 58.

${ }^{5}$ REVEL, Jacques. Microanálise e construção do social. In: REVEL, Jacques (org.). Jogos de escalas. Rio de Janeiro: FGV, 1999, pp. 21-22.
} 
Pierre Bourdieu, em 1986, já nos alertava sobre os perigos da ilusão biográfica, ao problematizar as trajetórias criadas a partir de uma série ordenada de fatos, na qual o biógrafo, juntamente ou não com seu biografado, acaba por selecionar os mais significativos fatos, dando-lhes conexão e coerência, muitas vezes artificializando os sentidos. Bourdieu comenta ainda que:

Tentar compreender uma vida como uma série única e por si suficiente de acontecimentos sucessivos, sem outro vínculo que não a associação a um "sujeito" cuja constância certamente não é senão aquela de um nome próprio, é quase tão absurdo quanto tentar explicar a razão de um trajeto no metrô sem levar em conta a estrutura da rede, isto é, a matriz das relações objetivas entre as diferentes estações. Os acontecimentos biográficos se definem como colocações e deslocamentos no espaço social, isto é, mais precisamente nos diferentes estados sucessivos da estrutura da distribuição das diferentes espécies de capital que estão em jogo no campo considerado. ${ }^{6}$

Inicialmente, minha intenção era fugir de uma narrativa que se organizasse por uma linearidade temporal. Depois compreendi que não era esse o maior problema. $O$ desafio maior seria realizar uma abordagem que dialogasse com a complexidade dessas temporalidades, levando em consideração os lugares onde determinadas memórias foram elaboradas. Compreendo que a articulação de diversas fontes é que ditaria como a África foi compreendida e até mesmo silenciada em diferentes momentos dessa trajetória, e como essas memórias também dialogam entre si na construção dessas africanidades. Não se trata, aqui, de fazer a história de um grande artista da música popular brasileira, como uma espécie de vida de santo, sem problemas, devaneios, desvios ou contradições, mas analisar a atuação de Gilberto Gil na condição de testemunha e sujeito da história. O artista não somente refletiu aspectos de sua época, como também, através de suas experiências artísticas, efetivamente transformou a vida de outras pessoas. Gil aqui é percebido como uma espécie de receptáculo e também agenciador de correntes de pensamento e de movimentos, processados numa construção feita de acasos e hesitações, e não processados em uma sucessão cronológica, organizada e dotada de sentido.

\footnotetext{
${ }^{6}$ BOURDIEU, Pierre. A ilusão biográfica. In: FERREIRA, Marieta de Morais; AMADO, Janaina. Usos e abusos da história oral. Rio de Janeiro: Editora FGV, 1998, p. 190.
} 
Levando em consideração a conjuntura em que essa trajetória se desencadeou, a escolha do recorte ${ }^{7}$ proposto pela pesquisa se faz acompanhada pela intenção de compreender o processo pelo qual a representação das africanidades ${ }^{8}$ passou a ter significado para Gilberto Gil, e como foi aos poucos sendo elaborada, construída e reconstruída através de várias camadas de sentido. Não pretendo, portanto, enquadrar a trajetória do artista na armadilha do esquema etapista, ${ }^{9}$ mas investigar a pluralidade de caminhos possíveis, as indeterminações e as incertezas desse passado, e o modo como a África foi construída e evocada em diferentes etapas dessa trajetória.

Selecionando os dados disponíveis, que vão desde as fontes da própria pesquisa às informações sobre o contexto na qual foram produzidas, procurei tecer uma relação entre eles, dando inteligibilidade a essa história.

Carlo Ginzburg chama atenção para o fato de que, mesmo que as pretensões de conhecimento sistemático se mostrem como veleidades, nem por isso a ideia de totalidade deve ser abandonada. Pelo contrário, a existência de uma profunda conexão que explica os fenômenos superficiais é reforçada no próprio momento em que se afirma que um conhecimento direto de tal conexão não é possível. Se a realidade é opaca, existem zonas privilegiadas - sinais, indícios - que nos permitem decifrá-la. O paradigma indiciário ou semiótico aborda minúsculas particularidades e as emprega como pistas que permite m reconstruir trocas e transformações culturais. Mais do que deduzir, o método reconhece que a força está na observação do pormenor revelador. ${ }^{10}$

Outra importante contribuição de Ginzburg é sobre a problemática confecção das documentações, já que, "em qualquer sociedade, a documentação é intrinsecamente distorcida, uma vez que as condições de acesso à sua produção estão ligadas a uma situação de poder e, portanto, de desequilíbrio". ${ }^{11} \mathrm{O}$ autor comenta ainda que, além de atentar para as anomalias das documentações, os obstáculos constitutivos da

\footnotetext{
${ }^{7}$ De 1942 (nascimento do artista) a 2008 (quando Gil finaliza seu mandato no MinC).

${ }^{8}$ Tentando fornecer dados para pensarmos nessa elaboração para além de simplificações como pureza ou até mesmo legitimidade.

${ }^{9}$ Mesmo porque as construções e inovações artísticas de Gil estão sendo a todo momento retroalimentadas.

${ }^{10}$ GINZBURG, Carlo. Mitos, emblemas, sinais: morfologia e história. São Paulo: Companhia das Letras, 1989, p. 177.

${ }^{11}$ GINZBURG, Carlo. Micro-história: duas ou três coisas que sei a respeito. In: O fio e os rastros: verdadeiro, falso, fictício. São Paulo: Companhia das Letras, 2007, p. 262.
} 
documentação, bem como as hesitações e lacunas, devem se tornar parte do relato, evidenciando que todas as fases que constituem a pesquisa são construídas, e não dadas.

Ao analisarmos a música como um objeto histórico, devemos refletir sobre o seu significado enquanto documento. Quanto a este, recorro ao conceito de Le Goff, para quem todo documento é também monumento. Uma obra musical, no caso desta tese a do cantor e compositor Gilberto Gil, é passível de interpretação histórica, na medida em que carrega em si a intencionalidade de quem a produziu, assim como os sentidos que thes foram impressos pela recepção, além das questões referentes à época em que foi produzida. É necessário levar em consideração, numa leitura crítica, a complexa construção deste nosso objeto de análise. Segundo Le Goff:

O documento não é inócuo. É, antes de mais nada, o resultado de uma montagem, consciente ou inconsciente, da história, da época, da sociedade que o produziu, mas também das épocas sucessivas durante as quais continuou a viver, talvez esquecido, durante as quais continuou a ser manipulado, ainda que pelo silêncio. ${ }^{12}$

Assim sendo, acho necessário analisar não somente a obra musical de Gilberto Gil, como a complexa relação existente entre a sua trajetória artística e os diferentes momentos políticos e culturais nos quais ela se constituiu. A música, como outros documentos em geral, capta várias dimensões do que seus autores vivenciaram e calamse sobre outros. Nesse sentido, cabe ao historiador somar à obra musical, tomada como documento, outras fontes capazes de enriquecer esse corpus. Mas, desde já, compreendese que a reconstituição dessa trajetória será sempre parcial e limitada, elaborada através da reunião de fragmentos de realidades descritas por indivíduos que, por sua vez, selecionaram no passado e, posteriormente, do passado, aquilo que thes parece significativo.

A questão da negritude, na percepção de Gil, e os problemas atrelados a ela, é algo que surgiu tardiamente em sua vida:

Eu não me via muito como negro. Não havia essa questão pra mim ainda. Eu vinha de uma família de negros bem sucedidos. Meu pai conseguiu, minha mãe era professora. (...). Isso que as

\footnotetext{
${ }^{12}$ LE GOFF, Jacques. História e memória. $5^{\circ}$ ed. Campinas, SP: Ed. Unicamp, 2003, p.538.
} 
pessoas chamam hoje, que os estudiosos chamam hoje de branqueamento, minha família fazia parte desse processo de branqueamento... ${ }^{13}$

Em entrevista ao Pasquim, em 1969, fica bem claro que a África, bem como questões ligadas à negritude, ou até mesmo à cultura afro-brasileira, estavam ainda distantes dos interesses de Gil. Questionado sobre a grande atração física dos brancos pelos negros, Gil respondeu:

\begin{abstract}
Eu, pessoalmente, como negro não sei. Quer dizer: não sou um cara incluído no que se chama "consciência da nacionalidade negra". Na verdade, nunca senti o problema da marginalização do negro. Nunca fui obrigado a uma tomada de consciência das diferenças entre o negro e o branco: digo tomada de consciência visceral. Não me sensibilizo muito com isso porque sempre fui, no Brasil, uma pessoa pertencente à classe média alta e sempre tive acesso às coisas que brancos, amarelos, pardos e azuis têm. ${ }^{14}$
\end{abstract}

Porém, passado algum tempo, a tal conscientização negra passou a acompanhar fortemente a carreira e a performance de Gil. Na letra de "Sarará Miolo", criada em $1976,{ }^{15}$ fica clara a intenção de problematizar a inferiorização do negro. A doença (racismo) do branco deveria ser sarada, seguida não só da aceitação, como da necessidade em orgulhar-se de ser crioulo: "Sara, sara, sara cura/ Dessa doença de branco/ De querer cabelo liso/Já tendo cabelo louro/Cabelo duro é preciso/Que é pra ser você crioulo”.

A ligação com a África continuou a ser parte integrante também da vivência política de Gil. Em 2003, a Folha de S. Paulo noticiava a participação do artista na comitiva presidencial brasileira em visita à África:

Se há consenso na comitiva presidencial à África, ela se chama Gilberto Gil, o compositor e cantor e ministro da Cultura que deu "canja" para presidentes e parecia à vontade, apesar de seu cansaço. "Eu me sinto em casa aqui, me sinto na Bahia", disse ele mais de uma vez, contando que conhece a África desde os

13 DVD GILBERTO GIL. La passion sereine. Direção: Ariel de Bigault. Produção: Feeling Productions/TF1/PI Production. Participação: Centre Nacional de La Cinematographie ET di Ministère dês Affaires Etrangères. Apresentação: Grande Othelo, 1987.

${ }^{14}$ LARA, Odete. Pasquim, 15/10/1969. In: COHN, Sergio (org.) Gilberto Gil - encontros. Rio de Janeiro: Beco do Azougue, 2007.

15 "Sarará miolo" (Gilberto Gil, 1976) gravada no álbum Realce (Warner Music, 1979). 
anos 80 e improvisando aulas sobre o continente para os jornalistas. (...) Lula elogiou seguidamente seu ministro da Cultura, que dançou com grupos locais de Moçambique e da Namíbia. Também cantou ao ar livre na inauguração da primeira embaixada brasileira em São Tomé e Príncipe e em recepções para os presidentes José Eduardo Santos, de Angola, e Joaquim Chissano, de Moçambique. ${ }^{16}$

As três citações feitas anteriormente possibilitam-nos afirmar que a conexão de Gil com a África nem sempre existiu, e que não foi a mesma em todas as fases de sua trajetória. Essa relação não será percebida, aqui, enquanto algo cristalizado, mas edificado por Gil num espaço de experiências aberto a inúmeras possibilidades, e sempre elaborada a partir de dados já vivenciados e sentidos também no presente de tais situações. As africanidades serão aqui abordadas enquanto um campo de lutas, onde posições passaram a ser assumidas, de apresentação e de representação das próprias africanidades. A intenção é descobrir, por meio das inúmeras fontes analisadas, as ações, falas, acontecimentos e performances em que essas africanidades foram tomando forma.

Não intenciono ser porta-voz, falar em nome ou me colocar na posição de sujeito das africanidades. Defendo um certo distanciamento daquilo que me é muito próximo, do que nos constitui e até mesmo nos inventa como brasileiros, evitando aderir ao discurso do resgate ou da preservação de raízes, defesa ou salvação das africanidades. Tomo as africanidades, sempre no plural, como elaboração material e imaterial, como construção imagético-discursiva engendrada quase sempre num complexo campo ideológico de disputas, resultado de práticas múltiplas. Minha tarefa é problematizar essas elaborações do passado, realizadas por Gil através de suas memórias, de lugares de memória, já que, em cada presente em que é contada uma história, esta se tinge com as cores de tal momento.

Aqui, a África é considerada uma construção moderna; são suas rotas que desembocaram no Novo Mundo que me interessam. Não intenciono traçar uma origem, mas sim compreender os diversos hibridismos e sincretismos, não apreendidos pelo modelo centro/periferia ou recuperados numa noção nostálgica de recuperação de antigas tradições. É preciso um olhar atento para a produção da cultura, mais especialmente para a música produzida por um negro brasileiro. Não existe uma herança africana que fluiu imutável por gerações, mas sim a produção da África dentro da narrativa brasileira. Não só na música, mas na literatura, no cinema, no teatro, cada uma dessas conjunturas

\footnotetext{
${ }^{16}$ Movimentos negros reagem à gafe de Lula. Folha de S. Paulo, 8 nov. 2003.
} 
dessas conjunturas forjando suas próprias questões e interpretação sobre a África, relendo o que a África significa hoje, após a diáspora. Sobre essas Áfricas, informa Stuart Hall:

Nãoé nem a África daqueles territórios ignorados pelo cartógrafo pós-colonial, de onde os escravos eram sequestrados e transportados, nem a África hoje, que é pelo menos quatro ou cinco "continentes" diferentes embrulhados num só, suas formas de subsistência destruídas, seus povos estruturalmente ajustados a uma pobreza moderna devastadora. A "África" que vai bem nesta parte do mundo é aquilo que a África se tornou no Novo Mundo, no turbilhão violento do sincretismo colonial, reforjada na fornalha do panelão colonial. ${ }^{17}$

A África aqui analisada é a que foi ressignificada no Brasil, especificamente, pelo artista Gilberto Gil. A cultura não é apenas uma viagem de redescoberta, mas o ato de produção constante de nós mesmos, já que estamos sempre em processo de formação. Entraram, nesse jogo de confecção de africanidades, texturas que miscigenaram desde aspectos referentes a tradições àqueles de críticas a determinados folclorismos.

Ao problematizar o agenciamento dos negros na construção da história moderna e contemporânea, Paul Gilroy elaborou a noção de Atlântico negro, ${ }^{18}$ que, segundo o autor, é mais profícua do que a utilização de conceitos como raça, etnia ou nação. Para Gilroy, o conceito de negritude é frágil, já que a origem de tudo está na história muito diferenciada de cada população. É necessário fugir de essencialismos e dar prioridade às construções feitas a partir da diáspora:

A contaminação líquida do mar envolveu tanto mistura como movimento. Dirigindo a atenção repetidamente às experiências de cruzamento e a outras histórias translocais, a ideia do Atlântico negro pode não só aprofundar nossa compreensão sobre o poder comercial e estatal e sua relação com o território e o espaço, mas também resume alguns dos árduos problemas conceituais que podem aprisionar ou enrijecer a própria ideia de cultura. Os ganhos potenciais aqui podem ser vislumbrados até mesmo através de um contraste simplificado entre nações

\footnotetext{
${ }^{17}$ HALL, Stuart. Da diáspora: identidades e mediações culturais. $1^{\circ}$ ed. atualizada. Belo Horizonte: Ed. UFMG, 2009, p. 39.

${ }^{18}$ Para Gilroy, o Atlântico negro é um termo que se refere metaforicamente às estruturas transnacionais criadas na modernidade, que se desenvolveram e deram origem a um sistema de comunicações globais, marcado por fluxos e trocas culturais de populações negras durante a diáspora africana. GILROY, Paul. $O$ Atlântico negro: modernidade e dupla consciência. 2. ed. São Paulo: Editora 34; Rio de Janeiro: Universidade Cândido Mendes, Centro de Estudos Afro-Asiáticos, 2012.
} 
estabelecidas e essencialmente sedentárias - baseadas num único centro, mesmo que seus tentáculos imperiais se estendam muito mais - e os padrões de fluxo e mobilidade que caracterizam a aventura extranacional e a criatividade intercultural. ${ }^{19}$

No Atlântico negro é dado destaque à cultura vernacular negra e a elementos antidiscursivos e extralinguísticos dos atos comunicativos definidos pela instituição da escravidão. Os escravos encontravam na música e na dança, por exemplo, um substituto para as liberdades políticas formais que lhes eram negadas, uma vez que "a arte se tornou a espinha dorsal das culturas políticas dos escravos e da sua história cultural "20, e são até hoje importantes nos processos de luta rumo à antecipação, cidadania e autonomia negras. De acordo com Gilroy, é preciso dar atenção à música, já que ela exerce um papel fundamental na reprodução da cultura do Atlântico negro e na conexão entre as diferentes comunidades da diáspora. O poder da música negra se faz presente no desenvolvimento das lutas políticas das comunidades negras: "ela é, ao mesmo tempo, produção e expressão dessa transvalorização de todos os valores precipitada pela história do terror racial no novo mundo". ${ }^{21}$

A música produzida por Gilberto Gil pode ser também abordada enquanto parte constitutiva dessa cultura negra na diáspora, na qual a mescla de elementos "locais" de africanidade, como ijexás e sambas, com elementos "globais" de africanidade, como rock e reggae, abrem espaço para questionamentos sobre identidades e representações, pureza, tradição e modernidade. O estudo das relações raciais e da cultura negra, bem como a ligação construída com referência à África, têm aqui a pretensão de contribuir para a pesquisa sobre a Música Popular Brasileira, mas também para a compreensão da cultura negra transatlântica, no sentido de desvendar os códigos que regem essa linguagem, como são processadas essas trocas e quais hierarquias permeiam essas práticas.

Sobre elaborações referentes à África, Hall assim se refere ao caso do Caribe:

$\mathrm{Na}$ verdade, cada movimento social e cada desenvolvimento criativo nas artes do Caribe neste século começaram com esse momento de tradução do reencontro com as tradições afro-

\footnotetext{
${ }^{19}$ GILROY, Paul. O Atlântico negro..., op. cit., p. 15.

${ }^{20}$ Ibid., p. 129.

21 Ibid., p. 94.
} 
caribenhas ou o incluíram. Não porque a África seja um ponto de referência antropológico fixo - a referência hifenizada já marca o funcionamento do processo de diasporização, a forma como a "África" foi apropriada e transformada pelo sistema de engenho do Novo Mundo. A razão para isso é que a "África" é o significante, a metáfora, para aquela dimensão de nossa sociedade e história que foi maciçamente suprimida, sistematicamente desonrada e incessantemente negada, e isso, apesar de tudo o que ocorreu, permanece assim. Essa dimensão constitui aquilo que Frantz Fanon denominou " $O$ fato da negritude". A raça permanece, apesar de tudo, o segredo culposo, o código oculto, o trauma indizível, no Caribe. É a "África" que a tem tornado "pronunciável", enquanto condição social e cultural de nossa existência. ${ }^{22}$

Além de dimensionar o lugar sempre periférico ocupado pela África, Hall, apesar de tratar do caso caribenho, oferece-nos importantes pistas para refletir sobre as representações elaboradas sobre o continente. Outro importante aspecto evidenciado pelo autor é que a 'África' é uma construção moderna, tendo sido constantemente inferiorizada, além de ocupar esse papel até os dias atuais. Mas o autor aponta também outro dado: a África constitui um espaço que permite pronunciar, que permite agrupar. Nota-se também que a África de Hall não é uma "mãe", ou mesmo mítica, ou ponto de referência intocada, mas sim que as culturas negras se ressignificaram em seus novos ambientes de atuação, por meio da tradução ou da invenção. O grande problema apontado por Hall é o modo como a África foi apropriada pelas culturas negras espalhadas pelo mundo.

Homi Bhabha nos informa sobre os possíveis sentidos de significância da cor escura:

O estereótipo é aomesmo tempo um substituto e uma sombra (...) A cor escura significa ao mesmo tempo nascimento e morte; ela é em todos os casos um desejo de retornar à completude da mãe, um desejo por uma linha de visão e de origem ininterrupta e nãodiferenciada.(...) O negro é ao mesmo tempo selvagem (canibal) e ainda o mais obediente e digno dos servos (o que serve a comida); ele é a encarnação da sexualidade desenfreada e, todavia, inocente como uma criança; ele é místico, primitivo, simplório e, todavia, o mais escolado e acabado dos mentirosos e manipulador de forças sociais. ${ }^{23}$

A cor escura está diretamente ligada às africanidades, e aos discursos sempre deturpadores daquele povo e continente. O negro é amedrontador, e na maioria das vezes

\footnotetext{
${ }^{22}$ HALL, Stuart. Da diáspora, op. cit., p. 40.

${ }^{23}$ BHABHA, Homi K. O local da cultura. Belo Horizonte: Ed. UFMG, 1998, p. 126.
} 
a negritude se faz acompanhada pela inferiorização realizada pela conceituação de primitivismo e selvageria. O desenfreamento da sexualidade vem acompanhado também de curiosidade, que tanto nega quanto deseja. Desde o século XV, o negro tem sido constantemente estereotipado com leituras depreciativas sobre o continente, que continuam com força nos dias de hoje.

De acordo com Achille Mbembe, a construção e a representação da identidade africana ao longo do século XX foi fortemente demarcada pela escravidão, o colonialis mo e o apartheid, e, a partir desses eventos, uma série de significados foi atribuída ao sujeito africano. Dentre estas, o sujeito negro não apenas não é reconhecido pelo Outro, como também não se reconhece a si mesmo. Mbembe comenta ainda que a maneira simplificada e clara de definição de uma identidade africana há um longo tempo vem falhando, e afirma ainda:

Talvez um passo além desse círculo seja reconceitualizar a própria noção de tempo em sua relação com a memória e a subjetividade. Já que o tempo em que vivemos é fundamentalmente fraturado, o próprio projeto de um resgate essencialista ou sacrificial do eu está, por definição, fadado ao fracasso. Apenas as diversas (e muitas vezes interconectadas) práticas através das quais os africanos estilizam sua conduta podem dar conta da qual o presente africano é feito. ${ }^{24}$

A intenção então é compreender a maneira como a África foi imaginada e traduzida pelo Brasil; pensar como um negro brasileiro, que até o início de sua vida adulta ainda não havia desenvolvido uma conscientização da negritude e posteriormente passou a visitar e construir uma representação de África para si, acabou por influenciar também grande parte da sociedade brasileira a perceber porções de África. Quais Áfricas? De que maneira? Através de quais experiências? Não partirei de nenhuma África em especial - a subsaariana, ou a banto ou a nagô -, mas sim trabalharei na compreensão da maneira como esse imaginário foi sendo alimentado nas vivências do artista e político Gil.

Tratar de negritude consiste em grande desafio. Muitos são os seus usos: desde a criação de tal conceito por pensadores afro-americanos na tentativa de desestigmatizar o

\footnotetext{
${ }^{24}$ MBEMBE, Achille. As Formas Africanas de Auto-Inscrição. Revista Estudos Afro-Asiáticos, ano 23, n. 1, 2001, p.199.
} 
negro, nos fins do século XIX, até uma festejada mestiçagem positiva, ${ }^{25}$ como afirma Antônio Risério, que a viu surgir na Bahia em fins dos anos 1970. Se hoje ainda temos dificuldade em abordar o conceito, que está longe de ter somente um sentido, sua elaboração, bem como suas diversas apropriações, e até mesmo ressignificações, se transformaram ao longo dos anos, desde que foi utilizado pelas primeiras vezes. Nossa intenção é entender não só os diferentes sentidos desse aspecto na trajetória de Gilberto Gil, mas também lançar luz sobre a compreensão das africanidades no contexto brasileiro.

É notório que, em qualquer época ou lugar, os negros estiveram sempre em situação de opressão em meio aos projetos de dominação ocidental - já era negritude. Assim sendo, 'negritude' é apenas uma palavra que depois batiza o que já existia no campo das experiências e das agências. O movimento ganhou caráter internacionalis ta, criou uma pauta própria, promoveu eventos, festivais e publicações, e passou então a operacionalizar a luta dos negros de acordo com os referenciais de modernidade. ${ }^{26}$

Questionar as africanidades no Brasil é problematizar o saber que é produzido em seu nome, compreender as formas como é reconhecida, pensando na ideia de movimento e em transformações. Essas africanidades serão analisada levando-se em consideração sua mobilidade, atentando para os afrontamentos políticos, as lutas pelo poder, as estratégias simbólicas envolvidas nessas questões, os projetos ideológicos que demarcaram suas fronteiras. As africanidades no Brasil, portanto, não preexistem aos fatos que a fizeram emergir: são um construto histórico, acontecimento político e estratégico. Relaciona m-se com dominação e apropriação, e referem-se àqueles que foram excluídos dos projetos que deram origem à identidade nacional. Falar de africanidades implica reconhecer fronteiras e os poderes que dimensionam quem está de dentro e quem está de fora.

Essas africanidades são, em grande medida, fruto dos saberes e dos discursos que as constituíram e até mesmo as sustentam. ${ }^{27} \mathrm{O}$ caso aqui não é defender as africanidades

\footnotetext{
${ }^{25}$ RISÉRIO, Antônio. Carnaval Ijexá: notas sobre afoxés e blocos afro do novo carnaval afrobaiano. Salvador: Corrupio, 1981.

${ }^{26}$ Para maiores informações ver OLIVA, Anders on Ribeiro. Diálogos entre as representações dos africanos no imaginário Ocidental e o ensino da História da África no Mundo Atlântico (1990-2005). Tese de doutorado em História. Universidade de Brasília, 2007.

${ }^{27}$ Mbembe afirma que "a África só existe na base de uma biblioteca preexistente que intervém e se imiscui por toda parte, mes mo no dis curso que afirma refutá-la, a tal ponto que, comrelação à tradição a à identidade africanas, hoje é impossível distinguir o "original" da cópia", ou mesmo de um simulacro". In: MBEMBE, Achille. As formas africanas..., op. cit., p.186.
} 
- se assim fosse, eu estaria defendendo a dominação que a instituiu -, mas sim analisar criticamente os saberes que a legitimaram e a justificaram. As africanidades se processam através do engajamento de grupos sociais, elites nacionais e regionais, pela militância de indivíduos que subjetivam essa identificação. E Gil certamente configura esse grupo que contribuiu para a criação de representações de África no Brasil.

Minha maneira de lidar com a noção de africanidades será através do processo da desconstrução. Não pretendo afirmá-las, mas sim colocá-las em questão, suspeitar de sua existência naturalizada, pensar nas diferentes camadas de sentido com as quais o artista Gilberto Gil construiu sua noção de africanidade, analisando práticas discursivas e nãodiscursivas responsáveis por fazer emergir as africanidades de Gilberto Gil.

A obra e a biografia do artista podem nos ajudar a compreender não apenas a leitura que o Brasil fez da África, mas também inúmeros outros dilemas e esperanças que configuraram um tempo. Sua carreira solidificou-se ao longo dos anos 1960 e 1970 e mantém-se forte nos dias atuais. Através de questionamentos sobre sua trajetória, obteremos informações sobre as experiências e estratégias de um artista que transitou tanto pela bossa nova como pelos festivais, foi um dos criadores do movimento tropicalista, como também manteve sempre diálogo com o universo pop, através do funk, punk, hip-hop ou da música eletrônica, mantendo com cada um desses estilos musica is um diálogo peculiar.

O que está em jogo nesta análise é bem mais que a individualidade de Gilberto Gil; é a objetividade do universo cultural, que, por se fazer representar em diversas materialidades artísticas - livros, pinturas, estátuas, arquitetura e música -, produz um testemunho do passado do país.

Analisarei nesta pesquisa a capacidade da música popular, como campo cultural, de agenciar tensões que perpassaram a invenção de um Brasil, e o espaço reservado ao negro e à África nessa construção. Realizarei uma análise polifônica tramada na trajetória de Gil: os espaços que ocupou - perpassando casos do cotidiano da produção musical -, as letras das músicas que interpretou, os instrumentos que utilizou, as tensões sociais das quais participou e o modo como influenciou e foi influenciado pela dinâmica política e cultural no decorrer de seis décadas.

A proposta deste trabalho, portanto, é pensar nas relações que Gilberto Gil elaborou através de suas estratégias textuais, musicais e também políticas, criando uma 
determinada identidade brasileira que perpassou, por determinados momentos, os conceitos móveis de África e negritude. As músicas gravadas por Gil serão analisadas enquanto testemunhos da condição de um brasileiro que abordou também os temas da raça, da negritude e da África.

A intenção não é mostrar um Gil engajado, tampouco fixá-lo em sua faceta "pop" ou tropicalista, mas compreender sua obra a partir da complexidade existente na articulação de conteúdos nacionais e internacionais que expressaram os conflitos de Gil em meio a uma sociedade que sofria várias e diferentes transformações políticas e culturais, em um longo percurso de mais de seis décadas. Gil também sofreu profundas transformações pessoais, inclusive no que diz respeito à sua condição racial, que o teriam levado a uma nova compreensão da cisão marcada pelo preconceito ao longo de sua trajetória artística, e que estão de alguma maneira expressas na escolha do repertório e no modo de interpretá-lo.

O recorte aqui abordado oportuniza investigar inúmeras temporalidades percorridas por um artista inquieto e sempre em busca de novos diálogos, fossem eles musicais ou não, que vão desde o debate em torno da valorização da música nacional até as discussões em torno das novas tecnologias e mídias.

Determinadas experiências, e em especial o contato com tão diferentes sociabilidades, foram alicerçando na vida do artista novas percepções, responsáveis por incorporar sempre novos índices identitários, expressos na carreira do artista. Compartilhando dos pressupostos de Hall, uma identidade nunca está completa, e sim "sempre em processo, e é sempre constituída interna e não externamente à representação".28 Quais traços identitários, experiências, sensibilidades, valores, musicalidades, crenças e conhecimentos foram desenvolvidos por Gil e o fizeram realizar determinadas leituras sobre a África? A partir de quais circunstâncias aflorou-se a conscientização da negritude? Quais rupturas? Quais inovações? Que espaço essas questões ocupam na trajetória, na arte e na experiência política de Gil?

As reflexões até aqui apresentadas foram desenvolvidas no decorrer de três capítulos. O primeiro deles volta-se as experiências que remontam à infância, estendendose a sua participação no movimento tropicalista. Nascido em uma família negra algumas

\footnotetext{
${ }^{28}$ HALL, Stuart. Identidade cultural e diás pora. Revista do Patrimônio Histórico e Artístico Nacional, $\mathrm{n}$. 24, Iphan, Rio de Janeiro, Graphos, 1996, p. 68.
} 
décadas após o fim da abolição da escravidão no país, e bem integrado à política do embranquecimento a que tiveram acesso algumas famílias de classe média, seus primeiros anos de vida são passados na pequena cidade baiana de Ituaçu, que procuro acompanhar a partir de biografias e depoimentos. Em seguida, debruço-me sobre os seus primeiros trabalhos musicais que culminam com sua participação no movimento tropicalista.

O segundo capítulo aborda o impacto do exílio nas percepções do artista e o retorno ao Brasil; a ligação de Gil com o Afoxé Filhos de Gandhy; a negritude acessada através da conexão de Gil com Jorge Bem; a análise musical, textual e das capas da trilogia Refazenda ${ }^{29}(1975)$, Refavela ${ }^{30}(1977)$ e Realce ${ }^{31}(1979)$; a análise do DVD Os doces bárbaros ${ }^{32}$; a viagem de Gil à África em 1977; as tensões entre Gil e o movimento negro brasileiro; além de ecos de África em sua produção musical nos anos posteriores ao lançamento da trilogia; bem como a análise de sua performance. Nesse momento foi possível perceber a maneira como a África passa a ser acessada pelo artista e como ele constantemente se reinventa, transpondo fronteiras, mas sempre se lançando na exploração de uma sonoridade transatlântica, em diálogo com a negritude construída pelas experiências musicais das Américas, especialmente através do reggae e do rock.

No terceiro e último capítulo, a atenção recai sobre o artista que se transforma também em político. Sua carreira política inicia-se em 1987, quando se torna presidente da Fundação Gregório de Mattos, em Salvador. Em 1988, elege-se vereador na mesma cidade, em mandato que durou de 1989 a 1992. Após a experiência, Gil retira-se da carreira política até 2003, quando aceita o convite do presidente Luiz Inácio Lula da Silva para ser ministro da Cultura, cargo que ocupou até 2008. Ao abordar a agenda e a experiência de Gil em cargos públicos, este trabalho tem por referência as ideias de Michel Maffesoli a respeito da política na contemporaneidade. Caracterizam-na elementos que escapam à tradição racionalista ocidental: a pulsão gregária, a ambiência afetual, o sentido de comunidade e a paixão coletiva. ${ }^{33}$ Essa conceituação norteia a abordagem da carreira do político Gilberto Gil, com ênfase sobre sua gestão ministerial.

\footnotetext{
29 Álbum Refazenda (Warner Music, 1975).

${ }^{30}$ Álbum Refavela (Warner Music, 1977).

${ }^{31}$ Álbum Realce (Warner Music, 1979).

${ }^{32}$ DVD Os doces bárbaros. Direção: Jom Tob Azulay, 1978.

${ }^{33}$ MAFFESOLI, Michel. A transfiguração do político: a tribalização do mundo. Porto Alegre: Sulina, 1997, p.21.
} 


\section{Capítulo 1}

\section{“Régua e compasso": Ituaçu, Salvador e São Paulo na trajetória de Gil}

"Porque os tempos passaram e passarão. Tudo que começa acaba, e outros cabras seguirão. Cruzando o atemporal do tao do baião..."34

Gilberto Gil

É perceptível que alguns momentos de deslocamento na trajetória de Gilberto Gil demarcaram mudanças não só de espaço, mas de perspectiva identitária na vida desse artista. O primeiro deles foi a mudança de Ituaçu para Salvador, quando ele tinha apenas nove anos de idade. Em 1965, após a conclusão do curso superior de Administração, foi a vez da mudança para São Paulo para trabalhar na empresa Gessy Lever, e logo depois, em 1969, o exílio forçado em Londres. As temporalidades e vivências analisadas neste capítulo serão a infância até o início da vida adulta antes do exílio.

Esta história, portanto, terá início com a infância de Gil. Foi nesse momento que seus ideais passaram a ser forjados e o artista passou a travar diálogo com a realidade, entrando em contato tanto com o universo da música quanto da política. E termina com a explosão tropicalista, a prisão e a experiência pré-exilio, pois o exilio demarcou uma mudança significativa na trajetória do artista. Vários aspectos ${ }^{35}$ serão reprocessados por Gil, chegando mesmo a demarcar uma nova fase de experimentações e edificações identitárias. Sobre essas viagens simbólicas e necessárias a todos nós, Stuart Hall argumenta que "Esta é a África a que devemos retornar - "mas por outra estrada": o que a África se tornou no Novo Mundo, o que nós fizemos da "África" - como re-

\footnotetext{
34“"Baião atemporal”. (Gilberto Gil, 1993). In: RENNÓ, Carlos (org.) Gilberto Gil todas as letras. São Paulo: Companhia das Letras, 1996, p. 353.

${ }^{35}$ A adesão à alimentação macrobiótica que Gil inicia na prisão; a curiosidade aflorada por conhecer melhor a cultura brasileira ao retornar de Londres; o conhecimento dos movimentos negros americanos, dentre outros.
} 
contamos através da política, da memória e do desejo". ${ }^{36} \mathrm{O}$ que a África se tornaria para Gil? O que ele faria da África? Como a re-contou? Já havia algum aspecto de africanidades vivenciado pela família Gil na infância do moleque Beto? A Bahia de alguma maneira representou, nesses primeiros contatos, alguma espécie de ligação de Gil com o mundo das africanidades? Como as experiências vivenciadas em Ituaçu afetariam a trajetória do jovem Gil? E os tempos de Salvador? E os de São Paulo?

\section{- Ituaçu, o sertão}

Gilberto Passos Gil Moreira nasceu no dia 26 de junho de 1942 na cidade de Salvador, e com poucos dias de nascido rumou para Ituaçu, uma pequena cidade do interior baiano, que na época contava com cerca de 800 habitantes, para morar com os pais, o médico José Gil Moreira e a professora primária Claudina Passos. Lídia ${ }^{37}$, a tia que criou José, pai de Gil, repetiria a proeza com Gil e Gildina, a irmã que chegara um ano após o nascimento de Gil, realizando o papel não só de avó, mas também de educadora dos irmãos. De acordo com Gil,

Minha avó cuidava do dia a dia. Aprendi a escrever, a ler, a contar, as primeiras histórias, Monteiro Lobato, os primeiros livros. Minha mãe era a disciplinadora, no sentido de exigir atenção aos valores morais, aos horários. A avó era mais liberal, era $\mathrm{o}$ afeto, a coisa lúdica. ${ }^{38}$

Ituaçu foi um lugar iniciático, local das primeiras compreensões sobre o mundo e para onde grande parte das recordações acabaria retornando. É também o universo rural que de certa forma se faz acompanhado de pureza, dos encantamentos com a natureza, com os abacateiros, as feiras e seus cantadores. É uma fase constantemente revisitada nas rememorações de Gil, e de extrema importância em suas elaborações pessoais. Sua infância foi vivenciada primeiramente em Ituaçu. Ao completar nove anos de idade, e na

\footnotetext{
${ }^{36}$ HALL, Stuart. Identidade cultural e diáspora. Revista do Patrimônio Histórico e Artístico Nacional, n. 24, Iphan, Rio de Janeiro, Graphos, 1996, p. 73.

${ }^{37}$ Lídia havia sido professora primária, e foi a responsável pela educação básica de Gil e Gildina. Era Lídia também quem cuidava dos afazeres domésticos da casa, enquanto José e Claudina realizavam seus respectivos trabalhos. ZAPPA, Regina. Gilberto bem perto. $1^{\mathrm{a}}$ ed. Rio de Janeiro: Nova Fronteira, 2013, p.16.

${ }^{38}$ Gil apud ZAPPA, Regina. Gilberto bem perto..., op. cit., p. 17.
} 
falta do ensino ginasial em Ituaçu, Gil mudou-se para a casa de sua tia Margarida em Salvador, em 1951.

De acordo com Hall, a necessidade de voltar ao começo se dá pelo fato desse lugar ter se constituído profundamente como uma plenitude imaginária, num constante desejo de retornar às origens, de ser de novo um só com a mãe, de voltar ao começo.

Quem não conheceu, nesse momento, uma opressiva nostalgia por origens perdidas, pelos "tempos passados"? Entretanto, "esse retorno ao começo" é como o imaginário de Lacan - não pode ser realizado nem esquecido, e é pois o começo do simbólico, da representação, a fonte infinitamente renovável de desejo, memória mito, busca, descoberta - em suma, o reservatório de nossas narrativas cinemáticas. ${ }^{39}$

Segundo Hall,

As identidades, longe de estarem alicerçadas numa simples "recuperação" do passado, que espera para ser descoberto e que, quando o for, há de garantir nossa percepção de nós mesmos pela eternidade, são apenas os nomes que aplicamos às diferentes maneiras com que nos posicionamos, nas narrativas do passado. ${ }^{40}$

Ou seja, as projeções que os sujeitos fazem do seu passado estão diretamente relacionadas a posicionamentos elaborados e sempre reelaborados no presente da rememoração, e estão longe de serem algo transcendental e universal, onde a história não deixou suas marcas, seus sinais. Essas histórias não são meros artifícios da imaginação: o passado continua a pulsar, e também "é construído sempre por intermédio de memória, fantasia, narrativa e mito". ${ }^{41} \mathrm{Em}$ outra obra, Hall complementa ainda mais essa conceituação mítica da origem:

Trata-se, é claro, de uma concepção fechada de "tribo", diáspora e pátria. Possuir uma identidade cultural nesse sentido é estar primordialmente em contato com um núcleo imutável e atemporal, ligando ao passado o futuro e o presente numa linha ininterrupta. Esse cordão umbilical é o que chamamos de

\footnotetext{
${ }^{39}$ HALL, Stuart. Identidade cultural e diáspora, op. cit., p.75.

${ }^{40}$ Ibid., p. 69.

${ }^{41}$ Ibid., p. 79.
} 
"tradição", cujo teste é o de sua fidelidade às origens, sua presença consciente diante de si mesma, sua "autenticidade". É, claro, um mito - com todo potencial real dos nossos mitos dominantes de moldar nossos imaginários, influenciar nossas ações, conferir significado às nossas vidas e dar sentido às nossas histórias. ${ }^{42}$

Ao rememorar Ituaçu, Gil cria uma situação social de justificação, da construção dele próprio, solicitado a relatar sua própria vida, elegendo, selecionando o que teve de mais representativo nessa trajetória. Em sua biografia, ${ }^{43}$ escrita conjuntamente com a jornalista Regina Zappa, Gil "não escreveu de próprio punho, mas nos contou e indicou tudo, em longas e repetidas horas de conversa. Depois leu, releu e "refalou". ${ }^{44} \mathrm{Na}$ obra, um grande espaço é dedicado à infância, e inúmeros são os detalhamentos dessa época, essas rememorações são traçadas pelo estímulo sensorial, tecidas por fios emocionais, que perpassam pela predileção de Gil por cominho, de sua indisposição com o leite e seus derivados, além da descrição dos tecidos com que eram confeccionadas as roupas de toda a família; e onde são citados os amigos e pessoas ilustres da cidade, as brincadeiras e passatempos mais comuns vivenciados nos tempos de Ituaçu.

Questionando o problema das identidades sociais, Michael Pollak afirma que a memória

É um elemento constituinte do sentimento de identidade, tanto individual como coletiva, na medida em que ela é também um fator extremamente importante do sentimento de continuidade e de coerência de uma pessoa ou de um grupo em sua reconstrução de si (...) sofre flutuações que são função do momento em que ela é articulada, em que ela está sendo expressa. As preocupações do momento constituem um elemento de estruturação da memória. Isso é também verdade para a memória coletiva, ainda que esta seja bem mais organizada. ${ }^{45}$

\footnotetext{
${ }^{42}$ HALL, Stuart. Da diáspora: identidades e mediações culturais. $1^{\circ}$ edição atualizada. Belo Horizonte: Ed. UFMG, 2009, p.29.

${ }^{43}$ ZAPPA, Regina. Gilberto bem perto..., op. cit..

${ }^{44}$ Ibid., p. 10.

${ }^{45}$ POLLAK, Michael. Memória, esquecimento, silêncio. Estudos históricos, Rio de Janeiro, FGV, vol. 2 , n.2, 1989, p. 5 .
} 
Olhando para o passado, de forma a poder se consultar e se pensar através do passado e do presente em retrospectiva, Gil oferece a si próprio a confecção de uma origem:

\begin{abstract}
A Refazenda ${ }^{46}$ todo esse referencial do meu imaginário, do meu mundo, acaba se referindo aqui a Ituaçu, que é a base da permanência da imagem do mundo rural dentro de mim. Todos os outros lugares do interior que eu vi no mundo, aqui, na Europa, nos EUA, no Japão. Todos lugares me remetiam pra cá, toda pequena margem de rio, tudo que eu fui vendo aí pelo mundo afora, tudo remetia a Ituaçu, a esse lugar aqui. Lugar que ocupa uma função mítica na minha vida. ${ }^{47}$
\end{abstract}

Sobre sua ascendência familiar, Gil disse que "era parte da comunidade dos negros e mestiços que subiram de posição na sociedade baiana, e é aí que começa a formação da classe média negra na Bahia pós-abolição." ${ }^{48}$ Segundo Zappa,

José, seu bisavô, era um escravo alforriado que comprou sua própria liberdade pouco antes da abolição. Progrediu, abriu um armazém na Cidade Baixa e se estabeleceu no Dique. Seu filho João entrou na Guarda Nacional e conseguiu um lugar na classe média de Salvador, mesmo sendo filho de ex-escravo. Ele casouse com Catarina e teve vários filhos, entre eles José. ${ }^{49}$

Assim sendo, José, pai de Gil, era um dos muitos filhos de Catarina e de João que trabalhou na Guarda Nacional. O cargo militar de João, filho do comerciante José, permitiu que seu filho José, pai de Gil, estudasse Medicina. A família de Gil do lado paterno era negra e ascendeu socialmente, aspecto esse que continuou a acontecer ao longo da vida do menino Gil.

De acordo com Zappa, a vida de moleque corria tranquila na pequena Ituaçu. Com os amigos Gil brincava de bola, soltava pipa; construía casinhas de barro com a irmã e ajudava a avó nos afazeres da cozinha. A música foi aos poucos entrando na vida de Gil, "primeiros nos rádios, nas vitrolas e nas bandas de Ituaçu". ${ }^{50}$ Quanto aos aspectos políticos, Zappa afirma que o doutor José Gil Moreira era do PSD (Partido Social-

\footnotetext{
${ }^{46}$ Álbum Refazenda (Warner Music, 1975).

${ }^{47}$ DVD Tempo Rei. Documentário dirigido por Lula Buarque de Hollanda, Andrucha Waddington e Breno Silveira. Produção: Gege Produções/Ravina Produções. Rio de Janeiro: Conspiração Filmes, 1996.

${ }^{48}$ ZAPPA, Regina. Gilberto bem perto..., op. cit., p. 23.

49 Ibid., p. 23.

50 Ibid., p. 38.
} 
Democrático), enquanto o outro médico de Ituaçu, Luiz Edson de Gouveia, era da UDN (União Democrática Nacional), chegando a dividir entre ambos os pacientes de cada partido. Mas esse fato não rivalizava os ânimos a ponto de causar maiores desconfortos entre os moradores da pequena Ituaçu.

Segundo Zappa, em Ituaçu não houve uma vez sequer que Gil tivesse sentido discriminação pelo fato de ser negro. De acordo com o próprio Gil, não havia divisão racial em Ituaçu: "nós éramos da classe média, mas era tudo muito misturado e as famílias se frequentavam. Meu pai tratava dos pobres, dos ricos, dos pretos ou dos brancos e se relacionava com os artesãos, os pedreiros, os sapateiros, os fogueteiros. "51

Gil rememora sua forte ligação com o universo musical quando informou à mãe com apenas dois anos de idade sobre seu desejo futuro:

Eu sou músico desde os dois anos de idade, desde que eu pude dizer, desde que eu pude perceber que eu era um indivíduo junto àquela comunidade, à família, à cidade, nas viagens, quando eu saí de Ituaçu pela primeira vez para ir a Salvador. Quando eu pude dizer qual era o meu lugar naqueles mundos todos que se apresentavam a mim em camadas cada vez mais numerosas, eu disse à minha mãe, no primeiro momento que eu pude, e a história famosa que ela repete até hoje: "Eu quero ser musgueiro! Eu tinha dois anos e pouco. Eu quero ser musgueiro, mãe, musgueiro e pai de filho". Ela ouviu e registrou, nunca se esqueceu, tanto que aos dez anos ela disse: Você ainda quer ser musgueiro? E eu falei: Quero, mãe! E ela disse: Então você vai para a escola, você vai estudar. O que você quer? Você quer uma sanfona? Você gosta de Luiz Gonzaga, quer um acordeão? Ela estava atenta, muito atenta. ${ }^{52}$

Essa recordação demonstra a intenção em viver fazendo música desde a mais tenra infância, mas também o apoio que a mãe sempre deu a Gil nessa escolha, que, de acordo com ambos, mãe e filho, foi desde muito cedo a escolha de Gilberto Gil. Numa entrevis ta realizada com Claudina, mãe de Gil, quando esta contava com a idade de 99 anos, ela rememora:

Beto adorava ouvir a música do alto-falante, e quando passavam os músicos da banda, saía correndo para a porta e

\footnotetext{
${ }^{51}$ ZAPPA, Regina. Gilberto bem perto, op. cit., p.41.

52 Ibid., p. 14.
} 
ficava marchando. Ele batia o pezinho e fingia que ia atrás. Ficava na porta. Na cidade havia duas bandas, a Lira e a Jandira. Beto acordava às seis da manhã, ia para a porta do meu quarto e perguntava: Mãe, posso ir na porta ver a banda? Era entusiasmado com a música. ${ }^{53}$

As duas rememorações transcritas anteriormente, de Gil e de sua mãe, apontam a forte ligação com o universo musical do artista, algo desde muito cedo presente nas falas da criança Gil. Sua ligação com as bandas da cidade foi recordada com carinho pela mãe, mas foi também incentivada por Claudina.

De acordo com Zappa, o pai de Gil era agnóstico e sua mãe, católica. Em nenhum momento da biografia, há menção a qualquer religiosidade afro-brasileira nessa primeira infância de Gil, e nem qualquer outro aspecto que tematize de alguma maneira a África. O que se evidencia na biografia é uma ligação forte com o ambiente familiar, com a fundação do ser, a vivência num ambiente rural, a descoberta do mundo, da música, dos primeiros sabores, das primeiras letras, o mundo da política dividido em dois grupos.

Outra fonte que nos informa sobre esses primeiros anos vividos em Ituaçu é o documentário $^{54}$ que celebra trinta anos da carreira artística de Gil. Ao retornar à cidade, 45 após sua saída, Gil comenta:

Saí em 1951, só tô voltando hoje. Queria vir de trem, mas o pessoal andou dizendo que o trem acabou, que não tem mais. Tive pra voltar muitas vezes, sonho constantemente com Ituaçu. É difícil passar um ano sem que sonhe quatro, cinco vezes com Ituaçu, em geral são sonhos muito coloridos, me lembro muito das cores das casas, tudo, todo o olhar, todo o ouvido, todo coração, todo sonho, toda imaginação sobre o mistério, todas as interrogações, as grandes primeiras interrogações, tudo aqui. Por isso que sonho, sonho sempre. É um lugar que não se pode esquecer nunca. Outros lugares você passa por eles, eles talvez até nem marquem, até lugares que eu possa ter morado mais tempo do que aqui, mas aqui foi uma década gravada a fogo. ${ }^{55}$

Mais uma vez fica reiterado o espaço ocupado por Ituaçu nas lembranças de Gil, espaço das primeiras interrogações, local idílico dos primeiros encantamentos com o

\footnotetext{
53 ZAPPA, Regina. Gilberto bem perto, op. cit., p. 39.

${ }^{54}$ DVD Tempo Rei. Documentário dirigido por Lula Buarque de Hollanda, Andrucha Waddington e Breno Silveira. Produção: Gege Produções/Ravina Produções. Rio de Janeiro: Conspiração Filmes, 1996. ${ }^{55}$ Ibid.
} 
mundo, representado pela segurança de um mundo rural, constantemente acessado através de sonhos. É uma rememoração que aciona o sentimento de identidade, de continuidade e até mesmo de coerência de Gil em sua reconstrução de si.

Ainda referendados no documentário, estão os cantores que Gil ouvia ainda em Ituaçu: "o primeiro disco que eu vifoi Bob Nelson, Vicente Celestino, Carlos Galhardo, Luiz Gonzaga, Orlando Silva...". ${ }^{6}$

Quanto aos aspectos de sua vivência musical em Ituaçu, Gil disse:

Primeiro o rádio! Era a primeira fonte de acesso à música. Nós ouvíamos muito a Rádio Nacional do Rio, que tinha uma programação ao vivo interessante. Vários programas de auditório transmitidos, aqui, da Praça Mauá. Programa do José de Alencar, Renato Mursse, Paulo Gracindo, César Ladeira, Crônicas de César Ladeira, todo dia a gente ouvia. O rádio ficava ligado quase o dia inteiro. Minha avó gostava, minha mãe gostava quando estava em casa, meu pai à noite. A Rádio Nacional era o principal canal que ficava ligado, mas, também, de vez em quando, sintonizávamos a Rádio Tupi do Rio, a Rádio Mayrink Veiga do Rio e, excepcionalmente, quando o tempo permitia, o fluxo das ondas permitia, nós sintonizávamos alguma rádio de São Paulo. ${ }^{57}$

Quanto às demais sonoridades experimentadas em Ituaçu, Gil comentou:

Passavam cantadores! A feira, que era aos sábados, e que mobilizava toda aquela produção agrícola. A mandioca, o aipim, a banana, as verduras, as leguminosas, os feijões, as farinhas... tudo aquilo vinha pra feira de sábado, que começava, na verdade, na sexta-feira. Os tropeiros vinham com as suas tropas e começavam a "armamontar" a feira, em geral, na sexta-feira, depois do meio-dia, eles começavam a montar a feira. Junto com eles vinham os violeiros, os cantadores que eram frequentes. Eles vinham com as suas violas e suas cantorias. Então nós tínhamos, em geral, cantorias já na sexta-feira à noite, quando eles se instalavam e dormiam pra amanhecer o dia, quatro, cinco, seis da manhã já com a feira a pleno vapor, recebendo as pessoas, as famílias, os compradores, enfim. Era esse o tipo de música que a gente tinha ao vivo, ali, na cidade. Praticamente era o único tipo

56 DVD Tempo Rei Documentário dirigido por Lula Buarque de Hollanda, Andrucha Waddington e Breno Silveira. Produção: Gege Produções/Ravina Produções. Rio de Janeiro: Conspiração Filmes, 1996.

${ }^{57}$ Depoimento do cantore compositor Gilberto Gil ao Museu da Imagem e do Som do Rio de Janeiro para a série "Depoimentos para a Posteridade", realizado em 6 de junho de 2012. 
de música que a gente tinha. As cantorias dos cantadores. ${ }^{58}$

Essas informações são importantes, pois revelam que o universo sonoro da primeira infância era composto pelas músicas das duas bandas da cidade, os cantadores das feiras, as músicas dos discos ouvidos nas vitrolas dos amigos e a rádio. Não há em Ituaçu, assim como havia em Santo Amaro da Purificação, terra de Caetano Veloso e Maria Bethânia, elementos culturais de tradição africana como os sambas de roda, capoeira ou casas de candomblé. E, se existiam, não faziam parte das práticas familiares de Gil.

Questionado quanto a frequentar a igreja aos domingos, Gil deu a seguinte resposta:

\begin{abstract}
Nem sempre. Minha mãe não era praticante, meu pai muito longe disso, porque ele era agnóstico. Não acreditava, não era católico, não professava, não confessava religião. E minha avó, já também, mais velha, eventualmente rezava um terço, mas não ia à igreja. Íamos à igre ja nas festas! Na festa de Nossa Senhora do Alívio, na festa de Santo Antônio, no Natal, na Semana Santa com a procissão do Cristo. Nas festas! Nessas ocasiões que íamos à igreja. A igreja toda enfeitada, banda de música tocando, a banda de música fazendo as alvoradas, saindo às 6 horas da manhã pelas ruas da cidade, tocando os dobrados. Aquilo era importante, aquilo foi uma das coisas importantíssimas pra minha formação musical. Foi ali que conheci uma banda de música com os bombardinos, os trompetes, os flautins, a tuba, as caixas e tudo aquilo tocando os dobrados maravilhosos. Dobrados brasileiros, Cisne Branco, os dobrados americanos, os dobrados militares e as marchas. E na igreja os hinos religiosos que eles tocavam, aí, já também, com o auxílio de alguém que tocava um harmônio. Não era um órgão! Era uma igreja pequena, não tinha um órgão, tinha um pequeno harmônio onde alguém tocava e entoava os cantos religiosos. Esse foi um aspecto importante na minha formação musical. A coisa da banda de música local. ${ }^{59}[$ grifos meus]
\end{abstract}

Já nos primeiros anos de vida, a música se fez notar na vivência do menino Gil. A ligação religiosa era quase inexistente, mas era das festas religiosas que vinha boa parte das músicas ouvidas por Gil. O relato nos dá indício dos primeiros encantamentos com toda uma gama de instrumentos ligados ao universo de tradição europeia. Essas bandas

\footnotetext{
${ }^{58}$ Depoimento do cantore compositor Gilberto Gil ao Museu da Imagem e do Som do Rio de Janeiro para a série "Depoimentos para a Posteridade", realizado em 6 de junho de 2012.

${ }^{59}$ Ibid.
} 
geralmente faziam parte de alguma agremiação, de caráter religioso, militar ou como grupo oficial do poder instituído (prefeitura, por exemplo). O repertório de polcas, dobrados e outros ritmos é uma herança da música europeia, tanto das tradições militare $s$ quanto festeiras. É interessante notar que Gilberto Gil teve suas primeiras audições musicais compostas dentro da tradição europeia ${ }^{60}$ de música.

Em entrevista realizada pelo Museu da Imagem e do Som, em 2012, questionado sobre a existência da consciência de ser de uma família negra no período em que viveu em Ituaçu, Gil respondeu:

Não havia. Porque não havia divisão. Primeiro, por ser de uma classe social elevada para os padrões, classe média alta! Minha família pertencia à burguesia daquela cidade, então, já por esse aspecto, que é um dos aspectos que marca a questão da divisão racial, a questão da emancipação social e econômica, que é essa a importância enorme nessa questão da situação racial, da raça (ou da cor se quisermos mais do que a raça, no caso do Brasil) como um elemento de apartação social. No caso, ali, não havia divisão por essas razões. Minha família era uma família importante da cidade, mas também porque no interior sempre foi um pouco diferente essa questão racial, sempre foi um pouco diferente dos centros urbanos. É que as pessoas são todas pobres, simples, iguais na dificuldade de enfrentar. É outro ambiente! Ainda que não tinham muitos negros na cidade. Osvaldo Conceição chegou a ser prefeito da cidade, e ele era negro. Era comerciante importante. Meu pai e outras pessoas eram negras, os caboclos, muitos descendentes da mistura de brancos com índios. Aquela "caboclada" imensa dos sertões, dos interiores brasileiros. E, portanto, eu vivia nesse ambiente. O ambiente das famílias que interagiam com a minha, aquelas famílias de classe média, de classe média alta da cidade. Eu interagia também com os artesãos, com os fogueteiros, com os sapateiros, os pedreiros... todos que tinham ofícios na cidade, que prestavam serviços e que tinham um dia a dia, permanente, de interação com as famílias. Eram todos, na verdade, clientes de meu pai que tratava dos pobres e dos ricos, dos pretos e dos brancos indistintamente. (risos) O consultório do meu pai era um cômodo ao lado da minha casa, então os clientes, as pessoas, os pacientes do meu pai transitavam por minha casa $o$

\footnotetext{
${ }^{60}$ Quando digo tradição europeia de música, estou compreendendo certos parâmetros que norteiam esta prática musical. São eles a divisão métrica de ritmo, a valorização da melodia e da harmonia, bem como a música tonal como predominante na composição. Enquanto na tradição da música africana, de maneira geral, a construção do ritmo é contramétrica, valoriza-se a polirritmia e os padrões harmônicos não seguem a mesmas regras do tonalismo. In: SANDRONI, Carlos. Feitiço decente: transformações do samba no Rio de Janeiro, 1917-1933. Rio de Janeiro: Jorge Zahar; Ed. UFRJ, 2001.
} 
tempo todo. E esse era o motivo de, também, interagir com essas famílias. ${ }^{61}$

Vale aqui refletir sobre essa longa elucubração do artista. Apesar de feita já na fase madura, a resposta foi pensada e respondida tendo como foco a maneira como a situação racial era vivenciada em Ituaçu. A situação social, de classe, de acordo com Gil era mais relevante do que a racial, e podemos até mesmo dizer que eram essas as questões que demarcavam o status na pequena cidade do interior. Outro aspecto que contribuía fortemente para o status da família Gil era o fato de seu pai ser médico, desdobrando-se tanto na demanda dos moradores da cidade por seus serviços quanto no forte convívio que esse laço proporcionava.

Ituaçu é produto de sonhos, utopias, simbolismo, mito, invenções poéticas, numa realização promovida por Gil que a toma como objeto e objetivo de suas práticas. Ituaçu foi ambiente de festejos juninos, de inocência, dos cantadores da feira, das bandas - um primeiro referencial de construção cultural e identitária na trajetória do artista Gil. Os bordados e temperos da avó, somados a diversos outros símbolos que não somente os musicais, como as brincadeiras com os amigos, juntos confeccionaram as primeiras subjetividades de Gil. Podemos dizer que esses primeiros anos formam um cenário nordestino, mas não aquele demarcado pela seca e pela pobreza. Ao menos podemos afirmar que, nas memórias do senhor Gil, essa não foi a dimensão elaborada sobre Ituaçu.

Refletindo sobre o problema da identidade cultural negra pós-colonial no Caribe, Hall articula sua teoria a partir da realidade do novo cinema dessa região, produzido na década de 1990. Sua análise muito nos informa e traz argumentos para uma problematização quanto às africanidades nessa primeira infância de Gil. As identidades culturais caribenhas são vistas, segundo o autor, sob a ótica de posicionamentos e reposicionamentos em relação a três presenças: a africana, a europeia e a americana. A presença africana assim é exposta por Hall:

É o lugar do reprimido. Silenciada aparentemente além da memória pela força da experiência da escravidão, a África, na realidade, fez-se presente em toda parte: na vida cotidiana e costumes das senzalas, nas línguas e linguajares da grande

\footnotetext{
${ }^{61}$ Depoimento do cantore compositor Gilberto Gil ao Museu da Imagem e do Som do Rio de Janeiro para a série "Depoimentos para a Posteridade", realizado em 6 de junho de 2012.
} 
lavoura em nomes e palavras frequentemente desconectados de suas taxionomias, nas misteriosas estruturas sintáticas através das quais eram faladas outras línguas, nos contos e histórias narrados às crianças, nas crenças e práticas religiosas, na vida espiritual, nas artes e artesanato, nas músicas e ritmos da sociedade escravista e pós-emancipação. África, o significado presente que não podia ser representado diretamente na escravidão, mantevese e se mantém como "presença" não dita, e indizível, na cultura caribenha. ${ }^{62}$

Essa ausência da África na infância e no cotidiano da família de Gil, essa presença não dita, se fez representar através dos relatos do homem Gil, realizados em sua biografia, no documentário produzido em comemoração aos seus trinta anos de carreira e no relato que deu ao Museu da Imagem e do Som, três momentos que podem ser interpretados como espaços de solidificação e construção identitária de Gil, sendo todas elas edificadas com o intuito de perenizar a imagem do artista. As experiências vividas nesses primeiros anos de vida, junto à família, no interior da Bahia, silenciaram a africanidade. Essa não se fez revelar nas crenças e práticas religiosas e nem na musicalidade vivenciada pelo menino Gil, ou em quaisquer outras experiências rememoradas pelo artista que se referem a Ituaçu. Não há pistas de nenhum traço de africanidade nessa primeira infância de Gil.

Esse aspecto pode ser também compreendido pela ótica daquilo que Michael Pollak denominou de memórias silenciadas e esquecidas. O autor reflete sobre a elaboração de memórias construídas em um momento pós-guerra, e identifica em certos momentos, geralmente demarcados por aspectos políticos, ou também quando certas gerações estão chegando perto do fim, a existência de memórias subterrâneas, representadas por culturas minoritárias e dominadas, em choque com a memória nacional. Segundo Pollak, há um momento em que essas memórias entram em disputa, sendo o tempo todo construídas, desconstruídas e reconstruídas: "O longo silêncio sobre o passado, longe de conduzir ao esquecimento, é a resistência que uma sociedade civil impotente opõe ao excesso de discursos oficiais. ${ }^{963}$

Pollak também ressalta que os discursos oficiais se fazem valer através de enquadramentos $^{64}$ que se alimentam de materiais fornecidos pela história, e que nunca

\footnotetext{
${ }^{62}$ HALL, Stuart. Identidade cultural e diás pora, op. cit., p. 72.

${ }^{63}$ POLLAK, Michel. Memória, Esquecimento, Silêncio..., op. cit., p. 5.

${ }^{64} \mathrm{De}$ acordo com o autor, esse termo é utilizado com o intuito de analis ar referencias que sustentama organização de memórias construídas por determinados grupos. O enquadramento comporta, de acordo
} 
são construídos arbitrariamente. Sobre essas disputas de memórias, o autor comenta ainda:

Embora na maioria das vezes esteja ligada a fenômenos de dominação, a clivagem entre memória oficial e dominante e memórias subterrâneas, assim como a significação do silêncio sobre o passado, não remete forçosamente à oposição entre Estado dominante e sociedade civil. Encontramos com mais frequência esse problema nas relações entre grupos minoritários e sociedade englobante. ${ }^{65}$

Pollak salienta a importância dos ditos e dos não-ditos para a construção de uma memória, seja ela individual ou oficial, quando a memória entra em disputa. O questionamento central de Pollak é de como lidar com a memória em situações extremas, como por exemplo, a dos sobreviventes dos campos de concentração, em que pessoas são arrancadas de seu ambiente, expropriadas de seus bens, e postas num universo estranho, degradante e violento. Aqui não nos interessa refletir sobre os casos relatos por Pollack, mas o silêncio tomado como um dado significativo de análise, permitindo que o silêncio sobre o passado seja concebido como uma forma de lidar, suportar ou superar determinado passado.

A experiência dos campos de concentração foi tomada como uma situação dificilmente comunicável. O silêncio foi abordado por Pollack na perspectiva da superação de determinados traumas, do bloqueio de lembranças singulares, ou mesmo através de sua integração ou diluição num discurso geral. Assim sendo, essa perspectiva de silenciamento é aqui tomada para questionarmos as africanidades não experimentadas por uma família de negros vivendo em Ituaçu décadas após a promulgação do fim da escravidão no país.

Há uma declaração ${ }^{66}$ de Gil, realizada em 2011, que dimensiona bem esse aspecto elucidado acima por Pollak, e que nos fornece indícios para reflexão sobre a convivência pacífica entre essas duas memórias, a silenciada e a oficial. Ao tratar da temática referente às memórias ligadas à negritude em seu âmbito familiar, fica claro nas falas de Gil

com Pollack, a manutenção da coesão de um grupo e é "guiado pela preocupação não apenas de manter as fronteiras sociais, mas também de modificá-las, esse trabalho reinterpreta incessantemente o passado em função dos combates do presente e do futuro". POLLAK, Michel. Memória, Esquecimento, Silêncio..., op. cit., p. 10.

${ }^{65}$ Idem.

${ }^{66}$ Programa $O$ som do vinil - Gilberto Gil. Canal Brasil (2011). 
que houve uma apropriação dos aspectos propagados pela memória oficial, mais do que um enfrentamento entre essas duas instâncias, uma oficial/estatal e outra de cunho mais pessoal, familiar. Segundo Gil,

\begin{abstract}
Minha família tinha sido de certa forma programada para viver aquilo que se chama de branqueamento. Vamos disfarçar na medida do possível, esconder os elementos, vamos seguir a norma social, vamos branquear, ascender socialmente a partir de um branqueamento. Então a mulatice da família já ajudava um pouco isso, você é mulato, então você não é propriamente preto, então ele pode descambar, pode reivindicar a porção branca ou indígena. E minha família, de uma certa forma, de uma maneira muito disfarçada. Até por questões culturais meu bisavô havia sido escravo alforriado, tinha pago sua própria alforria, depois tinha se estabelecido como comerciante próspero em Salvador, então essa coisa da trilha branca, do branqueamento e ra uma coisa herdada, que já vinha desde a família da minha mãe como pela família do meu pai. Eu havia então sido criado nesse sentido. ${ }^{67}$ grifos meus]
\end{abstract}

Sobre esse branqueamento enquanto forma de ascendência social, Hall analisa o caso caribenho e afirma a necessidade de reunião dessas rotas fragmentadas, ilegais, para então reconstruirmos essas genealogias não ditas, para que possamos "conferir sentido à matriz interpretativa e às autoimagens de nossa cultura, para tornar o invisível visível".

Sobre traços negros e brancos, o autor comenta:

$\mathrm{Na}$ formação cultural caribenha, traços brancos, europeus, ocidentais e colonizadores sempre foram posicionados como elementos em ascendência, $\mathrm{o}$ aspectodeclarado: os traços negros, "africanos", escravizados e colonizados, dos quais havia muitos, sempre foram não ditos, subterrâneos e subversivos, governados por uma "lógica" diferente, sempre posicionados em termos de subordinação e marginalização. As identidades formadas no interior da matriz dos significados coloniais foram construídas de tal forma a barrar e rejeitar o engajamento com as histórias reais de nossas sociedades ou de suas "rotas" culturais. ${ }^{68}$

O negro, diferentemente do branco, tinha sua imagem atrelada à marginalização e à subordinação, e ao se aproximar dos traços brancos, realizava uma estratégia de legitimação, e até mesmo de ascendência social, como afirmou Hall. Na elaboração de

\footnotetext{
${ }^{67}$ Programa $O$ som do vinil - Gilberto Gil. Canal Brasil (2011).

${ }^{68}$ HALL, Stuart. Da diáspora..., op. cit., p. 40.
} 
Gil quanto ao branqueamento de sua família, ele nos revela essa lógica, não só do silenciamento da negritude, como uma conexão com as falas e políticas dos discursos oficiais daquele momento.

A construção dessa memória nacional/oficial brasileira referente à África e à negritude, e seus possíveis desdobramentos nas concepções raciais da família Passos Gil Moreira, pode ser abordada através da pesquisa realizada por Lilia Moritz Schwarcz. A autora traçou um perfil histórico da construção das teorias raciais brasileiras de 1870 a 1930, e a análise desse período recaiu sobre os homens de ciência, bem como as ideias que influenciaram tais sujeitos. Sujeitos esses que ajudaram a criar enquadramentos de memória ou discursos oficiais sobre essa temática.

Uma visão pessimista sobre o país e sua enorme miscigenação é antiga e se radicalizou em meados do século XIX, quando vários viajantes, dentre eles o Conde Arthur de Gobineau, tentaram aplicar no Brasil as teorias raciais europeias. De acordo com Schwarcz, esse tipo de interpretação "via no Brasil um modelo da falta e atraso em função de sua composição étnica e racial. ${ }^{909}$

Segundo Schwarcz, acreditava-se naquele momento que as diferenças internas se fariam solucionar através da adoção dos discursos evolucionistas (onde no topo estava a civilização europeia e na base a africana) e deterministas (a raça negra era inferior e seria preciso "embranquecer" a população para nos tornarmos mais civilizados); ambas as teorias eram consideradas científicas, no entanto, de cunho extremamente racista, aspecto que só seria problematizado posteriormente. Os homens de sciencia ${ }^{70}$ passaram então a adotar as teorias cientificistas da Europa Ocidental, acreditando que nelas estaria a solução para o destino do país. Nesse cenário, a disputa se fazia perceber entre os "profissionais de sciencia" e os "homens de letras", mas ambos se utilizavam de modelos evolucionistas e social-darwinistas para definir a inferioridade dos negros em relação aos brancos. $^{71}$

\footnotetext{
${ }^{69}$ SCHWARCZ, Lilia Moritz. O espetáculo das raças: cientistas, instituições e questão racial no Brasil 1870-1930. São Paulo: Companhia das letras, 1993, p.48.

${ }^{70}$ Segundo Schwarcz, esses homens não chegavam a formar um grupo homogêneo, e o que de fato os unia era a busca por uma certa legitimidade para discutir e aportar os impasses que se faziam notar naquele momento.

${ }^{71}$ SCHWARCZ, Lilia Moritz. O espetáculo das raças..., op. cit., p. 176.
} 
De acordo com Schwarcz, no final do século XIX a mestiçagem e o "branqueamento" se configuravam como soluções para o problema da raça no Brasil. Esses ideais demoraram a aportar no país, mas ganharam muita força no período pósabolição. No Brasil, o ensino brasileiro embasava-se em questões que mesclavam positivismo, evolucionismo e determinismo, e em muito se deixavam influenciar por ideias que vinham de fora, especialmente da Europa e dos Estados Unidos. Segundo Schwarcz, o termo raça ganhou contornos diferentes para cada série de discursos no qual foi apropriado, ganhando em cada um deles uma utilidade original:

\begin{abstract}
Raça é um dado científico e comparativo para os museus; transforma-se em fala oficial nos institutos históricos de finais do século; é um conceito que define a particularidade da nação para os homens de lei; um índice tenebroso na visão dos médicos. $\mathrm{O}$ que se percebe é como em determinados contextos reelaboramse símbolos disponíveis, dando-lhes um uso original. Se a diferença já existia, é nesse momento que é aditivada. ${ }^{72}$
\end{abstract}

Construído histórica e socialmente no Brasil em diferentes séries de discursos, o conceito de raça foi elaborado primeiramente nos IHGBs e museus, e posteriormente nas escolas de Direito e Medicina, e em todos esses discursos oficiais ele se fez ecoar, influenciando uma série de estudos posteriores sobre raça no decorrer de todo o século XX. Schwarcz comenta ainda que o tema racial foi o argumento para se pensar um projeto de cunho nacional brasileiro não só no século XIX, mas também no século XX.

De fato, a interpretação racial, a constatação de que essa era uma nação singular porque miscigenada, é antiga e estabelecida no país. Tema do ensaio vitorioso do naturalista Von Martius para o IHGB em inícios do séc. XIX, retomada principalmente por Silvio Romero nos anos 80, para surgir reelaborada em início do século XX com Gilberto Freyre, eis que a interpretação persiste mesmo em momentos e modelos teóricos diversos. Da constatação da hibridação em Von Martius à afirmação darwinista em Romero, para se chegar ao elogio à democracia racial com Gilberto Freyre, percebe-se como é arraigado o argumento de que o Brasil se define pela raça. ${ }^{73}$

No momento pós-abolição, logo nos primeiros tempos de República, a intelectualidade brasileira, em especial aquela ligada aos IHGB, às primeiras faculdades

\footnotetext{
72 SCHWARCZ, Lilia Moritz. O espetáculo das raças, op. cit., p. 317.

${ }^{73}$ Ibid., p. 324.
} 
brasileiras, ou mesmo aos primeiros escritos de pensadores brasileiros, como os de Euclides da Cunha e Nina Rodrigues, foi guiada por teses eugenistas e deterministas, numa clara tentativa de retirar a população negra da constituição da nova nação, fosse através das políticas de branqueamento ou da importação de mão-de-obra europeia. Essas posturas buscavam justificativa em teorias tidas como científicas e eram amplamente aceitas por grande parte da população. Não se percebe, em nenhum momento, menções à África no discurso da intelligentsia; muito pelo contrário, a intenção maior era exterminar qualquer resquício de negritude da população brasileira.

O "silenciamento" que notamos na família Passos Gil Moreira quanto a aspectos das africanidades, pode ser detectado também nos discursos oficiais do período, nos quais a África deveria ser a todo custo evitada e até mesmo negada quando se tratava de identificar a nação brasileira. As rememorações de Gil apontam para a utilização por parte de sua família de "estratégias de branqueamento".

Achille Mbembe também questiona o silenciamento quando a temática é a escravidão. O autor analisa a colonização, o apartheid e o holocausto, enquanto fenômenos de expropriação do eu, mas também eventos que demarcaram a morte em massa, numa completa desvalorização da vida. São eventos históricos que representam "status de sofrimento na história, as várias maneiras com que as forças históricas afligem dano psíquico aos corpos coletivos, e as formas através das quais a violência molda a subjetividade." ${ }^{74}$ Segundo Mbembe, diferentemente do holocausto, não há nenhuma memória africana da escravidão, e quando existe, é fragmentada; comenta ainda que,

Entre a memória dos afro-americanos sobre a escravidão e aquela dos africanos do Continente, há uma zona de sombra que dá margem a um profundo silêncio: o silêncio da culpa e da recusa dos africanos em enfrentar o inquietante aspecto do crime que envolve diretamente sua responsabilidade. Pois o destino dos escravos negros na modernidade não é apenas resultado da vontade tirânica e da crueldade do Outro - mesmo que estas sejam bem conhecidas. ${ }^{75}$

\footnotetext{
${ }^{74}$ MBEMBE, Achille. As Formas Africanas de Auto-Inscrição. Revista Estudos Afro-Asiáticos, ano 23, n. 1, 2001, p. 187.

${ }^{75}$ Ibid., p. 188.
} 
Mbembe ao se referir à memória da escravidão no Novo Mundo, bem como a maneira como foi reprimida pelos descendentes de escravos africanos, problematiza o silenciamento:

O drama familiar que está na base desta tragédia, assim como, atualmente, a miséria de suas existências, são constantemente negados. Para ser exato, esta negação não é equivalente ao esquecimento. Ela é simultaneamente uma recusa de reconhecer a própria ancestralidade e uma recusa a lembrar um ato que provoca sentimentos de vergonha. Sob tais condições, a prioridade não é realmente restabelecer contato consigo mesmo e com suas próprias origens. Nemé uma questão de restaurar uma relação plena e positiva consigo mesmo, posto que este eu foi danificado e humilhado para além de qualquer limite. Já que a narrativa da escravidão foi condenada a ser elíptica, um fantasma persegue e ronda o sujeito e inscreve em seu inconsciente o corpo morto de uma linguagem que deve ser constantemente reprimida. $^{76}$

Assim, Mbembe demarca que diferentemente de esquecida a memória da escravidão é continuamente repudiada. Assim como em Pollak, o silenciamento é chamado à cena e anunciado por Mbembe quando se trata de evidenciar esses momentos tão traumáticos da história da humanidade. O fim da escravidão no Brasil data de 1888 . Gil nasceu em 1942, apenas 54 anos após o fim da abolição. Seu bisavô comprou sua alforria e possibilitou ao filho ascender socialmente, e assim sucessivamente, até chegar a Gil. Essa falta de ligação com quaisquer traços de africanidades pode significar aquilo que Pollak, Mbembe e Hall chamaram de "silenciamento" ou "esquecimento" enquanto estratégias de proteção. Constantemente, em vários momentos de sua trajetória, Gil afirma que o fato de sua família pertencer à classe média alta atenuava os fatores de racismo a eles dirigidos.

O silenciamento de certas memórias, de acordo com Pollak, se fez necessário e se deu por razões bastante complexas. Dentre elas, pode-se evidenciar a dificuldade em encontrar uma escuta, a necessidade de investimento de todas as energias na construção do pós-guerra, que pode ser associada, no caso da família Gil, à preocupação familiar desde seu bisavô em ascender socialmente, esquecer os traumas experimentados na escravidão, e a construção do pós-abolição, além daquilo que consiste em querer poupar os filhos de crescer na lembrança das feridas dos pais. ${ }^{77}$

\footnotetext{
${ }^{76}$ MBEMBE, Achille. As formas africanas de auto-inscrição, op. cit., pp. 188-189.

${ }^{77}$ POLLAK, Michel. Memória, Esquecimento, Silêncio, op. cit., p. 6.
} 
No entanto, essa África indizível e silenciada mais cedo ou mais tarde apareceria e se faria entender, tornando-se até mesmo motivo para Gil lançar um disco-manifesto negro. Ituaçu estava muito perto e ao mesmo tempo muito longe, e foi sempre conectada pela imaginação e pelo sentimento, retorno constante por representar não só a ambiência familiar, mas uma época de pureza, inocência e das primeiras descobertas musicais, ponto de partida para as construções identitárias do artista Gilberto Gil.

\section{- Salvador: "Na Bahia que é meu lugar" 78}

Aqui abordarei o período em que Gil viveu em Salvador, dos nove aos 24 anos de idade, atentando para os possíveis traços de africanidades experimentados nesse tempo. O aprendizado musical, a participação nos primeiros conjuntos musicais, a criação de jingles para o rádio, a conclusão do curso superior, o início dos estudos de acordeom, bem como sua posterior troca pelo violão trazem à cena a discussão da vivência na capital da Bahia, e podem aqui ser interpretados também enquanto espaço de modernização. ${ }^{79}$ É nesse momento que a música começa a tomar forma de aprendizado e posteriormente de profissionalização. Neste sentido, cabe entender as primeiras aulas de acordeom como a continuidade do sertão se inscrevendo na construção identitária de Gill, caracterizando sua ligação com a tradição, bem como a adesão à bossa nova e ao violão como uma espécie de sintonia com as manifestações estéticas e culturais surgidas naquele momento, mais marcadas pela modernidade.

Como afirma Néstor Canclini, as operações científicas e políticas que colocaram em cena o popular devem ser desconstruídas. Aqui o popular não é dotado de um sentido: há tanto o popular conectado a Luiz Gonzaga e atrelado a um consumo de massa, como o popular que é ideológico e ligado aos CPCs. ${ }^{80} \mathrm{Não}$ há uma unanimidade na utilização do termo, mas sim uma complexa trama que deve ser analisada através do contexto no

\footnotetext{
78،"Eu vim da Bahia" (Gilberto Gil, 1965). In: RENNÓ, Carlos. Gilberto Gil: todas as letras: incluindo letras comentadas pelo compositor. São Paulo: Companhia das Letras, 1996, p. 58.

${ }^{79}$ Nesse caso, também em oposição a um universo mais rural vivenciado em Ituaçu.

${ }^{80}$ Os centros populares de cultura, geralmente atrelados à União Nacional dos Estudantes, tinham uma proposta pedagógica revolucionária. Acreditavam que o artista deveria assumir um papel de militância política em prol da libertação material e cultural do nosso povo. E, paralelamente, preconizavam a autonomia da obra de arte como algo equivalente a um discurso que anunciava, com antecedência, transformações sociais a serem implantadas, futuramente, pela revolução social. In: CONTIER, Arnaldo. Edu Lobo e Carlos Lyra: O Nacional e o Popular na Canção de Protesto (Os Anos 60). Rev. Bras. Hist., vol. 18, n. 35, São Paulo, 1998.
} 
qual estão inseridos esses muitos populares. Seguindo o pensamento de Canclini, hoje temos mais clareza a respeito das irresistíveis pressões da modernidade, bem como da existência de várias modernidades. A chamada modernidade não pode mais ser vista como homogênea, nem como um poderoso instrumento que reorganiza as práticas culturais. Segundo Canclini, não se pode pensar em um isolamento completo. Os grupos a seu modo reagem, mas também interagem com o mercado transnacional que se apresenta. $^{81}$

O universo das práticas culturais sempre foi repleto de contradições e conflitos, mas também de adaptações, traduções e apropriações. Esquecer que esses processos se desencadeiam através de uma série de conflitos é perder de vista a possibilidade de compreensão dessas práticas. Minha proposta é pensar sob essa perspectiva o mundo da cultura, especialmente entre os setores artísticos, e nesse caso, artísticos musicais. O importante, é demarcar que, diferentemente de uma perspectiva folclorista, não irei buscar "a" África em questão, ou mesmo uma África que não muda, mas sim como ela foi apreendida por Gil, e como esse imaginário muda e interage com a modernidade.

Canclini defende que o popular não se concentra em objetos. $\mathrm{O}$ importante são as mudanças de significados, resultantes de interações. A arte popular, por exemplo, não seria uma coleção de objetos; nem a ideologia subalterna, um sistema de ideias, nem repertórios fixos de práticas. O popular não é nem mesmo monopólio dos populares. Não se pode mais buscar uma identidade de ouro da cultura popular no sentido de ter se mantido independente, sem contatos de espécie alguma. Uma mesma pessoa, e nesse caso Gil, pode participar de vários grupos e circuitos culturais. Canclini insiste também na ideia de que o popular não é vivido pelos agentes sociais como uma manutenção melancólica das tradições. ${ }^{82}$ Segundo Canclini, é necessário desconstruir essa divisão entre o culto, o popular e a cultura de massa, e investigar aquilo que denominou de hibridismo; nessa perspectiva, nada é puro, as culturas são hibridas, e é dessa maneira que abordarei a cultura, não como simples oposição entre o tradicional e o moderno, africano ou brasileiro, popular ou erudito, local ou estrangeiro, mas como um complexo processo capaz de gerar novas estruturas, objetos e práticas. ${ }^{83}$

\footnotetext{
${ }^{81}$ CANCLINI, Néstor. Culturas híbridas: estratégias para entrar e sair da modernidade. São Paulo: Edusp, 2008.

${ }^{82}$ Ibid., pp. 207-214.

${ }^{83}$ Ibid., pp.71-75.
} 
De acordo com Homi Bhabha, a complexidade do mundo moderno substituiu as categorias conceituais "classe" e "gênero" por raça, local institucional, localidade geopolítica, orientação sexual, dentre outras conceituações que passaram a melhor identificar consciências da posição de sujeito. Ainda segundo esse autor, é no entre-lugar que se elaboram as estratégias de subjetivação - singular ou coletivo -, possibilitando acessar novos signos de identidade. Refletindo sobre os locais da cultura, Bahbha aponta que

\begin{abstract}
Os termos de embate cultural, seja através de antagonismo ou afiliação, são produzidos performativamente. A representação da diferença não deve ser lida apressadamente como reflexo de traços culturais étnicos preestabelecidos, inscritos na lápide fixa da tradição. A articulação social da diferença, da perspectiva da minoria, é uma negociação complexa, em andamento, que procura conferir autoridade aos hibridismos culturais que emergem em momentos de transformação histórica (...) $\mathrm{O}$ reconhecimento que a tradição outorga é uma forma parcial de identificação. Ao reencenar o passado, este introduz outras temporalidades culturais incomensuráveis na invenção da tradição. Esse processo afasta qualquer acesso imediato a uma identidade original ou a uma tradição "recebida". ${ }^{84}$
\end{abstract}

É, portanto através da performance de Gil que analisarei os embates culturais por ele vivenciados. Ao pensar em cultura, logo tomo por referência o campo da produção das identidades, sejam elas as nacionais, regionais, étnicas, de gênero, de classe, ou outras, fugindo da ideia de resgate que traz em si embutido o mito da pureza das origens, quando isso na verdade não existe no campo cultural ou em qualquer aspecto das práticas humanas, no qual qualquer evento, mesmo com repetições, é marcado pela criação, pela invenção e pelo deslocamento de sentidos e significados. Assim, a trajetória de Gil é aqui percebida como fenômeno histórico e aberto a escolhas: suas ações, apesar de informadas pelo contexto, são também ressignificadas através de ações e questionadas perante novas contingências, já que a ressignificação de inúmeros signos culturais foi constantemente percebida tanto em seus projetos pessoais como artísticos.

Cultura aqui é percebida enquanto um conjunto múltiplo e multidirecional de fluxos de sentido, de matérias e formas de expressão que circulam permanentemente, nunca respeitando fronteiras, e que sempre carrega em si a potência do diferente, do criativo, do inventivo, da mistura. As identidades também são fabricações sociais e

${ }^{84}$ BHABHA, Homi K. O local da cultura.- Belo Horizonte: Ed. UFMG, 1998, p. 21. 
históricas; não são originais, não vêm da origem, porque também teríamos que nomear e datar esta origem e descobri-la como invenção social. Buscarei compreender as construções identitárias referentes a esse período através das rememorações de Gil em diálogo com outras fontes que se referem a esse período.

A capital baiana era nas férias o local de destino da família Gil Moreira. A mudança para Salvador aconteceu quando Gil completou nove anos, por motivo dos estudos ginasiais. ${ }^{85}$ Para a casa da tia Margarida se mudaram Gil, a irmã Gildina e a avó Lídia. Foi em Salvador que Gil começou a estudar acordeom, num curso de quatro anos com o professor espanhol José Benito Colmonero. Também em Salvador, Gil começou a participar de programas de televisão. Lá, conheceu e passou a conviver com Caetano, Maria Bethânia e Maria da Graça, com os quais manteria fortes laços pessoais e artísticos ao longo de toda sua trajetória artística.

Em sua biografia, Gil assim define o lugar de Salvador em sua formação:

É na adolescência em Salvador que aparece a pessoa, propriamente dita, diante das outras pessoas. A cidade exige isso, essa caracterização da individualidade, que você comece a ter noção do que quer ser na vida. Tudo se configura ali em Salvador. ${ }^{86}$

Sobre a transferência para a capital baiana, Gil contou em depoimento ao Museu da Imagem e do Som que

Desde a primeira infância com dois, três, quatro anos de idade, cinco anos de idade... Nós íamos todos os verões para Salvador, na casa da minha tia Margarida e da minha avó Lídia. Elas tinham uma casa em Salvador, na Rua dos Marchantes, número 11, ali, no Santo Antônio, bairro importantíssimo da cidade! Ao lado do Plano Inclinado do Pilar, aos poucos metros do Convento do Carmo, a 200 metros, mais ou menos, do Largo do Santo Antônio. Um bairro de importância extraordinária! Onde surgiram muitos blocos de carnaval, onde havia muitas casas de candomblé, onde havia toda uma vizinhança de árabes, comerciantes importantes. Árabes, sírios e libaneses. Onde havia, também, uma grande colônia galega! Galegos da parte norte de Portugal e da Espanha, que também compartilhavam com os árabes o comércio, os bares, os armazéns. Esse foi o ambiente que eu fui viver depois da infância, início da adolescência (aos

\footnotetext{
${ }^{85}$ ZAPPA, Regina. Gilberto bem perto, op. cit., p. 46.

${ }^{86}$ Ibid., p. 46.
} 
10,11 anos de idade) quando me mudei pra Salvador. ${ }^{87}$

Ambos os depoimentos transcritos acima dimensionam a importância da cidade na formação de Gil. Diferentemente da pacata e familiar Ituaçu, Salvador foi identific ada por Gil através de sua pluralidade cultural. Além de demarcar também que o deslocamento, se fez notar desde cedo na trajetória do artista. A mudança para um local marcado pela diversidade étnica e de classes, certamente se faria notar na elaboração identitária do artista. E é novamente Hall quem nos diz sobre essas elaborações sempre inacabadas das identidades:

\begin{abstract}
A identidade é realmente algo formado, ao longo do tempo, através de processos inconscientes, e não algo inato, que existe na consciência no momento do nascimento. Existe sempre algo "imaginário" ou fantasiado sobre sua unidade. Ela permanece sempre incompleta, está sempre em "processo", sempre "sendo formada." As partes "femininas" do "eu" masculino, por exemplo, que são negadas, permanecem com ele e encontram expressão inconsciente em muitas formas não reconhecidas, na vida adulta. Assim, em vez de falar da identidade como uma coisa acabada, deveríamos falar de identificação, e vê-la como um processo em andamento. A identidade surge não tanto da plenitude da identidade que já está dentro de nós como indivíduos, mas de uma falta de inteireza que é "preenchida" a partir de nosso exterior, pelas formas através das quais nós imaginamos ser vistos por outros. Psicanaliticamente, nós continuamos buscando a "identidade" e construindo biografias que tecem as diferentes partes de nossos "eus" divididos numa unidade porque procuramos recapturar esse prazer fantasiado da plenitude. " 88
\end{abstract}

Refletindo sobre a elaboração dessas identidades culturais não fixas e produzidas através de complicadas misturas culturais, Hall afirma que

Esse conceito descreve aquelas formações de identidades que atravessam e intersectam as fronteiras naturais, compostas por pessoas que foram dispersadas para sempre de sua terra natal. Essas pessoas retêm fortes vínculos com seus lugares de origem e suas tradições, mas sem a ilusão de um retorno ao passado. Elas são obrigadas a negociar com as novas culturas em que vivem, sem simplesmente serem assimiladas por elas e sem perder completamente suas identidades. Elas carregam os traços

\footnotetext{
${ }^{87}$ Depoimento do cantore compositor Gilberto Gil, ao Museu da Imagem e do Som do Rio de Janeiro para a série "Depoimentos para a Posteridade", realizado em 6 de junho de 2012.

${ }^{88}$ HALL, Stuart. A identidade cultural na pós-modernidade, op. cit., p. 24.
} 
das culturas, das tradições, das linguagens e das histórias particulares pelas quais foram marcadas. A diferença é que elas não são e nunca serão unificadas no velho sentido, porque elas são, irrevogavelmente, o produto de várias histórias e culturas interconectadas, pertencem a uma e, ao mesmo tempo, a várias "casas" (e não a uma "casa" em particular). As pessoas pertencentes a essas culturas híbridas têm sido obrigadas a renunciar ao sonho ou à ambição de redescobrir qualquer tipo de pure za cultural "perdida" ou de abs olutis mo é tnico. Elas estão irre vogavelmente traduzidas ${ }^{89}$ [ grifos meus]

Assim como Hall, Bhabha também reflete sobre a tradução, e diz que

O trabalho fronteiriço da cultura exige um encontro com "o novo" que não seja parte do continuum de passadoe presente. Ele cria uma ideia do novo como ato insurgente de tradução cultural. Essa arte não apenas retoma o passado como causa social ou precedente estético; ela renova o passado, refigurando-o como um "entre-lugar" contingente, que inova e interrompe a atuação do presente. $\mathrm{O}$ "passado-presente" torna- se parte da necessidade, e não da nostalgia, de viver. ${ }^{90}$

Bhabha afirma ainda que todas as formas culturais estão de alguma maneira relacionadas umas com as outras, continuamente em processo de hibridação, e que a tradução

\begin{abstract}
É também uma maneira de imitar, mas num sentido traiçoeiro e deslocante - o de imitar em original de tal modo que sua prioridade não é reforçada, e sim, pelo próprio fato de ele poder ser simulado, reproduzido, transferido, transformado, tornando um simulacro e assim por diante: nunca o original se concluiu ou se completou em si mesmo. O "originário" está sempre aberto à tradução, portanto nunca pode ser dito que tenha um momento antecedente, totalizado de sentido ou de ser - uma essência. E o que isso de fato quer dizer é que as culturas só são constituídas em relação a essa alteridade interna à sua própria atividade formadora de símbolos que as faz estruturas descentradas - e que através desse deslocamento ou liminaridade abre-se a possibilidade de se articularem práticas e prioridades culturais diferentes e mesmo incomensuráveis. ${ }^{91}$
\end{abstract}

\footnotetext{
${ }^{89}$ HALL, Stuart. A identidade cultural na pós-modernidade, op. cit., p. 52.

${ }^{90}$ BHABHA, Homi K. O local da cultura, op. cit., p. 27.

${ }^{91}$ RUTHERFORD, Jonathan. O terceiro espaço: uma entrevista com Homi Bhabha. Revista do

Patrimônio Histórico e Artístico Nacional, n. 24, Brasília, 1996, p. 36.
} 
As várias rememorações de Gil aqui exploradas, capturadas também através de suas músicas, de inúmeras entrevistas concedidas pelo artista ao longo de sua trajetória, assim como de filmes dos quais participou enquanto idealizador ou mediador, são visibilidades históricas, são espaços discursivos que nos deixam ver a construção identitária de Gil, as hibridações culturais das quais participou, os espaços que ocupou, por quais tendências culturais transitou, com quem dialogou, quais signos culturais traduziu. São marcas desse "entre-lugar" que não é somente a leitura e a continuidade do passado, mas como ele passa a ser traduzido no presente, gerando sempre uma nova configuração.

Gil bem dimensiona essa caracterização identitária processual e em formação sempre em relação a um outro, já que foi na adolescência em Salvador que aparece a pessoa, propriamente dita, diante das outras pessoas. Gil foi obrigado a negociar com as novas e diferentes culturas do bairro Santo Antônio, em Salvador, sem simplesmente ser assimilado por elas e sem perder completamente sua identidade; mas também teve que renegociá-la inúmeras vezes ao se deslocar para locais sempre diferentes ao longo de sua trajetória, como, por exemplo, quando foi para São Paulo em 1965, para Londres em 1969, e quando voltou a viver na Bahia na década de 1980. Gil pertence a culturas híbridas, e não realiza uma busca por redescobrir uma pureza cultural "perdida", ou mesmo um absolutismo étnico. Gil, ao longo de toda a sua trajetória, habitou várias identidades, ${ }^{92}$ falou muitas linguagens culturais, traduziu e negociou com elas.

O segundo capítulo da biografia de Gil, que retrata a época em que morou em Salvador, se inicia com um relato de discriminação, que de acordo com Zappa "foi um fato raro e não uma regra". ${ }^{93}$ Sobre essa situação, a autora conta que o primeiro choque aconteceu na sala de aula, quando um professor interrompeu com brutalidade um questionamento do menino Gil, dizendo "cala a boca, seu negro boçal”. Esse indício, aqui exposto por Zappa, de que a discriminação referente à cor de Gil foi mais um fato raro do que uma regra, pode ter contribuído para que a identificação com questões raciais, bem como a busca por questões ligadas à cultura africana, tardasse a aparecer enquanto demanda para Gil.

\footnotetext{
${ }^{92}$ Não só a das africanidades, a da política, mas também as do sujeito leitor do I-ching que medita e tem uma alimentação macrobiótica, apropriando-se de diferentes aspectos da cultura oriental, além de muitos outras.

${ }^{93}$ ZAPPA, Regina. Gilberto bem perto, op. cit., p. 45.
} 
Sobre a religiosidade vivenciada em Salvador, Zappa comenta que Gil frequentava missas e rezava diariamente no colégio. Quanto à ligação com as religiosidades afro-brasileiras àquela época, Zappa assim a descreve:

\begin{abstract}
A relação de Gil com o candomblé nessa fase da vida era quase nenhuma. Ele tinha chegado de Ituaçu, onde nunca tinha ouvido falar de candomblé, e foi direto para o colégio Marista, vivendo num círculo de relações ligadas a religiões confessionais. Observava apenas de longe as famílias negras e pobres, algumas de classe média, que seguiam a religião. $\mathrm{O}$ candomblé estava à margem e a maioria de seus seguidores morava na periferia. Ele não fazia ainda a associação entre o candomblé e o Carnaval, não sabia ainda que o Filhos de Gandhy tinha sido formado por gente como estivadores das docas de Salvador, todos egressos das comunidades afro-brasileiras ligadas aocandomblé nas periferias da cidade. ${ }^{94}$
\end{abstract}

E Gil complementa a informação, afirmando que "tudo isso só fui saber depois do exílio. A primeira vez que entrei num terreiro de candomblé foi quando voltei de Londres". A pista da não existência de qualquer ligação do garoto Gil com a religiosidade afro-brasileira é clara, além também do fato de essa ligação passar a existir somente após o retorno do exílio em Londres. De acordo com Gil, o culto aos orixás não fazia parte de sua origem familiar.

Bethânia só entrou no candomblé pelas mãos de Mãe Menininha, e Gal a mesma coisa, eu também. Fui muito levado pelo interesse em me aproximar do mundo descrito nos livros de Jorge Amado, que veio com a vida universitária, com a sociologia e a antropologia. ${ }^{95}$

Esse depoimento dimensiona a inexistência da ligação com o candomblé no período em que Gil morou em Salvador, e demonstra que a aproximação do artista não se dera através de uma vivência familiar e não se processou enquanto uma busca pessoal por devoção religiosa. Foi um processo embasado na racionalidade, de forma mais intelectualizada, com o intuito mesmo de conhecer melhor aspectos referentes à cultura brasileira. A atenção aqui dada à existência ou não de alguma ligação com a religiosid ade afro-brasileira na trajetória de Gil se faz relevante, pois é especialmente além dos traços físicos, na música e na religiosidade que se demonstra fortemente a presença africana

\footnotetext{
${ }^{94}$ ZAPPA, Regina. Gilberto bem perto, op. cit, p.51.

95 Ibid., p. 51.
} 
entre nós. Cabe agora continuar a busca por outros possíveis traços de africanidades que marcaram essa vivência em Salvador.

Outro aspecto relevante a ser questionado, ao tratar do tema religiosidade afrobrasileira, é a enorme quantidade de perguntas referentes a esse universo por grande parte dos entrevistadores consultados ao longo desta pesquisa. Ao tentarem retratar a ligação de Gil com algum aspecto de africanidades, a ligação com o universo do candomblé, além de ser sempre o primeiro, é o ponto mais frequentemente questionado. É como se o candomblé pudesse representar sem sombra de dúvidas traços de cultura africana, ou, ao menos, que este seria um legítimo marcador simbólico de africanidade.

Assim que chegou a Salvador, Gil começou a estudar acordeom, e no repertório interpretado havia um pouco de tudo, "a começar pelos baiões de Luiz Gonzaga, e depois Dorival Caymmi e os sambas-canções clássicos." 96 No site oficial do artista, assim se noticiam seus primeiros contatos com o acordeom: "Por influência de Luiz Gonzaga e do baião, começa a aprender acordeom; no início tem aulas particulares, depois -e até 1956 - frequentará a Academia de Acordeom Regina. ${ }^{, 97}$

Sobre o repertório executado no acordeom, Gil relembrou:

As músicas de Antenorgenes Silva, o "Tico Tico no Fubá", algumas peças clássicas europeias e muita música popular que eu tirava de ouvido: baião, as toadas, as músicas da Rádio Nacional... Aquilo tudo que eu tocava foi, ali, foi o meu primeiro instrumento. ${ }^{98}$

A infância de Gil foi demarcada fortemente pela presença da radiodifusão, e coincide com o auge do sucesso do rádio no país - décadas de 1940 e 1950 -, período de consolidação desse meio de comunicação, principalmente por meio da Rádio Nacional. ${ }^{99}$ Gil relatou ao MIS suas primeiras lembranças musicais:

\footnotetext{
96 ZAPPA, Regina. Gilberto bem perto, op. cit., p. 52.

${ }^{97}$ Site: 〈www.gilbertogil.com.br>. Aces so em 12 mar. 2015.

${ }^{98}$ Depoimento do cantor e compositor Gilberto Gil, ao Museu da Imagem e do Som do Rio de Janeiro para a série "Depoimentos para a Posteridade", realizado em 6 de junho de 2012.

${ }^{99}$ A radiodifusão surgiu nos Estados Unidos no início dos anos 1920. A primeira emissora brasileira foi fundada em 1923: a Rádio Sociedade, de Roquette Pinto e Enrique Morize, que tinha como principal objetivo acabar com os males culturais do país, através de uma programação que seguis se uma cartilha mais erudita e didática. A popularização da programação iniciou-se com a Rádio Mayrink Veiga, fundada em 1926, e que, a partir de 1927, introduziu a música popular em suas transmissões. Essa popularização do rádio passou a sofrer críticas em relação à programação musical voltada para sambas, marchas
} 
Era quase impossível sintonizar as rádios da Bahia porque elas não tinham potência suficiente. Elas não eram de 50 quilowatts como era a Rádio Nacional, a Rádio Tupi e essas outras. As rádios da Bahia tinham 30, 20 quilowatts. Não tinha potência para alcançar aquele lugar do interior. Mas ouvíamos rádio! Era isso que a gente ouvia. Lá em casa não tinha, não sei a razão, meu pai e minha mãe optaram por não ter vitrola. Em Ituaçu não tínhamos, mas algumas dessas pessoas: seu Juvenal Vanderlei, seu Osvaldo Conceição, seu Tuninho Guimarães... Essas pessoas importantes da cidade, comerciantes importantes da cidade, eles tinham vitrolas, e eu, de vez em quando, ia na casa deles e ouvia discos. Lembro bem, ouvindo discos do Bob Nelson na casa do seu... (Gil é interrompido) ${ }^{100}$

Sobre sua preferência musical nas rádios, Gil conta que ouvia "Carlos Galhardo, Orlando Silva, Dalva de Oliveira, Bob Nelson e as irmãs Batista... Dorival Caymmi, Cauby Peixoto, Ângela Maria."101

Nos depoimentos acima transcritos, percebe-se que a audiência musical do menino Gil em sua infância e adolescência em Ituaçu, mas também em Salvador, nos anos 1940 e 1950, eram os cantores do rádio, dentre eles Bob Nelson, Luiz Gonzaga e Ângela Maria. As músicas interpretadas por esses cantores chegavam até Gil não somente através do rádio, mas também pelos discos. Há uma característica marcante nessas rememorações e escolhas de audição do menino Gil: a predileção pela música popular brasileira e a pouca influência estrangeira em seu gosto musical.

A importância do sertão, da primeira infância em Ituaçu, em grande medida está relacionada à imagem de Luiz Gonzaga. A ligação de Gil com Luiz Gonzaga e com o baião se fez notar na escolha de seu primeiro instrumento, o acordeom. Mas, ao longo de toda a trajetória do artista, essa relação é revisitada. ${ }^{102}$

e canções populares. Lia Calabre aponta que, durante a década de 1930, o rádio despertou inúmeros sentimentos, que iam do fascínio à rejeição. O ambiente radiofônico estava impregnado de estereótipos:ao mesmo tempo que era visto como lugar de fama e de ascensão social, era visto enquanto ambiente de marginalidade, impróprio para pessoas de "boa família", utilizando expressão da autora, que a recupera de suas fontes. De acordo com a autora, a busca por ouvintes de novas camadas sociais produziu programas cada vez mais populares, gerando uma "via de mão dupla" na relação rádio/sociedade, em que o gosto popular tinha peso fundamental. Os programas lançados eram avaliados quanto à sua audiência. Para maior detalhamento sobre o processo de formação do rádio no Brasil. CALABRE, Lia. A era do rádio. Rio de Janeiro: Jorge Zahar Editor, 2004.

${ }^{100}$ Depoimento do cantore compositor Gilberto Gil ao Museu da Imagem e do Som do Rio de Janeiro para a série "Depoimentos para a Posteridade", realizado em 6 de junho de 2012.

${ }^{101}$ ANTENORE, Armando. Eu não existiria sem Gonzagão. Revista Bravo!, São Paulo, Ed. Abril, dez. 2012, p.30.

${ }^{102}$ Para ficar apenas com alguns exemplos de alguns álbuns: Refazenda (Warner Music, 1976), Dia Dorim Noite Neon (Warner Music, 1985) ou no documentário Viva São João! (2003). 
Em 1968, questionado sobre os fatos essenciais para sua evolução musical, Gil respondeu:

\begin{abstract}
O primeiro fenômeno musical que deixou um lastro muito grande em mim foi Luís Gonzaga. Em grande parte pela intimidade que a música de Luiz Gonzaga teve comigo. Eu fui criado no interior do sertão da Bahia, naquele tipo de cultura e de ambiente que forneceu todo o material para o trabalho dele em relação à música nordestina. Uma outra coisa bacana no Luís Gonzaga - e a consciência disso realmente só veio depois, quando eu já especulava em torno dos problemas da MPB - foi o reconhecimento de que Luiz Gonzaga foi também, possivelmente, a primeira grande coisa significativa do ponto de vista da cultura de massa no Brasil. ${ }^{103}$
\end{abstract}

No ano de 1989, em motivo do falecimento de Luiz Gonzaga, Gil dá o seguinte depoimento:

Luiz Gonzaga iluminava a minha vida, do mandacaru ao pé de serra. Eu era menino, vivia no sertão, na caatinga, numa pequena cidade do interior da Bahia. Gonzaga refletia a nossa cara. Vinha com uma temática que até nos envaidecia, porque falava de nossa vida. Da vida no mundo rural do sertão brasileiro. E a gente ficava vaidoso porque nossa vida era tocada no rádio. Ele interpretava o homem sertanejo. A vida Severina. O humor característico do homem do sertão. Era um misto de crítica, felicidade e nostalgia. Fazia uma certa crítica da cidade, celebrava a alegria interiorana e falava de uma certa nostalgia do mundo sertanejo. Podia ser melancólico em "Vozes da seca" e bem-humorado em "Baião de dois". E ele soava com essa alegria porque era cioso do seu pioneirismo em desbravar a cidade com o sertão. Descre via o imbuzeiro, o romeiro, o tropeiro, o retirante, o boiadeiro, a função da feira na vida social sertaneja, o gado, etc. ${ }^{104}$

Tanto na rememoração de 1968, quanto na de 1989, separadas temporalmente por mais de duas décadas, a identificação de Gil com o sanfoneiro Gonzaga é descrita quase que da mesma maneira, embora a segunda seja mais detalhada, mais pormenorizada. Mas a ideia que permeia as duas é semelhante: a representação da vida sertaneja, do mundo rural, do aprendizado em desbravar a cidade com a força de uma nostalgia catingueira.

\footnotetext{
${ }^{103}$ CAMPOS, Augusto de. Conversa com Gilberto Gil. Entrevista realizada em 6 abr. 1968. In: Balanço da Bossa e Outras Bossas. $4^{\circ}$ ed. São Paulo: Perspectiva, 1986, p. 191.

${ }^{104}$ RISÉRIO, Antônio. O solo da sanfona: contextos do rei do baião. Revista USP, n. 35, São Paulo, 1990, p. 35 .
} 
A cultura nordestina é celebrada, exaltando-se o orgulho e a alegria; todo o seu ambiente fornecendo material para o trabalho musical de Gonzaga.

Outra fonte que nos indica a forte identificação de Gil com Gonzaga é o documentário Viva São João!, produzido em 2001 e lançado em 2003. Gil é coapresentador, junto com Chiquinha Gonzaga, a irmã de Luiz. O documentário mostra toda uma ambiência festiva, com bandeiras, música, comidas e bebidas, com imagens da procissão de Santo Antônio (Barbalha, CE), da Novena de São João (Exu, PE), da Festa de São João (Junco do Salitre, BA). Quem dita o motivo destas festas de São João é o lavrador Seu Toti.

Toda colheita só sai no mês de São João, que é um tempo bom e "ispiciá". É o melhor tempo pra se fazer a colheita e a plantação, a gente planta no mês de março, no dia 19 de março pra tirar agora na fogueira pro São João. O milho e o feijão, tudo isso, o melhor quadro é no dia 19 de março. A alegria da gente é um tempo desse, é a fartura, a verdura, se não tiver nada do milho, não tem amendoim, não tem laranja, então não tem alegria pra São João. É o tempo melhor que nós temos no mundo é tempo de São João. Se o tempo todo fosse assim a gente andava bem alegre e pegava muito mais dinheiro. ${ }^{105}$

A festa é o fio condutor dessa narração, realizada por motivo das colheitas, tempo de fartura, de ganhar dinheiro e comemorar. É a hora de agradecer à natureza e à interseção dos santos por providenciar a fartura dos alimentos. ${ }^{106}$ De acordo com Gil, o São João é "Festa integradora, com esse relacionamento profundo do homem com a natureza, essa gratidão profunda, pela colheita, pela safra, pelo alimento, pela provisão das coisas que ele necessita."107

O documentário não explora a seca geralmente associada ao sertão, mas sua riqueza, riqueza compreendida através da colheita, de sua comemoração, de sua musicalidade. Gil não é apenas o mediador que apresenta o documentário, mas alguém que está inserido naquele contexto e dele se apropria, que se faz notar em sua performance

\footnotetext{
${ }^{105}$ DVD Viva São João! Direção: Andrucha Waddington. Produção: Gege Produções. Roteiro: Emílio Domingos e Andrucha Waddington. Rio de Janeiro: Conspiração Filmes, 2001.

${ }^{106}$ GAMA, Valeska Barreto. "Louvado seja!": representações do sagrado nas canções de Luiz Gonzaga. Dis sertação (Mestrado em História) - Universidade de Brasília, Brasília, 2012.

${ }^{107}$ DVD Viva São João! Direção: Andrucha Waddington. Produção: Gege Produções. Roteiro: Emílio Domingos e Andrucha Waddington. Rio de Janeiro: Conspiração Filmes, 2001.
} 
e também em sua musicalidade, realizando suas traduções. Sobre as músicas juninas no

Brasil e o papel de Luiz Gonzaga nessa popularização, Gil comenta:

Uma das contribuições extraordinárias de Gonzaga foi ele pegar essa coisa popular, daqui que de outra forma não sairia nunca, ficaria aqui no folclore e levou pro pop, pro popular, popularizou, levou para a canção popular. E foi uma coisa que deu partida pra vários aproveitamentos, de várias outras manifestações folclóricas de outras regiões também. ${ }^{108}$

A ligação de Gil com o seu primeiro grande ídolo também está conectada, em parte, pelo fato de Luiz Gonzaga ter sido um grande articulador, por meio de canções que falavam e tocavam coisas do Nordeste, mas ainda mais importante foi Gonzaga ter aproveitado e desbravado com maestria o espaço de divulgação e de popularização da música popular brasileira. Seguem abaixo algumas passagens de uma entrevista, onde Gil reitera a influência de Luiz Gonzaga em sua trajetória:

Devia ter uns quatro ou cinco anos quando descobri Gonzaga pelo rádio... O surgimento de Gonzaga, porém, me tirou do sério. Ele canta como o pessoal de Ituaçu, notei, maravilhado. Ele é o nosso cantor! Virei fã na hora, me identifiquei de imediato com aquela voz, aquele palavreado, aqueles ritmos. Gonzaga acabou se transformando em me u prime iro ídolo. Eu me esforçava para acompanhar a carreira dele (...) Um dia, já em Salvador, consegui avistá-lo de perto. Eu rondava os dez anos... Ele fazia uma turnê, patrocinada pelo colírio Moura Brasil, que cruzava o país inteiro. Observá-lo em cena me deixou enlouquecido. Aquilo parecia uma epifania. Fiquei com a impressão de que Gonzaga descera dos céus para pousar bem ali, diante de nós. Um negócio extraordinário! Era como uma planta. Era agreste, né? Inculto e belo... Uma força bruta. Misturava-se naturalmente à terra. Pertencia de maneira orgânica àquele universo árido que retratou. Não dispunha do afastamento crítico que os novos cantores preconizavam. ${ }^{109}$

Gonzaga encantava Gil não só por representar a sua infância no sertão, mas também por ser um grande representante da crescente indústria fonográfica brasileira. $\mathrm{O}$ fato de ter sido Gonzaga o primeiro ídolo de Gil não está conectado à ideia de autenticidade ou de uma pureza nordestina, mas é uma identific ação que se processa no rastro das mestiçagens, já que Gonzaga além de cantar como o pessoal de

\footnotetext{
${ }^{108}$ DVD Viva São João! Direção: Andrucha Waddington. Produção: Gege Produções. Roteiro: Emílio Domingos e Andrucha Waddington. Rio de Janeiro: Conspiração Filmes, 2001.

${ }^{109}$ ANTENORE, Armando. Eu não existiria sem Gonzagão, op. cit., pp. 30-33.
} 
Ituaçu, desenvolveu um espaço para a produção, representação e difusão ampla da cultura nordestina, e esse "sertão de memórias", guardado no "matulão" de Gonzaga, em contato com as novas experiências de sobrevivência na cidade grande, metamorfoseou-se em um repertório que não pode ser identificado somente com uma tradição nordestina, mas como algo dinâmico e conectado com a modernidade. Gonzaga inseriu-se numa trama que mesclou diversos elementos em sua composição musical, conectando símbolos e sonoridades nordestinas à sua popularidade nas mídias do período e essa atuação dinâmica e tradutória encantou Gil quando menino e continuou a encantar Gil ao longo de toda sua trajetória.

Refletindo acerca de questões que tematizam os hibridismos dessa cultura nordestina, na tentativa por ultrapassara busca por uma pureza sertaneja, encontramos uma importante divagação do próprio artista Luiz Gonzaga, que assim se referiu a Dominguinhos:

Quem urbanizou mesmo a música que eu criei foi Dominguinhos, êmulo meu, que se mantém fiel ao Nordeste. Eu vim com a linguagem do sertão, com uma mensagem autêntica do nortista para a cidade grande. Dominguinhos veio com uma técnica muito avançada, com harmonias modernas, coisas que não amarram o público simples. Dominguinhos urbanizou o forró, levou-o para todas as classes, nos grandes centros urbanos, que é onde ele se apresenta. ${ }^{110}$

De acordo com Gonzaga, foi Dominguinhos quem modernizou sua música, urbanizando o forró com uma harmonização moderna, chegando mesmo a conquistar novos públicos. Vale aqui informar que foi com Dominguinhos que Gil excursionou pelo interior do país e com quem gravou Refazenda, em 1975. Assim, Gil estava entre aqueles que modernizaram a música do Rei do Baião. Carregou os traços das culturas, das tradições, das linguagens e das histórias particulares pelas quais foi marcado ainda em Ituaçu, mas não unificadas no velho sentido, porque essas reinterpretações são, irrevogavelmente, o produto de várias histórias e culturas interconectadas: são traduzidas por códigos que os artistas vão adquirindo e reinventando ao longo de sua trajetória. Músicos e outros artistas integram, em sua bagagem de memória, tanto padrões musicais globalizados quanto aquelas matrizes oriundas de suas vivências culturais da infância.

\footnotetext{
${ }^{110}$ Luiz Gonzaga Apud DREYFUS, Dominique. Vida do Viajante: A Saga de Luiz Gonzaga. $3^{\mathrm{a}}$ ed. São Paulo: Ed. 34, 1996, p. 273.
} 
Isso lhes confere a condição de tradutores, mas também de mestiços, ao realizarem uma série de hibridações, representando aquela categoria de indivíduos que transitam, com desenvoltura, no âmbito da transculturalidade.

Ao questionar a "invenção" do Nordeste, Durval Muniz de Albuquerque analisa sua institucionalização enquanto espaço de tradição e de saudade que se faz ver através dos discursos sociológico ou literário. Também a pintura e a música participam dessa visibilidade, contribuindo para a formação de um arquivo de imagens-símbolos da região. Ao Nordeste é atribuído um espaço de saudade, tanto para aqueles que viram sua vida declinar, quanto para os que foram obrigados a migrar para São Paulo e Rio de Janeiro em busca de trabalho. Espaços onde a migração foi sentida enquanto liberdade, e o sul "tornava-se, principalmente a partir da década de 40, a miragem de uma vida melhor para estes homens pobres, já que o processo de decadência da economia nordestina só se acentuava". 111

De acordo com Albuquerque, a música faz sucesso porque faz menção a elementos de sensibilidade pré-existentes, como por exemplo, saudades do lugar de origem ou enfrentamento das dificuldades urbanas. E o sucesso de Luiz Gonzaga se deu em grande medida entre os migrantes, por solidificar uma identidade regional: nordestinos em transmutação nas grandes cidades. Sobre Gonzaga, o autor afirma:

É na década de quarenta que surge Luiz Gonzaga, como o criador da "música nordestina", notadamente do baião (...) Nascido na fazenda Caiçara, município de Exu, Pernambuco, em 1912, Gonzaga era filho de camponeses pobres, Januário seu pai era sanfoneiro (...) Em 1943 assume a identidade de um artista regional, ser um representante do "Nordeste", criando para isso uma indumentária típica que reunia a roupa do vaqueiro nordestino com o chapéu usado pelos cangaceiros (...) A música de Gonzaga é dirigida, principalmente, ao migrante nordestino radicado no Sul do país, e ao público das capitais do país que podiam consumir discos (...) É necessário chamar a atenção, no entanto, para o fato de que, não sendo o letrista de suas próprias composições, embora delas participasse, mas sendo parceiro de vários letristas, seu trabalho não apresenta uma unidade de pontos de vista, notadamente no que tange a uma postura política. A música de Gonzaga vai ser pensada como a representante desta identidade regional, dará a esse recorte uma sonoridade que ainda não possuía, ao realizar um trabalho de recriação comercial de uma série de sons, ritmos e temas folclóricos dessa área do país.

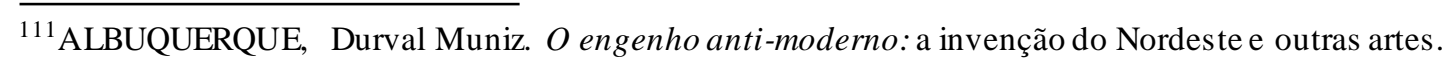
Campinas: Unicamp (tese de doutoramento), 1994, p. 214. 
(...) O baião será a "música do Nordeste”, por ser a primeira que fala e canta em nome dessa região (...) Luiz Gonzaga se tornou aquele artista capaz de entender a necessidade do migrante, de escutar coisas familiares, sons que lembravam sua terra, sua infância, sons que o levavam até este espaço da saudade em meio a toda polifonia do meio urbano. O sucesso de Luiz Gonzaga foi fruto, por um lado, de um código de gosto que valorizava as músicas dançantes, as de nature za lúdica e, por outro lado, atende ao consumo crescente de signos nordestinos e regionais como signos da nacionalidade. ${ }^{112}$ [grifos meus]

Albuquerque comenta ainda que nas músicas de Gonzaga o sertão é lugar de pureza, local onde ainda se brinca de roda, onde se comemora o São João, lugar idílico onde homem e natureza não se separaram, um lugar simples, mas de grande personalidade cultural. Características essas que estão claramente reiteradas pela visão do artista Gil no documentário Viva São João!.

A longa exploração da identificação de Gil com Gonzaga nos oferece pistas para refletirmos sobre as africanidades na trajetória de Gil, mostrando que nesse momento ela é marcada pela ausência. Não há nos relatos de Gil nenhuma rememoração clara de conexão com a África referente a esse período vivido em Salvador, já que a primeira e grande identificação musical de Gil se conecta a Gonzaga e na escolha pelo acordeom e, portanto, fortemente demarcada pelo imaginário do sertão.

A ligação de Gil com Luiz Gonzaga se faz notar novamente em 1986, na canção "Treze de dezembro", música de Luiz Gonzaga e letra composta por Gil, em referência ao aniversário de Gonzaga:

Bem que essa noite eu vi gente chegando

Eu vi sapo saltitando ao longe

Ouvi o ronco alegre do trovão

Alguma coisa forte pra valer

Estava pra acontecer na região

Quando o galo cantou

Que o dia raiou

Eu imaginei

É que hoje é treze de dezembro

O nosso rei do baião

${ }^{112}$ ALBUQUERQUE, Durval Muniz. O engenho anti-moderno, op. cit,,pp. 216-219. 
A maior voz do sertão

Filho do sonho de dom Sebastião

Como fruto do matrimônio do cometa Januário

Com a estrela Sant'Ana

Ao romper da Era do Aquário

No cenário rico das terras de Exu

O mensageiro nu dos orixás

É desse treze de dezembro que eu me lembrarei

E sei que não esquecerei jamais ${ }^{113}$

$\mathrm{Na}$ letra composta para homenagear o rei do baião fica perceptível a força da natureza. No vaivém dessas lembranças e vivências aclamando Gonzaga está o sentido da infância, da cultura popular do sertão, da rítmica do baião. Em terras de Exu/o mensageiro nu dos Orixás, a africanidade atrelada à Gonzaga que não passou despercebida por Gil, ao demarcar o poder da terra e da espiritualidade; mas aparecem aí também símbolos católicos, como o mito português de dom Sebastião, e a astrologia, num amálgama de diversas referências culturais. Tanto o Nordeste quanto a África são nessa canção abordados por Gil através da festa e da natureza, e não através de dicotomias como centro/periferia, rural/urbano, tradição/modernidade. São práticas e elaborações condicionadas e confeccionadas sentimentalmente através de um processo de negociações de diferenças, possíveis negociações pelo ritmo, questionando os mistérios do sertão, de um tempo bem mais circular do que sucessivo, assim como o da natureza.

Acredito ser proveitoso me deter em compreender a ligação com a identidade sertaneja, dentre as inúmeras identidades do artista Gilberto Gil, por acreditar que essa participa da formação musical do artista nesse momento de suas primeiras edificações identitárias. Tanto o sertão quanto as africanidades são representações históricas, não preexistem às realidades sociais e ao mecanismo do discurso. Elas foram elaboradas em um longo processo de traduções, apropriações, identificações, sempre processadas através de escolhas nem sempre conscientes. E, ao afirmar que representações são inventadas, estou negando uma noção essencialista, que busca uma origem pura, um tempo primeiro,

\footnotetext{
113“Treze de dezembro" (Gilberto Gil, 1986). RENNÓ, Carlos (org.) Gilberto Gil todas as letras. São Paulo: Companhia das Letras, 1996, p. 318.
} 
para abordar então essas construções como complexas séries culturais em diálogo com as temporalidades nas quais estão inseridas.

Sobre os primeiros conjuntos musicais que integrou e suas experiências musicais com o acordeom, Gil contou ao MIS-RJ:

Isso foi na escola! Nos Maristas! Os Maristas tinham muitas atividades: esportes, futebol, vôlei, basquete, corridas, mas também tinham atividades culturais. Eles tinham uma biblioteca interessante, franqueada aos alunos, e tinha um conjunto chamado "O Bando Alegre" que era um conjunto formado por alunos da escola, alunos de vários cursos, de várias séries, que juntavam pra tocar nas ocasiões festivas do colégio. Eles vinham, tocavam, cantavam e, como eu estava tocando aos onze, doze anos, ali, já tocando acordeom, me chamaram pra fazer parte d'“O Bando Alegre". Então eu passei a fazer parte d' "O Bando Alegre" tocando acordeom. Nos finais de ano, todos os finais de ano, eles faziam concursos musicais. Programa de calouros com os alunos, onde os alunos vinham cantar. Eu me lembro bem que no primeiro concurso que eu participei, não foi o último porque eu cheguei a participar de um outro depois, mas no primeiro concurso que eu participei eu fui cantar com o "O Bando Alegre", com a turma que me acompanhava, e u fui cantar um samba que era uma criação importante do Jorge Veiga naquela época (...) Os meninos do bairro de Santo Antônio formam um grupo pra tocar em festinhas e bailes. Me chamaram pra fazer parte desse grupo, pra eu tocar acordeom, mas já tinha um outro menino, o Everton, que também era acordeonista. Eles me pe dem pra sair do acorde om e ir para o vibrafone, então eu vou tocar vibrafone nesse conjunto. $E$ a gente, por causa da Bossa Nova, resolvemos denominar de Os Desafinados. ${ }^{114}$ [grifos meus]

Sobre o repertório e a formação dos Desafinados, Gil conta "éramos um baterista e dois acordeonistas. A gente tocava para a elite, em aniversários e bailes (...) tocávamos Standards norte-americanos e cubanos." 115

De acordo com Zappa, quando Gil tinha seus 15 anos, foi convidado pelo amigo Hamilton para gravar um jingle na rádio, tocando seu acordeom. Nessa gravação, acabou conhecendo Jorge Santos. Demarcou-se assim um importante encontro, a partir do qual Gil passou a se relacionar profissionalmente com o mundo da música. Zappa conta ainda

\footnotetext{
${ }^{114}$ Depoimento do cantor e compositor Gilberto Gil ao Museu da Imagem e do Som do Rio de Janeiro para a série "Depoimentos para a Posteridade", realizado em 6 de junho de 2012.

115 ANTENORE, Armando. Eu não existiria sem Gonzagão, op. cit.
} 
que, nos primeiros anos da década de 1960, Jorge Santos, além de dono de estúdio de gravação e agência de publicidade, criou também um programa de televisão na TV Itapuã, que ia ao ar aos sábados. Era um programa de variedades, com sorteios de eletrodomésticos como liquidificadores e batedeiras, e show de calouros, e Gil o frequentava bastante, além dos trabalhos realizados nos outros empreendimentos de Santos. A convite de Jorge Santos, Gil gravaria em 1963 seu primeiro disco autoral, com cinco músicas suas, duas de Everaldo e uma de Silvan Neto e Jorge Santos.

Gil grava e lança, em 1963, pela JS Discos, seu disco de estreia, Gilberto Gil sua música, sua interpretação, um compacto duplo (EP) com quatro músicas suas: "Serenata de teleco-teco", "Maria Tristeza", "Vontade de amar" e "Meu luar, minhas canções". ${ }^{116}$ Sobre essas primeiras gravações, a canção "Maria Tristeza" é a única que se enquadra naquilo que podemos chamar de uma música engajada; as outras canções tematizam romanticamente o amor. As composições estão arranjadas num samba mais influenciado pelo jazz da bossa nova do que pelo samba de roda ou das escolas de samba. Há orquestração com metais na maior parte das músicas, e o acompanhamento percussivo ocorre sem destaque.

A escolha do primeiro instrumento tocado por Gil - o acordeom - pode muito bem ser interpretado como uma afiliação ao segmento dos sanfoneiros, representados especialmente para o imaginário de Gil por Luiz Gonzaga, e a troca do acordeom pelo violão representa a afiliação de Gil à bossa nova. Sobre a mudança do acordeom para o violão, Gil contou ao MIS-RJ:

Eu já estava com 17, 17 pra 18. Antes de entrar na universidade. Em seguida entrei na universidade. Todas essas coisas aconteceram na passagem da adolescência pra idade adulta. Quando eu termino o ginásio, vou fazer a faculdade, termino o curso de acordeom, vou começar a tocar violão, saio d'“O Bando Alegre", do colégio Marista, formo "Os Desafinados", no bairro de Santo Antônio... Passo a frequentar o estúdio de Jorge Santos a convite dele pra fazer gravações de jingles, passo a fazer jingles também. É a primeira forma de composição, propriamente, são os jingles que começo a fazer pra produtos variados de Salvador. ${ }^{117}$

\footnotetext{
116 <www.gilbertogil.com.br>. Acesso em 14 mar. 2015.

${ }^{117}$ Depoimento do cantor e compositor Gilberto Gil ao Museu da Imagem e do Som do Rio de Janeiro para a série "Depoimentos para a Posteridade", realizado em 6 de junho de 2012.
} 
Quando Gil tinha 17 anos, oito dos quais morando em Salvador, pelos idos de 1959, a cidade vivenciava uma grande efervescência cultural. Agitação que teve como idealizador o reitor Edgard Santos, da Universidade Federal da Bahia, que entre 1946 e 1962investiu no avanço cultural da UFBA e da cidade, instituindo escolas de dança, música e teatro na instituição. A partir do final da década de 1940, Edgard Santos, juntamente com Clemente Mariani e Rômulo de Almeida, criaram uma organização nãogovernamental voltada para o desenvolvimento e modernização da Bahia. Da mesma forma como ocorria num âmbito nacional no período de democratização e industrialização, vanguardismo estético etc. - a Bahia também ensaiava sua própria modernização. A proposta de Edgard Santos estava intimamente relacionada com o que ocorria no cenário nacional em termos culturais: o vanguardismo estético em uma sociedade que se desenvolvia. ${ }^{118}$

Antônio Risério chama atenção para essa modernidade estético-intelectual em terras baianas. Segundo o autor, esta produção não se resumiu à atuação da dupla Lina Bo Bardi, com seu olhar antropológico do ambiente, e Koellreutter no âmbito musical, mas sim a partir deum contexto mais amplo. Para melhor compreendê-lo, Risério aponta a importância do entrelaçamento das culturas boêmia e universitária, onde prevalecia uma compatibilidade entre a prática acadêmica e o nomadismo criativo da "inteligência notívaga", para utilizar a expressão do autor. Neste sentido, a rua, o bar, a praça enriqueceram o circuito diário dos signos inovadores de vanguarda. ${ }^{119}$

Foi nesse espírito da Universidade como "geradora de turbulências culturais" que as estéticas vanguardistas europeias chegaram à Bahia. Durante os anos1950, Edgard levou para Salvador artistas e pensadores de vanguarda, muitos deles ligados às estéticas construtivistas do período. Convidou o maestro alemão Hans Joachim Koellreutter para dirigir a Escola de Música; a coreógrafa e bailarina polonesa Yanka Rudzka, responsável pela primeira Escola de Dança de ensino superior do país; os músicos suíços Anton Walter Smetak e Ernst Widmer; o antropólogo francês Pierre Verger; e o escritor português Agostinho da Silva, expulso de seu país pela ditadura salazarista - criador do Centro de Estudos Afro-Orientais; Martim Gonçalves ficou responsável pela Escola de Teatro; e, para completar, o então governador Juracy Magalhães levou a arquiteta italiana Lina Bo

\footnotetext{
${ }_{118}$ RISÉRIO, Antônio. Uma história da Cidade da Bahia. Rio de Janeiro: Versal, 2004, p. 526.

119 Ibid., p. 529.
} 
Bardi, radicada em São Paulo, para dirigir o Museu de Arte Moderna da Bahia. ${ }^{120}$

Outro aspecto importante é que, apesar de a Bahia ser fortemente demarcada pela cultura popular afro-brasileira, não há recordações da ligação de Gil com quaisquer aspectos dessas práticas culturais. Sua ligação com o Afoxé Filhos de Gandhy só se desenvolveria a partir do seu retorno do exílio, em 1972. Através da análise de inúme ros relatos referentes a essa época é possível afirmar que Gil estava bem mais atrelado ao mundo boêmio e universitário, bem como imerso na sonoridade da bossa nova.

Sobre sua vida acadêmica e a militância estudantil, Gil contou que "Eu não era propriamente alinhado com aquela turma. Eles tinham uma denominação específica para esse tipo de gente: linha auxiliar. Eu tomava conta da escola de samba Unidos do CPC. E dizia claramente: não acredito nessa utopia."121

A longa transcrição a seguir é um relato sobre a época da faculdade e a posição política adotada por Gil naquele momento:

Bom, eu estava lendo $O$ Capital de Marx na alfândega, né? (risos). Você imagina que eu já estava interessado nessa discussão. Essa questão estava posta. Eu vou pra Escola de Administração e conheço Caetano, que estava na Escola de Filosofia. As escolas tinham a União Estadual, a UEB (União dos Estudantes da Bahia). Cada escola tinha um diretório e, ali, era uma vida de estudo, de aprendizado, de aproximação com esses temas: tema social, tema econômico (eu estava estudando numa escola de economia, escola de administração) então eu estava começando a entender como era o mercado. O que era o Estado, todas essas dimensões conflitantes, até certo ponto na vida da sociedade. Eu estava me integrando em tudo isso. Lendo Marx, lendo Adam Smith e, ao mesmo tempo, ouvindo as canções de protestos. A maneira como o Vinícius de Moraes escrevia sobre os pobres desprotegidos. Todas essas coisas já configuravam, pra mim, um mundo de responsabilidade social, de militância. É aí que começa, incidentalmente, uma espécie de militância. Em 1964, quando vem o golpe e eu já inserido nesse mundo de questões das desigualdades $e$ explorações, as questões do negro na sociedade brasileira, já de posse de todas essas novas referências, nos deparamos com o golpe de 1964 e a gente tem que ter uma posição. Pertencendo ao grêmio estudantil da faculdade de Administração e teve, portanto, uma interação permanente com o equivalente na

\footnotetext{
${ }^{120}$ CALADO, Carlos. Tropicália: a história de uma revolução musical. São Paulo: Ed. 34, 1997, pp.3435.

${ }^{121}$ ZAPPA, Regina. Gilberto bem perto, op. cit., p.76.
} 
faculdade de Medicina, na faculdade de Engenharia, de Filosofia, nós criamos, como todo o Brasil criou naquele momento, um movimento estudantil pra resistir ao golpe, de apoio à resistência ao golpe da incumbência do pessoal, do próprio Jango, dos governos estaduais em posições variadas (...)no CPC da Bahia estávamos eu, Tom Zé, Caetano e dávamos certa assistência. Eu e ra incumbido da escola de samba. Eu tomava conta da escola de samba. Chamava-se: Escola de Samba Unidos do CPC. Engraçado, né? (risos) A sede do CPC era em um dos porões da minha escola onde nos reuníamos. Essa sede ficava ao lado da Roça do Lobo que era uma espécie de favela, uma comunidade de baixa renda com gente simples, gente pobre e, como sempre, onde tem gente simples e gente pobre é onde o samba está! (risos). Ali era um dos redutos do samba, em Salvador. Foi de lá que eu trazia os meninos da Roça do Lobo e com eles formamos a escola de samba Unidos do CPC. A Unidos do CPC chegou a desfilar um carnaval. Nós desfilamos muito modestamente. Não tínhamos fantasias, fizemos um traje qualquer, uma indumentária qualquer apropriada pra aquele momento, juntamos os tambores. Eu não me recordo, mas tinha uma canção que Tom Zé, se eu não me engano, chegou a compor e eu também, mas como não gravamos, não registramos, aquilo passou no carnaval e nunca mais. Mas chegamos a ter no CPC da Bahia a Escola de Samba Unidos do CPC, desfilando no carnaval, dirigida pelo "linha auxiliar" Gilberto Gil. ${ }^{122}$ [grifos meus]

Foi através da leitura de Marx e Adam Smith e das canções de protesto de Vinícius de Moraes que emergiram em Gil questionamentos referentes a um mundo de responsabilidade social e de militância. E, aqui, mais um traço de africanidade: Gil a tomar conta de uma escola de samba, a Escola de Samba Unidos do CPC. Gil contou que as reuniões aconteciam perto da favela Roça do Lobo, onde buscava os meninos, e que chegaram até a desfilar modestamente no carnaval. A música que compôs para o bloco, juntamente com Tom Zé, não foi gravada, ${ }^{123} \mathrm{e}$, de acordo com essa rememoração, a Escola de Samba Unidos do CPC não foi algo que teve longa duração na vida de Gil, afinal logo ele estaria fazendo shows.

Caetano Veloso assim descreve seu encontro com Gil pelos idos de 1962 ou 63:

Roberto Santana me apresentou a Gil num encontro casual na rua Chile (eu ia sozinho no sentido Praça Castro Alves - Praça da Sé e eles dois vinham ao meu encontro) e nós todos nos sentimos

\footnotetext{
${ }^{122}$ Depoimento do cantor e compositor Gilberto Gil ao Museu da Imagem e do Som do Rio de Janeiro para a série "Depoimentos para a Posteridade", realizado em 6 de junho de 2012.

${ }^{123}$ Não permitindo aqui um maior aprofundamento sobre a composição.
} 
inteiramente à vontade, cada um querendo falar mais do que o outro. Gil parecia tão feliz de me conhecer quanto eu a ele. Dirse-ia que ele também vinha me vendo em algum vídeo transcendental e esperava por esse encontro tanto quanto eu. Meus elogios à sua técnica e musicalidade logo nos levaram à apreciação dos mestres da bossa nova (principalmente João, Jobim e Carlos Lyra), tema de nossa paixão comum, e a conversa (sem violões) dispensou um teste de minhas capacidades musicais para estimular o interesse de Gil: ele se entusiasmava com observações de ordem geral que esclarecessem o significa do da música - o que não é muito comum em músicos -, de forma que o que eu dizia já valia por uma boa sequência de acordes. Algumas vezes ao longo dos anos, ouvi, comovido, Gil dizer que ao me encontrar se sentiu saindo de uma espécie de solidão: ao me ver e ouvir teve certeza de que achara verdadeira companhia. ${ }^{124}$

O encontro reuniu dois amigos que tinham na bossa nova sua grande paixão. Pouco tempo depois desse encontro, em 1964, Gil, Caetano, Bethânia e Gal inaugurariam o Teatro Vila Velha em Salvador com o show Nós, por exemplo; posteriormente fariam um show chamado Nova bossa velha, velha bossa nova e $O$ Inventário, show individual de Gil com direção de Caetano.

Sobre esses espetáculos realizados na primeira metade da década de 1960 em Salvador, o Nós, por exemplo, Caetano conta que tinham a intenção de renovar a música popular brasileira a partir da perspectiva da bossa nova, numa relação de continuidade, não de ruptura. Além de Caetano, Gil, Bethânia e Gal, o grupo era composto por Fernando Lona, Djalma Correia e Alcyvando Luz. O repertório era composto por canções anteriores àquele momento, abrangendo composições de Dorival Caymmi, Noel Rosa, Vinícius de Moraes, Sérgio Ricardo, Zé Kéti e Carlos Lyra. ${ }^{125}$ As duas músicas de Gil presentes no espetáculo são "Maria Tristeza" e "Samba Moleque". ${ }^{126}$ A primeira apresenta uma forte ligação com a bossa nova engajada e nacionalista por tratar de questões como fome e miséria.

Sobre esse espetáculo, realizado em 1964, Gil disse:

Conhecemos Caetano, Bethânia, Gal, Tom Zé... Começamos a conviver ali... Trocamos figurinhas... Isso e aquilo... Interesses em comum... Todos apaixonados por João Gilberto... Ficamos

\footnotetext{
${ }^{124}$ VELOSO, Caetano. Verdade tropical. São Paulo: Cia. das Letras, 1997, p. 285.

${ }^{125}$ CALADO, Carlos. Tropicália: a his tória de uma revolução musical. São Paulo: Ed. 34, 1997, p. 53.

${ }^{126}$ Não existe menção a essa música nem no site oficial de Gil e nem no livro RENNÓ, Carlos (org.).

Gilberto Gil: todas as letras. São Paulo: Companhia das Letras, 1996.
} 
apaixonados pela Bossa Nova... Vai-se, então, inaugurar o Teatro Vila Velha, em 1964. O grupo desse teatro que... Um grupo de teatro com Othon Bastos, João Augusto, que era o diretor, Martha Overbeck, Carlos Petrovick. Todos eles formavam esse grupo e construíram um teatro. Construíram esse teatro, em Salvador, e fizeram uma semana de inauguração com várias manifestações: teatro, dança, música clássica... E queriam um show de música popular. João Augusto e outros desses construtores do grupo já conheciam Bethânia, porque Bethânia era muito interessada em teatro, frequentava muito a escola de teatro do Canela. Caetano, também, conhecia por causa de Álvaro Guimarães. Já tinham feito... Não lembro agora exatamente, o nome de uma peça que Alvim já havia montado para qual Caetano havia feito músicas. Já havia, então, esse conhecimento. João Augusto pede a essas pessoas que inventem um show de música popular. Eles, então, sabedores da nossa existência, vão a Bethânia, vão a Caetano, pedem pra juntar a turma pra fazer aquilo que a gente já estava fazendo nas casas, nas casas dos amigos, que fizéssemos aquilo no teatro. Então chamaramo Roberto Santana. Era um ator ligado a todos eles, muito ligado a Caetano, muito ligado ao pessoal de música. Junta o pessoal... Caetano, como sempre, toma a frente das coisas: escreve, imagina, conceitua o que vai ser aquela apresentação. Então nós fomos lá: eu, Caetano, Bethânia, Gal, Tom Zé... Vamos fazer esse show na semana de inauguração do Teatro Vila Velha. E foi, ali, que fomos lançados pra cidade, em Salvador, aí surgiu logo aquele burburinho: "Ah! Os meninos..."127

Há aqui um indício, referente a essa situação, que nos permite problematizar o universo das africanidades acessado por Gil nesse momento. Juntamente com um dos integrantes do grupo de Teatro Vila Velha, Othon Bastos, Gil compôs a música 'Iemanjá' em 1964. A música faz parte da coletânea das letras de Gil organizada por Carlos Rennó, mas não foi gravada em nenhum dos LPs de Gil e nem fez parte do repertório do espetáculo Nós, por exemplo. Foi possível ter acesso a um áudio dessa canção pelo Youtube $^{128}$ sem, no entanto, ter acesso a data da gravação. O arranjo é nitidamente bossa novista e a letra, escrita por Othon, dimensiona a temática nacional- popular como fica perceptível na letra a seguir:

Mulher tá na praia, homem tá no mar

Mulher tá rezando pro homem voltar

Mané foi pra pesca pescar pra viver

Peixe bom pra comida

\footnotetext{
${ }^{127}$ Depoimento do cantor e compositor Gilberto Gil ao Museu da Imagem e do Som do Rio de Janeiro para a série "Depoimentos para a Posteridade", realizado em 6 de junho de 2012.

$128<$ https://www.youtube.com/watch?v=itWagdEU1Ng> Acesso em 19 mar. 2015.
} 


$$
\begin{aligned}
& \text { Peixe bom pra vender } \\
& \text { Iemanjá - só se vê mar } \\
& \text { Iemanjá - só se vê mar }
\end{aligned}
$$

Mulher tá rezando, já passou da hora

Mulher tá chorando, meu deus, que demora

Iemanjá tá querendo ficar com Mané

Iemanjá é rainha

É bonita, é mulher

Iemanjá - só se vê mar
Iemanjá - só se vê mar

Não foi desta vez, desta vez não será

Lá vem a jangada chegando do mar

Trouxe pouca pesca, mas Mané voltou

Salve Nossa Senhora

Salve Nosso Senhor

$$
\begin{aligned}
& \text { Iemanjá - só se vê mar } \\
& \text { Iemanjá - só se vê mar }{ }^{129}
\end{aligned}
$$

A letra faz referência ao "popular" através da reza da esposa pelo retorno do pescador que se lança ao mar para vencer as dificuldades de sobrevivência e faz citação ao sincretismo religioso do catolicismo com o candomblé. A mensagem dessa canção está conectada ao ideário do nacional-popular dos artistas de esquerda, participantes da arte engajada, filiados aos CPCs, intencionando conscientizar os ouvintes sobre a situação política do país num momento pós-golpe militar. O pescador é idealizado por sua coragem e modelo a ser seguido, em que o trabalhador tem que ter coragem de enfrentar a situação, que nesse caso é também uma alusão à política. Lançar-se ao mar é uma metáfora para todos aqueles que têm atitudes a tomar.

O segundo espetáculo do grupo chamou-se Nova bossa velha, velha bossa nova e sobre ele, Caetano conta que

\footnotetext{
129 “Iemanjá" (Letra de Othon Bastos/ Música de Gilberto Gil, 1964). RENNÓ, Carlos. Gilberto Gil: todas as letras. São Paulo: Companhia das Letras, 1996, p. 58.
} 
Diferentemente do Opinião, nossos espetáculos pretendiam, além de fazer referências às questões políticas e sociais, criar uma perspectiva histórica que nos situasse no desenvolvimento da música popular brasileira. Os títulos dizem muito: Nós, por exemplo, o primeiro, era um concerto de apresentação de jovens músicos quase todos absolutamente desconhecidos - o "por exemplo" queria dizer não que nós éramos um modelo a ser seguido, um exemplo, mas que tínhamos certeza de que havia muitos outros, toda uma geração a que nós, "por exemplo", pertencíamos, e que devia sua existência ao aparecimento da bossa nova $(\ldots)^{130}$

Tanto na citação de Gil quanto na de Caetano fica clara a intenção dos amigos de reverenciar a bossa nova, e em especial João Gilberto. Demonstram também o papel catalisador de Caetano, aquele que organiza, e também o fato de desejarem nada menos que realizar "uma perspectiva histórica que nos situasse no desenvolvimento da música popular brasileira".

Quem nos informa sobre essa perspectiva do espetáculo Novabossa velhaé Carlos Calado:

Tỉnha um caráter assumidamente didático e histórico. Era um espetáculo que buscava não apenas divulgar o sentido e a estética musical da bossa nova, mas também refletir sobre ela. Caetano, Gil e seus parceiros baianos considerava m-se descendentes diretos da bossa e, com esse espetáculo, pretendiam inscrever-se numa perspectiva de renovação da música popular brasileira. ${ }^{131}$

O Inventário, o primeiro show individual de Gil, foi dirigido por Caetano e foi onde apresentou "Eu vim da Bahia". Ao se formar, Gil recusou um convite para fazer pós-graduação nos EUA e aceitou trabalhar na Gessy Lever, em São Paulo. Os irmãos Veloso se mudaram para a capital paulista para que Bethânia substituísse Nara Leão no espetáculo Opinião e sobre esse fato Gil disse: "no fundo, eu queria era continuar com a música e com a amizade. E foi isso que me levou, aos poucos, a abandonar a ideia de me tornar um executivo."132

Salvador é o espaço que demarca o início da formação musical de Gil, do aprendizado de acordeom e posteriormente sua substituição pelo violão aos primeiros passos da profissionalização musical; da gravação de jingles à realização de espetáculos

\footnotetext{
130 VELOSO, Caetano. Verdade tropical, op. cit., p. 78.

${ }^{131}$ CALADO, Carlos. Tropicália, op. cit., p. 54.

${ }^{132}$ ZAPPA, Regina. Gilberto bem perto, op. cit., p.81.
} 
musicais, já se delineia também a adesão a uma militância política via música popular brasileira, que se desdobraria e aprofundaria em São Paulo por meio de sua participação nos festivais e no tropicalismo, além de ter sido também período de formação intelectual e do primeiro casamento. ${ }^{133}$ Os traços de africanidades aparecem levemente delineados na direção da escola de samba do CPC, mas não demarca ainda com clareza uma adesão à conscientização de uma negritude militante e nem mesmo musical. Suas letras nessa época estavam bastante atreladas aos ideais dos CPCs e à sonoridade de suas músicas conectada à bossa nova.

\section{- São Paulo}

Levando em consideração que o repertório musical de Gil até 1965 consiste em canções de cunho quase que exclusivamente amoroso, e a quase total ausência referente a traços de africanidades, abordarei nessa passagem, principalmente, possíveis vestígios de africanidades nas experiências vivenciadas em São Paulo, através do LP Louvação, assim como a participação de Gil nos festivais e posteriormente na Tropicália.

O Brasil teve, na produção musical dos anos 1960 e início dos 1970, um papel decisivo na construção de novas identidades nacionais, que a partir deste momento passaram a ser marcadas pela articulação do "próprio" e do "alheio". A música tornou- se um meio para discutir questões ideológicas e que representassem o país. Os artistas posteriormente identificados como criadores da MPB, a partir dos anos 1960 auxiliaram a criação de um novo tipo de relação identitária, marcada pela identificação com símbolos e elementos nacionais, sobretudo quando a parcela mais jovem da população passou a ser sua maior receptora, nos auditórios e pela televisão. Assim, podemos pensar na música enquanto uma das possíveis leituras da sociedade em questão e, em especial, através da trajetória artística de Gilberto Gil, seus posicionamentos, escolhas, migrações, dos processos musicais de hibridação dos quais participou, e assim passar a melhor compreender as maneiras como a África foi sendo apropriada e inventada ao longo dessa trajetória.

É interessante notar que grande parte dos sujeitos citados ao longo desta análise, bem como os locais destinados à execução musical, estão de alguma maneira todos ligados ao eixo Rio-São Paulo, fato este que fez com que Gil tivesse que se mudar para

${ }^{133}$ Casa-se com Belina Aguiar Gil Moreira em 29 de maio de 1965. 
a capital paulista a fim de encaminhar melhor sua carreira musical. A carreira de Gilberto Gil se consolidou ao mesmo tempo em que se criava no Brasil o conceito de Música Popular Brasileira - MPB. Essa denominação surgiu em meados dos anos 1960, reunindo o que então se considerava representativo da genuína cultura brasileira, no âmbito da música.

No período de ascensão e consolidação da bossa nova, Gil tinha relativo sucesso em Salvador, e, ao chegar a São Paulo, fora aos poucos alcançando seu espaço. Primeiramente, com participações no programa televisivo de Elis Regina, O Fino da Bossa, e nos espetáculos musicais de Augusto Boal; ${ }^{134}$ posteriormente, nos festivais e na elaboração da explosão cultural conhecida como tropicalismo. Pode-se dizer que Gil deu seus primeiros passos profissionalizantes em Salvador, uma vez que o grande centro irradiador de cultura, o eixo Rio/São Paulo, só seria explorado por Gil em meados dos anos 1960 - 1965, mais especificamente -, permitindo ao artista ter um reconhecime nto em âmbito nacional, quando a bossa nova já havia se firmado como gênero musical de extrema importância no cenário musical brasileiro. A bossa nova foi, nesse momento, como em grande parte da trajetória de Gil, não apenas inspiração, mas, como o próprio Gil e Caetano repetiram inúmeras vezes, uma espécie de devoção.

De acordo com Renato Ortiz:

Se os anos 40 e 50 podem ser considerados como momentos de incipiência de uma sociedade de consumo, as décadas de 60 e 70 se definem pela consolidação de um mercado de bens culturais. Existe, é claro, um desenvolvimento diferenciado dos diversos setores ao longo deste período. A televisão se concretiza como veículo de massa em meados dos 60 , enquanto o cinema nacional somente se estrutura como indústria nos anos

70. O mesmo pode ser dito de outras esferas da cultura de massa: indústria do disco, editoria, publicidade, etc. ${ }^{135}$

Para compreendermos a década de 1950 e parte da de 1960, segundo Ortiz, é necessário levarmos em consideração o sentimento de esperança e a profunda convicção de seus participantes de estar vivendo um momento particular da história brasileira. A recorrente utilização do adjetivo "novo" traz todo o espírito daquela época: bossa nova, cinema novo, teatro novo, arquitetura nova, música nova. Ortiz afirma que várias das

\footnotetext{
${ }^{134}$ Arena conta Bahia e Tempos de Guerra.

${ }^{135}$ ORTIZ, Renato. A Moderna Tradição Brasileira: Cultura Brasileira e Indústria Cultural. São Paulo: Brasiliense, 1988, p.113.
} 
produções culturais do período se fizeram em torno de movimentos, e não exclusivame nte no âmbito da esfera privada do artista. Bossa nova, teatro de arena, tropicalismo, CPC da UNE eram tendências que congregavam grupos de produtores culturais animados, se não por uma ideologia de transformação do mundo, pelo menos de esperança por mudança. Neste sentido, de acordo com Ortiz, podemos dizer que cultura e política caminhavam juntas, nas suas realizações e nos seus equívocos. ${ }^{136}$

De acordo com Marcelo Ridenti, as lutas pelas reformas de base no pré-1964, e contra a ditadura após essa data, bem como o florescimento cultural e político na década de 1960, se ligavam a uma série de condições materiais comuns a diversas sociedades em todo o mundo: aumento quantitativo das classes médias; acesso crescente ao ensino superior; peso significativo dos jovens na composição etária da população; cenário crescente de urbanização e consolidação de modos de vida cultural típicos das metrópoles; e tempo de recusa às guerras coloniais e imperialistas. Havia também os avanços tecnológicos, que incorporavam ao cotidiano o uso de eletrodomésticos, especialmente a televisão. No entanto, essas condições materiais não explicam as ondas de rebeldia e revolução, nem as estruturas de sentimento que as acompanharam por toda parte. ${ }^{137}$

Segundo Ridenti, nos anos 1960 e início dos 1970 os meios artísticos e intelectualizados de esquerda questionavam o problema da identidade nacional e política do povo brasileiro, e a busca era por encontrar as raízes desse povo, bem como a ruptura com o subdesenvolvimento. Adotando o conceito de romantismo revolucionário, o autor percebe que esse período foi marcado pela utopia da integração do intelectual com o homem simples do povo brasileiro, supostamente não contaminado pela modernidade capitalista, podendo dar vida a um projeto alternativo de sociedade desenvolvida. Esse tipo de romantismo embasou as artes, as ciências sociais e a política. O período também se caracterizou por procurar no passado uma cultura popular genuína, para construir uma nova nação, antiimperialista, progressista e, no limite, socialista. Ridenti analisa os meios

\footnotetext{
${ }^{136}$ ORTIZ, Renato. A Moderna Tradição Brasileira, op. cit., p. 110.

${ }^{137}$ RIDENTI, Marcelo. Brasilidade revolucionária: um século de cultura e política. São Paulo: Ed. Unesp, 2010, p. 95.
} 
artísticos e intelectuais de esquerda, que se queriam populares, e não propriamente o povo. ${ }^{138}$

O autor chama atenção também para o fato de haver grupos mais românticos que outros, mas todos respiravam e ajudavam a produzir a atmosfera cultural e política do período, impregnada pelas representações de povo, libertação e identidade nacional - que já vinham de longe na cultura brasileira, mas traziam, especialmente a partir dos anos 1950, a novidade de serem mescladas com influências de esquerda, comunistas ou trabalhistas. O romantismo das esquerdas não era uma simples volta ao passado, mas também modernizador. Buscava-se no passado elementos para a construção da utopia do futuro. Visava-se resgatar um encantamento da vida, uma comunidade inspirada no homem do povo, cuja essência estaria no espírito do camponês e do migrante favelado a trabalhar nas cidades. A volta ao passado seria a inspiração para construir o homem novo. Propunha-se pensar a superação da modernidade capitalista cristalizada nas cidades, e não a mera condenação moral das cidades e a volta ao campo. ${ }^{139}$

O nacional-popular - e consequentemente os questionamentos sobre a realidade desejada para o povo brasileiro - configurou-se como tema presente nos diferentes meios artísticos daquele momento. Reflexões sobre o cenário social e político fizeram-se presentes em canções, peças e filmes.

Gil participou de várias dessas movimentações artísticas que demarcaram a ambiência artística dos anos 1960 no Brasil, transitando por cada uma delas. A bossa nova foi a responsável pelo fato de Gil querer aprender a tocar violão, e também fez parte do repertório executado por ele em seus primeiros espetáculos musicais em Salvador. No teatro de Arena, dirigido por Augusto Boal, Gil foi diretor musical da peça Arena conta Bahia. Fez parte do CPC da UFBA quando ainda cursava Administração e ajudou na elaboração do movimento tropicalista. Assim, a trajetória do artista perpassou muitos desses significativos movimentos artísticos que demarcaram fortemente a arte brasileira da década de 1960, conectados ao ideal nacional-popular.

Num momento em que se discutia a realidade brasileira através de questões como tradição e modernidade, nacional e estrangeiro, Gil é uma importante peça para melhor compreendermos esses pressupostos em debate. Se em 1967 ele saía na passeata contra

\footnotetext{
${ }^{138}$ RIDENTI, Marcelo. Em busca do povo brasileiro: artistas da revolução, do CPC à era da TV. Rio de Janeiro: Record, 2000.

${ }^{139}$ RIDENTI, Marcelo. Em busca do povo brasileiro, op. cit., p. 25.
} 
as guitarras elétricas, nesse mesmo ano participaria com o rock dos Mutantes no III Festival da TV Record. Se em 1965 ele era parte integrante de peças de Boal, marcadas por um forte ideal nacional-popular, em 1967, juntamente com outros tropicalistas, seria agredido pelo próprio Boal, acusado de alienação e fuga desse mesmo ideal. Esses aspectos tão contraditórios desafiam uma análise que intenciona seguir uma linha coerente e lógica na trajetória do artista, e exigem explicações que incluam em sua órbita aspectos como a contradição, demonstrando assim que os sujeitos e os lugares não são determinados. Gil criou suas regras em movimento, num emaranhado de efeitos culturais descontínuos. Minha argumentação é que certas escolhas são arbitrárias, assim como o são as escolhas humanas em inúmeras situações, e que são sempre reavaliadas na prática e dependentes de certas conjunturas e contextos.

\section{- O Fino da bossa e Arena conta Bahia}

Em 1965, Gil foi para São Paulo trabalhar como administrador na Gessy Lever, uma empresa fabricante de sabonetes, pastas de dente, dentre outros produtos. Naquele mesmo ano, recebeu um telefonema de Elis Regina pedindo que ele fosse à sua casa lhe mostrar algumas músicas. ${ }^{140}$ Logo, Gil estaria participando como cantor convidado do programa $O$ fino da bossa.

Assim o Jornal do Brasil definia o programa O fino da bossa em 1967:

Com um excelente repertório, cantando músicas de Vinícius, Carlos Lira, Baden Powell, Ataulfo Alves, Cartola e dos velhos compositores do samba, Elis Regina, enquanto ampliava seu público, obrigava-o a discutir e defender a música brasileira. (...) Houve uma época, em meados de 1965 e começo de 1966, em que se formou, naturalmente, e - depois com uma linha de ação - um movimento Nacional de Música Popular Brasileira. Elis Regina, em São Paulo, e Nara Leão, no Rio de Janeiro, trabalharam sem cessar para divulgação da nossa música, enfrentando um grande adversário, que aqui chegou munido de todas as armas, com uma engrenagem publicitária colossal: o iêiê-iê. ${ }^{141}$

\footnotetext{
${ }^{140}$ ZAPPA, Regina. Gilberto bem perto, op. cit, p.87.

${ }^{141}$ DOIS anos de Bossa com sucesso. Jornal do Brasil, Rio de Janeiro, 28 maio 1967.
} 
Um jornal de amplo alcance e reconhecimento dava a Elis o status, juntamente com Nara, de defensora e divulgadora da música nacional, dimensionando o caráter de disputa entre aqueles que a defendiam ou não. Outro vestígio deixado pelo jornal é o repertório do programa, que contava com sambistas mais tradicionais e com representantes de uma certa modernidade bossa-novista. Em 1974, Elis assim definiu o que teria sido o seu programa:

\begin{abstract}
....aparecia muita gente nova (ou muito antiga) para fazer $O$ fino... Contudo, por mais extenso que fosse, não havia espaço para todos. E, em vez de assumirem a responsabilidade pelos cortes, os responsáveis pelo programa jogavam-na para cima de mim, dizendo que eu não gostava deste ou daquele, que preferia um terceiro. Ora, meu temperamento, de fato, sempre foi explosivo, difícil. Juntavam-se as duas coisas, o boato e a minha personalidade irritadiça, e pronto - nascia a fama. ${ }^{142}$
\end{abstract}

No depoimento da artista, fica claro que o programa contou sempre com a participação de convidados e que não era um espaço para todos. Havia uma seleção dentre aqueles que se enquadrassem na temática do programa, que, a notar pelo seu título, convidava o fino da bossa, estendendo a essa bossa os sambistas mais tradicionais. A ligação de Gil com Elis não se deu apenas no âmbito desse programa; ao longo de sua carreira artística Elis gravaria ainda muitas músicas de Gil, tendo sido inclusive intérprete dos primeiros grandes sucessos de Gil. ${ }^{143}$

Ainda em 1965, Gil também participaria do espetáculo dirigido por Augusto Boal, Arena conta Bahia. Tanto o programa musical de Elis Regina quanto os espetáculos de Boal eram para o ideário nacional-popular. De acordo com Zappa, nesse período o teatro era polo de resistência e protesto, e apostava na dramaturgia nacional e popular. Sobre este espetáculo, a autora conta que

No mesmo ano de Zumbi, 1965, Boal escreveu e dirigiu Arena conta Bahia, com direção musical de Gilberto Gil e Caetano Veloso, com Maria Bethânia e Tom Zé no elenco. O espetáculo

\footnotetext{
${ }^{142}$ LANCELLOTTI, Silvio. Quero apenas cantar. Veja, 1 maio 1974.

${ }^{143}$ Cito a seguir as gravações de Elis de músicas de Gil até o retorno de seu exílio: "Louvação", no LP Dois na Bossa $n^{\circ} 2$ (CBD-Philips, 1966), "Roda" e "Lunik 9", no LP Elis (CBD-Philips, 1966), "Serenata do teleco-teco" em Dois na Bossa n 3 (CBD- Philips, 1967), "Viramundo" no LP Elis Especial (CBD- Philips, 1968), "Aquele abraço" no LP Elis no Teatro da praia com Miéle e Bôscoli (CBD - Philips, 1970), "Fechado pra balanço" no Em pleno verão (CBD - Philips, 1970);"Oriente", "Doente morena", "Meio de campo" e "Ladeira da preguiça", no LP Elis (CBD - Phonogram/Philips, 1973). In: www.discosdobrasil.com.br
} 
foi encenado no Teatro Brasileiro de Comédias, o TBC, em Salvador. Em seguida, com texto de Boal e Guarnieri, o teatro Oficina, fundado por Amir Haddad, José Celso Martinez Corrêa e Carlos Queiroz Telles, mostrou Tempo de Guerra, construído com poemas de Brecht, com Gil, Gal Costa, Tom Zé e Maria Bethânia no elenco. ${ }^{144}$

Sobre a participação dos baianos nesse espetáculo, as rememorações de Caetano fornecem indícios para a reflexão sobre a representação da Bahia realizada por Boal. Seguem trechos memorialísticos do artista que se referem a esse espetáculo:

Para o espetáculo que planejou fazer conosco - cujo título seria Arena conta Bahia-,ele nos encomendou canções especiais, uma seleção de canções já existentes relativas à Bahia e sugestões para um roteiro (...) Boal considerou - com extrema delicadeza - que tendíamos para uma atmosfera demasiado lírica e, abandonando de todo as nossas ideias de enredo, passou a escolher, entre as canções que selecionamos, um repertório que lhe permitisse encenar algo condizente com o seu prestigiado teatro de luta. Duas coisas me saltaram à vista: Boal não aceitou uma só canção de Dorival Caymmi e minha restrição aos arranjos, cheio de tiques nitidamente inspirados nos números de Elis Regina. Boal justificou dizendo mais ou menos o seguinte: "Você pensa em termos de buscar uma pureza regional e por isso reage a esses efeitos, eu penso em toda uma juventude urbana que eu preciso atingir e que entende essa linguagem." 145

Esse é o depoimento de Caetano, que não participaria do segundo espetáculo dirigido por Boal, Tempo de guerra, do qual Gil participou. Mas dá-se aqui a dimensão da participação dos baianos na elaboração do espetáculo, ou seja, uma ínfima participação na escolha do repertório. Existem aqui duas Bahias em questão: a de Caetano, que é cheia de lirismo e fortemente representada por uma memória afetiva dos pescadores e mares de Caymmi, e a de Boal, que intencionava acessar um público jovem, urbano e já adaptado a uma linguagem moderna, posicionando-se contra a opressão do regime militar. No entanto, não há em nenhuma dessas interpretações interesses claros pelas coisas da África ou da negritude. ${ }^{146}$

\footnotetext{
${ }^{144}$ ZAPPA, Regina. Gilberto bem perto, op. cit., p.91.

145 VELOSO, Caetano. Verdade tropical, op. cit., pp. 83-85.

${ }^{146}$ De acordo com Risério, a emergência de uma consciência afro em Salvador aconteceu no carnaval baiano, e vem se modificando desde meados da década de 1970. Risério compreende esse período através de um processo de "reafricanização" baiana; onde "os pretos se tornam mais pretos; se interessam cada vez mais pelas coisas da África e da negritude." Risério analisou a década de 1970 enquanto momento de
} 
A participação de Gil no programa O fino da bossa e nos espetáculos dirigidos por Boal é fortemente demarcada pelo ideário nacional-popular, e demonstra que, ao chegar a São Paulo, o artista estava afinado com esses ideais, bem como com a música de protesto produzida naquele momento. Essa temática se faz notar também no repertório de seu LP Louvação.

\section{- LP Louvação e a viagem a Recife}

Em 1967, Gil lançou seu primeiro LP, ${ }^{147}$ intitulado Louvação, diferentemente daquele que havia lançado em Salvador com apenas quatro músicas suas. Segue abaixo a transcrição de textos inseridos na contracapa do LP que dimensionam a musicalidade e os caminhos até então já traçados por Gil nas vozes de seus quatro amigos e parceiros musicais:

\section{Torquato Neto}

Há várias maneiras de se cantar e fazer música brasileira: Gilberto Gil prefere todas. Assim, ele se entende com o público. E daí o espanto dos incautos que não entendem (ou aceitam) a extraordinária musicalidade de Gil e o modo pelo qual ele apreende e pode utilizar - do jeito mais pessoal - qualquer forma musical nossa, do baião ao samba, da marcha-rancho à canção romântica. $\mathrm{O}$ repertório desse seu primeiro elepê foi escolhido para que o público possa ter uma visão geral do caminho que ele vem seguindo, no trabalho que desenvolve ativamente de uns cinco anos para cá, primeiro na Bahia, depois em São Paulo e no Rio. Portanto, estão aqui sucessos recentes, como "Roda", "Lunik 9" ou "Louvação", ao lado de composições novas, inéditas ("Água de Meninos", "Beira Mar", "A Rua") e outras, mais antigas, como "Maria", "Amor de Carnaval" ou "Procissão". No todo, este disco pretende deixar claro que meu querido amigo e parceiro Gilberto Gil está pronto para assumir o lugar que o situa - entre Chico Buarque de Hollanda e Edu Lobo - como o compositor mais fértil e importante da música popular brasileira atual.

invenção de um grupo étnico denominado juventude black-baiana, costurando informações sobre a elaboração dessas identidades, além de registrar o surgimento de um movimento político negro, com influência de caráter afro-internacional. In: RISÉRIO, Antônio. Carnaval Ijexá, op. cit.

147 ÁlbumLouvação (Universal, 1967). Produzido por João Mello. Arranjo Dory Caymmi, Carlos Monteiro e Souza e Bruno Ferreira. Gravado em 4 canais nos estúdios CBD (RJ) em março de 1967. 


\section{Chico Buarque de Hollanda}

Grande é o coração do baiano. Se bem que me convidaram a escrever sobre Gilberto Gil, o compositor, é difícil separar o baião de seu peito, visto que dançam tão juntos. Como é impossível desligar de sua cara redonda os rodeios que sua melodia faz. Sua música se desenrola tal qual uma serpentina que, antes de terminar seu passeio, dá um giro a mais, só para nos surpreender. Há uns tempos atrás, em São Paulo, Gil mostrou-me uma safra, uma dúzia de composições novas. Estranhei a princípio. Depois, confesso que senti certa inveja. Mas o sorriso redondo de Gil venceu, deixando todo mundo doido de vontade de jogar serpentina logo atrás. Pelas letras de seu samba, fui apresentado a Torquato, Capinam e Caetano. Gilberto Gil, que também é ótimo letrista, quando não encontra as palavras de seu samba sabe quem as pode adivinhar. É notável como a poesia pessoal de cada um de seus parceiros leva uma marca de Gil como denominador comum. É que Gilberto Gil contagia, no batepapo, no bate-caixa, na sinceridade de cantar. Senão, ouçam.

\section{José Carlos Capinam}

O pessoal da nossa moderna música popular encontrou uma montanha de perguntas pelo caminho. Perguntas que o samba e seus mais autênticos artistas deixaram, como também deixou o baião, o chorinho e poderá deixar o iê-iê-iê. Caetano Veloso, Edu Lobo, Chico Buarque, Sidney Miller, Torquato Neto, Paulinho da Viola - geração ótima de compositores e letristas - estão aí respondendo com o violão, o coração e os vários estilos de cada um, que sãoo conflito entre a formaçãoque tiveram e o momento que enfrentam. Entre eles, Gilberto Gil, com sua herança de Luiz Gonzaga, sua posterior paixão por João Gilberto, Baden e Vinícius, e com sua resposta sensual, densa e alegre - no mesmo caminho de Caymmi - tendo a Bahia no fundo e a realizada preocupação de ser popular. Gil é, como os outros, a melhor medida do mais jovem em nossa música, porque responde. E porque, em nível diferente, cria novas perguntas sobre o caminho desta música, de nossa saudade e amor, e sobre, principalmente, o caminho de nós mesmos nestes tempos de Procissão e Lunik.

\section{Caetano Veloso}

Penso que o canto de Gilberto Gil se situa no centro da única discussão verdadeira sobre a música brasileira no nosso tempo: uma extraordinária musicalidade que se perde entre as emoções da cidade e do sertão, do depuramento das tradições e a vulgaridade total - essa musicalidade que tenta reencontrar-se além de tudo isso - e que é a mais vigorosa exigência de que se coloquem em outro nível as relações de nossa música com a realidade. Conheço de muito tempo o agrado com que se pode ouvir o que Gilberto Gil faz em música e sei que isso nasce da espontaneidade com que ele escolhe as notas, da intimidade 
bruta com que se aproxima das formas musicais. Mas prefiro descobrir e ressaltar que a verdade mais profunda da beleza do seu trabalho está no risco que corre de descobrir uma beleza maior: a capacidade de criar uma obra íntegra, assumindo o Brasil inteiro.

Um aspecto que se repete em todas as análises de seus amigos e parceiros de profissão é a força do sertão em sua composição. Aparecem também o samba e a marcha, mas não há ainda, atrelados a Gil, elementos do rock em sua musicalidade nesse lançamento e nem mesmo algum elemento que demarque fortemente o mundo das africanidades.

A sonoridade toda do disco é identificada com a bossa nova, e a temática das letras é caracterizada pela forte associação ao ideário do CPC. Essa identificação com a politização do momento fica bastante clara nas letras de "Louvação", 148 "Ensaio Geral", ${ }^{149}$ "Roda"150 e "Viramundo". ${ }^{151}$ Encontra-se nessas canções a ideia da conscientização popular, anunciando um novo porvir, mais justo e igualitário.

Sobre "Procissão", Gil disse posteriormente:

A locação da música é Ituaçu, minha cidade, no interior da Bahia, onde nos dias de festa religiosa as procissões passavam e eu, criança, olhava. Uma canção bem ao gosto do CPC, o Centro Popular de Cultura; solidária a uma interpretação marxista da religião, vista como ópio do povo e fator de alienação da realidade, segundo o materialismo dialético. A situação de abandono do homem do campo do Nordeste, a área mais carente do país: eu vinha de lá; logo, tinha um compromisso telúrico com aquilo. ${ }^{152}$

\footnotetext{
148 "Louvação" (Gilberto Gil/ Torquato Neto): "Louvo quem canta e não canta/Porque não sabe cantar/ Mas que cantará na certa/ Quando enfim se apresentar/O dia certo e preciso/ De toda a gente cantar" 149 "Ensaio geral" (Gilberto Gil) "Minha gente, vamos lá/Nossa turma vai sair/ Nossa escola vai sambar/ Vai cantar pra gente ouvir/Tá na hora, vamos lá/Carnaval é pra valer/Nossa turma é da verdade/ E a verdade vai vencer"

150 "Roda"(Gilberto Gil/João Augusto) "Se morre o rico e o pobre/ Enterre o rico e eu/ Quero ver quem que separa/O pó do rico do meu/Se lá embaixo há igualdade/Aqui em cima há de haver/Quem quer ser mais do que él Um dia há de sofrer"

151 "Viramundo" (Gilberto Gil/Capinam) "Sou viramundo virado/Pelo mundo do sertão/ Mas inda viro este mundo/ Em festa, trabalho e pão/Virado será o mundo/ E viramundo verão/O virador deste mundo/ Astuto, mau e ladrão/Ser virado pelo mundo/ Que virou com certidão/Ainda viro este mundo/ Em festa, trabalho e pão"

152 RENNÓ, Carlos (org). Gilberto Gil: todas as letras. São Paulo: Companhia das Letras, 1996, p. 56.
} 
São canções que tematizam uma mobilização política, assim como as várias canções de protesto compostas nesse período, conclamando o povo a ir à luta, coadunando com a denúncia social que perpassava boa parte da criação artística dos anos 1960.

Além da gravação de seu primeiro LP, há outro importante episódio ocorrido em 1967, que nos fornece fortes indícios para compreendermos a relação de Gil com a cultura popular brasileira, e consequentemente com aspectos afro-brasileiros, e como esse universo passa então a ser significado pelo artista. Em inúmeros depoimentos realizados ao longo de sua trajetória, a viagem de Gil ao Recife é uma demarcação importante e constante na elaboração identitária do artista.

Sobre essa viagem ao Recife, Zappa conta que Gil ficou um mês inteiro na cidade para o lançamento de Louvação, além de afirmar que a ida a Pernambuco foi fundamental para Gil. Nas palavras de Gil, assim se deu essa experiência:

Tudo isso provocou em mim um desejo muito grande de revolver o terreno todo, arar de novo, replantar, semear coisas novas, trazer sementes novas, fazer os cultivares híbridos, plantar coisas novas, misturar laranja com mamão, o abacateiro, a ideia de Refazenda já estava ali. A lembrança flui: Ave Maria, eu ia engolindo tudo aquilo. Eu me identificava com algo que já era minha identidade, porque aquilo tudo era uma reconstituição do Recôncavo da Bahia, dos subúrbios cariocas com o dedo do samba, era todo esse Brasil essência, autóctone, forte e aomesmo tempo Sgt. Pepper's, esse estrangeiro sedutor que vinha com tanta coisa. ${ }^{153}[$ grifos meus]

Aqui há fortes pistas para compreendermos a África e a sua importância para a edificação identitária de Gil. Algo foi captado nessa viagem, e, a partir desse encontro com o Recife, Gil passaria a acessar novas significações culturais. O que era ainda desconhecido, e que no decorrer de sua trajetória seria associado à Bahia, ao samba carioca e à negritude, teve início, muito provavelmente, nessa viagem. $\mathrm{Na}$ feira de Caruaru, nas cirandas de Lia de Itamaracá, sem deixar de ser levada em consideração a influência da música inovadora dos Beatles, numa alusão do artista a sempre realizar hibridismos culturais. A identidade então lembrada por Gil e acessada na viagem à Recife partia de dados conectados à tradição, e nesse caso, fortemente demarcada pela negrit ude,

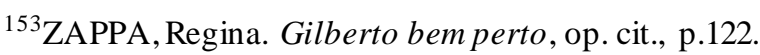


aqui representados pelo Recôncavo e pelo samba, mas também representados pela insígnia do autóctone e do autêntico, sem, no entanto, deixar de levar em consideração o dado da ressignificação pela miscigenação.

Em 1972, portanto num momento não tão distante dessa viagem ao Recife, realizada em 1967, Gil deu o seguinte depoimento:

Eu cheguei no Recife, fui fazer um show no Teatro Popular do Nordeste. Fiquei lá um mês e o pessoal do Recife tinha muito aquela coisa de cultura popular, naquela época era uma coisa bem viva pro pessoal universitário, tudo o mais eles tinham essa preocupação com folclore. Então, como eles achavam que eu era um compositor, um dos compositores, um dos artistas brasileiros interessados naquela coisa, então eles faziam questão de levar, de gravar ciranda pra mim, me levar para ver a banda de pífaros em Caruaru. Eu chorei, fiquei emocionado, de ver aquela coisa tremenda. Então eu voltei do Recife pro Rio com a certeza de que alguma coisa tinha que ser feita em termos de movimento, em termos de integração daquelas necessidades que eu achava que já existiam no universitário brasileiro ali. Onde Recife é bem um exemplo, cê tá entendendo? Nessa época Sérgio Ricardo era Sérgio Ricardo, Caetano Veloso era Caetano Veloso, Vandré era Vandré, e eu era eu, tudo o mais. Eu tava muito...sei lá... foi uma porrada que eu tomei lá e que me fez vir tomar outra no Rio, tá entendendo? Quando eu comecei a reunir o pessoal, para ver o que a gente fazia...isso foi em 1967, pouco antes do Festival de "Domingo no parque", de "Alegria, alegria". Então aí nessa tentativa de reunir o pessoal, nada deu certo... era reflexo de uma má consciência política, tentando misturar tudo com aquela confusão na cabeça de música de protesto, aquela cois a toda de música participante, não sei quê. Foi uma época em que eu estava realmente muito confuso. Muito por fora, cê tá entendendo? Mas também me desencantei logo, tudo ficou logo muito claro que não dava certo, aí fiz "Domingo no parque", fiz o "Frevo rasgado", fui aproveitar eu mesmo o material que tinha conseguido em Recife. ${ }^{154}$ [grifos meus]

Assim que retornou de Pernambuco, Gil dimensionou a viagem pela via da emoção, do encantamento e também a identificou como uma espécie de má consciência política, que pode aqui ser interpretada como aquela adotada pelos CPCs. De acordo com Caetano, a viagem de Gil ao Recife acabou por reunir pontos dispersos e tendências difusas projetadas conscientemente numa espécie de militância:

\footnotetext{
${ }^{154}$ ALMEIDA, Hamilton. O sonho acabou, Gil está sabendo de tudo. O Bondinho, 16 fev. 1972.In: COHN, Sergio (org.). Gilberto Gil-Encontros, op. cit.
} 
Suponho que só houve duas dessas reuniões. Capinam, Torquato Neto, Sidney Miller, Edu, Chico Buarque e eu, além de Sérgio Ricardo e Gil, estávamos presentes em ambas. Talvez Francis Hime e Dori tenham ido a uma ou outra. O que lembro com certeza é que, se por um lado, Chico boêmio e desconfiado de programas, embriagava-se e ironizava o que mal ouvia, Sérgio

Ricardo tomava algumas palavras de Gil pelo que este não quereria que elas fossem tomadas: por exemplo, "ser realme nte popular" le vava-o a suge rir que fizéssemos shows em portas de fábricas. Gil tinha enormes dificuldades em se fazer entender. Quando ele mencionava a música rural de Pernambuco, quase se ouvia alguém responder que Edu já trabalhava com isso satisfatoriamente; e quando ele falava nos Beatles, alguns olhos baixavam, outros arregalavam-se, todas as bocas silenciavam. Ele nem ousava falar em Roberto Carlos. $\mathrm{E}$, depois de uma pausa tensa, alguém se manifestava para tentar mostrar que entendera tratar-se de uma estratégia esperta e um tanto desonesta - mas fadada ao fracasso -, a qual consistiria em fazer uma música mais comercial para assim poder melhor veicular ideias revolucionárias. Enfim, Gil não chegou a desistir de se fazer entender, pois os outros é que desistiram de tentar segui-lo. Restava-nos seguir sozinhos. ${ }^{155}$ [grifos meus]

De acordo com as rememorações de Caetano, as massas que suas intenções artísticas, assim como as de Gil, queriam alcançar eram as concebidas enquanto sociedade de massa, de largo consumo. A popularidade não estava ali, naquele momento, conectada ao universo dos trabalhadores das fábricas, ou mesmo ligada a uma nostalgia folclórica. O popular a que Gil se referia, de acordo com Caetano, era aquele vivenciado na viagem à Recife, aquele presenciado nas feiras, nas cirandas, mas que o popular era e poderia ser também a música dos Beatles, ou qualquer outro dado que fizesse menção à popularidade de outras localidades, nacionais ou internacionais. A mensagem que Gil estava começando a elaborar nessas primeiras reuniões trazia à tona questionamentos de boa parte da intelectualidade e dos artistas daquela época, o que deveria ser levado em consideração no ato da criação artística; se salvaguardar a "essência" de determinadas tradições ou se deixar tocar por elementos artísticos de quaisquer paragens.

Há um movimento de fuga da dicotomia entre um discurso cujo sentido é a necessidade da revolução proletária, e outro mais conectado à lógica da publicidade. No lugar dessa oposição, se busca uma síntese complexa entre a tradição dos símbolos populares e a modernidade. Esse lugar intermediário - no qual se situará o Tropicalismo

${ }^{155}$ VELOSO, Caetano. Verdade tropical, op. cit., p. 133. 
- busca justapor referência tanto do popular do rádio, mas também aquele das feiras com a modernidade que pode tanto aportar via rock'n'roll dos Beatles ou de Roberto Carlos.

Carlos Calado conta que o Teatro Popular do Nordeste era parecido com o CPC, por promover uma espécie de intercâmbio entre os artistas convidados e a cultura popular recifense. Sobre as reuniões feitas por Gil ao retornar do Recife, Calado conta:

O encontro acabou acontecendo no Rio, onde vivia a maioria dos compositores. No dia combinado, na casa de Sérgio Ricardo, estavam presentes Dori Caymmi, Edu Lobo, Sidney Miller, Chico Buarque, Francis Hime e Paulinho da Viola, além de Caetano, Torquato e Capinam. Gil abriu a reunião com uma longa prelação. Para começar, deu detalhes de suas experiências musicais em Pernambuco, incluindo a "descoberta" da banda de pífaros de Caruaru. Em seguida, afirmando que considerava os Beatles a manifestação musical mais importante daquela época, Gil falou da necessidade de se passar a compreender a música popular como um meio de cultura de massas. E que, numa sociedade dominada pela cultura de massas, a música tinha se transformado em uma mercadoria para um consumo mais rápido e fácil. Assim, o nacionalismo defensivo das canções de protesto, que impregnava também quase toda a produção da MPB daquela época, não teria mais sentido. Estava na hora de todos se unirem para criar um movimento que revigorasse a música brasileira. ${ }^{156}$

Tanto a viagem como seus desdobramentos, em reuniões organizadas por Gil, dimensionam uma tentativa de criar um movimento de reconfiguração da música popular brasileira. Mas o entusiasmo de Gil, ao propor mesclar cultura popular com cultura de massa, pífaros e Beatles, não teve tantos adeptos como gostaria. Continuaram a partilhar essas ideias com Gil Torquato, Caetano e Capinam.

É importante salientar que essas reuniões, bem como a viagem à Recife, estavam trazendo à cena para a trajetória de Gil questionamentos referentes à cultura e à sua função enquanto artista. Somente em rememorações posteriores, e, portanto, afastadas desse período é que Gil abordou o evento atrelando-o à construção de sua identidade tracejada por fios de negritude. No calor do evento e no afã de ressignificar em atos a musicalidade e experiência pernambucana as reuniões foram demarcadas pela tentativa de traçar planos para questões referentes especialmente à popularidade e à nacionalidade.

${ }^{156}$ CALADO, Carlos. Tropicália, op. cit., p. 98. 


\subsection{3- A passeata contra as guitarras elétricas}

Outro evento que não pode passar despercebido foi a participação do artista na passeata contra as guitarras elétricas. No dia 18 de julho de 1967, sairia do Largo São Francisco, no centro de São Paulo, até o templo da bossa nova, o Teatro Paramount, uma passeata pela MPB contra as guitarras elétricas. O evento tinha à frente Elis Regina, Gilberto Gil, Jair Rodrigues e Edu Lobo, entre outros. A passeata era na verdade um evento de lançamento do novo programa da Record, Noite da $M P B$, que deveria suceder ao $O$ Fino da Bossa; porém, acabou sendo vista como uma manifestação ideológica contra a turma do iê-iê-iê. Em relação a essa passeata, Caetano Veloso declarou que: “... Ficou claro para nós que todo aquele folclore nacionalista era um misto de solução conciliatória para o problema de Elis dentro da emissora e saída comercial para os seus donos..." ${ }^{157}$ Esse episódio é um fato relevante, pois poderia demarcar um posicioname nto ideológico nacionalista de Gilberto Gil tão em voga naquele momento, já que o artista estava à frente de tal passeata.

Quem analisa esse evento é Eleonora Zicari, que afirma que essa passeata não pode ser simplesmente decifrada através da contestação, imbricando elementos de música e política. De acordo com a autora, em 1967, artistas identificados com a MPB, saíram em passeata contra as guitarras elétricas, ou seja, contrapondo-se àqueles representantes da Jovem Guarda, seus concorrentes diretos pela audiência da TV Record. Estavam presentes em jogo naquele momento diversos projetos de representação, bem mais complexos do que se posicionar a favor ou contra elementos representativos de certa nacionalidade. Esse evento, de acordo com Zicari, entrelaçou uma série de elementos que fazem menção à resistência política, à luta cultural, mas também a motivações comerciais. $^{158}$

\footnotetext{
${ }^{157}$ CONTIER, Arnaldo. Edu Lobo e Carlos Lyra..., op. cit., pp. 13-52.

${ }^{158}$ BRITO, Eleonora Zicari. Costa de. A música popular brasileira nos conturbados anos de chumbo: entre o engajamento e o desbunde. Projeto História (PUC-SP), n. 43, 2011.
} 
$\mathrm{O}$ aspecto apontado por Zicari e Caetano, de uma saída estratégica e comercial da emissora, se faz valer também para Zuza Homem de Mello, que afirma que a Record tentaria solucionar a crise de $O$ fino substituindo-o e se aproveitando do chavão político da Frente Ampla entre Carlos Lacerda, Juscelino Kubitschek e Jango - Frente Única Noite da Música Popular Brasileira com os principais contratados da emissora, Elis, Jair, Vandré, Simonal, Chico, Nara e Gil; numa clara tentativa de reconduzir Elis aos índices de audiência que já tivera. No entanto, de acordo com Mello, o programa não emplacou, e não chegou a completar sequer três meses de existência. Foi uma fase de "maré baixa" para Elis. ${ }^{159}$

Sobre essa passeata, Gil comentou:

Eu fui pela Elis, por causa dela, atendendo a ela e evidentemente também a um grupo de colegas interessantes que estavam lá, que foram cada um com sua visão, cada um com sua maneira de ver a coisa. A minha visão era essa, aquela disputa era saudável até certo ponto, nesse sentido de estimular competições benignas e tal, mas eu não acreditava, não era um defensor ideológico da divisão dos territórios. ${ }^{160}$

Contratado pela emissora e frequentador assíduo dos programas de Elis, Gil conta, em outra situação, ter participado da passeata até mesmo por forças sentimentais. ${ }^{161}$ Anos depois, ao rememorar sua participação na passeata, Gil mais uma vez reelabora sua identidade, dizendo-se um sujeito sem fronteiras e que não coaduna com a divisão de territórios. Essa falta de fronteiras claramente delimitadas foi um aspecto repetido inúmeras vezes ao longo da trajetória do artista, e com grande frequência na época do tropicalismo. Pouco tempo depois da passeata, ainda em 1967, Gil convidaria Os Mutantes para tocar uma música sua no festival, acompanhando-o com guitarras e tocando rock'n'roll.

Essa ação que poderia ser concebida como contraditória é aqui abordada como uma espécie de ação cultural reveladora, num dinamismo que levou em conta certas intencionalidades, tanto comerciais quanto sentimentais, que em momentos seguintes já

\footnotetext{
${ }^{159}$ MELLO, Zuza Homem de. A Era dos Festivais: uma parábola. São Paulo: Ed. 34, 2003, p. 178.

160 TERRA, R.; CALIL, R. Uma noite em 67. Documentário. Videofilmes, 2010.

${ }^{161}$ Gil disse:Eu era louco por ela, fui apaixonado por ela, ela não sabia, eu ficava quieto. Numa entrevista realizada pela Rede Globo para o Especial Elis Regina, em 2007.
} 
não se faziam tão importantes quanto anteriormente, e representa aqui um bom exemplo de deslizamento na postura sobre certos assuntos, que vai sendo reelaborada no tempo.

\subsection{4 - Os festivais}

Ao tratar deste período, é imprescindível levar em conta o debate estético que se travou acerca das "verdadeiras raízes" da Moderna Música Popular Brasileira, que chegava mesmo a se confundir com questões político-ideológicas. O depoimento de Gil, realizado no período do festival, referente à apresentação de sua música no festival da TV Record em 1967, bem dimensiona a conturbação vivenciada naquele momento, numa fala em que imperava o medo e a incerteza:

Sinto-me hoje como num tribunal, onde sou acusado de trair a verdadeira música popular brasileira. E não tenho muitas respostas para dar, porque eu mesmo não sei se estou agindo certo ou errado, como ninguém no mundo pode ter a certeza de alguma coisa antes de se arriscar a fazê-la. Também não posso me arvorar e dizer que eu estou certo, os outros é que estão errados. ${ }^{162}$

De acordo com Zappa, foram os festivais que acabaram por impulsionar a escolha de Gil por fazer da música sua profissão. Sobre a realização dessa escolha, Gil disse: "era uma confusão danada, uma hora da manhã, duas horas da manhã eu voltava, tendo que acordar às seis para chegar no trabalho no centro, cochilando pelos banheiros da companhia. Não podia dar certo." 163

Solano Ribeiro, idealizador dos festivais de música no Brasil, criou na TV Excelsior o I Festival de Música Popular Brasileira, e depois foi para a Record, onde criou os Festivais da Record. ${ }^{164}$ De acordo com Ribeiro,

Os festivais romperam o ritual das gravadoras e do rádio, tendo se transformado na grande porta para o novo. Também passou a ser nova a postura da televisão em relação à música popular, tendo sido, ao mesmo tempo, sua maior divulgadora $\mathrm{e}$ beneficiária (...). A repercussão e o sucesso dos festivais não

\footnotetext{
162 GIL espera tranquilo outra vaia. Jornal da Tarde, São Paulo, 4 out. 1967.

163 ZAPPA, Regina. Gilberto bem perto, op. cit., p. 94.

${ }^{164}$ RIBEIRO, Solano. Prepare seu coração. São Paulo: Geração Editorial, 2002, p. 10.
} 
teriam acontecido não fosse a escolha da televisão como seu veículo, que então começava a ter cobertura nacional e dava os primeiros passos no conceito de rede, na época já consagrado como sistema (network) nos Estados Unidos. ${ }^{165}$

Ribeiro comenta ainda que no Brasil as gravadoras eram em geral ligadas às suas matrizes internacionais, que por sua vez direcionavam a política e a filosofia do que deveria ser gravado e tocado nas rádios. Ribeiro afirma ainda que não conseguiria fazer um trabalho isento se dependesse da indústria do disco, embora soubesse que, no caso do sucesso do festival, ela seria sua maior beneficiada, e afinal esse sucesso, mais adiante, dependeria do interesse dessa mesma indústria pelos artistas e as músicas que eles iriam lançar. Ribeiro resolveu que, para sua independência e lisura do festival, não permitiria a participação de qualquer editora ou gravadora. Sua estratégia era colocar no mercado uma porção de músicas, cantores, cantoras e conjuntos musicais, e as gravadoras que se servissem, de acordo com a sua agilidade e competência. ${ }^{166}$

No documentário Umanoite em 1967, produzido em 2010, Ribeiro afirmou:

Eu não tinha preferência, eu queria que aquilo tudo desse certo. Eu tava lá morrendo de medo que acontecesse alguma coisa, tinha um problema, às vezes você ia procurar o artista, cadê o Chico? Ele tá tomando uma coisa no botequim ao lado. Quando a gente tava fazendo tudo aquilo, o objetivo era fazer um bom programa de televisão, o festival nada mais era do que um programa de televisão. Só que de repente por força de uma série de circunstâncias ele adquiriu até uma importância histórica, política, sociológica, musical e transcendentale etc. Mas naquela hora você não tá sabendo que isso vai acontecer, porque isso aconteceu ao longo do tempo. Pra mim aquele espetáculo tinha que acontecer sem erros. Ao vivo, a gente tava ao vivo, uma plateia tensa, os jurados tensos, artistas também num clima de nervos à flor da pele, onde se jogava a possibilidade de que um deles se transformasse em astro da noite para o dia. ${ }^{167}$

É interessante notar que a intenção dos idealizadores dos festivais acabou se desdobrando em um processo que nem mesmo eles imaginaram. Suas preocupações eram apenas realizar um bom programa de televisão, sem maiores erros, pois se tratava de uma programação ao vivo. A intenção de montar um espetáculo que não apresentasse maiores

\footnotetext{
${ }^{165}$ RIBEIRO, Solano. Prepare seu coração, op. cit., p. p.16.

166 Ibid., p. 68.

167 TERRA, R.; CALIL, R. Uma noite em 67. Documentário. Videofilmes, 2010.
} 
furos era central, e fica também evidente nas falas do diretor da emissora na época, Paulo Machado de Carvalho:

Eu sempre acheique os festivais poderiam ser organizados como os espetáculos de luta livre, tem que ter o mocinho, tem que ter o bandido, tem que ter o pai da moça, tem que ter tudo. Mais ou menos a filosofia na minha cabeça era assim, organizar um espetáculo, selecionar os intérpretes mais ou menos dentro disso. Então o Chico era o bonitinho, o outro era sei lá o que, era mais ou menos isso. A gente achou que poderia organizar um espetáculo para que ele despertasse maior interesse do público. ${ }^{168}$

Fica demonstrado nos fragmentos que para os responsáveis pelo festival da TV Record a motivação para a realização desses programas era meramente comercial, de busca pela realização de um bom trabalho. Da parte deles, não havia convicções políticas ou ideológicas na elaboração desse festival, ou seja, a maneira como ele foi recepcionado e apropriado pelo público acabou até mesmo ultrapassando a expectativa de seus idealizadores. A TV era um novo meio de comunicação, e eles estavam aprendendo, criando mecanismos de produzir espetáculos. Esse tipo de aposta era novidade, e por isso não preexistiam técnicas de lidar com essas músicas e seus compositores; era tudo ao vivo e novo. A criação dos festivais estava atrelada a aspectos comerciais e de institucionalização da televisão no país. No entanto, por meio da televisão, os programas musicais acabaram encontrando um meio de divulgação de seus ideais. Assim sendo, Gil em São Paulo daria seus próximos passos profissionalizantes juntamente com a também profissionalização do meio musical televisivo.

Sobre a música "Domingo no parque", composta em 1967 para o festival da Record, ${ }^{169}$ Gil conta que morava no hotel Danúbio com sua nova parceira Nana Caymmi, e com ela foi visitar um pintor amigo de Dorival, e que depois desta visita realizou a composição. Gil conta:

\footnotetext{
168 TERRA, R.; CALIL, R. Uma noite em 67. Documentário. Videofilmes, 2010.

${ }^{169}$ Em 1966, Gil concorreu como compositor no $1^{\circ}$ Festival Internacional da Canção, da TV Rio, com "Minha senhora" (parceria com Torquato Neto), apresentada por Gal Costa. Elis defendeu "Ensaio Geral" de Gil no II Festival da Música Popular brasileira, na TV Record, e ficou em quinto lugar. Em 1967, além de "Domingo no parque", acompanhado do conjunto Os Mutantes, no $3^{\circ}$ Festival de Música Popular Brasileira, concorreu também no mesmo festival com "Bom dia", parceria com Nana Caymmi, da TV Record; a canção "Domingo no parque" terminou classificada em segundo lugar. Em primeiro lugar ficou "Ponteio", de Edu Lobo e Capinam.
} 
Tínhamos conversado muito. Ele, o Clóvis Graciano, pintava barcos, paisagens marinhas, era muito caymmiano nesse sentido, mas também do ponto de vista pictórico. Caymmi também experimentava pintar algumas coisinhas e segui um pouco essa escola. E eu estava impregnado com aquelas histórias todas da Bahia, de pescadores, que tinha sido um dos temas básicos da conversa toda do jantar. Fiquei com aquilo tudo na cabeça, aquelas imagens, aqueles negros fortes, pescadores, aquela gente praieira da Bahia, e pronto! Peguei o violão e veio logo a ideia de um som de berimbau. Queria dar um toque de capoeira à música. Além disso, tinha visto a ciranda em Pernambuco e fiquei com aquilo na cabeça. Aí veio a ideia de que a cena se passava na Ribeira, um lugar importante da Bahia, e na Boca do Rio, que é outro. Saiu todo de uma vez só. Nana dormindo. Amanhecendo, cinco da manhã, as primeiras luzes do dia, eu cutuquei a Nana e disse 'ouça aqui'. Era "Domingo no parque". E Nana disse: 'Você fez! Está bonito! Está ótimo!' Foi assim. A canção vai variando, variando, é uma espécie de suíte, montagem de vários movimentos... é muito interessante! ${ }^{170}$

Através dessa ambiência baiana, representada pelos pescadores, a temática dessa criação musical de Gil ainda estava colorida pela ligação com a temática nacionalpopular, ou seja, uma temática do cotidiano popular baiano, mas trazia toda a inovação de tocá-la ao som do rock dos Mutantes com o arranjo de Rogério Duprat, misturando, ao som das guitarras, barulho de um parque de diversões, numa letra cinematográfica que remetia a melodramas mexicanos. Segundo Gil, "a canção nasceu, portanto, da vontade de mimetizar o canto folk e de representar os arquétipos da música de capoeira com dados exclusivos, específicos: com um romance desse, essa história mexicana. Está tudo casado." ${ }^{171}$

Há um depoimento feito à época do festival sobre a sonoridade dessa canção, que muito nos informa sobre a maneira como o mundo das africanidades era acessada nesse momento pelo artista:

No festival, sob o aspecto visual, a experiência resultou interessante. De um lado os três Mutantes, com os instrumentos elétricos; no meio eu, com um violão simples; e do outro lado, o Dirceu, com o berimbau. A usina, de um lado. O artesanato no meio. E o primitivismo do outro (...) eu precisava de um berimbau para o "Domingo no parque". Como ele ia tocar a bateria, era mais viável que ele tocasse também a parte do berimbau. Dirceu também se mostrou sensível aos problemas da

\footnotetext{
170 ZAPPA, Regina. Gilberto bem perto, op. cit., p. 113.

${ }^{171}$ RENNÓ, Carlos (org). Gilberto Gil, op. cit., p. 81.
} 
minha música, sem aquele preconceito que muitos tinham com relação aos músicos do iê-iê-iê. Participou de todas as faixas do meu LP e do de Caetano. ${ }^{172}$

As africanidades aqui aparecem associada a um primitivismo, ${ }^{173}$ no qual Gil associava a capoeira à ciranda que ele acabara de conhecer há pouco tempo. Sua intenção sonora abria-se, naquele momento, a novos elementos. Ao mesmo tempo em que o som do parque se fazia presente, numa colagem até então pouco usual, o berimbau retratava a presença da Bahia; são elementos que apontam bem mais para a confecção de uma musicalidade híbrida do que demarcadores de um espaço de valorização especialme nte da tradição. Segundo Gil, "a gente tenha se jogado ao exercício da liberdade, que a gente tenha percebido a necessidade de uma nova linguagem, que inclua uma visão mais total do homem." ${ }^{174}$ Abordando a modernidade das guitarras de um lado, a tradição representada pelo berimbau da capoeira do outro, e o violão no meio realizando o papel de decodificador e artesão do diálogo dessas três dimensões, essa experiência conota uma combinação histórica que pode aqui ser interpretada enquanto um local de cultura, já que o moderno/futuro/guitarra se fragmenta e se mistura, Gil se utiliza de tecnologias avançadas e ao mesmo tempo busca no passado representado pelo berimbau/capoeira uma densidade cultural baiana.

Em 1967, Gil declararia ao Jornal da Tarde sua apreensão sobre uma possível vaia ao apresentar "Domingo no parque" acompanhada de guitarras elétricas:

\begin{abstract}
Mas estou tranquilo. Seria muito mais cômodo se eu estivesse concorrendo ao Festival com músicas como "Roda" ou "Louvação", composições minhas já aceitas pelo público. Mas isso seria uma desonestidade para comigo mesmo e para com o público, porque não representariam a minha maneira de pensar atual. E não faço isso em termos de desafio, acho apenas que todas as experiências são válidas na música, vista de maneira universal. ${ }^{175}$
\end{abstract}

\footnotetext{
${ }^{172}$ CAMPOS, Augusto de. Balanço da bossa e outras bossas. $4^{\mathrm{a}}$ ed. São Paulo: Pers pectiva, 1986.

${ }^{173}$ Aqui não havia um maior conhecimento do artista em relação ao universo da cultura popular afrobrasileira, e o primitivismo não carrega aqui uma conotação pejorativa, mas sim denota algo que na concepção do artista veio primeiro, como se fez desdobrar em pensamentos elaborados por ele posteriormente.

${ }_{174}$ Apud CAMPOS, Augusto de. Balanço da bossa..., op. cit, p. 194.

${ }^{175}$ GIL espera tranquilo outra vaia, op. cit.
} 
Esses depoimentos de Gil, além de dimensionarem a consciência quanto ao ato de fazer canções, de buscar os arranjadores e músicos específicos para cada trabalho, das cobranças ideológicas e comportamentais daquele momento, são elaborações que tratam da necessidade do artista de se sentir atualizado com as questões que canta e de criar um diálogo respeitoso com seu público. Mostram-nos também como era pesado o clima da música popular naquela época, dificuldade essa expressa nas palavras "tribunal", "traição" e "verdadeira música". A busca por uma universalidade musical também fazia parte dos desejos de Gil, e em breve se aglutinaria na motivação de criar o tropicalismo.

Em depoimento de 2010, quando se refere a "Domingo no parque", a rememoração de Gil assim colore essa composição:

\begin{abstract}
Depois do impacto dos Beatles, sobretudo causados sobre nós, e de toda aquela música que eles traziam, vinha junto com eles o pop americano, o pop rock inglês, e a minha visita ao Nordeste brasileiro com impactos muito fortes também sobre mim, da música local, da música regional, das manifestações típicas da música nordestina, tudo isso provocou em mim um desejo muito grande de revolver de uma forma mais generosa, mais ampla e mais ousada o terreno, o terreno todo. Arar de novo o terreno, replantar, semear coisas novas, trazer sementes novas, fazer os cultivares híbridos, misturar pra dar coisas novas, a laranja com o mamão, o abacateiro que amanhecerá tomate e anoitecerá mamão, que eu vim a fazer depois no Refazenda. Essa ideia do Refazenda já tava ali naquilo tudo. Eram os Beatles e o Luiz Gonzaga, eram os Rolling Stones e Jorge Ben, era banda de pífaros de Caruaru e o Jefferson Airplane. Era assim que eu pensava, é assim que eu continuo pensando. ${ }^{176}$
\end{abstract}

Mais uma vez fica evidente a força que a viagem ao Recife teve para Gil e essa necessidade de misturar, hibridizar toda a cultura, sem privilegiar ou resguardar as manifestações típicas das culturas populares ou sobrevalorizar a música pop americana ou inglesa, mas misturá-las todas; a intenção era libertar a música de qualquer forma ou fronteira, fazendo coexistir o tradicional com a modernidade.

Na abordagem da trajetória e arte de Gil, se delineiam concepções sobre o culto e o popular, o moderno e o tradicional, o nacional e o estrangeiro. A música produzida por Gilberto Gil é criada a partir de uma complexa rede de diálogos vinculada à

${ }^{176}$ TERRA, R.; CALIL, R. Uma noite em 67. Documentário. Videofilmes, 2010. 
indústria cultural, fazendo uso de referentes tanto "primitivos", populares ou pops, todos se nutrindo uns dos outros. Não há a supervalorização de nenhuma dessas categorias em detrimento de outras; não houve na atitude artística de criação de Gil em "Domingo no parque" a intenção de sobrevalorizar nenhum aspecto, mas a criação livre e por ele denominada de universal.

Na trajetória de Gil o que se percebe é a existência de uma dimensão muitas vezes caótica, contemplando especialmente misturas e hibridismos. Através dos depoimentos realizados ao longo dessa trajetória é possível perceber que a curiosidade com aspectos referentes à cultura afro-brasileira começou a fazer parte dos questionamentos e interesses do artista a partir da viagem realizada em 1967 à Recife. Inserido num cenário marcado fortemente pelas ideologias do nacional-popular, Gil, nesses primeiros tempos de morada em São Paulo, acabou realizando um trabalho conectado com o que havia sido feito até aquele momento, tanto em suas composições musicais quanto em sua participação nas peças teatrais dirigidas por Boal ou nos programas televisivos, e, dentre eles os festiva is. Isso se transformaria com o tropicalismo.

\section{4 - O tropicalismo}

Ao questionar as identidades no mundo pós-moderno e o impacto "global" gerando um novo interesse pelo "local", Stuart Hall nos fornece indícios para refletirmos acerca do tropicalismo

Ao invés de pensar no global como substituindo o local seria mais acurado pensar numa nova articulação entre o global e o local. Este local não deve, naturalmente, ser confundido com velhas identidades, firmemente enraizadas em localidades bem delimitadas. Em vez disso, ele atua no interior da lógica da globalização. Entretanto, parece impossível que a globalização vá simplesmente destruir as identidades nacionais. É mais provável que ela vá produzir, simultaneamente, novas identificações "globais" e novas identificações "locais". ${ }^{177}$

Hall identifica, na segunda metade dos anos 1960, "o grande marco da modernidade tardia", cuja característica é a transformação das identidades culturais, que se encontram inconstantes no atual contexto histórico da pós-modernidade, a qual sofre

${ }^{177}$ HALL, Stuart. A identidade cultural na pós-modernidade. Rio de Janeiro: DPA, 2001, p. 45. 
as interferências da dispersão de linhas teóricas modernas e da globalização. Hall problematiza ainda a ideia de localidades, periféricas ou não, fechadas; apontando para a pluralidade e a descontinuidade. Segundo o autor, as sociedades do final do século XX têm sofrido uma mudança estrutural transformando as "paisagens culturais", antes sólidas e estáveis, agora pluralmente demarcadas pelo gênero, sexualidade, etnia, raça e nacionalidade.

O tropicalismo é aqui interpretado como uma manifestação político-cultural da juventude brasileira do final da década de 1960 que aborda aspectos referentes à nacionalidade, questionando temas relacionados à cultura de massa e ao ambiente intelectual e cultural brasileiro, a partir do âmbito da música popular brasileira. Questionando a canção popular ou a canção culta/protesto a partir de parâmetros "locais", bem como as informações "globais" através especialmente do pop e do rock, sugeriu novos modos de apropriação e tradução de diferentes códigos culturais, não somente musicais, mas também comportamentais. Não caberia aqui problematizar os vários aspectos da construção do movimento tropicalista, e nem mesmo os desdobramentos do movimento para a cultura nacional, mas sim compreender a busca empreendida pelos tropicalistas na "descoberta" pelo Brasil e qual o papel ocupado pela África nessa cadeia de significantes.

O tropicalismo ${ }^{178}$ foi criado em um período de acirramento das discussões ideológicas, principalmente no questionamento do nacional e do popular. O tropicalis mo não só estava inserido nesse campo de discussão, como também ofereceu subsídios para a elaboração da insurgente indústria cultural brasileira. Os estudiosos, tanto os do momento de sua eclosão ${ }^{179}$ quanto àqueles que o analisaram

\footnotetext{
${ }^{178} \mathrm{O}$ tropicalismo teve enorme repercussão cultural não só no momento de seu surgimento, em fins dos anos 1960, mas ecoa até hoje enquanto um movimento cultural que instaurou ruptura e inovação estética, chegando mesmo a ser considerado atualmente como um "divisor de águas" da cultura brasileira. É constante em programas de televisão ou em matérias jornalísticas a comparação de tudo o que é inovador com a Tropicália, como se essa tivesse inaugurado no país a ruptura com determinados padrões conservadores, e que tudo que tente a inovação se configuraria como continuidade do tropicalismo. CYNTRÃO, Sylvia Helena (org). A forma da festa-tropicalismo: a explosão e seus estilhaços. Brasília: Editora Universidade de Brasília; São Paulo: Imprensa Oficial do Estado, 2000. Sobre alguns desses pontos, sobretudo o último deles, há interessantes críticas que podem ser conferidas em: BRANCO, Edwar de Alencar Castelo. Todos os dias de paupéria: Torquato Neto e a invenção da tropicália. São Paulo: Annablume, 2005; BAY, Eduardo Kolod. Qualquer Bobagem: uma história dos Mutantes. Dis sertação de Mestrado em His tória. Universidade de Brasília, 2009; COBELO, Guilherme. O desbunde do Udigrudi. In: BRITO, Eleonora Zicari C. de; PACHECO, Mateus; ROSA, Rafael (orgs). Sinfonia em prosa. São Paulo: Intermeios, 2013.

${ }^{179}$ Dentre eles Roberto Schwarz e Augusto de Campos.
} 
posteriormente, ${ }^{180}$ creditam ao movimento a articulação entre elementos modernos e arcaicos, sem, no entanto, concordar em suas interpretações sobre o significado estético e político dessas apropriações.

Analisando tanto a fala dos agentes envolvidos com o tropicalismo quanto dos estudiosos do tema, é possível perceber que a intenção tropicalista tinha dentre seus principais ideais a abertura para o mundo, para o pop, para a modernidade, a elaboração de uma nova linguagem musical e comportamental, de trazer "novas" peças e inseri-las num contexto impregnado pela cultura nacional-popular, sem, no entanto, deixar de considerar elementos característicos do Brasil. O interesse aqui é compreender como o tropicalismo articulou essas referências ao Brasil, e, mais ainda, encontrar o espaço destinado à África nessa coloração tropical.

De acordo com Durval Albuquerque, após o golpe militar de 1964, tanto a identidade nacional quanto seu papel social passaram a ser repensados pela esquerda e por uma intelectualidade traumatizada pela crise geral de seus paradigmas:

\begin{abstract}
A realidade brasileira, que parecia tão bem facilmente explicada, no período anterior a 64 , surge com outra realidade, que não cabe mais facilmente nos esquemas destes intelectuais. Com a ruína destas grades de interpretação, destes projetos, com a crise desta formação discursiva, a realidade, a verdade construída anteriormente parecem se desfazer. Parece que o mundo gira, rodopia, entra em transe. A riqueza de processos e acontecimentos e a aceleração de processos de transformação parecem trazer o caos. O Brasile seu povo se tornam complexos, o que parecia explicado torna-se novamente objeto de luta pela instauração de uma nova verdade. Busca-se novamente a identidade do país, de seu povo, como forma inclusive de encontrar a própria identidade. A questão da cultura, seu caráter nacional e popular são repostos como problemas que podem ser respondidos, ainda, a partir dos mesmos pressupostos do período anterior, por setores que não conseguem descolar de sua antiga máscara e simular novos territórios. Eles insistem na percepção da mudança, como uma superficialidade, como uma aparência e como uma manutenção da mesma essência das questões anteriores. Já o movimento tropicalis ta tentará dar novas res postas a estas questões, procurando, a partir da sensação da mudança e da de scontinuidade, construir uma nova forma de cartografar
\end{abstract}

\footnotetext{
${ }^{180}$ Tropicália - Alegoria, Alegria de Celso Favaretto, Brasilidade revolucionária: um século de cultura e política de Marcelo Ridenti, Tropicália: a história de uma revolução musical de Carlos Calado, Todos os dias de paupéria: Torquato Neto e a invenção da tropicália de Edwar Castelo Branco, dentre outros.
} 
a realidade, o país e seus componentes culturais ${ }^{181}[$ grifos meus]

Albuquerque afirma ainda que só foi possível a emergência de um movimento como o tropicalismo devido à progressiva crise do ideal nacional-popular. E comenta que o mercado, cada vez mais demarcado pela internacionalização e a expansão de uma cultura de massa, acabou por fornecer indícios para a intenção tropicalista, que era abrir caminho para múltiplas possibilidades, libertando o campo cultural e musical para uma criatividade sem fronteiras, cheio de misturas, não havendo mais uma clara divisão entre arte e mercadoria. Não era a busca pela pureza ou pela autenticidade, mas um processo de mistura das coisas de um mundo moderno e urbano, onde a cultura brasileira "teria como caráter o fato de não possuir caráter, teria como identidade o fato de não ter identidade, de ser barroca, misturada; teria como nossa originalidade a de não sermos originais, de dançarmos, divina e maravilhosamente, entre o tudo e o nada."182

A obra ${ }^{183}$ de Celso Favaretto avalia o sentido estético e histórico do tropicalis mo e é considerada um clássico, sendo constantemente citada em grande parte das análises que tratam do tema. É a dissertação de mestrado do autor, publicada em 1979, pouco mais de década após a eclosão do movimento, e certamente acabou por influenciar grande parte das produções referentes ao tropicalismo, fossem elas acadêmicas ou não. A intenção dos tropicalistas, de acordo com Favaretto, consistia em questionar a tradição, reinventandoa crítica e culturalmente, através de uma postura de abertura para uma internacionalização, e ao mesmo tempo de busca por uma identidade nacional. Segundo Favaretto, o tropicalismo aproximou os signos da indústria cultural e os emblemas da tradição brasileira de uma maneira tão forte que deslocou o debate nacional dos planos políticos para os estéticos.

De acordo com Favaretto, o que demarcou o início do movimento tropicalista foi o III Festival da Record, realizado em outubro de 1967, com as músicas "Domingo no parque", de Gilberto Gil, e "Alegria, alegria", de Caetano Veloso. ${ }^{184}$ Segue a síntese da maneira como Favaretto aborda o movimento:

\footnotetext{
${ }^{181}$ ALBUQUERQUE, Durval Muniz. O engenho anti-moderno, op.cit., p. 360.

${ }^{182}$ Ibid., p. 372.

${ }^{183}$ FAVARETTO, Celso Fernando. Tropicália - Alegoria, Alegria. São Paulo: Ateliê Editorial, 1996.

184،Alegria, Alegria" (quarto lugar) e "Domingo no Parque" (segundo lugar).
} 
A mistura tropicalista notabilizou-se como uma forma suigeneris de inserção histórica no processo de revisão cultural, que se desenvolvia desde o início dos anos 60. Os temas básicos dessa revisão consistiam na redescoberta do Brasil, volta às origens nacionais, internacionalização da cultura, dependência econômica, consumo e conscientização. Tais preocupações foram responsáveis pelo engajamento de grande parte dos intelectuais e dos artistas brasileiros na causa da construção de um Brasil novo, através de diversas formas de militância política (...) estas produções se dirigiam a um público intelectualizado de classe média, principalmente estudantes e artistas. ${ }^{185}$

Mais adiante, prossegue:

Rearticulando uma linha de tradição abandonada desde o início da década, retomando pesquisas do modernismo, principalmente a antropofagia oswaldiana, rompeu com o discurso explicitamente político, para concentrar-se numa atitude "primitiva", que, pondo de lado a "realidade nacional", visse o Brasil com olhos novos. Confundindo o nível emque se situavam as discussões culturais, o tropicalismo deu uma resposta desconcertante à questão das relações entre arte e política. ${ }^{186}$

Essas citações dimensionam a visão de Favaretto sobre o movimento, sempre calcado em revolucionar, em criar um novo Brasil, e que para isso passou a considerar a influência estrangeira. Favaretto cita um trecho de um artigo escrito por Caetano Veloso em 1966 para a Revista Civilização Brasileira, onde pela primeira vez Caetano fala de sua teoria sobre a linha evolutiva ${ }^{187}$ da música brasileira. Na análise de Favaretto, o conceito é tomado sem nenhum tipo de questionamento e até mesmo como parâmetro de análise, como fica perceptível no trecho transcrito a seguir:

Em nenhum momento os tropicalistas perderam de vista o seu objetivo básico: desde o simples uso de instrumentos

\footnotetext{
${ }^{185}$ FAVARETTO, Celso Fernando. Tropicália - Alegoria, Alegria, op. cit., p. 28.

186 Ibid., p.30.

${ }^{187}$ De acordo com Caetano: “Ora, a música brasileira se moderniza e continua brasileira, à medida que toda informação é aproveitada (e entendida) da vivência e da compreensão da realidade brasileira (...). Para is so nós da música popular devemos partir, creio, da compreensão emotiva e racional do que foi a música popular brasileira até agora; devemos criar uma possibilidade seletiva como base na criação. Se temos uma tradição e queremos fazer algo de novo dentro dela, não só temos que senti-la, mas conhecê-la. É este conhecimento que vai nos dar a possibilidade de criar algo novo e coerente com ela. Só a retomada da linha evolutiva pode nos dar uma organicidade para selecionar e ter um julgamento de criação (...) Aliás João Gilberto, para mim, é exatamente o momento em que isto aconteceu: a informação da modernidade musical utilizada na recriação, na renovação, no dar um passo à frente na música popular."
} 
eletrônicos, ruídos e vozes em "Alegria, alegria" e "Domingo no parque", o emprego de recursos aleatórios e seriais, a incorporação do grito por Gal Costa e até a trituração da melodia por Gilberto Gil, mantiveram-se fiéis à linha evolutiva, reinventando e tematizando criticamente a canção. ${ }^{188}$

Como a intenção da investigação aqui proposta é perceber a maneira como foi elaborada uma noção de africanidades na trajetória de Gilberto Gil, em especial nos interessa atentar para o que Favaretto denomina ritmos regionais, manifestação folclórica e música urbana, e de que maneira elementos afro possam estar inseridos nessas conceituações. Quanto ao popular, a descrição a seguir dimensiona a abordagem do autor:

O tropicalismo tinha em comum com o pop o interesse de problematizar os comportamentos e a linguagem antitradicionalistas de uma área determinada da juventude - os universitários saídos, em grande parte, da classe média. O tropicalismo não fugiu à regra: não tematizou o popular; explorou os mitos urbanos. ${ }^{189}$

Ainda em função da elaboração tropicalista em relação ao popular, em outra passagem do texto, Favaretto afirma:

O que o tropicalismo retém do primitivismo antropofágico é mais a concepção cultural sincrética, o aspecto de pesquisa de técnicas de expressão,o humor corrosivo, a atitude anárquica com relação aos valores burgueses, do que sua dimensão etnográfica e a tendência em conciliar as culturas em conflito. ${ }^{190}$

Para Favaretto o tropicalismo metaforiza o Brasil, por fazer alusão a sua indefinição, mesclando arcaísmos e modernismos. As referências aos aspectos que podem ser associados ao popular são em todas as passagens desprovidos de maiores explicações, e podem bem ser sintetizados através da seguinte frase de Favaretto: "mistura de ritmos populares em formas cultas de música" ${ }^{191}$ De acordo com o autor, o movimento da Tropicália surgiu com a intenção de reorganizar a cultura nacional, em especial sua interferência política na realidade, pela experimentação em diálogo com outras artes, que

\footnotetext{
${ }^{188}$ FAVARETTO, Celso Fernando. Tropicália - Alegoria, Alegria, op. cit., p. 41.

189 Ibid., p. 49.

${ }^{190}$ Ibid., p. 57.

${ }^{191}$ Ibid., p. 136.
} 
se fez notar não só nos discos, mas também em shows, nos seus programas de televisão, mas especialmente através da influência no comportamento dos jovens. Nas análises de Favaretto, o popular para os tropicalistas estava mais conectado ao pop, ao universo da cultura de massa, do que propriamente a uma dimensão etnográfica, ou seja, com um sentido de "coletar" experiências sonoras de determinadas tradições populares brasileiras.

Outra análise que nos possibilita pensar sobre a questão do popular no tropicalismo é a realizada por Hilda Lontra:

\begin{abstract}
Na busca das raízes nacionais, Caetano Veloso e Gilberto Gil atualizavam ídolos do passado, reinterpretando as canções de Carmem Miranda e de Vicente Celestino, por exemplo, incorporavam temas e recursos da literatura de cordel em suas canções, faziam uma releitura de textos antológicos como Iracema, de José de Alencar, e "Luar do sertão", de Catulo da Paixão Cearense; e mencionavam, nos textos, autores contemporâneos como Roberto Carlos e Chico Buarque de Hollanda. ${ }^{192}$
\end{abstract}

O popular referenciado pelos tropicalistas nesse momento, de acordo com Lontra, era Roberto Carlos, Catulo, Celestino, Carmem, e não o popular dos candomblés, dos sambas de roda, dos afoxés, ${ }^{193}$ aspectos fortemente identificadores, entre outras coisas, de africanidades na cultura brasileira. Esse popular estava mais atrelado à grande popularidade dos cantores da era do rádio, mas recapitulados pelos tropicalistas como fortes representantes de um Brasil arcaico.

Edwar Castelo Branco questiona a existência de um "grupo-núcleo" tropicalista, e pondera que o movimento deve ser interpretado como um guarda-chuva que abrigou diversas virtualidades:

E não se trata de propor uma inversão do exercício discursivo, excluindo a arte de Caetano Veloso e Gilberto Gil deste universo de "ondas portadoras". Trata-se, antes, de demonstrar que o processo de nomeação do movimento tropicalista varre para a margem - portanto impede sua interpelação em sujeito - outros tantos nomes que, a partir da década de sessenta,

\footnotetext{
${ }^{192}$ LONTRA, Hilda O. H. Tropicalismo: a explosão e seus estilhaços. In: CYNTRÃO, Sylvia Helena (org). A forma da festa-tropicalismo: a explosão e seus estilhaços. Brasília: Editora Universidade de Brasília; São Paulo: Imprensa Oficial do Estado, 2000, p. 48.

${ }^{193}$ Que posteriormente em muito irão interessar a Gil, como veremos nos capítulos seguintes.
} 
estiveram empenhados no processo de redefinição e de universalização da arte brasileira. Se há um ponto de comunicação entre as diversas vanguardas artísticas dos anos sessenta, este está no esforço para justapor - nos diferentes campos da arte brasileira e não apenas na música -elementos diversos das culturas brasileiras e internacional, como objetivo de trazer para o centro da produção artística nacional, operando um processo de desmistificação, as contradições históricas do Brasil tropical. Não é suficiente, portanto, pensar apenas o cafonismo e o humor como práticas construtivas de um projeto tropicalista, assim como não é suficiente pensar apenas as rupturas no campo da música como expressão-síntese da atualização do campo artístico nacional à emergência da pós-modernidade no Brasil. O tropicalismo é múltiplo, tanto do ponto de vista de seus campos de ocorrência, quanto em relação a seus sujeitos. A identidade entre as diversas virtualidades tropicalistas não está no modo como estas virtualidades se comunicam esteticamente, mas na unanimida de destes sujeitos em relação à necessidade de desentranhar novas linguagens. ${ }^{194}$ [ grifos meus]

Não somente Castelo Branco, mas outros autores também apontam o fato de que o movimento tropicalista é na verdade multifacetado, embora muitas vezes percebido a partir de uma totalidade coerente e programática, priorizando-se quase sempre o aspecto musical. Questionamentos semelhantes foram realizados por Frederico Coelho, que argumenta que o tropicalismo é uma "história contada diversas vezes, com pequenas nuanças de personagens e eventos... em um circuito vicioso de referências", ${ }^{195}$ e também por Marcos Napolitano e Mariana Villaça, que afirmam que "a fala das fontes acaba por se confundir com a própria historicidade". ${ }^{196}$

Não tenho a intenção aqui de reforçar a ideia de que Caetano e Gil foram as figura s mais importantes desse movimento, e nem mesmo tomar seus depoimentos como a própria historicidade do tropicalismo. A frequente utilização dos depoimentos transcritos a seguir, alguns feitos no calor dos acontecimentos aqui narrados e outros concedidos mais de quatro décadas após o acontecido, trazem uma série de complicações, já que muitas vezes carregam olhares desses presentes, mas não deixam de contribuir para a compreensão do passado. No entanto, mesmo com a existência problemática de um relativismo temporal, acredito que esses depoimentos ajudam não só a elucidar aspectos

\footnotetext{
${ }^{194}$ BRANCO, Edwar de Alencar Castelo. Todos os dias de paupéria: Torquato Neto e a invenção da tropicália. São Paulo: Annablume, 2005, p. 139.

${ }^{195}$ COELHO, Frederico. A formação de um tropicalista: um breve estudo da coluna "Música popular", de Torquato Neto. Estudos Históricos, Rio de Janeiro, FGV, n ${ }^{\circ}$ 30, 2002, p. 131.

${ }^{196}$ NAPOLITANO, Marcos e VILLAÇA, Mariana. Tropicalismo: As Relíquias do Brasil em debate. Revista Brasileira de História, vol. 18, n 35, São Paulo, 1998.
} 
culturais e políticos daquele momento como também a sua sobrevivência no presente. $\mathrm{E}$ ainda mais importante é perceber a maneira como Gil estava inserido no contexto tropicalista, questionando a realidade cultural brasileira e de que maneira as africanidades se fizeram delineadas nesse esforço voltado à compreensão do Brasil.

Em 1968, em entrevista dada por Gil a Augusto de Campos, o tropicalismo ainda não era nomeado. Falava-se então em movimento. Na ocasião, Gil deu o seguinte depoimento:

\begin{abstract}
Agora, do ponto de vista do significado do nosso trabalho diante da música brasileira, eu acho que talvez seja isso: que a gente tenha se jogado ao exercício da liberdade, que a gente tenha percebido a necessidade de uma nova linguagem, que inclua uma visão mais total do homem (...) Então, isso que a gente pretende hoje, incluir uma linguagem mais cruel, mais realista em relação ao homem. É uma proposta nova dentro da música brasileira, que seria talvez uma das características do nosso trabalho. Que mais? $\mathrm{O}$ risco. Essa necessidade de assumir o risco. Esse descompromisso total com os estilos, com os modismos, com as coisas descobertas e exauridas ${ }^{197}$ [ grifos meus]
\end{abstract}

Liberdade, novidade, totalidade e risco são palavras que representam bem o ideal que Gil, Caetano, mas também Torquato Neto, Capinam, Gal, Rogério Duarte, Os Mutantes, Rogério Duprat, dentre outros, estavam assumindo naquele momento enquanto ideia e atitude.

Transcrevo a seguir o trecho de uma reportagem ${ }^{198}$ publicada em 1969, do período de eclosão do movimento, que nos fornece mais alguns indícios de análise:

Segundo os tropicalistas, como o plástico é coisa da era industrial, Caetano achou oportuno usar colares de macumba como "um lembrete do nosso subdesenvolvimento". Colares, cintos, plumas e outros detalhes de vestimenta são às vezes trocados pelos baianos num sistema de rodízio, rigorosamente disciplinado por Guilherme Araújo. Foi ele quem obrigou Gilberto Gil a deixar crescer a barba e o bigode, a três meses de regime, a emagrecer e a vestir roupas estilo africano.

${ }^{197}$ CAMPOS, Augusto de. Balanço da bossa e outras bossas, op. cit., p.194.

${ }^{198}$ EXISTE algo de concreto nos baianos. Veja, 13 nov. 1968. 
A utilização dos colares de macumba, ideia de Caetano Veloso, tinha a intenção de celebrar o "atraso" brasileiro. De acordo com a reportagem, as ideias eram criadas em grupo e em especial fomentadas pelo empresário, e em nenhum momento parece ter partido do próprio Gil o desejo de vestir roupas africanas, nem mesmo em outras passagens da reportagem. Os sentidos atrelados ao candomblé e às roupas africanas não foram citados com o intuito de reverenciar a tradição cultural afro-brasileira, ou mesmo celebrá-la de modo apologético, mas utilizadas enquanto simbologia para rememorar nosso subdesenvolvimento.

No entanto, uma importante referência sobre a ligação de Gil com o universo afro, fez-se notar em outra matéria sobre a inserção da música de terreiro ${ }^{199}$ no samba. Numa reportagem publicada em 1969, é possível perceber que não há menção à África e a negritude que, de fato não faziam parte dos símbolos adotados por Gil ao descrever sua criação musical nessa fase tropicalista. Assim Gil é apresentado pela revista:

Gilberto Gil, 26 anos, apesar de baiano, nunca foi a um terreiro de macumba: "juro por todos os santos". Gil não espera ver sua "batmacumba" nos terreiros. "Foi composta como poema concreto mesmo". Na Europa, em janeiro, Gil vai apresentar "batmacumba" com três batmacumbeiros brancos - Os Mutantes: "não quero dar a impressão de folclore". ${ }^{200}$

A postura em tentar desassociar sua música do folclore é uma constante em toda a trajetória de Gil. Através do depoimento transcrito acima, realizado em 1969, é possível perceber até mesmo certa resistência de Gil em associar sua criação musical ao terreiro de candomblé, demarcando bem mais sua conexão com a poesia concreta.

Em outro depoimento de Gil, realizado em 1971, ele questiona sua participação no movimento tropicalista, demonstrando que nem sempre o movimento se deu de forma lógica e sem maiores confrontos pessoais:

$\mathrm{Na}$ verdade, eu não tinha nada na cabeça a respeito do tropicalismo. Então a imprensa inaugurou aquilo tudo com o nome de tropicalismo. E a gente teve que aceitar, porque tava lá, de certa forma era aquilo mesmo, era coisa que a gente não podia negar. Afinal, não era nada que viesse desmentir ou negar a nossa condição de artista, nossa posição, nosso pensamento, não era.

\footnotetext{
${ }^{199}$ Músicas tocadas nas cas as de candomblé.

${ }^{200}$ SEGURA este samba, não deixa cair. Veja, 1 jan. 1969.
} 
Mas a gente é posta em certas engrenagens e tem que responder por elas. ${ }^{201}$

Diferentemente de Gil, Caetano parece sempre ter visto uma lógica no movimento.

Em 1968, já no auge do tropicalismo, afirmou:

Eu e Gil estávamos fervilhando de novas ideias. Havíamos passado bom tempo tentando aprender a gramática da nova linguagem que usaríamos, e queríamos testar nossas ideias, junto ao público[...] Trabalhando noite adentro, juntamente com Torquato Neto, Gal, Rogério Duprat e outros. Ao mesmo tempo, mantínhamos contatos com artistas de outros campos, como Glauber Rocha, José Celso Martinez, Hélio Oiticica e Rubens Gerchman. Dessa mistura toda nasceu o tropicalismo e a tentativa de superar nosso subdesenvolvimento partindo exatamente do elemento "cafona" da nossa cultura, fundindo-o ao que houvesse de mais avançado industrialmente, como guitarras e as roupas de plástico. Não posso negar o que já li, nem posso esquecer onde vivo. ${ }^{202}[$ grifos meus $]$

Em 1972, Gil disse ao Jornal da tarde sobre os Beatles:

... O meu envolvimento pela música dos Beatles foi, principalmente, pelo exercício de liberdade nova que eles propuseram à música popular mundial - uma coisa flagrante (...) os Beatles quase que puseram em liquidação todos os valores sedimentados da cultura nacional anterior. Eles procuraram colocar tudo no mesmo nível: o primitivismo dos ritmos latinoamericanos ou africanos em relação ao desenvolvimento musical de um Beethoven, por exemplo. ${ }^{203}$ [grifos meus]

É interessante salientar que, no momento em que fermentavam os ideais do tropicalismo, envoltos por uma série de discussões que tematizavam através da música os valores da cultura nacional, o próprio ato de exaltar os Beatles já significava colocar- se contra aqueles que defendiam a pureza da sonoridade brasileira. E aqui nos é de grande importância o local ocupado pela África, aqui representada pelos ritmos africanos, colocados em paridade com os latino-americanos. É a menção a uma África ainda

\footnotetext{
${ }^{201}$ His tória da Música Popular Brasileira, São Paulo, Abril Cultural, 1971, fasc. 30, p. 10. In:

FAVARETTO, Celso Fernando. Tropicália - Alegoria, Alegria, op. cit., p. 24.

${ }^{202}$ BAR, Décio. Acontece que ele é baiano. Realidade, ano III, n. 33, dez 1968, p. 197. In: FAVARETTO, Celso Fernando. Tropicália-Alegoria, Alegria,op. cit.

${ }^{203}$ In: GÓES, Fred. Gilberto Gil -seleção de textos, notas, estudos biográfico, histórico e crítico e exercícios. São Paulo: Abril Educação, 1982, p. 5.
} 
desconhecida, já que Gil chega ao continente indiretamente, pelo contraste, através da conceituação e elaboração que faz da música dos Beatles.

Os depoimentos de Gil realizados na época do florescimento do tropicalis mo denotam a busca pela libertação. A menção à novidade era constante em grande parte das entrevistas concedidas por Gil naquele momento, além do comprometimento com a música brasileira. Não foram encontradas nas fontes citadas, e nas demais analisadas produzidas na época do movimento, nenhum indício que demonstrasse a busca de Gil por elementos que representassem especificamente o mundo das africanidades. Essa era uma questão não posta para o tropicalista Gilberto Gil.

Em depoimento concedido em 2010 o diretor de cinema Carlos Diegues dimensiona como havia naqueles idos dos anos 1960 um sentimento, um desejo caracterizado por compreender o país:

(...) a minha geração foi a última safra de uma série de redescobridores do Brasil. O Brasil começa a se conhecer, sobretudo com o romantismo (...) aquele desejo de uma identidade (...). Minha geração, do cinema novo, do tropicalis mo, é a última representação desse esforço secular. ${ }^{204}$

Essa mesma intenção presente na fala de Diegues, em (re)descobrir o Brasil, também está presente em várias passagens do livro de memórias de Caetano Veloso. Apesar de se tratarem de rememorações, dimensionam como esses sujeitos conceberam sua participação para a cultura brasileira. Em depoimento a Zappa, Gil, ao tratar do tropicalismo, se refere a esse esforço no qual os artistas estavam empenhados em meados dos anos 1960:

\begin{abstract}
A Tropicália queria ser o Cinema Novo de Glauber, do Terra em transe, o teatro de $O$ rei da vela, de Oswald de Andrade, os Beatles e os Rolling Stones, o rock'n'roll, o iê-iê-iê. Era um movimento para anunciar isso. Caetano muito consciente, muito culto, dominando como ele dominava todas as movimentações do cinema mais contemporâneo da Europa, do Godard, do Fellini, do Rossellini, do Truffaut, dos grandes filmes, do cinema americano (...) E, naquele momento, o papel foi esse, foi essa instauração de uma base moderno-pós-moderno nova, uma base de complexidade, uma base de simultaneidade para onde tudo convergia aqui no Brasil. Era essa a missão. Todas as
\end{abstract}

\footnotetext{
${ }^{204}$ Entrevista a Zuleika Bueno. In: RIDENTI, Marcelo. Brasilidade revolucionária, op.cit., 2010, p. 92.
} 
novas mentalidades convergiam, havia o espírito de um novo tempo, o movimento de uma nova era. ${ }^{205}$

Os depoimentos de Caetano, Gil e Diegues demonstram que não só havia uma ambiência em busca de algo novo no meio artístico daquele momento, como também o interesse em compreender e reinventar as coisas do Brasil; esse desejo era uma espécie de missão, de esforço para forjar uma nova identidade brasileira.

Caetano, em seu livro de memórias, comenta que o tropicalismo pretendia "acabar de vez com a imagem do Brasil nacional-popular". 206 De acordo com Caetano,

... o nacionalismo dos intelectuais de esquerda, sendo uma mera reação ao imperialismo norte-americano, pouco ou nada tinha a ver com gostar das coisas do Brasil ou - o que eu mais me interessava-com propor, a partir do nosso jeito próprio, soluções originais para as soluções do homem e do mundo... ${ }^{207}$

A intenção não era o rompimento com o nacionalismo, até mesmo porque a preocupação de Caetano com o Brasil passava pela intenção de criar soluções para os problemas nacionais; no entanto, sem deixar de levar em consideração as mudanças do cenário internacional. Dessa forma, de acordo com Caetano, os tropicalistas

Queriam poder mover-se além da vinculação automática com as esquerdas, dando conta ao mesmo tempo da revolta visceral contra a abissal desigualdade que fende um povo ainda assim reconhecivelmente uno e encantador, e da fatal e alegre participação na realidade cultural urbana universalizante e internacional, tudo isso valendo por um desvelamento do mistério da ilha Brasil. ${ }^{208}$

Em depoimento ao programa Roda viva, sobre o nacionalismo cultural dos anos 1960, Caetano disse:

Uma das primeiras coisas que a gente pensou no tropicalismo foi sair desse grilo. Ele representava uma ameaça de fazer a cultura brasileira estacionar numa visão do que tinha sido o modernismo, virar um mero nacionalismo populista. Isso nós percebemos e não queríamos (...) A questão do nacionalismo a gente tem que

\footnotetext{
205 ZAPPA, Regina. Gilberto bem perto, op. cit., p. 126.

${ }^{206}$ VELOSO, Caetano. Verdade Tropical, op. cit., p. 28

207 Ibid., p. 87.

${ }^{208}$ Ibid., p. 16.
} 
ver, rever a toda hora. (...) O tropicalismo, para Tinhorão, afinal de contas, era mais palatável (que a bossa nova), porque naquela confusão muitas coisas que soavam populistas vinham de cambulhada. ${ }^{209}$

Uma constante no livro de memórias de Caetano é a oposição que o compositor faz ao ideal nacional-popular, bem como a percepção de uma alienação da esquerda, que se fazia notar em especial pela tentativa de preservar a cultura nacional sem atentar para as informações que vinham de fora. A saída apontada por Caetano para esse problema, no período do tropicalismo, era uma busca que não se pautasse simplesmente pela imitação, atentando para a produção e a superação do complexo de inferioridade dos brasileiros.

No documentário Uma noite em 1967 é possível perceber a ambiência de intensidade e paixão experimentada pela plateia dos festivais, bem como acompanhar o depoimento de vários artistas e envolvidos nos festivais. Para Gil, sua participação no movimento tropicalista se dera através da força de Caetano:

Pra que eu pudesse minimamente contribuir pro projeto tropicalista, que teve que se destacar do resto, eu tive o tempo todo que ser puxado pelo Caetano. Puxado literalmente, por mim mesmo eu não teria feito a cizânia, a divisão, aquilo tudo era uma agonia pra mim. O espírito da minha música não é esse... Minha música é o OM ${ }^{210}$ né? É o que ela quer ser, não cabe divisão nenhuma. Aquilo tudo, o Tropicalismo era uma fase agônica. ${ }^{211}$ [grifos meus]

Anos após o que fora considerado uma revolução estética, e também com maturidade e distanciamento para uma análise menos emotiva e mais racional do evento, Gil conta que

Nós fazíamos uma tentativa de adaptação de elementos brasileiros, elementos da música baiana e nordestina, elementos da tradição urbana do Rio e de São Paulo, da bossa nova, de Jobim. Juntávamos tudo isso para produzir uma música pop brasileira; que ainda que se utilizasse de coisas que vinham de fora e se baseassem ne las, acabavam transformando em cois as completamente diferentes. Foi uma coisa de se jogar, uma coisa de paixão absoluta de expressão pela coisa da

\footnotetext{
${ }^{209}$ Programa Roda Viva, TV Cultura, 1996.

${ }^{210}$ Um mantra evocado com o intuito de pedir proteção e sustentação.

211 TERRA, R.; CALIL, R. Uma noite em 67. Documentário. Videofilmes, 2010.
} 
música. Eu não tinha projeto intelectual, isso ficava mais a cargo de Caetano Veloso. ${ }^{212}$ [grifos meus]

Ao refletir sobre o tropicalismo, Gil contou à Zappa que se define como um ser que funciona "da cabeça para baixo." E conta ainda que "era uma espécie de batedor, desbravador pela intuição, pelo impulso, pelo empuxo, o ser empurrado e puxado pelas coisas, meio índio africano na floresta, ameríndio das matas, aquela coisa que sou até hoje." 213 Sobre esse sentimentalismo, Gil conta ainda que

\begin{abstract}
Você vê como eu me expresso, como eu falo, é tudo daqui pra baixo (aponta para o pescoço). Isso aqui (a cabeça) funciona apenas como um armazém de signos verbais, palavras e tudo, porque a caixa da ressonância da vontade, do sentimento é tudo aqui (aponta para o coração). No sentido de movimento, de articulação, de lógica, de racionalidade, tudo foi obra de Caetano, que explicava e contextualizava o que estava ao redor, fazia a ligação histórica com tudo aquilo, explicava o que se buscava resgatar ou aposentar, no que fosse conveniente resgatar e aposentar. ${ }^{214}$
\end{abstract}

Essas referências de Gil deixam claro que cabia a Caetano conceituar o movime nto enquanto um projeto também intelectual. Nesses depoimentos, fica claro que a busca musical tropicalista tendia a incorporar elementos que estivessem conectados com a pósmodernidade, misturando aspectos da música nordestina e da música urbana, numa reapropriação que mesclou música contemporânea, ${ }^{215}$ poesia concreta, cantores considerados bregas, colagens de sons, gritos e inovação nas performances, além de figurinos até então desconhecidos para a época, que utilizavam plástico, acompanhados de vastas cabeleiras.

Gravado em maio de 1968, o disco Tropicália ou Panis et Circensis ${ }^{216}$ teve como regente e arranjador Rogério Duprat, e como produtor, Manuel Barenbein. Os participantes do LP são Caetano, Gil, Gal, Nara Leão, Tom Zé, Capinam, Torquato e Os

\footnotetext{
${ }^{212}$ Gilberto Gil - La passion sereine. Produzido no Brasil em 1987 pela TF1 em associação com o "Centre de la Cinematographie Et Du Ministeire Des Affaires etrangeres", dirigido pelo diretor francês Hubert Niogret.

${ }^{213}$ ZAPPA, Regina. Gilberto bem perto, op. cit., p. 120.

${ }^{214}$ Ibid., p. 121.

${ }^{215}$ Representada especialmente através da parceria com o compositor e arranjador Rogério Duprat, através da utilização dentre outros aspectos da música eletrônica, criada ou modificada através do uso de equipamentos e instrumentos eletrônicos, como por exemplo sintetizadores, gravadores digitais, computadores ou softwares de composição.

216 Álbum Tropicália ou Panis et Circensis (Universal, 1968).
} 
Mutantes. A sonoridade do LP explora colagens de muitos efeitos sonoros, como conversas em sala de jantar, bombas, barulhos de uma missa, além de intervenções de orquestra em todo o LP. Dentre os ritmos populares utilizados em sua produção estão o bolero, a marcha, a polca, o rock, ritmos latinos, e não há, para além de pequenas citações ao baião e ao samba, nenhuma referência explícita a manifestações musicais ligadas a culturas populares afro brasileiras.

Sobre a sonoridade tropicalista, afirma Albuquerque:

O tropicalismo desnacionaliza sons e temas, também os de regionaliza, retirando a marca folclórica e tradicional destes. As canções tropicalistas agenciam, como base, sonoridades nordestinas, que são retrabalhadas com elementos musicais modernos, deixando de ser um som do Nordeste ou do Sul, mas um som do Brasil para o mundo. O arquivo musical nordestino deixa de ser a "reserva de raízes" para proliferar como rizomas de novas sonoridades. ${ }^{217}$

Quanto à aparição de aspectos africanos nesse disco, a música "Batmakumba" é bastante elucidativa do modo como o tropicalismo se apropriou desses elementos em suas composições. De acordo com Gil,

Caetano e eu sentados no chão do apartamento dele, na Avenida São Luís, centro de São Paulo, compondo a música: o que a gente queria, hoje me parece, era fazer uma canção com um dístico que fosse despida de ornamentos e possível de ser cantada por um bando não musical, algo tribal, e que, por isso mesmo, estivesse ligada a um signo da nossa cultura popular como a macumba, essa palavra nacional para significar todas as religiões africanas, não cristãs, e que é um termo que o Oswald de Andrade usou. O Oswald estava muito presente na época; nós estávamos descobrindo a sua obra e nos encantando com o poder de premonição que ela tem. A ideia de reunir o antigo e o moderno, o primitivo e o tecnológico, era preconizada em sua filosofia; Batmakumba é de inspiração os waldiana. E concretista - na ligação das palavras e na construção visual do $\mathrm{K}$ como uma marca; no sentido impressivo, não só expressivo, da criação. Não é só uma canção; é uma música multimídia, poema gráfico, feita também para ser vista. Naquele momento, nós vivíamos cercados de elementos de interesses múltiplos, ligados nas novidades sonoras e literárias trazidas pelos poetas concretos e pelos músicos de vanguarda de São Paulo. Sobre a adoção, a partir de agora, do $\mathrm{K}$ na microestrutura do poema, em lugar do c (em decorrência do que também o y passa a substituir o anteriormente

${ }^{217}$ ALBUQUERQUE, Durval Muniz. O engenho anti-moderno, op.cit., p. 437. 
grafado i, para melhor expressão tipográfica da alusão ao gênero de música estrangeira em moda na época) - Eu tenho a impressão de que chegamos a grafar a palavra com $\mathrm{k}$ porque vimos que $\mathrm{o}$ poema formava um K. O k passava a ideia de consumo, de coisa moderna, internacional, pop. E também de um corpo estranho; não sendo uma letra natural do alfabeto português-brasileiro, causava uma estranheza que era também a estranheza do Batman. Sobre "bá", "obá", "baobá" como alguns dos sentidos sintetizados nas duas grandes palavras-valises da canção - Pode ser que para o Caetano essas palavras tenham sido percebidas ou colocadas conscientemente ali, mas eu não descobri a presença delas na época, pelo menos; são extrações posteriores. Para mim não havia, por exemplo, o 'obá' entidade, só o 'oba' saudação, inte rje ição. A palavra 'bat', morcego, $\operatorname{sim}^{218}$ [grifos meus]

Essas reflexões posteriores sobre a composição de "Batmakumba" em muito nos informam, pois, a música foi inspirada em Oswald de Andrade e no concretismo, e não em qualquer tipo de ligação ou vivência de seus autores com a religiosidade afrobrasileira. Não há, por exemplo, nenhum canto de ponto de terreiros. Sua confecção não está associada a símbolos de tradição africana, mas sim a uma modernidade mais pop e a um poema gráfico. Visualmente arquitetado, levou em conta a forma do texto escrito e também o universo pop do Batman das histórias em quadrinhos. Os aspectos sonoros também indicam que não havia a intenção de reproduzir as músicas dos rituais do candomblé. Seja na rítmica utilizada ou no instrumental, o gênero utilizado na composição é um rock acompanhado de um bongô, sem nenhuma referência a qualquer ritmo executado no candomblé e nenhum canto para qualquer Orixá.

Aqui a macumba não é sacralizada, mas citada enquanto elemento da tradição cultural brasileira, traduzida e transformada em símbolo pop, integrando diferentes materiais nessa produção artística. Não é a leitura da tradição, mas sua (re)leitura urbana e concretista, na qual a modernidade forneceu novas possibilidades para a interpretação tropicalista. Aqui o "local" representado pela macumba e pelo concretismo se mesclou ao "global" do rock e do Batman produzindo uma música processada pela hibridização.

Quem nos fornece outros indícios para compreendermos a confecção dessa canção tropicalista é Eduardo Kolody Bay. O autor analisa os elementos que compõem a música e a compara a um mantra nada calmo, mas sim vigoroso e pulsante. Bay afirma que "muito embora o ritmo de Bat macumba não seja idêntico a nenhum ritmo religioso

\footnotetext{
${ }^{218}$ RENNÓ, Carlos (org). Gilberto Gil, op. cit., p. 98.
} 
específico, sua incorporação é alegórica: carrega um fragmento simbólico dessas religiões, o timbre do terreiro ao timbre industrial das guitarras. "219

Ao investigar a hibridização da cultura contemporânea, Canclini demonstra ser importante compreender não somente os processos de produção de bens simbólicos realizados nos movimentos sociais, mas também a atuação política e cultural desses movimentos. De acordo com Canclini, a transnacionalização dos mercados simbólicos não só desconstruiu os antagonismos modernos - cosmopolitismo versus nacionalismo - como possibilitou hibridizar o global e o local. Nessa perspectiva, uma cultura hîbrida é "um lugar híbrido, no qual se cruzam os lugares realmente vividos."220

Entrevistado por Ana Paula de Oliveira e questionado sobre as poucas referências em relação à questão étnica no tropicalismo, Gil acaba nos dando várias pistas sobre as experiências que contribuíram para sua conscientização da questão da negritude:

Eu nunca tinha ido ao candomblé. Só fui depois do exilio. Aí é que me aproximei dos blocos, do significado profundo do carnaval da Bahia. Salvador é uma cidade já muito misturada. Vivi a infância e a adolescência no bairro de Santo Antônio, que é médio por excelência. Quer dizer, um bairro onde convivem árabes, negros, espanhóis, brancos, mestiços, mulatos, cafuzos, gente do sertão... E todos de classe média, com casa e profissão liberal. E a média é a média. Vivi ali, na média das coisas, sem perceber os polos. Só fui sentir o racismo quando comecei a ir ao Colégio Marista, de pequenos burgueses, na maioria brancos. [...] Por isso, e u não tinha noção dessa profunda divisão racial e muito menos da cultural. Os blocos eram afros, mas incluíam todo mundo! Era a própria cidade de Salvador, como nós, mulatos. Durante o exílio, vi que na Inglaterra a questão racial tinha mais peso. Então conheci a consciência negra como um trabalho apoiado no mundo inteiro pelos ativistas americanos, e a informação exaustiva sobre os movimentos de libertação na África... Isso culminou em mim quando saí nos Filhos de Gandhi. Depois fui ao Festival de Artes Negras na África. E aí vem

\footnotetext{
${ }^{219}$ BAY, Eduardo Kolody. Sobre atabaques, máquinas de costura distorcidas e macumbeiros picarescos. In: BRITO, Eleonora Zicari Costa de; PACHECO, Mateus de Andrade; ROSA, Rafael (orgs). Sinfonia em prosa: diálogos da história com a música. São Paulo: Intermeios, 2013.

${ }^{220}$ CANCLINI, Néstor. Culturas híbridas: estratégias para entrar e sair da modernidade. São Paulo: Edusp, 2008, p. 327.
} 


\section{Refavela, que é o primeiro manifesto negro, não é? [grifos meus] $]^{221}$}

Esse depoimento nos dá a forte dimensão da ligação de Gil com tais questões já num momento em que sua carreira havia se consolidado. Foi no exílio e através dos movimentos de libertação na África que Gil começou a elaborar essa conscientização, que foi reforçada quando saiu no Afoxé Filhos de Gandhy. Após o exílio, sua busca por conhecer o Brasil acabou esbarrando na forte configuração negra da cultura musical do nosso país. Resta agora encontrar mais vestígios sobre a construção da temática negra tanto na trajetória quanto na musicalidade de Gil.

Em 1993, Gil e Caetano lançaram o disco Tropicália 2 em comemoração pelos 25 anos do tropicalismo. Sobre esse lançamento, Gil declarou:

Como manifesto geral, é uma manifestação de crença na liberdade e na pluralidade. É um disco democrático. No plano individual, é um disco de reafirmações de origens - o sertão, o baião, o samba de roda da Bahia, a minha expressividade afrobaiana, as músicas americanas que eu ouvia quando criança, o pop dos anos 1960. No sentido íntimo, é um disco saudosista, de reminiscências (...) Cair na direita ou na esquerda é pouco. Quando eu era do centro acadêmico da Universidade Federal da Bahia, já era visto como um delirante, um sonhador, como alguém que falava de depois da ação, e não da ação. Eu já não era bem visto e fui piorando cada vez mais. Não sirvo para nada a não ser para este projeto de todos, de tudo de uma vez, de tudo para melhor. Sou imprestável para questões parciais. A vida é feita muito por parcialidade, pelas melhores escolhas possíveis que se fazem. Eu tenho uma dificuldade para escolher. ${ }^{222}$

É interessante notar que, na elaboração dessa nova Tropicália revisitada, relançada quase três décadas após a primeira, já existe na identidade de Gil a presença de africanidades, que se fazem inclusive demarcadas pela Bahia; é uma expressividade afrobaiana. Se nas falas realizadas no calor do aparecimento do movimento a liberdade era a peça inaugural, anos após essa continua a ser o elemento primordial do tropicalismo.

Retornando ao período de surgimento do tropicalismo, outra fonte que nos possibilita acessar o universo sonoro explorado pelo artista naquele momento é o disco

\footnotetext{
${ }^{221}$ OLIVEIRA, Ana Paula (entrevistadora). Tropicália revisitada. Para o site: www.tropicalis mo.com.br. In: COHN, Sergio (org.). Gilberto Gil-Encontros. Rio de Janeiro: Beco do Azougue, 2007, p. 253.

${ }^{222}$ AZEVEDO, Eliane. Os jovens querem MPB. Veja, 8 set. 1993.
} 
lançado em $1968^{223}$ por Gil. O LP já mostra na capa a forte influência dos Beatles, que se faz presente também na sonoridade do LP. Gil utiliza linguagem de frevo, orquestração, rock, rock experimental, pífaro, samba, colagens sonoras, barulhos, bateria fazendo ritmos com levadas que sugerem música latina, além de uma levada de capoeira em "Domingo no parque". Assim como Tropicália ou Panis et circensis, esse LP teve como produtor Manoel Barenbein, com arranjo e regência de Rogério Duprat e participação dos Mutantes, e ambos se assemelham em sonoridade e estética. Trata-se de uma espécie de LP tropicalista de Gil. Misturando a sonoridade do rock psicodélico com orquestração e música brasileira, o mundo das africanidades diaspóricas começa a dar seus sinais de presença através do rock e das levadas latinas.

Depois da tentativa de compreender as experiências, memórias, bem como algumas das análises referentes ao movimento tropicalista, e da produção musical de Gil naquele momento, e, de que maneira foram realizadas nessas vivências menções à África, resta-nos agora demarcar o que contribuiu para que o tropicalismo deixasse de ser celebrado, tornando possível que Caetano e Gil fossem exilados.

Não somente o som ou as roupas, mas especialmente o comportamento de um modo geral dos tropicalistas incomodava aos mais conservadores. Ao se posicionare m como críticos do ideal nacional-popular e aderirem a uma postura libertária na maneira de se vestir e de produzir música, os tropicalistas não apenas eram atacados por parte da juventude nacionalista, como também passaram a chamar a atenção dos militares. No Festival Internacional da Canção de 1968, Caetano apresentou “É proibido proibir", e foi desclassificado. Depois de agressões e até mesmo tomates e ovos atirados ao palco, Caetano proferiu um discurso que dias depois foi lançado em um compacto, juntamente com a canção "É proibido proibir":

\footnotetext{
Vocês estão por fora! (...). Mas que juventude é essa? Vocês jamais conterão ninguém. Vocês são iguais a sabe quem? São iguais sabem a quem? Tem som no microfone? Vocês são iguais sabe a quem? Àqueles que foram na Roda Viva e espancaram os atores! Vocês não diferem nada deles, vocês não diferem em nada. E por falar nisso, viva Cacilda Becker! Viva Cacilda Becker! Eu tinha me comprometido a dar esse viva aqui, não tem nada a ver com vocês. O problema é o seguinte: vocês estão querendo policiar a música brasileira (...) Mas eue Gil já abrimos
}

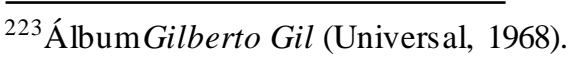


o caminho. O que é que vocês querem? Eu vim aqui para acabar com isso! $!^{224}$

Envolto por um clima de tensão, ao ser agredido pela plateia Caetano a agride de volta. Com os ânimos exaltados, a fala de Caetano é agressiva e quase gritada. Caetano identifica os agressores da plateia com os militares e ressalta que o caminho aberto por ele e Gil está sendo policiado. Ainda em 1968, após o FIC, Caetano, Gil e Os Mutantes anunciaram um show na boate carioca Sucata. Sobre esse espetáculo, Calado relembra:

O norte-americano David Drew Zingg instalou duas bandeiras, com as inscrições Yes, nós temos bananas e Seja marginal, seja herói - esta uma obra de Hélio Oiticica, criada em homenagem ao bandido Cara de Cavalo, já exposta em outras ocasiões (...) Caetano rebolava, dava cambalhotas, plantava bananeiras, arrastava-se pelo chão. Gil mergulhava em longos improvisos vocais, recheados de gritos e gemidos (...) Durante os nove dias do show, a boate se manteve lotada. ${ }^{225}$

Calado conta ainda que a temporada desses shows foi interrompida quando a boate foi interditada, sob a alegação de que um promotor na plateia teria sido desacatado depois de ter exigido a retirada da bandeira de Hélio Oiticica do palco no dia anterior. Segundo o autor, após essas apresentações, um diretor musical da TV Tupi fechou contrato para um programa tropicalista semanal, e os programas seriam uma adaptação desse show. Fernando Faro, diretor do programa, disse à época:

Acredito no "Divino Maravilhoso", porque se os artistas tropicalistas foram discutidos, isto é um sinal de popularidade. Se foram agredidos, é porque se comunicaram com mais força. Se eles irritam, causamperplexidade, é porque essa comunicação foi feita fora dos códigos. ${ }^{226}$

De acordo com Calado, cartas indignadas quanto ao conteúdo do programa chegavam constantemente à emissora. O próprio diretor do programa, Cassiano Gabus Mendes, tentou de toda maneira amenizar a violência da cena da noite de 23 de dezembro, em que Caetano, ao interpretar "Boas festas", de Assis Valente, apontava um revólver para a própria cabeça. Segundo Calado, policiais à paisana frequentavam a plateia do

\footnotetext{
224 CALADO, Carlos. Tropicália, op. cit., p. 222.

225 Ibid., pp. 229-230.

226 Ibid., p. 234.
} 
programa, e Jô Soares chegou a avisar Caetano e Gil de que seus nomes constavam numa lista de artistas visados após o AI5. ${ }^{227}$

Caetano associa sua prisão e a de Gil a essa cena com o revolver anteriormente narrada por Calado:

Tínhamos um programa já escrito pra ser exibido na semana do Natal. Eu próprio, numa homenagem ao grande compositor suicida Assis Valente, e numa desmistificação das róseas sentimentalidades natalinas, cantaria a linda e triste canção "Boas festas" daquele autor, apontando um revólver para minha própria têmpora. E assim fiz. A canção, originalmente uma marchinha e que no Brasil está tão identificada com o Natal quanto "Jingle Bell"-, fora despojada de seu ritmo e era apresentada como um adágio com as sílabas da letra escondidas. O resultado era assustador. Fiquei orgulhoso porque considerei que ali havia densidade "poética", mas intimamente arrependido por crer ter talvez - mais uma vez - ido longe demais. No dia 27 de dezembro, Gil e eu fomos presos. ${ }^{228}$

Caetano Veloso e Gilberto Gil foram presos e depois exilados, de dezembro de 1968 até janeiro de 1972. Assim o site de Gil noticia sua prisão:

27 de dezembro- Gil e Caetano são presos em São Paulo, vítimas das medidas de exceção advindas com a edição, em 13 de dezembro, do Ato Institucional $\mathrm{n}^{\circ} 5$, que cerceou a liberdade artística e dos cidadãos. Os dois são levados para o quartel do Exército de Marechal Deodoro, no Rio. ${ }^{229}$

De acordo com Albuquerque,

O AI5, a deportação e perseguição da maioria deles, veio colocar ordem na casa, garantir as identidades cristalizadas, repor a velha ordem no lugar, apaziguar as desterritorializações, com o oferecimento dos velhos territórios existenciais, políticos e sociais; veio garantir a vida do cadáver, mumificando nação e regiões, construções imagético-discursivas gastas, múmias, de

\footnotetext{
${ }^{227}$ Ato Institucional n.5, conhecido como "o golpe dentro do golpe", no qual os setores militares mais direitistas lograram oficializar o terroris mo de Estado, que passaria a deixar de lado quaisquer pruridos liberais, até meados dos anos 1970. RIDENTI, Marcelo. In: O Brasil Republicano: o tempo da ditadura regime militar e movimentos sociais em fins do século XX. RJ: Civilização Brasileira, 200, p.152.

228 VELOSO, Caetano. Verdade tropical, op. cit., p. 343.

${ }^{229}$ Site: <www.gilbertogil.com.br>. Acesso em 15 mar. 2015.
} 
cujos trapos nós vivemos, desenrolando e descobrindo, à medida que o fazemos, que estas múmias não existem. ${ }^{230}$

O AI5 representou a radicalização da censura e a perseguição a todos aqueles considerados subversivos pelos militares. A novidade da vestimenta e performance dos tropicalistas, suas aparições nada formais para os padrões da época nas televisões dos lares brasileiros, colocava frente a frente as incertezas em relação ao futuro dessas ações sob a ótica da ditadura e o sonho de uma revolução cultural conclamada por esses jovens libertários. O fato de Caetano e Gil serem presos e posteriormente exilados é indicativo da força e do potencial questionador ou até mesmo "perigoso", sob a ótica dos militares, do discurso tropicalista.

A inserção de Gil no movimento tropicalista demonstra haver, desde o início de sua carreira artística, questionamentos que problematizaram a cultura brasileira. $\mathrm{O}$ papel creditado à África nessa busca pela descoberta do Brasil tropicalista demonstra que ela continua de certa forma ${ }^{231}$ silenciada. Ela é referenciada na "Batmakumba" concretista ou ao primitivismo quando comparada aos Beatles. Não se configurava em foco para os tropicalistas ou mesmo para Gil questionar a ideia de africanidade nesse momento. Interessava aos tropicalistas questionar a cultura nacional, e em especial o nacionalpopular, sem priorizar elementos da tradição folclórica ou qualquer outro elemento em especial. A proposta era partir de leituras que mesclassem inúmeras informações musicais e extramusicais, como por exemplo, o concretismo ou a afinidade com o cinema novo.

As fontes aqui analisadas - depoimentos de Gil e Caetano, estudos referentes ao tema e o repertório dos discos gravados até então por Gil - deram a dimensão de que a sua vivência artística nesse período está mais associada à busca por experimentações e pluralidade cultural, partindo especialmente dos dados musicais da bossa nova, baião, do rock e do samba. Não havia no tropicalismo uma leitura da tradição enquanto algo que remetesse ou mesmo buscasse a "verdadeira" cultura brasileira, e menos ainda a necessidade de proteger o que fosse original nessa cultura, mas sim compreender o que era nesse momento popular e pop e mesclar a isso outras informações. O popular em tempos de tropicalismo estava bem mais relacionado à popularidade do que denotando

\footnotetext{
${ }^{230}$ ALBUQUERQUE, Durval Muniz. O engenho anti-moderno, op. cit., p. 378.

${ }^{231}$ Nas músicas de Gil gravadas nesse período, ele utiliza o samba, o frevo e o rock. Mesmo que nesse primeiro instante essa sonoridade não fosse ainda conscientemente ligada por Gilà temática negra, essas escolhas já demonstram a afinidade do artista com es se universo, que pas saria a lhe interes sar cada vez mais após o exílio.
} 
caracterizações do nacional. Nesse instante, a órbita girava mais em torno de deglutir e traduzir as informações que eram, até então, quase todas muito novas no cenário nacional, como a bossa nova, o rock, a música serial, a poesia concreta, o cinema novo, o teatro, as músicas de protesto e as músicas regionais. É a partir da vida no exílio londrino que a cultura brasileira passa a interessar a Gil de maneira mais aprofundada, como se verá adiante.

Enquanto a canção de protesto intencionava se apropriar da forma e dos ritmos da cultura popular para imprimir um conteúdo pedagógico que se julgava revolucionário, o tropicalismo, ao contrário, buscou reunir menções ao universo pop dos quadrinhos e dos Beatles, à cultura popular nordestina e à música latina. Assim sendo, percebemos que a brasilidade acessada por Gil nos tempos da tropicália jogava com significações que se afastavam dos discursos adotados até então pelos grupos defensores da temática nacionalpopular. Na concepção estética do movimento tanto o local quanto o global tinham espaço, numa leitura que hibridizou e traduziu diferentes referências culturais.

Na prisão, Gil somaria novos dados à construção de sua identidade. A partir daí, ficaria mais atento à alimentação, assim como a preocupações metafísicas. Assim o artista comentou sua situação na prisão:

Até então, na minha vida, nunca tinha sofrido o problema da supressão da liberdade física e da psíquica. Ela significava primeiro que eu estava sendo fisicamente tirado do meu espaço geral para uma prisão mesmo, e depois porque aquilo era uma sanção ao meu pensamento, à minha atitude, era uma coisa toda contra os limites de expansão da minha condição psíquica (...) Comecei a fazer ioga e regime vegetariano. Eu tinha um certo espaço, 5 metros quadrados nos quais eu me movimentava durante aqueles dois meses que fiquei preso, e tinha o meu espaço psíquico que exatamente procurou ultrapassar as fronteiras do cotidiano vivenciado até então. E vieram aquelas coisas cósmicas de sair mesmo da terra, proporcionadas pelas meditações, respirações, posturas, relaxamentos, diminuição da riqueza alimentar, pela parcimônia que passeia adotar em relação à vida. ${ }^{232}$

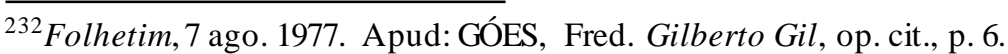


Gil aproveitou o tempo de terror da imposição da falta de liberdade para se repensar e recriar estratégias de ser. A prisão foi fator determinante de uma forte modificação tanto interna quanto externa de Gil. 


\title{
Capítulo 2
}

\section{A construção de africanidades na trajetória e obra de Gilberto Gil}

\author{
“... Trago a minha banda \\ Só quem sabe onde é Luanda \\ Saberá lhe dar valor \\ Dar valor \\ Vale quanto pesa \\ Pra quem preza o louco bumbum do tambor \\ Do tambor... "233
}

Gilberto Gil

A construção de africanidades na trajetória e obra de Gil será abordada, neste capítulo, a partir do período relacionado sobretudo ao exílio e ao momento imediatame nte posterior à sua volta, que para o artista se configurou em um período de intensas experimentações, que perpassam desde a busca por uma melhor compreensão de si mesmo, e posteriormente da cultura brasileira, à modificação de sua performance artística, até o período em que Gil passa a atuar na vida política brasileira (1987), que será o enfoque do terceiro e último capítulo.

Para as reflexões que aqui serão desenvolvidas, foram selecionados eventos como o lançamento da trilogia "Re"; filmes como O demiurgo ${ }^{234}$ ou Os Doces Bárbaros ${ }^{235}$, dentre outros; a ligação de Gil com o afoxé Filhos de Gandhy; sua parceria com Jorge Ben Jor; a viagem à África; a conexão de Gil com o movimento negro, dentre outros, com o intuito de perceber como se deu o processo de construção de sua identidade. Mas não só: buscamos compreender como o artista formulou suas africanidades. Em quais tramas e através de quais pontos a África foi enveredada nessa trajetória artística?

\footnotetext{
233 “Palco"(Gilberto Gil, 1980) In: RENNÓ, Carlos (org.) Gilberto Gil todas as letras. São Paulo: Companhia das Letras, 1996, p. 238.

${ }^{234}$ ODEMIURGO. Produção: Jorge Mautner. Londres, 1970.

${ }^{235}$ DVD Os Doces bárbaros. Direção: Jom Tob Azulay. Produção artística: Guilherme Araújo. Rio de Janeiro: Biscoito Fino, 1978.
} 
Esse período, especialmente a segunda metade da década de 1970, foi fortemente marcado pela criação de uma imagem de Gil conectada à África. Essa associação foi uma construção agenciada não somente pelo artista através de suas escolhas estéticas, mas também pela mídia daquele momento. Após a metamorfose londrina, as falas e experiências de Gil explicitam sua relação com uma representação das africanidades. Vale ressaltar que essa construção identitária se relaciona de maneira complexa com diversas tradições musicais diaspóricas de origem africana ${ }^{236}$, entrelaçando diferentes heranças culturais, experiências e memórias. Não intenciono fixar essencialismos ou mesmo buscar a autenticidade de determinados elementos frente a outros, uma vez que não estamos tratando a cultura enquanto forma pura, mas sim como o resultado de negociações, engajamentos, adaptações, traduções, e primordialmente hibridizações. A estética negra, através de seus repertórios culturais e representações, formam uma espécie de narrativa negra e estão presentes em diferentes momentos da trajetória de Gil e em cada um deles com suas especificidades.

\section{- O pré-exílio}

Depois de dois meses aprisionados no Rio de Janeiro, Gil e Caetano ficariam ainda mais cinco meses detidos em regime de prisão domiciliar em Salvador. No Teatro Castro Alves fizeram um show de despedida do Brasil, que anos depois seria lançado em LP com o título Barra $69 .{ }^{237}$ É interessante salientar que as reportagens referentes a Gil e Caetano nesse período não faziam sequer menção à prisão de ambos. Numa reportagem realizada por um jornal baiano, ${ }^{238}$ que anunciou elogiosamente o espetáculo do Teatro Castro Alves, não há qualquer citação referente ao exílio. Esse silenciamento também se fez notar em outra reportagem publicada no Jornal da Bahia, que apenas menciona a mudança dos artistas para Londres, mas não o seu motivo:

Os dois famosos compositores brasileiros farão primeiro uma temporada em Lisboa e depois seguirão para Londres, onde pretendem fixar residência. Duas mil pessoas foram vê-los nesta apresentação de adeus. ${ }^{239}$

\footnotetext{
${ }^{236}$ Dentre elas o samba, o rock, o reggae, juju music ou o afoxé.

237 Álbum Barra 69 - Caetano e Gil ao vivo na Bahia. (Universal Records, 1972).

${ }^{238}$ FERREIRA, Jurandir. Teatro em foco: Caetano e Gil no TCA. 12/07/1969. Acervo Tom Jobim (GPj_07.JPG) Acesso em: 02 jun. 2015.

${ }^{239}$ Sem referência de autoria. Caetano e Gil fazem do TCA Parque Encantado em sua despedida do Brasil. 22/07/69. Acervo Tom Jobim (GPj_05.jpg). Acesso em: 02 jun. 2015.
} 
Além do espetáculo no Teatro Castro Alves, Caetano e Gil gravariam, separadamente, nesse breve espaço de tempo em Salvador, discos apenas com suas vozes para posteriormente serem inseridos os sons de guitarras, bateria e outros instrumentos em arranjos feitos por Rogério Duprat. ${ }^{240}$ Sobre a elaboração desse LP $^{241}$, feito durante a prisão domiciliar em Salvador, e na busca por pistas que possibilitem aprender possíveis redefinições identitárias pelas quais passava Gil no contexto pré- exílio, a parceria desenvolvida com Rogério Duarte pode aqui nos oferecer alguns indícios.

Rogério, além de design gráfico ${ }^{242}$ e poeta, era um pouco mais velho que Caetano e Gil, e exerceu grande influência sobre o primeiro. Como nos conta Caetano em suas memórias,

Nossas conversas - que se estendiam até de madrugada no Solar e não raro continuavam na casa dele em Santa Teresa, onde muitas vezes eu ficava pra dormir - consistiam em considerações a respeito do que acontecia à nossa volta (teatro, cinema, canção popular - além de comentários meio morais meio psicológicos sobre o comportamento de conhecidos, ou a mera maledicência), quando não se resumiam a monólogos inspirados de Rogério que podiam ter como tema Proust, Mozart, Heidegger, Villa-Lobos ou Lota Macedo Soares. ${ }^{243}$

A Rogério, Caetano também pedia conselhos e, de acordo com ele, através dessas conversas ambos se enriqueciam intelectual e existencialmente. Essa rememoração de Caetano em muito nos é útil, pois dimensiona que Rogério Duarte era um artista conectado com o universo pop, além de conhecedor dos "cânones" da cultura ocidental. ${ }^{244}$

\footnotetext{
${ }^{240}$ O arranjo foi feito por Rogério Duprat, somente com a voz de Gil, sem nem mesmo a sua presença nas finalizações da mixagem do disco. A sonoridade é bastante parecida com as dos LPs lançados anteriormente por Gil, muito parecida com a estética tropicalista, um rock com muitas guitarras distorcidas com pitadas de samba e baião.

${ }^{241}$ Álbum Gilberto Gil (Universal, 1969).

${ }^{242}$ Foi Rogério Duarte quem criou a capa do filme de Glauber Rocha Deus e o diabo na terra do sol.

${ }^{243}$ VELOSO, Caetano. Verdade tropical. São Paulo: Cia. das Letras, 1997, p. 113.

${ }^{244}$ É interessante ainda evidenciar que dentre os artistas citados nas conversas de Caetano e Duarte configuravam nomes que de alguma maneira tangenciavam questões relacionadas à homossexualidade, ou mes mo artistas que representaram alguma espécie de rompimento ou inovação na sociedade da qual fizeram parte. Abordando aspectos referentes a eventuais estruturas opressivas ou mesmo temas relacionados ao universo das artes, os diálogos entre Caetano e Duarte não gravitavam em torno de aspectos ligados de alguma maneira à cultura brasileira ou mesmo às africanidades, mas especialmente ao advento da modernidade.
} 
Sobre o encontro ${ }^{245}$ de Gil com Rogério, Calado nos informa que:

Até mesmo quando Gil decidiu fazer uma espécie de retiro espiritual para compor as canções do disco, durante cerca de um mês, numa casa que ficava no alto de uma colina, em Piatã, Rogério também o acompanhou. Foi dessa convivência diária que nasceram os textos recitados de Objeto Semi-Identificado, além da canção "A Última Valsa", que até hoje não foi gravada. Por essas e outras, ao pensar na capa de seu LP, Gil não teve dúvidas: usou um poema-desenho que Rogério Duarte fizera durante as semanas que passaram juntos. ${ }^{246}$

Gil, ao comentar o modo como compôs Objeto semi-identificado, ${ }^{247}$ em parceria

com Duarte, complementa ainda mais as informações citadas por Calado:

Uma leitura de pequenos excertos dos nossos cadernos de anotações - meu e de Rogério Duarte -, fruto das longas conversas que tivemos durante os três meses [após a prisão no Rio] em que convivemos em Salvador; das nossas especulações sobre s obrenaturalidade e hipe rrealidade; das nossas le ituras sobre ioga; das elaborações que fiz de minhas meditações na prisão. O Rogério Duprat colocou a música depois. ${ }^{248}$ [grifos meus]

\footnotetext{
${ }^{245}$ Segundo Calado, nesses encontros eles discutiam de teosofismo ao esoterismo, encontros sempre regados a muita maconha.

${ }^{246}$ CALADO, Carlos. Tropicália: a história de uma revolução musical. São Paulo: Ed. 34, 1997, p. 258. 247 “Objeto semi-identificado" (Texto de Gilberto Gil e Rogério Duarte/Música de Rogério Duprat, 1969). Diga lá./Digo eu/Diga você/E línguas como que de fogo tornaram-se invisíveis/E línguas como que de fogo tornaram-se invisíveis. E se distribuíram e sobre cada um deles assentou-se uma. E todos eles ficaram cheios de espírito santo e principiaram a falar em línguas diferentes./ Eu gosto mesmo é de comer com coentro. Uma moqueca, uma salada, cultura, feijoada, lucidez, loucura. Eu gosto mesmo é de ficar por dentro, como eu estive na barriga de Claudina, uma velha baiana cem por cento./Tudoé número. $\mathrm{O}$ amor é o conhecimento do número e nada é infinito. Ou seja: será que ele cabe aqui no espaço beijo da fome? Não. Ele é o que existe, mais o que falta./O invasor me contou todos os lances de todos os lugares onde andou. Com um sorriso nos lábios ele disse: "A eternidade é a mulher do homem. Portanto, a eternidade é seu amor"./Compre, olhe, vire, mexa. Talvez no embrulho você ache o que precisa. Pare, ouça, ande, veja. Não custa nada. Só lhe custa a vida./Entre a palavra e o ato, desce a sombra. O objeto identificado, o encoberto, o disco-voador, a semente astral./A cultura, a civilização só me in teressam enquanto sirvam de alimento, enquanto sarro, prato suculento, dica, pala, informação. /A loucura, os óculos, a pasta de dentes, a diferença entre o 3 e o 7. Eu crio./A morte, o casamento do feitiço com o feiticeiro. A morte é a única liberdade, a única herança deixada pelo Deus desconhecido, o encoberto, o objeto semi-identificado, o desobjeto, o Deus -objeto. /O número 8 é o infinito, o infinito em pé, o infinito vivo, como a minha consciência agora./Cada diferença abolida pelo sangue que escorre $\mathrm{d}$ as folhas da árvore da morte. Eu sou quem descria o mundo a cada nova descoberta. Ou apenas este espetáculo é mais um capítulo da novela "Deus e o Diabo etc. etc. etc."/O número 8 dividido é o infinito pela metade. O meu objetivo agora é o meu infinito. Ou seja: a metade do infinito, da qual metade sou eu, e outra metade é o além de mim./E fim de papo./Tá legal. RENNÓ, Carlos. Gilberto Gil: todas as letras. São Paulo: Cia. das Letras, 1996, p. 108.

${ }^{248}$ RENNÓ, Carlos. Gilberto Gil..., op. cit., p. 108.
} 
Comentando sobre outra composição musical ${ }^{249}$ feita nesse período, Gil acaba revelando seus anseios e buscas experimentadas em Salvador momentos antes de ser exilado, dimensionando o espaço dedicado à espiritualidade naquele momento:

Os termos vêm do procedimento concretista de ligar palavras e inventar neologismos compostos. Começando a estudar religiões orientais e ciências ocultas, eu convivia com as palavras não popularmente difundidas, algumas de cujo significado até então eu não sabia e que eram novidade pra mim. A música foi composta na Bahia quando encontro com o Rogério Duarte e o Walter Sme tak ${ }^{250}$, e se dá a trans posição desses intelectuais e espirituais em minha música. ${ }^{251}$ [grifos meus]

Esses laços de sociabilidade são frequentes em toda a trajetória de Gil, e nesse momento pré-exílio o convívio com Duarte e com Smetak expressa a busca pelo aprofundamento da espiritualidade e pela compreensão da cultura oriental ${ }^{252}$ e seus ensinamentos. Aponta também para a ausência nesse período de questionamentos referentes à cultura brasileira, africana ou afro-brasileira. É importante destacar que nesse período Gil estava empenhado em absorver e desenvolver conhecimentos relacionados ao esoterismo e ao ocultismo. Nas conversas com Duarte, mas também com Smetak, as indagações gravitavam em torno desses temas, que passaram a ter importância, ou mesmo a serem conhecidos por Gil, no momento da prisão.

Além dessas parcerias musicais e na tentativa de compreender a construção identitária do artista Gil nesse momento pré-exílio, bem como o espaço dedicado às africanidades nesse processo, tanto a música "Cultura e civilização"253 , quanto à

249 “Alfômega" (Gilberto Gil, 1969), que não faz parte do LP de 1969. RENNÓ, Carlos. Gilberto Gil, op. cit., p.109.

${ }^{250}$ Walter Smetak é músico violoncelista, compositor, inventor de instrumentos musicais, escultore escritor. Nasceu em Zurique em 1913 e veio para o Brasil em 1937. Em 1957, foi convidado pelo compositor alemão Hans Joachim Koellreutter a ir para Salvador, para integrar os Seminários Livres de Música. Na Bahia, Walter Smetak iniciou pesquisas microtonais inspiradas pela teosofia, e começou a construir instrumentos musicais com materiais inusitados, como tubos de PVC, cabaças e isopor. Criou cerca de 150 desses "instrumentos-esculturas", os quais denominou genericamente de "plásticas -sonoras". A partir de 1969, a sua oficina de experimentação sonora passou a serfrequentada por importantes artistas da música brasileira: Gilberto Gil, Rogério Duarte, TomZé, Gereba, Tuzé de Abreu, Djalma Correia e Marco Antônio Guimarães (fundador do grupo Uakti), entre outros. In: http://www.waltersmetak.com.br. Acesso em:01 jun. 2015.

${ }^{251}$ Apud RENNÓ, Carlos, op. cit., p. 109.

${ }^{252}$ Em especial a ioga, a meditação e as ciências ocultas.

253 "Cultura e civilização" (Gilberto Gil, 1969) A cultura, a civilização/Elas que se danem/Ou não/Somente me interessam/Contanto que me deixem/meu licor de genipapo/O papo/Das noites de São João/Somente me interessam/Contanto que me deixem meu cabelo belo/Meu cabelo belo/Como a juba de um leão/Contanto que/me deixem/Ficar na minha/Contanto que me deixem/Ficar com minha vida na mão/Minha vida na mão/Minha vida/A cultura, a civilização/Elas que se danem/Ou não/Eu gosto 
rememoração de sua criação, ajudam a elucidar a maneira como Gil concebia esses conceitos nos idos de 1969:

\begin{abstract}
Depois dos rebeldes com causa, os rebeldes sem causa: derrubando os muros e as prateleiras. A cultura e a civilização que se danem ou não, pouco importa; sou inaugural, seminal; ponto zero: aqui começa outra história. Essa expressão do dístic o, slogan de época, placa, palavra de ordem. Em seguida, a afirmação do particular, do eu individuo, baiano. Quero estar no turbilhão das ruas, no olho do furacão do meu tempo, mas também quero paz; viver o tempo histórico, mas trazer até ele a história do meu passado, os elementos formadores do meu cerne. Como mostra o jogo desses contrastes, não se trata de um mergulho irracional na rebeldia. $\mathrm{O}$ disco é niilista, mas os versos seguintes, ao contrário de justificá-lo, são preservadores. ${ }^{254}$
\end{abstract}

Na confecção da letra, o termo cultura não aparece sozinho, mas é acompanhado pelo de civilização, conceito esse que se associa tanto ao progresso quanto à evolução. Mas, nessa canção, o termo civilização não significava apenas a busca pelo aperfeiçoamento atrelado à modernidade, pois o passado deveria permanecer como cerne, como aquele que também informa e traz sentido. O questionamento sobre cultura e civilização era importante para Gil especialmente a partir do dado individual, que rompia, inovava, mas mantinha-se conectado à preservação. Apresenta-se aqui a complexidade do sujeito que enuncia algo, a construção de si, mas também sua compreensão do mundo, que perpassa fortemente pela sua individualidade demarcada pela experiência do tempo vivido na Bahia. Vale demarcar que essa reflexão foi elaborada por Gil quase três décadas após o lançamento do disco.

Ao mesmo tempo em que a cultura poderia se danar, ou não, como diz a letra, ela foi também tema de outra canção desse LP, e já referida momentos atrás, Objeto semiidentificado, inserida nos seguintes versos: "a cultura, a civilização só me interessam enquanto sirvam de alimento, enquanto sarro, prato suculento, dica, pala, informação"; e informam o modo como Gil abordava o tema em fins dos anos sessenta. No momento pré-exilio, Gil concebia cultura enquanto significação de ordenação, ou mesmo desorganização do mundo em termos simbólicos, mas o mais importante para Gil era a leitura, a sua leitura de toda essa série de significados, que faziam sentido principalme nte através de sua individualidade, nesse caso representada pela sua forte ligação com

mesmo/É de comer com coentro/Eu gosto mesmo/É de ficar por dentro/Como eu estive algum tempo/Na barriga de Claudina/Uma velha baiana/Cem por cento. RENNÓ, Carlos. Gilberto Gil, op. cit., p. 114. ${ }^{254}$ Apud RENNÓ, Carlos, op. cit., p. 114. 
Salvador, representada através dos versos: Eu gosto mesmo é de comer com coentro. Uma moqueca, uma salada, cultura, feijoada, lucidez, loucura. Eu gosto mesmo é de ficar por dentro, como eu estive na barriga de Claudina, uma velha baiana cem por cento. Essa conexão com a Bahia é a mesma da canção "Cultura e civilização", que evoca também Claudina, sua mãe, as noites de São João, o coentro, e seu cabelo indicando aí um tímido sinal referente à negritude: Contanto que me deixem meu cabelo belo/Meu cabelo belo/Como a juba de um leão/ os cabelos belos como a juba de um leão. A sonoridade dessas músicas é uma espécie de colagem de palavras e sons. A utilização de colagens sonoras vem ao encontro do desenvolvimento da música experimental, que já acontecia desde o início do século XX no meio musical erudito. Em meados dos anos 1960, compositores envolvidos com música experimental dialogaram com artistas populares, como foi o caso de Rogério Duprat e Smetak, por exemplo.

De acordo com Bhabha, é através da enunciação que a diferença cultural é descoberta e até mesmo reconhecida. Interrogando a identidade, o autor conceitua a situação social pós-colonial como um entre-lugar, já que, ao demarcar uma fronteira de marginalidade, possibilita a visibilidade do signo da identidade não somente como passado ou futuro, mas sim como o local onde os sujeitos se recompõem. Esse espaço de fronteira para Bhabha está além. Para o autor, estar no além:

É habitar um espaço intermédio, como qualquer dicionário nos informará. Mas residir "no além" significa também ser parte de um tempo revisionário, um retorno ao presente para redescrever nossa contemporaneidade cultural; reinscrever nossa comunalidade humana, histórica; tocar o futuro em seu lado de cá. Nesse sentido, então, o espaço de intermédio "além" torna- se um espaço de intervenção no aqui e no agora. ${ }^{255}$

Complementando essa ideia em outro trecho do livro, Bhabha afirma:

... deveríamos lembrar que é o "inter" - o fio cortante da tradução e da negociação, o entre-lugar - que carrega o fardo do significado da cultura. Ele permite que se comecem a vislumbrar as histórias nacionais, antinacionalistas, do "povo". E, ao explorar esse Terceiro Espaço, temos a possibilidade de evitar a política da polaridade e emergir como os outros de nós mesmos. ${ }^{256}$

\footnotetext{
${ }^{255}$ BHABHA, Homi K. O local da cultura. Belo Horizonte: Ed. UFMG, 1998, p. 27.

256 Ibid., p. 69.
} 
Bhabha acredita que uma nova percepção da diferença modificaria a comum visão da existência de uma hierarquia, suposta ou mesmo imposta. A ideia demarca, assim, que a identidade pode ser reconhecida mais como performática do que essencialista, como tem sido abordada. Isso não significa que devamos abandonar os discursos identitários anteriores, mas sim ressignificá-los através da transitoriedade e hibridez que permeiam as relações culturais.

Enquanto a postura de Gil se remete nesse período a uma busca pela novidade, atrelada ao universo pop e ao conhecimento dos saberes orientais, demarcado pelo recolhimento, sua ligação como passado baiano ${ }^{257}$ não deixa de fluir, fazendo com que ele se entrelace com as novas experiências. Cabe ressaltar que nesse LP as menções à Bahia remetem as mais diferentes imagens, como fica perceptível em toda a série discursiva ${ }^{258}$ utilizada na produção desse disco. No instante de sua criação, Gil buscava um autoconhecimento através dos ensinamentos orientais e sentia o medo de ser exilado. E foi nesse entre-lugar que as ideias de Gil foram traçadas, podendo ser aqui compreendidas como uma espécie de narrativa de sua própria diáspora. A busca esotérica representa o tempo presente do Gil que enuncia; a civilização representa o espaço almejado e o passado está simbolizado pela experiência baiana.

\section{- O exílio}

Gil e Caetano partiram para a Europa em julho de 1969 com suas companheiras, respectivamente as irmãs Sandra e Dedé Gadelha. Passaram um tempo na França e se estabeleceram em Londres, onde ficaram por dois anos e meio, para então retornarem ao Brasil em janeiro de 1972. Em uma entrevista concedida no momento mesmo do exílio, em 1969, para a revista Pasquim, Gil elucubrou sobre a opção por Londres:

\footnotetext{
${ }^{257}$ De acordo com Antônio Risério, a emergência de uma consciência afro no carnaval baiano vem se modificando desde meados da década de 70 . Risério compreende esse período através de um processo de "reafricanização" baiana, no qual "os pretos se tornam mais pretos; se interessam cada vez mais pelas coisas da África e da negritude." Risério analisou a década de 1970 enquanto momento de invenção de um grupo étnico denominado juventude black-baiana, costurando informações sobre a elaboração dessas identidades, além de registrar o surgimento de um movimento político negro, com influência de caráter afro-internacional. In: RISÉRIO, Antônio. Carnaval Ijexá: notas sobre afoxés e blocos do novo carnaval afro-baiano. Salvador: Corrupio, 1981, p. 13.

${ }^{258}$ Nas letras desse LP, Gil questionou a tecnologia através de "Cérebro eletrônico"; a alegria em passear com seu pai e família em "Volks-Volkswagen blue"; despediu-se do Brasil através do samba exaltação "Aquele abraço"; citou o baião em "17 léguas e meia"; questionou as perspectivas de mundo novo em "Futurível" e em "Vitrines" tematizou um namorico que teve; cantou o medo em "Com medo, com Pedro"; além de cantar canções de Caetano, Tom Zé e Rita Lee.
} 
Não sei. Estou com vontade de ficar em Londres. Mas quando a gente fala "gostaria de ficar", isso depende de uma série de coisas, implica necessidades, exigências. Por exemplo: eu gostaria muito de morar na Espanha, ou na Grécia, ou no sul de Portugal. Gostaria de ficar na região mais tropical possível, por uma questão de hábito. Mas em termos de compromisso com a civilização, talvez tenha de preferir Londres ou Paris. ${ }^{259}[$ grifos meus]

Se na letra da música "Cultura e civilização", ambas poderiam importar ou não, na seleção pelo local de morada em motivo do exilio, "a civilização" contou como importante prerrogativa de preferência. A escolha por Londres, de acordo com Gil, também se deu pelo fato de ser a terra dos Stones e dos Beatles. De acordo com esse relato, a opção por Londres levou em consideração a efervescência cultural, bem como a importância desse local enquanto cidade estratégica e representativa dentro de uma hierarquia de importância cultural. Em sua biografia, Gil esclarece porque a primeira opção, Paris, logo seria descartada:

Eles nos tratavam mal e eu e Caetano sofríamos muito com aquilo. Hoje é diferente, mas naquela época era terrível e faziam questão de mostrar que não gostavam de estrangeiros. A gente sofria, precisando de um mínimo de acolhimento, de algo minimamente cortês. ${ }^{260}$

De acordo com Denise Rollemberg, o exílio muitas vezes é associado ao desenraizamento, à desestabilização e à solidão:

A história do dia-a-dia no exilio é, portanto, a história do choque cultural renovado constantemente; do mal-estar em relação ao outro e, sobretudo, em relação a si mesmo, entre o que se era ou se pretendia ser-, e o que se acabou sendo de fato.É a história da desorientação, da crise de valores que significou, para uns, o fim de um caminho e, para outros, a descoberta de outras possibilidades. É a história do esforço inútil e inglório para manter a identidade. É a história da sua redefinição e da sua reconstrução, que se impunham num processo que se estendeu ao longo das fases do exílio e que continuou para muitos, mesmo depois da volta ao Brasil. ${ }^{261}$

As reflexões pós-exílio realizadas por Gil parecem ser uma espécie de resposta à análise acima realizada por Rollemberg:

\footnotetext{
${ }^{259}$ Entrevista de Gil a Odete Lara, quando Gil esteve na Itália para o Festival de Cinema de Pesaro. A entrevista foi publicada no jornal O Pasquim, do Rio de Janeiro, ${ }^{\circ} 16,9$ a 15 de outubro de 1969. In: RISÉRIO, Antônio. Gilberto Gil Expresso 2222. Editora Corrupio, 1982.

${ }^{260}$ Apud ZAPPA, Regina. Gilberto bem perto. 1. Ed. - Rio de Janeiro: Nova Fronteira, 2013, p. 145.

${ }^{261}$ ROLLEMBERG, Denise. Exílio: Refazendo identidades. Revista da Associação Brasileira de História Oral, Rio de Janeiro, v. 2, pp. 39-73, 1999, p. 41.
} 
Precisávamos estar em grupo, precisávamos ser uma tribo, precisávamos estar unidos, precisávamos ter o espelho permanente um do outro pra nos identificarmos. A nossa identidade era basicamente dada por esse traço coletivo, por esse desejo, esse querer. Essa nova tribo tinha que ser assim, não tinha outro jeito, uma andorinha só não faz verão. ${ }^{262}$

A desorientação, e o consequente esforço para manter traços identitários que permitiam naquele momento dizer quem eles eram, fez com que a vida em tribo, como Gil se refere, tivesse um importante papel na experiência londrina. O agrupamento com outros brasileiros era uma tentativa de amenizar as inseguranças do exilio, de se resguardar da rejeição e dos preconceitos lançados contra os estrangeiros, de evitar o estranhamento em relação à sociedade. Pode ser interpretada como uma estratégia de sobrevivência, já que muitos desses artistas viam suas identidades ameaçadas ou questionadas, e formar um grupo era boa estratégia. Voltando-se para os que tinham uma história comum, Gil buscava preservar no presente o passado que dera sentido à sua vida, reconhecendo-se naquela turma que falava sua língua e sentia as mesmas inquietações. Sob o rigoroso frio europeu, havia o medo de não poder voltar ao Brasil.

De acordo com Denise Rollemberg, o exilio brasileiro não se deu de maneira massiva, assim como em outros lugares da América Latina, e foi mais qualitativo que quantitativo, atingindo especialmente a classe média escolarizada, cumprindo "o papel de afastar e eliminar as oposições identificadas a projetos de mudança, fossem eles de reforma ou de revolução. ${ }^{263}$ Gil e Caetano se enquadram melhor entre aqueles que foram exilados pela revolução, que nesse caso estava atrelada aos comportamentos juvenis e desafiadores ${ }^{264}$, mas também pelas letras carregadas de sentidos que se opunham à ditadura. Se o país fechava suas portas às inovações, percebido pelo ato militar de expulsar os artistas, na Europa ambos teriam contato constante com o universo pop que tanto cultuaram na época do tropicalismo, além de toda a efervescência cultural da Europa no pós-1968, o feminismo, o combate ao racismo, as lutas de libertação nacional das colônias portuguesas na África, entre outros.

\footnotetext{
${ }^{262}$ DVD TROPICÁLIA. Documentário. Direção: Marcelo Machado. Rio de Janeiro: Bossa Nova Filmes , 2012.

${ }^{263}$ ROLLEMBERG, Denise. Memórias no exílio, memórias do exílio. In: FERREIRA, Jorge; AARÃO REIS, Daniel. (orgs.). As Esquerdas no Brasil. Revolução e democracia (1964...). Vol. 3. Rio de Janeiro: Civilização Brasileira, 2007, p. 11.

${ }^{264}$ Desde as performances de Caetano, passando pelos gritos de Gil às vastas cabeleiras de ambos, tão ameaçadoras aos olhos moralistas da época.
} 
Os anos 1960 foram marcados pelo despertar individual, por levantes políticos, pelo movimento beat $^{265}$ da década anterior, desencadeando um processo de desalienação da juventude. A contracultura e o ativismo político questionavam a autoridade e propunham novos sistemas de valores. Foi época de muitos protestos estudantis, utilização de drogas para expansão da mente e experiências alucinógenas.

Sobre a revolução cultural por que passava a sociedade ocidental na segunda metade do século XX, Eric Hobsbawm afirmou que inúmeras transformações identificadas como "modernizantes" foram demarcadas especialmente pelas lutas geracionais e em prol da igualdade entre os sexos, e especialmente pelo surgimento de uma cultura juvenil. Hobsbawm afirma ainda que "foi a descoberta desse mercado jovem em meados das décadas de 1950 que revolucionou o comércio da música popular e, na Europa, o mercado de massa das indústrias de moda. ${ }^{, 266}$ Para o autor, a juventude nesse momento era parte importante na revolução dos modos e costumes, nos meios de gozar o lazer e nas artes comerciais.

Liberação pessoal e liberação social, assim, davam-se as mãos,
sendo sexo e drogas as maneiras mais óbvias de despedaçar as
cadeias do estado, dos pais e do poder dos vizinhos, da lei e da
convenção. O primeiro, em suas múltiplas formas, não tinha de
ser descoberto. (...) As drogas, por outro lado, com exceção do
álcool e do tabaco, haviam até então se limitado a pequenas
subculturas de sociedade alta, baixa e marginal, e não se
beneficiavam de legislação permissiva. Espalharam-se não só
como um gesto de rebelião, pois as sensações que elas tornavam
possíveis podiam ser atração suficiente. Apesar disso, o uso de
drogas era por definição uma atividade proscrita, e o próprio fato
de a droga mais popular entre os jovens ocidentais, a maconha,
ser provavelmente menos prejudicial que o álcool e o tabaco
tornava a fumá-la (tipicamente uma atividade social) não apenas
um ato de desafio, mas de superioridade em relação aos que a
proibiam. Nas loucas praias dos anos 60 americanos, onde se
reuniam os fãs de rock e estudantes radicais, o limite entre ficar
drogado e erguer barricadas muitas vezes parecia difuso. ${ }^{267}$

Envoltos por essa ambiência libertadora, Gil e Caetano chegaram a Londres como profissionais da música, e não tardaria muito para que ambos recebessem convites para a

\footnotetext{
${ }^{265}$ Formado por um grupo de jovens escritores, poetas e dramaturgos americanos, entediados com a vida ordenada da América pós-guerra, resolveram, em meio à inspiração de ambientes permeados pelo jazz, drogas, sexo livre, realizar a exploração física do território americano. HOLMES, A.M. In: KEROUAC, Jack. Geração beat. Tradução de Edmundo Barreiros. Porto Alegre, RS: L\&PM, 2013.

${ }^{266}$ HOBSBAWM, Eric J. Era dos Extremos: o breve século XX: 1914-1991. São Paulo: Cia. das Letras, 1995 , p. 321.

267 Ibid, p. 326.
} 
gravação de discos. Fariam shows não só na Europa, como também nos EUA. Ambos contavam com ajuda financeira provenientes dos direitos autorais dos trabalhos realizados no Brasil. Assim Gil resumiu sua experiência londrina:

Viver nessa cidade ao mesmo tempo em que havia ali naquele momento uma renovaçãodo repertório inglês com a música, com os Beatles, os Stones, Traffic; com a nova moda, a minissaia, todas aquelas coisas. A cultura psicodélica com impactos enormes no design, na moda, no visual, na manifestaçãopsíquic a, no psiquismo da cidade, fortemente marcada por essa presença, e Londres com essa presença no psicodelismo. Então você imagina, eu passei a viver nessa cidade toda em meio a essas questões. E começavaa já ser marcante os jamaicanos, os west indians, e dos indianos também paquistaneses que traziam o sabor especial para a vida em Londres com seus costumes, suas indumentárias, sua culinária, tudo isso. Então eu fui muito marcado por tudo isso e de uma certa maneira fui obrigado a traduzir essas vivências na minha música. Voltei empunhando uma guitarra elétrica, uma coisa que eu não fazia até ter ido pra lá, voltei de lá tocando guitarra base, me tornei um band leader, no sentido que o Jorge Ben fala na música dele (sambaby posso não ser um band leader...) Posso não ser um band leader mas me tornei uma imitação de band leader quando vivi em Londres e quando voltei pra cá. ${ }^{268}$ [grifos meus]

Os jamaicanos seriam novamente citados em sua biografia como uma importante influência experimentada no contexto londrino. De acordo com Zappa:

Em Elgin Crescent, também na área de Notting Hill, havia também a grande comunidade West Indian, de jamaicanos, e Gil começou a entrar em contato com a cultura emergente do país em que o reggae, que tanto o influenciou, era elemento central. Havia o Mangrove, um restaurante jamaicano muito frequentado por Gil, que ficava perto de sua casa. Ele ia sempre a pé saborear a comida típica, que tinha feijão, banana frita, aquela soul food apreciada por Gil e tão parecida com as comidas brasileiras. ${ }^{269}$

Se a convivência com diferentes nacionalidades foi possibilitada pelo deslocamento forçado, a experimentação de novidades sonoras e de costumes também o foram. A tradução, ao lidar com a novidade, ressignificava o passado num diálogo sempre complexo; se a vida em Londres se fazia acompanhada de agitações ligadas à moda, ao psicodelismo ou ao convívio com nacionalidades diversas, frequentar um restaurante jamaicano significava reviver a familiaridade de uma alimentação parecida com a da

\footnotetext{
${ }^{268}$ SÉRIE MPB \& Jazz 2012 - Gilberto Gil: Gil e Caetano falam sobre Londres. Disponível em: <https://www.youtube.com/watch?v=NettqMeY2BE> Acesso em: 12 maio 2015.

${ }^{269}$ ZAPPA, Regina, op. cit., p. 151.
} 
Bahia. A vivência do exílio tanto possibilitou inovação quanto reafirmou em alguns momentos a tradição, demonstrando assim que não existiu de maneira esquemática uma simples separação entre aspectos relacionados à modernidade ou à tradição.

Quando Gilberto Gil chegou ao exilio, vivia-se na Europa e nos EUA a era de ouro do capitalismo. Dilaceradas por anos de guerra, as nações europeias receberam maciços investimentos e empréstimos dos EUA a partir de 1945, e, mais do que uma mera reconstrução econômica, passaram por um dos mais virtuosos ciclos de desenvolvimento desde o advento da Revolução Industrial, no século XVIII. A Inglaterra, maior potência imperialista da Europa no pré-guerra, beneficiou-se de uma identidade compartilhada com as antigas colônias, num sistema em que tais países do além-mar, corroídos por séculos de exploração econômica, agora forneciam mão de obra barata para as antigas metrópoles, como é o caso da Inglaterra.

Jamaicanos, guianenses, barbadianos e pessoas egressas das Índias Ocidentais west indians - formavam agora um grande contingente de moradores das grandes cidades britânicas, como Manchester, Liverpool, Bristol e, evidentemente, Londres. Como nota Stuart Hall, “a formação das diásporas negras no período das migrações pós-guerra, nas décadas de 1950 e 1960, transformou a vida social, política e econômica da

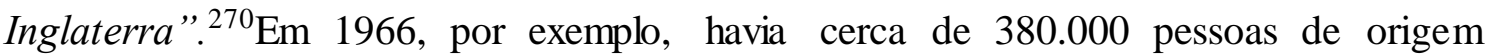
caribenha na Inglaterra, dos quais 50.000 haviam nascido no próprio país. A população britânica era de 54,5 milhões de habitantes. ${ }^{271}$ A migração em massa de países de capitalismo periférico para o centro da Europa representa uma importante mudança no padrão de migrações: nos séculos anteriores, eram os europeus que deixavam suas fortalezas nacionais rumo à colonização de territórios além-mar; agora, os colonizados rumam à metrópole, num contrafluxo histórico explicado, principalmente, pelo desenvolvimento propiciado pelo capitalismo nos países industrializados.

\footnotetext{
${ }^{270}$ Tradução livre do original em inglês: "The formation of the Black diasporas in the period of post-war migration in the fifties and sixties has transformed English social, economic and political life". In: HALL, Stuart. Old and new identities; old and new ethnicities. In: KING, A.D. (ed). Culture, globalizationand the world-system: contemporary conditions for the representation of identity. Minneapolis: University of Minnesota Press, pp. 41-68.

${ }^{271}$ STRATTON, Jon. When music migrates: crossing British and European racial faultlines, 1945-2010. Farnham: Ashgate, 2014, p. 8.
} 
Os migrantes caribenhos eram em sua franca maioria negros, o que traz questões sobre relações raciais e culturais na Inglaterra da segunda metade do século XX. Como afirma Jon Stratton, em seu trabalho crucial sobre a importância da música caribenha para a cultura popular britânica, a construção da diferença racial e as tensões decorrentes dessa diferença são atravessadas por formas musicais e essas formas musicais se modificam ao longo dos processos sociais. Assim, tanto o social quanto o musical se interpenetram, construindo "zonas de contato" nas quais as identidades culturais e sociais ganham forma. $^{272}$

A diáspora caribenha para a Inglaterra reproduziu nas relações sociais a brutal desigualdade entre a velha metrópole e suas ex-colônias. Os expatriados econômicos eram mutilados em seus direitos. Havia na sociedade britânica um racismo estrutural, no qual os "verdadeiros" ingleses eram brancos, cristãos, nascidos na metrópole, favorecidos historicamente pelo arcabouço do imperialismo. Os negros, especialmente os da diáspora caribenha, eram considerados um grande Outro que ameaçaria a suposta unidade da identidade britânica. Desde a década de 1950, quando cresce exponencialmente na Inglaterra uma população negra, são evidentes os casos de racismo e de desrespeito aos direitos civis. Tal desrespeito era embasado por estereótipos construídos por europeus a respeito dos negros, como o mito da sexualidade excessiva, o paganismo e a suscetibilidade à violência. ${ }^{273}$

Nesse contexto, a música desponta como um importante elemento de coesão social e de identidade da diáspora caribenha. A cultura musical dos west indians é o cerne de uma negritude que se afirma no confronto com a branquidade inglesa. Junto à ideia da diáspora, que como já vimos é tão cara ao pensamento de Stuart Hall, é fundamental pensar a Londres habitada por Gilberto Gil como espaço social e geográfico que permitiu o fenômeno da hibridização cultural, em pleno coração da Europa. Para os caribenhos da Inglaterra, a música é parte essencial da bagagem diaspórica. ${ }^{274} \mathrm{~A}$ música ofereceu lugares para a memória e a identidade, um refúgio do presente e novas possibilidades aos migrantes. Nesse contexto, de acordo com Stratton, as trocas culturais com a cultura dominante eram inevitáveis. ${ }^{275}$ A cultura dos colonizadores é modificada pela dos colonizados, e vice-versa, numa espécie de subversão das relações de poder coloniais.

\footnotetext{
${ }^{272}$ STRATTON, Jon. When music migrates, op. cit., p. 1.

273 Ibid., p. 10.

274 Ibid., p. 12.

275 Ibid., p. 13.
} 
Constrói-se, segundo Bhabha, uma nova hibridização cultural na Inglaterra, a qual, mais do que uma simples fusão, traz também uma articulação dialética. Nesse sentido, tanto os ritmos caribenhos - como o ska e o reggae - sofrerão influências do rock britânico, como este também jamais será o mesmo após o sucesso em terras britânicas do ska e do reggae, somente para ficar em um exemplo. ${ }^{276}$

Gilberto Gil, ao que parece, esteve atento às transformações vividas pela sociedade britânica, especialmente no que tange à cultura, durante o exílio. Sua convivência com artistas de origem caribenha e britânica parece ter the proporcionado uma sensibilidade sociológica e cultural para compreender a delicadeza das relações raciais na capital da antiga metrópole e as novas configurações musicais advindas dessas trocas culturais. Voltemos a seguir os rastros do artista baiano por Londres.

De acordo com Calado, a casa em que Gil, Sandra, Caetano, Dedé e o produtor Guilherme Araújo moravam em Londres era frequentada por Hélio Oiticica, Rogério Sganzerla, Júlio Bressane, Jorge Mautner, dentre outros. O autor conta que Caetano se sentia muito deprimido, enquanto Gil se lançou numa busca musical. Segundo Calado, Gil saía "quase todas as noites para ir a concertos de músicas pop, rock ou jazz. Além disso, graças aos baseados que fumava diariamente, qualquer possibilidade de depressão ou melancolia estava afastada em seu caso". ${ }^{277}$ Calado conta que depois do nascimento de Pedro, filho de Gil com Sandra, eles resolveram se mudar para uma casa na Kensington Park Road, na localidade de Notting Hill, e que Gil comprou sua primeira guitarra, uma Gibson 335. Conta ainda que Gil gostava especialmente da banda Traffic, indo com frequência a shows dos Stones, Jimi Hendrix e Dominos. De acordo com o autor, tais incursões acabaram por funcionar como um curso superior de música pop para Gil. Segundo Calado:

Esse intensivo curso musical não se resumiu apenas à música pop. Gil também costumava frequentar o Ronnie Scott's, o mais tradicional clube de jazz britânico, onde ouviu grandes astros do gênero, como band leader Sun Ra e sua Arkestra, o saxofonista Rahsaan Roland Kirk e a banda Weather Report. Com esta, também chegou a participar de uma canja, tocando violão e

\footnotetext{
${ }^{276}$ BHABHA, apud STRATTON, Jon, op. cit., p. 14.

${ }^{277}$ CALADO, Carlos. Tropicália, op. cit., p. 268.
} 
percussão ao lado de Wayne Shorter, Joe Zawinul, Miroslav Vitous e do baterista brasileiro Dom Um Romão. ${ }^{278}$

Essa informação nos dá pistas sobre as sonoridades exploradas por Gil nesse momento de exílio, que não se configuravam somente em rock'n'roll, mas também no jazz e outras sonoridades, como a dos jamaicanos, por exemplo; afinal, muitos dos relatos de Gil e Caetano são de que todas as noites Gil saía em busca de experiências musicais. Não há, em nenhum desses relatos, sejam aqueles feitos à época ou mesmo em rememorações feitas posteriormente, situações que evidenciem a busca por determinado som, mas sim a pluralidade deles, sendo o jazz e o rock as músicas que mais interessava m a Gil.

O relato de Caetano, em Verdades Tropicais, referente à vida em Londres, nos informa que, depois de passado um ano de exílio foram para Notting Hill Gate, "onde a presença de um grande número de jamaicanos fazia tudo parecer mais alegre". ${ }^{279}$ Segundo ele, diferentemente de Gil, Londres representou um período de fraqueza. "Gil, ao contrário, tentava tirar vantagens da situação. Saía mais, estudava com mais afinco, encontrava músicos, ia a muitos concertos". ${ }^{280}$

Ainda de acordo com Caetano dois artistas tiveram grande importância na convivência londrina, chegando mesmo a influenciar decisivamente na sua formação ideológica. Eram eles Jorge Mautner e Antônio Cícero. A relação com o primeiro deles possui especial interesse aqui, pois a ligação de Gil com Mautner em muito nos informa sobre as africanidades acessadas por Gil naquele momento e até mesmo posteriormente. Caetano conta que em Londres Mautner falava de Marx, Heidegger e Nietzsche, e também que,

Mautner percorria esse círculo sem cessar, sempre enriquecendo nossa visão, e temperando tudo com os batuques afrobrasileiros que dizia terem-no enfeitiçado através de sua muito amada babá negra. ${ }^{281}$ [grifos meus]

Em 1996, comentando os estilhaços do tropicalismo, Jorge Mautner disse:

Primeiramente eu vou expor um sumário porque bondosamente Caetano e Gil me chamaram de pai, alguns diriam "o avô do Tropicalismo". Ele disse que tanto eu quanto Jorge Ben

\footnotetext{
278 Ibid., p. 274.

279 VELOSO, Caetano, op. cit., p. 422.

${ }^{280}$ Ibid, p. 425.

281 Ibid., p.445
} 
surpreendemos. (...) Agora, minha ligação com o Tropicalismo é de toda espécie, ele é um universo paralelo ao $\operatorname{Kaos}^{282}$. Eu os encontrei pessoalmente porque fui um dos primeiros exilados da revolução de 1964. Em 65 fui um dos primeiros, senão o primeiro, escritor incluso na Lei de Segurança Nacional e pornografia. Eu os encontrei em Londres quando fiz o filme. Caetano e Gil quando me encontraram disseram "Jorge Mautne ré o primeiro intele ctual branco a respeitar a cultura negra por igual". E a partir daí é um caso de trabalho, não vou dizer conjunto, mas paralelo, e até hoje continua. Caetano acabou de lançar um livro no qual ele diz que eu já previ esse futuro agora, o violino vermelho com o qual eu toco é presente de Gilberto Gil, minha carreira artística não existiria sem Caetano Veloso e Gilberto Gil. 'grifos meus] ${ }^{283}$

Tanto nas recordações de Caetano quanto nas de Mautner, a cultura negra representou um símbolo de enlace e interesse desde os primeiros contatos. Durante o exilio, Jorge Mautner, além de compor juntamente com Gil parte do repertório de seu LP londrino $^{284}$, dirigiu e produziu em 1970 o filme $O$ demiurgo ${ }^{285}$, que será aqui analisado enquanto vestígio histórico do exílio e da vivência londrina, já que testemunha e contextualiza a experiência de um grupo de amigos que participaram do filme. Numa reportagem escrita para O Pasquim em 1971, Mautner disse que o filme "foi uma viagem de prazer e agonia (...). O filme é uma farsa, uma fábula. Oh! La Fontaine, se as pessoas soubessem como você é atual!"286

\footnotetext{
${ }^{282}$ Sobre o fundamento do Kaos, em dezembro de 1982 Mautner afirmaria: Kaos = aparente repetição, é como o ato sexual; deixaria de ser gostoso por ser sempre aparentemente a mesma coisa? Kaos = introdução da monotonia oriental no proceder e na arte do homem ocidental. Nova noção de tempo Kaos

= avanço em espiral, rebelião pura e permanente, luta contra a III guerra mundial absorvendo-a, dormindo com ela, tornando-a comestível, realidade sexual, palpável, gustável Kaos = tensão dramática, enlouquecedora, purificadora, da exis tência. Tensão que aumenta sempre, tensão contraditória com e stados de alma os mais opostos e diversos, convergindo sempre para uma tensão maior e para uma ampliação maior dos opostos em intensidade e fúria, aumentando assim a intensidade da tensão. Sadomasoquismo, depois um supra sadomasoquismo, e depois e depois um supra-supra sadomasoquismo, e assim por diante, consciência-intuição, razão-irracional, triste-alegre, luz-escuridão, Yang-Yin, tudo aumentando sem cessar, em intensidade e fúria, aumentando assim a tensão que une os opostos em crescimento contínuo, crescimento que inclui recuos, mortes, não-crescimentos, assassinatos Kaos = o que eu sou. Ilegível e legível, sábio e burro, queimação, fogo que arde dentro da gente, necessidade de dizer, de dizer, de roubar o segredo dos deuses. Edepois de cada roubo, a certeza de que há um segredo maior e que é preciso roubálo também, e assim por diante. In: MAUTNER, Jorge. Fundamentos do Kaos. São Paulo: Nova Stella editorial, 1985, p.18.

${ }^{283}$ CYNTRÃO, Sylvia Helena (org). A forma da festa-tropicalismo: a explosão e seus estillhaços. Brasília: Editora Universidade de Brasília; São Paulo: Imprensa Oficial do Estado, 2000, pp. 107-108.

${ }^{284}$ Juntamente com Mautner, Gil compôs três das onze músicas do LP Gilberto Gil (Universal, 1971) (The three mushrooms, Babylon e Crazy pop rock) além de músicas dos Beatles e Jimi Hendrix, e outras autorais. 285 O DEMIURGO. Direção: Jorge Mautner. Londres, 1970. Disponível em
} <http://www.panfletosdanovaera.com.br/detalhe/3936> Acesso em: 03 mar. 2016. ${ }^{286}$ Disponível em: <www.planfletosdanovaera.com.br> Acesso em: 05 mar. 2016. 
O filme é uma produção da Kaos Filmes. Caetano é o Demiurgo, uma espécie de oráculo e profeta, discípulo de Sócrates. Gil é o deus Pan e Mautner é Satã, a negação. O filme intercala inquietações filosóficas em cenas aleatórias, em que os amigos ora dançam ciranda, ora cantam músicas. É um filme que não intenciona retratar Londres, mas sim a saudade que aqueles amigos sentiam do Brasil. Os diálogos e as cenas são cheios de simbologismos. O Demiurgo ao mesmo tempo em que castiga as mulheres também lê suas mãos e, de repente, grita "viva a lógica", numa sátira ao logos grego. As amazonas matam o Demiurgo e bebem o seu sangue, mas ele ressuscita e discursa sobre a divina comédia humana, a saudade da Bahia e do sol dos trópicos.

No documentário que conta sua trajetória, Mautner fez uma sinopse d' $O$ demiurgo:

Foi a felicidade do meu encontro com Caetano, com Gil, Marilena e Artur. Então o mundo todo era um clima político. O filme é uma chanchada filosófica e ele tem metáforas que esperávamos exibir no Brasil. Então tem metáforas poéticas, fala de essências do que estava no ar, mas sem falar nada de política, tanto que quando exibiram aqui acho que foi o Cacá Diegues que disse: nunca vi filme tão casto, ficaram espantados. A própria censura quando viu não compreendia e falava não porque não tinha nada entre aspas de subversivo nesse sentido. Então ele é o encontro da cultura, da arte, da música e com saudades do Brasil. 287

Esse filme significou um modo de retratar o exílio através de uma produção criada pelos exilados, levando em consideração a diversidade das trajetórias nele envolvidas, das vivências, das lutas e das atividades cotidianas, sejam elas de militância ou de trabalhos artísticos. Pode ser aqui interpretado como uma espécie de sonho, brincadeira criativa entre amigos vivendo em terras distantes, com constantes alusões aos conhecimentos da filosofia ocidental. O filme $O$ demiurgo é uma espécie de texto/discurso que buscou romper com as fronteiras do exilio ao misturar cânticos, poesias e profecias, numa alusão à falta do Brasil. As fronteiras novamente se mostraram diluídas. A narrativa não é tensa: é cheia de pausas, dinâmicas, deboches, numa trama repleta de invenções. Não há no filme a representação da raiva, fosse ela direcionada diretamente ao regime militar ou aos militares, à Europa ou mesmo ao exilio. Representa a alegria do encontro, uma criação artística conjunta, espécie de adaptação, em que a resistência se fez através da atuação, da curtição, do absurdo, da comicidade e da tragédia. Ironia que provoca o riso,

${ }^{287}$ DVD O FILHO do Holocausto. Documentário. Produção: Canal Brasil. Direção e roteiro: Heitor D'Alincourt e Pedro Bial. Rio de Janeiro: Canal Brasil, 2012. 
tratando da superação do destino, num confuso diálogo entre deuses, realidade e caos.

A convivência de Gil com Mautner teve início em Londres nos idos de 1970, mas as constantes e atuais postagens dos encontros dos artistas pelo Instagram ${ }^{288}$ de Flora, mulher de Gil, demonstram a relação existente e perene que demarcou toda a trajetória desses dois artistas. Assim Gil descreveu Mautner no ano de 1977:

Jorge Mautner é uma criança distraída e tola. Sua tolice é como a lente potente do telescópio do monte Palomar: traz as estrelas para perto, para dentro, para o centro do pensar. Pensar tolices de menino numa máquina de ampliar. Assim é como eu já vi Jorge Mautner, tantas vezes, a pensar. Ele é, não tenho dúvidas, ele é um menino distraído que nos pede para lhe ensinar. Um mestre. Ele é um mestre. ${ }^{289}$ [grifos meus]

A ligação de Gil com Mautner, mas em especial a grande conectividade existente entre ambos, foi ainda reiterada mais uma vez nas páginas da Folha de S. Paulo, dessa vez em 1979, quando Gil divagava sobre as artes, sobre suas percepções do lado cósmico da música, sobre gostar de compor apenas quando está alegre. Na reportagem, Gil salientou o papel que Mautner ocupava em sua vida, como aquele que sabe mesmo traduzi-lo:

Eu tento sempre nos meus shows reconstruir essa atmosfera primordial do encontro para as artes, né? Que é o que eu gosto. Que eu falei, aquele pensar primitivo, pré-socrático. Aí teria que invocar Jorge Mautner, a essa altura da conversa. Só Jorge Mautne r poderia dizer tudo que eu penso (rindo). Só ele, ele! Faça uma entrevista com ele depois, ele vai the dizer tudo que eu penso, pode crer. ${ }^{290}$ [grifosmeus]

Assim sendo, invoquemos então Mautner, que em seu livro Fundamentos do Kaos dedica um longo trecho a traduzir Gil:

Gil é como os pré-socráticos, vai além da filosofia, pensa, é um pensador que canta, dança, melodiza \& harmoniza seus pensamentos. Como nas tribos primitivas (primitivas = supercontemporâneas porque ideogrâmicas como a flecha e o relâmpago) os feiticeiros são sábios, e no taoísmo do Yang \& Yin. Ao mesmo tempo é a encruzilhada do movimento tropicalista, seu lado mais negro, que acabou com o mal entendido separatista de artes elitistas versus arte popular,

\footnotetext{
${ }^{288}$ Um aplicativo instalado em celulares que captura e compartilha fotos.

${ }^{289}$ Apud CARDOSO, Jary. Mautner. Folha de S. Paulo,17 jul. 1977.

${ }^{290}$ Apud CARDOSO, Jary e PAZ, Maria da. Gilberto Gil com o pé na estrada. Folha de S. Paulo, 01 jul. 1979.
} 
acabou numa união-unidade, para além dos (se comparados ao tropicalismo) ainda estreitos horizontes descortinados pela bossa-nova, e pela canção política de protesto linear. Gil absorve tudo isso e torna-se diferente. Ausência de dogmatismo e encruzilhada de tudo: máquina e antimáquina, ascetismo e drogas, campo e cidade (Refazenda e Sociedade anônima), negritude dos tãs-tãs \& cultura branca até universidade de economia. Eis Gil: o viajante dos opostos, e que os amalgama de modo surreal dentro do cotidiano nacional daquele bom- humor antes do zen de "aquele abraço" escrito na prisão, uma prisão misteriosa e enigmática como só acontece a um pré-socrático cantante, como Lao-Tsé, Anaxágoras, Pitágoras, Heráclito. Há sempre uma mensagem filosófica em suas músicas. Um chamado de pai, pai de família, de nação, de tribo, de santo. Gil tem muito de líder e estadista. Por isso apoia o profeta Jorge Mautner! Namora a agudeza de diamantes do concretismo e apoia-se na genial base populista de um Jackson do Pandeiro, através das tradições assimiladíssimas de Dorival Caymmi, João Gilberto e Ary Barroso. Avança para além de Jimi Hendrix, com Strauss e Mahler e Walter Smetak da Bahia, um radical de erudito que virou misticismo além-além-atonal com instrumentos precários e perecíveis. A matéria plástica da guitarra elétrica e o som de pau de um berimbau suado. Gil gosta de encarar as contradições e apresentá-las apaziguadas, eis o que eu acho sua maior qualidade, prontas pra comer, por isso sua mais profunda seiva poética é o ser e o dizer mais completo daquilo que se poderia chamar de alma democrática brasileira, a surgir surgindo, absolutamente original, negra e mestiça, sonora e pensadora, calma, disposta a superar e a cicatrizar feridas, o rio de um continente e o mar de Atlântida misturados na batucada da pororoca. Gil gosta do Amazonas, ele é como um todo pra mim, o Amazonas da essência poético- filosófica autêntica, sem dogmatismos. ${ }^{291}$

A tradução que Mautner faz de Gil perpassa especialmente por uma conceituação abrangente de hibridização, que considera filosofias ocidentais, mas também orientais, invocando músicos populares e eruditos, rock e atonalismo, tudo isso temperado pela negritude e pela batucada. Em outro trecho de Fundamentos do Kaos, Mautner especifica o que compreende por negritude:

Foi o samba quem tudo me ensinou. A negritude é uma cultura tão profunda, se não for mais, que a chamada caucasiana, ocidental, fáustica. Heidegger, Mozart, iguais senão um pouco infe riores a: batuques, maracatus e blues. Orixás e axé! Um dia, brevemente, os tambores dos terreiros ecoarão em Londres, Paris, Viena, até mesmo em Buenos Aires, alimentando os pálidos vampiros que necessitam de nosso

${ }^{291}$ MAUTNER, Jorge. Fundamentos do Kaos..., op. cit., p. 34. 
sangue, vitamina B12 para sobreviver e rir e ter alegria. ${ }^{292}$ [grifos meus]

É interessante destacar que, na visão de Mautner, a cultura negra é tão profunda quanto a cultura caucasiana ocidental, se "não for mais", além de ser aquela que contém a força da transformação, especialmente porque é capaz de subverter problemas através da alegria. Outra situação que dimensiona o espaço ocupado pela negritude nas criações de Mautner, bem como dos tropicalistas, pode ser identificada também numa entrevista realizada com Mautner em 2007. Convidado a refletir sobre a ligação do Kaos com o Tropicalismo, assim Mautner os associou:

O Kaos antecedeu o tropicalismo. Rolou dez anos antes. Nós nos encontramos depois e Caetano diz que eu sou um dos precursores do tropicalismo, por causa dessa ideia. O Kaos sempre manteve essa linha original, marginal e universal ao mesmo tempo. No fundo, eu acho que nós partimos de um mesmo berço de ideias, que é a visão da antropofagia de Oswald de Andrade e a visão da afirmação da cultura das várias negritudes brasileiras. Havia um senso de inferioridade da cultura brasileira, mas nós tocamos a supe rioridade da cultura brasileira. ${ }^{293}$ [ grifos meus]

Para Mautner, as várias negritudes brasileiras são o vínculo que associa sua teoria ao tropicalis mo. No entanto, Mautner não somente cita o papel ocupado por essas culturas marcadas pela inferioridade, como propõe uma releitura desses papéis, uma vez que a cultura negra é para ele mais profunda que a caucasiana, como afirmou no seu Fundamentos do Kaos.

Em 1987, quando Gil ingressou como secretário de cultura na Fundação Gregório de Matos, em Salvador, Jorge Mautner foi seu assessor cultural, e nesse mesmo ano lançou em parceria com Gil o espetáculo intitulado O poeta e o esfomeado ${ }^{294}$, em que se tematizava a negritude e o racismo.

A parceria de Gil com Jorge Mautner se inicia em Londres, em 1970, e permanece constante até a atualidade. Não apenas criaram esse espetáculo juntos, como foi Mautner quem convenceu Gil a visitar o cientista Mario Schenberg, que acabou the incumbindo

\footnotetext{
${ }^{292}$ Ibid, p. 33.

${ }^{293}$ FRÓES, Marcelo e PETRILLO, Marcos. Entrevista com Jorge Mautner. Publicado originalmente na International Magazine, em 6 de março de 1996. In: COHN, Sérgio (org.) Jorge Mautner-Encontros. Rio de Janeiro: Beco do Azougue, 2007.

${ }^{294}$ A ser analisado no terceiro capítulo.
} 
da missão de criar uma música ${ }^{295}$ que tratasse da luta antiapartheid na África do Sul. Mautner, além de dividir com Gil uma inquietação filosófica, foi seu assessor na Fundação Gregório de Mattos e também no Ministério da Cultura, demonstrando dessa forma que a relação desses artistas foi contínua. Tal elemento é importante nesta análise, pois nos ajuda a elucidar como se formulou uma representação de africanidades na trajetória e obra de Gil.

Outro elemento que nos permite questionar o surgimento para Gil dessa representação no momento do exilio perpassa novamente pelas assertivas de Caetano.

Gil nunca parecia consciente do fato de que era preto. Isso não o humilhava ou enaltecia: ele simplesmente se portava como um cidadão desembaraçado. Sua desenvoltura natural fazia com que a negritude nele correspondesse ao tom em que minha mãe se referia a ela (Caetano, venha ver aquele preto que você gosta). No final da década - sobre tudo sob o impacto de Jimi Hendrix - Gil vestiu a máscara do negro com consciência racial, e essa nova persona, em vez de meramente ocultar o homem resolvido além dos conflitos, revelou conteúdos de mágoa e orgulho havia muito latentes sob o antigo véu. Era como se ele se tivesse longamente submetido à crença de que não era preciso bater no peito e gritar "sou negro!" ou protestar contra discriminações, considerando bastante ter uma vida digna e formar-se social e intelectualmente como fizera seu pai. Agora, com o aspecto "Black is beautiful" da cultura pop que ele abraçava como consequência de seu refinamento pessoal, ele encontrava africanidades em suas reminiscências domésticas e revolta contra os aspectos raciais da injustiça da sociedade brasileira. É revelador de profunda verdade sobre essa questão no Brasil o fato de Gil ter sido um exemplo perfeito de filho de "preto doutor" baiano, e à medida que os negros pobres foram dominando a paisagem humana da Cidade do Salvador com sua afirmação cultural popular pós-60, e, ao mesmo tempo, perdendo chances de se tornarem profissionais liberais por causa da intensificação das desigualdades sociais e da ruína da educação pública, ter se tornado um líder mítico dessas novas massas negras. Assim, o pequeno burguês bossa-nova de 63 é cantado pelos blocos afro dos anos 80 e 90 como aquele que ficou no lugar de Bob Marley na defesa de seu povo. ${ }^{296}$

De acordo com Caetano, a negritude era indiferente para Gil nos momentos préexílio, e só no final dos anos 1960afloraria em Gil uma consciência racial. Acreditando que Caetano, pela grande afinidade e longa convivência, assim como Mautner, é capaz

\footnotetext{
${ }^{295}$ A música é "Oração pela libertação da África do Sul", lançada no LP Dia Dorim Noite Neon, cf. GIL, Gilberto. Dia Dorim Noite Neo (Warner Music, 1985). O caso é contado por Gil em: GIL, Gilberto e OLIVEIRA, Ana. Disposições amoráveis. São Paulo: Iyá Omin, 2015, p. 226.

${ }^{296}$ VELOSO, Caetano, op. cit., p. 288.
} 
de traduzir o artista Gil, tomamos essas reflexões para adensarem ainda mais nossa compreensão sobre a construção de uma africanidade na trajetória de Gil.

Podemos aqui interpretar o impacto de Hendrix como mais um dado dessa construção identitária, mas especialmente, nesse caso, através de elementos de africanidade. A conexão de Gil com Hendrix foi parte da emersão do artista no mundo pop. Há um contexto, do qual ele participa e que já estava presente em Salvador nos anos 60, como inclusive afirma Caetano, e que vai se aprofundar em Londres, que enaltece a questão da negritude e o faz "ler" de outra maneira essa questão.

Jimi Hendrix, lembrado por Caetano na citação como importante referência para Gil, foi um guitarrista negro norte-americano cujo reconhecimento deu-se em Londres antes de o ser nos EUA. Antes do sucesso, Hendrix era apenas mais um integrante da banda do cantor Little Richard. Seu sucesso deveu-se ao fato de interpretar as músicas abusando das distorções e de outros timbres acessados pelo domínio do amplificador, inaugurando uma nova abordagem na utilização do instrumento. Numa performance sempre explosiva, Hendrix parecia entrar em transe ao tocar sua guitarra. Era um artista que abusava dos recursos visuais, usando sempre casacos muito coloridos ou cheios de detalhes, além de faixas no seu cabelo black power.

Musicalmente, Hendrix recriava as sonoridades afro-americanas. Seu repertório incluía o blues, funk e rock americanos, mas com uma nova identidade sonora, através da exploração da guitarra e seus recursos elétricos. Além disso, Hendrix também incorporava em seu repertório o rock inglês dos Beatles, de Eric Clapton e de The Wings. Um instrumentista que recriou a maneira de utilizar a guitarra, que trazia consigo as raízes afro-americanas, mas era aberto a novas assimilações musicais. ${ }^{297}$

Assim, a negritude de Gil conectou diversos elementos culturais elaborados na rede atlântica que originou e abrigou a diáspora negra. O rock é uma referência transnacional que circulou conectando boa parte dessa rede; além disso, esse gênero musical é um bom exemplo das formas estético-comportamentais hibridas/sincréticas que muito circularam nesse Atlântico Negro.

${ }^{297}$ 〈https://www.youtube.com/watch?v=Dah-IEZwzlk> Acessado em: 17 abril 2016. 
Não apenas através dos comentários de Caetano, mas do próprio Gil, ${ }^{298}$ é possível perceber que o exilio forneceu a Gil novo material para questionar com outro olhar sua negritude, num momento em que esse universo vivenciava também essa espécie de demanda. No exilio, Gil conectou-se com realidades internacionais e transculturais (britânica, americana, jamaicana, indiana), compactuando com a tese de Paul Gilroy sobre a fragilidade da ideia de Nação nas culturas da diáspora. De acordo com Paul Gilroy:

As culturas negras da diáspora mostram-se abertas, inacabadas e internamente diferenciadas. Elas são formadas a partir de múltiplas fontes por movimentos que se entrecruzam no mundo atlântico (...). Elas são continuamente criadas e recriadas com o tempo, e a sua evolução é marcada pelos processos de deslocamento e de reposição dentro do mundo atlântico, e pela disseminação através de redes mundiais de intercâmbio de comunicação e cultura. ${ }^{299}$

A conexão de Gil com Hendrix, ou mesmo com o rock inglês, mas também com a cultura jamaicana e o jazz, são um bom exemplo das formas culturais híbridas/sincréticas/mestiças que se modelaram na rede atlântica. Ao se deixar contagiar por Hendrix, Gil referência não diretamente a África, mas as muitas africanidades experimentadas nas Américas e que circularam também pela Europa, e no caso de Hendrix e Gil, por Londres.

No fervilhar do retorno, em 1972, Gil dividiu sua experiência londrina em três diferentes momentos:

Eu tive um problema de abafamento neurótico (...) era mais um negócio de assumir o recolhimento, uma situação que era mesmo essa. Londres - como eu dizia uma vez num filmezinho que a gente fez lá - é um mosteiro ajardinado, um lugar de recolhimento, onde a gente não tem calor, não tem sol, então é

\footnotetext{
${ }^{298}$ De acordo com Gil: Eu vou na verdade me interessar profundamente pela questão negra nesses dois momentos, na volta de Londres e no segundo momento mais fortemente quando eu faço a Refavela. In: O SOM do vinil. Rio de Janeiro: Canal Brasil, 2011. Programa de TV. Nessa citação quando Gil desloca para a sua volta do exílio o aprofundamento desse processo nos dá indícios de que tanto o deslocamento forçado quanto a imersão num universo demarcado pelo hibridismo, não somente das culturas negras da diás pora, demarcou seu retorno ao Brasil como um tempo de olhar com novos olhos para a cultura brasileira, como para as questões referentes ao mundo da negritude. Algo foi acessado emLondres, mas seria o retorno ao Brasil que possibilitaria o aprofundamento dessas questões. Se Gil teve uma visão ampliada do Brasil por se afastar do país, ao regressar sua intenção era conhecer de perto as complexas construções culturais brasileiras, compreendendo o que décadas mais tarde denominaria de do-in antropológico.

${ }^{299}$ GILROY, Paul. O Atlântico negro: modernidade e dupla consciência. $2^{\mathrm{a}}$ ed. São Paulo: Editora 34 ; Rio de Janeiro: Universidade Cândido Mendes, Centro de Estudos Afro-Asiáticos, 2012, pp. 252-259.
} 
um lugar onde a gente tem que...eu por exemplo colocava muito pra mim mesmo, como proposta, como exercício, a ser feito, a coisa de ficar calado, de falar pouco, de pensar mais, de reflexão, que estava tudo ligado à minha postura mística, de ioga, que eu fazia, que eu cheguei lá fazendo, da macrobiótica; então eu não comia na mesa a comida que o pessoal comia, eu tinha os horários completamente diferentes, isso na época em todos nós vivíamos juntos, cê tá entendendo? No primeiro ano que a gente esteve lá. Então eu era assim um marginal, um marginalizado na casa, mas sem nenhum sofrimento, aquilo era por coisas que eu estava assumindo. $\mathrm{O}$ sofrimento era interior. Era uma consciência generalizada de toda a situação. $\mathrm{O}$ sofrimento era o fato de eu estar lá, o fato de eu ter tido de sair daqui. Era dizer: Poxa, eu agora estou nessa situação, eu tenho que aprender essa situação vivenciando ela inteiramente. Vencendo todos os aspectos. Não adiantava eu tentar criar uma ebulição, um feerismo que não existia. Isso de certa forma prejudicava os planos do Guilherme, que ele não para, aquela coisa, ele está ali: pá-pá-pá-pá... Eu queria muito essa coisa de recolhimento, no primeiro ano. No segundo ano, foi a casa aberta. Abri a casa, passou a entrar todo mundo, eu aí nem tinha tempo mais de recolhimento, nem de meditar sozinho. Eu estava sempre com todo mundo. Aí foi o ano mesmo de alegria. Isso foi até agosto do ano passado. Quando eu resolvi ir pro campo, pra fora de Londres, com Sandra, sozinho, com Pedro, Tuti e Ina, pra me concentrar em coisa de música; já era uma terceira fase, digamos assim, uma mistura entre recolhimento e extroversão; para o trabalho, para cuidar daquilo que a gente estava fazendo lá, de música. ${ }^{300}$

Esse longo depoimento realizado logo após a experiência do exilio demonstra como se deu o processo e exílio para Gil. Se em um primeiro momento sua escolha foi por aprofundar seu recolhimento na busca por autoconhecimento, o segundo foi vivenciado através da casa aberta, da alegria em conviver com muitas pessoas, do nascimento de seu filho Pedro, para retornar na última fase do exilio a uma nova forma de recolhimento, escolhendo a vida no campo para se dedicar ao labor musical. Em sua experiência londrina, Gil mudou-se algumas vezes para melhor adequar seus planos pessoais e profissionais; através desses constantes deslocamentos, acabou por redefinir constantemente seus questionamentos, sempre adensando o diálogo com diferentes situações culturais.

Stuart Hall, refletindo sobre a terra no exterior, e em especial sobre os caribenhos que migraram para a Grã-Bretanha, afirma que "na situação de diáspora, as identidades

\footnotetext{
${ }^{300}$ Gil apud ALMEIDA, Hamilton. O sonho acabou, Gil está sabendo de tudo. O Bondinho, 16 fev. 1972, apud: COHN, Sergio (org).Gilberto Gil - Encontros. Rio de Janeiro: Beco do Azougue, 2007.
} 
se tornam múltiplas. Junto com os elos que as ligam a uma ilha de origem específica, há outras forças centrípetas. ${ }^{\text {301 }}$ Hall questiona:

Que luz, então, a experiência da diáspora lança sobre questões da identidade cultural e epistemológica, além de empírica, o que a experiência da diáspora causa a nossos modelos de identidade cultural? Como podemos conceber ou imaginar a identidade, a diferença e o pertencimento, após a diáspora? Já que "a identidade cultural" carrega consigo tantos traços de unidade essencial, unicidade primordial, indivisibilidade e mesmice, como devemos "pensar" as identidades inscritas nas relações de poder, construídas pela diferença, e disjuntura? ${ }^{302}$

O que essa diáspora forçada, ainda que curta, causou aos modelos de identidade cultural de Gil? Como passou a imaginar sua identidade, a diferença e o pertencimento? A vida em Londres foi especialmente experimentada juntamente com uma comunidade brasileira, uma espécie de família ampliada; assim, uma mesmice ou mesmo uma unicidade primordial foi mantida. Os impulsos em traduzir esse novo mundo, suas várias estéticas, inúmeras linguagens, diferentes musicalidades permitiram ao artista Gil deglutir ou mesmo ler esses lugares e praticar esses novos espaços, numa espécie de tradução construída pela diferença.

Bhabha questiona a construção cultural como uma forma de afiliação social e textual, e afirma que:

De certa forma é em oposição à certeza histórica e à natureza estável desse termo que procuro escrever sobre a nação ocidental como uma forma obscura e ubíqua de viver a localidade da cultura. Essa localidade está mais em torno da temporalidade do que sobre a historicidade: uma forma de vida que é mais complexa que "comunidade", mais simbólica que "sociedade", mais conotativa que "país", menos patriótica que patrie, mais retórica que a razão do Estado, mais mitológica que a ideologia, menos homogênea que a hegemonia, menos centrada que o cidadão, mais coletiva que "o sujeito", mais psíquica do que a civilidade, mais híbrida na articulação de diferenças e identificações culturais do que pode ser representado em qualquer estruturação hierárquica ou binária do antagonismo social. $^{303}$

Assim, vemos que as construções culturais realizadas por Gil são hibridizadas na articulação entre diferenças e similitudes, já que o artista que chega a Londres o faz

\footnotetext{
${ }^{301}$ HALL, Stuart. Da diáspora: identidades e mediações culturais. $1^{\circ}$ ed. atualizada. Belo Horizonte: ed. UFMG, 2009, p. 26.

${ }^{302}$ HALL, Stuart. Da diáspora..., op. cit., p. 28.

303 BHABHA, Homi K.O local da cultura...,op. cit., p. 199.
} 
empunhando um violão, recém-tropicalista e fortemente inclinado, juntamente com Caetano, a trabalhar na continuidade da linha evolutiva da música brasileira que tinha na bossa nova seu ápice, e, a partir do exílio londrino, passa a incorporar de maneira cada vez mais definitiva o rock, o jazz e também o reggae. ${ }^{304}$ Não é o caso de afirmarmos a criação de uma estruturação hierárquica ou mesmo binária de antagonismos culturais na vivência do exílio, mas sim a forte existência da hibridação e da tradução.

Desse modo, podemos pensar sobre a vida experimentada por Gil no exilio - ou mesmo questionando qual o local da cultura nessa abordagem - que foi no entre-lugar que a identidade do artista foi sendo formulada, através da força narrativa e musical como uma potente força simbólica e afetiva de identidade cultural. Se o que tempera o disco londrino é o canto em inglês ao som do rock'n'roll, e quase nenhuma menção à sonoridade brasileira, o alimento do corpo era procurado nos restaurantes jamaicanos que faziam a comida familiar (soul food) tão parecida com aquela baiana. O que se apreende é que existiu um grande trânsito de diferentes códigos culturais que se misturaram, ora valorizando mais aspectos da tradição, ora outros ligados à modernidade, mas sem elencar ou supervalorizar um em detrimento do outro, já que a experiência do exilio foi fortemente marcada pela experimentação, pela inserção em novos espaços musicais - a troca do violão pela guitarra, o abandono do banquinho e a ocupação da frente do palco de pé e com a guitarra. A aquisição ou mesmo a escolha de elementos ligados à modernidade não significou o abandono ou a negação de elementos que representassem a tradição, mas sim o amálgama dessas diferentes informações.

Questionado sobre a vida em Londres ter sido uma espécie de pós-graduação no mundo urbano e pop, assim Gil respondeu:

Era uma época incrível. Os festivais, as raves, festas que duravam noites inteiras, dias inteiros, tudo aquilo era muito intenso, era uma vivência, um aprendizado muito grande, muito forte. $\mathrm{E}$ ao mesmo tempo tínhamos de manter familia, manter trabalho e a cabeça no lugar. Era tudo muito desafiador, mas muito rico. Pra mim foi uma experiência incrível que ajudou muito na questão da expansão do horizonte musical, a coisa toda de querer um processo mais aventureiro com a música, mais experimental, de romper barreiras, que deu em discos como Expresso 2222 quando eu voltei ao Brasil. Acho que foram elementos que deram base de sustentação estética, de visão musical para os meus dez anos seguintes. É dali que saíram as bases para Refazenda, Refavela, Realce, que marcaram a minha presença na música

\footnotetext{
${ }^{304}$ Gêneros esses fortemente informados pelas africanidades.
} 
popular, com aquele território demarcado de liberdade, de experimentação. Isso tudo vem, claro, do tropicalismo, mas a sequência em Londres foi fundamental. ${ }^{305}$

Na rememoração referente a Londres e a essa fase de sua vida, o relato de Gil expõe o exílio como uma fase positiva, atrelada a experimentações e à expansão de seu horizonte musical. No entanto, é preciso questionar essa vivência do exilio, já que suas experiências não foram somente positivas ou apenas uma espécie de pós-graduação no mundo pop. Afinal, nem sempre as situações foram favoráveis ao grupo brasileiro, e em especial a Gil. Se o grupo foi capaz de realizar shows, produzir um filme e gravar LPs londrinos, houve também momentos de revolta e sofrimento. A carta escrita por Gil para a revista Pasquim em 1970, intitulada $R E C U S O+A C E I T O=R E C E I T O$, em resposta à recusa ao prêmio Golfinho de Ouro, a ele concedido pelo Museu da Imagem e do Som em reconhecimento pelo samba "Aquele abraço", é uma situação aqui retomada com o objetivo de refletir sobre a realidade experimentada nos tempos londrinos, procurando evidenciar diferentes sensações experimentadas naquele cenário, como o medo e a angústia, além de nos informar sobre o modo como a negritude era concebida por Gil naquele momento. Segue abaixo a transcrição de boa parte da carta:

(...) Pois, um golfinho de mares cariocas resolve tirar o meu sossego ajudado pela ingenuidade ou pela burrice de meia dúzia de pessoas que de repente resolvem achar importante o fato de eu aceitar ou não um prêmio que me deram. A velha mania brasileira de se meter nos problemas domésticos do vizinho. Mesmo se o cara mora na Inglaterra. Para mim, a essa altura, aceitar ou não prêmios ao trabalho que fiz no Brasil, já não tem a menor importância. Agora eu estou on the road. Sábado passado no Festival Hall, amanhã, de pois e sempre em outros lugares I'm wasted but I can't find my way home. Repito que recusar ou aceitar esse prêmio não tem a menor importância e eu resolvi recusar pra ver se vocês estão mesmo a fim de entender alguma coisa. Pois é. Porque não acredito como pensam meu pai $\&$ amigos do Brasil que o golfinho me tenha sido concedido por aqueles que reconhecem meu trabalho, que realmente gostam de mim e não pelos que menosprezam e ignoram. Ingenuidade. Embora muita gente possa realmente respeitar o que fiz no Brasil (talvez até mesmo gente do Museu), acho muito difícil que esse museu venha premiar a quem, claramente, sempre esteve contra a paternalização cultural asfixiante, moralista, estúpida e reacionária que ele faz com relação à música brasileira. Sempre estive contra toda forma de fascismo cultural de que o museu - à sua maneira - vem representando uma parcela no Brasil.

${ }^{305}$ Gil apud ZAPPA, Regina, op. cit., p. 175. 
Se, quando eu estava aí, eu nunca perdi tempo atacando diretamente organizações como o Museu da Imagem e do Som é porque meu trabalho já fazia isso; minha música já assumia essa responsabilidade. E se eu continuasse aí não estaria sendo premiado. Claro que eu não acredito nesse prêmio. Pelo que me é dado saber o museu continua o mesmo e portanto eu continuo contra e recusar o prêmio é só pra deixar isso bem claro. Se ele pensa que com "Aquele abraço" eu estava querendo pedir perdão pelo que fizera antes, se enganou. E eu não tenho dúvida de que o museu realmente pensa que "Aquele abraço" é samba de penitência pelos pecados cometidos contra "a sagrada música brasileira". Os pronunciamentos de alguns dos seus membros e as cartas que recebi demonstram isso claramente. $\mathrm{O}$ museu continua sendo o mesmo de janeiro, fevereiro e março: tutor do folclore de verão carioca. Eu não tenho porque não recusar o prêmio dado para um samba que eles supõem ter sido feito zelando pe la "pureza" da música popular brasileira. Eu não tenho nada com essa pure za. Tenho três LPs gravados aí no B rasil que demonstram isso. E que fique claro para os que cortaram minha onda e minha barba que "Aque le abraço" não significa que eu tenha me "regenerado", que eu tenha me tornado "bom crioulo puxador de samba" como eles bem querem que se jam todos os negros que realmente "sabem qual é o se u lugar". Eu não sei qual é o me u e não es tou em lugar nenhum; não estou mais servindo a mesa dos senhores brancos e nem estou mais triste na senzala em que eles estão transformando o B rasil.(...) O que meu pai precisa saber é que o museu sempre esteve contra o meu gorjeio, que sempre achou desnaturado, desarmonioso, inautêntico e incômodo; sempre esteve contra tudo que na música, no disco e na TV, tenha tido um sentido de abertura compatível com a liberdade criativa de um povo novo e fogoso como o brasileiro. Pelo que sei, as aristocráticas e puritanas prateleiras do museu não guardam até hoje um só programa do Chacrinha, o mais lindo que alguém jamais pôde encontrar em qualquer televisão do mundo. Pra mim o museu e o nazi-fascismo comem no mesmo prato, e, exatamente por não compreenderem isso, meu pai e meus ingênuos amigos acabam comendo também desta suculenta e colorida pasta de miséria tropical, sal, mal, mel, fel \& fé (a geléia geral brasileira que o Jornal do Brasil anuncia - e que o Pasquim também?) (...) Mas estou longe, sozinho e não quero saber de nada. Por favor entendam, é fácil, é primário. (...) receito uma dose de formicida de tatu para esse assunto. Não há nenhum herói nem nenhum gênio para ser condecorado; não há nada para ser premiado. Somos todos muito pobres e eu já estou longe, muito longe, vendendo minha miséria para comer. (...) PS: Com a publicação desta carta, o prêmio está implicitamente recusado. Que o golfinho volte para as águas tranquilas de sua insignificância. ${ }^{306}$

${ }^{306}$ Gil apud RISÉRIO, Antônio. Gilberto Gil: Expresso 2222..., op. cit., pp. 43-47. 
É longa a transcrição, mas de extrema riqueza sobre a temática aqui abordada, que é a construção de africanidades na trajetória de Gil, e em muito nos informa sobre suas elaborações identitárias nesse momento em questão. Motivado anão aceitar o prêmio, mas também a explicitar suas posições frente às expectativas de seu pai e dos amigos pela recusa, Gil nos fornece muitos indícios que fomentam nossa compreensão sobre seu estado de espírito nesse instante. O museu foi identificado tanto com a opressão e o moralismo que o enviaram ao exílio como com a incapacidade de perceber a inovação cultural pela qual passava o país. A carta expressa a percepção de Gil quanto ao entrelugar de onde fala; em outras palavras, podemos afirmar que estar em trânsito é o seu lugar.

Especialmente incomodado com o lugar no qual os agentes do museu quiseram colocá-lo, Gil se contrapôs ao ideal de bom crioulo puxadorde samba. Questionando que o lugar do negro já é algo determinado, Gil afirmou: Eu não sei qual é o meu e não estou em lugar nenhum; não estou mais servindo a mesa dos senhores brancos e nem estou mais triste na senzala em que eles estão transformando o Brasil. E, ao não se fixar a nenhum lugar, Gil conclama pra si a liberdade, além da fuga da imposição de papéis préestabelecidos.

Aqui o local da cultura e suas possíveis interpretações se mostram em questão. A intenção do museu em premiar o exilado Gil gerou no artista um grande mal-estar, fazendo-o interpretar essa ação como uma tentativa de enquadrar sua canção "Aquele abraço" como a de um negro que deve saber seu lugar. Frente a essa situação, e questionando esse enquadramento, Gil cita um trecho da música "Can't find my way home”, lançada em seu LP londrino; ao se sentir perdido e sem saber o caminho de casa, Gil sabe que seu lugar não é o dessa negritude representada por uma suposta autenticid ade e pureza. Nesse enfrentamento e recusa frente à pretensão do museu em fixar seu lugar, Gil em 1970, dimensiona a localidade de sua negritude, que nesse instante é a negação da imposição de um papel que associa ser negro, por exemplo, a saber puxar um autêntico samba.

Entrelaçando a negação para si do passado sofrido na senzala à negação de cumprir funções subservientes no presente, e reunindo a isso a convivência com o universo pop desde o advento da Tropicália, Gil intencionou nesse instante a criação de uma nova situação no futuro. A interseção desse "passado-presente" é o entre-lugar, é 
parte da necessidade de renovação e não nostalgia, não é continuidade, mas sim revolta com o que está estabelecido como verdade para determinadas instâncias da sociedade.

De acordo com Bhabha, boa parte das teorias críticas contemporâneas compactua com a ideia de que cultura está para além dos objetos de arte e para além da canonização estética, como "produção irregular e incompleta de sentido e valor, frequentemente composta de demandas e práticas incomensuráveis, produzidas no ato da sobrevivência cultural. "307 $\mathrm{O}$ autor afirma ainda que:

A cultura como estratégia de sobrevivência é tanto transnacional como tradutória. Ela é transnacional porque os discursos póscoloniais contemporâneos estão enraizados em histórias específicas de deslocamento cultural, seja como "meiapassagem" da escravidão e servidão, como "viagem pra fora" da missão civilizatória, a acomodação maciça da migração do Terceiro Mundo para o Ocidente após a Segunda Guerra Mundial, ou o trânsito de refugiados econômicos e políticos dentro e fora do Terceiro Mundo. A cultura é tradutória porque essas histórias espaciais de deslocamento - agora acompanhadas pelas ambições territoriais das tecnologias "globais" de mídia tornam a questão de como a cultura significa, ou o que é significado por cultura, um assunto bastante complexo. ${ }^{308}$

Essa carta representa uma espécie de sobrevivência cultural, e denota muito mais hibridez do que rigidez na escolha dos valores culturais com os quais Gil dialoga. Enquanto sujeito que enuncia sua cultura musical, ele o faz a partir dos "signos" referentes aos contextos que frequenta, mas especialmente com os quais se identifica. Seu deslocamento constante, e nesse caso forçado, o colocou em contato com uma série de elementos que não conheceria se estivesse no Brasil. A guitarra, por exemplo, foi um instrumento que em sua experiência londrina ganhou um novo significado.

Bhabha, ao tratar da agência, afirma:

Minha passagem do cultural como objeto epistemológico à cultura como lugar enunciativo, promulgador, abre a possibilidade de outros "tempos" de significado cultural (retroativo, prefigurativo) e outros espaços narrativos (fantasmático, metafórico). Minha intenção ao especificar o presente enunciativo na articulação da cultura é estabelecer um processo pelo qual outros objetificados possam ser transformados em sujeitos de sua história e de sua experiência. Minha argumentação teórica tem uma história descritiva em

\footnotetext{
${ }^{307}$ BHABHA, Homi K.O local da cultura..., op. cit., p. 240.

${ }^{308}$ Ibid., p. 241.
} 
desenvolvimento recente nos estudos literários e culturais de afro-americanos e escritores negros ingleses. ${ }^{309}$

Gil aqui é sujeito de sua história e de sua experiência. No exílio, foi ator do filme produzido pela fraternal comunidade brasileira, escritor de uma carta direcionada ao MIS questionando o papel de negro ao qual queriam sujeita-lo, atração artística e muitas vezes plateia. Londres representou um espaço de ampliação de horizontes e diluição de fronteiras, revelando fortes traços de solidariedade e aprendizado.

O exílio possibilitou a Gil uma viagem para fora do seu país natal, e, em Londres, um deslocamento constante no próprio espaço geográfico daquela metrópole. O filóso fo francês Michel Onfray busca estabelecer uma teoria da viagem ${ }^{310}$ que pode ajudar a compreender essa dinâmica. Ele diferencia a viagem do viajante daquela empreendida pelo turista. A viagem turística é pautada pela fruição de locais turísticos como "bens de consumo", comodamente impostos por agências e não questionadas em sua condição de lugar-comum. É um olhar à margem, pois o turista apenas "confere" o local visitado com o cartão-postal que ele traz no bolso. $\mathrm{O}$ viajante, por sua vez, sai pelo mundo em busca de um contato consigo mesmo, para talvez descobrir-se em sua verdade interior: perderse para achar-se. É, por isso, uma atitude baseada no ideal socrático do autoconhecime nto. As viagens, enquanto exercícios de nomadismo, são por isso mesmo um processo iniciático, que possibilita, em última instância, ao conhecimento de si e do mundo.

As experiências vivenciadas no exilio, e em especial o contato com tão diferentes sociabilidades e com diversas sonoridades, foram alicerçando na vida de Gil novas percepções, responsáveis por incorporar novos índices identitários, expressos nos discursos textuais e musicais do artista. O exilio representou uma espécie de viagem transatlântica, possibilitando a Gil dialogar com diferentes musicalidades. A música de Jimi Hendrix representa uma africanidade pop moderna transnacional; o reggae, ecos de militância nas lutas antirracistas do povo afro-caribenho; e o jazz, marcado por um grande desenvolvimento harmônico absorvido em muitas culturas do mundo, como, por exemplo, a bossa-nova no Brasil, e sua posterior articulação com outros gêneros musica is brasileiros, como o baião. Gil ouvia tudo isso por lá, formando uma espécie de conexão com estéticas de negritudes modernas das Áfricas pelo mundo.

\footnotetext{
309 Ibid., p. 248.

${ }^{310}$ ONFRAY, Michel. Teoria da viagem, poética da geografia. Porto Alegre: L\&PM, 2009, p. 81.
} 
Não houve uma simples apropriação musical referente a essa vivência intensa, de determinados padrões musicais, mas sim reelaborações que acabaram por desembocar numa transformação musical. O esforço de Gil era edificar cada vez mais conhecimentos musicais, explorar a guitarra, mas também tocar seu bongô em algumas situações. Essas atividades revelam que Gil estava em constante busca por não se enclausurar em um mundo estático, e sim adentrar e compreender o que aquele universo podia the oferecer.

\section{- Back in Bahia: o retorno do exílio}

O desejo de retornar para o Brasil era mais latente em Caetano ${ }^{311}$, que tentou realizá-lo quando conseguiu uma permissão frente às autoridades militares, a pedido de Maria Bethânia, para participar da comemoração de quarenta anos de casamento de seus pais. Caetano embarcou com o visto de permanência validado para um mês, juntamente com Sandra e Dedé, em agosto de 1971. No desembarque, foi levado por militares, interrogado e ameaçado por seis horas seguidas. Sobre a curta estadia no país, Caetano contou:

Não podia recusar entrevistas com a imprensa, mas teria que dálas por escrito e submetê-las a leitura prévia por parte de agentes federais que me vigiariam durante toda estadia; finalmente, era obrigado a fazer duas apresentações na TV, uma no programa do Chacrinha e outra no Som Livre Exportação, o novo musical da TV Globo, para que "tudo parecesse normal". ${ }^{312}$

Alguns meses depois desse breve retorno, de volta a Londres e gravando seu LP Transa, Caetano contou que um telefonema de João Gilberto mudou o rumo de tudo. João ligou tarde da noite para Caetano, convidando-o para participar com ele e Gal de um programa especial de TV a ser gravado em São Paulo. No telefonema, João Gilberto teria dito a Caetano: "É Deus quem está me pedindo para eu lhe chamar. Ouça bem: você vai saltar do avião no Rio, todas as pessoas vão sorrir pra você. Você vai ver como o Brasil te ama". ${ }^{313} \mathrm{E}$, de acordo com Caetano: "Ao desembarcar no Rio, tudo se deu como João Gilberto tinha profetizado. As pessoas da imigração nos trataram como se nunca tivesse

$\overline{{ }^{311} \text { Dado abordado tanto na biografia }}$ de Caetano quanto na de Gil.

312 VELOSO, Caetano. Verdade..., op.cit.,p. 452.

313 Ibid., p. 459. 
havido problema comigo no país. ${ }^{314}$ Depois disso, voltaram para Londres apenas para ajeitar as pendências, e em janeiro de 1972 retornaram Caetano e Dedé para o Brasil.

Tanto na biografia de Gil como na de Caetano, esse retorno aconteceu de modo pacífico. Depois das primeiras truculências vivenciadas por Caetano em sua primeira viagem ao Brasil, não há menção alguma, nem nas biografias e nem nas demais fontes que tratam da temática do exílio, a existência de qualquer resistência a sua volta.

Numa longa e reveladora entrevista realizada ainda em Londres, momentos antes de retornar ao Brasil, Gil disse:

Fico uns dias no Rio e no fim do mês vou pra Bahia. A Bahia vai serminha base. Vou ver a feira de Caruaru, em Pernambuco, visitar minha família no interior. Devo ficar no Brasil por dois ou três meses (...) Meus planos são de voltar à Inglaterra, mas é claro que existe a possibilidade de tudo mudar

... O que acontece, agora, é que tenho uma curiosidade enorme em torno das coisas brasileiras. Sinto que não sabia tanto quanto imaginava. O alargamento de visão que se adquire aqui fora equivale a enxergar um quadro em toda a sua perspectiva. $O$ quadro se ampliou e agora quero examinar com ate nção os de talhes. Por exemplo, o samba em si, o samba como forma. O fato de eu me sentir aqui, digamos, culturalmente irresponsável, engajado numa música pop que não sofre a força da gravidade, me faz sentir falta da coisa brasileira. Quero ir ao morro falar com os sambistas. No meu caso pessoal, o importante é que eu comecei o meu contato com a música num nível mais estratificado, numa camada de elite. Meu contato com a música foi com a base da bossa nova. Agora, quero um contato com a "real thing". Eu era um músico de elite. Minha forma de tocar violão só hoje se aproxima da que os músicos naturais conseguem. A minha volta está ligada a isso. Que ro me expor a toda essa experiência, conversar com músicos brasileiros, como o Paulinho da Viola, ir a algumas cidades do Nordeste encontrar violeiros repentistas... ${ }^{315}[$ grifos meus]

As numerosas páginas dessa entrevista parecem ser não somente o testemunho de toda a experiência vivenciada em Londres, como também uma espécie de autorrefle xão. É bastante clara a postura de busca pela brasilidade no instante do retorno, bem como a modificação na performance do artista, que, ao sair do palco e ocupar a plateia, acabou absorvendo novas informações e se reinventando. Vários são os indícios de que naquele momento o que Gil considerava a coisa real brasileira eram os sambistas das favelas,

\footnotetext{
${ }^{314}$ Ibid., p. 459.

315 Apud KUCINSKI, Bernardo. As experiências e a volta de Gilberto Gil. Veja, 19 jan. 1972.
} 
era Paulinho da Viola ou os violeiros do Nordeste. É interessante ressaltar que Gil se apresenta como um músico de elite e formado num universo musical estratificado, e que sua busca listou duas regiões como aquelas mais representativas da brasilidade da qual estava em busca: o Rio de Janeiro e o Nordeste.

Gil pondera ainda o fato de ter vivenciado a possibilidade de enxergar, pelo distanciamento do exílio, o Brasil de uma maneira ampliada, atrelando ao seu retorno a necessidade de examinar ou mesmo aprofundar esse conhecimento. Já no Brasil, em 1972, Gil disse:

Aquela coisa, rapaz, de eu ficar sozinho lá, com meu violão, e com minhas lembranças e com as minhas saudades, e com meus desencantos, meus novos encantos etc., me trouxeram essas questões de origem, de raiz, de célula-máter à qual eu pertenço, coisas desse tipo, negócio de brasilidade, negócio da verificação desse fator, o homem brasileiro, o homem da América Latina, o que isso significa. ${ }^{316}[$ grifos meus $]$

Se antes de ira Londres seu discurso pautava-se na absorção do universo pop, do rock e da bossa nova, seu retorno foi demarcado pela necessidade de conhecer melhor o Brasil. Vale ressaltar que Gil não faz uma clara ligação dessas "coisas brasileiras" com o universo da negritude; mas de fato percebemos através de outras entrevistas e depoimentos que essas "coisas brasileiras" acabaram por se identificar também com a negritude, fosse através de sua participação no Afoxé Filhos de Gandhy ou em suas viagens pelo interior do país, como veremos mais adiante.

Em uma longa entrevista que durou dias, realizada logo após o retorno de Londres, Gil declarou:

Essa coisa de se atribuir importância, ou não, e em que área das suas possibilidades de criação você deve se concentrar. Quer dizer, tudo isso é uma coisa que começou a me preocupar muito ultimamente lá em Londres. A minha relação com coisa brasileira, em que termos eu de veria me colocar diante dessa situação confusa, embaraçosa e indefinida pra quase todo mundo. Essas perguntas povoavam a minha mente o tempo todo, no sentido de que aquilo devia passar do nível da preocupação, da especulação, pro nível da atitude tomada mesmo. Traduzida no movimento que você faz, ou seja, numa mudança de lugar, numa mudança de postura. Eu resolvi de repente vir ao Brasil exatamente por causa disso tudo, porque não havia condições de, permanecendo lá fora, responder a essas perguntas: o que é que e u sou realmente, o que eu estou que rendo ser, o que é que

316 ALMEIDA, Hamilton. O sonho..., op. cit., p. 97. 
deve restar do que eu fui antes, daquele Gilberto Gil comprometido com aquelas coisas todas, com aquela confusão (...) essa coisa de eu sair por aí, por exemplo, entrando pelo sertão adentro, não tem nenhuma caracterís tica vampiresca, é mais uma continuação daquela atitude humilde assumida em Londres. Estou com 29 anos e sou um homem de dados, eu preciso de dados mais profundos, mais próximos, das coisas de onde eu provenho, do mundo de onde eu saí, pra saber até que ponto eu devo me afastar dele ou até que ponto eu devo chegar mais perto dele. ${ }^{317}[$ grifos meus $]$

Sobre a maneira como essa busca se realizaria, Gil disse:

Eu quero ir porque eu quero saber até que ponto eu posso me comunicar com essa gente simples, porque isso vai definir os termos da minha própria simplicidade. Se eu tenho que assumir posições mais sofisticadas, digamos, como os músicos compositores brasileiros assumiram há alguns anos. Se há vanguarda ou não em termos de música agora, considerando que há algum tempo eu estava incluído no processo de trabalho que era considerando vanguardismo no Brasil. Quer dizer, o que restou disso tudo? ${ }^{318}$

Se antes da partida o acesso ao Brasil se dava especialmente através da antropofagia oswaldiana, da bossa nova e do concretismo, a partir do retorno do exilio as falas de Gil demonstram a intenção de conhecer o Brasil "real", e não aquele mais estratificado do qual fazia parte. Suas falas, preocupações e demandas são processadas no campo das identidades. Que dados já conhecia e que outros ainda iria conhecer, e como essa mistura seria processada: essas eram suas dúvidas.

Numa outra reportagem, também publicada no ano de seu retorno, Gil contou que foi em Londres que aprendera a tocar guitarra, que estava sendo acompanhado por músicos ingleses e que "a sua música continua a ter elementos nordestinos, brasileiros, mas inclui também novas experiências, um contato maior com a música negra norteamericana." E comentou também "minha música está com muitos elementos, tudo misturado, então a pessoa ouve um pedacinho e lembra Ray Charles e pronto, a comparação é inevitável. ${ }^{319}$ A relação de novidade presente na musicalidade de Gil é apresentada através da africanidade norte-americana; além do mais, a própria formação instrumental, com baixo, guitarra e bateria ${ }^{320}$, desenham uma sonoridade mais próxima

\footnotetext{
$\overline{317}$ ALMEIDA, Hamilton. O sonho..., op. cit.

${ }^{318}$ Ibid., loc. cit.

${ }^{319}$ GILBERTO Gil com novos “ingredientes”. Folha de S. Paulo, 21 jan. 1972.

${ }^{320}$ BARSILINI, Leandro. A inserção da bateria na música popular brasileira: aspectos musicais e representações estéticas. ArtCultura, Uberlândia, v. 14, n. 24, pp.33-46, 2012.
} 
dos sons afro-americanos do que a do violão e percussões, que caracterizariam uma musicalidade mais brasileira.

Sobre o retorno de Gil do exílio, Calado afirma:

Ao desembarcar no Rio de janeiro, com Sandra, o filho Pedro e três guitarras, Gil não escondera sua necessidade de reabastecer as antenas musicais com um banho de raízes. Logo ao descer do avião, disse que estava ansioso para se encontrar com Paulinho da Viola e Martinho da Vila. Também não via a hora de poder dar um beijo em Luiz Gonzaga, seu ídolo desde a infância, cujos discos passava horas ouvindo em Londres. ${ }^{321}$

Essas informações de Calado somam à lista de desejo de Gil um encontro também com Gonzagão e Martinho da Vila, indicando que aspectos relacionados à tradição estavam fortemente identificados com a busca de Gil. No entanto, a busca pela tradição não excluía a busca também pela inovação, que se fazia notar pelas várias guitarras e o flerte com a música afro-americana. Não havia no discurso de Gil um claro e nítido modelo a ser seguido. Conviviam em paz tanto a sua necessidade de conhecer melhor os músicos mais ligados à tradição quanto a postura adotada de band leader e guitarrista.

Ainda em 1972, Gil nos dá um importante depoimento:

Vi tudo vivi tudo, o sonho acabou, os anos sessenta passaram, a música levou tudo às últimas consequências. Bem, então agora eu vou ver o que é que sobrou, o que é que eu sou, o que é que eu posso. Eu sou músico? Então o que é que eu toco? Que tipo de música eu faço? Eu sou cantor? Então que tipo de coisa eu canto? Eu sou de algum lugar? Então de onde e u sou? Minhamúsica tem alguma raiz? Quais são elas? Essas são as perguntas que vêm povoando o meu trabalho, eu diria, de um ano, um ano e pouco pra cá. Resultados? Tenho já alguns. Eu sei hoje, por exemplo, que eu toco violão diferente do que eu tocava há uns três anos. Melhor? Não sei. Mas rico? Eu diria sim. Encontrei as raízes? Sim. E eu diria que estou mais próximo. Sou muito nordestino, sou muito popular, sou bem pop, sou cantor de feira, sou cantador. A distância do Brasil me ajudou a chegar a isso. A distância ampliou o quadro e eu pude ver melhor. Eu pude entender mais profundamente. ${ }^{322}$ [grifos meus]

É importante salientar que as reflexões sobre o seu trabalho e sua identidade foram constantemente reprocessadas no momento em que Gil retornara de Londres. Ao afirmar

${ }^{321}$ CALADO, Carlos. Tropicália, op. cit., p. 288.

${ }^{322}$ HUNGRIA, Júlio. [Nota sem título]. Jornal do Brasil, 15 jan. 1972. 
sua identidade e lugar, Gil afirmou: Sou muito nordestino, sou muito popular, sou bem pop, sou cantor de feira, sou cantador. Não há nesse momento qualquer menção específica às africanidades. O Gil que retorna de Londres tinha sua identidade demarcada pela nordestinidade e pelo universo pop, um sujeito híbrido na busca por se traduzir.

Essa busca de Gil por aprofundar seu conhecimento sobre a cultura brasileira pode ser identificado no primeiro LP lançado logo após seu retorno do exílio. ${ }^{323}$ Podemos interpretar esse LP como a realização e até mesmo a concretização dessa busca, como se o resultado dessa produção fosse a consubstanciação desse "ideal", desse encontro com suas "raízes". Lançado em julho de 1972, a abertura do álbum se dá com a Banda de Pífaros de Caruaru. A seguir a transcrição da letra da canção "Back in Bahia", que pode ser interpretado como uma espécie de reflexão sobre o retorno:

Lá em Londres, vez em quando me sentia longe daqui

Vez em quando, quando me sentia longe, dava por mim

$$
\text { Puxando o cabelo }
$$

Nervoso, querendo ouvir Cely Campelo para não cair Naquela fossa

Em que vi um camarada meu de Portobello cair Naquela falta

De juízo que eu não tinha nem uma razão pra curtir Naquela ausência

De calor, de cor, de sal, de sol, de coração pra sentir

Tanta saudade

Preservada num velho baú de prata dentro de mim

Digo num baú de prata porque prata é a luz do luar

Do luar que tanta falta me fazia junto com o mar

$$
\text { Mar da Bahia }
$$

Cujo verde vez em quando me fazia bem relembrar Tão diferente

Do verde também tão lindo dos gramados campos de lá

Ilha do Norte

Onde não sei se por sorte ou por castigo dei de parar

\footnotetext{
${ }^{323}$ ÁlbumExpresso 2222 (Universal, 1972).
} 
Por algum tempo

Que afinal passou depressa, como tudo tem de passar

Hoje eu me sinto

Como se ter ido fosse necessário para voltar

Tanto mais vivo

De vida mais vivida, dividida pra lá e pra cá 324

A letra de "Back in Bahia" dimensiona a maneira como Gil retornara do exílio, quais sentimentos o nutriam naquele momento, especialmente a imensa saudade do Brasil. Findo o exilio, a Bahia é escolhida como pouso, como a fronteira que demarca a morada do sujeito que retorna para casa; no entanto, é importante demarcar que a amargura por ter ido não é em nenhum momento mencionada, os sentimentos são de saudade de sua terra natal, mas também de fascínio pela metrópole multicultural. O verso hoje eu me sinto como se ter ido fosse necessário para voltar alude não somente à experiência, à barra pesada de ter sido obrigado a deixar o Brasil, mas expressa também que a vida experimentada no exilio foi um importante elemento para sua formação pessoal. A sonoridade expressa a influência do rock, tanto pela formação de baixo/guitarra/bateria/teclado, quanto pela linguagem da música e a exploração da distorção da guitarra.

Grande parte do repertório é composta por músicas do cancioneiro nordestino, como "O canto da ema" 325, "Chiclete com banana" 326, "Sai do sereno" 327 e "Cada macaco no seu galho" ${ }^{328}$. Essa escolha não apenas homenageia esses compositores como representa o intuito em celebrar e homenagear o Nordeste. A sonoridade do Expresso $2222{ }^{329}$ misturou o baião com guitarra elétrica, fundindo tradição e modernidade com pitadas generosas de um som psicodélico.

Assim Zappa descreve a maneira como Gil retornara de Londres:

O final do exílio em Londres trouxe de volta para o Brasil um Gil musicalmente mais rico, com fortes influências do rock'n'roll inglês e americano, do reggae jamaicano, ainda inflado pelos ventos tropicalistas, mas com muitas saudades das raízes

\footnotetext{
324 “Back in Bahia" (Gilberto Gil, 1972). In: RENNÓ, Carlos (org.) Gilberto Gil todas as letras. São Paulo: Companhia das Letras, 1996, p. 130.

325 "O canto da ema" (Ayres Viana, Alventino Cavalcanti e João do Vale).

326 "Chiclete com banana" (Gordurinha e Almira Castilho).

327 "Saido sereno" (Onildo Almeida).

328 "Cada macaco no seu galho" (Riachão).

329 Álbum Expresso 2222 (Universal, 1972).
} 
brasileiras. Essa mistura cimentou as bases para a vigorosa produção musical que se seguiu após sua chegada. ${ }^{330}[$ grifos meus]

Vale novamente ressaltar que o livro biográfico de Gil fora escrito a quatro mãos, e também que Gil fizera uma ampla revisão sobre tudo o que havia sido escrito; assim, podemos perceber no trecho transcrito acima que a memória e os sentimentos que tangenciam o período do retorno estavam fortemente demarcados pela necessidade de fortificar os laços com a cultura brasileira, com as raízes brasileiras. Essa busca de Gil vai ser analisada, a seguir, não somente através dos depoimentos dados a jornais e revistas daquele momento, ou rememorações referentes a esse período, mas especialmente através de sua participação no afoxé Filhos de Gandhy, já que essa adesão aqui representa um forte demarcador de africanidades em sua trajetória.

\section{- Filhos de Gandhy}

Ao retornar do exílio com o empenho em conhecer melhor o Brasil, Gil buscou vivenciar novas experiências ligadas ao universo das culturas populares, que podem tanto ser representadas pela gravação da banda de pífaros de Caruaru, na faixa de abertura do LP Expresso 2222, ou através da visita ao candomblé em Itaparica. Porém, especialmente importante para a construção de africanidades na trajetória do artista é seu reencontro com o afoxé Filhos de Gandhy.

Em 1973, Gil realizou um show com duração de quase três horas na USP, acompanhado somente pelo seu violão, e conversou sobre vários assuntos com a plateia. Umas das falas do artista em muito aqui nos interessa. Foi aquela proferida antes da execução da canção "Filhos de Gandhy" ${ }^{331}$, que no trecho transcrito a seguir nos dá inúmeros indícios das motivações que o levaram a se filiar ao bloco. A performance do artista, no que tange ao modo como ele proclamou o texto, assemelha-se ao modo como os pretos velhos ${ }^{332}$ falam; tocando apenas o ritmo do ijexá no tampo do violão, Gil deu um longo depoimento sobre a entidade:

\footnotetext{
${ }^{330}$ ZAPPA, Regina. Gilberto bem perto, op. cit., p.179.

${ }^{331}$ Uma espécie de invocação onde todos os orixás, Senhor do Bonfim e Deus são convocados a descer pra ver Filhos de Gandhy.

332 Os pretos velhos são entidades sábias cultuadas na umbanda que se apresentam através do transe da incorporação. São as sociados coma memória da escravidão e seu modo de falar está as sociado ao modo
} 
Afoxé em nagô quer dizer o sopro do pó. O pó soprado pela boca formando o som, o verbo. Na Bahia afoxé é outra coisa, na Bahia afoxé é bloco de carnaval, cordão de carnaval, uma coisa ispecial, uma coisa original que é no carnaval, mas não é no carnaval. Afoxé não é escola de samba, não é trio elétrico, não é frevo, não é marcha, é afoxé, afoxé, afoxé. Vem do candomblé, candomblé, candomblé, candomblé, candomblé. Um bocado de preto tudo vestido de branco, cantando umas invocação, umas melodia com ritmo próprio, os atabaque bateno, os agogô cantano, e eles invocando os orixá. Então é uma coisa religiosa no carnaval, por isso que eu disse que é no carnaval, mas não é no carnaval. $O$ afoxé vem pro carnaval cantar as tradições religiosas dos pretos da Bahia. Outro dia, eu tive com Didi, filho de Senhora, que foi uma das maiores babalorixás que já teve na Bahia, salvo Menininha, que tá viva, ainda lá. Didi tava me dizendo que o primeiro afoxé que teve foi ele que botou na rua, ele e uns amigo dele. E se chamava Filhos de Gandhy, eu perguntei: Didi, porque essa história de Gandhy, essa coisa oriental, ele disse não sei, deu na veneta do pessoal. O afoxé é assim as mulhé de baiana, tudo de branco e os homi com uns turbante, umas túnica, carregano umas alegoria, uns elefante, uns camelo, umas coisa tudo oriental. Uma mistura de norte da África com Índia, um ne gócio pare cido com Jorge Ben, é a coisa mais parecida com is so que tem, podes crer, é isso mesmo. E eles cantam aquelas invocação, então eu disse os Filhos de Gandhy. Aí outro dia depois que eu tive com Didi eu tive umas informação, sabe, como a gente sempre tem umas informação, a gente lê uns livros, a gente conversa com as pessoas, a gente acaba sabendo de umas coisa. Então eu tive sabendo que na Bahia no fim do século passado, veio uns preto quase perto da abolição, vieram uns preto, da tribo dos Malê, os índios Malê e eles acreditavam em Alá, e falavam árabe, então vai vê que afoxé deve ter alguma coisa com isso do norte da África. Didi me disse que o Gandhy saiu no primeiro ano, aí saiu no segundo ano, no terceiro foi fazendo sucesso, as pessoas gostavam daquilo na rua, aquela brincadeira de carnaval, mas concentrada, tranquila, era uma espécie de procissão alegre, uma procissão em nome da alegria, em nome da euforia, em nome da brincadeira e ligado aos orixá, aos santos da religião negra, que foi preservada na Bahia graças a Deus. E agora o Afoxé tá pra acabar, Didi me disse Gandhy foi crescendo ficou grande, chegou a sair com duzentos, trezentos, quinhentos, até mil, e agora tá pra acabar. Depois de Gandhy surgiram muitos outros, ficaram importantes também, deixa a vida de quelé, mercadores de Bagdá, filhos de Obá e um bocado uns outros pequenininho também, que são mais bacana ainda, que tem uns caboclo, eles se veste de índio e saemdançando junto com as baiana, é uma mistura danada, é tudo é um pandemônio e agora tá tudo pra acabar, ameaçado. É engraçado outro dia fui passar o carnaval na Praça da Sé, no carnaval que passou e de repente eu me lembrei do afoxé, tinha um rapaz eu perguntei pra ele: meu irmão, onde tá o afoxé? Ele: tinha um hoje por aqui, passou aí mais cedo, deve tá pra lá, eu fui, mas aíeu já achei

como falavam os velhos escravos africanos. São falas marcadas por um conjunto de traços linguísticos que a caracterizam como desviante em relação ao português brasileiro. 
estranho porque antigamente quando o afoxé tava na praça, não tinha nada que procurar, o som enchia tudo, a gente chegava na praça e era aquele mundo de gente era quatrocentos, quinhentos tudo vestido, aqueles turbantes, aquela maré branca, aquelas cantigas de arrepiá, tudo cantado em iorubá. Iorubá é um dialeto que tem na Nigéria, de onde veio a maioria dos pretos que tão na Bahia, da NaçãoJêje. Antigamente não era assim, afoxé não tinha que procurá, os afoxé tava na praça, os atabaque batendo, os agogô cantano, a gente se arrepiano e aquela coisa mística no carnaval, o carnaval já é uma coisa mística em si mesmo, mas eu falo esse outro lado explícito, específico, religioso trazido de lá dos terreiro, aquilo era um negócio magnetizante. É a coisa que eu mais gosto no carnaval da Bahia, aí eu cheguei num canto da praça, eu vi um grupinho lá, os menino com um turbante branco, umas calças azul aí eu disse os Filhos de Gandhy, que é azul e branco, me aproximei de um deles e disse meu irmão como é que tá o afoxé? Ele: afoxé tá pra acabar, afoxé não dá mais pé, esse ano quase que não dá, acho que ano que vem não dá, ele: os diretor deram tudo pra brigar, o vice presidente qué uma coisa, o presidente qué outra e tem um diretor que disse que esse ano a gente tem que comprá um pano que não amarrota e não perde o vinco, porque pode chover e fica parecendo os deputado e os ministro, aqueles pano brilhante, o departamento de turismo não quer ajudá, tá tudo ruim, esse ano só tem uns vinte, trinta que conseguiram sair. Eu fiquei, aquilo ali me chocou, eu vim todo animado, aí eu fui pra casa meio triste, passou o carnaval eu vim pro Rio trabalhar. Outro dia eu tava em casa no Rio aí eu me lembrei de novo do afoxé e disse assim meu Deus do céu Afoxé tá pra acabá, e logo a cois a que eu mais gosto no carnaval da Bahia, fiquei pensando, de repente eu disse assim ah quem sabe, a gente sabe cantar, pelo menos um bocadinho a gente sabe cantar, se a gente cantar Deus até pode escutar, claro ele tá é aqui dentro mesmo, ele escuta tudo, também tem os orixá que tão lá por cima que são os Deuses, porque Deus mesmo tá em tudo, mas tem os Deuses, os negos tem os dele, os orixá Ogum, Oxum, Oxumaré, Iansã, Iemanjá e etc. e tal. Então e u digo: quem sabe se a gente cantá eles pode tudo se juntar lá por cima e resolver ajudar a gente e o Afoxé não acabar. ${ }^{333}$ [ grifos meus]

O longo testemunho de Gil, já ao fim do show, antes de cantar "Filhos de Gandhy", indica não só grande interesse e curiosidade do artista pelo afoxé, como também o fato de ele ter ido em busca do bloco em 1973, no carnaval baiano, e de ter se deparado com um bloco com poucos integrantes. Indica também que Gil foi investigar a história dos negros de Salvador pela curiosidade causada pelo bloco. Outro importante indício presente na fala de Gil nesse momento é a associação que ele cria entre o Filhos de Gandhy e Jorge

\footnotetext{
${ }^{333}$ Disponívelem: <https://www.youtube.com/watch?v=dIwKGsjRqGQ>. Acesso em: 16 dez. 2015.
} 
Ben, um antigo parâmetro de africanidade para o artista. ${ }^{334}$ É interessante ainda demarcar que a cultura oriental foi, desde o momento da prisão, algo que passou a fazer parte dos interesses de Gil. O que o levou a se filiar ao bloco foi especialmente o medo de ver a tradição que ele mais amava do carnaval da Bahia se acabar.

Quase uma década após seu ingresso no bloco, Gil disse:

Só quando eu voltei de Londres, dentro daquele processo de retomada, de redescoberta, de sofisticação do gosto, é que eu fui procurar especificamente os afoxés, porque, mesmo no carnaval da minha infância, eles me pareciam como bálsamos, oásis de paz naquele caos de rua. Me lembro que assim que voltei, no meu primeiro carnaval aqui, me disseram que os afoxés não existiam mais. E, de fato, fui encontrar uns vinte Filhos de Gandhy, com os tambores no chão, num canto da Praça da Sé. Eles não tinham mais recursos, mais força para ocupar um espaço no carnaval baiano. Fui procurá-los para entrar no afoxé. Foi como uma cois a de vocional, uma promessa, uma vontade de por o meu es pírito para funcionar em prol daquela coisa bonita que é o afoxé. E saí seis anos no Filhos de Gandhy, fazendo todo o percurso de 12 horas, cantando e tocando, parando nos pontos de devoção, obedecendo à disciplina, que é muito rigorosa. E, no ano passado (1980), já eram mil Filhos de Gandhy, alguns deles muito jovens, como o Badauê, que é uma espécie de afoxé jovem, um afoxé pop, progressivo. ${ }^{335}$ [grifos meus]

Além de dimensionar que seu retorno estava atrelado a redescobrir, após o exílio, as coisas do Brasil, Gil também afirma o papel devocional, ou mesmo sua participação no bloco como o cumprimento de uma promessa. Estar novamente no Brasil naquele momento significava para o artista aprofundar seu conhecimento sobre a cultura brasileira, e uma das primeiras ações que realizou após seu retorno foi buscar os afoxés no carnaval de Salvador.

Quem nos informa sobre os afoxés é Risério:

Olhando mais de perto a transação mística dos afoxés é bom notar que eles já nasceram ligados a terreiros de candomblé e dirigidos por babalorixás ou outras personalidades do culto. Edison Carneiro cita alguns exemplos, como o do Lordes Ideais (...) Antes de iniciar o desfile, realiza-se, nos afoxés, uma cerimônia religiosa: o padê, despacho de Exu, entidade mágica que, intermediando entre nós humanos e os orixás, pode fazer com que

\footnotetext{
334 Questão explorada no tópico a seguir.

${ }^{335}$ A pud RISÉRIO, Antônio. Carnaval Ijexá: notas sobre afoxés e blocos do novo carnaval afro-baiano. Salvador, Corrupio, 1981, p.53.
} 
toda e qualquer festa transcorra em paz e em alegria (...). ${ }^{336}$

Outra autora que afirma a ligação dos afoxés com o sagrado é Goli Guerreiro.

Para ela, os afoxés:

(...) Podem ser descritos como "candomblés de rua". Quase todos os membros dos afoxés se vinculam ao culto. Seus músicos são alabês, suas danças reproduzem a dos orixás, seus dirigentes são babalorixás (chefes de terreiro que dominam a língua iorubá) e o ritual do cortejo obedece à disciplina da tradição religiosa. No entanto, a preservação dos fundamentos secretos da religião é preservada. A orquestra chamada "charanga", que executa o ritmo ijexá, é composta de agogôs, xequerês e três tipos de atabaques (rum, rumpi e lê), tal como nas cerimônias religiosas (...) os afoxés trouxeram para o espaço do carnaval o repertório musical e a estética dos candomblés. ${ }^{337}$

Vale aqui realizarmos uma breve elucidação sobre as etnias africanas que vieram ao Brasil e especialmente para Bahia. Durante quatro séculos o Brasil recebeu escravos africanos pertencentes principalmente a dois grandes grupos étnicos-linguísticos: os bantos, pertencentes a vários grupos da África Centro-meridional e os sudaneses da África Ocidental, também denominados de jêje-nagô. ${ }^{338}$ De acordo com José Jorge de Carvalho "essa tradição iorubá está viva no Candomblé da Bahia, onde se identifica segundo os nomes de duas Nações: a nação Kêtu e a nação Ijexá." ${ }^{339}$ Os afoxés baianos se apropriaram do nome da nação iorubana para definirem o ritmo tocado em suas agremiações, bem como em seus rituais sagrados.

Em 1999, quando questionado sobre sua ligação com o candomblé, Gil disse a Bené Fonteneles:

(...) Durante toda minha infância, no mês de junho, rezava-se a Trezena com todos aqueles cantos. Montava-se o presépio de Natal, com todas as figuras, os três Reis magos, tudo aquilo que era meu mundo. Depois é que veio o mundo dos orixás e os de us es indígenas que vieram completar esse mundo cristão (...) E eu só vim mesmo a entrar num terreiro de candomblé - e foi num de Egun, na Ilha de Itaparica - quando voltava de

\footnotetext{
${ }^{336}$ RISÉRIO, Antônio. Carnaval Ijexá, op. cit., p. 56.

${ }^{337}$ GUERREIRO, Goli. A trama dos tambores: a música afro-pop de Salvador. São Paulo: Ed. 34, 2000, pp. 71-72.

${ }^{338}$ SLENES, Robert W. Malungu, ngoma vem!:África coberta e descoberta do Brasil. Revista USP, São Paulo, n. 12, 1992.

${ }^{339}$ CARVALHO, José Jorge. A tradição musical Iorubá no Brasil: um cristal que se oculta e se revela. In: TUGNY, Rosângela, QUEIROZ, Ruben Caixeta (orgs.). Músicas africanas e indígenas no Brasil. Belo Horizonte: Editora UFMG, 2006, p. 266.
} 
Londres, depois do exílio. Foi aí que cheguei ao candomblé, lá no Barro Branco, na ilha onde fiquei hospedado bem pertinho da casa de santo (...) Nessa ocasião, eu já tinha tomado contato com o candomblé através da literatura, dos livros de Jorge Amado, através da discussão sobre cultura no Brasil, das "coisas brasileiras", dos símbolos da africanidade, do interesse pelo negro e pela negritude. Tudo isso me aproximou intelectualmente do candomblé. Quando eu fui visitar, já fui por ato de vontade explícita; fui pela busca de querer ir mesmo ver o mistério. Entender, ir lá. Fui comple tamente aberto, com a alma generosamente pre disposta a ver, ouvir, pegar, tocar, sentir tudo que fosse possível. Fui sem nenhum preconceito, sem nenhum medo. Fui assim, iniciaticamente, ter convivência com o candomblé levado pelo Mestre Didi e por Juanita (...). Logo em seguida, por força desse interesse renovado e reforçado nessa noite, passei a frequentar. Conheci Mãe Menininha do Gantois. Passei a ir ao Gantois lá pelo ano de $1973 .^{340}$ [grifos meus]

Um aspecto importante a ser destacado é que o universo religioso do artista foi por muito tempo habitado apenas por símbolos e signos católicos, e que tardiamente vieram outros deuses a adensar essa religiosidade. Gil não abandonou ou mesmo substituiu sua vivência católica, mas trouxe outros deuses para completá-la. Há um depoimento do artista ${ }^{341}$ que bem dimensiona sua visão holística sobre as crenças religiosas:

Sou religioso, mas não tenho religião, parece um paradoxo, mas o ser moderno é assim. O homem hoje é assim, a religiosidade é uma coisa profunda de fé, de positividade, quer dizer, dessa coisa de afirmação, o sim ao sim, o não ao não, isso é que é religiosidade. Isso não carece especificamente de um sistema de ritos, de um sistema de mitos especificamente religiosos. A religiosidade se nutre de mitos de outras áreas também, mitos dos vários aspectos da cultura, não necessariamente só da religião. ${ }^{342}$

Não há no discurso do artista, nem nessa época em questão e nem em períodos posteriores ao retorno do exilio, sinais que supervalorizem determinadas escolhas religiosas em detrimento de outras, mas sim a coexistência pacífica entre diferentes devoções, sendo o I-ching um contínuo companheiro do artista ao longo de sua trajetória.

\footnotetext{
${ }^{340}$ FONTENELES, Bené. Giluminoso: a pó. Ética do Ser. Brasília: Editora Universidade de Brasília; São Paulo: SESC, 1999, pp. 118-124.

${ }^{341}$ Fragmento de uma entrevista inserida no documentário Tempo Rei. Pelo visual do artista a entrevista parece ser meados dos anos 1970.

${ }^{342}$ DVD Tempo Rei. Documentário dirigido por Lula Buarque de Hollanda, Andrucha Waddington e Breno Silveira. Produção: Gege Produções/Ravina Produções. Rio de Janeiro: Conspiração Filmes, 1996.
} 
Em Carnaval Ijexá, Antônio Risério relata suas percepções acerca da emergência de uma consciência afro no carnaval baiano desde meados da década de 1970, através de um processo denominado por ele de "reafricanização" baiana: "os pretos se tornam mais pretos; se interessam cada vez mais pelas coisas da África e da negritude." ${ }^{343}$ A obra de Risério pode ser compreendida enquanto um ensaio, feito através do relato de amigos, dentre eles Jorge Amado e o próprio Gil, além de integrantes dos blocos afro baianos. Ao retratar o surgimento de uma onda de negritude na Bahia nos anos 1970, Risério nos oferece indícios preciosos sobre o surgimento da noção de negritude na própria trajetória de Gil. Seu livro por certo deve ter influenciado na criação dessa imagem africanizada para a Bahia e também para Gil.

Risério analisou a década de 1970 enquanto momento de invenção de um grupo étnico denominado juventude black-baiana, costurando informações sobre a elaboração dessas identidades, além de registrar o surgimento de um movimento político negro com forte influência de caráter afro-internacional. Se a reafricanização vivenciada pela cidade de Salvador nos anos 1970 em muito foi informada por Gil, como afirmou Risério, o contrário também certamente aconteceu, numa complexa rede de produção e circulação de ideias. Sobre a reafricanização, Risério, em entrevista ao jornal A tarde em 1982, diria:

É uma palavra mais leve. Mas também desconfio dela por causa do prefixo latino "re", que significa regressão, movimento para trás. E não é isso o que se dá. O que se dá é uma recuperação da coisa negra no presente, que não é nostálgica. O termo parece lembrar "restauração", que é o que se quer fazer no Pelourinho, mas não é o caso, não se está buscando a pintura original do sobrado, e sim construindo outros. ${ }^{344}$

Essa reafricanização era ainda mais experimentada na época do carnaval: "tratase de uma convenção social, certamente, de uma suspensão delirante da vida rotineira por um curto espaço de tempo. ${ }^{.345}$ Risério comenta ainda que:

A Bahia sempre foi afro. Salvador é uma cidade negra. O simples
fato de negros e mestiços somarem quase a totalidade da
população da cidade já impregna e imanta o ambiente. A
presença cultural e humana da África, por aqui, é de tal

${ }_{343}$ RISÉRIO, Antônio. Carnaval Ijexá..., op. cit., p. 13.

${ }^{344}$ CERQUEIRA, JOSÉ. A transa cultural da periferia baiana. Originalmente publicado no jornal A tarde, 21 jan. 1982. In: COHN, Sergio (org.). Antônio Risério - Encontros. Rio de Janeiro: Beco do Azougue, 2009, p. 17.

${ }^{345}$ RISÉRIO, Antônio. Carnaval Ijexá..., op. cit., p. 19. 
grandeza que Salvador já foi chamada de "Roma Negra" e de "Nova Guiné". ${ }^{346}$

Risério também liga a reafricanização da cidade de Salvador à figura de Gilberto Gil, e afirma que "atualmente, em meio à juventude negra, a grande figura é Gilberto Gil. Nas palavras de Jonga, um dos diretores do bloco afro Melô do Banzo (já extinto), Gil 'é o símbolo da liberdade negra no Brasil."” 347

De acordo com Risério, o que estava realmente acontecendo na década de 1970 no Brasil passaria despercebido pela intelectualidade brasileira, que se via atrelada ao nacionalismo e tinha os olhos fechados para o novo. Não era um modismo imposto pela comunicação de massa atrelada ao imperialismo norte-americano, mas sim a identific ação do preto brasileiro com o preto norte-americano, no terreno da negritude:

Não sejamos lineares. Quando digo que o que se deu, na Bahia, foi uma passagem do black soul ao afro-ijexá, não penso em termos de corte drástico. Todas essas coisas vão se mesclando, se superpondo, numa mistura total que, por sinal, exclui qualquer raciocínio que ingenuamente porventura se guie nos termos da velha metáfora bíblica do joio e do trigo. Trata-se, isto sim, de uma justaposição ideogrâmica, da qual um terceiro sentido ou elemento deve ser extraído. Estamos, aqui, num terreiro (ou conga) cuja feição é misturadamente black-ijexá. Primeiro o fubá, depois o dendê, mas sem esquecer a nega baiana que sabe mexer. E que não para de mexer, que é pra não embolar. ${ }^{348}$

Há aqui um dado importante para nossa reflexão sobre mais indícios de africanidade na trajetória de Gilberto Gil. A seguir transcrevo as palavras de Risério, já adiantando que há que se problematizar se Gil fora de fato um "enviado" para salvar o bloco Filhos de Gandhy:

Não me interessa aqui a trajetória histórica do Filhos de Gandhy. O que me interessa é seu renascimento na segunda metade da década de 70, depois de um período de míngua em que todos os sinais indicavam seu desaparecimento. Pois é justamente o renascimento do afoxé Filhos de Gandhy que marca, de modo decisivo, o segundo momento-chave no processo de "reafricanização" do carnaval baiano. Graças a Deus. E ao seu enviado: Gilberto Gil. E é preciso que isso seja dito de uma vez por todas: Gil é o grande responsável pelo ressurgimento do Filhos de Gandhy. O afoxé estava a menos de um passo do túmulo e o crioulo foi lá, com a força invencível de um filho de Xangô (embora ele diga ser filho de Logun-edé), para aplicar

\footnotetext{
346 Ibid., p. 20.

${ }^{347}$ RISÉRIO, Antônio. Carnaval Ijexá..., op. cit, p. 21.

348 Ibid., p. 32.
} 
uma injeção astral de vitalidade. Todo mundo sabe disso na Bahia. ${ }^{349}$

De acordo com Risério, no Brasil os pretos foram desafricanizados e remodelados. O novo visual afro adotado pelos negros nos anos 1970 é testemunho de uma mudança, o início de uma transformação interior que provocou mudanças de atitude também na sociedade. Risério analisa o carnaval e a reafricanização da vida baiana, comentando o risco de tudo ser um superficial verniz de negritude, e que "a valorização hiperbólica do homem negro é uma decorrência, penso eu, do fato da cultura preta estar se impondo no mundo ocidental, depois de séculos em que o preto foi considerado um 'ser inferior'. Agora dá-se o troco. ${ }^{, 350} \mathrm{O}$ autor afirma ainda que inverter a polarização, na qual o negro passa a ser superior ao branco, não representa nenhum progresso, e que somente um aprofundamento crítico sobre a negritude redefinirá melhor a mitificação na qual se encontra o negro na sociedade brasileira.

Caetano também superdimensiona a participação de Gil como aquele que fez o Filhos de Gandhy ressurgir com força. Sobre a ligação de Gil com a entidade, Caetano afirmou:

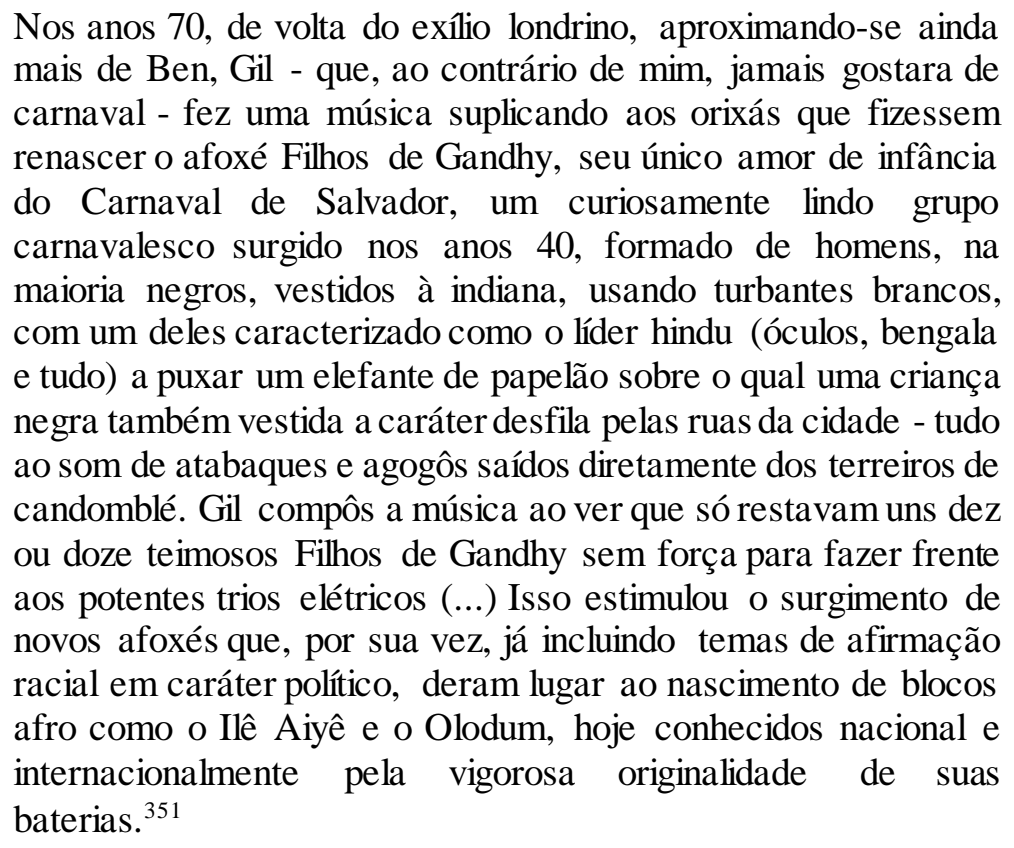

Quanto a sua participação no ressurgimento do bloco, assim Gil elabora essa experiência:

\footnotetext{
349 Ibid., p. 53.

350 RISÉRIO, Antônio. Carnaval Ijexá..., op. cit., p. 119.

351 VELOSO, Caetano. Verdade tropical, op. cit., p. 289.
} 
Quando eu cheguei do exilio em 73, na rua encontrei o Gandhy pequenininho na Praça da Sé encurralado, sem poder entrar na avenida, não tinha massa pra poder entrar na avenida. Eu disse ano que vem eu vou porque o Gandhy era uma coisa muito presente na minha memória desde a infância, que era um encanto desde o primeiro momento, no Carmo, no Santo Antônio, que eu era menino do Santo Antônio, eu morava lá. Eu morava na cruz do Pascoal com 8, 10 anos, 12 anos eu via o Gandhy todo ano e se tornou meu bloco preferido. Quando eu voltei do exilio e encontrei o Gandhy na rua, ali naquela situação, na Praça da Sé parado, nove horas da noite sem poder entrar na avenida, porque não tinha isso, não tinha aquilo, aquela confusão danada, pequenininho(...) Aí no ano seguinte eu saí, me animei, fiz a música. ${ }^{352}$

É importante assinalar que se Gil fora importante para a revitalização do Filhos de Gandhy, como afirmaram Risério, Caetano e o próprio artista, bem como essa revitalização ter impulsionado o surgimento de outros blocos, são questionamentos que ultrapassam a pesquisa aqui em andamento. ${ }^{353}$ No entanto, a referida importância de Gil no fortalecimento do bloco certamente contribuiu para a criação de uma imagem de Gil relacionada não somente à negritude, mas a um ativismo político-cultural de resistência, através de um significativo referencial de luta pela preservação. A principal questão aqui é compreender qual o papel e a importância do bloco Filhos de Gandhy na construção de africanidades na trajetória e na obra de Gilberto Gil.

No documentário Filhos de Gandhy, ${ }^{354}$ realizado em motivo da comemoração de 50 anos de funcionamento da entidade, o grupo contava, em 1999, com a participação de quatorze mil integrantes. Conhecida pelo forte apelo à paz, a confraria nasceu logo após a Segunda Guerra Mundial, criada por um grupo de estivadores que se adornavam com lençóis brancos em homenagem a Mahatma Gandhi. Os idealizadores da agremiação rememoraram sua fundação e elencaram o divertimento e a brincadeira como os principa is fundamentos do grupo. Vavá Madeira, reconhecido pelos demais fundadores como o responsável pela ideia de utilizar o título do filme Gunga Din, conta que, depois de retirarem o Gun, restou Gandin. Mica, outro fundador da agremiação, conta que:

O que inspirou também foi a filosofia do Mahatma Gandhi que naquele momento estava desenvolvendo um movimento em

\footnotetext{
${ }^{352}$ DVD FILHOS de Gandhy. Documentário. Direção Lula Buarque de Hollanda, 2000.

${ }^{353}$ Para maiores informações ver GUERREIRO, Goli. A Trama dos tambores..., op. cit.; e SANSONE, Lívio e SANTOS, Jocélio (org.) Ritmos em transito: sócio-antropologia da música baiana. São Paulo: Dynamis Editorial; Salvador, BA: Programa A cor da Bahia e Projeto S.A.M.B.A., 1997.
}

${ }^{354}$ DVD FILHOS de Gandhy, op. cit. 
prol da pobreza, dos menos protegidos, era uma contestaçãolá na Índia, então vem daí também a nossa mensagem, quer dizer uma mensagem de protesto a favor de Gandhi. ${ }^{355}$

A primeira cena do documentário mostra a filiação de um integrante ao bloco, com a seguinte orientação: "Por você ser sócio novo do Gandhy, você vai receber um quite completo, onde você vai receber, lençol, toalha, alfazema, faixa, fita, flâmula. E por você ser sócio do grupo Gandhy, sendo sócio novo a filosofia do Gandhy é a paz." E o presidente do grupo, Agnaldo Silva completa:

Nós fazemos um cadastro dos associados, identidade, CPF, duas fotos e bons antecedentes. Esse associado passa por um processo de sindicância. O Gandhy é uma entidade indo- África, nós usamos o traje hindu, mas cultuamos o sincretismo do candomblé. É África porque nosso ritmo é ije xá. [ grifos meus]

Em nenhum momento do documentário houve qualquer associado que afirmasse a necessidade dos integrantes da associação terem de seguir os preceitos do candomblé para poderem se filiar ao afoxé Filhos de Gandhy. Em outra cena, momentos antes de sair na avenida, Gil relata muito emocionado:

Quando eu tô no Gandhy eu gosto do canto, da dança do ijexá. Aí eu me sinto parte integrante, molécula, partícula de uma cois a grande que é o canto e a dança da Bahia, o canto e a dança que vie ram da África, a tradição do candomblé . O mais interessante é isso, é se diluir numa coisa que é muito grande, tanto que se estica para o passado, que se estica pro futuro e que a gente é apenas uma partícula quântica ali na passagem do momento em que a gente dança e canta ali na avenida. É insubstituível o momento, tem muitas outras coisas boas na vida, mas tocar seu agogô ali na avenida não dá nem pra falar. [grifos meus]

Aqui é enunciada por Gil uma forte memória afetiva e o encantamento com a entidade desde sua infância. Sua ligação com o bloco se encaixa novamente na dimensão do entre-lugar cunhado por Bhabha, na afirmação de que sua participação no bloco é algo maior, que se direciona tanto para passado quanto para o futuro; não está fixada, mas paira entre aquilo que foi e ainda será; não é o reflexo de traços culturais étnicos préestabelecidos, mas sim uma negociação complexa, em andamento. Sua narrativa dimensiona a Bahia como continuidade da África, criando signos de uma identidade que é singular e subjetiva, mas também coletiva e colaborativa. Essa dimensão temporal que está "além", que promete o futuro, vivendo além da fronteira de um determinado tempo

${ }^{355}$ DVD FILHOS de Gandhy, op. cit. 
presente, busca referências no passado, que no Gandhy é representado pela África e pelo candomblé, mas em nenhum momento expressa pureza ou simples continuidade, mesclando repetição, mas também descontinuidade. O hibridismo desse Afoxé mescla Índia com África e a tradição do candomblé com a paz professada por Mahatma Gandhi, num ritual que reúne solenidade e coletividade, transbordamento, alegria e consagração. Vale aqui ressaltar que no discurso produzido pelos membros do grupo, ao menos no que tange às falas realizadas em motivo da comemoração de seus 50 anos de existência e captadas pelo documentário, não há menção a um enraizamento africano puro. É a captação de uma criatividade brasileira que se apropriou de elementos africanos vivenciados no candomblé e os mesclou com elementos orientais.

Considerando que os valores culturais estão sempre em negociação, a filiação de Gil ao bloco Filhos de Gandhy não é aqui percebida através da busca pela fixação a determinada tradição, ou mesmo a uma determinada África, mas através de uma performatividade que intenciona estar constantemente reinventando essa tradição, vivenciando-a constantemente através do canto e da dança do ijexá. Gil filiou-se ao bloco Filhos de Gandhy em 1974, e saiu nos cortejos do bloco por anos consecutivos. Também assumiu o cargo de vice-presidência da entidade (1999-2001), além de ter idealizado e participado do documentário Filhos de Gandhy (2000), tendo oferecido em cada um desses momentos diferentes contribuições para a entidade. $\mathrm{O}$ desejo de permanecer por tanto tempo filiado pode ser aqui interpretado através da seguinte afirmativa de Bhabha:

As diferenças sociais não são simplesmente dadas à experiência através de uma tradição cultural já autenticada; elas são os signos da emergência da comunidade concebida como projeto - ao mesmo tempo visão e uma construção - que leva alguém para "além" de si para poder retornar, com um espírito de revisão e reconstrução, às condições políticas do presente. ${ }^{356}$

A participação contínua de Gil no Filhos de Gandhy representa um constante refazer dessa identidade, através do ritual vivenciado a cada carnaval. O que autentica uma tradição cultural é a efetiva participação de um grupo de pessoas que não só acredita num determinado ideal compartilhado como o reverencia de tempos em tempos, fazendoo valer, concebido enquanto projeto. Estar além de si, junto ao grupo, criando e

\footnotetext{
${ }^{356}$ BHABHA, Homi K. O local da cultura ..., op. cit., p. 21.
} 
usufruindo de uma identidade de negritude e pertencimento, zelando pela paz num constante revisar e reconstruir, para então retornar a si. Uma identidade compartilhada com um grupo que preza pela paz utilizando os mesmos símbolos, as mesmas roupas, revivendo a cada carnaval os mesmos rituais e costumes. A memória dessa identidade é a cada folia reconquistada e celebrada.

Em 2011, Gil comentou sobre o Gandhy:

Quando comecei a sair, em 1974, gravei duas ou três canções ligadas ao Gandhy, dar entrevistas, propagar aquela cultura. E isso foi ajudando o bloco a crescer. $\mathrm{O}$ atrativo de ter um artista renomado entre eles atraiu os jovens. E o Gandhy foi crescendo e daqueles 100 de 1973 hoje são 10 mil. É uma beleza, sempre. Os rituais se consolidando, os jovens, o gesto sedutor de "amarrar" com as contas a menina fora da corda! Uma beleza também como se manteve essa ideia de bloco pacífico, baseado na cordialidade. ${ }^{357}$

Ao rememorar sua participação no bloco, Gil reconhece seu papel enquanto mediador que possibilitou a transformação desse afoxé, ao mesmo tempo em que reitera a perpetuação de determinados valores inerentes à agremiação. No discurso do artista, ao abordar sua ligação com o Filhos de Gandhy, notamos tanto transformações como a continuidade de certos padrões de conduta do bloco, como, por exemplo, a propagação da cordialidade, que é também uma premissa de Gil.

A participação de Gil no afoxé Filhos de Gandhy inicia-se em 1974 e estende-se aos dias de hoje, representando fortemente a inserção de Gil no mundo da negritude. A filiação ao bloco não significou que Gil tenha reforçado seus laços com o candomblé, uma vez que nem todos os integrantes têm necessariamente que ter ligação com o culto. Os preceitos da religião são respeitados pelos integrantes da agremiação, e há aqueles responsáveis pelas obrigações religiosas.

O afoxé Filhos de Gandhy é aqui compreendido através do conceito de hibridação, assim como o concebeu Néstor Canclini:

Entendo por hibridação processos socioculturais nos quais estruturas ou práticas discretas, que existem de forma separada, se combinam para gerar novas estruturas, objetos e práticas. Cabe esclarecer que as estruturas chamadas discretas foram

${ }^{357}$ GILBERTO, Gil. O MUNDO é Gandhy. Serafina, São Paulo, v. 1, n. 35, p. 12, 27 fev. 2011, apud CAMPOS, Paulo M. E. Estetizar a política e politizar a estética: As tensões entre arte e práxis políticosocial na obra e na ação política de Gilberto Gil. 2012. Dissertação (Mestrado em Educação) - Faculdade de Educação da Universidade Federal de Minas Gerais, 2012. 
resultado de hibridações, razão pela qual não podem ser consideradas fontes puras. ${ }^{358}$

Numa hibridação que combinou a expressão da negritude através da rítmic a africana do candomblé tocado na rua, com a vestimenta branca indiana e a figura política de Mahatma Gandhi, vivenciados no afoxé de Gandhy, não foram eleitos determinados símbolos em grau de importância sobre os demais. O bloco não cultua especificamente alguma etnia ou uma classe social, ao mesmo tempo em que o componente de africanização é reforçado pela ligação com o candomblé, numa espécie de valorização da religião afro-brasileira como patrimônio histórico e cultural regional, ligando-o à luta contra a violência através do simbolismo de Mahatma Gandhi. Ao associar símbolos nacionais a outros internacionais, realizam uma espécie de valorização diaspórica, configurando uma espécie de rede antirracista transnacional.

A relação desenvolvida por Gil com os Filhos de Gandhy é antes de tudo emotiva, de rememoração de sua infância, do encantamento que sentia ao visualizar o bloco nas ruas de Salvador. As relações estabelecidas na vida de cada sujeito são tecidas, dentre outros aspectos, com diferentes fios de aprendizagem, e é a partir da vivência no bloco afro Filhos de Gandhy que a ideia de africanidade em Gil passa a ser mais fortemente experimentada; uma africanidade demarcada pelo apelo da ligação com a Bahia e com a musicalidade do afoxé, que transporta o candomblé dessacralizado para a avenida. Como em toda tessitura, ora nos embolamos, ora nos encontrarmos em nossos próprios fios. Contudo, é importante salientar que a tessitura se faz constantemente. Desses fios de aprendizagens, aqui a participação no afoxé Filhos de Gandhy é compreendido enquanto uma espécie de saber/vivência étnico-cultural, os quais são entrelaçados na história que vem sendo construída pelo artista Gil. Essa história incorporada, vivenciada em cada carnaval, por conseguinte, constrói-se, perpetua-se e manifesta-se na relação com a dança e o canto, expressando tanto o ato de filiação ao bloco quanto a experimentação de africanidades.

É interessante destacar que a África descrita nas falas de Gil é o local que antecedeu a Bahia e se faz representar através da dança, do canto e do ritmo ijexá. Não houve, em nenhuma das rememorações de Gil referentes ao afoxé Filhos de Gandhy, ou mesmo na fala dos fundadores do grupo, qualquer tipo de recordação referente ao

\footnotetext{
${ }^{358}$ CANCLINI, Néstor. Culturas híbridas: estratégias para entrar e sair da modernidade. São Paulo: Edusp, 2008, p. 9.
} 
cativeiro, mas sim de louvação à liberdade! Esse afoxé escolhido por Gil reelabora a tradição africana, fundindo-a com tradições indianas, sem alusão à pureza e se alinhando à construção de uma realidade miscigenada, tornando-se um instrumento de conciliação, de vida grupal; de cura do sofrimento na busca pela paz.

\section{Gil Jorge Ogum Xangô $\hat{o}^{359}$}

Em 1975 Gil e Jorge Ben lançam um álbum em parceria. ${ }^{360}$ Este trabalho é mais uma chave para que se compreenda como foi sendo elaborada a representação das africanidades na obra do artista Gilberto Gil.

Sobre o impacto da música de Jorge Ben em sua vida, Gil disse:

Eu ia ser cover do Jorge Ben pro resto da vida, era o que eu queria, aquela batida, aquele modo até então inusitado de escrever sentimentos. Quando eu comprei o disco Samba esquema novo eu fiquei impressionadíssimo. ${ }^{361}$

Em outra situação, Gil detalhou ainda mais o impacto que sofreu com o Samba esquema novo, primeiro LP de Jorge Ben:

O disco saiu no momento em que eu tava começando a me relacionar com Caetano, Bethânia, Gal, enfim, a formação inicial, o início da formação daquele grupo, ali em Salvador. Eu me lembro de um dia que tava conversando com Caetano, eu disse pra ele: eu vou deixar de compor, porque eu acho que Jorge Ben já pree nche tudo. Eu vou me dedicar a cantar as músicas dele e a tentar aperfeiçoar o estilo dele, ou qualquer coisa desse tipo, vou me tornar um discípulo dele. Eu me lembro, eu comecei a tocar em bares, casas noturnas e durante um período, meses, quase que aquele ano inteiro eu só tocava música do Jorge Ben. Eu tocava o disco, o Samba esquema novo todo, aí já não ligava mais pras minhas músicas. Achava todas secundárias e sem interesse ${ }^{362}[$ grifos meus $]$

\footnotetext{
${ }^{359}$ Álbum Gil Jorge Ogum Xangô (Universal, 1975).

${ }^{360}$ Gil lançou ainda discos em parceria com Milton Nascimento Gil \& Milton (2000), Tropicália 2 com Caetano (1993); Brasil com João Gilberto, Caetano e Bethânia (1981), Refestança com Rita Lee (1978), os Doces bárbaros com Gal, Caetano e Bethânia (1976) e Tropicália ou Panis et circensis (1968). 361 MOSAICOS: a arte de Jorge Ben. TV Cultura. Disponível em: <https://youtu.be/lX3iu7v-C48>. Acesso em: 20 dez. 2015.

${ }^{362}$ Imbatível ao extremo: assim é Jorge Ben Jor. Apresentado pela Rádio Batuta do Instituto Moreira Sales. Produção: Adriana Maciel, Heloísa Tapajós e Paulo da Costa e Silva, 2012. Disponível em: $<$ http://www.radiobatuta.com.br/Episodes/view/20>. Acesso em: 18dez. 2015.
} 
Em entrevista ao Museu da Imagem e do Som, Gil explicou tecnicamente sua admiração por Ben Jor:

Que até então era só o violão de João Gilberto que tinha me interessado, que tinha me feito tocar violão. Era o violão de João Gilberto que me emulava, que me estimulava, que me dava referência pra buscar coisas. A partir do violão do Jorge Ben foi um outro ele mento, essee lementoé o lado percussivo. João Gilberto e todo o pessoal da Bossa Nova é o planger de cordas no sentido clássico, mas a BN tinha isso apesar de ter feito essa condensaçãode acordes mais fechados eles eram produzidos com esse tanger mais suave das cordas com o polegar e os três dedos, o polegar tangendo as cordas graves e o indicador e o médio e o anular puxando as cordas agudas. No Benjor o movimento do punho é que determina a pulsação, que determina as acentuações, o que dá a possibilidade de inovações rítmicas, invenções, alte rações na incisão da incidência do ritmo em cada canção. $O$ que popularmente se chama a levada, a coisa com o punho e a paleta dá essa possibilidade de invenção de novas levadas. Então foi o primeiro violão popular no Brasil, primeira guitarra popular que se aproxima do rock'n'roll, dos grandes guitarristas negros americanos do rock, do rhythm and blues, especialmente o Chuck Berry. Então o primeiro Chuck Berry brasileiro é o Jorge Ben Jor. E tudo isso com a presença fragmentária de todos os elementos africanos. ${ }^{363}$ [grifos meus]

É interessante salientar que a afinidade e admiração de Gil por Jorge se dava no campo da negritude, na maneira de Jorge tocar o violão como os negros americanos do rock e do blues, através do violão, que era o instrumento dos dois, e especialmente pelo dado percussivo de Jorge Ben. Gil denomina de elementos africanos na musicalidade de Jorge a maneira percussiva como Jorge toca seu violão, a grande força do ritmo em suas levadas.

As falas transcritas acima nos apresentam material para algumas indagações. Se Jorge fora companheiro nas gravações do disco de 1975, fora também mestre do discípulo Gil, jovem e pré-tropicalista, morador da cidade de Salvador. Apesar de se tratar de elucubrações juvenis de Gil, o desejo de largar suas próprias composições e tentar aperfeiçoar o estilo de Jorge Ben, são exemplos da grande admiração que Gil nutria pelo artista. Sobre a africanidade envolta nessa relação, destaco que, antes do encontro com Mautner no exilio, Jorge Ben já fazia as vezes do artista que transitava no universo

\footnotetext{
${ }^{363}$ Depoimento do cantor e compositor Gilberto Gil, ao Museu da Imagem e do Som do Rio de Janeiro para a série "Depoimentos para a Posteridade", realizado em 6 de junho de 2012.
} 
musical negro, a ponto de Gil afirmar querer abandonar a carreira de compositor, uma vez que Jorge já teria feito tudo aquilo que pretendia fazer. Assim sendo, temos a informação de que entre suas primeiras experiências ligadas a aspectos das africanidades está o contato com a obra de Ben Jor, que assim como Mautner, não era um representante de culturas populares tradicionais de matriz africana, mas sim artistas conectados com esse universo e sonoridade. Isso significa que os primeiros dados de africanidades acessados por Gil estavam alocados no mundo artístico musical e pode ser representado especialmente por Jorge Ben, Jorge Mautner e também por Jimi Hendrix.

Posteriormente a essas identificações artísticas, Gil frequentaria candomblés e faria parte do afoxé Filhos de Gandhy, que conotam a busca do artista por manifestações da cultura popular afro-brasileira. Essa situação aqui é relevante e não significa que a ligação de Gil com o mundo das africanidades seria mais ou menos autêntica se fosse processada somente no universo das tradições populares afro-brasileiras mais do que no universo artístico, não se trata aqui de exercer um juízo de valor, elencando signos ou situações mais ou menos demarcadoras de diferentes graus de africanidades. Essa ligação apenas nos possibilita interpretar que a afinidade de Gil com tais Jorges dimensionam que a construção referente às africanidades se processou em Gil de maneira transatlântica, através de códigos nem sempre ligados especificamente à uma continuidade da África, mas que Gil re-criou e reinterpretou diversos signos de uma identidade que se pretendia desconectada de essencialismos.

Nessa dimensão temporal que mescla o "além", que busca referências no passado/presente, as africanidades acessadas pela conexão com os Jorges e Hendrix se dão no campo da reinterpretação da África pelos americanos, não através da expressão de pureza ou continuidade, mesclando tradição e repetição, mas sim demarcadas por reelaborações e descontinuidades. Vale aqui salientar que não se trata de reconhecer que determinados elementos são mais ou menos fortemente africanos, mas que apontam bem mais para a captação de uma criatividade brasileira que se apropriou de elementos africanos e os mesclou a inúmeros outros elementos numa construção pós-moderna e transatlântica.

1963 é a data de uma entrevista em que Jorge Ben Jor é arguido sobre ser um "macumbeiro da bossa nova", já que mencionava muito os pretos velhos em suas canções: 
Jorge: Os que me consideram assim não conhecem as raízes da minha música, bem como meus ancestrais, eu como já declarei (...) tive o meu avô nascido na Abissínia (...) Dele herdei o sangue e quem sabe? Um pouco das coisas e dos costumes etíopes, daí até ser macumbeiro é coisa muito diferente. Revista: Julga então seu estilo de cantar diferente dos pontos de macumba? Jorge: Para ser absolutamente sincero, nem sequer conheço os tais pontos, excluídos aqueles tão copiados para músicas de carnaval. Revista: Confessa que já assistiu a uma sessão de macumba? Jorge: Eu jamais estive em um terreiro. Se isso não fosse verdade teria a coragem de dizer, pois não constitui desdouro para ninguém, coisas que aqui no Rio, pela beleza folclórica, tornou-se até um atrativo turístico. Eu não fui, mas na primeira oportunidade irei. ${ }^{364}$

Nesse período, assim como Gil na época da Tropicália, com diferença de poucos anos, ${ }^{365}$ Gil respondeu algo bem próximo a essa resposta de Jorge; assim, podemos afirmar que nem pra Gil e nem pra Jorge a identificação com a cultura negra estava especificamente ligada ao candomblé, ao menos ao longo da década de 1960, quando ambos consolidaram suas carreiras. Cabe agora perguntarmos: a negritude em Jorge e Gil se conectava a quais representações? Os símbolos de africanidade desses artistas se relacionavam mais a elementos da tradição afro-brasileira ou estariam mais conectadas a códigos transatlânticos?

Em entrevista ao programa Roda Viva, Jorge pontuou vários aspectos relacionados à sua composição e também à sua negritude:

Eu tinha referência de músicos que meu pai ouvia em casa. Meu pai era amigo do Ataulfo Alves, tinha discos do Ataulfo, eu gostava do rei do baião Luiz Gonzaga, rock do Little Richard (...) A influência de samba eu tinha de escolas de samba, meu pai me levou pela primeira vez no Salgueiro, era uma coisa diferente, eu sempre gostei de percussão e a primeira vez que eu vi uma bateria de samba eu achei incrível, um monte de gente tocando juntinho, certo (...) O Tábua de esmeralda é o meu melhor trabalho (...) Eu sempre faço música alegre, até minhas músicas tristes têm final feliz (...) Sempre fui apolítico (...) Sou cristão, sou católico, apostólico, sou ecumênico também (...) Faz parte da minha mistura musical, João Gilberto foi meu ídolo, a maneira tão coloquial dele tocar, a divisão dele cantar (...) Os músicos que tocavam samba no Rio eles não tinham uma leitura da minha batida, era um samba mas não era, tanto que meu primeiro disco foi uma banda de jazz que gravou comigo, foram eles que tiveram uma leitura própria (...) Minha ge ração muito

\footnotetext{
${ }^{364}$ Revista do Rádio, Ed 732, 1963, apud: REIS, Alexandre. "Eu quero ver quando Zumbi chegar": Negritude, política e relações raciais na obra de Jorge Ben (1963, 1976). 2014. Dissertação (Mestrado em História): CCHS/UFF, 2014, p. 125.

${ }^{365}$ Ver capítulo 1, p. 91.
} 
poucos bemaventurados me entenderam, umdeles é Caetano Veloso, que sempre me entendeu, porque tudo que eu fiz antes, eu faço agora é a mesma coisa que eu faço agora, eu só aproveito mais a te cnologia (...) Eu ouvi muitos cantos etíopes por caus a da minha mãe, muitos batuques, dos parentes, eu era menino criança, eles falavam numa língua que eu não entendia e um batuque e isso foi misturando tudo (...) Ainda não fui pra Etiópia, tô pra ir (...) Eu uso o maracatu, o jongo (...) A participação no Festival da Argélia, foi a festa da juventude e era um festival africano, eu fiquei surpreso porque fui o único da América do Sul a ser convidado para participar desse festival, era só música africana $(\ldots)^{366}[$ grifos meus $]$

É interessante salientar que tanto Gil quanto Benjor tinham João Gilberto e Luiz Gonzaga como ídolos. Jorge remete à mistura a força de sua musicalidade. Dentre os símbolos que representam sua africanidade, estão sua família vinda da Etiópia com suas linguagens e batuques, o rock ouvido nas rádios e o samba que frequentava com seu pai.

Diferentemente de Gil, que estudou música desde pequeno, Jorge conta que aprendeu sozinho a tocar seu violão. Sobre a maneira como Jorge Ben concebe suas músicas, o jornalista e crítico musical Tárik de Souza disse:

Na verdade, o método de composição do Jorge Ben é o fluxo da inconsciência que vai e ele vai escrevendo e aquilo sai daquela maneira. É inacreditável aquelas coisas eu descobri que sou um anjo, ele descrevia que saia pela rua e começava a voar, pensando que era um anjo, ele sentia aquelas coisas mesmo. Então tudo aquilo que ele colocava nas músicas era descritivo porque ele era capaz de sentir. É um psicodélico sem a psicodelia, sem o LSD. É um cara que não precisa tomar LSD porque a cabeça dele já é tão louca, tão imagética, sãotantas coisas, tão colorida, realmente não precisa do LSD. É impossível explicar, o Jorge Ben ou você sente ou você não sente, não tem explicação lógica. Ele foge da lógica, ele é a música. Ele é aquela fratura que existe entre o poema de livro e o poema da música, se você escrever um poema de Jorge você acha uma porcaria, mas aquilo na música funciona de uma maneira tão absurda que só ele consegue fazer, mas ele não tem uma explicação pra isso. ${ }^{367}$

Dessa vez quem nos informa sobre as composições de Jorge é o próprio Gil:

\footnotetext{
366 Programa Roda Viva, TV Cultura, $1995 . \quad$ Disponível em: <https://www.youtube.com/watch?v=oOXfloyjrpQ>. Acesso em: 18dez. 2015.

${ }^{367}$ IMBATÍVEL ao extremo: as sim é Jorge Ben Jor. Apresentado pela Rádio Batuta do Instituto Moreira Sales. Produção: Adriana Maciel, Heloísa Tapajós e Paulo da Costa e Silva, 2012. Disponível em: <http://www.radiobatuta.com.br/Episodes/view/20>. Acesso em: 17 ago. 2015.
} 
Eu vejo a música de Jorge como a que mantém elementos mais nítidos da complexidade negra na formação da música brasileira. Modos diferentes musicais vieram para o Brasil através de várias nações africanas. Jorge assume o que veio do norte da África, o muçulmano, como elemento básico do seu trabalho. Ele não gosta de perder a perspectiva primitivista, não deixa de se ligar no jêje, Kêtu, iorubá. Mas ele tem um outro lado que inclui o moderno. ${ }^{368}$

Ainda sobre o modo de compor de Jorge Ben, Caetano comentou:

Toda essa coisa tosca tem a ver, por exemplo, com toda a produção de canções dos blocos afro de carnaval da Bahia, que só começaram da segunda metade da década de setenta, tem a ver com o modo de Jorge Ben fazer letra de música. Cópias literais de livros didáticos que ele leu. Isso você vem ouvir nas canções do Olodum, do Ilê Ayê, do Muzenza, às vezes de você ficar com lágrimas nos olhos de resultados tão ao mesmo tempo ingênuos e sábios, bonitos e toscos, isso Jorge Ben foi profeta disso, ele fez antes. É uma revolução de classe o caso Jorge Ben mais do que o João Gilberto que tudo tá incluído, mas o Jorge Ben é uma virada de classe no sentido de áreas não sofisticadas e sem pagar tributo à sofisticação poderem se expressar cruamente. ${ }^{369}$

Caetano, que de acordo com o próprio Ben o entende, comenta que o recurso das colagens das etnias africanas são passagens enciclopédicas, e, assim sendo, temos outros indícios das africanidades cantadas por Jorge. Essa informação fornecida por Caetano, juntamente com as de Benjor, possibilita ainda dizermos que parte desses conteúdos referentes à África, presentes nas canções de Ben, correlacionam ideias às práticas. Ambos, Gil e Jorge, visitaram a África e passaram a criar laços mais estreitos com o continente, apenas depois da gravação do LP Gil Jorge Ogum Xangô no ano de 1975. São representações de africanidades imaginadas, mas também praticadas. Gil e Jorge não frequentavam terreiros de candomblé, não eram batuqueiros de escolas de samba, e nem por isso eram menos ou mais negros do que outros negros, e muitas vezes fizeram com que muitos negros se orgulhassem de ser negros. Pois ambos transitavam pela fronteira da negritude, ao executarem gêneros musicais como samba, rock, ijexá ou reggae. Suas canções são carregadas de suingue, com muita ênfase no aspecto rítmico, seus cabelos assumidamente sararás, caracterizando que a escolha pelo universo afro não se deu apenas no âmbito musical.

\footnotetext{
${ }^{368}$ LUIZ, Marco Aurélio (entrevistador), 1977 apud RISÉRIO, Antonio. Expresso 2222..., op. cit., p. 171. ${ }^{369}$ IMBATÍVEL ao extremo..., op. cit.
} 
Alexandre Reis, refletindo sobre negritude, política e relações raciais na obra de Jorge Ben, destaca que:

No vestuário, no cabelo, nas performances e, sobretudo, nas suas
canções, Jorge Ben se afirma orgulhosamente como negro. Este
seu texto negroestá presente emsua obra desde os seus primeiros
álbuns de 1963 e 1964, quando articulava uma memória da
escravidão onde os negros eram retratados como agentes. Nos
anos 70 , o texto negro de Jorge louvava a beleza negra, em
diálogo com os movimentos estadunidenses. Essa interlocução
aparece tambémnas homenagens que presta a sujeitos negros que
lutaram contra o racismo como Miriam Makeba e Mohammed
Ali. ${ }^{370}$

Reis afirma ainda que Jorge Ben exalta a beleza dos negros. Suas musas são dignas e belas, distanciando-se das visões comumente estereotipadas das representações de mulatas em voga no imaginário do período. De acordo com Reis, o mais importante para Jorge Ben era transmitir uma mensagem de empoderamento e esperança. Ao invés de utilizar termos como escravidão ou açoite, Jorge preferiu falar das lindas princesas africanas, dos "pretos velhos" e do guerreiro Zumbi. Segundo Reis, a maneira como Jorge se posicionava perante a negritude:

Estaria entre "nem Pelé, nem Toni Tornado"; nem um sujeito que por vezes é considerado "quase branco" por setores mais aguerridos da imprensa, nem aquele que foi considerado o músico mais radical na denúncia contra o racismo. Diferentemente de Pelé, Jorge reconhece a existência do preconceito, mas, ao contrário de Tornado, não assumiu posturas muito ostensivas. Entre um polo e outro há uma infinidade de estratégias de que os sujeitos do período lançaram mão. ${ }^{371}$

De acordo com Reis, portanto, Jorge não estava conectado a posturas radicais tampouco alienadas. Não escolheu denunciar as mazelas africanas, ou mesmo as brasileiras. Sua carreira pautou-se em celebrar a vida e a alegria; suas canções intencionam criar uma identidade racial negra e positiva.

Gil nutria por Jorge, desde o lançamento de Samba esquema novo, em 1963, uma grande admiração. Em 1975, Gil e Jorge gravaram em parceria o único LP lançado pela dupla. Já no título, encontramos a presença de dois orixás, Ogum e Xangô, dois

\footnotetext{
${ }^{370}$ REIS, Alexandre. Eu quero ver quando zumbi chegar, op. cit., p. 102.

371 Ibid., p. 151.
} 
orixás guerreiros. Gil é o filho de Xangô, juntamente com Logunedé. ${ }^{372}$ Participaram da gravação, além dos dois compositores, o baixista Wagner Dias e o percussionista Djalma Corrêa. ${ }^{373}$

Ainda sobre o disco lançado por Gil e Ben, na mesma edição da revista, Tárik de Souza comentou que "de fato, nada pode ser mais contagiante e enérgico que a reunião em disco de Jorge Ben e Gilberto Gil, dois dos mais ilustres e ecléticos praticantes das variadas seitas africanas da música brasileira." E comenta ainda que "nem Jorge Ben é unicamente intuitivo ou Gilberto Gil, radicalmente teorizador." ${ }^{374}$ Ainda nessa mesma edição, Veja, na sua sugestão de discos, assim identificou Refazenda, LP lançado naquele ano: "Incansável descobridor sonoro, Gil parece reinventar a simplicidade, menos procurada em gravações anteriores. Seu disco é uma sequência de novidades". Aqui a relação de africanidade se faz notar por adjetivos como contagiante, enérgico e intuitivo, além de creditar a Gil e Jorge Ben o papel dos maiores praticantes das variadas seitas africanas da música brasileira.

O LP Gil Jorge Ogum Xangô ${ }^{375}$ é demarcado pela experimentação e improvisação do início ao fim, com faixas que chegam a durar mais de treze minutos. Sobre a motivação da criação deste LP, nos relata o produtor André Midani que:

Me telefona um amigo inglês, se chamava Robert Stick, extremamente bem-sucedido porque foi ele que concebeu Jesus Cristo Superstar, Hair e tinha uma companhia de disco. Um dia ele me telefona e me diz: olha eu tô contratando o Eric Clapton e eu quero levar ele pro Rio para passar uns dias lá. Eu te peço para arrumar uma reunião com os músicos brasileiros que você acha que o Eric poderia se interessar. Então isso foi arrumado, ou seja, eu organizei isso em casa muito informalmente. O Eric chegou com a guitarra dele, naquela época todo mundo ficou ôhhh, uma guitarra toda branca, e aí os meninos foram buscar cada qual um instrumento qualquer. O Caetano o violão, o Gil o violão, a Rita tomou emprestado um violão, tinha esses que eu mencionei, tinha certamente o Erasmo, tinha Cat Stevens também, era um grupo de certa qualidade (risos). Então teve um momento em que todo mundo se sentou no chão e começaram assim como quem não quer nada a tocar, aí foi, foi, foi e o CatStevens resolveu cair fora porque não sou guitarrista pra ficar nesse time, eu acho que o Caetano fez a mesma coisa, e Rita também. Aí num momento era

\footnotetext{
${ }^{372}$ Afirmação do próprio artista a Leda Nagle que acrescentou ao panteão um pouquinho também de Oxum, no programa Sem Censura, publicado no Youtube pela TV Brasil em 09 de maio de 2012.

${ }^{373}$ Disponívelem: <www.discosdobrasil.com.br> Acesso em: 11 nov. 2015.

${ }^{374}$ SOUZA, Tárik. Inadiável prazer. Veja, ed. 344, 09 abr. 1975.

375 Ficha técnica original: Direção de produção: P. Tapajós e P. Albuquerque In: <www.gilbertogil.com.br>. Acesso em: 15 mar. 2016.
} 
Eric Clapton, Gil e o Jorge. Aíficou, ficou, ficou os três tocando, tocando, tocando e adorando tocar. Dali o Eric disse pra mim chega. Aí parou. Aí ficaram os dois e a particularidade daquele encontro ali entre dois homens que têm para a função rítmica uma admiração muito grande, então ficou uma luta, uma guerra, nem Jorge nem Gil gostam que eu fale isso, mas na verdade foi uma guerra amistosa, respeitosa, mas uma puta de uma gue rra. Porque quem é o dono do ritmo comanda o resto. Então o Jorge com aquela coisa ingênua dele, absolutamente que sai dele mesmo tá lá com o ritmo, é dele, aí o Gil ficou cantando, até o momento onde Gil diz eu quero agora pegar o ritmo. Aí fazia oooo feito uma águia aí tentava pegar o ritmo do outro. Como águia que pega a presa e leva a presa, aí chegava lá e não pegava a presa, a presa ficou com o Jorge. Isso duas ou três vezes até um momento onde o Gil realmente conseguiu pegar o ritmo, dois minutos depois ele perdeu o ritmo. E quando eu falo perdeu o ritmo não tem nenhuma conotação de dizer ele perdeu e o Gil podia ser melhor, não é isso não. Porque a história não era esta. Era a alma da música brasileira que se confrontava naquele momento. Eu fiquei tão impressionado, mas tão impressionado, que eu virei pro Armando e disse amanhã os dois têm que entrar em estúdio. Não foi amanhã claro, todo mundo foi dormir cinco horas da manhã, mas dois, três, quatro dias depois foi gravado aquele disco duplo muito rapidamente, dois dias direto. E não há mais, quando duas pessoas assim se encontram não há mais essa história de estar afinando, não estar afinando, está no ritmo, não está no ritmo, é uma outra história. Então vai tocando e vai fazendo que tá tudo isso mesmo. E a personalidade forte de cada um resolve os seus embates, né? Então é isso. ${ }^{376}$ [ grifos meus]

De acordo com o produtor Midani, o encontro de Gil e Jorge foi tão estrondoso que ele logo arranjou um jeito de juntar os dois artistas em estúdio para gravar o tal encontro. Midani enfoca a força do encontro desses artistas, principalmente através do aspecto rítmico, que chegou mesmo a ser causa de disputa entre Gil e Jorge. Sobre a gravação do disco, Jorge disse:

O disco com Gil foi uma coisa incrível (...) Fomos pro estúdio e fizemos ao vivo, era free, tem faixa de nove, onze minutos, era direto errando ou não, foi eu, Gil mais um baixo e uma percussão. Foi uma coisa diferente, que acho que só tinha que fazer aquele disco mesmo, porque o segundo acho que não ia sair igual, ia ter que fazer música pra tocar três minutos (...). ${ }^{377}$

As músicas do LP não seguiram padrões. São como mantras: não existem fortes delimitações de início, meio ou fim das músicas. O encadeamento é demarcado pelo

\footnotetext{
${ }^{376}$ IMBATÍVEL ao extremo..., op. cit.

${ }^{377}$ Programa Roda Viva, TV Cultura,1995.
} 
ritmo, são músicas sem forma musical; são músicas circulares, que são característica s africanas de fazer música. Quem nos informa sobre essas características africanas é Leda Martins, que, ao abordar a cultura negra, seus jogos ritualísticos de linguagem e performance culturais, afirma que:

\begin{abstract}
Nesse movimento, a própria noção de centro se dissemina, na medida em que se desloca, ou melhor, é deslocada pela improvisação rítmica e melódica. Diz Elisson: “[...] porque o jazz encontra seu ponto vital numa infindável improvisação sobre materiais tradicionais, o jazzista deve perder sua identidade, mesmo quando a encontra". Assim como o jazzista, metonímia das culturas negras nas Américas, retece os ritmos milenares, transcriando-os dialeticamente numa relação dinâmica e prospectiva, essa cultura, em seus variados modos de asserção, funda-se dialogicamente, em relação aos arquivos das tradições africanas, europeias e indígenas, nos jogos de linguagens, intertextuais e interculturais, que performa. ${ }^{378}$
\end{abstract}

A improvisação é o elemento mais marcante do LP, principalmente das vozes e dos violões. A estruturação da música é circular, e a ênfase é dada aos elementos rítmicos, e não ao desenvolvimento de acordes ou harmonia. A percussão não desenha padrões rítmicos, nem africanos e nem europeus, e não é polirrítmica. Ela acompanha a levada dos violões. O samba é tocado em "Quem mandou" e "Essa é pra tocar no rádio". A menção à música nordestina se faz notar em "Jurubeba" e "Morre o burro fica o homem", e do ijexá em "Filhos de Gandhy"; além dessas canções, nenhuma outra é acompanhada por nenhum gênero musical específico.

As letras do LP que tematizam africanidades ou negritudes são "Nêga (Photograph blues)"379 e "Filhos de Gandhy", ambas de Gil. A primeira foi gravada anteriormente no LP Gilberto Gil, em 1971, em Londres. Nega é um adjetivo carinhoso que pode se referir ou não a uma pessoa negra. Na letra da canção, o termo tem o sentido de inspiração, de uma boa companhia. Na letra de "Filhos de Gandhy", Gil clama a todos os orixás, ao

\footnotetext{
${ }^{378}$ MARTINS, Leda Maria. Afrografias da memória: o Reinado do Rosário no Jatobá. São Paulo: Perspectiva; Belo Horizonte: Mazza Edições, 1997, p. 29.

379 "Nega" (Gilberto Gil, 1971)Tradução: Nega/ Você passou tão feliz/ Os últimos tempos comigo/ Nega/ Eu também passeitão bem/ os últimos tempos com você/ Quando te conheci/Foi tão bom/ Não falei demais com você/E só comentei sobre seu cabelo macio/ Você fez um discurso sobre shampoo/ Nós tiramos várias fotografias no centro da cidade/ Enquanto passávamos/Você ia onde quer que eu fosse/Você esteve com todos os meus amigos/ Eu fazia o que você fizesse/ Agora já posso curtir o seu barato/ Deixemos nossos momentos serem/ O que eles tinham que ter sido/Revele nossas fotografias/Como sonhos simples que se tornam verdade/ Talvez elas te façam rir/ Ou te tragam certezas sobre nós/ Talvez elas não te revelem nada/ Além de uma sombra de tristeza. In: RENNÓ, Carlos (org.) Gilberto Gil todas as letras. São Paulo: Companhia das Letras, 1996, p. 124.
} 
Senhor do Bonfim e a Deus do céu, que o afoxé receba bênçãos e proteção divina para participar do carnaval baiano.

O estilo black dos artistas, os búzios, juntamente com o título do LP, são também elementos que demarcam africanidades:

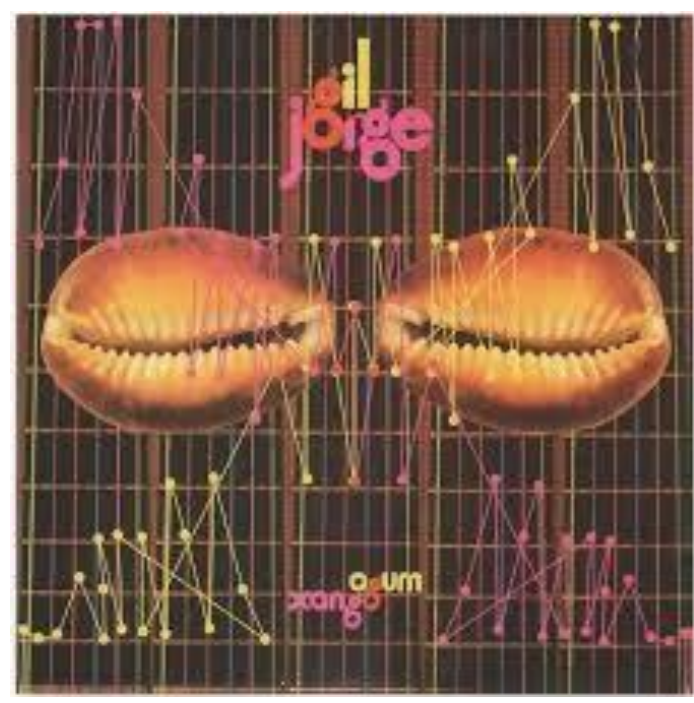

Figura 1 - Capa do disco Gil Jorge Fonte: 〈www.brasileiros.com.br >

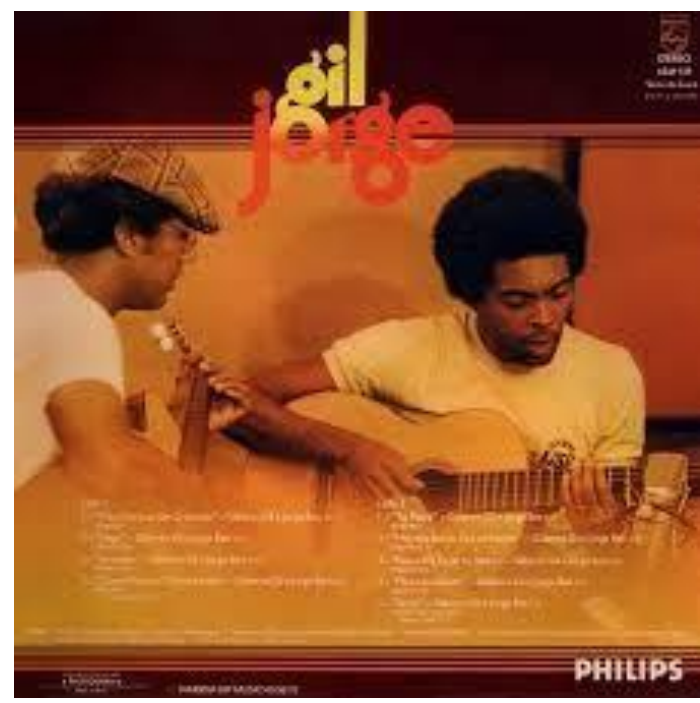

Figura 2 - Contracapa do disco Gil Jorge Fonte: 〈www.brasileiros.com.br>

Esses sentidos recriados mais na musicalidade, menos nas letras das músicas, no visual da capa ${ }^{380}$ do LP e no visual dos artistas, caracterizam códigos organizadores de africanidades. Essas representações entrecruzam-se, compondo uma simbolização de

\footnotetext{
${ }^{380}$ Capa: Aldo Luiz e Rogério Duarte. Foto: João Castrioto.
} 
negritude, conectando seus autores aos seus espectadores. As africanidades já existiam anteriormente nos relatos e performances de Gil e de Jorge, e são fragmentos retirados de histórias anteriores e reatualizados em experimentações dinâmicas como as desse LP. Não houve nesse LP a busca por uma África mítica, ou mesmo especificada em determinadas etnias. As africanidades se fazem notar através dos significados musicais, mas também extramusicais.

\title{
A trilogia "Re"
}

Dentre os discos lançados por Gilberto Gil na década de 1970 está a trilogia $^{381}$ Refazenda $^{382}$ (1975), Refavela ${ }^{383}$ (1977) e Realce $^{384}$ (1979). Sobre essa tríade, o artista afirmou:

\begin{abstract}
Resumidamente acho que me deram o meu assentamento definitivo dos gêneros que mais significam, elementos de formação básica para minha vida musical. Os três são a versão amadurecida desse compromisso meu com essas vertentes mais importantes da minha base musical. A da infância, a da adolescência e a vida madura pós-exílio. ${ }^{385}$
\end{abstract}

Esta fala do artista, de 2011, em muito nos informa, desde a concepção da maturidade estar atrelada ao seu retorno de Londres, mas também que o repertório dos anos 1980, 1990 e 2000 foram reedições daquilo que o artista consolidou na década de 1970, especialmente nessa obra, dividida em três partes. Nesse repertório encontraremos rock, reggae, baião, música experimental, sambas; enfim, nele Gil construiu uma música híbrida, utilizando estratégias de sempre sair e entrar na modernidade. ${ }^{386}$ Sobre a realização dessa trilogia, Gil disse:

Eram três movimentos que me remetiam muito aos que Antonioni fez em seus três filmes: A aventura, $A$ noite e $O$ eclipse, que, na época, foram muito importantes para mim. Foi com eles que tomei conhecimento pela primeira vez do que era uma trilogia e sua utilização na arte. Eu quis fazer a minha. Foi

\footnotetext{
${ }^{381}$ Para a audição e análise da trilogia, contei com o apoio dos músicos Vladmir Cerqueira (violonista) e André Mendes (percussionista).

382 ÁlbumRefazenda (Warner Music, 1975).

383 Álbum Refavela (Warner Music, 1977).

384 Álbum Realce. (Warner Music, 1979).

${ }^{385}$ Programa O SOM do vinil. Canal Brasil, 2011.

${ }^{386}$ CANCLINI, Néstor. Culturas Híbridas..., op. cit.
} 
ali, quando surgiu Refazenda e quando vi Refavela. Me animei, porque Refazenda era interessante e Refavela era tão bonito. ${ }^{387}$

Sua trilogia começou a ser confeccionada quando Gil tinha seus 33 anos de idade e havia vivenciado inúmeras experiências artísticas e pessoais. Nesse momento já era pai de quatro filhos, vivenciava seu terceiro casamento e também excursionava com sua banda pelo Brasil e exterior. O objetivo aqui é procurar entender como se deu a construção desta trilogia como esta se vincula à construção de africanidades. Quando Gil afirmou que essa trilogia representava o seu compromisso com as vertentes mais importantes de sua base musical, cabe perguntar: quais eram essas vertentes?

\section{- Refazenda}

Sobre as ideias que permeavam a criação de Refazenda, Gil afirmou:

É uma coisa de poesia concreta, uma aglutinação de conceitos poéticos - "refazenda", de refazer, andar de ré, fazendo tecido, de verde, de área:de refazendo, sendo, senda, trilho, trilha, caminho, caminhar, dar em nada, feito, feita: é a fé, refeita, fé recémnascida, fé menina, que eu criei para o meu próprio governo, para me proporcionar uma reciclagem. ${ }^{388}$ [grifos meus]

O LP que iniciou a abertura da trilogia representava para Gil uma busca interior, de sua essência marcada pela transmutação, pela possibilidade inventiva de criar um abacateiro que frutificasse não apenas frutos, mas diferenciados frutos, ideias, sonoridades; uma árvore metafórica que também dialogasse com a musicalidade de Caetano $^{389}$, caracterizando o tecer, desdobrando-se em entrelaçamento, arquitetando uma releitura de sua trajetória até então traçada, dando importância à natureza e à infância, mas especialmente à transformação. Foi uma espécie de refazenda pessoal, balizada pelo rigor da macrobiótica e da yoga.

Refazenda foi lançado em agosto de 1975, com produção de Marco Mazola, arranjos de base feitos por Gil, arranjos de orquestra por Perinho Araújo e a arte de capa

\footnotetext{
${ }^{387}$ Apud FONTENELES, Bené. Giluminoso..., op. cit., p. 204.

${ }^{388}$ Apud FONTENELES, Bené. Gil 60: todas as contas. Rio de Janeiro: Gege Edições, 2002, p. 89.

${ }^{389}$ Nessa mesma entrevista, Gil afirmou: "É um diálogo meu com uma árvore que dá "joia” e "qualquer coisa." O LP Joia de Caetano Veloso foi lançado em 1975 pela Philips, sendo "Qualquer coisa" a outra metade do disco, produzido pelo mesmo arranjador do LP Refazenda Perinho Albuquerque. Dis ponível em: <www.caetano.com.br> Acesso em: 19 dez. 2015.
} 
por Rogério Duarte. Na arte da capa ${ }^{390}$, encontramos muitos indícios do que existe em seu conteúdo:

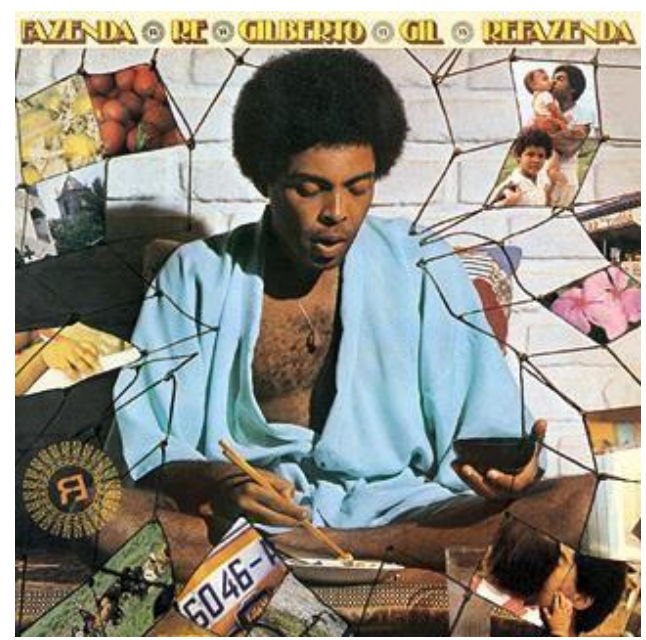

Figura 3 - Capa do LP Refazenda

Fonte: <tempoesia.wordpress.com>

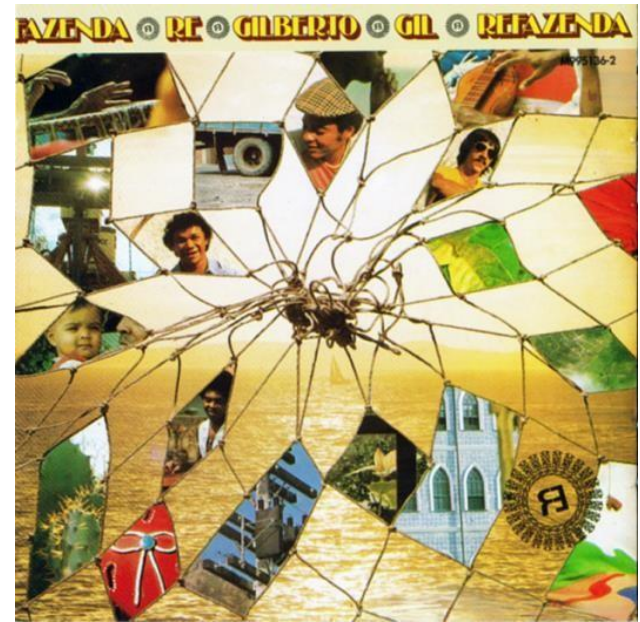

Figura 4 - Contracapa do LP Refazenda

Fonte: <tempoesia.wordpress.com>

Enquanto a capa apresenta Gil vestindo um quimono e se alimentando através da macrobiótica, simbolizando sua conexão com símbolos da cultura oriental, as teias que entrelaçam capa e contracapa são e funcionam como a rede de um pescador, preenchidas por fragmentos de fotos, emaranhadas numa malha cheia de sentidos, com o mar ao fundo, numa clara alusão à Bahia. As fotos demonstram a ligação de Gil com seus filhos, com paisagens do interior, com os músicos de sua banda, instrumentos musicais (tabla indiana e uma viola de cocho) e frutas. No entanto, essa afetividade pessoal é também

\footnotetext{
${ }^{390}$ Capa: Aldo Luiz e Rogério Duarte. Foto: João Castrioto.
} 
entremeada por fragmentos de imagens que fazem alusão à modernidade, como o caminhão, a eletricidade e a fábrica. Esse entrelaçamento de rede tem por fundo a Bahia e como centro Gil, formando uma complexa composição identitária que mescla distintas séries de códigos, que tanto podem fazer menção ao oriente como à tabla, ao quimono ou à comida ou à tradição representada pelas feiras e frutas variadas, além das velhas construções coloniais.

Os fragmentos das imagens que simbolizam a modernidade como os postes de eletricidade ou as rodas de um caminhão representam a possibilidade de contato e permuta entre as diversas regiões, do rompimento do provincianismo, de um maior acesso não apenas a uma infinidade de produtos, mas à cultura e aos conhecimentos de diversos territórios. Assim, a simbologia da capa aponta bem mais para a ampliação de visões sobre o mundo do que para a busca por revelar uma suposta pureza do interior do país. Esse refazer-se de Gil não se enquadrava numa busca que referenciasse apenas sua Ituaçu. Na construção dessa leitura, o interior, sua família e parceiros musicais são importantes, bem como os lugares, frutas e as novas tecnologias. Essa farta combinação de elementos variados na capa informa que a busca de Gil não estava empenhada em essencializar uma verdade rural que tematizasse alguma espécie de valorização do interior em detrimento de uma vida urbana, mas sim abordar suas conexões e entrelaçamentos.

A capa de Refazenda apresenta uma mistura de informações pessoais, locais e musicais, como, por exemplo, a escolha da viola de cocho representando a tradição e a musicalidade produzida no interior do país e a tabla indiana indicando uma sonoridade do exterior. Tal mistura é conectada à busca pelo conhecimento oriental e aponta bem mais para o hibrid ismo do que pronuncia um desejo em demarcar fronteiras culturais, sendo a teia o elemento que aglutina essa variedade de possíveis traduções.

A sonoridade do LP passeia pela experimentação e pela introspecção, bem mais do que a explosão que será a marca dos dois discos posteriores da trilogia. A primeira música é uma homenagem a "Ela", 391 deusa música. A sentimental canção mistura o rock a uma levada funk com elementos de jazz americano. As canções "Tenho sede",

\footnotetext{
391“Ela"(Gilberto Gil, 1975). Ela/Eu vivo o tempo todo com ela/Ela/Eu vivo o tempo todo pra ela/Minha música/Musa única, mulher/Mãe dos meus filhos, ilhas de amor/Cada ilha, um farol/No mar da procela, ela/Ela/Ela que me faz um navegador/Sobretudo ela/Ela que me faz um navegador. In: RENNÓ, Carlos (org.) Gilberto Gil todas as letras. São Paulo: Companhia das Letras, 1996, p. 166.
} 
"Essa é pra tocar no rádio", "Lamento sertanejo" e "Refazenda" não são demarcadas por nenhum gênero específico.

"Tenho sede"392 é um bom exemplo do hibridismo que permeia a construção sonora do LP. A bateria americana com uma levada de rock divide o arranjo com o acordeom de Dominguinhos e o triângulo, que, apesar de fazer uma referência sonora aos gêneros nordestinos, não faz o desenho rítmico característico do baião ou do xote. No arranjo aparecem também flauta, cordas, baixo e violão, numa resultante que mistura a base rítmica no rock, mas sem deixar de flertar com as sonoridades brasileiras.

Na canção "Refazenda" 393, a letra nonsense tematiza a natureza, numa brincadeira com o abacateiro, que amanhece tomate e anoitece mamão, fazendo referência ao cancioneiro popular nos versos Tu me ensina a fazer renda, que eu te ensino a namorar. São recordações sobre a vida no interior, sua conexão com a natureza, bem como o aprendizado de sua transformação. Conjecturando sobre o repertório do LP e sobre a música "Refazenda", Gil afirmou:

Eu estava terminando o repertório de Refazenda e queria usá-la como um fecho minimal que emblematizasse a ideia reflexiva, introspectiva, do disco. Havia um compromisso com os espaços das frases sonoras: eu não podia escrever o que quisesse (para construir a letra de uma música que já está feita, a gente já parte com esse dado limitador - não no sentido qualitativo, de expressão, mas no quantitativo). Por isso eu precisava de instrumentos muito precisos que me levassem aos lugares onde as palavras estivessem; de anzóis muitos afiados e linhas de comprimento muito bem medido para poder fazer a pescaria das palavras que expressariam numa suma o que eu sentia. E precisava da confirmação temporal do significado da meditação - de que ela trouxesse para o sujeito, que era eu, a sensação que a palavra meditação traz, de escorrer no tempo. ${ }^{394}$

\footnotetext{
392“Tenho sede" (Dominguinhos/Anastácia). Traga-me um copo d'água, tenho sede/E essa sede pode me matar/Minha garganta pede um pouco d'água/Eos meus olhos pedem teu olhar/A planta pede chuva quando quer brotar/O céu logo escurece quando vai chover/Meu coração só pede teu amor/Se não me deres, posso até morrer.

393 "Refazenda" (Gilberto Gil, 1975) Abacateiro/Acataremos teu ato/Nós também somos do mato/Como o pato e o leão/Aguardaremos/Brincaremos no regato/Até que nos tragam frutos/Teu amor, teu coração

/Abacateiro/Teu recolhimento é justamente/O significado/Da palavra temporão/Enquanto o tempo /Não trouxer teu abacate/Amanhecerá tomate /E anoitecerá mamão/Abacateiro/Sabes ao que estou me referindo/Porque todo tamarindo tem/O seu agos to azedo/Cedo, antes que o janeiro /Doce manga venha ser também/Abacateiro/Serás meu parceiro solitário/Nesse itinerário/Da leveza pelo ar/Abacateiro/Saiba que na refazenda/Tu me ensina a fazer renda/Que eu te ensino a namorar/Refazendo tudo/Refazenda/Refazenda toda/Guariroba. In: RENNÓ, Carlos (org.) Gilberto Gil todas as letras. São Paulo: Companhia das Letras, 1996, p. 168.

${ }^{394}$ Apud RENNÓ, Carlos. Gilberto Gil: todas as letras..., op. cit., p. 175.
} 
Assim como a capa do LP faz menção à rede de um pescador, Gil buscou nas letras e na musicalidade a habilidade de manusear o anzol com as palavras. Se pensarmos que as músicas, tanto as letras quanto sua forma musical, foram apanhadas com muita acuidade, podemos interpretar essa obra enquanto um processo meticuloso na tentativa de revelar e revolver o terreno de sua identidade e representações, tanto pessoais quanto artísticas, que nesse momento estavam completamente emaranhadas numa mesma rede. O arranjo tem uma presença maior das cordas, também misturando timbres como o violão, acordeom, bateria, baixo, percussão, mas novamente sem uma definição de gênero. Apesar disso, podemos perceber elementos do rock nas levadas do baixo, da música nordestina no acordeom e no triângulo, bem como da música erudita das cordas. Estas três músicas têm em comum a síntese de diferentes informações sonoras, sem se caracterizar com algum gênero musical em particular.

Em "Pai e mãe", ${ }^{395}$ música composta no dia em que completaria 33 anos de idade, Gil homenageia seus pais e compreende que todos os homens são uma extensão de seu pai, assim como todas as mulheres são a extensão de sua mãe. Representa também a busca por transcender estereótipos e clichês relacionados à sexualidade humana. É uma canção que nos traz uma definição maior de gênero musical. Trata-se de um choro tocado de uma forma mais próxima ao tradicional, com o diferencial de incorporar o som do acordeom.

O Jeca, de "Jeca total" ${ }^{396}$, pode ser analisado, de acordo com o próprio Gil, como o personagem desse disco:

\footnotetext{
395 "Paie mãe" (Gilberto Gil, 1975) Eu passei muito tempo/Aprendendo a beijar/Outros homens/Como beijo o meu pai/Eu passeimuito tempo/Pra saber que a mulher/Que eu amei/Que amo/Que amarei/Será sempre a mulher/Como é minha mãe/Como é, minha mãe?/Como vão seus temores?/Meu pai, como vai?/Diga a ele que não/Se aborreça comigo/Quando me vir beijar/Outro homem qualquer/Diga a ele que eu/Quando beijo um amigo/Estou certo de ser/Alguém como ele é/Alguém com sua força/Pra me proteger/Alguém com seu carinho/Pra me confortar/Alguém com olhos/E coração bem aberto/Pra me compreender. In: RENNÓ, Carlos (org.) Gilberto Gil todas as letras. São Paulo: Companhia das Letras, 1996, p. 170.

396 "Jeca total” (Gilberto Gil, 1975) Jeca Total deve ser Jeca Tatu/Presente, passado/Representante da gente no senado/Em plena sessão/Defendendo umprojeto/Que eleva o teto/Salarial no sertão/Jeca Total deve ser Jeca Tatu/Doente curado/Representante da gente na sala/Defronte da televisão/Assistindo Gabriela/Viver tantas cores/Dores da emancipação/Jeca Total deve ser Jeca Tatu/Um ente querido/Representante da gente no olimpo/Da imaginação/Imaginacionando o que seria a criação/De um ditado/Dito popular/Mito da mitologia brasileira/Jeca Total/Jeca Total deve ser Jeca Tatu/Um tempo perdido/Interessante a maneira do tempo/Ter perdição/Quer dizer, se perder no correr/Decorrer da história/Glória, decadência, memória/Era de Aquarius/Ou mera ilusão/Jeca Total deve ser Jeca Tatu/Jorge Salomão/Jeca Total Jeca Tatu Jeca Total Jeca Tatu/Jeca Tatu Jeca Total Jeca Tatu Jeca Total. In: RENNÓ, Carlos (org.) Gilberto Gil todas as letras. São Paulo: Companhia das Letras, 1996, p. 171.
} 
O fato de que a obra de Jorge Amado tinha antecedido ao período televisivo e agora estava na televisão (era a época da novela Gabriela) me fez pensar nas interseções entre os mundos rural e urbano - muito presentes em seus livros - e no encaminhamento evolutivo dos vários Brasis no sentido campo- cidade, vindo daí a ideia de traçar um risco do Jeca Tatu a um personagem ligado já a um tempo de mudanças técnicas e socioculturais recentes no país, que seria o Jeca Total. ${ }^{397}$

O Jeca é um sujeito que deixa de ser tatu para ser total. O Jeca se emancipou. Sua trajetória passada, demarcada pela via da exclusão social no sertão, reconfigura-se em total, não mais demarcado pela falta. A questão central da canção não é a exclusão, mas sua superação. A memória não se conecta apenas ao passado, mas anuncia a transformação desse Jeca, agora politizado e representante da gente no Senado. A canção não denuncia ou se lamenta pelo Jeca, mas celebra sua transformação. Sua sonoridade nos traz elementos presentes no baião, como os blocos sonoros marcando os contratempos e a utilização do triângulo, que, apesar de marcar o tempo, compõe a sonoridade do baião. Outro elemento é o da tuba, que repete um ostinato ${ }^{398}$ com as divisões do ritmo característicos do baião. No entanto, a bateria, o acordeom, o violão e a melodia não nos remetem ao baião. Trata-se, portanto, de outra música em que convivem elementos de diferentes musicalidades, com menção ao rock e ao baião. Outra música que nos traz elementos do baião é "Retiros espirituais". As divisões rítmicas da levada do violão, assim como da bateria e de uma clave que acompanha a música são as mesmas do baião, mas a maneira como os timbres são utilizados, assim como o arranjo de cordas, não caracteriza a música como um baião. Podemos dizer que ela possui elementos do baião, mas novamente nasce uma sonoridade sem gênero específico, apesar de trazer elementos que fazem referência ao baião.

"Essa é pra tocar no rádio" mostra a proximidade de Gil com o jazz e a música instrumental, bem como com a música africana. A utilização do ostinato do violão, em torno do qual se desenvolve ideias rítmicas e melódicas, mostra a influência da música africana da Nigéria, a juju music. $\mathrm{O}$ arranjo também mistura bateria, piano, baixo, violão e acordeom, sem uma especificidade de gênero. A letra explicita o desejo de Gil de maneira simples e direta, numa época em que o rádio era o melhor termômetro de sucesso de uma canção; no entanto, é interessante mencionar que a música em que o compositor

\footnotetext{
${ }^{397}$ Apud RENNÓ, Carlos, op. cit., p. 171.

${ }^{398}$ Conceito da música ocidental no qual uma ideia musical é repetida de forma constante.
} 
explicita este desejo tem uma sonoridade pouco comercial. "ÊE, povo ê"399 tematiza a esperança em tempos futuros; é uma música que podemos definir como rock de influência inglesa, demarcado pela característica pop dos ingleses, como a utilização de mais sessões harmônicas e a não utilização da fórmula do blues. "O rouxinol” ${ }^{400}$, que pescado do céu cantou um rock com um toque do oriente, tem a levada do violão, explorando uma harmonia complexa, e as intervenções da guitarra se caracterizam pelo rock tradicional americano.

Das doze canções do disco, duas tematizam diretamente a ligação de Gil com o universo da meditação. São elas "Retiros espirituais"401 e "Meditação". 402 Sobre a canção "Retiros espirituais", Gil disse:

É uma das músicas minhas que mais prezo, por ser das primeiras que dão uma radiografia da minha subjetividade e visceralidade interior, álmica. E é dividida em três partes para apresentar o movimento de tese-antítese-síntese de que gosto muito. ${ }^{403}$ [grifos meus]

\footnotetext{
399 “Êpovo, ê" ((Gilberto Gil, 1975) Tão longe/A alegria estava então/Tão longe/O seu sorriso de verão/Eu sei/Quanto custou ter que esperar/Até/Seu precioso bom humor voltar/Ê, povo, ê, povo, ê/Desabafa o

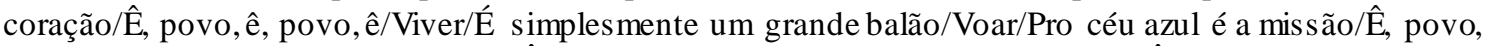

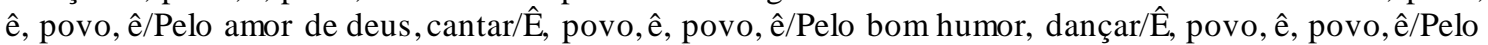
céu azul voar/ÊE, povo, ê, povo, ê-ê. In: RENNÓ, Carlos (org.) Gilberto Gil todas as letras. São Paulo: Companhia das Letras, 1996, p. 172.

400 “O rouxinol” (Gilberto Gil, Jorge Mautner) Joguei no céu o meu anzol/Pra pescar o sol/Mas tudo que eu pesquei/Foi um rouxinol/Foi um rouxinol/Levei-o para casa/Tratei da sua asa/Ele ficou bom/Fez até um som/Ling, ling, leng/Ling, ling, leng, ling/Cantando um rock com um toque diferente/Dizendo que era um rock do oriente pra mim/Cantando um rock com um toque diferente/Dizendo que era um rock do oriente pra mim/Depois foi embora/Na boca da aurora/Pássaro de seda/Com cheiro de jasmim/Cheiro de jasmim.

401 "Retiros espirituais" (Gilberto Gil, 1975)Nos meus retiros espirituais/Descubro certas coisas tão normais/Como estar defronte de uma coisa e ficar/Horas a fio com ela/Bárbara, bela, tela de TV/Você há de achar gozado/Barbarela dita assim dessa maneira/Brincadeira sem nexo/Que gente maluca gosta de fazer/Eu diria mais, tudo não passa/Dos espirituais sinais iniciais desta canção/Retirar tudo o que eu disse/Reticenciar que eu juro/Censurar ninguém se atreve/É tão bom sonhar contigo, ó/Luar tão cândido/Nos meus retiros espirituais/Descubro certas coisas anormais/Como alguns instantes vacilantes e só/Só com você e comigo/Pouco faltando, devendo chegar/Um momento novo/Vento devastando como um sonho/Sobre a destruição de tudo/Que gente maluca gosta de sonhar/Eu diria, sonhar com você jaz/Nos espirituais sinais iniciais desta canção/Retirar tudo que eu disse/Reticenciar que eu juro/Censurar ninguém se atreve/É tão bom sonhar contigo, ó/Luar tão cândido/Nos meus retiros es pirituais/Descubro certas coisas tão banais/Como ter problemas ser o mesmo que não/Resolver tê-los é ter/Resolver ignorá- los é ter/Você há de achar gozado /Ter que resolver de ambos os lados/De minha equação/Que gente maluca tem que resolver/Eu diria, o problema se reduz/Aos espirituais sinais iniciais desta canção/Retirar tudo que eu disse/Reticenciar que eu juro/Censurar ninguém se atreve/É tão bom sonhar contigo, ó/Luar tão cândido. In: RENNÓ, Carlos (org.) Gilberto Gil todas as letras. São Paulo: Companhia das Letras, 1996, p. 172. 402“Meditação"(Gilberto Gil, 1975) Dentro de si mesmo/Mesmo que lá fora/Fora de si mesmo/Mesmo que distante/Eassim por diante/De si mesmo, ad infinitum/Tudo de si mesmo/Mesmo que pra nada/Nada pra si mesmo/Mesmo porque tudo/Sempre acaba sendo/O que era de se esperar. In: RENNÓ, Carlos (org.) Gilberto Gil todas as letras. São Paulo: Companhia das Letras, 1996, p. 174.

${ }^{403}$ Gil Apud RENNÓ, Carlos. Gilberto Gil, op. cit., p. 173.
} 
Esse depoimento de Gil nos dá a dimensão, pela afirmativa de ser essa uma de suas canções prediletas e de que cumpre a função de traduzir sua alma, da grande importância que o paradoxo da incerteza tem em sua vida, numa constante brincadeira com a falta de nexo, juntando o caótico, unindo imagens com referências nem sempre óbvias. Essa radiografia se faz representar principalmente pelas três estrofes: Retirar tudo que eu disse, Reticenciar que eu juro e Censurar ninguém se atreve.

Das músicas do LP, apenas uma não é composição de Gil, que é "Tenho sede", de Dominguinhos e Anastácia. "Lamento sertanejo", 404 uma parceria de Gil com Dominguinhos, é demarcada por uma estética minimalista, tanto na letra, que evoca o sertão, quanto na melodia, que tem um forte apelo sentimental. Ambas as canções cumprem a função no disco de retratar o respeito e a admiração de Gil pelo sertão.

O disco como um todo é repleto de elementos musicais de diversas vertentes, passeando pelo baião, choro, rock, jazz, música instrumental e funk. A sonoridade é construída em torno de um violão fortemente demarcado pelo aspecto percussivo. De uma forma geral, esses elementos aparecem entrecortados. De forma sutil e não clara, eles permeiam as criações sonoras que sintetizam estas informações e as transformam em algo novo.

Como dito anteriormente, Refazenda intencionava reelaborar, por um processo de reciclagem, a musicalidade e até mesmo a identidade de Gil, através de um exercício de memória. Compreendendo que a memória é uma construção seletiva, os símbolos utilizados por Gil para compor esse trabalho foram a natureza, o sertão e a meditação, porém apimentados pelo rock, jazz, o choro e experimentações musicais. Sua memória reformulou sua identidade através da experimentação de antigos códigos trabalhados sob uma nova interpretação. Se esse LP foi feito com o intuito de produzir uma autocompreensão, foi também um momento de transição para Gil, e, nesse caso, de reprocessar seu passado, porém com ares de inovação.

O interior, avivado em forma de sertão, não é celebrado através de exaltação; não é vibrante, mas introspectivo. A cadência das músicas é lenta, parecem mesmo

\footnotetext{
404“Lamento sertanejo”(Gilberto Gil, Dominguinhos) Por ser de lá do sertão/Lá do cerrado/Lá do interior, do mato/Da caatinga, do roçado/Eu quase não saio/Eu quase não tenho amigo/Eu quase que não consigo/Ficar na cidade sem viver contrariado/Por ser de lá/Na certa, por is so mesmo/Não gosto de cama mole/Não sei comer sem torresmo/Eu quase não falo/Eu quase não sei de nada/Sou como rês desgarrada/Nessa multidão boiada/Caminhando a esmo.
} 
aflorar das meditações de Gil. A descoberta da sensação de liberdade do Jeca ou a recuperação das alegrias de quintal em que um abacateiro dá mamão revelam que a intenção não se constrói através de um elogio mítico a esse passado: ele vem à tona com ares de admiração e transformação; e não como prisão em nenhum tipo de representação, pois sua interpretação se baseia na visceralidade. Esse passado é reconstruído levando em conta o presente, a tecnologia, mas também os desejos, amores e o Oriente.

Mais viável seria pensarmos essas canções como estratégias de tradução das experiências musicais vivenciadas até então. Gil interpreta essas músicas através de códigos mais relacionados ao urbano, moderno, ou até mesmo pop, do que à busca por enfatizar o tradicional ou uma suposta pureza rural nordestina. Há também nessas canções certa preocupação documentarista. Os sertanejos são personagens reais, nem todos se emancipam como o Jeca, que de tatu vai a total, já que também existem as rêses desgarradas caminhando a esmo. O lamento sertanejo não é construído em tom de crítica, mas é uma espécie de constatação daquele sujeito que ama tanto sua terra que não consegue se ver longe dela.

A narrativa engendrada no LP focava em redescobrir-se, mas também em recriarse. Por meio das canções e da musicalidade de Refazenda, Gil construiu uma trama de si mesmo, cantou a natureza, falou da música como musa e como estratégia para viver melhor, sobre suas meditações, além de elaborar reflexões sobre a identidade nordestina. A sonoridade do LP é mansa, calma, reflexiva, prima pela tranquilidade; não é o agito que pulsa nas canções. Diante dessa volta ao passado, o desejo de revistá-lo foi apimentado com ares de pop.

Nem sempre menções a símbolos que remetam às africanidades se fazem acompanhados de forte apelo à percussão, muitas vezes são sutis essas ligações, como em Refazenda. Há nesse disco a utilização de aspectos musicais que estão ligados às africanidades, o que se dá em menor grau nas letras e mais fortemente nos arranjos das canções. $\mathrm{O}$ violão percussivo e a utilização de ostinatos são elementos musicais muito comuns na música africana e afro-brasileira, e são marcantes no modo de Gil tocar, utilizando de forma sutil elementos timbrísticos de diversas musicalidades africanas, e, principalmente, aquelas mais ligadas ao universo pop e recriadas no contexto da diáspora negra, como funk, rock, jazz, choro e samba. 


\section{-Refavela}

O LP Refavela foi lançado em 1977, produzido por Roberto Santana, com arranjos de base de Gil e Perinho Santana, arranjos de metais de Meirelles e Perinho Santana e arranjos de cordas de Perinho Santana. A capa é de Aldo Luís e a arte final, de Jorge Vianna. Sobre a capa do disco, Gil comentou:

Tinha chegado do Festac, da Nigéria, cheio de roupas africanas, coisas africanas. Tanto é que a estatueta que tem na contracapa de Refavela, uma estatueta de madeira, é que eu pedi que fosse fotografada em close, fosse incluída. ${ }^{405}$

Essa informação concedida por Gil nos permite analisar a capa para além de um simples invólucro de seu conteúdo musical, fazendo parte de um texto maior, formando uma complexa rede de relações de sentidos. A capa e a contracapa quase sempre nos oferecem muitos indícios das intenções sonoras contidas em seu interior, uma vez que sua função é comunicar uma mensagem destinada ao seu receptor:

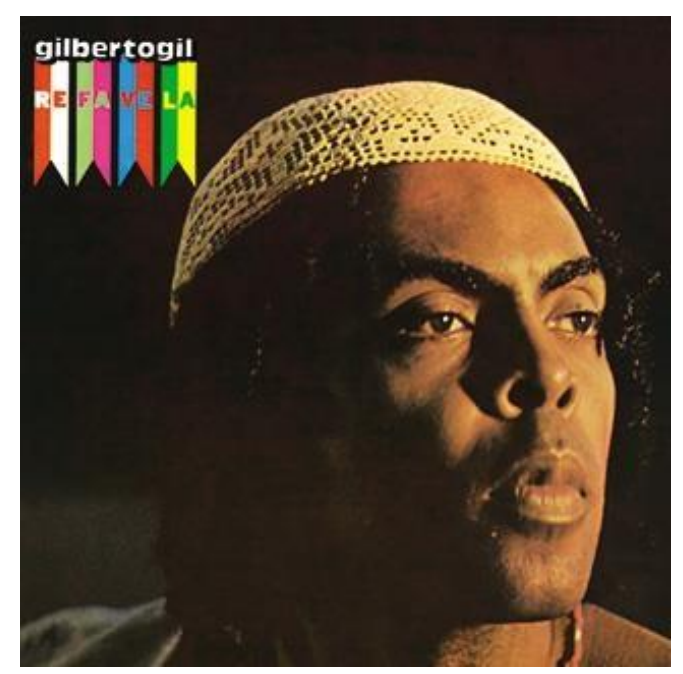

Figura 5 - Capa do LP Refavela

Fonte: 〈www.vinilrecords.com.br>

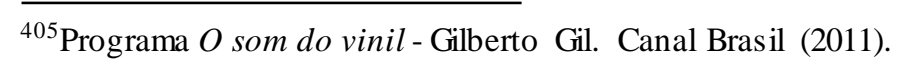




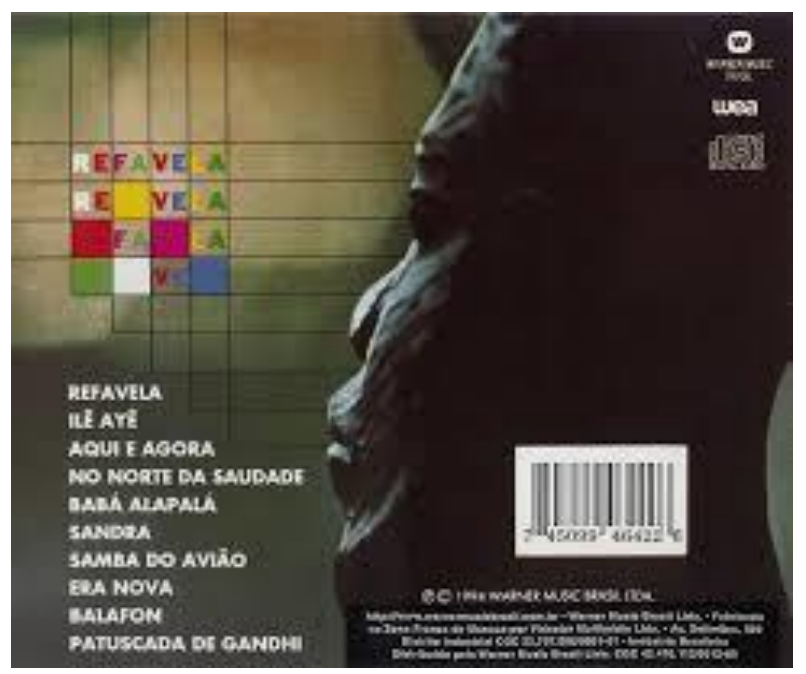

Figura 6 - Contracapa do LP Refavela

Fonte: 〈www.vinilrecords.com.br>

Diferentemente do amálgama emaranhado da capa do primeiro LP da trilogia, Refavela foca apenas em Gil, mostrando apenas o rosto do artista com um semblante bastante sério e um olhar fixo, adornado por uma touca de crochê branca, tranças nos cabelos e um colar de contas. Apenas o rosto de Gil está iluminado, contrastando com o absoluto escuro que marca o fundo. Tanto a touca quanto o colar e as tranças simbolizam africanidades, e também a escultura africana de madeira presente na contracapa do disco.

O título do álbum está inserido em bandeiras coloridas. Somadas às muitas cores em um detalhe da contracapa, podem tanto fazer menção às bandeirolas das festas de São João, ou também representar bandeiras de países africanos, já que a maior parte dessas bandeiras são demarcadas pelas cores vermelha, verde, amarela e azul, além do preto e do branco. Porém, a cor rosa da bandeira, que contém a sillaba FA, pode bem representar a escola de samba Mangueira, bem como o branco e o azul o afoxé Filhos de Gandhy, nos dando a dimensão de que essas cores extrapolam apenas o sentido de exaltar países africanos, podendo representar também as africanidades das culturas populares afrobrasileiras, mas especialmente aquela da diáspora.

Essa obra é de grande relevância nesta investigação, pois significou para o próprio Gil um manifesto negro. Entrevistado por Ana Paula de Oliveira e questionado sobre as poucas referências em relação à questão étnica no tropicalismo, Gil acabou nos dando várias pistas sobre as experiências que contribuíram para a conscientização de sua negritude: 
Eu nunca tinha ido ao candomblé. Só fui depois do exílio. Aí é que me aproximei dos blocos, do significado profundo do carnaval da Bahia (...) Vivi ali, na média das coisas, sem perceber os polos. Só fui sentir o racismo quando comecei a ir ao Colégio Marista, de pequenos burgueses, na maioria brancos. (...) Por isso, e u não tinha noção dessa profunda divisão racial e muito me nos da cultural. Os blocos eram afros, mas incluíam todo mundo! Era a própria cidade de Salvador, como nós, mulatos. Durante o exílio, vi que na Inglate rra a questão racial tinha mais peso. Então conheci a consciência negra como um trabalho apoiado no mundo inteiro pelos ativistas americanos, e a informação exaustiva sobre os movimentos de libertação na África. Isso culminou em mim quando saí nos Filhos de Gandhy. Depois fui ao Festival de Artes Negras na África. E aí vem Refavela, que é o primeiro manifes to negro, não é? [grifos meus] ${ }^{406}$

Esse depoimento nos dá a dimensão da ligação de Gil com tais questões, num momento em que sua carreira já havia se consolidado. Foi no exílio que Gil começou a elaborar essa conscientização, a qual teve sua realização/confirmação quando se junt ou ao afoxé Filhos de Gandhy, em 1973. Os símbolos elencados por Gil para se referir a essa conscientização que se referem às africanidades são: candomblé, carnaval, racismo, blocos afro, a experiência inglesa - e nesse caso a força do pós-colonialismo -, o ativis mo norte americano, os movimentos internacionais de libertação da África, além da própria África. Ao criar um disco manifesto, o artista propõe declarar, e nesse caso também denunciar, algo que até então não se fazia tão notório, ou mesmo enfatizado, em sua experiência artística.

De acordo com Stuart Hall, para compreendermos qual é esse "negro" na cultura negra, é preciso atentarmos para quatro grandes eixos: o deslocamento dos modelos europeus de alta cultura; o surgimento dos EUA como potência mundial, transformandose num centro de produção e de circulação global de cultura; a descolonização do Terceiro Mundo; e a emergência dessas sensibilidades descolonizadas. Hall comenta ainda que:

Dentro da cultura, a marginalidade, embora permaneça periférica em relação ao mainstream, nunca foi espaço tão produtivo quanto é agora, e isso não é simplesmente uma abertura, dentro dos espaços dominantes, à ocupação dos de fora. É também o resultado de políticas culturais da diferença, da produção de

\footnotetext{
406 Apud OLIVEIRA, Ana Paula (entrevistadora). Tropicália revisitada. Para o site: www.tropicalismo.com.br. In: COHN, Sergio (org.). GILBERTO GIL - Encontros. Rio de Janeiro: Beco do Azougue, 2007, p. 253.
} 
novas identidades e do aparecimento de novos sujeitos no cenário político e cultural. ${ }^{407}$

Vale aqui ressaltar que Gilberto Gil pertence mais ao universo do mainstream do que propriamente à marginalidade acima descrita por Hall. Gil configura uma equipe de "monstros sagrados" diálogo com diferentes estéticas musicais, numa confluência com inúmeras tradições culturais, ${ }^{409}$ da poesia concreta do período tropicalista ao afrobeat ${ }^{410}$ produzido na Nigéria.

Segundo Hall, os repertórios culturais negros:

São sempre o produto de sincronizações parciais, de engajamentos que atravessam fronteiras culturais, de confluência de mais de uma tradição cultural, de negociações entre posições dominantes e subalternas, de estratégias subterrâneas de recodificação e transcodificação, de significação crítica e do ato de ressignificar a partir de materiais pré-existentes. ${ }^{411}$

Temos que nos atentar para os processos de transformação presentes nessa cultura negra em questão, lembrando que Gil vivenciou diversas experiências com diferentes culturas negras, que vão desde sua ligação com o afoxé Filhos de Gandhy, com o reggae, mas também pelo apreço de Gil pela música negra americana, a vestimenta e o cabelo afro, num complexo jogo de significações. Não se trata, no caso de Gil, de lidar ou mesmo de ressignificar formas de tradição intactas, mas de tecer sua sonoridade em diálogo com questões sempre novas, como, por exemplo, a juju music ou o reggae, que são já criações contemporâneas que mesclam música local negra com música ocidental.

Entrevistado em 1977, ano de lançamento de Refavela, por Ana Maria Baiana em sua casa, com um pôster de Bob Marley na parede da sala, Gil revelou sobre o conceito do disco que:

O disco ficou muito assim sobre o conceitual de Refavela, mesmo, essa coisa de arte dos trópicos, comunidades negras

\footnotetext{
407 HALL, Stuart. Da diáspora..., op. cit, p. 320.

${ }^{408}$ Descrição comumente utilizada por grande parte da mídia ao tratar de cantores como Chico Buarque, Milton Nascimento, Caetano Veloso, Maria Bethânia, dentre outros.

${ }^{409}$ Muitas delas ligadas ao universo afro.

${ }^{410} \mathrm{O}$ afrobeat foi um movimento musical da Nigéria onde a música ocidental foi re-inventada dentro das referências musicais nigerianas. Um dos principais representantes desse gênero musical é Fela Kuti.

${ }^{411}$ HALL, Stuart. Da diáspora..., op. cit., p. 325.
} 
contribuintes para a formaçãode novas etnias e novas culturas no Novo Mundo, Brasil, Caribe, Nigéria, Estados Unidos... todas essas coisas, essas culturas emergentes como presença forte do dado negro. $O$ disco acabou ficando uma coisa que eu diria 60 a $70 \%$ orientada nesse sentido, no sentido de manifestar essa visão desse universo. ${ }^{412}$

O texto transcrito acima oferece um ótimo indício para entendermos quais africanidades estavam naquele momento povoando a imaginação de Gil ao compor Refavela. Se a viagem à Nigéria ocorrera em janeiro, e em maio Gil lançou o LP, a memória da experiência vivida na África era ainda fresca e forte. Gil nesse momento apontava seu olhar aguçado para a descoberta do dado negro, para as africanidades da diáspora construídas no Novo Mundo. Nessa mesma entrevista, Gil reivindicou:

Mas o que eu gostaria de evitar, gostaria de esclarecer como não necessariamente intencional no meu trabalho, nessa escolha de repertório e tudo, é uma coisa política no sentido de uma política de negros contra brancos ou qualquer coisa. Nãoé racista, é uma coisa que eu estava escrevendo: pra mim, comunidades negras, $\mathbf{0}$ Continente Africano especificamente, pra mim, é uma reserva, mas não uma reserva no sentido de uma coisa que vai ter o seu momento particular para si. A cor negra é como combustível luminoso, vibrátil, que fornece uma espécie de energia para toda a humanidade, da qual a humanidade está cada vez mais care nte, essa energia telúrica, tá entendendo? Ela dá no sentido principalmente da miscigenação que vai se fazendo cada vez mais no mundo. ${ }^{413}$ [grifos meus]

No momento em que Gil se posicionava em relação ao dado negro na configuração da sociedade - e nesse caso podemos afirmar que suas elucubrações e criações artísticas não enfocavam ou mesmo privilegiavam especificamente apenas o caso brasileiro -, a África foi acessada e significada por Gil como um lugar capaz de contribuir positivamente para a humanidade, uma identidade africana enquanto frutos espalhados pelo mundo através da diáspora.

O título do disco dá nome à primeira música ${ }^{414}$, que é também uma espécie de manifesto:

\section{A refavela}

Revela aquela

\footnotetext{
412 BAIANA, Ana Maria. A paz doméstica de Gilberto Gil. O Globo, 10 jul. 1977, Apud RISÉRIO, Antônio. Gilberto Gil: Expresso 2222, op. cit., p. 155.

413 Ibid., p. 158.

${ }^{414}$ A maior parte das letras se encontra nas notas de rodapé; no corpo do texto estão inseridas aquelas que tratam diretamente do tema desta pesquisa.
} 
Que desce o morro e vem transar

$\mathrm{O}$ ambiente

Efervescente

De uma cidade a cintilar

A refavela

Revela o salto

Que o preto pobre tenta dar

Quando se arranca

Do seu barraco

Prum bloco do BNH

A refavela, a refavela, ó

Como é tão bela, como é tão bela, ó

A refavela

Revela a escola

De samba paradoxal

Brasileirinho

Pelo sotaque

Mas de língua internacional

A refavela

Revela o passo

Com que caminha a geração

Do black jovem

Do black-Rio

Da nova dança no salão

Iaiá, kiriê, kiriê, iáiá

A refavela

Revela o choque

Entre a favela-inferno e o céu

Baby-blue-rock

Sobre a cabeça

De um povo-chocolate-e-mel 
A refavela

Revela o sonho

De minha alma, meu coração

De minha gente

Minha semente

Preta Maria,Zé, João

A refavela, a refavela, ó

Como é tão bela, como é tão bela, ó

A refavela

Alegoria

Elegia, alegria e dor

Rico brinquedo

De samba-enredo

Sobre medo, segredo e amor

A refavela

Batuque puro

De samba duro de marfim

Marfim da costa

De uma Nigéria

Miséria, roupa de cetim

Iaiá, kiriê, kiriê, iáiá ${ }^{415}$

É uma música que mescla as africanidades tanto em sua sonoridade quanto em sua letra. O desenho da melodia faz menção ao berimbau. O coro, bem como a abertura das vozes que cantam Iaiá kiriê, assemelha-se aos coros do reggae ou ao gospel, e o atabaque, tocado com vara ao invés das mãos, é uma referência ao quebra-prato, ritmo do candomblé. A harmonia composta de maneira simples intenciona valorizar a sobreposição de variados elementos rítmicos e melódicos. Na letra, Gil pronuncia a negritude em primeira pessoa do singular, ligada à sua alma e coração, indicando que a via pela qual irá abordar essa temática passa muito mais pelo sentimento do que pela razão. A canção

415“Refavela" (Gilberto Gil, 1977) In: RENNÓ, Carlos (org.) Gilberto Gil todas as letras. São Paulo: Companhia das Letras, 1996, p. 194. 
denuncia a má qualidade de vida dos habitantes das periferias, através do preto que quer melhorar de vida. O samba aqui representado mescla o choro de Waldir Azevedo para logo em seguida celebrar a internacionalização da música popular; a juventude Black Rio $^{416}$ conota inovação e modernidade. O batuque puro fica a cargo da Costa do Marfim e da Nigéria, menções claras à África.

Na sequência vem "Ilê Aiyê" ${ }^{417}$, uma composição de Paulinho Camafeu que pode ser aqui interpretada não somente como uma espécie de homenagem ao bloco afro, mas também enquanto denúncia do racismo:

Que bloco é esse?

Eu quero saber,

É o mundo negro

Que viemos mostrar pra você

Pra você

Somos criolo doido

Somos bem legal

Temos cabelo duro

Somos black power

\section{Branco, se você soubesse \\ $O$ valor que o pre to tem,}

\section{Tu tomava um banho de piche, branco}

\section{E ficava preto também}

Não te ensino minha malandragem

Nem tão pouco minha filosofia

$$
\text { Por quê? }
$$

Quem dá luz ao cego

É bengala branca

\footnotetext{
${ }^{416}$ Movimento musical de jovens negros iniciado na periferia do Rio de Janeiro no final dos anos 1970.

${ }^{417}$ Primeiro bloco afro da Bahia inicia suahistória em $1^{\circ}$ de novembro de 1974, no Curuzu-Liberdade, bairro de maior população negra do país: 600 mil habitantes. O objetivo da entidade é preservar, valorizar e expandir a cultura afro-brasileira. Para isso, desde que foi fundado, vem homenageando os países, nações e culturas africanas e as revoltas negras brasileiras que contribuíram fortemente para o processo de fortalecimento da identidade étnica e da autoestima do negro brasileiro, tornando populares os temas da história africana e vinculando-os com a história do negro no Brasil, construindo um passado comum, uma espécie de linha histórica da negritude. Disponível em: <www.ileaiye.org.br> Acesso em 25 set.2015.
} 


\section{E Santa Luzia}

\section{$\mathrm{Ai}$, ai meu \\ Deus! $!^{418}$}

Buscando inverter a invisibilidade à qual foram sujeitados os negros por tanto tempo no país, a letra não apenas exalta a figura do negro e seu valor positivo, mas realiza uma crítica dirigida aos brancos por não conhecerem o mundo negro. A canção exalta também o próprio Ilê Aiyê ${ }^{419}$, associando aos negros aspectos como esperteza e malandragem. Os vários gritos soltos ao longo da música, bem como a forma improvisada de dar esses gritos, são muito distantes do formalismo presente na música ocidental. A sonoridade refere-se à musica de uma África moderna, bem parecida com aquela produzida pelo Fela Kuti. ${ }^{420}$ Quem nos informa sobre a importância desse hino e discurso fundador do bloco de 1975 no cenário carnavalesco baiano é Rafael Rosa Ribeiro, que afirma que essa canção demarcou a modificação desse cenário através de seu discurso afirmativo e etnicizado, passado a ser seguido esse padrão a partir de então. Se antes dessa canção as agremiações negras levavam seus carros alegóricos e cantos em iorubá para o contexto do carnaval, essa música do Ilê Ayiê representou o início de discursos musicados comunicando e divulgando ideias de contestação social e afirmação política. ${ }^{421}$

A força expressiva relacionada à negritude na sonoridade das duas primeiras músicas do disco faz contraponto à terceira faixa, "Aqui e agora", ${ }^{422}$ em que Gil traça

\footnotetext{
418“Ilê Aiyê" (Paulinho Camafeu).

${ }^{419}$ O bloco surge em 1974 na cidade de Salvador/BA e seu primeiro LP Canto Negro é lançado em 1984, A música que abre o LP, ${ }^{419}$ intitulada Que bloco é esse?, é interpretada por Gilberto Gil, que também foi o produtor do disco. Disponível em: <www.ileaiye.org.br〉 Acesso em 25 set. 2015.

${ }^{420}$ Gil comenta ter conhecido Fela na época em que foi a Festac, que ele era contrário à política naquele momento e não participou do festival. Gil disse ainda sobre Fela: "fazia apresentações paralelas ao festival, num teatro, num pagode que ele tem lá, e que era o maior sucesso do festival - era cheio todo dia, todo mundo ia ver. Ele é uma espécie de big chief lá, uma espécie de Obá lá em Lagos.” In: RISÉRIO, Antônio. Gilberto Gil: Expresso 2222, op. cit., p. 180.

${ }^{421}$ RIBEIRO, Rafael Sampaio Rosa. Na trajetória do trio: a canção do carnaval baiano entre uma mirada mágica e os espaços da alegria (1968-2010). 2011. Dissertação (Mestrado em História)-Universidade de Brasília, Brasília, 2011, p. 92.

422 "Aqui e agora" (Gilberto Gil, 1977) O melhor lugar do mundo é aqui/E agora/O melhor lugar do mundo é aqui/E agora/Aqui, onde indefinido/Agora, que é quase quando/Quando ser leve ou pesado/Deixa de fazer sentido/Aqui, onde o olho mira/Agora, que o ouvido escuta/O tempo, que a voz não fala/Mas que o coração tributa/O melhor lugar do mundo é aqui/E agora/O melhor lugar do mundo é aqui/E agora/Aqui, onde a cor é clara/Agora, que é tudo escuro/Viver em Guadalajara/Dentro de um fig o maduro/Aqui, longe, em Nova Deli/Agora, sete, oito ou nove/Sentir é questão de pele/Amor é tudo que move/O melhor lugar do mundo é aqui/E agora/O melhor lugar do mundo é aqui/E agora/Aqui perto passa um rio/Agora eu vi um lagarto/Morrer deve ser tão frio/Quanto na hora do parto/Aqui, fora de perigo/Agora, dentro de instantes/Depois de tudo que eu digo/Muito embora muito antes/O melhor lugar do mundo é aqui/E agora/O melhor lugar do mundo é aqui/E agora. Baião atemporal. (Gilberto Gil, 1993). In: RENNÓ, Carlos (org.) Gilberto Gil todas as letras. São Paulo: Companhia das Letras, 1996, p. 196.
} 
novamente suas reflexões ligadas à filosofia oriental, através do jogo de associação. As cordas e a leveza da música evocam a ideia da bossa nova, na utilização de um número maior de acordes e uma levada da bateria com vassourinhas.

Sobre o modo como "No norte da saudade" ${ }^{423}$ surgiu, Gil disse:

Nós estávamos andando pelo Norte, com um trabalho que era a Refazenda, com a presença de Dominguinhos etc., eu, Moacir Albuquerque, Perinho Santana e etc., ao mesmo tempo que escutávamos muito Django, o guitarrista (Django Reinhart), escutávamos Herbie Hancock, Bob Marley, e a gente vivia ao mesmo tempo todo aquele clima musical do norte, do Nordeste, de ser refazenda, de ser de lá, no habitat básico da refazenda, de ser Campina Grande, Mossoró, Natal, João Pessoa, ser tudo aquilo e ao mesmo tempo estar discutindo sobre reggae, sobre a emergência de movimentos musicais na América, o punk, e a salsa e o reggae. ${ }^{424}$

Essa composição foi composta junto como conjunto musical que participou do disco, cruzando memórias de diferentes músicos, numa emissão sincronizada e compartilhada com outras vozes, não só dos integrantes da banda, mas envolve ndo também o jazz, o reggae, além do som do Norte; englobando parceria, localidade e temporalidade. Nesse caso, a memória é também performance, ao ressignificar sons de outras paragens. A sonoridade traz elementos de reggae, mas se constrói num manancial pop.

Quanto a "Babá Alapalá":

\author{
Aganju, Xangô \\ Alapalá, Alapalá, Alapalá \\ Xangô, Aganju \\ O filho perguntou pro pai: \\ "Onde é que tá o meu avô $\mathrm{O}$ \\ meu avô, onde é que tá?" \\ O pai perguntou pro avô: \\ "Onde é que tá meu bisavô
}

\footnotetext{
423 "No norte da saudade" (Gilberto Gil, Moacyr Albuquerque e Perinho Santana) Logo cedo, pé na estrada/Pra não ter porém/Pra não ter noite passada/Pra não ter ninguém /Atrás /Mais ninguém/Vou pra quem/Vai me ver noutra cidade/No norte da saudade, que eu vou ver/meu bem /Meu bem, meu bem/Vai me ver noutra cidade/No norte da saudade, que eu vou ver/meu bem /Meu bem, meu bem. Baião atemporal. (Gilberto Gil, 1993) In: RENNÓ, Carlos (org.) Gilberto Gil todas as letras. São Paulo: Companhia das Letras, 1996, p. 198.

${ }^{424}$ BAIANA, Ana Maria. A paz doméstica de Gilberto Gil. O Globo, 10 jul. 1977, apud RISÉRIO, Antônio. Gilberto Gil: Expresso 2222, op. cit., p. 157.
} 
Meu bisavô, onde é que tá?"

Avô perguntou pro bisavô:

"Onde é que tá tataravô

Tataravô, onde é que tá?"

Tataravô, bisavô, avô

Pai Xangô, Aganju

Viva egum, babá Alapalá!

Aganju, Xangô

Alapalá, Alapalá, Alapalá

Xangô, Aganju

Alapalá, egum, espírito elevado ao céu

Machado alado, asas do anjo Aganju

Alapalá, egum, espírito elevado ao céu

Machado astral, ancestral do metal

Do ferro natural

Do corpo preservado

Embalsamado em bálsamo sagrado

Corpo eterno e nobre de um rei nagô

Xangô ${ }^{425}$

Vale uma reflexão levando em consideração a análise realizada pelo etnomusicólogo José Murilo Jorge de Carvalho sobre essa canção. Refletindo sobre a influência da tradição religiosa iorubá na música popular comercial brasileira e os estereótipos estéticos sobre uma africanidade musical no Brasil, Carvalho sugere que essa influência é de baixíssima assimilação no país. ${ }^{426}$ Para o autor, Caetano e Gil são os dois maiores astros da música popular a simbolizarem a ideologia da presentificação da cultura iorubá na música popular brasileira. Assim Carvalho analisa a música "Babá Alapalá":

A letra utiliza os sons da língua iorubá. Quando escutei essa música pela primeira vez, no final do filme Tenda dos Milagres, de Nelson Pereira dos Santos, pareceu-me fortemente "africana", como se fosse um ícone da própria presença iorubá no Brasil. Contudo, uma audição mais analítica permite constatar que sua textura rítmica é inteiramente binária, não muito distante da música pop dançante, próxima do rock nacional. Os poucos elementos de acentuação estão a cargo do contrabaixo e da

\footnotetext{
425“Babá Alapalá" (Gilberto Gil, 1976) In: RENNÓ, Carlos (org.) Gilberto Gil todas as letras. São Paulo: Companhia das Letras, 1996, p. 185.

${ }^{426}$ CARVALHO, José Jorge. A tradição musical Iorubá no Brasil: um cristal que se oculta e se revela. In: TUGNY, Rosângela, QUEIROZ, Ruben Caixeta (orgs.). Músicas africanas e indígenas no Brasil. Belo Horizonte: Editora UFMG, 2006, p. 283.
} 
guitarra, porém todos os instrumentos obedecem ao compasso binário sem sequer quebrarem os acentos em contratempos. A percussão não joga papel nenhum no arranjo da canção. A impressão de influência iorubá se restringe, de fato, às palavras Xangô Aganju e Babá Alapalá. ${ }^{427}$

Os elementos que simbolizam as africanidades, não apenas nessa música, mas em todo o disco - e na verdade podemos abranger para toda e qualquer obra produzida por Gil -, não se fazem presentes somente na sonoridade produzida pelo artista. De quais africanismos exotizantes estamos falando? Preponderância das percussões, línguas africanas, instrumental das tradições musicais afro-brasileiras? Tanto o funk utilizado enquanto parâmetro nessa composição, ou mesmo o rock citado por Carvalho fazem parte do mundo afro, e, nesse caso, afro americano. No entanto, são musicalidades bem mais enquadradas numa sonoridade moderna, pop e da diáspora do que necessariamente de matriz pura, ligada à África pré-colonial ou das tradições mantidas nas Américas póscoloniais.

As africanidades também se fazem notar por aspectos imagéticos e performáticos, como, por exemplo, as capas dos discos, os figurinos, ou mesmo nos discursos de Gil ou sobre Gil proferidos pela mídia. Acredito que os sentidos atrelados às africanidades na obra do artista estão especialmente ligados à modernidade. A menção ao rock, jazz, juju music, funk ou bossa nova, se reatualiza através de uma perspectiva da memória enquanto prática, na qual o passado invocado, especialmente através da atividade musical, adquire significação em função das condições de vida do presente.

"Sandra" 428 é uma canção de estrutura romântica, cuja letra tematiza a liberdade amorosa numa cadência leve do swing de funk americano. Nessa canção se misturam elementos do jazz, como no solo de saxofone, muito próximo ao que Wayne Shoter

\footnotetext{
${ }^{427}$ CARVALHO, José Jorge. A tradição musical Iorubá..., op. cit., p. 284.

428“Sandra" (Gilberto Gil, 1976) Maria Aparecida, porque apareceu na vida/Maria Sebastiana, porque Deus fez tão bonita/Maria de Lourdes /Porque me pediu uma canção pra ela/Carmensita, porque ela s ussurrou: "Seja bem-vindo"/Na primeira noite quando nós chegamos no hospício/E Lair/Porque quis me ver e foi lá no hospício/Salete fez chafé, que é um chá de café que eu gosto/E naquela semana tomar chafé foi um vício/Andréia na estreia/No segundo dia, meus laços de fita/Cintia, porque, embora choque, rosa é cor bonita/E Ana, porque parece uma cigana da ilha/Dulcina, porque/É santa, é uma santa e me beijou na boca/Azul, porque azul é cor, e cor é feminina/Eu sou tão inseguro porque o muro é muito alto/E pra dar o salto/Me amarro na torre no alto da montanha/Amarradão na torre dá pra ir pro mundo inteiro/E onde quer que eu vá no mundo, vejo a minha torre/É só balançar/Que a corda me leva de volta pra ela. In: RENNÓ, Carlos (org.) Gilberto Gil todas as letras. São Paulo: Companhia das Letras, 1996, p. 186.
} 
fazia na época ${ }^{429}$. O triângulo utilizado na primeira estrofe remete ao xote, e o solo de guitarra, ao fusion (jazz rock).

A inserção da música "Samba do avião", ${ }^{430} \mathrm{em}$ homenagem a Tom Jobim, sintetiza bem a musicalidade do LP, um jeito híbrido de interpretar o samba. "Samba do avião" não é arranjado através do samba, mas faz referência ao samba através da black music, do baixo e nos improvisos vocais do jazz, além da influência do samba rock de Jorge Ben na forma ritmada de tocar o violão. Nesse caminho, que é também um manifesto, essa canção está associada ao passado através de Tom Jobim, mas apimentada numa releitura a la Benjor.

Em "Era nova", ${ }^{431}$ a oposição passado-presente perpassa toda a ideia do texto, e a sonoridade faz menção ao pop inglês, numa psicodelia sonora através dos efeitos de guitarra.

"Balafon" ${ }^{432}$, além de título da canção, é um instrumento africano que aparece incidentalmente no arranjo. A interpretação é toda embasada na juju music. A utilização de instrumentos ocidentais ocorre de uma forma africana. Temos o caso do ostinato da guitarra, bem como seu timbre próximo ao dos guitarristas africanos. Em um segundo momento, ela se transforma em um rock mais pesado, com solos de guitarra e bateria forte.

\footnotetext{
${ }^{429}$ Como, por exemplo, no disco Native dancer (EMI cedido pela CBS, 1975) que Wayne Shorter gravou em parceria com Milton Nascimento.

430 "Samba do avião" (Tom Jobim) Eparrê/Aroeira beira de mar/Canôa Salve Deus e Tiago e Humaitá/Eta, costão de pedra dos home brabo do mar/Eh, Xangô, vê se me ajuda a chegar/Minha alma canta/Vejo o Rio de Janeiro/Estou morrendo de saudades/Rio, seu mar/Praia sem fim/Rio, você foi feito prá mim/Cris to Redentor/Braços abertos sobre a Guanabara/Este samba é só porque/Rio, eu gosto de você/A morena vai sambar/Seu corpo todo balançar/Rio de sol, de céu, de mar/Dentro de mais um minuto estaremos no Galeão/Copacabana, Copacabana/Cristo Redentor/Braços abertos sobre a Guanabara/Este samba é só porque/Rio, eu gosto de você/A morena vai sambar/Seu corpo todo balançar/Aperte o cinto, vamos chegar/Água brilhando, olha a pista chegando/E vamos nós/Pousar...

431 "Era nova" (Gilberto Gil, 1976) Falam tanto numa nova era/Quase esquecem do eterno é/Só você poder me ouvir agora/Já significa que dá pé/Novo tempo sempre se inaugura/A cada instante que você viver/O que foi já era, e não há era/Por mais nova que possa trazer de volta/O tempo que você perdeu, perdeu, não volta/Embora o mundo, o mundo, dê tanta volta/Embora olhar o mundo cause tanto medo/Ou talvez tanta revolta/A verdade sempre está na hora/Embora você pense que não é/Como seu cabelo cresce agora/Sem que você possa perceber/Os cabelos da eternidade/São mais longos que os tempos de agora/São mais longos que os tempos de outrora/São mais longos que os tempos da era nova/Da nova, nova, nova, nova, nova era/Da era, era, era, era, era nova /Da nova, nova, nova, nova, nova era/Da era, era, era, era, era nova /Que sempre esteve e está pra nascer/Falam tanto. In: RENNÓ, Carlos (org.) Gilberto Gil todas as letras. São Paulo: Companhia das Letras, 1996, p. 190.

432 "Balafon" (Gilberto Gil, 1977) Isso que toca bem, bem/Isso que toca bem, bem/Chama-se balafon/Em cada lugar tem /O nome deve ser outro qualquer /No Camerum/Isso que a gente chama marimba/Tem na África todo mesmo som/Isso que toca bem, bem/Num lugar, não lembro bem/Chama-se balafon/Marimbajé/Iré-xiré/Balafonjá/Orim-axé. In: RENNÓ, Carlos (org.) Gilberto Gil todas as letras. São Paulo: Companhia das Letras, 1996, p. 197.
} 
Em "Patuscada de Gandhy", ${ }^{433}$ Gil homenageia o afoxé em um arranjo somente percussivo, reinventando o ijexá ${ }^{434}$ ao modificar a função de seu instrumental, trocou a função de clave do gam ${ }^{435}$ para o tamborim, que geralmente é o responsável por fazer a clave do samba. O apito que aparece na tradição dos afoxés ou dos maracatus para ordenar inícios, fins e convenções, nessa canção aparece apenas como ornamento. A música acaba em fade out ${ }^{436}$ e é circular, como o são em geral as músicas de matriz africana da cultura popular.

A percussão está bem mais presente do que no LP Refazenda. Os gritos soltos em várias das canções do disco fazem menção tanto à tribo quanto ao transe. É um disco que enfatiza a presença do homem negro nas grandes cidades, nas favelas. A inspiração nos ancestrais africanos fica a cargo de Xangô. Há temática negra não apenas na linguagem, mas na construção melódica e de certa forma nos ostinatos das cadeias harmônicas.

Se em Refazenda Gil tematizou tanto o passado quanto o interior, em Refavela foi a vez de problematizar as periferias das grandes cidades, demarcadas pela forte desigualdade, a favela enquanto fronteira a ser atravessada. O signo re-favela traduz a favela apartada pela diferença social, mas é também uma espécie de reinvindicação por aqueles negros que foram marginalizados ao longo da história, buscado dar visibilidade a uma população silenciada quando se trata de poder, além de denunciar também a racialização. Na Refavela de Gil, há espaço para a ancestralidade, África, Tom Jobim, Filhos de Gandhy, funk, jazz, Movimento Black Rio, sabedoria oriental, numa performance de reviver e confeccionar a memória do Brasil na busca pela conquistada dignidade do negro brasileiro.

Rememorando a elaboração do disco Refavela,${ }^{437}$ Gil afirmou:

Nós temos os seguidores de James Brown no Brasil, os admiradores do funk americano, uma necessidade, isso é um movimento cultural mundial, é o movimento da diáspora

\footnotetext{
433 "Patuscada de Gandhy" (Afoxé Filhos de Gandhy) Onde vai, papai ojô/Vou depressa por aí/Vou fazer minha folia/Com os filhos de Gandhi/A nossa turma/É alinhada/Sai do meu bloco/Pra fazer a patuscada/É mori, moriô, babá/Babá, ô, kiloxê, jocô.

${ }^{434}$ Nome de um dos ritmos das cerimônias rituais do candomblé.

${ }^{435}$ Dentro das funções rítmicas, chamamos de clave uma frase rítmica que se repete em ostinato, dando uma base de sustentação aos outros instrumentos. No candomblé, o instrumento que funciona como clave é o gan, peça de metal que produz um som agudo.

${ }^{436}$ Expressão inglesa utilizada para falar de uma lenta diminuição de volume do áudio até o silêncio.

${ }^{437}$ GIL, Gilberto. Refavela, op. cit.
} 
negra, é uma articulação. Isso tem que ser respeitado, tem que ser visto, tem que ser adotado como uma manifestação legítima importante. ${ }^{438}$ [ grifos meus $]$

Unida à análise realizada anteriormente, a recordação sobre esse documento chamado Refavela, demonstra que a intenção de Gil não era jogar luz apenas nos problemas do Brasil, até mesmo porque a imagem da favela e dos conjuntos habitacio nais do Banco Nacional de Habitação (BNH) foi acessada por Gil ainda na Nigéria, na viagem de 1977, mas sim, abraçar o mundo, ser pop, internacional, transitando pelo mundo da diáspora negra.

\title{
-Realce
}

Realce é o último disco da trilogia e foi lançado em 1979. Foi produzido por Marco Mazzola, com design de capa de Noguchi. Sobre a elaboração do disco quem nos informa é seu produtor, Marco Mazzola:

\begin{abstract}
Propus que fizéssemos um disco com uma banda que misturasse músicos brasileiros e americanos. Eu sentia que a música de Gil precisava de uma injeção de elementos mais pop, que os americanos poderiam proporcionar. Gil topou. (...) Expliquei que gostaria de fazer essa música de uma forma diferente, queria chamar alguns mús icos ame ricanos para tocar na base, queria uma pegada mais internacional. (...) Com a aprovação dele, tinha um desafio grande pela frente - mostrar que eu sabia o que estava fazendo. Chamei os músicos que comporiam a base rítmica e harmônica: o baterista Rick Schlisser, do grupo Al Jarreau; o baixista Kloud de Cindy Lauper; os tecladistas Michael Boddicker e Mark Lordan, de Michael Jackson; e o guitarrista Steve Lukather, de Madonna; todos músicos vedetes do cenário americano naquele momento. ${ }^{439}$ [grifos meus]
\end{abstract}

O desejo de Mazzola foi dar uma roupagem pop e internacional ao disco, convidando um casting de músicos que faziam parte do mainstream da música pop americana. A intenção era associar a música brasileira de Gil a novas possibilidades tecnológicas de composição, em direção a um mercado mais amplo.

Interrogando essa obra como documento, é interessante destacar que ela representa um registro do artista naquele momento histórico. Nosso foco é abordar

\footnotetext{
${ }^{438}$ Programa O SOM do Vinil, op. cit.

${ }^{439}$ MAZZOLA, Marco. Ouvindo estrelas [autobiografia]. São Paulo: Editora Planeta do Brasil, 2007, p. 109.
} 
como o disco foi concebido, sem perder de perspectiva que as músicas podem e são reinventadas constantemente, em cada versão são reatualizadas e ganham nova roupagem. A cada vez que uma canção é regravada, ela ganhará uma nova ambiência sonora.

O título na capa ${ }^{440}$ e na contracapa é acompanhado por um brilhoso arco-íris:

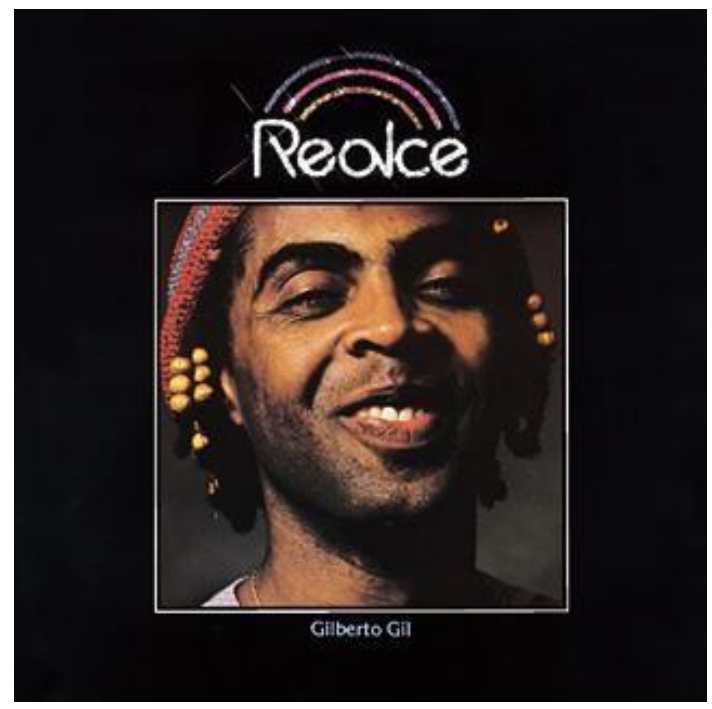

Figura 7 - Capa do disco Realce

Fonte: 〈www.vinilrecords.com.br>

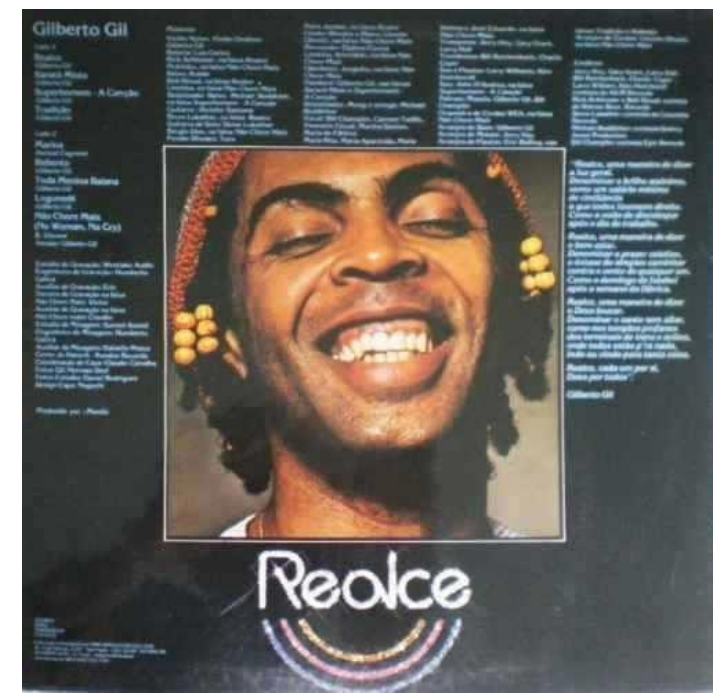

Figura 8-Contracapa do disco Realce

Fonte: <www.vinilrecords.com.br>

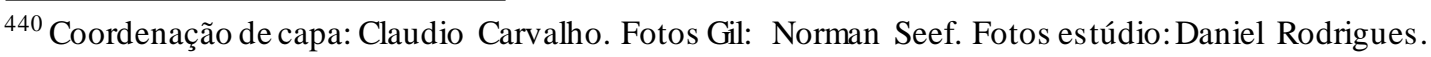
Design capa: Noguchi.
} 
Assim como na capa de Refavela, o foco é no rosto de Gil, mas em Realce a seriedade é trocada pelo largo sorriso, o tom é de alegria. As africanidades se fazem notar pela touca colorida e pelas tranças finalizadas por contas. Não há muitos símbolos nesse invólucro, o produto ofertado é um Gil risonho e feliz.

Em uma entrevista realizada em 1977, portanto dois anos antes do lançamento de Realce, Gil conjecturou sobre a sonoridade que buscava:

A minha forma de ver, ao contexto em que minha música atua, que é um contexto funk, dançante, discoteque, sei lá, que é um contexto que eu estou tentando abordar aos poucos, uma coisa para a qual a minha música se encaminha cada vez mais. Quer dizer o consumo de agora. Qual a qualidade mais moderna do consumo de música? É essa coisa funk, dançante, é o que qualifica mais a música, agora. É para onde se encaminharam todos os grandes criadores de jazz, desde Miles Davis, essa coisa negra bem tribalizante, de cantar e dançar. ${ }^{441}$ [grifos meus]

É interessante salientar que o aspecto dançante da música que Gil intenciona produzir aqui é definido pelo artista enquanto caráter tribal: coisa negra é cantar $e$ dançar.

Explorando o pop, sem utilizar nenhum gênero musical específico, o brilho ficou muito a cargo das intervenções dos metais, além dos sintetizadores, que demarcaram a sonoridade produzida em fins dos anos 70 e toda a década de 80 . Se a intencionalidade musical é pop, a escolha em inserir no repertório canções do Ilê Aiyê e dos Filhos de Gandhy aponta também para a valorização da tradição.

"Realce" ${ }^{442}$ é a primeira música do álbum e também nome do disco que contém esse texto na contracapa:

Realce, uma maneira de dizer a luz geral. Denominar o brilho anônimo, como um salário mínimo de cintilância a que todos

\footnotetext{
${ }^{441}$ Apud BAIANA, Ana Maria. A paz doméstica de Gilberto Gil. O Globo, 10 jul. 1977. In: RISÉRIO, Antônio. Gilberto Gil: Expresso 2222, op. cit., p. 157.

442 "Realce" (Gilberto Gil, 1979) Não se incomode/O que a gente pode, pode/O que a gente não pode, explodirá/A força é bruta/E a fonte da força é neutra/E de repente a gente poderá/Realce, realce/Quanto mais purpurina, melhor/Realce, realce/Com a cor do veludo/Com amor, com tudo/De real teor de beleza/Não se impaciente/O que a gente sente, sente/Ainda que não se tente, afetará/O afeto é fogo/E o modo do fogo é quente/Ede repente a gente queimará/Realce, realce/Quanto mais parafina, melhor/Realce, realce/Com a cor do veludo/Com amor, com tudo/De real teor de beleza/Não desespere/Quando a vida fere, fere/E nenhum mágico interferirá/Se a vida fere/Como a sensação do brilho/De repente a gente brilhará/Realce, realce/Quanto mais serpentina, melhor/Realce, realce/Com a cor do veludo/Com amor, com tudo /De real teor de beleza. In: RENNÓ, Carlos (org.) Gilberto Gil todas as letras. São Paulo: Companhia das Letras, 1996, p.222.
} 
tivessem direito. Como a noite de discothéque após o dia de trabalho.

Realce, uma maneira de dizer o bem-estar. Denominar o prazer coletivo, o êxtase do simples caminhar contra o vento de qualquer um. Como o domingo de futebol após a semana de fábrica.

Realce, uma maneira de dizer o Deus louvar. Denominar o santo sem altar, como nos tempos profanos dos terminais de trens e aviões, onde todos estão pra nada, indo ou vindo para tanta coisa.

Realce, cada um por si, Deus por todos. ${ }^{443}$

O texto funciona como uma espécie de manifesto, mas dessa vez pelo direito de todos terem um mínimo de dignidade, de alegria; é uma mensagem dirigida a toda a sociedade brasileira.

"Sarará miolo", além de lembrar saravá, uma saudação utilizada em cultos afrobrasileiros, faz também alusão à cura do negro:

Sara, sara, sara, sarará

Sara, sara, sara, sarará

Sarará miolo

Sara, sara, sara cura

Dessa doença de branco

Sara, sara, sara cura

Dessa doença de branco

De querer cabelo liso

Já tendo cabelo louro

Cabelo duro é preciso

Que é para ser você, crioulo ${ }^{444}$

Tanto sara quanto cura se referem à doença, que se findaria pela aceitação em ser crioulo. O cabelo é aqui abordado como um forte símbolo da identidade negra, e, de acordo com Gil, o uso consciente desse símbolo reforça a imagem do negro perante o branco e para si mesmo. Além disso, consiste em reconhecimento e aceitação de suas origens, como forma de valorização cultural e fortalecimento racial. A sonoridade da canção é pop e faz menção a vários gêneros musicais, dentre eles o xote e o reggae.

\footnotetext{
${ }^{443}$ Texto de Gil estampado na contracapa do Álbum Realce (Warner Music, 1979).

444“"Sarará miolo" (Gilberto Gil, 1976). In: RENNÓ, Carlos (org.) Gilberto Gil todas as letras. São Paulo: Companhia das Letras, 1996, p. 192.
} 


\section{Sobre "Super homem - a canção" ${ }^{445}$, Gil afirmou:}

Sobre a "porção mulher": "Muita gente confundia essa música como apologia ao homossexualismo, e ela é o contrário. O que ela tem, de certa forma, é sem dúvida uma insinuação de androginia, um tema que me interessava muito na ocasião - me interessava revelar esse imbricamento entre homem e mulher, o feminino como complementação do masculino e vice-versa, masculino e feminino como duas qualidades essenciais ao ser humano. Eu tinha feito "Pai e Mãe" antes, já abordara a questão, mais explicitamente da posição de ver o filho como o resultado do pai e da mãe. Em "Superhomem - a Canção", a ideia centralé de que "Pai é mãe", ou seja, todo homem é mulher (e toda mulher é homem). ${ }^{446}$

A música foi criada em torno da letra e não tem nenhum gênero específico, é uma balada pop. E é interessante também por descortinar a ideia de como as canções de Gil mantêm um sentido interno e acabam se desdobrando em diferentes trabalhos e de diferentes maneiras. São como uma mesma ideia que se desdobra em outras. A temática da androginia estava presente no primeiro disco da trilogia e retorna nessa canção de Realce.

"Tradição", 447 música composta por Gil seis anos antes de sua gravação em Realce, retrata sua Bahia dos anos 50 através da história de um jovem casal da cidade de Salvador, que, de acordo com Gil, a garota representa seu desejo sexual e o garoto seu

\footnotetext{
445 "Superhomem - a canção" (Gilberto Gil, 1979) Um dia/Vivi a ilusão de que ser homem bastaria/Que o mundo masculino tudo me daria/Do que eu quisesse ter/Que nada/Minha porção mulher, que até então se resguardara/É a porção melhor que trago em mim agora/É que me faz viver/Quem dera/Pudesse todo homem compreender, oh, mãe, quem dera/Ser o verão o apogeu da primavera/E só por ela ser/Quem sabe/O Superhomem venha nos restituir a glória/Mudando como um deus o curso da his tória/Por causa da mulher. In: RENNÓ, Carlos (org.) Gilberto Gil todas as letras. São Paulo: Companhia das Letras, 1996, p. 224. ${ }^{446}$ Apud RENNÓ, Carlos. Gilberto Gil: todas as letras..., op. cit., p.225.

447 “Tradição"(Gilberto Gil, 1973) Conheci uma garota que era do Barbalho/Uma garota do barulho/Namorava um rapaz que era muito inteligente/Um rapaz muito diferente/Inteligente no jeito de pongar no bonde/E diferente pelo tipo/De camisa aberta e certa calça americana/Arranjada de contrabando/Esair do banco e, desbancando, despongar do bonde/Sempre rindo e sempre cantando/Sempre lindo e sempre, sempre, sempre, sempre, sempre/Sempre rindo e sempre cantando/Conheci essa garota que era do Barbalho/Essa garota do barulho/No tempo que Lessa era goleiro do Bahia/Um goleiro, uma garantia/No tempo que a turma ia procurar porrada/Na base da vã valentia/No tempo que preto não entrava no Bahiano/Nem pela porta da cozinha/Conheci essa garota que era do Barbalho /No lotação de Liberdade/Que passava pelo ponto dos Quinze Mistérios/Indo do bairro pra cidade/Pra cidade, quer dizer, pro Largo do Terreiro/Pra onde todo mundo ia/Todo dia, todo dia, todo santo dia/Eu, minha irmã e minha tia/No tempo quem governava era Antonio Balbino/No tempo que eu era menino/Menino que eu era e veja que eu já reparava/Numa garota do Barbalho/Reparava tanto que acabei já reparando/No rapaz que ela namorava/Reparei que o rapaz era muito inteligente/Um rapaz muito diferente/Inteligente no jeito de pongar no bonde/E diferente pelo tipo/De camisa aberta e certa calça americana/Arranjada de contrabando/Esair do banco e, desbancando, despongar do bonde/Sempre rindo e sempre cantando/Sempre lindo e sempre, sempre, sempre, sempre, sempre/Sempre rindo e sempre cantando. In: RENNÓ, Carlos (org.) Gilberto Gil todas as letras. São Paulo: Companhia das Letras, 1996, p. 144.
} 
objeto de desejo cultural. ${ }^{448} \mathrm{O}$ espaço creditado aos negros na canção se apresenta nos seguintes versos: No tempo que preto não entrava no Bahiano, Nem pela porta da cozinha. A sonoridade passeia pelo samba interpretado de maneira pop, teclado cheio de efeitos, guitarra e bateria americana, e não através do instrumental do samba tradicional, como o cavaquinho, pandeiro e tamborim.

"Marina" ${ }^{449}$, com roupagem moderna, é uma homenagem a Dorival Caymmi. Na gravação de Gil ela não foi interpretada segundo algum padrão específico dos ritmos brasileiros. Sua articulação rítmica navega entre o samba rock e o pop americano. Os timbres dos teclados demarcam uma sonoridade moderna, associado comum a guitarra que traz o elemento do suingue americano do funk. É uma fusão de todos esses elementos. Não há menção a um gênero musical específico.

A sonoridade de "Rebento" ${ }^{450} e ́$ um jogo entre aspectos modernos e aqueles mais associados à tradição. O início é samba interpretado bem à bossa nova, violão e tamborim, para num segundo momento se transformar num samba tradicional, interpretado com tamborim e reco.

"Toda menina baiana" ${ }^{451}$ foi composta para a filha mais velha de Gil, Nara, e fala da Bahia e dos defeitos e qualidades inerentes ao ser humano. É uma espécie de ijexá moderno, com roupagem pop: as congas e as levadas de baixo e violão desenham o contorno do ritmo, mas ao mesmo tempo a bateria faz o pulso de uma música dance disco. E isso não tem a ver com ijexá, podendo aqui ser interpretada enquanto uma espécie

\footnotetext{
448 RENNÓ, Carlos. Gilberto Gil: todas as letras..., op. cit., p. 145.

449“Marina"(Dorival Caymmi).

450“Rebento"(Gilberto Gil, 1979)Rebento, substantivo abstrato/O ato, a criação, o seu momento/Como uma estrela nova e o seu barato/Que só Deus sabe lá no firmamento/Rebento, tudo que nasce é rebento/Tudo que brota, que vinga, que medra/Rebento raro como flor na pedra/Rebento farto como trigo ao vento/Outras vezes rebento simplesmente/No presente do indicativo/Como a corrente de um cão furioso/Como as mãos de um lavrador ativo/Às vezes mesmo perigosamente/Como acidente em forno radioativo/Às vezes, só porque fico nervoso/Ầs vezes, somente porque eu estou vivo/Rebento, a reação imediata/A cada sensação de abatimento/Rebento, o coração dizendo: "Bata"/A cada bofetão do sofrimento/Rebento, esse trovão dentro da mata/E a imensidão do som/E a imensidão do som/E a imensidão do som desse momento. In: RENNÓ, Carlos (org.) Gilberto Gil todas as letras. São Paulo: Companhia das Letras, 1996, p. 226.

451 “Toda menina baiana" (Gilberto Gil, 1979) Toda menina baiana tem um santo, que Deus dá/Toda menina baiana tem encanto, que Deus dá/Toda menina baiana tem um jeito, que Deus dá/Toda menina baiana tem defeito também que Deus dá/Que Deus deu/Que Deus dá/Que Deus entendeu de dar a primazia/Pro bem, pro mal, primeira mão na Bahia/Primeira missa, primeiro índio abatido também/Que Deus deu/Que Deus entendeu de dar toda magia/Pro bem, pro mal, primeiro chão na Bahia/Primeiro carnaval, primeiro pelourinho também/Que Deus deu/Que Deus deu/Que Deus dá. In: RENNÓ, Carlos (org.) Gilberto Gil todas as letras. São Paulo: Companhia das Letras, 1996, p. 226.
} 
de tradução. A clave do agogô aparece como referência explícita do ijexá, ou nas congas ou no violão.

Em "Logunedé", ${ }^{452}$ Gil homenageia seu orixá:

Uma homenagem a meu orixá, à sua natureza brincalhona, jovial, matreira, sestrosa e dengosa; ao seu caráter bissexual também, na referência a Oxum e Oxóssi, seus pais, igualmente homenageados. Uma composição minimalista, musicalmente única, construída só sobre uma tríade de notas que atravessam toda a harmonia, e uma letra igualmente econômica, modernista na capacidade descritiva de, com dois, três traços, compor uma paisagem. ${ }^{453}$

Essa paisagem sonora não faz menção a nenhum ritmo de candomblé. A sonoridade é toda referendada no universo pop, os teclados somados ao violão também não fazem menção a nenhum gênero musical específico.

"Não chore mais"454 é uma versão de Gil para o reggae "No woman, no cry" de B. Vincent, gravado por Bob Marley. A canção se tornaria o seu maior hit de 1979. O disco vendeu 750 mil cópias, além de se transformar numa espécie de hino da anistia no Brasil. ${ }^{455}$ O reggae de "Não chore mais", lançado no momento em que estava se iniciando a abertura política no país, acabou sendo identificado com o período de repressão ao se referir aos amigos presos, amigos sumindo assim, mas especialmente por fazer referência à possibilidade de ter confiança no futuro.

A Lei da Anistia, de 1979, representou um dos movimentos finais da ditadura militar. É obra da própria ditadura, e não dos presos políticos e dos exilados. Esses retornaram ao Brasil, após longos anos de exílio, a reboque de uma lei "ampla, geral e

\footnotetext{
452،"Logunedé”(Gilberto Gil, 1979)É de Logunedé a doçura/Filho de Oxum, Logunedé/Mimo de Oxum, Logunedé - edé, edé/Tanta ternura/É de Logunedé a riqueza/Filho de Oxum, Logunedé/Mimo de Oxum, Logunedé - edé, edé/Tanta beleza/Logunedé é demais/Sabido, puxou aos pais/Astúcia de caçador/Paciência de pescador/Logunedé é demais/Logunedé é depois/Que Oxóssi encontra a mulher/Que a mulher decide ser/A mãe de todo prazer/Logunedé é depois/Épra Logunedé a carícia/Filho de Oxum, Logunedé/Mimo de Oxum, Logunedé - edé, edé/É delícia. In: RENNÓ, Carlos (org.) Gilberto Gil todas as letras. São Paulo: Companhia das Letras, 1996, p. 227.

${ }^{453}$ Apud RENNÓ, Carlos. Gilberto Gil: todas as letras..., op. cit., p. 227.

454“Não chore mais" (No woman, no cry, de B. Vincent/Versão de Gilberto Gil 1977)Bem que eu me lembro/Da gente sentado ali/Na grama do aterro, sob o sol/Ob-observando hipócritas/Disfarçados, rodando ao redor/Amigos presos/Amigos sumindo assim/Pra nunca mais/Tais recordações/Retratos do mal em si/Melhor é deixar pra trás/Não, não chore mais/Não, não chore mais/Bem que eu me lembro/Da gente sentado ali/Na grama do aterro, sob o céu/Ob-observando estrelas/Junto à fogueirinha de papel/Quentar o frio/Requentar o pão/E comer com você/Os pés, de manhã, pisar o chão/Eu seia barra de viver/Mas se Deus quiser/Tudo, tudo, tudo vai dar pé/Tudo, tudo, tudo vai dar pé/Tudo, tudo, tudo vai dar pé/Tudo, tudo, tudo vai dar pé/Não, não chore mais/Não, não chore mais. In: RENNÓ, Carlos (org.) Gilberto Gil todas as letras. São Paulo: Companhia das Letras, 1996, p. 204.

${ }^{455}$ Disponível em: <www.gilbertogil.com.br>Acesso em: 18 dez. 2015.
} 
irrestrita" que perdoou, igualmente, os torturadores do próprio regime, agentes do terrorismo de Estado. A anistia reintegrou os agentes de resistência da ditadura à vida política brasileira, criando as condições para a queda final do regime, em meados dos anos 1980, com os grandes comícios em favor de eleições diretas para presidente da República. A anistia mexeu com o imaginário político do Brasil, e a música de Gil representa, hoje, um importante documento desse momento de efervescência.

Ao rememorar a trilogia, Gil nos dá ainda valiosas pistas ao referenciar as africanidades:

Às raízes desse "Re", que depois prosseguirão com Refavela, que é uma visita de volta à Mãe África. É o reconhecimento da África negra, suas grandezas e seus deuses, suas luzes. A luz negra. Depois Realce fechava, mas era essa luz com todas as cores; e já não era mais nenhuma luz negra ou branca. Era a mesma luz do arco-íris, o refratário. O "Re" de refração, luz refratada, dissociada em todas as suas miríades: o arco-íris. Tanto que ele é símbolo de Realce. Refavela é a luz do negro com o brilho encoberto pelo sofrimento, pela história da escravidão e da exclusão. ${ }^{456}$

A busca estética de Realce pode ser resumida numa negritude pop, voltada para a cena dançante. Esse disco foi paramentado como brilho pop internacional, sem deixar de mencionar as africanidades, que foi experimentada pela homenagem à Logunedé e pela aclamação a um empoderamento negro em "Sarará miolo". A sonoridade remete ao afroamericano, derivado do funk, soul, jazz, mas com o toque de pop do momento, como por exemplo, o uso de efeitos de teclados e guitarras, além, é claro, da referência brasileira do violão de Gil, que traduz diferentes musicalidades desde o primeiro $R e$, e que agora se desdobrou no universo pop do mainstream da época.

A trilogia de Gil, e suas músicas em geral, aqui são analisadas através dos parâmetros do Atlântico Negro, uma vez que foram criadas através de um complexo jogo de apropriações de elementos locais, como, por exemplo, o afoxé dos Filhos de Gandhy ou o baião, além de elementos globais, como o rock inglês ou o reggae jamaicano, sempre marcados por contínuas trocas culturais. Esse entrelaçamento, de acordo com Gilroy, possibilitou durante a diáspora africana que as populações negras formassem uma cultura que não pode ser identificada exclusivamente como americana, caribenha, africana, britânica ou brasileira, mas todas elas ao mesmo tempo. A cultura do Atlântico Negro tem

${ }^{456}$ Apud FONTENELES, Bené. Giluminoso..., op. cit., p. 203. 
um caráter fortemente hibrido, e não pode se circunscrever a fronteiras étnicas ou nacionais.

O conceito de diáspora foi importado por Gilroy de fontes judaicas para a política e a história negra, e não representa para o autor uma forma de dispersão catastrófica, e sim um processo que redefiniu a mecânica cultural e histórica do pertencimento. Para Gilroy, a diáspora não só rompe com a sequência dos laços explicativos entre lugar, posição e consciência, mas também com o poder do território para determinar a identidade. Gilroy rejeita a ideia de uma cultura territorial fechada e codificada no corpo, e afirma que:

Sob a chave da diáspora nós poderemos então ver não a raça, e sim formas geopolíticas e geoculturais de vida, que são resultantes da interação entre sistemas comunicativos e contextos que elas não só incorporam, mas também modificam e transcendem. ${ }^{457}$

Esse circuito comunicativo, ao extrapolar as fronteiras étnicas do Estado-nação, permitiu às populações dispersas conversar, interagir e efetuar trocas culturais. No entanto, essa mistura não deve ser interpretada como perda de pureza, e sim como um princípio de crescimento que ajudou a formar o mundo moderno. Um dos aspectos mais explorados por Gilroy é o reconhecimento da duplicidade ${ }^{458}$ como sinal diacrítico da história intelectual do Atlântico Negro, uma vez que o negro integra o Ocidente sem fazer parte dele completamente. Segundo Gilroy, essa dupla consciência emerge das experiências de deslocamento e reterritorialização das populações negras, que acabam redefinindo o sentimento de pertença e formando uma transcultura negra que relaciona, combina e une experiências e interesses de negros de várias partes do mundo.

Gilroy sublinha as formas nas quais as culturas vernaculares têm viajado. A cultura musical e as histórias de deslocamento, empréstimos, transformação e reinscrição contínua que lhe são características, remetem à complexidade sincrética das culturas expressivas negras. Elas fornecem o melhor exemplo do tráfego bilateral que vem se processando historicamente entre as formas culturais africanas e as culturas políticas dos negros da diáspora. A história de hibridação e mesclagem desaponta o desejo de

\footnotetext{
${ }^{457}$ GILROY, Paul. O Atlântico negro..., op. cit., p. 25.

${ }^{458}$ A teoria da dupla consciência elaborada por W. E. Du Bois constituium dos principais temas abordados pelo autor, através do qual Gilroy discute a construção e a plasticidade das identidades negras. O sujeito negro de Du Bois vive uma dualidade, dividido entre as afirmações da particularidade racial e o apelo aos universais modernos que transcendem a raça.
} 
pureza racial acalentado pelo afrocentrismo e pelo eurocentrismo. A história do Atlântico Negro nos ensina que a reprodução das tradições culturais não pode ser interpretada como a transmissão pura e simples de uma essência fixa ao longo do tempo. Ela se dá nas rupturas e interrupções, sugerindo que "a invocação da tradição pode ser, em si mesma, uma resposta distinta, porém oculta, ao fluxo desestabilizante do mundo contemporâneo". ${ }^{459}$

O estilo de análise de Gilroy não se limita a estabelecer oposições, mas tenta demonstrar as vantagens de uma abordagem que seja capaz de estabelecer relações, procurando criticar os perigosos efeitos de um pensamento dualista binário no qual um elemento do par é dominado por outro - racionalirracional ou branco/preto. Em muito essa superação nos informa, uma vez que os códigos acessados por Gil em sua criação musical mesclam sonoridades do mundo branco como os arranjos orquestrais e a exploração harmônica, como também do mundo negro, com o uso de ostinatos percussivos no violão, por exemplo. Em alguns momentos, todas as características citadas são encontradas em uma única canção, mostrando como esses elementos sonoros estão entrelaçados na obra de Gil.

As rotas abertas por Gilroy nos possibilitam pensar a cultura atlântica negra percorrida por Gil. A identidade negra acessada por Gil nessa trilogia enfatiza sua ancestralidade via Logunedé e Xangô, e celebra sua negritude através dos Filhos de Gandhy e do Ilê Aiyê, demarcando sua africanidade baiana; e faz contundentes críticas não apenas ao racismo, mas também à desigualdade a que estão assujeitados os negros brasileiros. É importante ressaltar, no entanto, que nessa trilogia as traduções culturais que Gil realizou não foram processadas através de uma leitura que contrapôs tradição à modernidade, mas realizou um sincretismo de diferentes códigos musicais e símbolos de negritude.

\section{- Os Doces Bárbaros}

Através do show, disco e filme Os Doces Bárbaros, as formulações identitárias constituídas nas práticas artísticas de Caetano Veloso, Gilberto Gil, Maria Bethânia e Gal Costa foram ainda mais reforçadas. O show Os Doces Bárbaros foi realizado em motivo

${ }^{459}$ Ibid., p. 208. 
de comemoração de dez anos de carreira dos quatro amigos e artistas. Por ter sido gravado no mesmo ano em que Gil lançou seu disco manifesto de negritude ${ }^{460}$ em 1977, ele em muito nos informa sobre as africanidades experimentadas pelo artista naquele momento.

Assim Gil afirmava no programa do show em 1976:

A gente quer fazer de novo as coisas de 16, 18 anos. Fazer de novo, mas novo. Doces bárbaros nasceu e se formou na gente sem dar tempo pra pensar no que a gente tá fazendo agora com relação às coisas e a todas as outras que a gente já fez aqui no Sul. A memória passa por debaixo sem saber. Nãoé potencializar as quatro forças. É usar o que a gente é. A gente cantar junto como quatro pessoas quaisquer. ${ }^{461}$

Essa fala de Gil, feita no ano em que o show foi concebido, demonstra que a intenção por detrás de sua criação era especialmente a liberdade, já que de acordo com o programa do show não havia uma clara intencionalidade pré-concebida para os Doces bárbaros, e tampouco havia o mote de fazer dos quatro um único ente, mas ressaltar a individualidade e potencialidade de cada um dentro do grupo.

Comentando o filme no período de seu lançamento, Gil disse:

O filme possui uma carga de informação meio densa, mas no fim, na última meia hora, ela flui para um tipo de revista mesmo, uma coisa mais up. Parece que foi bem aceito, tanto em termos de ocorrência quanto em crítica do público. (...) Eu acho que vai ser um clássico um dia. Um filme étnico, uma coisa de raça sobre uma tribo, que foi mesmo tudo que a gente sonhou para os Doces Bárbaros. Não tínhamos a intenção de fazer uma coisa regional, confinada ao âmbito muito restrito de nossas relações mais privadas. Que ríamos que os Doces Bárbaros fossem uma visão de uma tribo brasileira. ${ }^{462}$ [ grifos meus]

Se ao estrear o show Gil afirmava em seu programa não existir nenhuma intenção pré-concebida, depois de assistir ao documentário o artista deu um sentido de tribo para o ideal do doce encontro.

\footnotetext{
460 Álbum Refavela (Warner Music, 1977).

${ }^{461}$ Texto do programa do show Doces bárbaros, de 1976. In: RISÉRIO, Antônio. Gilberto Gil: Expresso $2222 \ldots$, op. cit., p. 122.

${ }^{462}$ TARDIN Vicente e HERKENHOLFF e MACEDO Paulo. Gilberto Gil: Viver o sonho da liberdade dentro da prisão da liberdade, apud: RISÉRIO, Antônio. Gilberto Gil: Expresso 2222, op. cit., pp. 185189.
} 
Jom Tob Azuley, diretor do filme, é quem nos informa sobre a produção de $O s$ Doces Bárbaros:

O filme $O s$ doces bárbaros foi de certa forma uma surpresa pra todo mundo, até mesmo para aqueles que o fizeram. Porque ele apenas começou como um documentário para televisão, um pequeno documentário de uns trinta minutos no máximo, mas com o decorrer dos acontecimentos, ele acabou ganhando dimensões de filme de ficção, porque o show ganhou aspectos dramáticos, feito através de muito sacrifício e muito esforço, principalmente depois que aconteceu aquele incidente policial com Gilberto $\mathrm{Gil}^{463}$ lá em Florianópolis. O filme se transformou de musical para um filme policial. ${ }^{464}$

O filme foi gravado em 1976, lançado em 1978 e remasterizado em 2004. Sua narrativa mescla imagens do show com entrevistas dos quatro artistas, depoimentos de fãs e o episódio da prisão de Gil e Chiquinho, comentários do delegado e cenas do tribunal. Há no show uma forte tendência à caracterização afro, que se faz notar especialmente pela indumentária dos quatro integrantes, confeccionadas para representar o orixá de cada um deles. Todos aparecem adornados de búzios, colares de contas, turbantes e pés descalços. Gil ${ }^{465}$ traz os cabelos trançados, finalizados com contas na ponta. O cenário é simples. Não há nada no palco além dos cantores e músicos e uma meia lua pintada ao fundo.

A fala de Caetano no documentário em muito se assemelha a inúmeras reflexões realizadas por Gil, supracitadas nessa pesquisa, em que o candomblé é muitas vezes celebrado enquanto parte integrante da cultura baiana, pela sua forte beleza e ritmo contagiante, além de conectado à negritude:

A gente sente necessidade de exercer a nossa religiosidade, embora a gente não esteja nitidamente seguindo a disciplina de nenhuma das religiões existentes, embora a gente sinta aproximação, atraçãoe fé com relação a muitos aspectos de todas elas. E no caso do candomblé que é muito forte pra nós é uma questão mesmo de área cultural nossa, quer dizer na Bahia e depois se você vai no Gantois, se você vê mãe Menininha, se você vê Cleusa, se você vê o ritmo do lugar, o que se passa lá,

\footnotetext{
${ }^{463}$ Azuley se refere ao fato de Gilberto Gil e o baterista Chiquinho Azevedo terem sido presos em decorrência de serem pegos e enquadrados por porte de maconha. O episódio é relatado no filme com riqueza de detalhes, demonstrando a reação positiva de Gil diante das acusações, assumidas integralmente pelo artista. Gil afirmou que o uso da erva não representava mal para si e foi condenado a um tratamento numa clínica psiquiátrica.

${ }^{464}$ Depoimento do diretor inserido nos extras do documentário DVD Os doces bárbaros. Direção: Jom Tob Azulay. Produção artística: Guilherme Araújo. Rio de Janeiro: Biscoito Fino, 1978.

${ }^{465}$ Gil utiliza dois figurinos no espetáculo, um lenço amarrado na cabeça e um colan branco com um machado de Xangô bordado no peito e uma mini blusa com uma calça branca.
} 
realmente você tenha uma experiência do que seja fé, que só enriquece sua alma. E depois é a nossa mitologia, quer dizer, sei lá... ${ }^{466}$

Já Bethânia, quando questionada sobre sua religiosidade e se era adepta da umbanda, respondeu: "Não, sou kêtu." Quando interrogada sobre frequentar terreiros disse: "Eu vou apenas na casa de mãe Menininha do Gantois." Além dessa afirmativa, Bethânia tinha em sua bancada, no camarim, a foto de mãe Menininha.

A sonoridade do espetáculo é mais relacionada ao universo pop do que a elementos de uma música regional. Tem mais pitadas de rock e baião do que referências à musicalidade reproduzida nos terreiros de candomblé. A única canção do espetáculo que reproduz a musicalidade dos terreiros é As ayabás, na qual soam apenas o atabaque e Gil tocando um ijexá no agogô, Caetano cantando e dançando para Obá, tampando a orelha em menção à mitologia desse orixá; ao final da canção, Gal e Bethânia se curvam em reverência a Oxum. O repertório do espetáculo totaliza 21 canções. Dessas, São João, Xangô menino ${ }^{467}$, Os mais doces bárbaros ${ }^{468}$, As ayabás ${ }^{469}$, Chuck Berry fields forever ${ }^{470}$ e $U m$ índio ${ }^{471}$ tematizam a religiosidade do candomblé em suas letras. Há um trecho do filme que mostra a ambiência dos ensaios e um momento em que tanto os músicos como os quatro cantores tocam e dançam várias cantigas de sambas de roda baianos.

A negritude identificada em Gilberto Gil, ao longo de sua trajetória - e, principalmente a partir de meados da década de 1970 - pode ser interpretada como cosmopolita ou mesmo transnacional, ao mesmo tempo em que valoriza aspectos de tradição, como o ijexá, por exemplo, dando sempre seu toque interpretativo, tentando sempre escapar da busca pela pureza. Um bom exemplo dessa hibridização referente aos

\footnotetext{
466 Caetano apud DVD Os doces bárbaros, op. cit.

467 “Xangô menino" (Caetano Veloso, Gilberto Gil). Ai, Xangô, Xangô menino/ Da fogueira de São João/ Quero ser sempre o menino, Xangô/ Da fogueira de São João/Viva São João/Viva o milho verde/ Viva São João/ Viva o brilho verde/ Viva São João/ Das matas de Oxóssi/ Viva São João...

468“Os mais doces bárbaros"(Caetano Veloso) Com a espada de Ogum/ E a benção de Olorum/ Como num raio de Iansã/ Rasgamos a manhã vermelha.

469“"As ayabás"(Caetano Veloso, Gilberto Gil).

470“Chuck Berry fields forever” (Gilberto Gil, 1976) Trazidos d'África pra Américas de Norte e Sul/ Tambor de tinto timbre tanto tonto tom tocou/Eneve, garça branca, valsa do Danúbio Azul/ Tonta de tanto embalo, num estalo desmaiou/ Vertigem verga, a virgem branca tomba sob o sol/ Rachado em mil raios pelo machado de Xangô/ E assim gerados, a rumba, o mambo, o samba, o rhythm'n'blues/ Tornaram-se os ancestrais, os pais do rock'n'roll...In: RENNÓ, Carlos (org.) Gilberto Gil todas as letras. São Paulo: Companhia das Letras, 1996, p. 178.

471 "Um índio" (Caetano Veloso). Virá/ Impávido que nem Muhammad Ali/ Virá que eu vi/ Apaixonadamente como Peri/ Virá que eu vi/ Tranquilo e infalível como Bruce Lee/ Virá que eu vi/ O axé do afoxé Filhos de Gandhi/ Virá...
} 
trânsitos culturais se faz notar em "Chuck Berry Fields Forever", trazendo indícios para reflexões acerca do lugar dos negros não só no Brasil, mas também no mundo. De acordo com Caetano, essa canção "é uma poética-histórica. Uma história do rock muito particular." ${ }^{472} \mathrm{O}$ título da canção, "Chuck Berry fields forever", homenageia o roqueiro Chuck Berry e também parodia uma canção dos Beatles. A hibridação já aparece no título ao referenciar tanto o rock americano quanto o inglês; Gil conta o surgimento do rock através do bater do tambor afro com as harmonias europeias, fazendo surgir nas Américas diversos gêneros musicais, abordando dessa forma o sincretismo afro- europeu. Vale ressaltar que nessa canção não se valoriza a tradição engessada, mas sim a mistura, a mestiçagem a que Gil se refere e homenageia.

A perspectiva adotada por Gilroy, ao considerar que as identidades negras se constituem no trânsito África-Europa-América, pode ser percebida particularmente no caminho traçado por Gil no que tangencia sua construção de negritude. Nos Doces Bárbaros é possível perceber a presença de elementos culturais afro-brasileiros, mas também internacionais, num hibridismo que se tornou emblemático em sua obra.

Para Gil, o negro pode ser baiano, brasileiro, inglês, jamaicano ou africano, não existindo a determinação de tipos ideais negros, enquadrados em uma classificação fixa ou simples.

O evento Os Doces Bárbaros surge como uma conexão de quatro carreiras. E, ao fazer referência aos orixás, através especialmente dos trajes e das letras das canções, performatizam a liberdade de se expressarem e cantarem o Brasil através de temas que vão da ancestralidade mítica ao som do rock'n'roll, trazendo para essa mistura o elemento africano.

A gravação do documentário aconteceu no contexto da reabertura política, durante o governo do general Ernesto Geisel, que preparou terreno para a anistia. Os sentimentos de liberdade expressos nesse acontecimento se tornam ainda mais significativos se colocamos como cenário um país com uma ditadura em vias de extinção. A canção "O seu amor", ${ }^{473}$ de Gil, composta para o show, parodia o slogan da própria ditadura -

\footnotetext{
${ }^{472}$ Texto do programa do show Doces bárbaros, 1976. In: In: RISÉRIO, Antônio. Gilberto Gil: Expresso 2222 , op. cit., p. 122.

473 "O seu amor" (Gilberto Gil, 1976) O seu amor/Ame-o e deixe-o livre para amar/Livre para amar/Livre para amar/O seu amor/Ame-o e deixe-o ir aonde quiser/Ir aonde quiser/Ir aonde quiser/O seu amor/Ame- o e deixe-o brincar/Ame-o e deixe-o correr/Ame-o e deixe-o cansar/Ame-o e deixe-o dormir em paz/O
} 
ame-o ou deixe-o -, o que a situa como uma resposta aos sinais da insustentabilidade daquele período histórico.

\section{- A viagem de Gil à África}

Em 1977, Gil participou do Festac-Festival Mundial de Arte e Cultura Negra e Africana, realizado em Lagos, na Nigéria, onde passou um mês com um grupo de artistas que representariam a arte brasileira no festival. Esses artistas foram escolhidos por uma delegação encabeçada pelo Itamaraty, e em muito nos informa, já que essa viagem creditou ainda mais a representação das africanidades à imagem de Gil.

Sobre a intenção do festival, é Gil que nos informa:

Trinta anos depois do primeiro que havia sido realizado em Dakar sob a inspiração do Léopold Senghor, grande líder senegalês, que foi presidente, mas era também poeta, homem de letras; onde participaram entre outros a Elizete Cardoso na delegação brasileira. Então trinta anos depois esse festival foi refeito em Lagos, aí já cobrindo aspectos mais amplos da diáspora, cobrindo questões políticas que haviam surgido na diáspora, como o movimento negro, o black panter, todas aquelas grandes questões surgidas no final da década de sessenta, início dos setenta. Além da emergência importante da música pop africana que surgia naquele momento, a juju music, o hylife. O festival dava conta da diáspora negra, os impactos dela na vida do Ocidente todo e as novas emergências africanas, como a África se preparava para entrar nesse mundo da cultura pop contemporânea. ${ }^{474}$

Em um artigo de 1976, encontramos muitos indícios para pensarmos na escolha dos artistas que representariam o Brasil na África:

O Brasil mandará vistosa delegação de artistas ao II Festival Mundial de Arte e Cultura Negra e Africana, que se realizará em Lagos, capital da Nigéria, com a participação de mais de 50 países, de 15 de janeiro a 12 de fevereiro de 77 . Já no $1^{\circ}$ festival em 1966, em Dakar, capital do Senegal, presidido por Leopold Senghor, nosso país obteve êxito através de uma apresentação eclética de alto nível. Agora, foram escolhidos pelo Itamaraty, com a cooperação do Departamento de Estudos Africanos da USP, e colaboração do Centro de Estudos Afro-Orientais da UNB (Bahia) e do Instituto Joaquim Nabuco de Pesquisas sociais (Pernambuco), estes artistas para representar a arte brasileira

seu amor/Ame-o e deixe-o ser o que ele é/Ser o que ele é. In: RENNÓ, Carlos (org.) Gilberto Gil todas as letras. São Paulo: Companhia das Letras, 1996, p. 180.

${ }^{474}$ Programa $O$ som do vinil - Gilberto Gil. Canal Brasil. (2011). 
em Lagos, que será abrigada num dos 9 pavilhões especialmente construídos, em exposição intitulada "O impacto da cultura africana no Brasil" ${ }^{475}$ [grifos meus]

Dentre as manifestações escolhidas ${ }^{476}$ para o evento estavam as artes plásticas, danças ritualísticas, filmes e outros. Entre os representantes da música, estavam Gilber to Gil e Paulinho Moura. Paulinho Moura é clarinetista e saxofonista, e seu repertório é composto por música instrumental (samba, choro e jazz). Levando em consideração que a escolha procurava realizar uma "apresentação eclética de alto nível", podemos já analisar a escalação desses artistas como o que de mais sofisticado poderia haver em se tratando de música negra no Brasil. A música negra que essa delegação escolheu não privilegiou uma arte mais ligada à tradição. Não foram escolhidos sambistas ou cantadores de coco, maracatu ou os blocos afro da Bahia, apenas para ficar em alguns exemplos, demonstrando a tônica da negritude que o Brasil queria enviar à África. A única escolha que tendenciou para uma caracterização mais ligada à tradição foi a dança ritualística de Olga de Alaketu.

Ainda em 1976, em outra reportagem, Gil disse que praticamente se convidou a ir para a África:

O convite oficial foi apenas um reflexo de uma intenção minha de ir. As pessoas da comissão encarregada de selecionar os artistas de várias áreas que participarão do festival sabiam da minha pretensão. E sabiam também que eu iria à Nigéria de qualquer maneira. Participaria do festival, mesmo se não fosse o representante oficial. Isso porque, quando morei em Londres, mantive contato com personalidades nigerianas, que inclusive me convidaram para gravar um disco lá. Infelizmente, não pude aceitar o convite na época, mas ficou certa minha atuação no festival. ${ }^{477}$

Na reportagem, comenta-se ainda que as trancinhas de Gil e a guia vermelha e branca no braço "já dão um certo toque africano no artista". Podemos analisar o pedido de Gil como a existência da identificação do artista com a África, além mesmo do convite que já havia sido feito antes, quando ele ainda morava em Londres, fornecendo ainda mais

${ }^{475}$ Arte negra em Lagos. Folha de S. Paulo,28 nov. 1976.

${ }^{476}$ Artistas plásticos: Caribé, Ruben Valentim, Miguel dos Santos, Maurino de Araújo, José de Dhome, Juares Paraiso, Edson Luz, Otávio de Araújo, Emanuel de Araújo, Waldeloir Rego, Helio de Souza Oliveira. Mostra de etnologia e reprodução de obras de: Aleijadinho, Mestre Valentim, Theófilo de Jesus, Manoel da Costa Ataíde. Arte popular: carrancas de São Francisco, escultura de Boaventura da Silva Filho, imagens de ex-votos (col. Van de Beuque). Danças ritualísticas : a cargo de Olga de Alaketu, da Escola de Música da Universidade da Bahia, grupo do coreógrafo Clyde Morgan e bailarinos descendentes de africanos. Música: Gilberto Gil e Paulo Moura. Filmes: Is so é Pelé, Partido alto de Rubem Confete e Artesanato do samba de Vera Figueiredo e Zózimo Bubul.

${ }^{477}$ Apud CAMBARÁ, Isa. GIL, Um show antes de ver a África. Folha de S. Paulo,17 dez. 1976. 
um indício de que foi em Londres que o contato com o mundo das africanidades começou a se solidificar. O posicionamento do Itamaraty, por sua vez, reifica essa identificação das africanidades ao aceitar o pedido de Gil para representar o Brasil na África. Gil, nessa reportagem, comentou ainda que a sua participação no Festival seria muito importante, já que "vem de encontro à (sic) vontade muito grande que tenho de intensificar minha ligação cultural com a África, e torná-la física."

Buscando compreender as experiências da viagem, encontramos referência num vídeo produzido no próprio festival e exibido, em 1977, pela TV Cultura. Gil, com cabelos trançados e bata africana, diz:

\begin{abstract}
Vim aqui cantar, cantei. Vi muita coisa, gostei muito do povo, da gente. É uma raça muito bonita, muito forte, muito íntegra, muito monolítica, é uma coisa muito bonita. Outro dia eu tava conversando com o Perinho e ele disse a gente vai ter agora pelo menos um ano agora para digerir essa África, esse um mês de Festac. Eu tava dizendo: é mesmo, é muito pano pra manga, muita coisa a repensar, a reconstituir depois que a gente estiver em casa com os quadros da integridade da nossa terra, cercado da nossa própria realidade, a gente vai refletir sobre isso daqui. ${ }^{478}$
\end{abstract}

É importante demarcar que a terra a quem Gil se referencia como sendo a sua é o Brasil. A África aparece enquanto dado de múltiplas realidades a serem reprocessadas e deglutidas no retorno à realidade mãe, brasileira.

Percebe-se então que, após o festival, amplamente divulgado pela Folha de São Paulo, a imagem de Gil passa a ser ainda mais frequentemente ligada às africanidades e à negritude. A Folha publicou uma entrevista com Gil sobre o evento. A transcrição a seguir se faz de grande utilidade para nossa pesquisa, pois nos fornece inúmeras pistas sobre a ligação de Gil com o continente, que passa pelo reconhecimento da África como característica básica de sua composição, bem como a intenção do artista em não querer utilizar uma "moldura" essencialmente africana em sua obra. Sua ligação com a África se dá de maneira complexa. Não há identificação direta com um aspecto específico que possa ser apontado, ou mesmo a escolha por determinadas etnias em detrimento de outras. Através das declarações de Gil, o que fica claro é o incômodo do artista em ser cobrado para criar uma música com essa influência. Segue a transcrição:

\footnotetext{
${ }^{478}$ FESTAC 77 - Lagos, Nigéria. Disponível em: 〈https://youtu.be/4sfOHLa98Rw〉. Acesso em: 03 jan. 2016.
} 
FSP: Esse contato pode implicar em modificações nas tuas coisas, claro.

Gil: Mas elas que ocorram naturalmente, sem uma predeterminação, porque eu não gosto desse desenho, eu não quero fazer uma moldura africana, para tudo que eu apresente esse ano, depois do trabalho na África. Não quero porque meu trabalho foi sempre muito livre, sempre muito dive rsificado, eu aprove ito elementos de várias áre as musicais. Embora esse elemento africanizante seja característica base do meu trabalho, eu acho que ele já estava antes, ele já era muito forte na Refazenda, por exemplo. Eu acho que ele continua mais forte ainda, mais vitalizado com essa injeção cultural que eu tomei. Ir à África, ver tudo que eu vi, experimentar tudo que eu experimentei foi uma das experiências culturais mais sérias que eu já tive; eu acho que para mim foi o mais importante, eu considero tão importante quanto ter saído da Bahia pra São Paulo, por exemplo. Meu próximo disco vai se chamar Refavela, que também é o nome de uma música, e essa música é muito por causa da África. (...) A transa extra-festival foi muito mais enriquecedora, sem dúvida. Aí foi que a gente realmente viu coisas extraordinárias, coisas espontâneas, e eram coisas que demonstravam se há necessidade de integração, que era a ideia inspiradora do festival, integração do mundo negro, aí eles realmente buscavam esse nível de integração. ${ }^{479}$ [grifos meus]

Ainda em 1977, numa entrevista para outro jornal, Gil comentou sobre as apresentações artísticas dos próprios africanos no Festival:

As coisas negras, mais negras, eram de lugares como Guiné, Congo, Uganda, Alto Volta, Mali, Gana, lugares mais autônomos, como modelo político-social mais pirado, menos alinhado com qualquer desses sistemas em jogo no Ocidente. Com coisas mais tribais. Nos espetáculos de Angola, muito rapidamente você sentia alguma coisa do homem africano, do povo africano, do que era a arte na aldeia. Não tinha quase nada, todos já muito uniformizados, vestidos com camisas ocidentais, muito pouca coisa de índio. Em contraposição ao resto, a maioria de outros países, onde tudo era muito indígena. ${ }^{480}$

Sobre as apresentações artísticas brasileiras realizadas na África, Gil comentou:

Olga foi apresentar o que ela faz no terreiro dela, dançou candomblé, e aí era presença total da África, era a identificação direta. Eles diziam: - Olha ali, olha a gente no Brasil. Enquanto o meu trabalho e o trabalho de Clyde e o trabalho de Paulo Moura, o que eles viam era assim, eles diziam: - Olha esses filhos

\footnotetext{
479 BRANCO, Ivo. África, Negro, Refavela: Gil. Folha de S. Paulo, 05 jul. 1977.

480 CAETANO, Caco e FILHO, João Santana. Transou-se, transitou-se, ou seja, entrou-se em transe. Jornal Invasão, 1977, apud RISÉRIO, Antônio. Gilberto Gil: Expresso 2222, op. cit., p. 176.
} 
da gente como eles são espertos, oh como eles são estranhos. ${ }^{481}$

Gil comentou ainda inúmeros aspectos vivenciados no festival:

Uma das substâncias básicas do ir ao festival da Nigéria, do estar ali, era ficar vendo toda aquela coisa étnica, que era muito interessante pra nós. Era observar a África como humanidade, como é que está o homem de lá, como raça, como busca de ser. (...) A Nigéria é um país com uma massa pobre imensa, uma população de 90 por cento de pobres e 10 por cento de chefes, estrutura de tribo ainda, fazendo um esforço de classe média, no sentido de encontrar padrões médios. A vila em que a gente ficou era uma vila BNH de 11 mil casas. (...) A África é uma grande reserva. Você vê, quando pintou arte moderna foi lá, pintura moderna, Picasso, bá bá bá, você vai ver tá tudo lá na África. O Picassonão tem nada, nada, nada, nada, nada de novo, ele apenas copia integralmente tudo que já se fez lá. A música moderna, tá tudo lá na África, o teatro moderno, a expressão cênica moderna, a expressão corporal, então é isso mesmo, é a grande reserva. Até clarear... custa muito tempo, Tá lá, novinha, a alma você vê que é nova, ingênua, infantil, a vitalidade. ${ }^{482}$

As citações acima transcritas se referem ao modo como Gil, naquele momento, percebeu o festival e dimensionou o mundo da negritude. A própria ideia de uma identidade negra pode ser aqui analisada enquanto difusa e complexa. Se a África é compreendida pelo artista enquanto reduto de riqueza cultural e de emotividade, ou mesmo enquanto uma espécie de reserva, como afirma Gil, a África é também espaço de reprocessamento do que ocorreu com a cultura negra na diáspora. No entanto, é importante destacar que estereótipos continuaram sendo utilizados na leitura intercultural processada através das apresentações artísticas do festival, como, por exemplo, esperteza e estranhamento.

As africanidades experimentadas nesse mês de convívio com aspectos da cultura africana, mas também com a cultura negra produzida fora da África, permitiram a Gil solidificar ainda mais um espaço de elaboração discursiva, fundamentado em especificidades históricas e culturais experimentadas no próprio continente africano. Dentre as principais identificações de Gil com o mundo negro no festival, e que se fizeram notar posteriormente em sua obra e trajetória, figuram especialmente o encontro com

\footnotetext{
481 Ibid., p. 178.

${ }^{482}$ In:RISÉRIO, Antônio. Gilberto Gil: Expresso 2222, op. cit., p. 183.
} 
Stevie Wonder ${ }^{483}$ e Fela Kuti, que tinham como marca de sua musicalidade o caráter pop e de modernização.

\section{- As tensões entre Gil e o movimento negro brasileiro}

Ressalto que a conceituação de "raça" será aqui abordada através da concepção de Hall, que a considera uma construção tanto social quanto política, e também enquanto:

Uma categoria discursiva em torno da qual se organiza um sistema de poder socioeconômico, de exploração e exclusão - ou seja, o racismo. Contudo, como prática discursiva, o racismo possui uma lógica própria. Tenta justificar as diferenças sociais e culturais que legitimam a exclusão racial em termos de distinções genéticas e biológicas, isto é, a natureza. Esse "efeito de naturalização" parece transformar a diferença racial em um "fato" fixo e científico, que não responde à mudança ou à engenharia social reformista. ${ }^{484}$

Assim como Hall, compreendemos que "é para a diversidade e não para a homogeneidade da experiência negra que devemos dirigir integralmente a nossa atenção criativa agora." ${ }^{485} \mathrm{O}$ disco manifesto negro de Gil foi lançado em 1976, que também foi o ano em que o artista visitou a África. Em 1975, ele lançou em parceria com Jorge Ben o LP Ogum \& Xangô, e em 1974 filiou-se ao afoxé Filhos de Gandhy. Boa parte da identificação de Gil com a negritude e as africanidades processou-se na década de 1970, período em que surgiu o Movimento Negro Unificado (MNU) ${ }^{486}$ no país. Como a intenção aqui é compreender a construção de uma identidade negra na trajetória e obra de Gil, e levando em consideração os diferentes contextos sócio-históricos nos quais essa construção teve lugar, trataremos a seguir do movimento negro brasileiro ${ }^{487} \mathrm{e}$ de como

\footnotetext{
${ }^{483}$ Que Gil afirmou ter conhecido no shrime de Fela, na Nigéria no Programa $O$ som do vinil - Gilberto Gil. Canal Brasil. (2011).

${ }^{484}$ HALL, Stuart. Da diáspora..., op. cit., p. 66.

${ }^{485}$ Ibid., p. 327.

${ }^{486}$ Éimportante salientar que data de 1931 a criação da Frente Negra Brasileira e de seu jornal. Antes desses já existiam outros periódicos negros atuantes, e em 1944 foi criado o Teatro experimental do Negro, criado por Abdias Nascimento. Maiores informações, ver: OLIVEIRA, Laiana Lannes. Entre a Miscigenação e a Multirracialização: Brasileiros negros ou Negros Brasileiros? Os desafios do movimento negro brasileiro no período de valorização nacionalista (1930-1950) - A Frente Negra Brasileira e o Teatro Experimental do Negro. Tese (Doutorado em His tória): UFF, 2008.

${ }^{487}$ A questão não é traçar parâmetros comparativos ou mesmo valorativos entre as escolhas individuais do artista e a militância política do $\mathrm{MN}$, mas sim compreender como ambos conceberam e mesmo conceituaram a negritude e as africanidades. Já salientando, desde já, que es sa relação não demarca que ter participado ou não do MN torna Gil mais ou menos consciente de sua negritude.
} 
as demandas e discursos dessa instituição se assemelharam, ou não, ao modo como Gil abordava sua negritude e as africanidades naquele momento.

Com o intuito de compreender a constituição do movimento negro contemporâneo, suas estratégias e suas formas de atuação, Amílcar Pereira e Verena Alberti nos informam que:

É sabido que um dos marcos principais de inauguração do movimento que se constituiu nos anos 70 e 80 foi o ato público contra o racismo, em 7 de julho de 1978, nas escadarias do Teatro Municipal de São Paulo, em protesto contra a morte de um operário negro em uma delegacia de São Paulo e contra a expulsão de quatro atletas negros de um clube paulista. Esse ato acabou resultando na formação, no mesmo ano de 1978, do Movimento Negro Unificado (MNU), entidade que existe até hoje e cuja formação parece ter sido responsável pela difusão da noção de "movimento negro" como designação genérica para diversas entidades e ações a partir daquele momento. ${ }^{488}$

De acordo com os autores acima citados, embasados em muitas horas de entrevistas com lideranças desse movimento em diferentes estados do país, grande parte do esforço desses sujeitos era combater o mito da democracia racial, primeiramente num âmbito pessoal, reconhecendo-se e valorizando-se como negros, para posteriormente organizarem formas de luta para a sensibilização de outros negros e brancos.

Para Jacques d'Adesky, as premissas básicas do MNU desde seus primórdios foram o combate ao racismo, a melhoria das condições socioeconômicas dos afrodescendentes e a reconstrução de suas identidades. De acordo com o autor, os grupos carnavalescos afro de Salvador e do Rio de Janeiro transformaram a dança, a música e a recuperação de uma estética negra em instrumentos privilegiados para propiciar a interiorização da valorização da consciência étnica. Até o final dos anos 80, esses grupos protagonizaram a criação e a divulgação de imagens positivas da África, concentrando se na recuperação e na preservação dos valores de origem africana ligados à tradição e ao costume, nos grandes momentos da história da África e na exaltação da beleza da mulher negra. 489

\footnotetext{
${ }^{488}$ ALBERTI, Verena; PEREIRA, Amílcar Araújo. Movimento negro e "democracia racial" no Brasil: entrevistas com lideranças do movimento negro. Rio de Janeiro: CPDOC, 2005, p. 2.

${ }^{489}$ D'ADESKY, Jacques. Pluralismo Étnico e multiculturalismo: Racismo e Antirracismos no Brasil. Rio de Janeiro: Pallas, 2001, pp. 157-158.
} 
Frequentar expressões religiosas de matriz africana, de acordo com d'Adesky, não é unanimidade entre os militantes negros, sejam eles cristãos ou não. Não existe um consenso sobre a conscientização da negritude, seja em nível individual ou coletivo, estar necessariamente atrelada a um retorno obrigatório ao candomblé ou mesmo a participação em qualquer uma das práticas religiosas de matriz africana. ${ }^{490}$

Amílcar Pereira ressalta que o movimento negro é um movimento social que tem como particularidade a atuação em relação à questão racial, e que:

Sua formação é complexa e engloba o conjunto de entidades, organizações e indivíduos que lutam contra o racismo e por melhores condições de vida para a população negra, seja através de práticas culturais, de estratégias políticas, de iniciativas educacionais, etc. ${ }^{491}$

Pereira nos informa que existe uma grande diversidade quanto às lideranças entrevistadas por ele, referentes a religião, formação acadêmica, gênero, gerações e visões políticas. De acordo com o autor, as características fundamentais do movimento negro contemporâneo são a denúncia da democracia racial e a afirmação de uma identidade racial negra positivada. A África acessada por grande parte dessas lideranças era aquela das lutas protagonizadas naquele momento histórico de descolonização. Segundo Pereira, a "consciência negra" do movimento se fez através de uma série de referências como Agostinho Neto, Martin Luther King, Angela Davis, Malcolm X, os Panteras Negras, as experiências de lutas pela libertação da África e o livro Os condenados da terra, de Franz Fanon. ${ }^{492}$

Assim como Paul Gilroy, nossa análise se afasta de qualquer tipo de essencialis mo racial, uma vez que nenhuma origem é capaz de explicar as construções culturais, que são experiências tecidas e trocadas ao longo dos últimos séculos pelas populações que compõem a diáspora negra. De acordo com Gilroy, a construção de uma identidade e cultura negras se processou em função da resistência à escravidão e ao terror racial vivenciado nas Américas. ${ }^{493}$

\footnotetext{
490 Ibid., pp. 159-160.

${ }^{491}$ PEREIRA, Amílcar A. O mundo negro: a constituição do movimento negro contemporâneo no Brasil(1970-1995). 2010. Tese (Doutorado em História): UFF, 2010, p. 81.

492 Ibid., p. 182.

${ }^{493}$ GILROY, Paul. O Atlântico negro..., op. cit.
} 
Outro pensador que nos informa sobre a construção das identidades, no caso a africana, é Kwane Appiah, que afirma que:

Toda identidade humana é construída e histórica; todo o mundo tem seu quinhão de pressupostos falsos, erros e imprecisões que a cortesia chama de "mito", a religião de "heresia", e a ciência de "magia". Histórias inventadas e afinidades culturais inventadas vêm junto com toda identidade; cada qual é uma espécie de papel que tem que ser roteirizado, estruturado por convenções de narrativa a que todo o mundo jamais consegue conformar-se realmente. ${ }^{494}$

Appiah afirma ainda que:

Falar de "raça" é particularmente desolador para aqueles de nós que levamos a cultura a sério. É que, onde a raça atua - em lugares onde "as diferenças macroscópicas" da morfologia são correlacionadas com "diferenças sutis" de temperamento, crença e intenção -, ela atua como uma espécie de metáfora da cultura; e só o faz ao preço de biologizar aquilo que é cultura, a ideologia. ${ }^{495}$

Levando em consideração que as identidades são construções históricas e sociais, intencionamos nesse momento compreender o discurso da negritude proferido pelo movimento negro brasileiro e a relação tensa de Gil com esses discursos. Ressaltamos que existe uma enorme série de discursos que tratam da negritude, desde aquele produzido por intelectuais, artistas, quanto aquele produzido por instituições como o MNU, grupos culturais como os afoxés e maracatus, escolas de samba, como também as políticas culturais que se referem a esse universo, etc. Cada um desses discursos elabora seus próprios enquadramentos para variantes de negritude e racismo, relacionando-se sempre com outras diferentes séries discursivas referentes a essa temática, ora priorizando determinados códigos, ora outros.

Martha Figueira Queiroz, ao analisar o movimento negro contemporâneo, o identifica enquanto um conjunto de ações e instituições voltadas para a valorização da cultura negra, e o mito da democracia racial como um grande obstáculo a ser vencido. Queiroz conecta práticas culturais afro-brasileiras e do carnaval pernambucano aos movimentos antirracistas, e reflete sobre a resistência cultural negra no século XX, o processo de construção da negritude e a afirmação identitária e reivindicatória desses grupos. Sobre a criação do MNU, Queiroz afirma que:

\footnotetext{
${ }^{494}$ APPIAH, Kwame Anthony. Na casa de meu pai. Rio de Janeiro: Contraponto, 1997, p. 243.

495 Ibid., p. 75.
} 
O eixo central da mobilização deixa de ser a inserção no modelo social existente para ser a descoberta e valorização dos valores negros e o uso desses valores como alicerce para a luta pela construção de uma sociedade racialmente plural. ${ }^{496}$

De acordo com a autora, a grande heterogeneidade referente a esse universo pode ser compreendida através da criação do Centro de Cultura e Emancipação da Raça Negra recifense:

Foi quando o grupo praticamente cindiu em dois blocos: o bloco dos "revolucionários das consciências" - ou apologistas da filosofia da negritude acima de qualquer outra causa -, e o bloco dos simpatizantes da questão "classe social" em função da qual achavam dever-se-ia procurar entender, no presente, o modelo racial brasileiro. ${ }^{497}$

Queiroz nos informa ainda que:

Na construção de suas estratégias discursivas, as múltiplas vozes negras que compunham o Movimento Negro recorreram a uma ancoragem marcada pela oposição ao 13 de maio e ao mito da democracia racial, pela valorização da ancestralidade africana, valorização da autoestima e enfrentamento do racismo em todas as frentes. ${ }^{498}$

Tanto no carnaval recifense, analisado por Queiroz, quanto nas entrevistas com lideranças de movimentos negros, realizadas por Pereira, foi possível perceber que o discurso dessas instituições e/ou sujeitos se pautaram principalmente pela recusa em aceitar a democracia racial brasileira e na luta por desmistificá-la. Ao reconhecer o racismo, e consequentemente a exclusão racial brasileira, o movimento negro enalteceu a raça negra, bem como signos de herança africana.

A seguir, buscamos indícios em diferentes fontes para compreender a ligação de Gil com o movimento negro brasileiro e com a África, para melhor compreendermos como a negritude foi acessada por sujeitos e/ou instituições que trataram desse tema naquele período.

Em uma reportagem da revista Veja de $1978^{499}$, comentou-se que Gil, “outra vez. em sua terra, reforçou o caráter pulsativo de suas composições, temperando-o com ecos de África e de América Central". É interessante salientar que mais uma vez a África

\footnotetext{
${ }^{496}$ QUEIROZ, Martha Rosa F. Onde cultura é política. Movimento Negro, Afoxés e Maracatus no carnaval do Recife (1979-1995). 2010. Tese (Doutorado em História), UnB, 2010, p. 98.

${ }^{497}$ QUEIROZ, Martha Rosa F. Onde cultura é politica..., op. cit., p. 123.

498 Ibid., p. 260.

${ }^{499}$ BAR, Décio e ECHEVERRIA, Regina. Eu quero é mel. Veja, ed. 540, 10 jan. 1979.
} 
é somente citada, sem nenhuma informação do que vem a ser essa presença. É como se o caráter pulsativo por si só caracterizasse a presença da África na música de Gil.

Ao comentar sua predileção pelos palcos e não pelos estúdios, Gil comentou: "no estúdio sou uma pessoa, e no palco sou outra", e ainda que "quando eu estou no palco, olhando a plateia, não sei por que, sempre me ocorre a imagem de tribo, da taba, de quarup." Além de esse depoimento dimensionar sua predileção pelo palco, sua descrição sobre estar no palco "é parecida - deve ser parecida - com as coisas que as pessoas sentem nos terreiros de candomblé, quando estão para entrar em transe". Essa fala de Gil nos permite conjecturar que ele se identifica com essa situação ao atuar artisticame nte. Não há na reportagem nenhuma outra menção a possíveis ligações de Gil com o candomblé, assim como o seu envolvimento com o movimento negro brasileiro.

O mesmo não pode ser dito em relação ao jornal Folha de S. Paulo. Nele é possível inferir uma outra leitura da relação de Gil com referência à negritude ou às africanidade $\mathrm{s}$ nos idos de fim da década de 1970. Um exemplo foi a reportagem, de 1979, intitulada "O negro descobre seu lugar", em que o entrevistado Clóvis Moura reflete sobre o surgimento do movimento negro unificado. Moura comenta que "além de lutar contra a discriminação, o MNU tem ainda a preocupação de desmistificar a aparente ausência de racismo no Brasil', em especial através da retomada de uma consciência étnica. Sobre a ligação do movimento negro com artistas negros, Moura comentou:

A comunidade negra é incapaz de pichar um artista negro mesmo que este não assuma suas origens, lutando diretamente contra a discriminação racial; "a cor da pele" - afirma Clóvis - é um elo muito forte. Vários cantores já consagrados pelo público, como por exemplo, Jair Rodrigues e Gilberto Gil, costumam, de vez em quando, oferecer shows à comunidade. São, em troca, classificados pela comunidade como burgueses progressistas. ${ }^{500}$

Moura segue comentando que o único artista que teve projeção nacional e não abandonou a comunidade negra foi Candeia: "Ele não largava suas origens, seu grupo étnico, tudo indicando que seria um elemento de ligação muito forte entre as comunidades negra e branca. Mas infelizmente morreu no ano passado." É interessante salientar que o que Moura está reconhecendo como negritude é a celebração de uma comunidade negra, além do orgulho étnico. De acordo com Moura, existem dois tipos de

${ }^{500}$ FONTOURA, Marília. O negro descobre o seu lugar. Folha de S. Paulo, 30 set. 1979. 
artistas: aqueles que contribuem indiretamente para o movimento negro e aqueles que contribuem de modo mais direto. Gilberto Gil, quando citado em relação ao MNU, se enquadra no grupo dos que ajudam indiretamente, classificados como "burgueses progressistas".

Segue a transcrição de um trecho de outra reportagem, sobre a escola de samba carioca, Quilombo ${ }^{501}$ que tem na temática de seus sambas-enredo "o negro como personagem que precisa lutar para afirmar sua etnia e seu papel social". A Escola, apadrinhada pelo sambista Candeia, tinha a finalidade de mostrar a cultura negra de forma simples e sem o espetáculo mercadológico que começava a predominar no carnaval carioca. A intenção da escola era mostrar aspectos da cultura negra partindo da própria comunidade afro-brasileira. A reportagem, sem especificar claramente quem está dando a afirmação, se o jornalista ou algum membro da escola, menciona Gilberto Gil como um artista de fora da cultura afro-brasileira, que incorpora elementos desta transformando-a em um modismo, como é possível notar no trecho citado abaixo:

Essa ênfase na cor da pele pode ser considerada uma extensão do atual contexto de negritude, reivindicada por alguns setores da comunidade negra. As trancinhas de Gilbe rto Gil são as mesmas de muitos quilombolas, mas a[Escola de Samba]Quilombo extrapola o possível modismo para desenvolver a consciência cultural negra entre seus adeptos, muitos deles também componentes de escolas grandes e, por isso, sujeitos aos vícios combatidos. ${ }^{502}$

É interessante, no entanto, atentar para o fato de que a negritude não tem apenas um significado.Diferentes agentes a conceituam de diversas maneiras. Se na reportagem da escola de samba Quilombo Gil e suas tranças foram atreladas a um simples modismo, o mesmo não pode ser dito do repórter que criticou Gil por querer exportar o exotismo brasileiro se utilizando de símbolos nitidamente africanos, dois anos antes. ${ }^{503}$

A seguir, a transcrição de uma reportagem que já traz em seu título - "Gil faz carnaval para agradar no exterior" - um tom sarcástico e até mesmo agressivo em relação a Gil:

\footnotetext{
${ }^{501}$ O Grêmio Recreativo de Arte Negra e Escola de Samba Quilombo foi uma escola de samba da cidade do Rio de Janeiro, fundada pelos compositores Candeia, Nei Lopes, Wilson Moreira e Mestre Darcy do Jongo, em 8 de dezembro de 1975. Sobre o tema ver: SAUTCHUK, João Miguel. Brasil, Ritmos e harmonias: samba e identidades na música popular brasileira (segunda metade do século XX/ tempo presente). TCC. (graduação em História) - Universidade de Brasília, 2003.

${ }^{502}$ DTÉRCIO, Jason. Uma escola sem plumas ou paetês. Folha de S. Paulo, 17 fev. 1980.

${ }^{503}$ SOARES, Dirceu. Gil faz carnaval para agradar no exterior. Folha de S. Paulo, 13 out 1978.
} 
Parece ter sido essa a velha chave a usada por Gilberto Gil, em 14 de julho, no festival passado de Montreux, na Suíça, para levantar a plateia de mais de quatro mil pessoas: o carnavale o exótico, tipo exportação, responsável pelo sucesso de nossas mulatas, dos nossos filmes coloridos, das nossas praias, das nossas bananas, das nossas cobras e da nossa capital, Buenos Aires. Sem dúvida uma apelação, como se nota agora nesse LP duplo da WEA... Mas, ao que tudo indica, a preocupação de Gil foi essa mesma: a de dar um recado exótico do Brasil. Chegou vestido de branco em homenagem a Oxalá, deus africano, e fez um roteiro turístico em nossa música, explicando tudo em inglês abaianado... ${ }^{54}$

Há aqui um incômodo e um deboche quanto às escolhas de Gil por referenciar o carnaval e o candomblé. A preocupação do repórter era com a imagem exótica que Gil passou do Brasil para o exterior, ou seja, a leitura das africanidades de Gil foi interpretada enquanto exotismo, tipo exportação e, portanto, nesse caso, bastante depreciativa.

Se até 1978 as reportagens que faziam menção a aspectos de africanidades na obra de Gil, como foi possível perceber através das citações de diferentes periódicos ao longo da pesquisa, eram em sua maioria de celebração, a partir desse momento as tranças de Gil passaram a ser interpretadas como um modismo pelos integrantes da escola de samba Quilombo. Gil foi visto como um "burguês progressista" por parte dos integrantes do movimento negro paulista, e também foi identificado pelo repórter Dirceu Soares como um artista exótico a carnavalizar/candombleizar o Brasil para o exterior. São diferentes tipos de interpretação, diferentes conceituações para as africanidades de Gil. Nenhuma dessas representações tem maior validade que as demais, apenas nos mostram que em um mesmo meio de comunicação o mesmo tema pode ser apresentado sob diferentes vieses. As reportagens não se excluem ou mesmo se contradizerem, apenas nos apresentam um vasto e problemático universo ao tratarmos da negritude e das africanidades referentes ao artista Gil. Se em alguns momentos a africanidade é questionada, em outros é atacada e em outros é celebrada e festejada, demonstrando assim que não há um só sentido, e sim uma pluralidade de possíveis interpretações referentes a diversas africanidades. São sentidos que vão sendo criados e constantemente reprocessados, a depender do meio nos quais estão inscritos.

Se as reportagens analisadas anteriormente apontam para a ênfase das africanidades e da negritude em sua trajetória naquele momento, as cenas de um documentário produzido quase uma década após a institucionalização do MNU indicam

\footnotetext{
504 SOARES, Dirceu. Gil faz carnaval para agradar no exterior. Folha de S. Paulo, 13 out 1978.
} 
claramente a postura crítica de Gil frente ao movimento. Segue a transcrição das falas

de Gil referentes à temática:

Ninguém tinha orgulho de ser negro, ninguém dizia negro é lindo. O que a gente poderia chamar de uma consciência negra é uma coisa muito recente. Em termos mais compactos, socialmente visíveis, como uma coisa identificável dentro do panorama todo da sociedade, isso vem de 20 anos pra cá. Com a tomada de consciência de alguns negros. Depois das conquistas americanas dos "black panters" e do Martin Luther King. Depois que há uma discussão internacional dessa questão do negro diferenciadamente do branco, como uma coisa em si mesma. Isso passa a existir no Brasil de 20 anos pra cá. No momento em que eles tomaram a consciência de que existe uma raça negra, de que existe uma cultura negra, de que existe um valor negro, aí o impulso imediato é no sentido de dizer então: somos uma coisa separada do resto. Nós fomos escravizados, explorados, utilizados, fomos menosprezados, desumanizados. Nos foi imposta uma selvageria pelo branco. Então agora é hora da revanche, é hora de nós nos separarmos. Isso é compreensível, então de uma certa forma a gente não concorda com essas intenções, essas metas do movimento negro, mas a gente concorda com os impulsos que os levam a tomar essas posições. E, portanto, a gente vive a posição trágica de ao mesmo tempo ser a favor e contra o movimento negro. ${ }^{505}$

De acordo com Gil, a tomada de consciência da raça negra, da cultura negra, do valor negro acabaram por delimitar uma separação entre eles e o resto, demarcando a hora da revanche, da separação. Gil vê-se então numa trágica posição, já que compreende essa necessidade de humanização e se coloca contra tal separatismo. No mesmo documentário, ao refletir sobre seu retorno à Salvador, Gil nos fornece ainda outros indícios para problematizarmos a questão da negritude:

É a cidade da Bahia, não dá pra ficar longe dela não, não dá pra viver longe. Claro que há a perspectiva do além-fronteiras, de ir adiante, de não se apegar, de não se reduzir a uma dimensão folclórica, enfim de se universalizar, de fazer as coisas que ficaram mais ou menos nítidas no meu trabalho, que acabaram se esboçando no meu projeto. Mas de qualquer maneira a perspectiva de voltar aqui, de vir pra cá, de ficar aqui, de respirar essa atmosfera absolutamente íntima, não dificultante, esse conforto, essa qualidade uterina de estar no colo da mãe. Isso sempre foi uma coisa que me habitou, o tempo todo, tanto que essa já é a terceira vez que eu volto. Agora eu volto pra trabalhar junto com a comunidade baiana. ${ }^{506}$

505 DVD GILBERTO GIL - La passion sereine. Direção: Ariel de Bigault. Produção: Feeling Productions/TF1/PI Production. Participação: Centre Nacional de La Cinematog raphie ET di Ministère dês Affaires Etrangères. Apresentação: Grande Othelo, 1987.

${ }^{506}$ Ibid. 
Apesar de se localizar no além-fronteiras, Gil continua a demarcar a capacidade afável e mesmo uterina da cidade de Salvador. No entanto, a cidade não está demarcada por velhas identidades, firmemente enraizadas, mas sim por novas identificações, novos projetos. O folclórico, aqui representado como uma espécie de protecionismo das purezas culturais, é questionado por Gil por apresentar o perigo do reducionismo. Frente a essa situação, Gil pretende buscar a universalização, numa intenção que, ao mesmo tempo em que se mostra modernizante, busca o colo materno.

Problematizando a globalização e o deslocamento das identidades, Hall nos diz que:

\begin{abstract}
Ela tem um efeito pluralizante sobre as identidades, produzindo uma variedade de possibilidades e novas posições de identificação, e tornando as identidades mais posicionais, mais políticas, mais plurais e diversas; menos fixas, unificadas ou trans-históricas. Entretanto, seu efeito geral permanece contraditório. Algumas identidades gravitam ao redor daquilo que Robins chama de "tradição", tentando recuperar sua pureza anterior e recobrir as unidades e certezas que são sentidas como sendo perdidas. Outras aceitam que as identidades estão sujeitas ao plano da história, da política, da representação e da diferença e, assim, é improvável que elas sejam outra vez unitárias ou "puras"; e essas, consequentemente, gravitam ao redor daquilo que Robins (seguindo Homi Bhabha) chama de tradução. ${ }^{507}$
\end{abstract}

Reside aí a chave da questão da representação da negritude para Gil e para o MNU. Enquanto os integrantes dos movimentos negros buscavam afirmá-la através especialmente da tradição, tentando recuperar sua pureza anterior e recobrir as unidades e certezas que são sentidas como sendo perdidas em resposta às experiência s de racismo e exclusão; Gil, que no momento desse documentário se empenhava numa empreitada política, estava mais conectado a aspectos de tradução. Sua intenção não configurava uma descoberta de algum tipo de pureza cultural "perdida" ou mesmo uma espécie de absolutismo étnico.

Em diálogo com Jorge Ben, ainda no mesmo documentário, a negritude e as africanidades são evocadas por Gil:

Na música popular o primeiro a trazer essa consciência a falar, a colocar as palavras das línguas africanas, a fazer os refrões das músicas, a usar os pequenos módulos melódicos africanos tribais, a buscar no violão, na guitarra, uma rítmica que contemplasse nitidamente a rítmica africana com o samba, mas ao mesmo

${ }^{507}$ HALL, Stuart. A identidade cultural na pós-modernidade. Rio de Janeiro: Lamparina, 2014, p. 51. 
tempo com um peso tribal africano foi o Jorge Ben. Toda essa ponte que você fez entre o samba e a África, por essa ponte também passa o baião. A coisa que a gente quer no Brasil, a gente luta pelo reconhecimento da negritude, o reconhecimento do valor do batuque. Tudo isso é luta comum minha e dele. Eu diria que não é nem luta, é expressão de espírito, verdadeira, tranquila. ${ }^{508}[$ grifos meus $]$

A negritude para Gil nesse momento está associada ao valor do batuque, e não é a luta que irá demarcá-la. A luta possui aqui mais o sentido de divulgação. A negritud e aqui oscila entre tradição e tradução. É uma identidade cultural que tem como códigos o peso tribal da África, das línguas africanas e a valorização do batuque, simbolizando aspectos tradicionais, enquanto o hibridismo referente ao samba, o baião e o rock está mais conectado à tradução, uma vez que esses elementos simbolizam uma transposição entre fronteiras, uma fusão de diferentes tradições culturais.

Para complementar mais profundamente a argumentação referente ao universo da negritude concebida por Gil, a seguir transcrevo um pequeno trecho de uma entrevista onde o artista frisou sua vocação sincretista:

\begin{abstract}
É, eu tenho uma dificuldade com a ortodoxia em qualquer sentido. O sentimento de aculturação é sempre mais forte do que o sentimento de preservação de culturas primitivas. Eu sempre tive dificuldades com essa posição puris ta com relação à influência indíge na ou africana. $\mathrm{O}$ meu empenho é muito mais no sentido de pegar, misturar, trazer a coisa para o plano do cosmopolitismo moderno. ${ }^{509}$ [ grifos meus $]$
\end{abstract}

Vale ressaltar que o espaço de negritude elaborado por Gil ultrapassa a pertença cultural a determinadas africanidades. Inúmeras são as identificações de Gil ligadas a uma afro-descendência, passando por vestimentas e penteados, sua participação no afoxé Filhos de Gandhy, sua musicalidade. Muitas dessas identificações foram acessadas pelo deslocamento geográfico, no qual o exercício da negritude ganhou, em novos contextos de sociabilidade, diferentes significações.

É importante salientar que diferentes agentes conceituaram a negritude de Gil de maneiras diversas, e também que o próprio artista revisitou o tema através de inúmeras experiências ao longo de sua trajetória, mas sempre buscando conceber sua identidade

508 DVD GILBERTO GIL - La passion sereine. Direção: Ariel de Bigault. Produção: Feeling Productions/TF1/PI Production. Participação: Centre Nacional de La Cinematographie ET di Ministère dês Affaires Etrangères. Apresentação: Grande Othelo, 1987.

${ }^{509}$ BIEHLER, Simone. A geleia geral literária de um baiano universal. Jornal Leia, abr. 1985, apud COHN, Sergio (org.). Gilberto Gil - Encontros, op. cit. 
negra de maneira tradutória, sempre misturando, trazendo a coisa para o plano do cosmopolitismo moderno. Nossa intenção é captar as muitas representações de negritude, tanto aquelas que se referem a Gil, quanto aquelas que partem do próprio Gil, nesse complexo jogo de construção identitária.

A busca de Gil pela compreensão de sua negritude não se deu em contato dire to com as manifestações dos movimentos negros brasileiros. Foi anterior a estes. Pode-se dizer que em alguns momentos houve contatos, mas nada que efetivasse as escolhas estéticas e políticas de Gil. O espaço da negritude para Gil não se traduz apenas pelo pertencimento racial, mas se projeta no jogo das relações sociais dos contextos pelos quais transitou, e nos quais laços de afinidade foram criados em inúmeras situações, na inconstância dos acontecimentos. Não podemos afirmar que o desenho identitário ligado à negritude tenha se processado numa perspectiva dotada de sentido. A negritude de Gil foi processada enquanto uma estratégia individualizada, mas sempre informada pelo diálogo com fenômenos coletivos, nacionais e internacionais.

\section{- Ecos de África}

Aqui iremos abordar aspectos que fazem referência às africanidades na obra e trajetória de Gilberto Gil, no período que compreendido entre os anos de 1980 até 1987, quando Gil ocupa seu primeiro cargo político, em Salvador. Serão analisadas a seguir apenas as músicas que fazem menção à África, negritude ou racismo, fotos de Gil das décadas anteriores à década de oitenta, que nos permitem identificar a modificação em seu visual, bem como a afirmação de sua negritude, um filme sobre a turnê do LP Luar, e também reportagens, especialmente as de dois importantes meios de comunicação brasileiros da década de 1980, em termos de vendagem, a revista Veja e o jornal Folha de São Paulo ${ }^{510}$, dentre outras fontes inscritas nesse contexto, principalmente aquelas

\footnotetext{
${ }^{510}$ Trata-se de aquide uma inves tigação de cunho es sencialmente qualitativo e interpretativo, dos periódicos Veja e Folha de São Paulo. Considerando a importância da imprensa na formação de opinião no país, nosso objetivo é abordar as concepções em torno da negritude referentes à Gilberto Gil em artigos do jornal Folha de São Paulo e da revista Veja. Tanto no jornal quanto na revista, foram selecionados os artigos que abordam, principalmente, os assuntos África, raça e negritude. Além de serem periódicos com grande poder de circulação, ambos contêm todo seu acervo digitalizado, o que em muito possibilitou a pesquisa. Ao selecionar os fatos que se tornarão notícia, o jornalismo exerce um papel crucial na sociedade, determinando o que o público deve ou não saber. E a constante presença de Gilberto Gil na mídia demonstra não só a importância do artista como também nos permite analisar quais foram os traços que contornaram sua carreira artística. Assim, ao acompanharmos o trajeto desses sentidos
} 
que se referem aos lançamentos dos LPs de Gil nessa fase. O modo como a musicalidade de Gil foi atrelada à África se fez notar nos dois periódicos, e foi processada diferentemente por ambos, como veremos a seguir.

Questionaremos quais são as ideias e símbolos negros utilizados na criação de uma negritude ligada a Gil. Aqui abordaremos como determinados meios de comunicação, como filmes e periódicos, demarcaram e até mesmo ajudaram a elaborar a imagem de um negro, nesse caso um artista, no contexto social brasileiro. Assim, a análise recairá sobre a elaboração de uma memória que foi aos poucos sendo construída através da articulação entre práticas discursivas e produção de identidades, analisando essas fontes enquanto objetos de produção social de sentidos. Acreditamos ser importante abordar tal questão porque a representação criada por esses meios de comunicação de grande circulação acabou por influenciar os ouvintes de Gil, mas também os demais leitores desses periódicos.

O início dos anos 80 foi um período em que Gil declarou à mídia estar vivenciando um momento de crise criativa. À beira de completar 40 anos, separando-se de Sandra, com quem estava casado há 12 anos, e em um novo relacionamento com a jovem Flora, Gil descartou todo o LP que estava gravando naquele momento e passou a viver uma fase de maior reclusão. Refletindo posteriormente sobre esse período de sua vida, Gil disse:

Eu estava havia três dias pensando em parar de cantar; em deixar a sequência profissional de discos e shows. Estava prestes a tomar essa decisão - e avisar todo mundo -, mas não por uma razão que tivesse a ver com cantar, que é a coisa que mais me encanta na vida. Minha sensação era de fastio; eu queria era um elemento que me trouxesse um novo ânimo. 'Se eu vou parar mesmo', pensei, 'eu tenho que fazer uma declaração pública, e essa declaração tem de ser musical. ' Aí eu fiz "Palco", uma canção que era na verdade pra não deixar dúvida a respeito de tudo o que cantar representa para mim, e a respeito da minha relaçãocom a música - simbolizada de forma completa pelo estar no palco. ${ }^{511}$

A música composta por Gil para se despedir da carreira artística foi "Palco", que seria lançada no LP Luar $^{512}$, que não só trouxe de volta o desejo de continuar a trajetória

em textos da mídia, poderemos perceber sua função na produção social das lutas pelas construções/reconstruções de uma identidade negra as sociada à Gilberto Gil.

${ }^{511}$ Apud RENNÓ, Carlos. Gilberto Gil: todas as letras..., op. cit., p. 238.

512 ÁlbumLuar (Warner Music, 1981). 
de músico como também ecoa a África enquanto parte integrante dessa caminhada. A letra de Palco:

\author{
Subo nesse palco \\ Minha alma cheira a talco \\ Como bumbum de bebê \\ De bebê \\ Minha aura clara \\ Só quem é clarividente pode ver \\ Pode ver \\ Trago a minha banda \\ Só quem sabe onde é Luanda \\ Sabe rá lhe dar valor \\ Dar valor \\ Vale quanto pesa \\ Pra quem preza o louco bumbum do tambor \\ Do tambor
}

Fogo eterno pra afugentar

$\mathrm{O}$ inferno pra outro lugar

Fogo eterno pra consumir

$\mathrm{O}$ inferno fora daqui

Venho para a festa

Sei que muitos têm na testa

$O$ deus Sol como um sinal

Um sinal

$\mathrm{Eu}$, como devoto

Trago um cesto de alegrias de quintal

De quintal

Há também um cântaro

Quem manda é a deusa Música

Pedindo pra deixar

Pra deixar

Derramar o bálsamo

Fazer o canto cântaro cantar

Lalaiá

Fogo eterno pra afugentar

$\mathrm{O}$ inferno pra outro lugar

Fogo eterno pra consumir

$\mathrm{O}$ inferno fora daqui ${ }^{513}$

513 “Palco"(Gilberto Gil, 1980) In: RENNÓ, Carlos (org.) Gilberto Gil todas as letras. São Paulo:

Companhia das Letras, 1996, p. 238. 
Ao se reinventar na profissão, através da criação dessa canção, Gil ressignificou sua crise e foi salvo pela deusa música. A letra, além de dimensionar o aspecto renovador e sempre pulsante do palco ${ }^{514}$ na trajetória do artista, também faz referência à importância da África, aqui representada por Luanda, enquanto código facilitador para a compreensão de sua criação musical.

Se grande parte das músicas que aludem às africanidades de Gil acabam muitas vezes mencionando a sonoridade do ijexá, Luanda aparece aqui referenciando a África banto $^{515}$, e, assim sendo, temos aqui outro indício que nos possibilita afirmar que as africanidades desenhadas por Gil não elencam determinadas etnias em sua trama, mas sim a pluralidade africana.

Outra situação que nos permite refletir sobre as africanidades experimentadas por Gil, ou a ele relacionadas, ainda nos anos 80 , pode ser apreendida por seu encontro com o jamaicano Jimmy Cliff. Assim o jornal Folha de São Paulo informa sobre o encontro, que se desdobrou num show que percorreu cinco capitais do país:

Através da ideologia que perpassa suas letras, fica fácil entender porque Gilberto Gil aceitou com prazer interromper seu longo recolhimento em Salvador ("para repensar as coisas, a carreira, tudo") (...) É que tanto Gil quanto Cliff identificam-se num tipo de visão do mundo que prega a necessidade de mudanças internas profundas em cada um de nós, para que realmente o mundo possa passar do caos à harmonia. ${ }^{516}$

Esse encontro certamente ajudaria a fixar ainda mais a simbologia das africanidades à imagem de Gil. Em outra entrevista que reuniu os dois artistas, Cliff disse:

Tínhamos que nos juntar, mais cedo ou mais tarde, vejam: não há mais terras a ser descobertas, o que temos a fazer agora, é juntar o que existe. Meu encontro espiritual com Gil já se deu há anos,

\footnotetext{
${ }^{514}$ Éconstante nas entrevistas Gil afirmar que prefere o palco ao estúdio.

515 Paulo Dias afirma que: A presença musical banto é noticiada por cronistas e viajantes a partir do século XVII, quando descrevem, sobretudo duas modalidades de eventos com música e dança: um de caráter mais recôndito, intracomunitário, feito à noite nos terreiros das fazendas ou nas senzalas, nos dias de descanso, a que denominaram batuques, outro de caráter público, em que os bantos das irmandades católicas de negros saem em cortejo nas festas religiosas ou oficiais acompanhando seus Reis Congos e louvando Nossa Senhora do Rosário, as congadas. In: Diásporas musicais africanas no Brasil. 2008 $<\mathrm{http}$ ://www.fluxosmusicais.com/debate/dias poras-musicais-africanas-no-brasil/>

${ }^{516}$ SILVA, José Antônio. O canto de paz de Jimmy Cliff, mas com embalo. Folha de S. Paulo, 19 maio 1980.
} 
quando nos conhecemos. O que vocês vão ver agora é apenas a manifestação física desse encontro. ${ }^{517}$

A ideia de um encontro espiritual pode ser analisada através da perspectiva do Atlântico Negro. Para Gilroy, a diáspora negra não só rompeu com a sequência dos laços explicativos entre lugar, posição e consciência, como também com o poder do território para determinar a identidade. Gilroy rejeita a ideia de uma cultura territorial fechada e codificada no corpo, e afirma que:

Sob a chave da diáspora, nós poderemos então ver não a raça, e sim formas geopolíticas e geoculturais de vida que sãoresultantes da interação entre sistemas comunicativos e contextos que elas não só incorporam, mas também modificam e transcendem. ${ }^{518}$

Esse encontro de Gil e Cliff representou a interação musical entre esses dois artistas, um laço criado pela identificação através dos códigos culturais negros, e, nesse caso, especialmente o reggae.

$\mathrm{Na}$ reportagem "A negritude como realce brasileiro", realizada em motivo do lançamento do LP Luar, Gil discorreu não apenas sobre sua maneira de compor, mas também sobre sua concepção de África e sobre a negritude experimentada naquele momento. A seguir, a transcrição de um trecho da reportagem:

Sua penúltima banda, montada especialmente para o show 'Realce', reunia apenas músicos negros. E a que formou recentemente, com a qual vem ensaiando diariamente, já conta com alguns instrumentistas brancos. É que Gil diz não acreditar num pensamento radical negro. Mas acrescenta que sua música o é. Sóque ela também faz uso do romantismo, do liris mo peculiar ao europeu branco, misturando tudo à sua vertente basicamente ne gra. Foi por essa razão que falou tanto do reggae. É a necessidade de se mostrar a existência de muitas Áfricas espalhadas pelo mundo. Ele diz: "O reggae me deu um gancho para mostrar o grande Is rael africano, espalhado por aí através das milhares de caravelas que saíram rodando os continentes." E acrescenta: "Temos de perceber que a visão que temos do mundo deve ser planetária, porque a informação está distribuída por todo o globo. E a tecnologia é básica em todos os países. Assim não era possível que o desterro do negro permanecesse. A África acabou por aparecer como a mãe pátria de todos os ne gros. A ne gritude é um te rmo emergente, mas não é um assunto somente do negro. A negritude mode rna não é uma conquis ta da sociedade moderna. Daí a identificação com os gays, lésbicas, as minorias. Não são os

\footnotetext{
${ }^{517}$ Apud CAMBARA, Isa. Cliff e Gil, com a mesma emoção. Folha de S. Paulo, 23 maio 1980.

${ }^{518}$ GILROY, Paul. O Atlântico negro..., op. cit., p.25.
} 
negros que são beneficiados com isso. É toda a sociedade, porque o negro está oferecendo aquilo que antes era proibido pelos brancos, ou seja, sua negritude. Assim nós estamos começando a ter um novo padrão estético, Steve Wonder, Bob Marley são importantes para o mundo inteiro porque estão ajudando a modificar a cabeça do branco. O que é necessário. ${ }^{519}$ [ grifos meus]

Gil mescla a concepção panafricanista somada à demanda de outras minorias na tentativa de reverter a superioridade civilizatória do Ocidente em relação às culturas de origem africana. A africanidade por Gil explorada é aquela da diáspora, representada nesse momento pelo reggae.

Outra fonte que nos permite compreender essa fase de Gil é o longa-metragem Corações a mil, gravado em 1981 e lançado em 1983 por Tob Azulay, dimensionando o universo artístico de Gil naquele momento. Gil é o personagem principal, interpretando a si mesmo, e também produtor do filme que acompanha sua excursão para a divulgação do LP Luar. A narrativa se constrói através do pesquisador/professor de comunicação chamado Jairo, que está escrevendo uma tese na intenção de compreender o sucesso de um astro. Sua missão é descobrir a fórmula secreta utilizada por Gil para conquistar as massas. Na trama, Regina Casé é uma fã apaixonada que acompanha a trupe e ajuda Jairo a encontrar Gil. Os figurinos, especialmente os de Gil, fazem menção ao universo pop, ou pelas sandálias de plástico, pelas roupas de cetim do figurino dos shows ou mesmo pela lua e estrela descoloridas e estampadas no seu cabelo. Não há no figurino ou no cabelo expressões de africanidades, como aqueles percebidos em momentos anteriores a esse, mas sim muitas menções referentes ao mundo pop e do rock. ${ }^{520}$

Em 1982, Gil lançou o LP Umbandaum ${ }^{521}$, e é ele quem nos informa, no ano de seu lançamento, sobre a escolha desse nome:

Adorei ter cunhado esse som 'Um banda', porque é uma maneira de homenagear a umbanda, a única religião brasileira, a meu ver. No entanto, nós temos vivido tanto essa coisa de candomblé como algo puro e nos esquecemos da umbanda, como se ela fosse impura. Por isso quis democratizar, homenageando

\footnotetext{
${ }^{519}$ ALMEIDA, Miguel. A negritude como realce brasileiro. Folha de S. Paulo, 29 mar. 1981.

${ }^{520}$ As tietes ou groupies geralmente são conhecidas por buscar intimidade emocional e/ou sexual com os músicos de uma banda. São termos utilizados para descrever garotas que perseguiam integrantes de bandas rock. Além da personagem de Regina Casé, no filme, Gil aborda também o tema na canção "Marcha da tietagem", presente no LP Luar.

521 Album Umbandaum (Warner Music, 1982).
} 
esse vira-lata da religião africana que é a umbanda. ${ }^{522}$

Em outra reportagem, sobre a concepção do disco, Gil afirmou:

Gosto de experimentar, mas sou conservador. Um pouco medroso. Talvez seja aquele medo de morrer que todos temos.

Umbandaum é o Refavela coado - diria. É uma cultura afro que não tem a ideologia do primitivismo. Não tem aquela localização africana. África do Brasil, África das Américas... Ah, eu não sei falar disso. ${ }^{523}$ [ grifos meus]

Além de dar título ao LP, “UmBandaUm” 524 é também a música que abre o disco, e pode ser sintetizada nas seguintes estrofes:

\author{
Banda Um que toca um balanço parecendo polka \\ UmBandaUmBandaUm \\ Banda Um que toca um balanço parecendo rumba \\ UmBandaUmBandaUm \\ Banda Um que é África, que é Báltica, que é Céltica \\ UmBanda América do Sul \\ Banda Um que evoca um bailado de todo planeta \\ UmBandaUm, Banda Um
}

A música apresenta a sonoridade pop dos anos 80, ou seja, bateria e baixo dançantes, além de teclados com efeitos muito presentes. Ao mesmo tempo, percebe-se o violão percussivo de Gil, e na terceira sessão a rítmica se organizando em torno do ijexá. $^{525}$

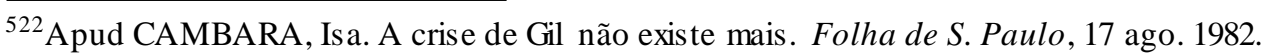

${ }^{523}$ Apud ALMEIDA, Miguel. A tristeza e rebeldia do amado Gilberto Gil. Folha de S. Paulo, 18 set. 1982. 524 "Banda um" (Gilberto Gil, 1981) BandaUmBandaUmBandaUmBanda - ô-iê/lê-iê-iê-iê /BandaUmBandaUmBandaUmBanda - ô-ô/(Iô-iô-iô-iô) /Banda Um que toca um balanço parecendo polka /UmBandaUmBandaUm /Banda Um que toca um balanço parecendo rumba /UmBandaUmBandaUm/Banda Um que é África, que é Báltica, que é Céltica /UmBanda América do Sul /Banda Um que evoca um bailado de todo planeta /UmBandaUm, Banda Um/BandaUmBandaUmBandaUmBanda - ô-iê/Iê-iê-iê-iê /BandaUmBandaUmBandaUmBanda - ô-ô/(Iôiô-iô-iô) /Banda pra tocar por aí /No Zanzibar /Pro negro zanzibárbaro dançar/Pra agitar o Baixo Leblon /O Cariri /Pra loura blumenáutica dançar /(Hum...) Banda Um, Banda Um/BandaUmBandaUmBandaUmBanda - ô-iê /Iê-iê-iê-iê/BandaUmBandaUmBandaUmBanda - ô, ô /Banda Um que soa um barato pra qualquer pessoa/UmBanda pessoa afins /Banda Um que voa, uma asa delta sobre o mundo /UmBanda sobre patins /Banda Um surfística nas ondas da manhã nascente /UmBanda, banda feliz /Banda Um que ecoa uma cachoeira desabando /UmBandaUm, bandas mis/BandaUmBandaUmBandaUmBanda - ô-iê//ê-iê-iê-iê /BandaUmBandaUmBandaUmBanda - ô-ô/(Iôiô-iô-iô)In: RENNÓ, Carlos (org.) Gilberto Gil todas as letras. São Paulo: Companhia das Letras, 1996, p. 245.

${ }^{25}$ Porém sem uma referência explicita de sua clave, embora sua marcação seja claramente exposta.
} 
É interessante salientar que não se trata de uma ode somente à África ou a algum simbolismo específico que caracterize a negritude, já que o título parece fazer essa invocação. A menção à umbanda aqui pode ser interpretada com a postura de Gil de compreender a etnicidade de maneira plural e não essencialista. Ao escolher a umbanda, e não o candomblé, ele aborda o hibrid is mo de uma religiosidade que mescla catolicis mo, kardecismo e politeísmo africano. Vários são os símbolos aqui mencionados, que vão desde locais que demarcam diferentes classes sociais, como o Zanzibar dos negros e a Blumenau das loiras, passando pela democratização de atingir com sua sonoridade um vasto número de pessoas. Não há um único mensageiro receptor dessa mensagem, que se destina tanto àqueles que gostam de asa-delta e de patins, mas também de surfe ou cachoeira. Novamente fica perceptível que as africanidades se misturam a outras referências, de diferentes povos, culturas. Gil evoca todo planeta.

Outra faixa do LP que tematiza a ligação com as africanidades é Afoxéé:

$$
\begin{gathered}
\text { Ê-ô, ê-ô } \\
\text { Ê-ô, ê-ô } \\
\text { É bom pra ioiô } \\
\text { É bom pra iaiá }
\end{gathered}
$$

O afoxé é da gente

Foi de quem quis

É de quem quiser

Sair do Pé do Caboclo

Até a Praça da Sé

O afoxé é semente

Plantou quem quis

Planta quem quiser

Tem que botar fé no bloco

Tem que gostar de andar a pé

Tem que aguentar sol a pino

Tem que passar no terreiro

E carregar o menino, oh, oh

Tem que tomar aguaceiro

Tem que saber cada hino

E cantar o tempo inteiro, oh

O afoxé, seu caminho

Sempre se fez

Sempre se fará

Por onde estiver o povo 


\section{Esperando pra dançar}

O afoxé vai seguindo

Sempre seguiu

Sempre seguirá

Com a devoção do negro

E a bênção de Oxalá 526

A letra retrata as "obrigações" do devoto junto ao afoxé; na sonoridade, a clave do ijexá é exposta claramente na levada do agogô, mas o que envolve essa clave é uma textura pop. É interessante novamente salientar, sobre o universo temático de Gil, que as onze canções desse LP tratam também do amor, da poesia e do esoterismo. A África é aquela da diáspora, das reconstruções realizadas na pós-colonialidade.

Em 1983, Gil foi convidado por Cacá Diegues para criar a trilha sonora do filme Quilombo. A sugestão de Gil foi que Waly Salomão fosse o letrista. A banda que gravou a trilha foi a mesma que acompanhou Gil em Umbandaum, mais o trompetista Márcio Montarroyos. Para reforçar ainda mais a percussão de Repolho, Gil convidou Jorge Santos e Djalma Correia. No Brasil, apenas uma versão reduzida da trilha foi lançada. Segundo Gil, "Eles aqui não se interessaram, por ser uma trilha com muitas incidentais e apenas três faixas com letra. ${ }^{, 527}$ Apesar de se tratar de um disco que não foi lançado no país e das letras não terem sido compostas por Gil, a escolha de Diegues indica que o cineasta buscou em Gil uma musicalidade que representasse as africanidades. ${ }^{528}$

Em 1983, Gil lançou o LP Extra ${ }^{529}$, e as africanidades podem ser expressas pela música "Funk-se quem puder":

$$
\begin{aligned}
& \text { Funk-se quem puder } \\
& \text { É imperativo dançar } \\
& \text { Sentir o ímpeto } \\
& \text { Jogar as nádegas } \\
& \text { Na degustação do ritmo } \\
& \text { Funk-se quem puder }
\end{aligned}
$$

\footnotetext{
526، Afoxé é” (Gilberto Gil, 1981). In: RENNÓ, Carlos (org.) Gilberto Gil todas as letras. São Paulo: Companhia das Letras, 1996, p. 246.

527 Encarte da caixa "Palco", texto de Marcelo Froes, junho 2002. Disponível em: <www.gilbertogil.com.br>.Acesso em: 21 dez. 2015.

528 em 1976, outro filme de Diegues, Xica da Silva, tematizando também a época da escravidão no Brasil, teve sua canção homônima composta por Jorge Benjor.

${ }^{529}$ ÁlbumExtra (Warner Music, 1983).
} 
É imperativo tocar

Fogo nas vértebras

Fogo nos músculos

Música em todos os átomos

A nossa atlântica é atlética

Romântica e poética

República da música

Conclama os físicos, místicos

Bárbaros, pacíficos

Índios e caras-pálidas

Nossos exércitos, políticos

Poder eclesiástico

E o comitê do carnaval

É hora de salvar a pélvis

Soltá-la, libertá-la

Agitá-la como o Elvis

Grande guerreiro e mártir

Da nação do rock'n'roll

Funk-se quem puder

Se é hora da barca virar

Não entre em pânico

Jogue-se rápido

Nade de volta à mãe África

Funk-se quem puder

Se é tudo que resta a fazer

Não perca o ânimo

Chegue mais próximo

Sambe e roque-role o máximo

$\mathrm{Na}$ degustação do ritmo

Música em todos os átomos

Nade de volta à mãe África

Sambe e roque-role o máximo ${ }^{530}$

A África é percebida enquanto espaço representado por ritmo e dança, e os ritmos evocados nessa construção de negritude são o rock, o funk e o samba. Nessa música, Gil trabalha uma sonoridade dançante, com uso dos metais, bateria e baixo em ritmo de funk americano, seguindo a estética da música afro-americana. É um funk com os timbres

530“Funk-se quem puder" (Gilberto Gil, 1983).In: RENNÓ, Carlos (org.) Gilberto Gil todas as letras. São Paulo: Companhia das Letras, 1996, p. 266. 
típicos dos anos 80, programações de efeitos de percussão, além de teclados muito presentes.

Em 1984, Gil lançou o LP Raça Humana ${ }^{531}$ e também gravou na Jamaica o reggae "Vamos fugir", com a participação do grupo The Wailers. ${ }^{532}$ Sobre a criação de Raça Humana, Gil disse à Veja:

Não me incluam na geração de samba \& mulatas. Eu poderia estar muito rico cantando samba, mas minha sedução é pela juventude internacionalizada, sem preocupações fronteiriças. Não abro mão da linha evolutiva que, afinal, ajudei a fundar no Brasil com a Tropicália. ${ }^{533}$ [grifos meus]

Segundo a reportagem, o show Raça Humana contava com dois grupos de dançarinos negros fazendo evoluções de break no palco. Gil comentou que se mantinha afastado de folclorizações, mas há que se notar que em outros momentos é justamente essa roupagem que Gil busca. Na maior parte das vezes, o que se faz notar pelos depoimentos de Gil é sua necessidade de não se ater a determinadas fronteiras.

No disco Raça humana, as letras todas trazem a experiência de uma amargura, que de acordo com Gil representam também o trauma de ter sido assaltado e ameaçado dentro de sua casa. Dentre as músicas do disco, uma nos é essencial para refletirmos sobre os ecos da África: "A mão da limpeza":

$$
\begin{gathered}
\text { O branco inventou que o negro } \\
\text { Quando não suja na entrada } \\
\text { Vai sujar na saída, ê } \\
\text { Imagina só } \\
\text { Vai sujar na saída, ê } \\
\text { Imagina só }
\end{gathered}
$$

Que mentira danada, ê

$$
\begin{gathered}
\text { Na verdade a mão escrava } \\
\text { Passava a vida limpando } \\
\text { O que o branco sujava, ê } \\
\text { Imagina só } \\
\text { O que o branco sujava, ê }
\end{gathered}
$$

\footnotetext{
531 ÁlbumRaça humana. (Warner Music, 1984).

${ }^{532}$ Disponível em: <www.gilbertogil.com.br>. Acesso em: 22 dez. 2015.

${ }^{533}$ Apud SOUZA, Okky. De passaporte novo. Veja, ed. 843, 31 out. 1983.
} 
Imagina só

O que o negro penava, $\hat{\mathrm{e}}$

Mesmo depois de abolida a escravidão

Negra é a mão

De quem faz a limpeza

Lavando a roupa encardida, esfregando o chão

Negra é a mão

É a mão da pureza

Negra é a vida consumida ao pé do fogão

Negra é a mão

Nos preparando a mesa

Limpando as manchas do mundo com água e sabão

Negra é a mão

De imaculada nobreza

Na verdade a mão escrava

Passava a vida limpando

O que o branco sujava, $\hat{\mathrm{e}}$

Imagina só

O que o branco sujava, $\hat{\mathrm{e}}$

Imagina só

Eta branco sujão $0^{534}$

Sobre a criação dessa letra, Gil comentou:

Eu fiz A Mão da Limpeza para repor certas coisas no lugar e remendar um preconceito histórico contra os negros; para responder, no mesmo tom, um desaforo - o velho ditado: 'Negro, quando não suja na entrada, suja na saída' (...) No fundo, o provérbio tem uma conotação nitidamente moral, além de física; o que se tenta considerar como sujo no negro é sua existência, sua pessoa, sua condição humana. Nesse sentido é muito mais terrível, e a música nem alcança a dimensão da crítica disso; ela apenas toca nisso. Mas jogando a sujeira como algo produzido preferencialmente pelos brancos, ela faz a limpeza da nódoa que quiseram impor aos negros. E deixa implícita também uma condenação moral aos brancos. Ou seja: 'Sujos na verdade são vocês, de corpo e alma; pelo menos, mais sujos que os negros

534“A mão da limpeza” (Gilberto Gil, 1984). In: RENNÓ, Carlos (org.) Gilberto Gil todas as letras. São Paulo: Companhia das Letras, 1996, p. 288. 
vocês são. Há muito mais sujeira a apurar ao longo do processo da civilização de vocês do que da nossa.' É o que a música diz. E ela diz o que tem a dizer, com contundência e eficácia. [ grifos meus $]^{535}$

Ao afirmar que no processo de civilização os brancos têm mais contas que acertar do que os negros, e ao utilizar a expressão "nossa sujeira" - negra, portanto -, Gil identifica nesse momento que o seu lugar e a sua identidade são negros. Quem nos informa sobre a luta pelo reconhecimento é d'Adesky, que afirma:

Antes de tudo, responder-se-á que o homem não procura somente o conforto material. Ele sonha também em estar no cume. Isso faz parte de suas ambições e de seus fantasmas. Ele sente necessidade de ter seus ídolos, de se ver numa história. Tais desejos simbólicos comprovam a importância para o indivíduo de ver conferidos atributos positivos aos elementos da etnicidade. 536

Assim sendo, a canção referencia seu desejo de reconhecimento para a identidade negra. Gil denuncia a maneira como os brancos durante séculos depreciaram os negros, situação essa que não apenas deformou, como oprimiu, gerando a introjeção de imagens quase sempre negativas referentes aos negros. Essa letra representa um exemplo de luta em prol do reconhecimento da dignidade humana, através da afirmação do negro marginalizado e excluído de seus direitos, condenados por muito tempo a permanecer na base da escala social. Denuncia uma situação da falta de perspectiva dos negros, revelando o enorme fosso existente entre o direito pela igualdade e a permanência da desigualdade. Quem trata dessa situação é Hall, que afirma que:

(...) que tipo de momento é esse para se colocar a questão da cultura popular negra? Esses momentos são sempre conjunturais. Eles têm sua especificidade histórica; e embora sempre exibam semelhanças e continuidades com outros momentos, eles nunca são o mesmo momento. E a combinação do que é semelhante com o que é diferente define não somente a especificidade do momento, mas também a especificidade da questão (...) ${ }^{537}$

O racismo na canção é denunciado através de situações de conflito entre brancos e negros, pelo não reconhecimento dos segundos pelos primeiros. Ao considerar tais sentimentos de inferioridade creditados aos negros, Gil pontua que tal situação se faz notar desde os tempos do cativeiro, mas as anuncia como um problema da atualidade.

\footnotetext{
${ }^{535}$ Apud RENNÓ, Carlos. Gilberto Gil: todas as letras..., op. cit., p. 288.

${ }^{536}$ D’ADESKY, Jacques. Pluralismo Étnico e multiculturalismo..., op. cit., p.75.

${ }^{537}$ HALL, Stuart. Da diáspora..., op. cit., p. 31.
} 
A sonoridade da música remete ao reggae, no qual a marcação da guitarra em contratempo se relaciona com a rítmica pop e os efeitos de percussão remetem ao reggae. A linha de baixo também expressa claramente o reggae, assim como as intervenções melódicas, mas tudo isso em torno da bateria pop e dos teclados que traziam a atmosfera pop dos anos 80. A sonoridade dialoga com a diáspora transatlântica da pós-colonialidade e o discurso é de descontentamento com o racismo.

Em 1985, a participação de Gil no Rock in Rio e os comentários sobre seu figurino nos dão indícios para pensarmos as africanidades experimentadas pelo artista naquele momento:

Contra a pirotecnia heavy metal, Gil, com um vis ual mais para o pop chique do que para o rastafári rastaquera, foi quem insinuou, pela primeira vez no festival, uma sonoridade inteligente e contemporânea. Foi "leve metal". Foi do rock ao funk, passando pelo reggae e homenageando Stevie Wonder, com uma ótima versão de "I just call to say I love you" ${ }^{338}$ [ grifos meus]

Juízos de valor à parte, o figurino de Gil não se fazia mais representar pelas tranças e batas de outrora. Em um vídeo do festival ${ }^{539}$, é possível perceber que o figurino de Gil estava atrelado ao universo pop pelo casaco brilhante encobrindo seu peito nu, além de um corte de cabelo em nada atrelado ao mundo afro, mas sim fortemente identificado com o universo pop.

Em Dia Dorim noite neon ${ }^{540}$, a temática do racismo é levantada nas canções "Touche pás a mon pote":

Touche pas à mon pote

Ça veut dire quoi?

Ça veut dire peut être

Que l'Être qui habite chez lui

C'est le même qui habite chez toi

Touche pas à mon pote

Ça veut dire quoi?

Ça veut dire que l'Être

Qui a fait Jean-Paul Sartre penser

Fait jouer Yannik Noah

Touche pas à mon pote

\footnotetext{
538 GONÇALVES, Marcos Augusto. Nacionais em nível internacional. Folha de S. Paulo, 15 jan. 1985. ${ }^{539}$ Dis ponível em: 〈http://www.youtube.com/watch?v=W xIBa7UmzlU〉. Acesso em: 12 fev. 2016. 540 Álbum Diadorim noite neon. (Warner Music, 1985).
} 
Il faut pas oublier que la France

A déjà eu la chance

De s'imposer sur la terre

Par la guerre

Les temps passés ont passé

Maintenant nous venons ici

Chercher les bras d'une mère

Bonne mère

Touche pas à mon pote

Touche pas à mon pote

Ça veut dire quoi?

Ça veut dire peut être

Que l'Être qui habite chez lui

C'est le même qui habite chez toi

Touche pas à mon pote

Ça veut dire quoi?

Ça veut dire que l'être

Qui a fait Jean-Paul Sartre penser

Fait jouer Yannik Noah

Il fait chanter Charles Aznavour

Il fait filmer Jean-Luc Goddard

Il fait jolie Brigitte Bardot

Il fait petit le plus grand Français

Et fait plus grand le petit Chinois

Touche pas à mon pote ${ }^{541}$

E também na letra de "Oração pela libertação da África do Sul”:

Se o rei Zulu já não pode andar nu

Se o rei Zulu já não pode andar nu

Salve a batina do bispo Tutu

Salve a batina do bispo Tutu

Ó, Deus do céu da África do Sul

\footnotetext{
${ }^{541}$ Tradução: "Não toque em meu amigo!/O que significa isso?/Isso quer dizer que o Ser/Que fez JeanPaul Sartre pensar/Fez jogar Yannik Noah/"Não toque em meu amigo"/Não devemos esquecer que a França/Já teve a chance/De se impor sobre a Terra/Pela guerra/Os tempos passados passaram/Agora vimos aqui procurar os braços de uma mãe boa mãe/"Não toque em meu amigo"/"Não toque em meu amigo"/O que significa is so?/Isto quer dizer, talvez/Que o Ser que habita nele/É o mesmo que habita em você/"Não toque em meu amigo"/O que significa is so?/Is so quer dizer que o Ser/Que fez Jean-Paul Sartre pensar/Fez jogar Yannik Noah/Ele faz Charles Aznavour cantar/Ele faz Jean-Luc Goddard filmar/Ele faz bela Brigitte Bardot/Ele faz pequeno o maior francês/E faz maior o pequeno chinês/"Não toque em meu amigo".
} 


\section{Do céu azul da África do Sul}

Tornai vermelho todo sangue azul

Tornai vermelho todo sangue azul

Já que vermelho tem sido todo sangue derramado

Todo corpo, todo irmão chicoteado - iô

Senhor da selva africana, irmã da selva americana

Nossa selva brasileira de Tupã

Senhor, irmão de Tupã, fazei

Com que o chicote seja por fim pendurado

Revogai da intolerância a lei

Devolvei o chão a quem no chão foi criado

Ó, Cristo Rei, branco de Oxalufã

Ó, Cristo Rei, branco de Oxalufã

Zelai por nossa negra flor pagã

Zelai por nossa negra flor pagã

Sabei que o papa já pediu perdão

Sabei que o papa já pediu perdão

Varrei do mapa toda escravidão

Varrei do mapa toda escravidão $0^{542}$

Em “Touche pás a mon pote”, a sonoridade tem a base no ijexá. A guitarra percussiva nos leva à marcação do samba-reggae e os efeitos dos teclados fazem menção à música pop. Em "Oração pela África do Sul”, a sonoridade é construída em torno da guitarra rítmica, evocando o reggae em compasso composto, mas o acompanhamento do piano, baixo e guitarra nos remete à música americana, algo entre o funk e o blues com um solo de guitarra bem ao estilo rock'n'roll. Sobre a criação dessas canções, Gil contou:

Eu tinha ido ao evento do movimento SOS Racismo, na Place de la Concorde, em Paris, e, lá, sido convidado a (e aceitado) participar da edição do mesmo no ano seguinte, marcada para a praça da Bastilha. Ao voltar ao Brasil - com o slogan deles, o 'touche pas à mon pote' ('não incomode meu chapa'), na cabeça, resolvi fazer a canção. "O que faz o Sartre pensar faz o Yannik Noah jogar (Noah: jogador de tênis de origem africana, exemplo de imigrante bem-sucedido na França). Ou: 'Como é que vocês, povo da Liberdade, da Igualdade e da Fraternidade, se deixam rebaixar por tamanha mesquinharia? Isso é coisa de Hitler, não de vocês!' É a exortação da canção à alma francesa, às suas grandes máximas cívicas - recorrendo particularmente ao truque

542“"Oração pela libertação da África do Sul” (Gilberto Gil, 1985) In: RENNÓ, Carlos (org.) Gilberto Gil todas as letras. São Paulo: Companhia das Letras, 1996, p. 305. 
de usar essa entidade tão importante que é o 'ser', que diz respeito profundamente à obra de Sartre -, para tocar na questão da intolerância racial. "Oração pela Libertação da África do Sul" foi feita para atender a um pedido explícito do físico Mário Schenberg, que queria uma música para, sobre a África do Sul. $\mathrm{Eu}$ ainda disse: 'Nós temos feito protestos, manifestações, assinado manifestos contra o apartheide tal'. E ele: 'Mas não é suficiente; é preciso uma canção'. Fiz a canção e a dediquei a ele. ${ }^{543}$

Ambas as canções referenciadas acima demonstram que foram criadas a partir de experiências vivenciadas pelo artista e transformadas em canção. Em 1986, Gil foi convidado especial da festa do movimento francês SOS Racismo, na praça da Bastilha, na mesma noite em que se apresentaram artistas franceses e africanos. ${ }^{544}$ No ano seguinte, Gil rememorou um fato vivenciado na França:

No ano passado botaram meu filho pra fora da boutique Saint Laurent da Rive Gauche. Chamei o SOS Racismo, que tem advogados especializados e nós fomos todos fazer uma manifestação em frente à loja. ${ }^{545}$

Não apenas as músicas de Gil simbolizam sua ligação com o continente africano, mas também seu figurino e a imagem de negritude a ele associada por diferentes meios de comunicação. Após a gravação da trilogia "Re" a negritude é especialmente conectada à denúncia contra o racismo. Não houve exaltação da África ou a seus ancestrais, e a opção estética pela musicalidade do rock, do funk e do reggae demonstram a afinidade de Gil com as africanidades musicais da diáspora, do Atlântico negro. Não há no artista a intenção de exaltar a escolha de uma africanidade, mas sim mesclá-la com uma série de outras temáticas e signos. O LP Umbandaum dimensiona bem a postura adotada por Gil por abordar uma África inventada no Brasil. É uma África multifacetada e recriada nas Américas, é essa a África que ele canta. As africanidades de Gil são plurais. Não estão demarcadas e nem encontram fácil localização. Elas se mostram híbridas, numa conexão que mescla o reggae, funk, rock, samba, ijexá e o pop, num diálogo processado através dos sintetizadores.

É possível também perceber os ecos de África nas transformações visuais de Gil através de fotos das décadas de 1960, 1970 e 1980. No acervo do Instituto Antônio Carlos Jobim, ${ }^{546}$ foi possível acessar imagens de Gil que em muito nos informam sobre seus

\footnotetext{
${ }^{543}$ Apud RENNÓ, Carlos. Gilberto Gil: todas as letras..., op. cit., p. 305-306.

${ }^{544}$ Disponível em:<www.gilbertogil.com.br>. Acesso 14 dez. 2015.

${ }^{545}$ Apud FORGANES, Rosely. O ANTIRRACISMO de Gil na França. Folha de S. Paulo, 03 jul. 1986.

$546<$ http://www.jobim.org/gil/>
} 
figurinos nessas três décadas, demarcadas tanto pela ausência de africanidades, nos anos 1960, como por sua forte e marcante presença nos anos 1970, para pequenas menções às africanidades nos anos 1980.

A seguir, fotos dos anos 1960:

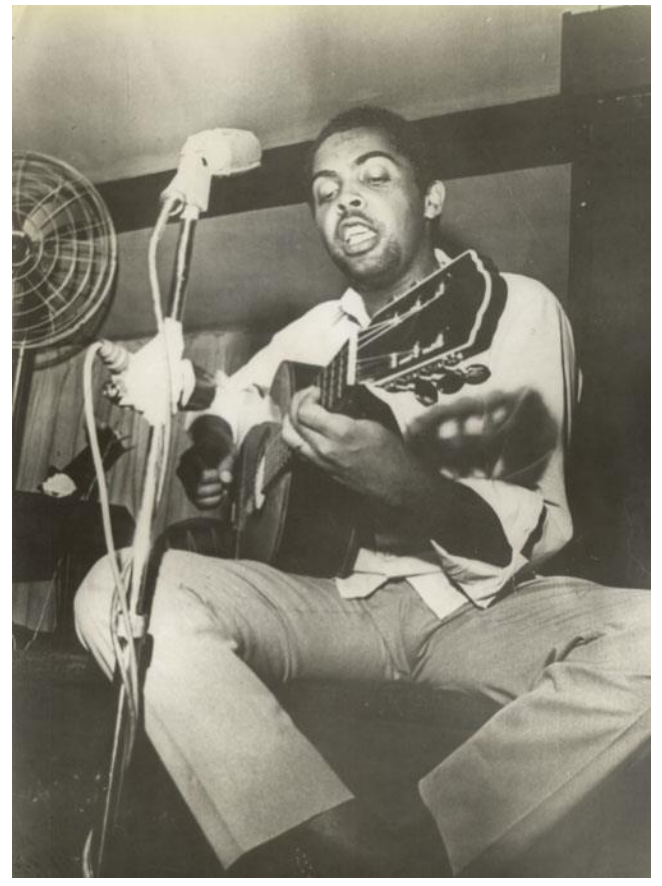

Figura 9 - Foto de 1966. Autor: Roberto Santana. Fonte: Acervo Gilberto Gil Instituto Antonio Carlos Jobim 


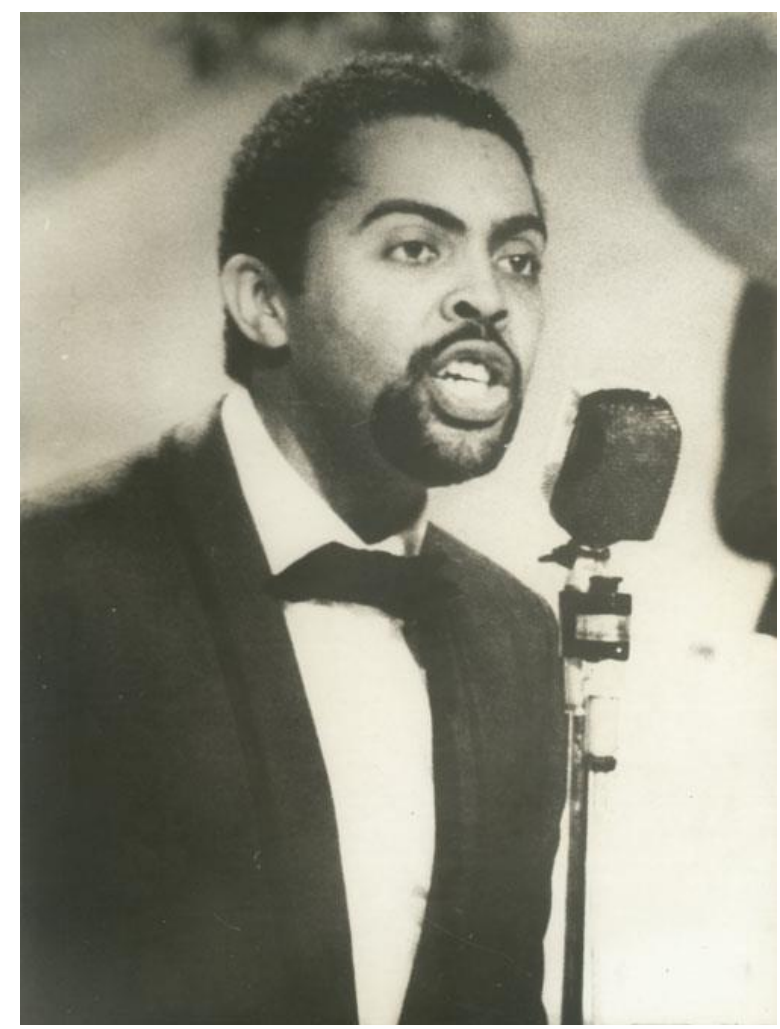

Figura 10 - Foto de 1996. Festival Internacional da Canção. Autor: não identificado. Fonte: Acervo Gilberto Gil Instituto Antonio Carlos Jobim

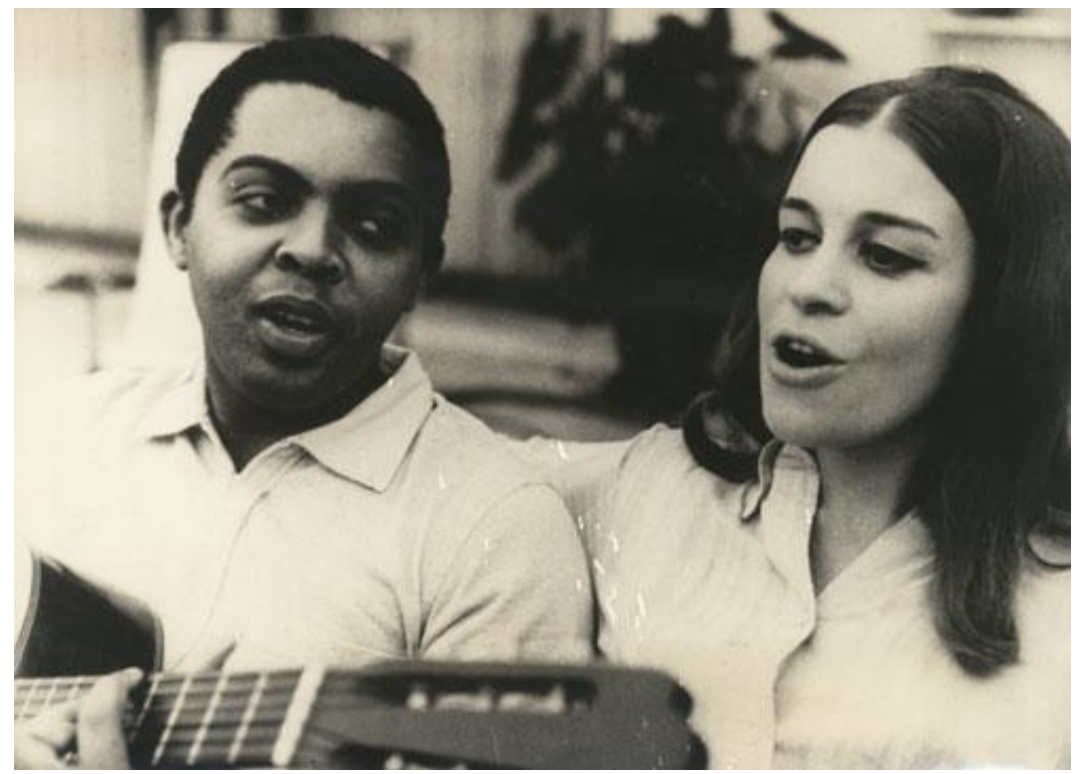

Figura 11 - Foto de 1966. Gilberto Gil e Wanda Sá, no Rio de Janeiro. Autor: não identificado. Fonte: Acervo Gilberto Gil Instituto Antonio Carlos Jobim 


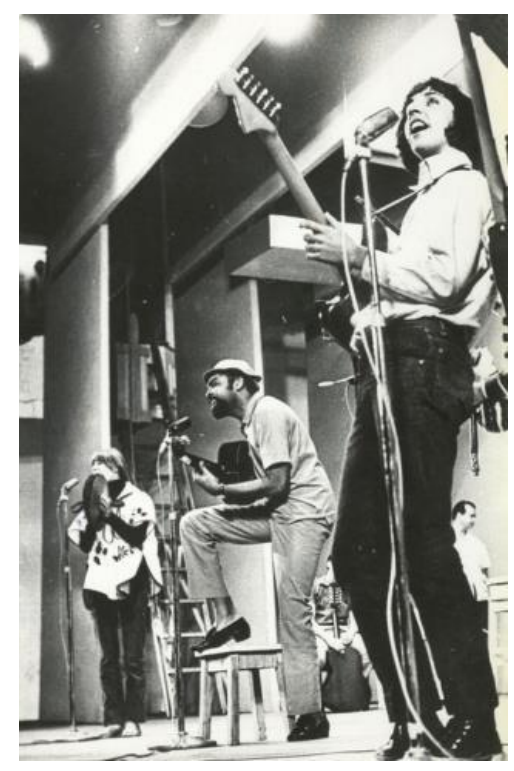

Figura 12 - Foto de 1967. Gil e Os Mutantes apresentando a música Domingo no parque. Autor: não identificado. Fonte: Acervo Gilberto Gil Instituto Antonio Carlos Jobim

O cabelo bem curto e as roupas ainda bastante formais faziam parte de um visual que não apresentava nesse momento pré-exilio nenhum identificador que representasse afinidade com o mundo das africanidades. Uma significativa mudança ocorreria no momento do exílio em Londres, como é possível perceber nas fotografias da época:

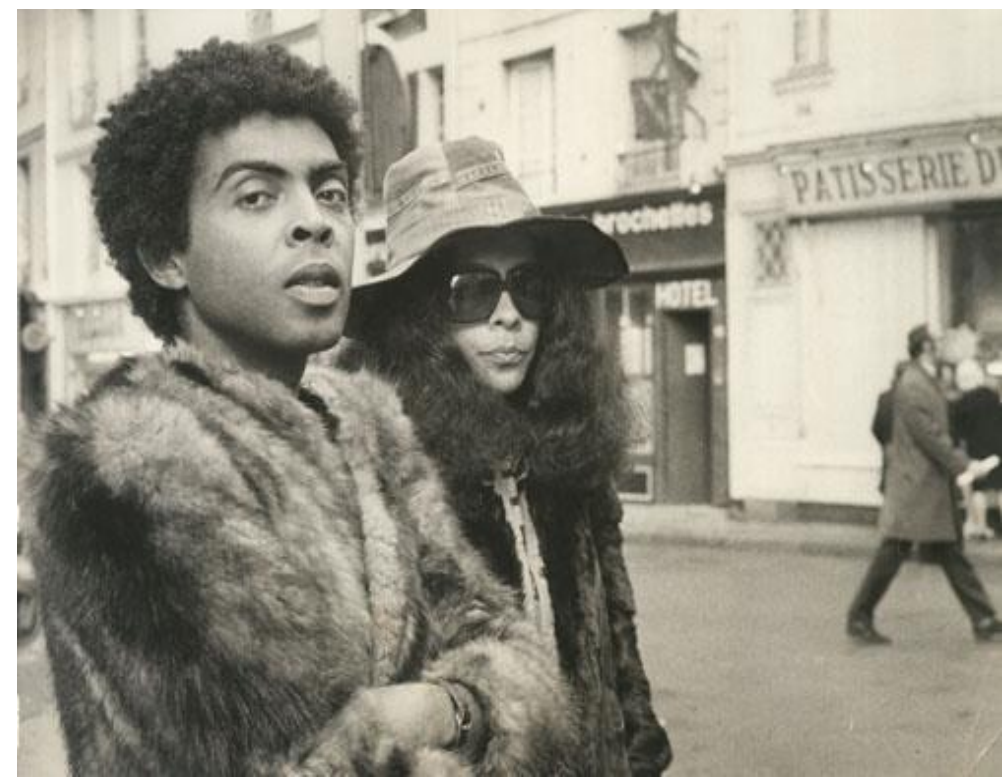

Figura 13 - Foto de 1971. Gil e Gal em turnê pela França. Autor: não identificado. Fonte: Acervo Gilberto Gil Instituto Antonio Carlos Jobim 


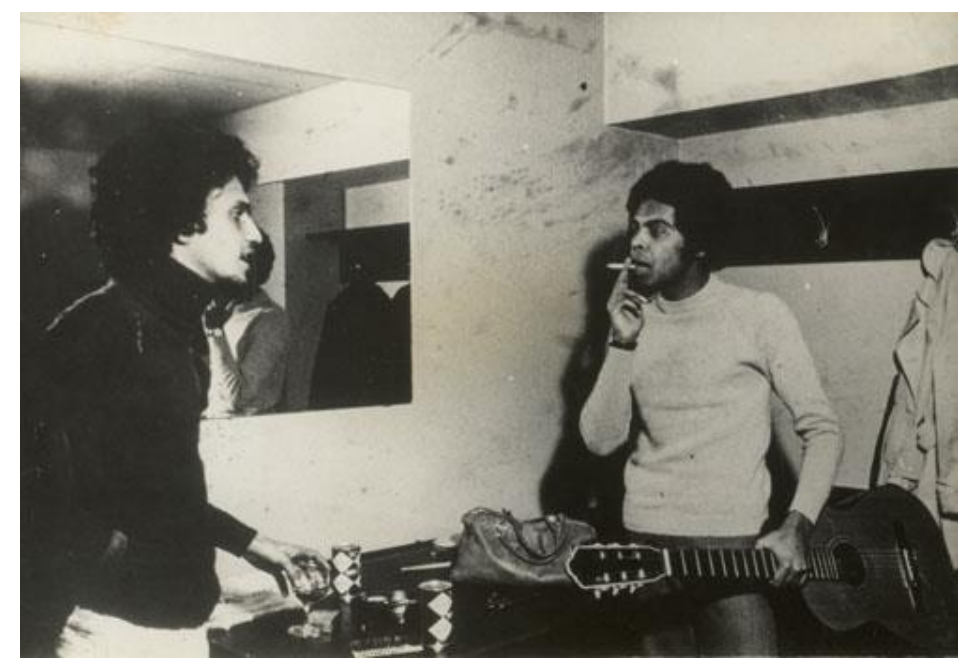

Figura 14 - Foto do início da década de 70. Gil com Caetano em Londres. Autor: não identificado. Fonte: Acervo Gilberto Gil Instituto Antonio Carlos Jobim

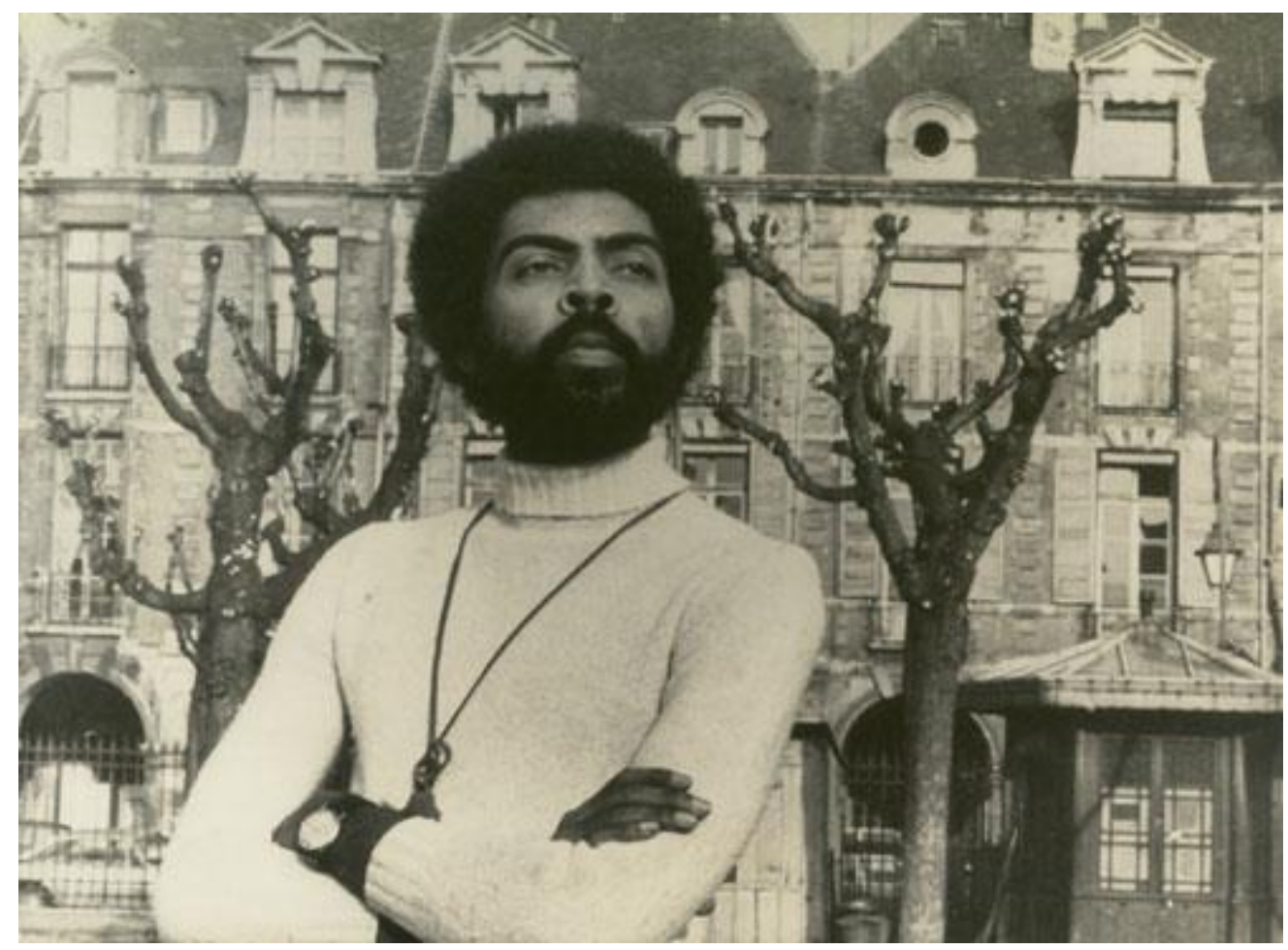

Figura 15 - Foto de 1972. Gil em Londres. Autor: não identificado. Fonte: Acervo Gilberto Gil Instituto Antonio Carlos Jobim

Foi nesse momento que Gil começou a adotar o cabelo black power e a vestir roupas menos formais. Os anos 70 são fortemente demarcados pela transformação de Gil quanto a suas africanidades, como se faz notar pelas fotografias a seguir. Registro que a utilização do black power também tem muito a ver com a proposta psicodélica. Caetano, Taiguara e vários outros também passam a usar cabelos assim nesse período. 


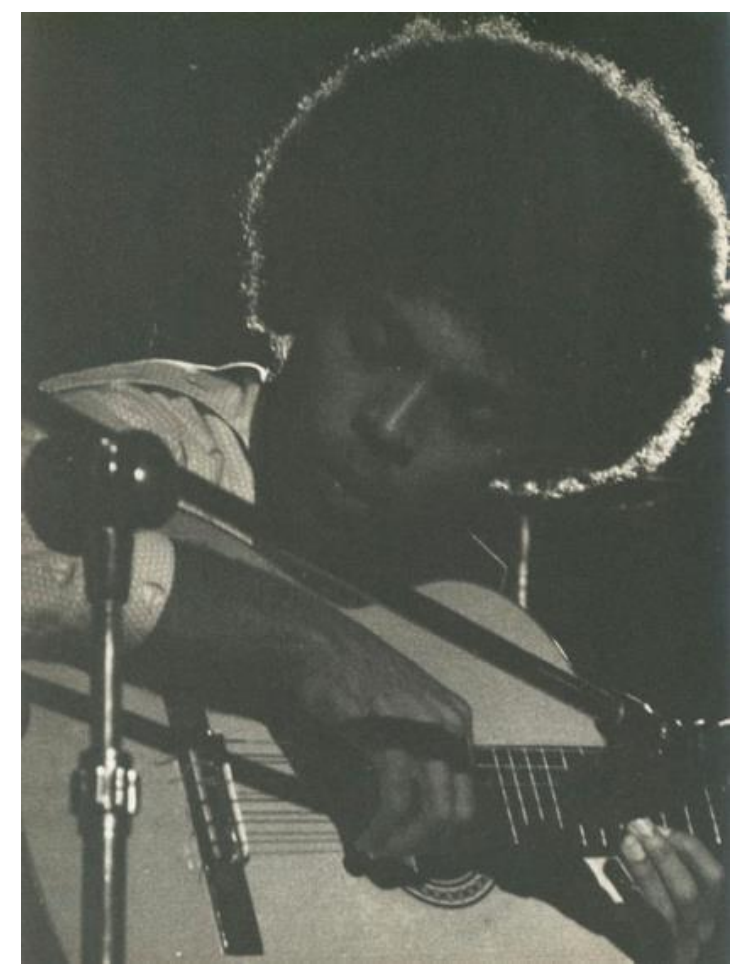

Figura 16 - Foto: década de 1970. Ator: Não identificado.

Fonte: Acervo Gilberto Gil Instituto Antonio Carlos Jobim

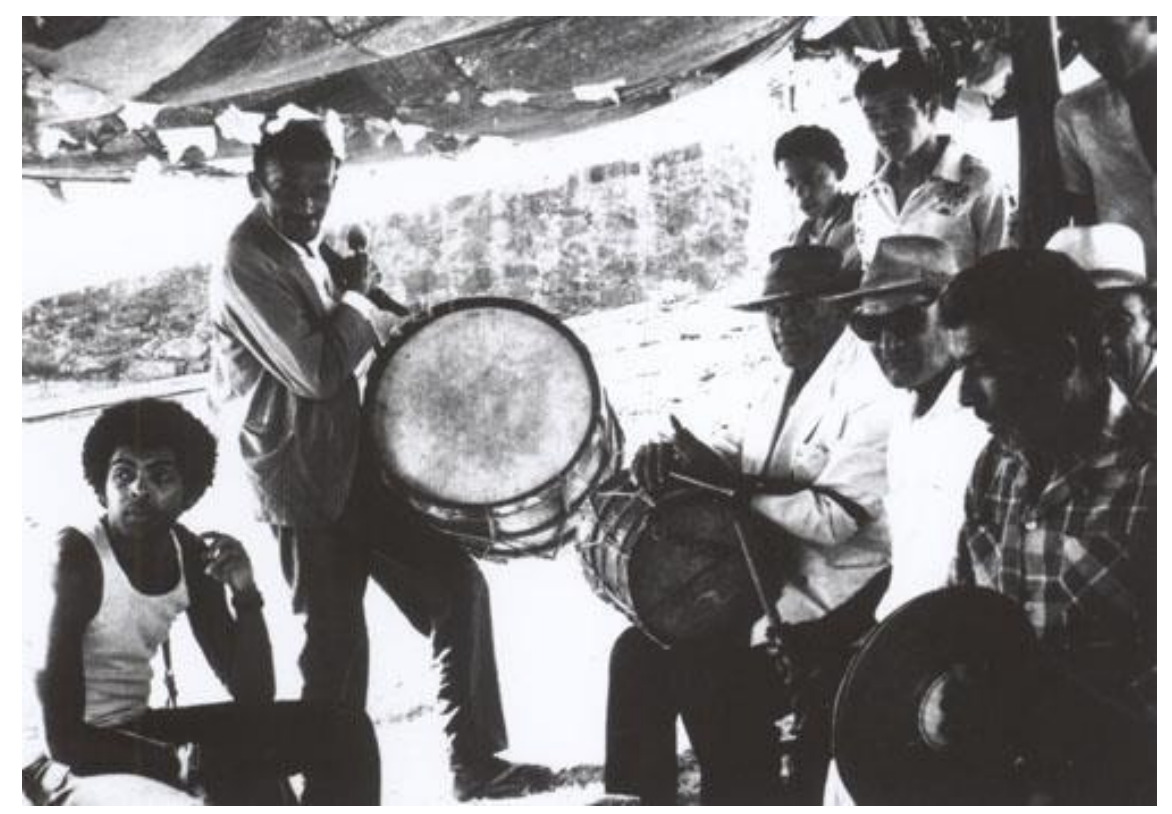

Figura 17 - Sem data definida, mas pelo visual de Gil se trata do momento pós-exílio, por volta de 1973. Autor: Não identificado.

Fonte: Acervo Gilberto Gil Instituto Antonio Carlos Jobim 


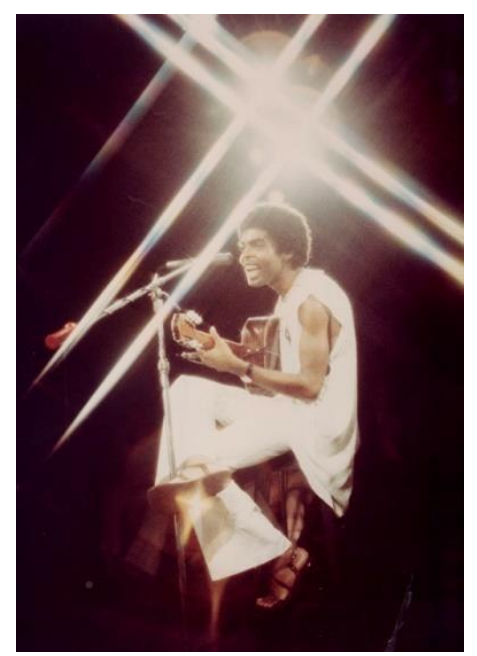

Figura 18 - Foto da década de 1970. Show em Nova York Fonte: Acervo Gilberto Gil Instituto Antonio Carlos Jobim

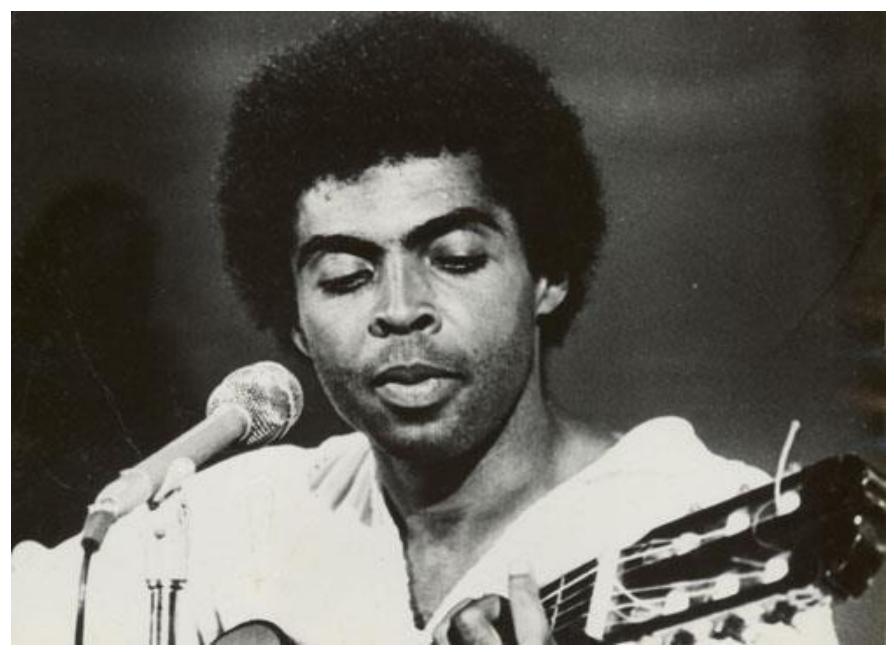

Figura 19 - Foto de 1974. Autor: Não identificado

Fonte: Acervo Gilberto Gil Instituto Antonio Carlos Jobim

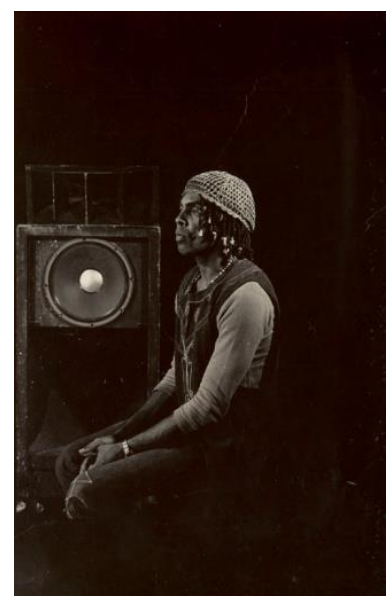

Figura 20 - Foto de 1975. Época de Refazenda. Autor: Não identificado. Fonte: Acervo Gilberto Gil Instituto Antonio Carlos Jobim 


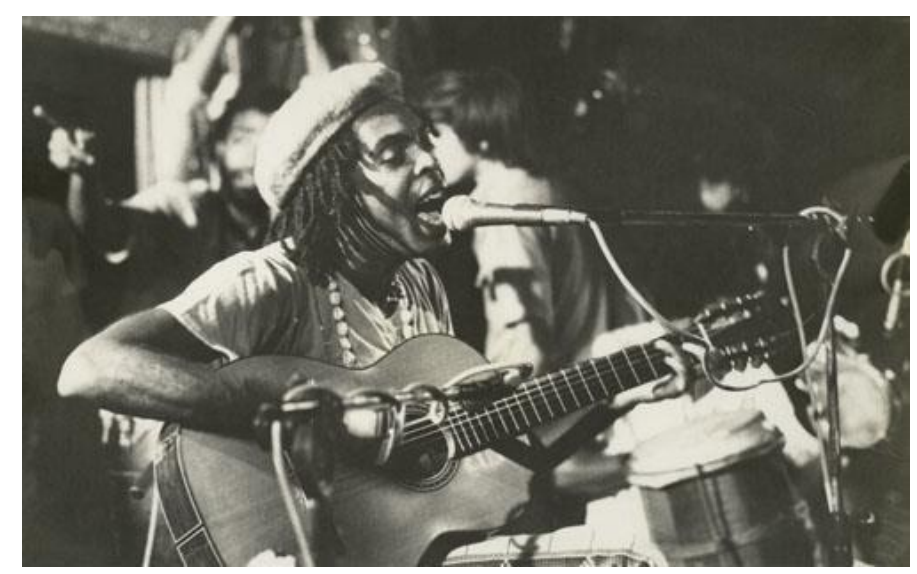

Figura 21 - Foto de 1977. Na época de Refavela. Autor: Não identificado. Fonte: Acervo Gilberto Gil Instituto Antonio Carlos Jobim

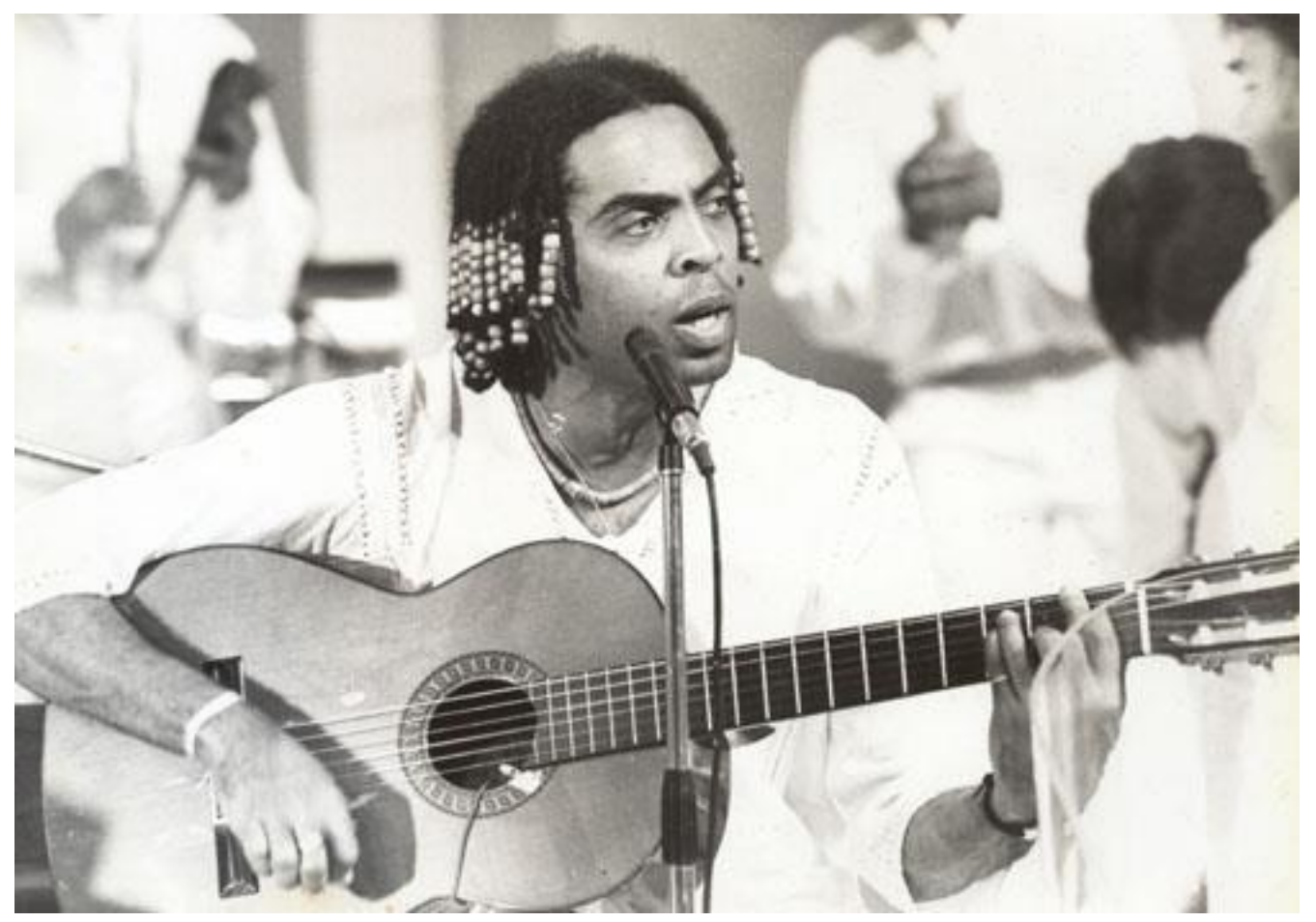

Figura 22 - Foto de 1979. Na época de Realce. Autor: Não identificado. Fonte: Acervo Gilberto Gil Instituto Antonio Carlos Jobim

Os anos 70 são demarcados pelo black power, as trancinhas, os colares de conta e toucas. Há uma guinada no visual de Gil nos anos 1980, quando passa a adotar um visual com elementos pop e hytech: 


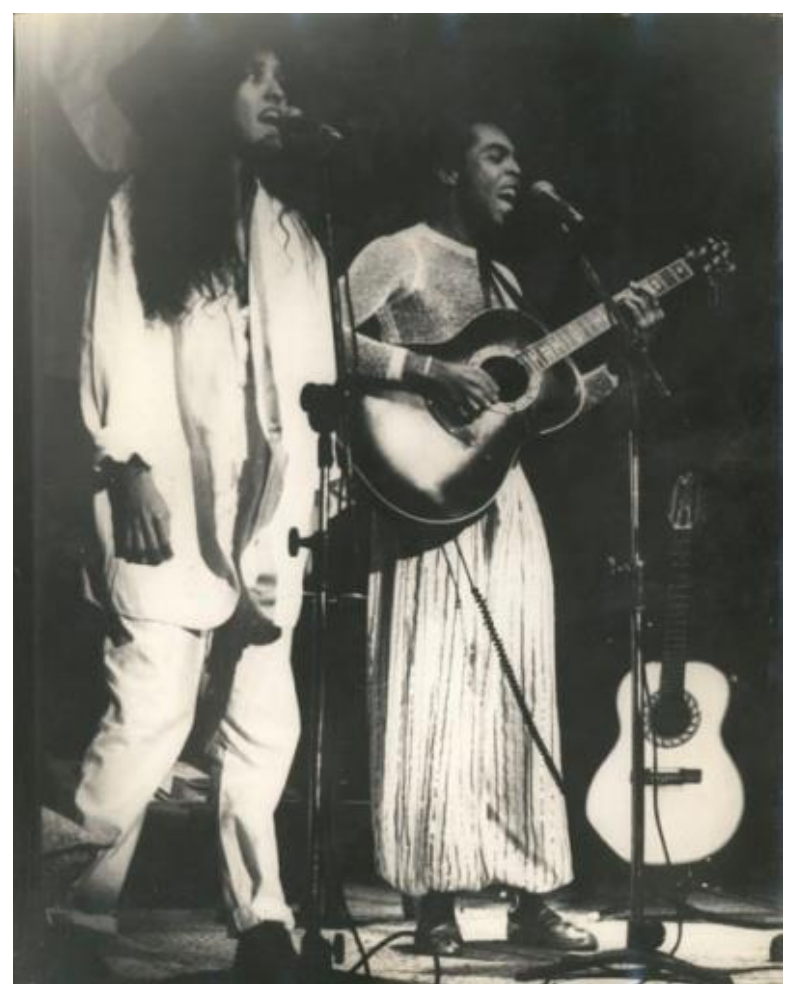

Figura 23 - Foto de 1981. Gil cantando em um show da turnê do disco Luar, ao lado de Regina Casé. Autor: não identificado.

Fonte: Acervo Gilberto Gil Instituto Antonio Carlos Jobim

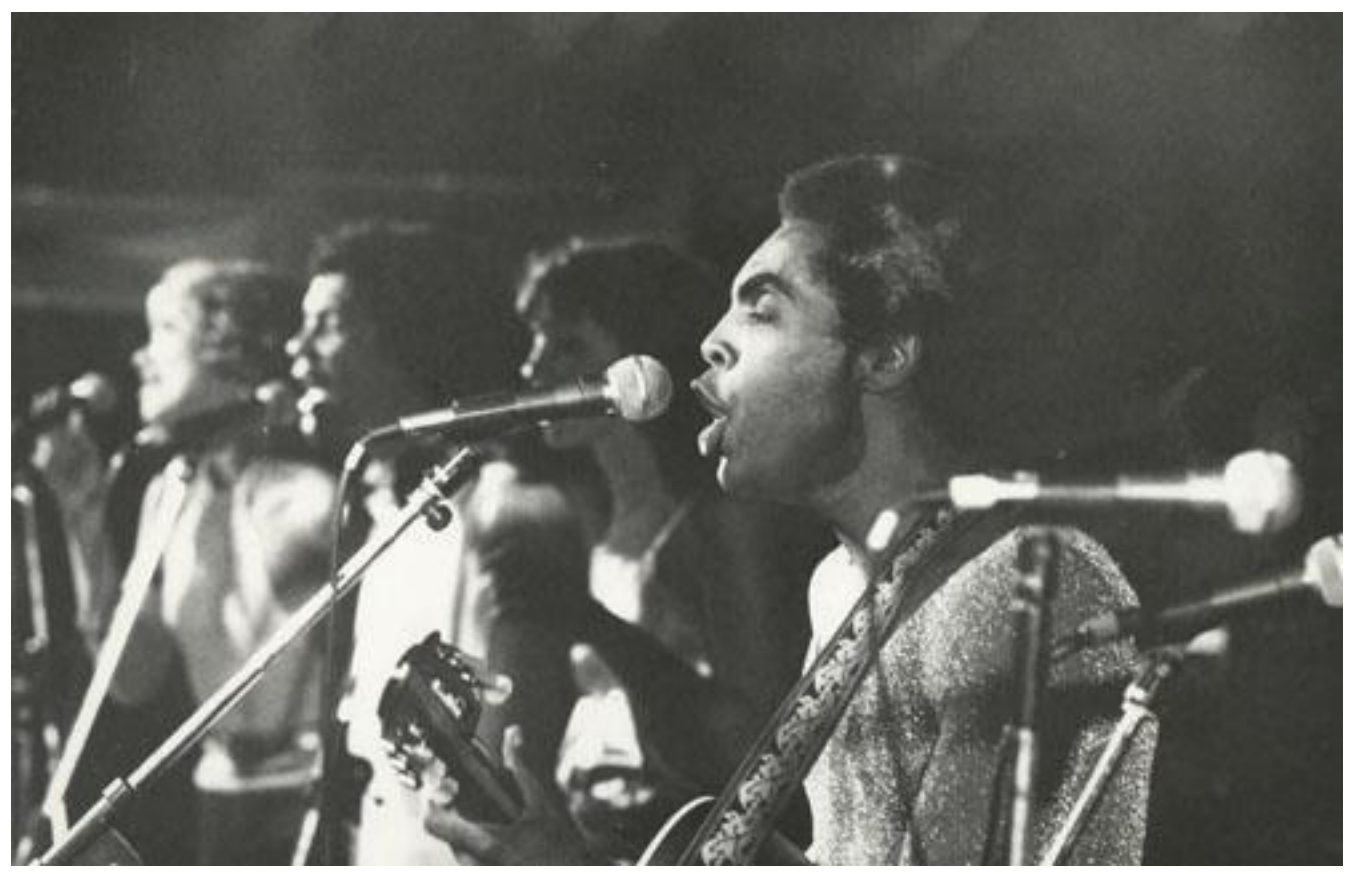

Figura 24 - Foto de 1981. Gil cantando em um show da turnê do disco Luar. Autor: não identificado. Fonte: Acervo Gilberto Gil Instituto Antonio Carlos Jobim 


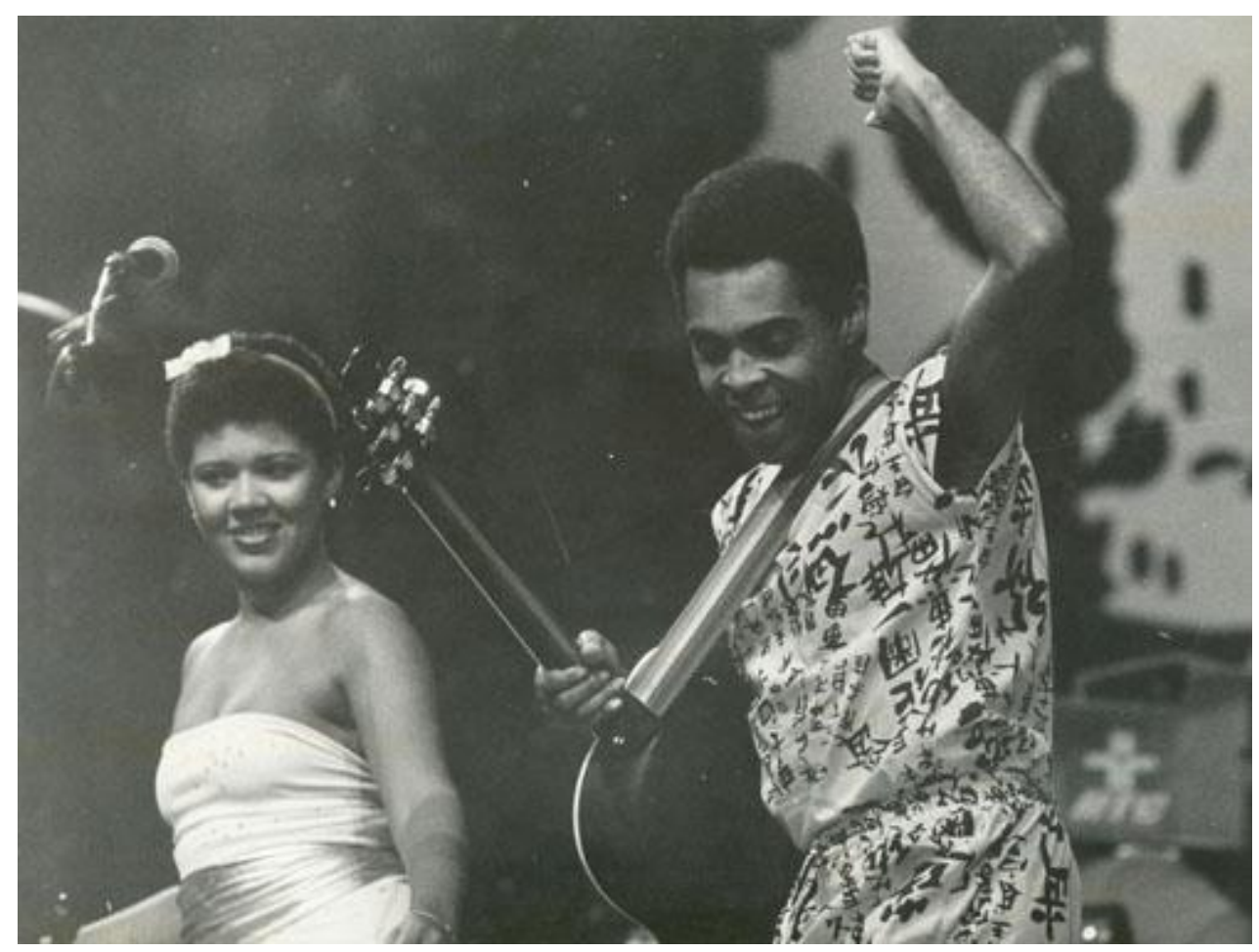

Figura 25 - Foto de 1982. Gil em turnê do disco Umbandaum. Autor: não identificado. Fonte: Acervo Gilberto Gil Instituto Antonio Carlos Jobim

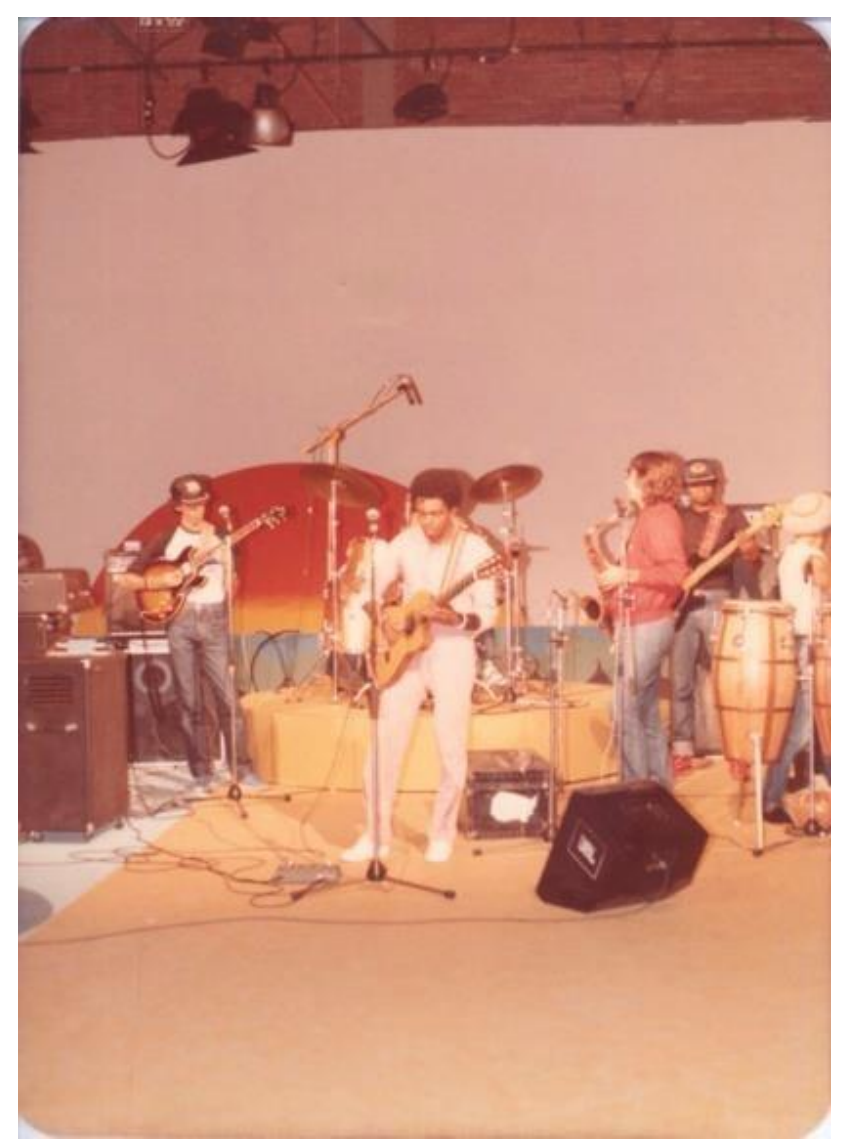

Figura 26 - Foto de 1983. Gil em Bogotá. Autor: não identificado. Fonte: Acervo Gilberto Gil Instituto Antonio Carlos Jobim 


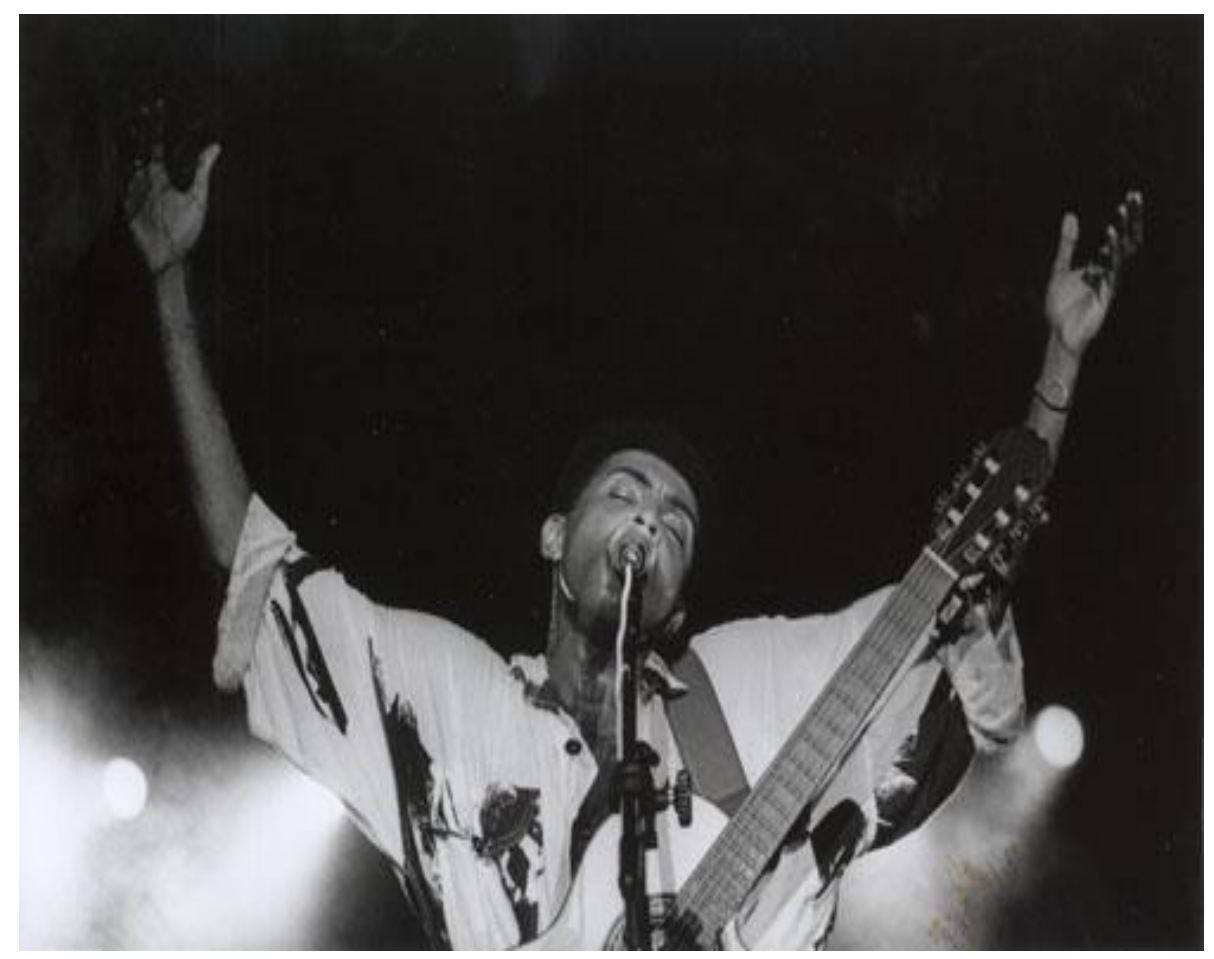

Figura 27 - Foto de 1983. Autor não identificado. Fonte: Acervo Gilberto Gil Instituto Antonio Carlos Jobim

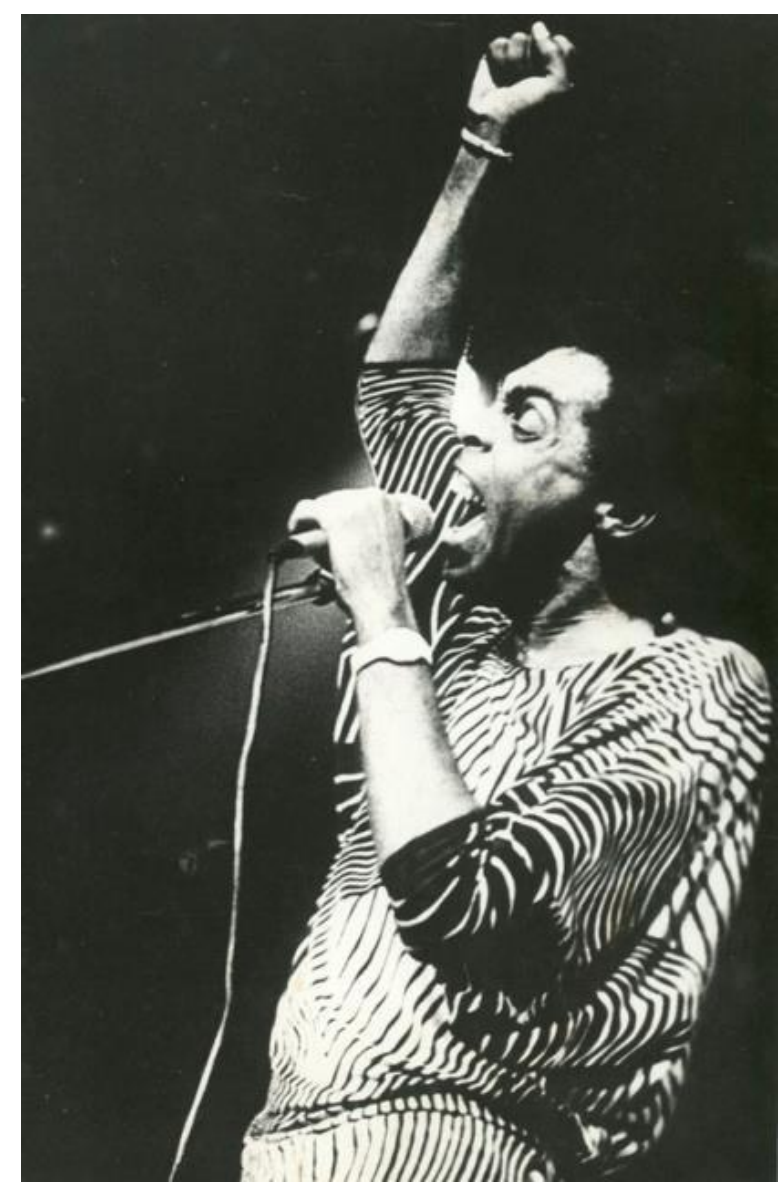

Figura 28 - Foto de 1983. Autor não identificado.

Fonte: Acervo Gilberto Gil Instituto Antonio Carlos Jobim 


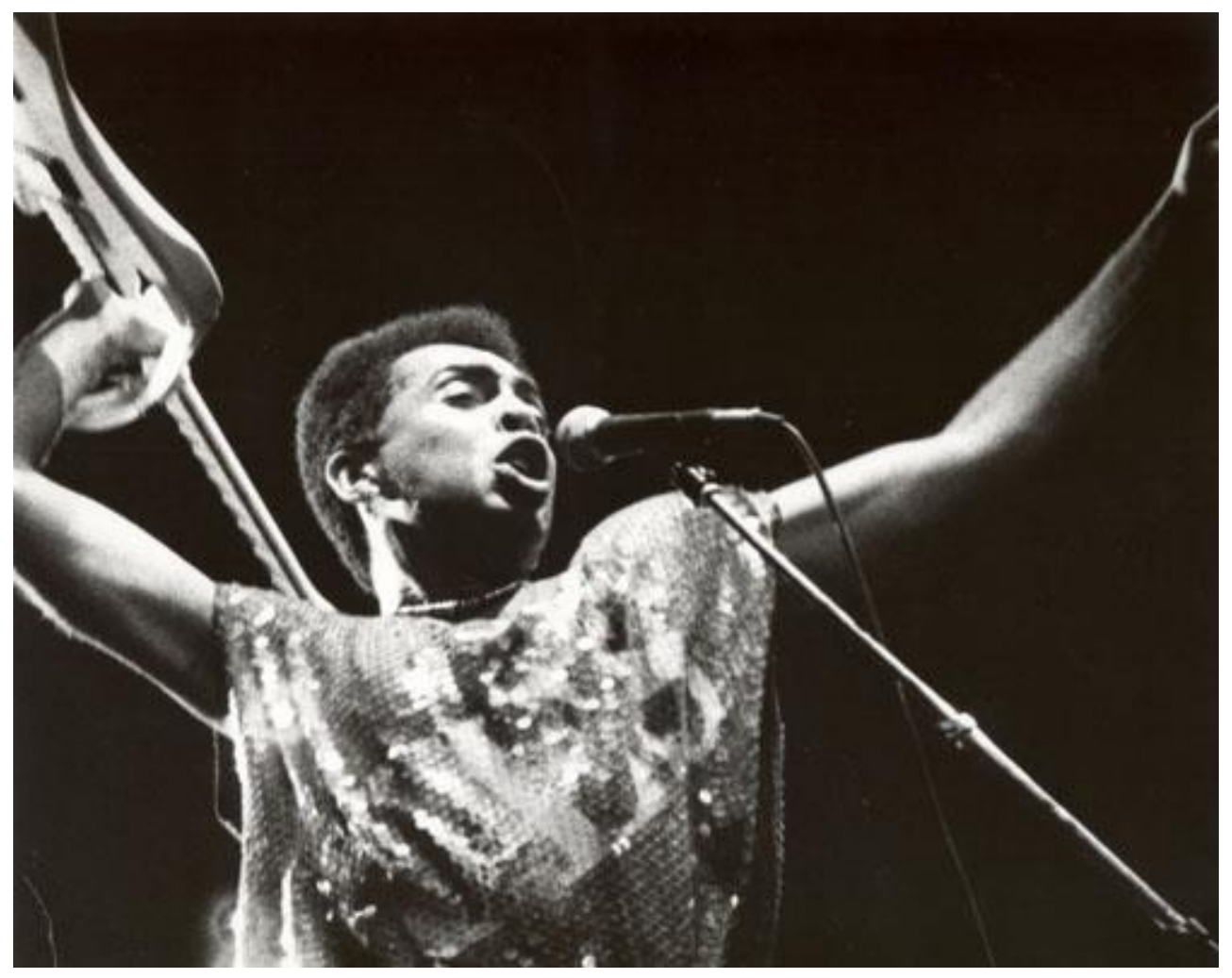

Figura 29 - Foto de 1985. Show em Londres. Autor: não identificado

Fonte: Acervo Gilberto Gil Instituto Antonio Carlos Jobim

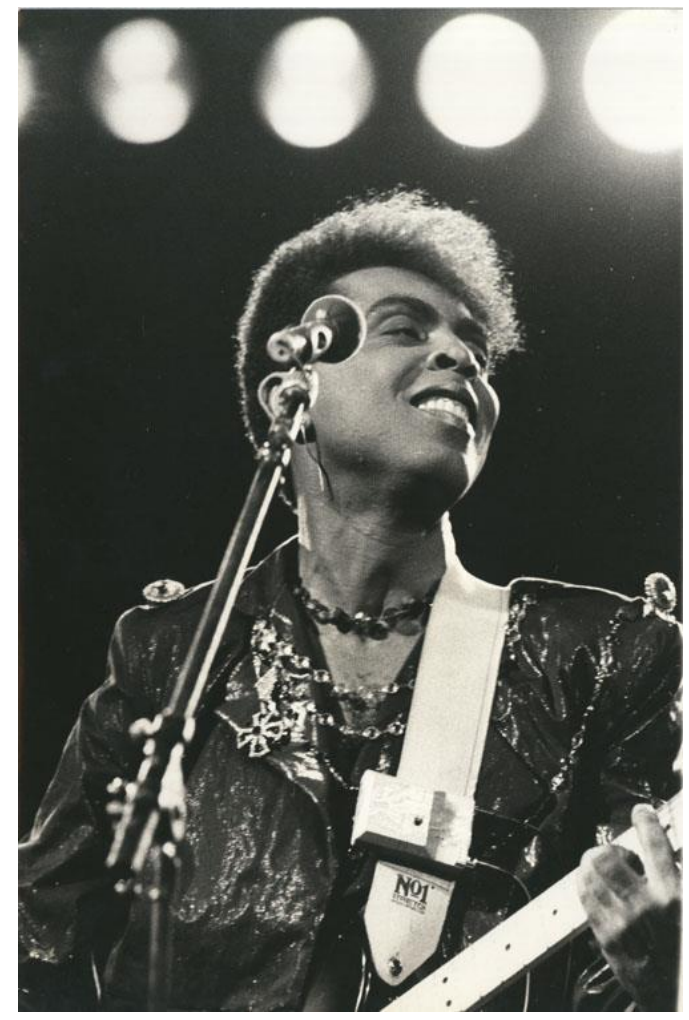

Figura 30 - Foto de 1985. Gil em apresentação na primeira edição do Rock N`Rio. Autor: Não identificado Fonte: Acervo Gilberto Gil Instituto Antonio Carlos Jobim 


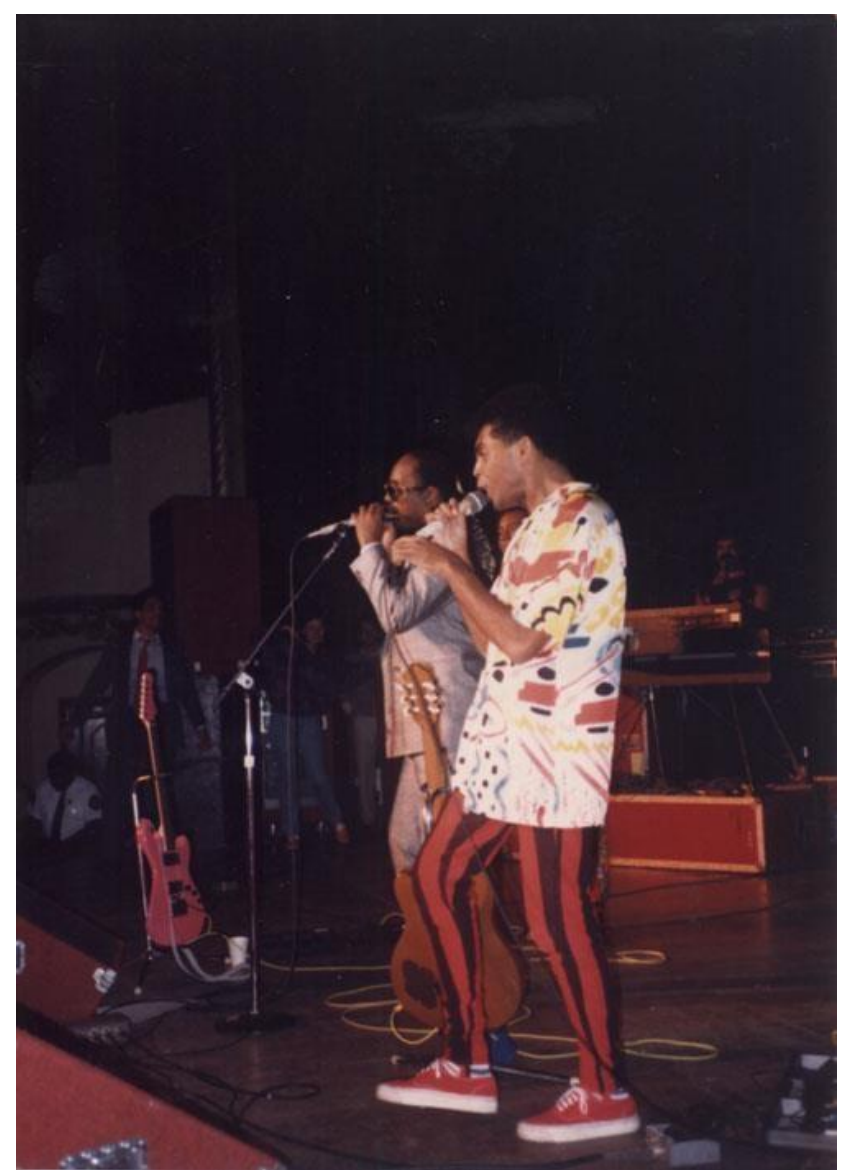

Figura 31 - Foto de 1985. Encontro de Gil com Stevie Wonder em Washington, durante a turnê nos Estados Unidos. Autor: não identificado

Fonte: Acervo Gilberto Gil Instituto Antonio Carlos Jobim

O visual dos anos 1980 foi marcado por purpurina, lantejoulas, guitarra cor-derosa e cabelo moicano. Pelas imagens desse período, é possível perceber que as batas africanas e demais símbolos de africanidades acessados na década anterior deram espaço à conexão de Gil com aspectos que retratavam a modernidade. São símbolos que mencionam mais o apelo ao futuro do que o apego ao passado.

As africanidades em Gil são uma produção contínua, um constante autofazer-se. Elas tomam forma a partir do processo de cosmopolitização da persona pública do artista, e não do contato com uma suposta essência negra experimentada no Brasil. A África de Gil nasce de fora: das conexões atlânticas, dos domínios britânicos no além-mar, da assimilação das culturas negras coloniais pelo centro do império britânico... em suma, de vastas experiências de hibridização cultural e modernização cujo epicentro é a sua atuação como artista brasileiro.

As africanidades de Gil são o navio, e não o porto; o céu, e não o hangar; a diversidade cultural da diáspora, e não a pretensão de unidade. Sob a África de Gilberto 
Gil, abre-se espaço de convergência para uma multiplicidade de experiências artísticas do século XX: a moderna música nigeriana, o jazz, o reggae jamaicano, o rap e o funk, o rock e o baião, as favelas e os sertões brasileiros.

É em Londres, no coração de um império colonial em franca decadência, que Gilberto Gil se descobre afro-brasileiro. Tal assertiva, mais do que identificar no artista um processo de construção de uma identidade negra, reforça os laços entre África e Brasil, agora desvendados. Não se trata unicamente da criação de uma consciência "racial", com toda a problemática presente nessa categoria, mas da consciência de uma subjetividade forjada nos laços culturais e sociais entre o continente africano e as terras da diáspora.

Nesse sentido, a África perpassa toda a obra do autor do final da década de 1960 à primeira metade dos anos 1980, deixando para os anos posteriores um forte produto típico da hibridização cultural. Jamais buscou-se o "puro" na obra de Gil. Talvez venha daí as suas tensões com parte do movimento negro brasileiro nos anos 1970. De qualquer forma, as africanidades de Gil seriam um dos pilares de sua atuação política, a partir da segunda metade dos anos 1980. Este é um dos temas do próximo capítulo. 


\title{
Capítulo 3
}

\section{A POÉTICA NA POLÍTICA}

\author{
"Minha ideologia é o nascer de cada dia \\ E minha religião é a luz na escuridão" 547
}

Gilberto Gil

Nos anos 1980, arte e política entrelaçam-se na trajetória de Gilberto Gil. Quem aqui nos elucida quanto aos fenômenos culturais e políticos é Renato Ortiz, que afirma que:

Os fenômenos culturais encerram sempre uma dimensão onde se desenvolvem relações de poder, porém seria impróprio considerá-los como expressão imediata de uma consciência política ou de um programa partidário. É importante ter em mente que as expressões culturais não se apresentam na sua concretude imediata como projeto político. Para que isso aconteça é necessário que grupos sociais mais amplos se apropriem delas, para reinterpretando-as, orientá-las politicamente. ${ }^{548}$

Assim, buscaremos abordar nesse capítulo quais foram os pontos de referência para a orientação política de Gil, bem como sua diversificação, e em que medida ela tangenciou aspectos relacionados ao mundo das africanidades.

A vida política de Gil teve início no ano de 1987, quando passou a ocupar o cargo de presidente da Fundação Cultural Gregório Matos, em Salvador, uma espécie de secretaria de cultura da cidade. Após um ano ocupando esse cargo, Gil tentou se candidatar a prefeito de Salvador, ${ }^{549}$ e acabou posteriormente se elegendo vereador, cargo que ocupou por quatro anos.

A seguir analisaremos quais foram as ações políticas de Gil nesse período e também quando ocupou o cargo de minis tro da Cultura no governo Lula, entre $2003 \mathrm{e}$

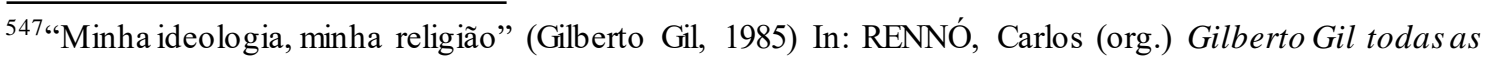
letras. São Paulo: Companhia das Letras, 1996, p. 302.

${ }^{548}$ ORTIZ, Renato. Cultura brasileira e identidade nacional.5.ed. São Paulo: Brasiliense, 1994, p. 142.

${ }^{549}$ São fartas as declarações de Gil aos jornais afirmando na época das eleições que fora desestimulado pelo grupo dominante do PMDB baiano a ocupar o cargo.
} 
2008, atentando especialmente para o espaço e o papel ocupados pela África e pela negritude em seus projetos políticos.

Para além das vivências políticas de Gil, analisaremos também neste capítulo o documentário Pierre Fatumbi Verger: mensageiro entre dois mundos, produzido em 1996, narrado e apresentado por Gil, tendo entre seus produtores Flora Gil e Pedro Buarque de Hollanda. Nesse documentário, as africanidades construídas por Gil são amplamente exploradas e nos fornecem inúmeros indícios de análise, num momento em que o artista já havia consolidado há tempos sua carreira e até mesmo experimentado a vida política. O documentário foi produzido no entremeio das experiências políticas de Gil e trata diretamente da temática do universo das africanidades acessada pelo artista. Realizado poucos anos após o artista ter ocupado o cargo de vereador em Salvador e anos antes de se tornar ministro é aqui inserido nessa análise para compreendermos ainda mais as africanidades confeccionadas por Gil nesse momento.

Questionaremos nesses três diferentes momentos como as representações de África ganharam visibilidade na trajetória de Gil. Dentre as fontes utilizadas neste capítulo para compreendermos a trajetória do artista, acessamos jornais, revistas, depoimentos e livros escritos por ele, os quais fazem referência direta à sua carreira política, além de vídeos e shows que tematizaram essa experiência. Tentamos ao máximo cruzar essas fontes, bem como os testemunhos dados a posteriori por Gil, que, em meio a um incessante jogo de memórias, buscou ressignificar o período aqui analisado.

Na década de 1980, assistiu-se ao desmantelamento do mundo socialista, que englobava parte dos continentes europeu e asiático. A cortina de ferro - expressão utilizada para definir o domínio da União Soviética (URSS) sobre estados-nação do Leste europeu - entra em profunda crise econômica e política. À estagnação da indústria e à anemia do setor de serviços, somaram-se outros fatores decisivos na queda do socialis mo: a falta de liberdade política e a asfixia da sociedade civil por parte do Estado. ${ }^{550}$ Vastos setores sociais das repúblicas sob a vigilância da URSS iniciaram ao longo da década uma revolução silenciosa, que culminou com a queda do Muro de Berlim (1989) e o fim da URSS (1991). A cruzada neoliberal implementada por Ronald Reagan e Margareth

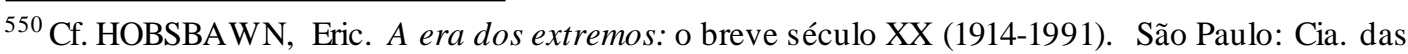
Letras, 1995.
} 
Tatcher foi uma importante pressão externa do Ocidente sobre o que ainda restava do chamado "socialismo real" 551 , e o protagonismo reformador de Gorbatchev deu fim à experiência política que durante décadas confrontou a essência do capitalismo.

O fim do "socialismo real" provocou na intelectualidade ocidental uma profunda revisão sobre o que é ser de direita ou de esquerda, bem como sobre os limites e as possibilidades da ação política libertária em meio ao fracasso do modelo oponente ao capitalismo. Artistas, políticos, pensadores - uma ampla teia de intelectuais ligados às universidades e de fora delas - passaram a ver o socialismo como algo ligado ao stalinismo, à supressão de direitos políticos, ao engessamento da economia. Se ser de esquerda era apoiar tal realidade, era preciso reinventar-se, criar um novo modo de ação no mundo. Gil inseriu-se ativamente nessa problemática. Sua ação política esteve permeada por essas preocupações históricas, como veremos adiante.

Quando questionado, em 1987, no ano em que iniciou sua carreira política, sobre as motivações que o levaram a entrar na vida política, Gil afirmou:

O grande sentimento estimulante do aparecimento do Gorbatchev na cena política internacional é o de que ele reverteu a expectativa. Ele colocou uma bomba, digamos assim, no arsenal dos chavões clássicos da esquerda informada pelo comunismo internacional. (...) Eu sempre acreditei numa convergência ne cessária entre as grandes conquis tas do capitalismo por um lado - produtividade e produtivismo - e as conquistas do socialismo, por outro. Desde menino, desde o tempo de política estudantil - quando me foram propostas as primeiras militâncias e os primeiros contatos com a esquerda brasileira, através do movimento político na universidade e a presença do Partido Comunista e dos vários movimentos da $\mathrm{AP}$, da Polop, aqueles vários galhos ideológicos que o Brasil tinha da época -, eu me lembro que meu sentimento sempre foi esse. Pela primeira vez na história um pós-stalinista - mesmo os que tinham se divorciado da fórmula e se insurgido contra o stalinismo, vinham, na verdade, dos quadros stalinistas - ele era um sopro renovador tanto na esquerda quanto na direita. ${ }^{552}$ [grifos meus]

É interessante salientar que esse desejo de se manter aberto para questões que muitas vezes são vistas como contraditórias, é uma constante na trajetória de Gil. Em

\footnotetext{
${ }^{551}$ HOBSBAWN, Eric. A era dos extremos..., op. cit.

552 SUZUKI, Matinas. O candidato Gil recusa o "folclore" e defende as instituições políticas. In: GIL, Gilberto e RISÉRIO, Antônio. O poético e o político e outros escritos. Rio de Janeiro: Paz e Terra, 1988, p. 23.
} 
2015, numa conversa/entrevista, ao ser abordado sobre sua militância, Gil nos dá ainda mais pistas para compreendermos o que poderia ser erroneamente interpretado como dualidade ou falta de posição. Assim ele se posiciona:

O caminho do meio, a metade das coisas. Buda falava isso: o importante é o caminho do meio. É onde as coisas se equilibram. O ponto das convergências é mais importante do que o ponto das divergências. Divergências são importantes, mas têm de buscar o convergir, porque assim se mantém o ciclo, o movimento, fecha e abre, fecha e abre, fecha e abre. O senso da oportunidade é coisa muito séria. Como é que você sente que é oportuno agora abrir? Ou, o contrário, fechar? (...) Tenho impressão de que a postura básica da alma é de que o tempo todo as coisas estão abertas e fechadas. A compreensão da simultaneidade talvez seja ainda uma das maiores dificuldades do processo civilizatório em relação a indivíduos e a grupos humanos. Não temos aparelhamento adequado para a compreensão perseverante do princípio da simultaneidade: tudo é e não é. Ao mesmo tempo. Eis uma das grandes dificuldades. ${ }^{553}$

Vale aqui ressaltar que a postura política experimentada e vivenciada por Gil é bem elucidada pela adoção do conceitual desenvolvido por Michel Maffesoli, que analisa o sentido político através de uma pulsão gregária, uma ambiência afetual, em que predominam "o ambiente, a vivacidade das emoções comuns e a necessária abundância de supérfluo que parece estruturar a sociedade pós-moderna." ${ }^{554}$ Maffesoli, ao questionar o amplo sentido do político, traz sua dimensão estética, além do aspecto emocional acima explicitado por Gil:

Se insisto sobre o impacto muito relativo da ação humana na construção social, é para bem ressaltar que o que chamei de paixão comum ou sentimento coletivo nos introduz num simbolismo geral: a comunidade é parte integrante de um vasto conjunto cósmico do qual não passa de um elemento. De fato, no sentido mais simples do termo, é próprio da paixão comum sentir com outros, experimentar-se com outros; coisas que nada têm a ver com o racionalismo ocidental, mas que se integram bem no aspecto global, holístico, da matriz natural. Ecologia contra economia, por assim dizer. ${ }^{555}$

Maffesoli afirma ainda que "a coerção moral ou a proteção impostas pelo líder, a paixão comum ou o enraizamento cósmico utilizados por ele, são causa e efeito da

\footnotetext{
553 GH, Gilb; OHIEIRA, Ande. Disposições amoráveis. São Paulo: IyáOmin, 2015, p. 124. ${ }^{554}$ MAFFESOLI, Michel. A transfiguração do político: a tribalização do mundo. Porto Alegre: Sulina, 1997, p.21.

555 Ibid., p.35.
} 
força imaginal necessária a toda vida em sociedade. ${ }^{" 56} \mathrm{O}$ pensamento político de Maffesoli, bem como seus textos a respeito das sociedades contemporâneas, vão ao encontro da guinada experimentada por Gil nos anos 1980, ao questionar o jogo político da esquerda tradicional. Embora Gil tenha jogado o jogo da democracia representativa, já desgastada aos olhos de Maffesoli, é interessante perceber que a atuação política do artista buscou potencializar a noção de "representativo" até o seu limite, como veremos ao longo do capítulo.

Às vésperas de se candidatar à prefeitura, questionado quanto ao fato de se dedicar à causa pública, assim Gil se posicionou:

Castro Alves, nosso grande poeta, se referia a uma unidade, uma união entre a aventura e o entusiasmo. Como símbolos, digamos assim, de um pacto entre Deus e a juventude. Considero que esse meu gesto deve ser entendido como algo que nasce justamente disso aí. Da mistura de um ímpeto de aventura, típico de uma personalidade do mundo artístico, com um entusiasmo, que também é muito do meu feitio. Sou uma pessoa realmente muito ligada a ímpetos entusiastas. $\mathbf{E}$ isso visto com um certo sentimento religioso de servir e também com uma certa jovialidade que venho conseguindo manter através dos anos da minha vida. Tenho a impressão de que essa colocação do Castro Alves explica esse meu sentimento. Por que deixar as benesses, as mordomias, o conforto de um mandarinato artístico exercido com tanto sentimento de solidariedade popular, a figura adulada e querida do público como eu sou, para o sacrifício de descer aos infernos? Mas é isso. A idade adulta chega, em muitos indivíduos, com essa carga de responsabilidade social. ${ }^{557}[$ grifos meus]

Referindo-se a esse aspecto devocional, ou mesmo religioso do ato político, Maffesoli nos informa que: "o que parece predominar é antes uma forma de sincretismo, de ecletismo religioso, moral, filosófico; em suma, o pluriculturalismo que favorece o compromisso com a natureza (ecologia), com os outros (consenso)" ${ }^{558}$. Analisando a emergência de uma cultura do sentimento, afirma ainda que:

Não há política sem religião. Religião no sentido estrito: o que une as pessoas partilhando um conjunto de pressupostos comuns. Pode-se exprimir isso de diversas maneiras, a exemplo do 'divino social' de Durkheim, ou ainda da 'política como forma profana da religião', de Marx; certo é que toda vida em sociedade repousa sobre uma necessidade fatal, a do descomprometimento consigo mesmo, e submeter-se, de 'entregar-se aos outros. Evidentemente

\footnotetext{
556 Ibid., p.38.

${ }^{557}$ GIL, Gilberto e RISÉRIO, Antônio. O poético e o político..., op. cit., p. 197.

558 MAFFESOLI, Michel. A transfiguração do político,op. cit., p. 122.
} 
esse descomprometimento exige uma legitimação encontrada no grande Outro. Divindade qualquer na maior parte do tempo, mas de múltiplos avatares: Estado, Partido, Progresso, Ciência, Moral, Serviço, etc. Longa é a lista dos substitutos ou das modulações de Deus. ${ }^{559}$

Ao tentar explicar que os contornos de socialidades não têm mais base na racionalização, Maffesoli trata de um estar-junto grupal que privilegia o todo em relação aos seus diversos componentes, valorizando a subjetividade enquanto fundamento do 'contrato social', bem como a utilização do barroco como metáfora do pluralismo da cultura dos sentimentos, que 'ilustra o aspecto antropológico da prevalência do 'nós', do grupo, sobre o indivíduo. ${ }^{, 560}$ Essa política permite estar-junto, já que considera a dinâmica de uma subjetividade de massa, em que a pós-modernidade é também o espaço de consolidação de contrastes.

A reflexão proposta por Maffesoli ajuda-nos a pensar, então, Gilberto Gil e sua atuação política em um contexto histórico em que as palavras de ordem passam a ser flexibilidade (contra a rigidez), sociedade civil (contra a supremacia do Estado), descentralização, pluriculturalismo e atenção às diferenças. Diante dos desafios da pósmodernidade, a utopia desloca-se: é recriada. Há lugar para novos sonhos, novos horizontes de expectativa. ${ }^{561} \mathrm{Tal}$ contexto ajuda-nos a compreender Gil e seus dilemas, deslocamentos e transformações como sujeito histórico, agora inserido no mundo da política. E o caminho percorrido por Gil começou em uma Fundação Cultural de Salvador.

\section{- Fundação Gregório de Matos (1987-1988)}

A Fundação Gregório de Matos (FGM) foi presidida por Gilberto Gil em 1987. O artista passou a ocupar o cargo com a intenção de concorrer a prefeito no ano seguinte. ${ }^{562}$ Para compreendermos o impulso que o levou a desempenhar, além do ofício de artista,

\footnotetext{
${ }^{559}$ MAFFESOLI, Michel. A transfiguração do político, op. cit., p. 38.

${ }^{560}$ Ibid., p. 201.

${ }^{561}$ No sentido estabelecido em KOSELLECK, Reinhart. Futuro passado: contribuições à semântica dos tempos históricos. Rio de Janeiro: Contraponto/Ed. PUC-Rio, 2006.

${ }^{562}$ Não era nenhuma espécie de segredo o desejo de Gil em se candidatar à prefeitura. Numa reportagem feita na época da posse da FGM fica claro o desejo de Gil: "O presidente regional do PMDB, deputado federal Genebaldo Correia, chegou cedo ao palácio Thomé de Souza, para participar da solenidade de posse de Gilberto Gil na Fundação Gregório de Mattos, onde o compositor e cantor dará o passo inicial da
} 
o de político, analisaremos a seguir dois depoimentos de Gil, um realizado anos após ter terminado seu mandato como ministro e outro proferido à época em que ocupou a presidência da FGM. Assim, poderemos analisar, à luz dos discursos proferidos em diferentes contextos, as alusões a essa escolha.

Em 2012, quando questionado sobre sua primeira experiência política em Salvador, Gil disse:

\begin{abstract}
Vou para o Estado. (risos) Representar as instituições do Estado brasileiro. Tinha uma turma instalada na Prefeitura de Salvador: Roberto Pinho, João Santana, Antônio José... Estavam todos, ali, na questão cultural com várias iniciativas de retomada de elementos importantes da tradição negra na Bahia, intensificação de relações coma África, es pecialmente comas Áfricas que tinham, dire tamente, a ver com a Bahia etc. Esse pessoal estava lá e eu fiquei animado e eu pensei: "Ainda acho que há vida útil na política.”. Eu, então, virei para esse pessoale disse: "Vocês não querem que eu vá para aí fazer parte dessa turma de vocês também?". Aí eles disseram: "Venha! Venha, sim!”. E como eu já era artista popular, conhecido, tropicalista, já tinha sido preso... Já tinha uma dimensão de ícone, já podia ser mascote daquela turma. Então me levaram à presidência da Fundação Gregório de Matos, que corresponde à Secretaria Municipal de Cultura de Salvador. ${ }^{563}$
\end{abstract}

Gil havia ingressado no PMDB do então prefeito Mário Kertész, cujo primeiro mandato, como prefeito de Salvador, ocorrera entre 1979 e 1981, sob a indicação de Antônio Carlos Magalhães. Em 1985, retorna à prefeitura em eleição direta, sob a égide de Waldir Pires, o principal peemedebista baiano, ministro da Previdência na presidência de José Sarney, entre 1985 e 1987 e, a partir desse ano, governador da Bahia. A Fundação Gregório de Matos foi criada pelo grupo político então ocupante do poder no estado. Gil tentara candidatar-se à prefeitura de Salvador, mas foi desestimulado pelo grupo dominante do PMDB baiano. Elegeu-se, em 1988, vereador da capital, cargo que ocupou entre 1989 e 1992. Seu chefe de gabinete foi Jorge Mautner, com quem Gil estabeleceu forte conexão artística na experiência do exilio em Londres (ver capítulo 2).

Aos poucos, a luta ambiental ganha espaço na atuação política de Gil. Em 1990, filiou-se ao Partido Verde (PV), talvez por influência de Mautner, que já era membro:

sua, já declarada, disposição de chegar à prefeitura de Salvador.” In: Coluna Política. Jornal A Tarde, Salvador, 8 jan. 1987. Disponível em: <www.jobim.org>. Acesso em: 19 mar. 2016.

${ }^{563}$ Depoimento do cantor e compositor Gilberto Gil, ao Museu da Imagem e do Som do Rio de Janeiro para a série "Depoimentos para a Posteridade", realizado em 6 de junho de 2012. 
Foi até interessante porque Jorge Mautner foi meu chefe de gabinete, eu me desliguei do PMDB e me filiei ao PV. Nós criamos a Comissão do Meio Ambiente, pois não havia, ainda, na Prefeitura de Salvador. Foi quando eu criei o movimento Onda Azul, também, movimento pelas águas... Então houve, ali, apesar dos pesares, uma mínima atuação política de um certo viés político novo, da política brasileira, viés ecológico, novas políticas culturais e foi no que deu, de uma certa forma, também, laços políticos, do ponto de vista político e, estritamente político, do Presidente Lula me chamar pra ser ministro. Claro que ele me chamou por outras razões, razões de representatividade, de simbologia... Mas me chamou, também, porque eu era um integrante do PV. Ele gostaria de ter um representante do Partido Verde no governo dele. ${ }^{564}$ [grifos meus]

No depoimento, Gil afirma ter se oferecido ao cargo para contribuir com questões culturais que the causavam interesse, e entre eles é forte a temática do contato com a África. De acordo com ele, havia na FGM, anteriormente à sua entrada, uma política de conexão com países africanos, especialmente aqueles que tinham ligação cultural com Salvador. No entanto, de acordo com seu depoimento e através da análise de inúmeras reportagens referentes a esse período, foi possível perceber que a tônica de seu mandato enquanto vereador acabou por priorizar questões referentes ao meio ambiente, como veremos a seguir.

Em janeiro de 1987, quando tomou posse na FGM, Gil disse:

Na verdade, isso já passava pela minha cabeça. Nos últimos tempos, tinha se insinuado em mim uma vontade de participar da questão política, da coisa pública. Isso chegou aos ouvidos de Mário Kertsz e de seus assessores, pessoas com quem tenho ligações (Mário e eu fomos colegas de escola). Ele levou em consideração e eu não hesitei. Eu já queria isso mesmo. Achoque esse impulso tem a ver com o passar do tempo. Essa dimensão já vem se insinuando no meu projeto natural de vida. Aqui e ali, você encontra momentos de liderança, dessa atitude gerencial, há um pouco disso na formação de minha personalidade. ${ }^{565}$

Referência ao impulso, projeto natural de vida ou formação de personalidade dimensionam o caráter de manifestações não-racionais, afetivas ou mesmo uma cultura do sentimento, como propõe Maffesoli. A intenção de se tornar político em muito se integrava a uma tribalização da política, obedecendo a um mecanismo de sedução,

\footnotetext{
${ }^{564}$ Depoimento do cantor e compositor Gilberto Gil, ao Museu da Imagem e do Som do Rio de Janeiro para a série "Depoimentos para a Posteridade", realizado em 6 de junho de 2012.

${ }_{565}$ MARIA, Cleusa. Um artista no poder. Jornal do Brasil, Rio de Janeiro, 4 jan. 1987. In: COHN, Sergio (org.). Gilberto Gil - Encontros. Rio de Janeiro: Beco do Azougue, 2007, p. 184.
} 
doação, aflorada, de acordo com as palavras de Gil, através da solidariedade. Aqui a fala de Gil dimensiona-se tanto através de desejo quanto de afeto.

Inúmeros jornais anunciaram a celebração da posse de Gil na FGM. Uma das reportagens anuncia que Gil chegou ao palanque rodeado por uma aglomeração que reunia mais de quatro mil pessoas, numa festa organizada por Wally Salomão. ${ }^{566}$ Estavam presentes afoxés e blocos afro, e Gil foi saudado por filhas e mães-de-santo que o receberam com flores e chuva de pipocas. De acordo com a reportagem, estavam presentes no evento muitas celebridades, dentre elas Darcy Ribeiro, Jorge Amado e Lulu Santos. Gil, em seu discurso de posse, além de pedir que fosse guiado pelo Senhor do Bonfim, pediu a benção de Mãe Menininha do Gantois e inspiração a Gregório de Matos. E disse ainda: "Não admitiremos a substituição da argumentação pelo insulto, do interesse pela leviandade irresponsável, enfim, da verdadeira crítica pela maledicência folclórica." A reportagem teceu ainda comentários sobre o figurino vestido por Gil no ato da posse: "Gil pôs um blazer brilhante, quadriculado, sobre uma camisa branca e um lenço florido utilizado como gravata, uma calça folgada rosa e uma sapatilha prateada." É interessante salientar que o artista Gil, a se notar pelo figurino, não seria sublimado no político Gil; travou-se aí uma simbiose. Outra reportagem assim anunciou a posse de Gil:

Em solenidade realizada ontem no palco armado na escadaria do Palácio Thomé de Souza, senhores engravatados misturaram-se com "baianas" vestidas a caráter e comunidades negras apareceram com berimbaus, atabaques, toques de afoxé e banhos de cheiro. (...) O compositor salientou a importância de novas ideias e deixou clara sua disposição de trabalhar para a revitalização do Centro Histórico de Salvador. ${ }^{567}$

Essas informações, somadas às informações das outras reportagens supracitadas, indicam que há diversos elementos representativos das africanidades de Gil em seu ato de posse, especialmente notado através da presença de um número significativo de representantes da cultura afro-baiana.

Passados poucos dias desse evento, outra reportagem nos informa sobre as primeiras ações políticas de Gil:

\footnotetext{
${ }^{566}$ GILBERTO Gil assume fundação na Bahia. Nacional, 8 jan. 1987. Disponível em: 〈www.jobim.org> Acesso em: 19 mar. 2016.

${ }^{567}$ ATABAQUES e gravatas na posse de Gil. Salvador, Bahia. 8 jan. 1987. O Recorte do jornal não fornece outros indícios, além da data de sua publicação. Disponível em: <www.jobim.org> Acesso em: 19 mar. 2016.
} 
O mais famoso estreante da política nacional embarca juntamente com o prefeito Mário Kertesz e comitiva para a República Popular do Benim, pequeno país socialista da costa ocidental africana, a convite do presidente Mathieu Kereku. A República popular do Benim e a Fundação Gregório de Matos tratarão de criar duas casas culturais: uma do Benim em Salvador e outra da Bahia em Benim (...) De volta a Salvador, Gil deverá cuidar da situação física dos terreiros de candomblé, cuidando das drenagens dos terrenos, e proteger as encostas dos morros onde eles se situam. Ao mesmo tempo deverá estar envolvido com a organização do carnaval baiano (...) e também terá que cuidar da criação do parque ecológico do Abaeté, quando deverá preocupar-se com a preservação de seu delicado ecossistema, suas tradições culturais como centro de magia e com os problemas sociais criados com a invasão de pessoas de baixa renda. E certamente não ficará só nisso: Gil - que estudou Administração de empresas na juventude - está à frente de uma Fundação criada pelo prefeito Mário Kertesz para ser a "alma antropológica da administração", ou seja, um centro de produção de ideias que devem nortear a ação administrativa. À Fundação cabe, entre outras coisas, pensar na forma de modernizar a cidade sem ferir suas tradições, e tem como prioridade a recuperação do centro histórico da cidade, hoje em ruínas, mas que daqui há dois anos terá por suas ruas o movimento dos bondes franceses. ${ }^{568}$

Além da viagem à África, Gil, bem no início de seu mandato, viajou a São Paulo para um encontro com a arquiteta Lina Bo Bardi. Ele afirmou estar empenhado numa espécie de aglutinação cultural, e também que Lina "foi a primeira pessoa a se interessar profundamente pela avaliação da grandeza arquitetônica de Salvador, pela dimensão antropológica dessa grandeza, por isso agora vim ouvir suas ordens" ${ }^{569}$ Gil também foi se encontrar com o então ministro da Cultura Celso Furtado, e com ele conversou sobre a contribuição do negro para a sociedade brasileira. ${ }^{570}$ Encontrou também com o então presidente José Sarney e "acompanhou os representantes de quatorze entidades do movimento negro que levaram suas reivindicações à Comissão da ordem social e à subcomissão dos Negros, Populações Indígenas, Pessoas deficientes e Minorias". 571

Nessas breves compilações, é possível perceber que essa aglutinação cultural se fez notar desde os primeiros dias de posse de Gil, que saiu em busca não apenas de contatos políticos, mas também culturais, capitaneando apoio e investimentos. Seus primeiros encontros políticos demonstram que sua estratégia focava a preservação do

\footnotetext{
568 GILBERTO Gil toma posse hoje. Folha de S. Paulo, 7 jan. 1987.

${ }^{569}$ LO PRETE, Renata. GIL Leva Lina de volta à Bahia. Folha de S. Paulo, 12 jan. 1987.

${ }^{570}$ GIL leva planos a Furtado. Folha de S. Paulo, 5 fev. 1987.

${ }^{571}$ GIL é recebido por Sarney. Folha de S. Paulo,14 abr. 1987.
} 
centro histórico da cidade de Salvador e assuntos ligados à negritude brasileira, tais como a criação de casas culturais em Benim e a preservação dos candomblés baianos.

Outra reportagem possibilita-nos perceber quais eram essas questões referentes ao mundo das africanidades abordados por Gil durante a estadia na FGM. Em 1988, Gil declarou que deu o nome Isabela à filha em homenagem à princesa Isabel, e disse ser favorável à comemoração do centenário da abolição:

Falta-se abolir muita coisa no Brasil, principalmente os escravos e o desprezo pelo nosso suor e as diferenças vergonhosas que existem no país. Deve ser comemorado com toda razão, pois isso recupera o sentido da luta, o sentido da vitória de que algo foi conseguido. ${ }^{572}$ [grifos meus]

Se no exílio, ao escrever uma carta ao Museu da Imagem e do Som (conforme já expomos no capítulo 2), Gil afirmava não saber qual era seu lugar, aqui, no ano do centenário da abolição, no exercício de um cargo político, seu lugar está claramente demarcado.

De acordo com Zappa, a gestão de Gil na FGM trabalhou com a recuperação do centro histórico da cidade, retomou as relações culturais da Bahia com a África, através de inúmeras viagens de Gil para Angola, Moçambique, Nigéria e Benim; além da abertura da Casa da Bahia no Benim e da Casa do Benim em Salvador. A autora conta ainda que Gil criou uma estrutura de sustentação para o candomblé, inaugurou o Teatro Gregório de Matos e criou um projeto denominado Boca de Brasa, possibilitando o acesso a peças teatrais em palcos móveis que circulavam por áreas carentes de Salvador. ${ }^{573}$

\section{- Movimento Figa Brasil}

O Movimento Figa Brasil foi criado por Gilberto Gil e Jorge Mautner em 1987, antes da candidatura de Gil a vereador e quanto este ocupava a presidência da FGM. De cunho filosófico e político, o Figa pleiteava um novo lugar para a política, no qual a burocracia deveria dar espaço à imaginação. Os artistas e intelectuais deveriam ser persuadidos a (re)pensar a ação política, de modo a inventar novos caminhos, novas

\footnotetext{
572 NEGROS refutam 13 de maio e exigem dia de Zumbi. Folha de S. Paulo,13 jan. 1988.

${ }^{573}$ ZAPPA, Regina. Gilberto bem perto. 1. ed. Rio de Janeiro: Nova Fronteira, 2013, p. 214.
} 
metodologias, novas possibilidades. O principal interesse do movimento era refletir sobre as desigualdades e injustiças que marcam a sociedade brasileira no início de um novo período democrático, após anos sob a tutela de um regime autoritário. O Figa Brasil possui relação direta com as reflexões de Maffesoli sobre o caráter utópico e gregário da política.

Emerge das memórias de Mautner e Gil uma série de depoimentos que expõem o caráter, ao menos é o que parece, deliberadamente vago, difuso e inconclusivo do movimento. Tratar-se-ia de uma tentativa de construção de um novo e amplo movimento cultural e político, na esteira do Pau Brasil ou da antropofagia? Qual seria a contribuição fundamental do Figa Brasil? Apesar de sua natureza demasiadamente utópica, é possível extrair das falas de ambos os artistas elementos em que se problematiza a formação de uma cultura negra no Brasil e suas relações com a chamada "cultura universal" (isto é, de matriz europeia).

Em 2007, Jorge Mautner rememoraria o Movimento Figa Brasil:

A proximidade com Gil é antiga e profunda. Ele é um grande amigo, o maior. É uma relação filosófica, e as relações políticoculturais são temas eternos de nossas conversas. Quando o conheci, durante seu exílio em Londres, em 1970, compusemos três músicas juntos. Anos depois, em 1987, fizemos juntos por todo país a turnê do show $O$ poeta e o esfomeado. Nessa época já tínhamos ideia de fazer um projeto cultural de participação social, e criamos o Figa Brasil. Nós convidávamos as pessoas depois dos shows e já tínhamos 7.000 adesões. O projeto só não foi adiante porque Gil se candidatou a prefeito, depois vereador, e foi eleito. Eu inclusive fui chefe-de-gabinete de Gil em seu período como vereador em Salvador. ${ }^{574}$

No que consistiria tal participação social? Em outra reportagem, datada dos idos de 1987, ao abordar o objetivo de Gil em aumentar a participação dos artistas na vida cultural do país, encontramos indícios desse movimento criado em parceria com Mautner:

Mas não só para lançar o novo disco Gil excursionará pelo país: o artista está se preparando para lançar o movimento "Figa Brasil", que segundo ele, deixa de lado o espírito do tipo "tem que dar certo" e o troca pelo "tem que fazer certo". A utopia e a inocência têm que voltar aopaís, sob o risco de, em caso contrário "não ter mais concerto", a firma Gil que quer mobilizar a classe artística em um grande mutirão para recuperação da

\footnotetext{
${ }^{574}$ EVANGELISTA, Ronaldo. Geleia geral. Folha de S. Paulo,10 jan. 2007.
} 
consciência nacional. Um grande passo para esse mutirão, segundo Gil, é a formação do eixo dos secretários. (...) Es tou na Fundação para criar, des cobrir novas formas de mobilização, fazer a revolução social pacífica. Este é o meu projeto político. Virar burocrata da cultura, atrás de uma mesa, não é comigo, finaliza. ${ }^{575}[$ grifos meus]

Mautner, em outro contexto, também explicou o Movimento Figa:

Um movimento cultural que pretende formar "clubes filosóficos" por todo país e tem como "presidente" o professor Mario Schenberg. É uma proposta de abertura e de liberdade engajada e participante, a união dentro da diversidade, a paz e as igualdades sociais e o primado da liberdade. ${ }^{576}$

Em outra situação, Gil complementou ainda mais a ideia do movimento e sua relação com Mautner:

O Mautner se refere ao projeto como sendo uma visão centroradical. Esse aparente paradoxo significa a busca de um entendimento mais nacional, mais brasileiro de todas as questões. Não temos um programa, apenas desejamos que as pessoas se reúnam e discutam nossos problemas por uma ótica nacional. ${ }^{577}$ [grifos meus]

O show O poeta e o esfomeado ${ }^{578}$ lançou o Movimento Figa e contou com Gil no violão, Jorge Mautner no violino e Repolho na percussão. O figurino de Gil é uma bata e calça com panos da costa, bem ao estilo afro, sandálias de couro, cabelo em formato quadrado e levemente black e um pequeno brinco na orelha. Mautner trajava calça jeans e camisa cor de rosa, e Repolho aparecia sem blusa, com calça estampada de onça e dreads no cabelo. O palco contava apenas com a presença dos músicos, que ao fim do show balançaram a bandeira do Movimento Figa Brasil, com estrelas rodeando uma mão negra fechada, simbolizando uma figa. Além das músicas do repertório, o show foi entremeado por declamações que ora eram de Gil, ora de Mautner, e às vezes um diálogo entre os dois.

Os arranjos da percussão exploraram inúmeros aspectos rítmicos brasileiros. Em algumas passagens, Repolho sintetizou vários elementos rítmicos presentes nas casas de candomblé, nos grupos de samba e em blocos de maracatu. A música "Maracatu

\footnotetext{
${ }^{575}$ GRILLO, Cristina. Gil lança projeto cultural e novo LP. Folha de S. Paulo, 19 fev. 1987.

${ }^{576}$ CALADO, Carlos. Gil. Folha de S. Paulo,12 mar. 1987.

577 GILBERTO Gil relança em São Paulo o projeto "Figa Brasil". Folha de S. Paulo,17 mar. 1987.

578 YouTube. 1987/Mar - O poeta e o esfomeado - Gilberto Gil e Jorge Mautner. Disponível em: <https://youtu.be/wrHNg7Uzy8U>. Acesso em: 19 mar. 2016. Postado por Mautner. Gravado no Palácio das Convenções do Anhembi São Paulo.
} 
atômico", por exemplo, fez uma referência explícita ao ritmo no surdo, e assim as africanidades se fizeram notar fortemente na percussão. A concepção do show promoveu a ideia de hibridação, ao mesclar instrumentos eruditos ocidentais com a percussão, que nesse show representou a África. Os discursos também estampavam hibridação, mesclando filósofos gregos, positivistas e os diferentes panteões africanos; e mencionouse ao longo de todo o espetáculo o desconforto e a necessidade de falar do racismo.

A seguir transcrevemos parte das declamações dos artistas durante o show. O longo trecho é de suma importância para nossa análise, uma vez que grande parte das falas trata diretamente do tema da negritude brasileira:

Mautner: Mozart compôs isto, que acabamos de ouvir, aos cinco anos de idade. Wolfgang Amadeus Mozart, de Salzburgo na Áustria, do católico império austro-húngaro, este gênio da música europeia. Este expoente branco, da cultura branca superior, poderia ser um irmão gêmeo daquele negro pobre, descendente de escravos da África pagã, fillho da favela, símbolo da cultura inferior dos primitivos, da horda dos escravos libertados subitamente mergulhados na liberdade selvagem? Poderia tal equiparação ser verdadeira? Vinícius de Moraes teve a coragem de fazê-la. Vinicius de Moraes, que como Jorge de Lima, cultivava e nutria-se da poesia e da filosofia nômades, dos que mesmo sob o açoite do chicote, inventavam os bálsamos da arte e da transcendência da dor. E nós acrescentamos, foram tropas negras de escravos negros que ganharam a guerra do Paraguai. Foram soldados de cor escura que triunfaram em Itororó e Tuiuti e foram estas tropas, que tiveram como prêmio pela vitória a permissão de virem a habitar como cidadãos livres os morros cariocas. Assim, iniciaram-se o que costumamos chamar de favelas, das escolas de malandragem e das escolas de samba. Acima de tudo, escolas da dignidade e do verdadeiro humanismo, da grande cultura negra do Brasil universal e toda a sua poesia legendária. $\mathrm{O}$ nome da primeira escola de samba, Deixa Falar, o seu primeiro presidente Ismael Silva e notem só, com muita atenção como também na letra desse samba Ismael Silva irradia cortesia, a doçura e a educação e a delicadeza de um príncipe negro, onde estão ausentes absolutamente qualquer machismo chauvinista, grosseria dos bárbaros e, aonde ao contrário justamente emerge e brilha a luz do respeito e da dignidade, do ser que ama para com o ser amado.

Mautner: é, pois acontece que a coisa vai ficando serena, serena eu não sei bem o que acontece.

Gil: acontece que quando a coisa vai ficando serena, serena vem aquela coisa negra. Que por ser tão real, mas tão real, acaba incomodando tanta gente e é talvez por isso mesmo que 
de vemos ter a obrigação, quase o dever sagrado de falar de la.

Mautner: Certas coisas são tão terríveis, são tão anti-humanas que é difícil não nos acorrer à memória, nomes de campos de concentração, pelourinhos, chicotes, metralhadoras e um grito de dor mundial, com crianças presas sendo torturadas. Oh Cristo quando retornarás de novo? O milagre do teu amor, para amenizar um pouco o sofrimento inevitável desse vale de lágrimas, mergulhado agora no seu mais profundo terror.

Gil: Três grandes mitologias, a da Grécia, do Olímpio, a de Walhala dos germânicos e a de Aruanda dos deuses africanos. A única viva a de Aruanda, a do candomblé. Lá em África os orixás eram categorias, realidades geográficas, até mesmo geopolíticas. Oxóssi, a brandir primeiramente seu arco funda o reino de Ketu e assim por diante. Iansã, Iemanjá, Ossanha, Omolu ao virem para o Brasil construir São Paulo, Curitiba, Salvador, Rio de Janeiro, fazerem a lavoura do café, da cana de açúcar, construírem materialmente toda essa riqueza do Brasil. Os negros tiveram seus orixás transformados em realidades psicológicas, categorias psicológicas, algo assim como arquétipos, além yunguianos e Xangô é um deles, o rei da justiça. Nessa canção que Jorge vai fazer dele, Xangô representa também o sentimento da solidão, do comando de quem luta pela justiça. Que se faça a jus tiça!

Nos discursos proferidos ao longo do show, a grandeza artística de Mozart é equiparada à dos sambistas negros. Rememora-se a participação de escravos negros como peças fundamentais para a conquista da Guerra do Paraguai, exaltando-se a malemolência e a criatividade negra, bem como a necessidade de enfrentar o racismo. A negritude é exaltada e positivada, sendo colocada em pé de igualdade com as contribuições culturais europeias. Ambos estavam conclamando seus ouvintes a forjarem novas identidades, relacionando símbolos e saberes das culturas populares e eruditas, estimulando a exploração das misturas, chamando à cena a cultura negra por tanto tempo silenciada e estigmatizada. A abordagem discursiva dos artistas privilegia a visão dos vencidos, por terem sido os negros os excluídos desse cenário por tanto tempo. Gil e Mautner reiteram ao longo de todo o show que essas construções culturais devem ser concebidas em pé de igualdade e grandiosidade.

O show termina com Mautner declamando: No momento de crer criando, contra as forças da morte, afeto. No momento da prece, orando pela fé que perderam, os outros no momento de fé, crivado com setas de amor, as mãos e os pés e o lado esquerdo amém; e Gil cantando o hino do movimento. Segue a letra: 


\section{O meu gesto político Figa \\ Este é meu gesto, é meu gesto de amor}

Ele não faz parte de uma doutrina, ele não pertence a nenhum senhor

É como o gesto de um fidalgo branco que acolhe em seu leito a mais negra escrava e nela crava o seu cravo de afeto

E então se trava a batalha do amor

Sem nenhum outro motivo que o sonho, de ao próprio sonho fazer vencedor

Sem nenhum outro querer que não seja ver a beleza distinta da cor

O meu gesto é o fogo sagrado, que não destrói, mas é abrasador, que faz a dor transmutar-se em alegria, pelo seu mais agradável calor

O meu gesto político figa nem uma mágoa, desprezo ou temor

O hino repete sempre a necessidade de se tratar esse gesto político pelo filtro do amor. Nesse momento, o sonho de ver vencido o preconceito no país é entoado. Mais uma vez, vemos surgir as tramas do sentimento guiando o ato político. A ação de Gil no camp o político configura o que Maffesoli chamou de transfiguração do político: das narrativas escatológicas à ação focada e limitada, nas condições de possibilidade oferecidas pela pós-modernidade.

Naquele mesmo período histórico, Gil foi objeto de uma polêmica midiática relacionada ao personagem Zelberto Zel, interpretado por Chico Anysio na TV Globo. Essa polêmica muito nos diz a respeito das reações à ação política de Gil e à construção de sua africanidade, conforme veremos a seguir.

\section{- Caso Zelberto Zel}

O personagem Zelberto Zel foi criado pelo humorista Chico Anysio para fazer parte de um dos quadros do programa Chico Anysio Show, da Rede Globo de televisão. A caricatura de Gil se fazia ecoar pela anedota "Soteropolitanos e soteropolitanas, vamos carnavalizar geral." 579 Zelberto Zel foi criado por Anysio na mesma época em que Gil iniciava sua candidatura à prefeitura de Salvador, e é aqui analisado enquanto parte de uma construção imagética, e até mesmo estereotipada, referente ao político Gil.

\footnotetext{
${ }^{579}$ Disponível em:<www.chicoanysio.com> Acesso em: 21 fev. 2016.
} 
A intenção aqui não é analisar se a recepção desse personagem pelo público influenciou ou não a candidatura de Gil, mas compreender nessa trama identitária como o artista foi exposto através de um complexo jogo de significações e representações que fizeram menção direta à sua negritude e ao racismo brasileiro.

Por meio de vídeos disponibilizados no Youtube ${ }^{580}$ é possível ter acesso aos trejeitos do personagem Zelberto Zel, suas falas complicadas e figurinos que remetiam às africanidades de Gil, ou através de batas ou turbantes, brincos sempre grandes e muitos anéis nas mãos, além de uma postura bastante afeminada. O estereótipo construído e acessado por Anysio mencionava também um jeito baiano preguiçoso, já que Zelberto Zel aparece sempre sentado em uma rede. A linguagem do personagem é sempre obscura, e por vezes até mesmo incoerente.

Bhabha, ao questionar a representação da alteridade, afirma:

O que é, portanto, uma simplificação no processo da representação estereotípica tem um efeito de colisão sobre o seu foco central de abordagem da política do ponto-de-vista. Eles operam com uma noção passiva e unitária de sutura que simplifica a política e a "estética" do posicionamento do espectador, ao ignorar o processo ambivalente, psíquico, de identificação que é crucial ao argumento. Ao contrário, proponho que, de forma bem preliminar, o estereótipo é um modo de representação complexo, ambivalente e contraditório, ansioso na mesma proporção em que é afirmativo, exigindo não apenas que ampliemos nossos objetivos críticos e políticos, mas que mudemos o próprio objeto de análise. ${ }^{581}$

Mais adiante, Bhabha complementa ainda que o estereótipo:

Não é uma simplificação porque é uma falsa representação de uma dada realidade. É uma simplificação porque é uma forma presa, fixa, de representação que, ao negar o jogo da diferença (que a negação do Outro permite), constitui um problema para a representação do sujeito em significações de relações psíquicas e sociais. ${ }^{582}$

Desse modo, Bhabha concebe que a representação da diferença não deve ser vista como reflexo de traços culturais inscritos por meio de discursos e estratégias que tentam fixar por meio de binarismos excludentes a identidade do Outro. Assim, não é dado a Zelberto Zel a possibilidade do reconhecimento da diferença, libertando o significante

\footnotetext{
580 Youtube. Chico Anysio e João Cláudio Moreno - Caetano e Gil. Disponível em:<https://youtu.be/JoXo7megdwo> Acesso em: 21 fev. 2016.

${ }^{581}$ BHABHA, Homi K. O local da cultura. Belo Horizonte: Ed. UFMG, 1998, p. 110.

${ }^{582}$ Ibid., p.117.
} 
de pele/sexualidade das fixações da tipologia racial e de gênero, das ideologias de dominação racial e cultural ou mesmo da degeneração. De acordo com Bhabha, o estereótipo impede a circulação e a articulação do significante "raça", a não ser em sua fixidez enquanto um ato de racismo.

Podemos analisar a construção desse personagem através da indignação de Risério frente à caricatura criada pelo humorista Chico Anysio. No primeiro parágrafo do item "Zelberto Zel: uma caricatura racista", tópico do livro $O$ poético e o político, Risério mostra sua frustração:

Hoje às 21:30h vai ao ar, mais uma vez, o Chico Anysio Show. Nãoestou aqui para comentar o programa, mas apenas um quadro daquele balaio de gatos: a caricatura reacionária e racista que Anysio faz de um Gilberto Gil em campanha para disputar a prefeitura de Salvador. E tomo a iniciativa por um motivo simples. Ainda não perdi a capacidade de indignação moral e política, nesses dias em que a falta de caráter e de grandeza se aliaram para tentar dominar definitivamente a cena. ${ }^{583}$

De acordo com Risério, Zelberto Zel é uma caricatura reacionária e racista, chegando mesmo a prejudicar a campanha de Gil. De acordo com o autor, Anysio "surge desta vez como porta-voz dos preconceitos mais rasteiros, para delícia dos pedantes e hipócritas guardiães dos "valores" pequeno-burgueses e para felicidade geral das oligarquias de direita e de esquerda". 584

Questionado, em 1988, sobre o personagem Zelberto Zel, Gil comentou:

É saber se vão ficar preocupados com o brinco na minha orelha ou vão se livrar desses estigmas absurdos, dessa coisa moralista terrível. Numa terra onde se vê um personagem como o de Chico Anysio insistindo nos estereótipos vulgarizantes da homossexualidade, da incomunicabilidade do artista sonhador, da insensibilidade do homem pequeno-burguês em relação ao povo desamparado, é preciso saber isso. Se o povo vai confundir esse simulacro da televisão com o original, se de repente vai ignorar tudo sobre Gilberto Gil, sobre todas as posições que já tomou, todo o empenho que já teve para desenterrar o sentido profundo da alma do Brasil e da Bahia e levar isso para o povo de um modo geral, sobre todas as lutas contra os processos antidemocráticos no Brasil, pela desrepressão do sistema, por todas essas questões progressistas.

\footnotetext{
${ }^{583}$ BHABHA, Homi K. O local da cultura. Belo Horizonte: Ed. UFMG, 1998, p.191.

584 Ibid., p. 192.
} 
Se não há essa capacidade de distinção, não cabe a nós insistir. ${ }^{585}$

Ambos, Gil e Risério, chegaram a mostrar preocupação com a aceitação e a influência do personagem nos possíveis votos destinados a Gil. Tanto na fala de Risério, quanto na de Gil, é possível perceber a indignação de ambos com a criação do personagem por Chico Anysio.

A discussão sobre a polêmica Zelberto Zel ocupou as páginas da Folha de $S$. Paulo, e abriu espaço para o debate com a participação tanto de Risério quanto de Chico Anysio. Assim se posicionou Risério:

(...) entra em cena o Anysio, gaiato de primeira hora. E entra em cena fazendo uma caracterização safada e sórdida de Gil. Papagaio velho, Anysio surge dessa vez como porta-voz dos preconceitos mais rasteiros, para delícia dos pedantes e hipócritas guardiães dos "valores" pequeno-burgueses e para felicidade geral das oligarquias de direita e de esquerda. Deverá ser calorosamente aplaudido, hoje à noite, por gente como Toninho Malvadeza, o salazarista Zé Lourenço este ou aquele xiita direitófobo, ou histórico histérico do PMDB. Bem vistas as coisas, a caricatura de Gil está montada basicamente em quatro linhas: 1) estereótipo racista do negro boçal e/ou do mulato pernóstico, de fala "difícil", rebarbativa; 2) na exploração do estigma homossexual (ênfase no brinco, os trejeitos, a fala melíflua - o personagem é também um novo "painho", o pai de santo gay); 3) no desprezo olímpico pelo voto e pela disputa eleitoral (há algo de "Justo Veríssimo" aî); 4) no estigma do artista irresponsável, deliberante, doidivanas (o programa político "carnavalizante"). Em suma, Gil é decodificado, via paródia, como um mulato boçal, elitista, leviano e aviadado. Cara de pau, Chico Anysio ainda afivela a máscara da candidatura e declara à imprensa que apoia Gil. ${ }^{586}$

Em resposta, Anysio, em nota publicada ao lado do texto de Risério, diz-se amigo

da família Gil, ataca Risério e resume seus pontos de vista em quatro itens:

(...) 1. Não há nada de homossexual no personagem Zelberto Zel. Todas as referências a homossexualismo vindas dos redatores do programa eu cortei pessoalmente. 2. Quem fez o Gil mulato foi a natureza, não eu. 3. Cinquenta por cento do que foi falado pelo personagem foi tirado ipsis litteris de entrevistas de Gilberto Gil. 4. Gil é retórico. Eu não estou inventando uma coisa. O Gil pega no anel. O Gil usa brinco. ${ }^{587}$

\footnotetext{
${ }^{585}$ TRAGO o que o povo quer, um novo sonho. Tribuna da Bahia, Salvador, 24 abr. 1988. Disponível em: <www.jobim.org> Acesso em: 21 fev. 2016.

${ }^{586}$ RISÉRIO, Antonio. "Zelberto Zel" é acusado de ser caricatura "racista". Folha de S. Paulo,21 abr. 1988.

${ }^{587}$ CHICO Anísio diz que homenageou Gil. Folha de S. Paulo,21 abr. 1988.
} 
Anysio, ao caricaturar Gil, articulou história e fantasia, produzindo efeitos que podem ser aqui interpretados como políticos. É interessante ressaltar, assim como nos sugere Bhabha, que grande parte dos estereótipos, nos textos coloniais, são também indicadores de identificação e alienação, medo e desejo. Ao abordar a trajetória de Gil como Zel, Anysio está dimensionando o alto grau de poder de identificação de Gil com o grande público. Apesar da leitura satírica, a negritude e o lado afeminado podem tanto representar fobia como fetiche. A criação desse personagem permite-nos pensar que tanto poder quanto desejo estão imbricados nessa representação, tratando especialmente do reconhecimento da diferença sexual e racial, bem como o seu repúdio.

Esse imbricamento entre poder e desejo também pode ser identificado no ato de mimetizar o candidato Gil. Ao personificar Zel, Anysio produz e reproduz imagens de Gil baseando-se nos valores da cultura baiana, na negritude e na homossexualidade que são tomados como dados nesse jogo de representação. Referindo-se a esse processo de imitação, Bhabha afirma:

\begin{abstract}
A mímica surge como objeto de representação de uma diferença que é ela mesma um processo de recusa. A mímica é assim o signo de uma articulação dupla, uma estratégia complexa de reforma, regulação e disciplina que se "apropria" do Outro ao vislumbrar o poder. ${ }^{588}$
\end{abstract}

A mímica é utilizada por Anysio como uma estratégia de garantir-se no poder através de seu ofício satirizador. No entanto, a criação desse personagem estereotipou o artista e político Gil, lidando/jogando com aspectos de "superioridade" cultural e racial. Vale ressaltar, porém, que tanto Gil quanto Risério demonstraram à época que a criação do personagem foi algo perturbador e conflituoso.

O personagem Zel faz parte de uma arena política, historicamente constituída, e nos parece ser uma peça na luta de representações travada em torno da imagem de Gil. De um lado, há a tentativa de estereotipá-lo, reduzindo-o a uma imagem pouco lisonjeira, com traços de leitura satírica; de outro, a busca por dignificá-lo, reforçando seus potenciais políticos e sua plataforma progressista. Essa segunda representação de Gil está presente no livro O poético e o político.

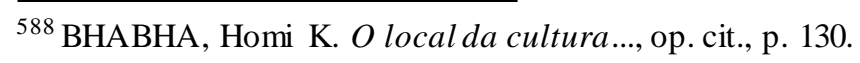




\section{4 - O livro O poético e o político}

No primeiro parágrafo do livro, Risério e Gil afirmam:

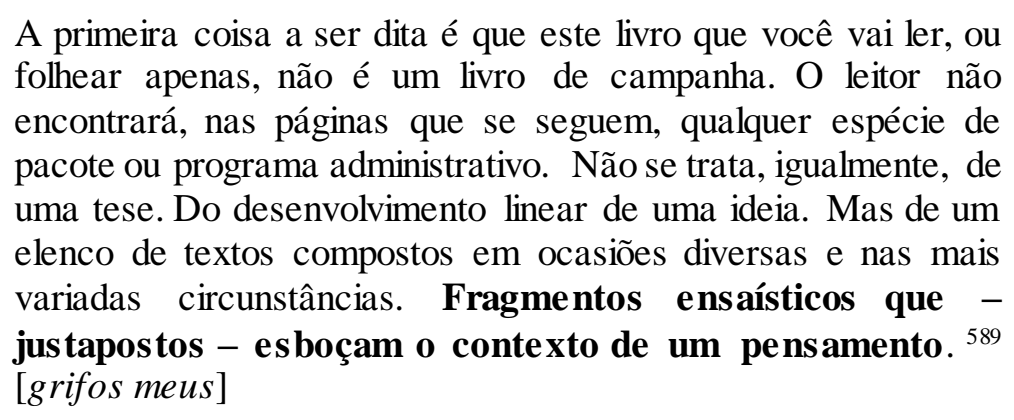

É interessante salientar que o livro escrito por Antônio Risério e Gilberto Gil, intitulado O poético e o político, seria editado primeiramente pela Editora Brasiliense, mas acabou sendo vetado pelo então diretor da editora, Caio Graco Prado, que afirmou ter cancelado o lançamento do livro por motivações políticas, especialmente depois de Gil apoiar o mandato de cinco anos do presidente José Sarney. Na ocasião Risério retrucou: "O livro é objeto de luta política, e não de palhaçada como o Caio está fazendo; não é uma tese, é um objeto de ação política, de campanha". 590

O livro acabou sendo lançado em 1988 pela Editora Paz e Terra, e, assim como nos dimensionou Risério no momento de lançamento do livro, a obra foi motivada pela candidatura de Gil à prefeitura. O poético e o político reúne entrevistas de Gil, bem como ensaios dos autores. Isso é de fundamental importância para este trabalho, pois nos fornece inúmeros indícios referentes não somente à políica adotada pelos autores, como também pelas muitas menções à África, à escravidão e a muitos outros aspectos que referenciam a negritude e a presença da África no contexto brasileiro da forma como aprendido por Gil.

O livro mescla textos de Risério e Gil; no entanto, há sempre o enfoque em questões sociorraciais brasileiras. A última parte do livro, em especial, em muito nos auxilia a compreender a experiência política de Gil no ano em que chefiou a FGM, já que ao final é apresentada a prestação de contas dos trabalhos executados, além da apresentação do projeto CERNE, Centro de Referência Negro-Mestiça, a ser implantado em Salvador.

\footnotetext{
${ }^{589}$ GIL, Gilberto e RISÉRIO, Antônio. O poético e o político..., op. cit., p. 11.

${ }^{590}$ LIVRO vetado de Gil prega liberdade mestiça. Folha de S. Paulo,28 maio 1988.
} 
Em um texto escrito conjuntamente pelos autores, chamado "Democracia e diferença", ambos sintetizam suas intenções:

E ocorre que a chamada "democracia racial" é o nosso mais belo sonho. É o sonho central da mitologia social brasileira. Ninguém pode pôr em dúvida o seu amplo e profundo alcance na sociedade que se formou entre a Amazônia e o Rio Grande do Sul. Temos, evidentemente, que desmascarar a construção ideológica elitista de um mito paralisante e neutralizador de conflitos. Mas o que nós queremos, enquanto descendentes de escravos, não é simplesmente negar o mito - e sim realizá-lo. Sabemos que mitos passados movem moinhos. E é necessário, para a sobrevivência e a afirmação do Brasil, que o mito se encarne na história, assim como na história se encarnaram a metalurgia e a malandragem. Este é o sentido de democracia que nos interessa. A história das Américas - articulada em complexa tessitura de astecas, europeus, tupinambás e nagôs - é a história de uma heterogeneidade. E esta heterogeneidade - este fascinante e meândrico conjunto multicultural de civilização - deve rebrilhar no horizonte democrático. Pois a democracia é a possibilidade o projeto de que as diferenças, todas as diferenças, se realizem em sua plenitude. ${ }^{591}$

O pensamento exposto no livro trata das intenções políticas e até mesmo ideológicas de ambos, caso Gil fosse eleito prefeito de Salvador. Ao invés de simplesmente atacarem a "democracia racial", ambos apontam a possibilidade de realizála, reconhecendo a hierarquia existente e sua necessária dissolução, bem como o empenho em valorizar o multiculturalismo brasileiro enquanto projeto.

Ao tratarem de temas como democracia, poder, política e diferença relacionandoos com aspectos raciais, assim se posicionam os autores:

(...) Nós, os negromestiços, conhecemos bem as perversões linguísticas de elite - e os poderes do encantamento verbal e da magia nominalista. Afinal, foi diante de nossos olhos incrédulos e confusos que a elite brasileira produziu o mito da "democracia racial", exportando, para o mundo inteiro, a imagem falsa de um paraíso étnico existente sob o sol do Atlântico Sul. (...) E a verdade é que a democracia jamais se realizará, no Brasil, caso o seu processo construtivo passe ao largo de nossa questão sociorracial e de nossa multiplicidade cultural. (...) Engravescendo ainda mais o panorama, estas elites não aboliram a escravidão. Os negros, que apoiaram a luta pela independência, puderam então medir a dimensão de sua frustração. Aquilo foi um golpe cruel, sádico mesmo, para quem saudara, com tanta esperança, a luta contra a dominação colonial portuguesa. $\mathrm{Na}$ verdade, os movimentos revolucionários da elite brasileira, entre o final do século 18 e o princípio do século seguinte, tocaram na

${ }^{591}$ GIL, Gilberto e RISÉRIO, Antônio, O poético e o político, op. cit., p.39. 
tecla da escravidão, mas para aí se confundirem - e aí se perderem. O sistema escravista encalacrou o liberalismo brasileiro. Porque o liberalismo brasileiro veio sendo, até aqui, o liberalismo da camada dirigente. Daí o fosso, o grande abismo, entre a retórica liberal e a realidade do país. Nossas formulações constitucionais desde sempre garantiram, perante a lei, a igualdade a todos... mas desde que, na prática social objetiva, pretos e pobres não estivessem incluídos neste "todos". É tão simples assim. (...)A discussão da "diferença não nos mobiliza em função da construção deste ou daquele astucioso ardil ideológico, mas no sentido nítido da realização democrática de nosso povo. Por uma razão muito simples. Atirados no mundo competitivo da venda de força de trabalho - no universo do modo de produção capitalista; da mão-de-obra conceitualmente livre-, os negromestiços brasileiros se viram atirados no porão de um novo navio negreiro: o barco da Revolução Industrial. Não foi por outro motivo que nos tornamos, no dizer dos estudiosos, uma "raça social". E é necessário que esta questão seja pensada e resolvida, simultaneamente, em suas duas dimensões. Trata-se de uma problemática sociorracial. E esta é uma questão democrática. Porque o autoritarismo é o último refúgio do etnocentrismo. Nós cultivamos outro sonho. Sabemos que o autoritarismo é uma versão higiênica do etnocentrismo. E denunciamos a canoa furada. A viagem democrática, não será demais repetir, é aquela que aposta na redução, e mesmo na supressão, das diferenças socioeconômicas - e aquela que aposta no negritar das diferenças de cultura. ${ }^{592}$

Uma vez mais, Risério e Gil não apenas se autodenominam negro-mestiços, como lutam pelo reconhecimento dessa potência dentro do quadro social brasileiro, apontando as elites como as responsáveis pela permanência da divisão injusta das riquezas do país. Suas demandas apontam para o fim das diferenças socioeconômicas e pela busca por uma lei que atenda a todos de maneira igualitária. Não apenas no trecho acima citado, mas no decorrer de todo o livro, ambos lutam pela igualdade de direitos para todos os cidadãos brasileiros, além de constantemente defenderem o respeito às diferenças.

No texto "Por um abolicionismo socialista", as ideias e o pensamento dos autoresartistas podem ser sintetizados no parágrafo a seguir:

Esta é a herança que temos que liquidar. Arquivou-se legalmente um sistema de trabalho, mas não se suprimiu um contexto discriminatório. A situação atual das massas negromestiças brasileiras é a prova da vinculação de nosso presente social às estruturas materiais e ideológicas da ordem escravocrata, cujas consequências e desdobramentos povoam e poluem o nosso dia-

${ }^{592}$ GIL, Gilberto e RISÉRIO, Antônio. O poético e o político, op.cit., pp. 37-41. 
-a-dia. E se a obra da abolição é coisa inconclusa, declaramos que esta é a obra que queremos concluir. Vem daí o ímpeto da releitura, da revisão e da retomada, prevendo um salto suficientemente ousado em direção ao futuro. Estamos ainda muito longe de atingir o estágio histórico pressentido pela vanguarda liberal- revolucionária do século que passou - o da "união das raças na liberdade". Mas essa é tarefa histórica de nossa geração tudo tentar para trazer este ideal para a dimensão pedestre e plebeia, fazendo com que ele se enraíze, cresça, oxigene e transforme a sociedade brasileira. Ou a mancha de Caim permanecerá resistente aos truques, detergentes e maquiagens das classes dominantes. ${ }^{593}$

Mais uma vez a discriminação racial é aludida e combatida. O período escravocrata, que perdurou no Brasil por mais de três séculos, aqui é retomado juntamente com a necessidade de extinção de sua presença até hoje entre nós. Novamente a tática das elites em camuflar tal situação é denunciada, bem como a necessidade de seu fim.

Em "Mistério perdido nos tempos", Gil dimensiona sua ideia e concepção sobre a África naquele momento:

O continente africano foi, desde cedo, um imã potente, atraindo homens da Europa com sua curiosidade e sua libido. Intensamente magnetizados por esta "usina nuclear" de sensualidade que é o continente negro, germânicos, romanos e gregos, uns após outros, vão buscar na África a reconstituição física e poética de uma paisagem primordial do serhumano mais orgânico, o homem-natureza. [...] Cotidiano lúdico, exis tência dançarina, beco de mistérios, caminho de riquezas, a vida da tribo africana apela à curiosidade cultural moderna através de múltiplos estímulos a uma antropologia distinta da que havia nos proporcionado a Ásia, a Europa e as Américas. Enquanto os modos de organização social asiáticos e europeus, já em suas codificações embrionárias, apontavam aqueles para um culto da sabedoria (Confúcio, Lao-Tsé) e estes para um culto da ação (conquista da natureza, techné), no modo africano vamos encontrar uma mediação, ao mesmo tempo conciliadora e transcendente às duas, na forma de culto à integração radical homem/natureza (vida selvagem, volúpia dos instintos). A África é a existência mais brincalhona e sensual; o pante ís mo radical dos corpos, mentes, espíritos nômades e árvores sábias. ${ }^{594}$ [grifos meus]

No contexto de sua pré-candidatura, no ano do centenário da abolição, a África é desnudada por Gil pelo seu exotismo, beleza, encantamento e sensualidade, demarcada

${ }^{593}$ GIL, Gilberto e RISÉRIO, Antônio. O poético e o político, op.cit., p. 59.

${ }^{594}$ Ibid., pp.70-71. 
pela forte ligação do homem com a natureza. É a África representada como um espaço extraordinário, experimentada através de instintos "primordiais", criando um tipo ideal, emanando sabedoria e liberdade.

No texto "Abo/lições", Gil problematiza o tema da abolição:

1888. Abolição. Qual a lição da Abolição? É o que nos perguntamos, mais e mais. E quando a pergunta é de fato uma pergunta - e não um truque de retórica previamente engatilhado no dispositivo desta ou daquela gramática política -, o perguntador está num ponto equidistante entre as mistificações de elite (o mito da "democracia racial", por exemplo) e as falas encruzilhadas dos assim chamados "xiitas da negritude" (que chegam ao absurdo de dizer que existe "apartheid" no Brasil, por exemplo). Nem uma coisa, nem outra. (...) É preciso destruir a obra da escravidão. Esta obra que dura e que perdura, confinando os negro-mestiços no vagão da segunda classe do Expresso Brasileiro. Infelizmente, ainda não alcançamos o estágio histórico profetizado pelo Movimento Abolicionista: a "união das raças na liberdade", dixit Nabuco. Mas a gente chega lá. ${ }^{595}$

Gil retoma novamente o tema em "Reabolição", acenando para a necessidade de comemorá-la:

A comemoração feérica, jubilosa, comovida da Abolição, possibilitaria reavivar no povo brasileiro o sentido, a razão e a necessidade do gesto; restauraria a lembrança do sentimento libertário e emancipador desbotado pelo tempo e pelas novas manobras da História; significaria uma reocupação do território abolicionista, uma reencarnação do seu ideal. (...)..$^{596}$

A relação de Gil com a abolição nesse momento político é aqui compreendida como uma espécie de pertencimento à negritude brasileira, numa história marcada pela experiência diaspórica, fortemente conectada à origem africana, situando o artista no espaço da tradição. A ideia de terra-mãe é fortemente conectada ao projeto de reinterpretar a abolição, questionando-a. Assim, Gil posiciona-se no entre-lugar, já que a abolição, aqui enunciada, e até mesmo "re-descoberta", ao ser questionada nesse contexto póscolonial, dimensiona como fatos passados podem ser reprocessados, na busca pela criação de um futuro libertário e emancipador. Ao questionar a reestruturação da abolição, possibilitando que ela se efetive de fato, Risério e Gil experimentam e propõem um tempo revisionário, tocando no futuro em seu lado de

\footnotetext{
${ }^{595} \mathrm{GIL}$, Gilberto e RISÉRIO, Antônio, O poético e o político, op. cit., pp.115-117.

${ }^{596}$ Ibid., pp. 139-142.
} 
cá. ${ }^{597} \mathrm{O}$ passado retorna ao presente através da necessidade de se comemorar de novo a abolição, numa crítica que denuncia a continuidade, senão da escravidão, da permanência da exclusão dos negromestiços do quadro social brasileiro, demarcado pelos autores como injusto e excludente. Ao experimentar diferentes temporalidades, os autores se situam na localidade do terceiro espaço ao abordar o encontro da descontinuidade da cultura negra no seio da cultura brasileira, mencionando uma história que não pôde ainda ser contada. O passado ressurge não como nostalgia, mas carregado de demandas a serem resolvidas, imbricando presente e futuro.

É V. Y. Mudimbe quem ressalta a invenção de uma ideia de África, salientando que até mesmo o nome dado ao continente conjuga um complexo processo histórico:

De qualquer modo, desde o século XV, a ideia de África misturou novas interpretações científicas e ideológicas aos campos semânticos de conceitos, tais como 'primitivismo' e 'selvageria'. ${ }^{598}$

De acordo com Achille Mbembe, existe um desejo de silenciar o processo escravagista, gerando uma espécie de fantasmagoria em torno dessa fala não dita. Não se trata, pois, apenas de reivindicar uma memória traumática, mas compreender essa interpretação descontextualizada que somente acentua a imagem de vitimização creditada ao continente africano. ${ }^{599}$

O discurso de Gil presente no livro não apenas celebra a África, mas nos suscita a perceber quem fala (político), de onde fala (Salvador/Brasil), com que vontade (concretizar um pensamento/ideal) e para quem (seus eleitores). Esse texto/pensamento/discurso/livro de Gil é aqui interpretado enquanto uma estratégia política, mas também enquanto uma espécie de mobilização social e identitária, que, além de uma comunicabilidade associada às africanidades, representa também o enfrentamento do poder hegemônico e racializado brasileiro.

Ao final do livro, aparece como apêndice um roteiro de intervenção políticocultural da FGM, que assim se assume:

A FGM entrou em cena para virar a mesa. Nada de se converter em caixa de repasse de verbas. Decidimos que nossa função não

\footnotetext{
${ }^{597}$ BHABHA, Homi K. O local da cultura, op. cit., p. 27.

${ }^{598}$ MUNDIMBE, V. Y. The Idea of Africa. London: Indiana University Press, 1994, p.11.

${ }^{599}$ MBEMBE, Achille. As formas africanas de auto-inscrição. Revista Estudos Afro-Asiáticos, Rio de Janeiro, ano 23, n. 1, 2001.
} 
poderia ser jamais a de distribuir migalhas insuficientes no banquete da cultura superior. Além de não repassar recursos, não elegeríamos uma clientela preferencial. Nossa preocupação é com o fenômeno cultural global, do qual a produção da "classe artístico-intelectual" é apenas um segmento. Importante, mas um segmento. Por outro lado, negando o papel de Xerox, a FGM não se estrutura por departamentos, compartimentos ou escaninhos burocráticos, ideologicamente orientados por uma concepção elitista e restritiva de cultura. ${ }^{600}$

Essa intenção de ação da FGM, ou mesmo sua política cultural, mostra-se aqui resumida, e seu principal objetivo é estender as verbas e condições a todos os artistas da cidade, e não apenas a poucos privilegiados, aqui identificados como cultura superior. A política adotada aponta para a modificação da distribuição, além de tentar explorar a cultura em seus variados aspectos.

As políticas públicas em andamento realizadas pela FGM foram explicadas pormenorizadamente ao final do livro; são elas: Projeto Centro Histórico (Recuperação), Parque histórico do Pelourinho (Revitalização), Projeto Bahia/Benim (Criação de canais comunicativos), Projeto Boca de Brasa (Equipamento tecnológico: carretas que se transformam em palcos e circulam pelas periferias da cidade levando arte para todos os cantos), Projeto Terreiro (Recuperação e proteção de templos), Projeto Carnaval (Revitalização), Projeto Arquivo (Recuperação), São Bartolomeu/Abaeté (Vitalização: lazer e turismo). Vale ressaltar que as ações políticas nesse momento visavam abarcar uma série de situações culturais, que podem ser identificadas através da diversidade. As africanidades estão presente entre as demandas sociais a serem atendidas, mas não são a prioridade entre as políticas públicas adotadas pela FGM, que tangenciou desde aspectos de recuperação à circulação de eventos em locais periféricos da cidade, demonstrando um caráter bem mais atento à pluralidade do que somente à tradição.

O Centro de Referência Negro-Mestiça, de acordo com seus idealizadores, ${ }^{601}$ intencionava enfrentar: "O desafio que representa a passagem do Centenário da Abolição da Escravatura no Brasil, marco histórico que assinala o término (ao menos, em termos sistêmicos) das práticas sociais escravistas no hemisfério ocidental".602

\footnotetext{
${ }^{600}$ GIL, Gilberto e RISÉRIO, Antônio. O poético e o político..., op. cit., p. 234.

${ }^{601}$ Assinaram o texto Juca Ferreira, Risério, Gil, Dulce Ferrero e Vanya King.

${ }^{602}$ GIL, Gilberto e RISÉRIO, Antônio. O poético e o político..., op. cit., p.249.
} 
As atuações do Centro da Referência Negro-Mestiça direcionam-se em duas frentes: "vibrando na frequência da memória histórica, mas sem mitificar ou folclorizar um passado africano"; e "procurando intervir construtivamente, de uma perspectiva socioantropológica, no urgente e completo tecido de nosso presente social". ${ }^{603}$

Assim, ao apresentar suas propostas, o CERNE dispôs-se a prestar serviço à comunidade, tendo como matéria-prima a informação, intencionando atuar como catalisador de demandas e "introduzir enzimas democráticas no metabolismo sociocultural" de Salvador. E ainda:

O CERNE será um lugar de captação, produção e disseminação de informações. E isto através do estabelecimento de nexos orgânicos com a vida comunitária. A leitura da demanda comunitária norteará a definição de prioridades temáticas e programas de ação. ${ }^{604}$

Se levarmos em consideração que o livro escrito em conjunto com Risério, além de um projeto político de atuação, é também uma espécie de roteiro ideológico précandidatura, ou até mesmo parte da campanha de Gil para a prefeitura de Salvador, percebemos que a África e a negritude ganharam papel de destaque em $O$ poético e $o$ político, uma vez que os autores reafirmaram constantemente no livro a necessidade de repensar a continuidade da escravidão no Brasil, onde a abolição merecia ser reavaliada no contexto do presente.

Aqui mais uma vez podemos fazer alusão ao Atlântico Negro, ${ }^{605}$ mas especialmente a seu caráter coletivo, bem como ao entendimento da realidade afrodiaspórica como um meio de salvação, de transformação, instrumento crítico para dinamizar a persistência do colonialismo. A força discursiva de Gil e Risério acena para a construção de laços de solidariedade, de pertença e revolta, denunciando a complexidade das relações de poder em voga nessa situação, a situação da diáspora africana pós-colonial.

Através dessa obra, os autores realizaram um discurso crítico, repensaram hierarquias sociais e econômicas, demarcaram o desequilibrio social brasileiro, mas principalmente a situação de exclusão dos negro-mestiços, e reivindicaram a aceitação

\footnotetext{
${ }^{603}$ GIL, Gilberto e RISÉRIO, Antônio. O poético e o político..., op. cit., p.233.

${ }^{604}$ Ibid., p. 256 .

${ }^{605}$ No entanto, vale ressaltar que Gilroy chama a atenção para o fato de que o particularismo étnico, bem como o nacionalismo e o essencialismo são perigos constantes, enfatizando especialmente as trocas culturais transnacionais no circuito transatlântico.
} 
da diversidade. É importante evidenciar que essa busca por justiça, em refazer a abolição após um século passado de sua instituição, era direcionada ao ideal de partilhamento do poder. Extinguir a desigualdade e a exclusão racial é uma busca por reparação social e econômica, desvelando conflitos e tensões, imaginando um Brasil mais justo e igualitário.

Embora, como vimos anteriormente, a candidatura de Gil à prefeitura de Salvador não tenha vingado, devido a disputas internas no PMDB e à preferência da cúpula por outro candidato, o compositor conquistou em 1988 o mandato de vereador, permanecendo nele de 1989 a 1992. As ações políticas de Gil serão analisadas no tópico a seguir.

\section{5 - Gil vereador (1989-1992)}

Em tempos de Zelberto Zel, a candidatura de Gilberto Gil à prefeitura de Salvador, preterida pelo mandarinato político baiano e substituída pela vereança, foi marcada pela denúncia do mito da democracia racial e do forte elitismo sociorracial dominante nos quadros da política brasileira.

No entanto, a prática de Gil no mandato de vereador apresenta uma aparente contradição: apesar de as críticas ao racismo terem sido uma constante nos discursos de Gil durante a candidatura, o período de legislatura foi marcado pela ênfase em questões ambientais, que tiveram como ápice a sua mudança do PMDB para o PV. Nossa intenção é partir do jogo de memórias construídas por Gil e, ao contrapô-las às fontes da época, buscar compreender essa transformação.

Em entrevista publicada em 1988, Gil se posiciona ao ser questionado sobre ser artista, político e negro:

Pois é, isso estabelece um plano de incompatibilidade total. $\mathrm{O}$ artista é o outro, foi expulso da República de Platão, não se conhecem casos, mesmo nas tribos, de simbiose de cacique com pajé. O palhaço nunca é dono do circo. Mas há um outro fato, o de ser negro. Embora isso não seja visto como negativo pela maioria, é estranho. O negro nunca esteve eficazmente presente na política, não pertence à classe dirigente brasileira. Como minha história tem um claro compromisso com essa questão sou negro assumido, não disfarço para viabilizar minha ascensão na sociedade - isso se torna um problema. Há outro - eu não 
tenho competência para administrar. Mas não há justificativa: a maioria dos políticos é de advogados, médicos, fazendeiros, todos egressos de mundos que não a administração. ${ }^{606}$

Questionado se sua negritude o ajudaria na política, Gil disse:

Ajuda ser negro e ter tido trânsito e ter sido agente desse processo de sedução, dessa política de cupim, como diz o mestre Didi. Aquele que come por dentro, até a casa cair. Estou muito liga do a esse trabalho. Que não quer uma ruptura ostensiva, que opera com a perspectiva utilizável do reformismo. Mas eu sou branco mulato e negro doutor. E isso irrita certas elites. ${ }^{607}$

Gil parecia ciente de sua ambígua condição social de "negro doutor". Preterido pelo partido, por razões que ele, ora de forma velada ora mais explicitamente, relaciona ao preconceito de cor, ele é também indagado se sua negritude - e não a de um cidadão comum - poderia servi-lo como algo positivo sob o ponto de vista político. As duas passagens anteriormente citadas lançam luz sobre a ambiguidade à qual nos referimos. $\mathrm{O}$ ser "branco mulato e negro doutor" é capaz de irritar "certas elites", ao passo que sua negritude, explicitamente tratada em sua trajetória artística, jamais traria a condescendência da classe política tradicional. Não se tratava de um "branco mulato" qualquer, mas de um artista que problematizou e colocou em jogo a diáspora, as origens africanas, o desvelar de um contexto que era seu e de centenas de milhares de afrodescendentes cuja voz não se fazia ouvir, nacionalmente, como a dele.

Em um de seus discursos para vereador, Gil afirmou que sua rejeição pelo PMDB para a prefeitura de Salvador se deu por "pessoas reacionárias e preconceituosas". 608 Depois de afirmar que queria "deixar muito claro ao público, na medida das minhas possibilidades de conhecimento dos fatos, esta questão toda", prosseguiu comentando sobre o racismo:

Eu fico profundamente chocado com a necessidade de concluir as coisas dessa forma, de que há um racismo subjacente no fato do governador afirmar que minha postulação é pretensiosa ou no fato de um seu cunhado, na Assembleia Legislativa, afirmar que cada macaco deve ficar no seu galho. Levando em consideração o governador Waldir Pires, levando em consideração o

\footnotetext{
${ }^{606}$ ADÁRIO, Paulo. Eu quero o poder. Jornal do Brasil, Rio de Janeiro, 21 fev. 1988. In: GIL, Gilberto e RISÉRIO, Antônio. O poético e o político...,op. cit., p. 182.

${ }^{607}$ GIL, Gilberto e RISÉRIO, Antônio. O poético e o político...,op. cit., p. 186.

${ }^{608}$ SUZUKY, Matinas. Gil seguirá na política e diz que Waldir Pires vetou sua candidatura. Folha de $S$. Paulo, 8 ago. 1988.
} 
governador, quadros políticos da Bahia e também áreas da classe dirigente da cidade - de quem procurei me aproximar com toda diplomacia, com todo cuidado, com todo respeito. Eu fico muito chocado em ter que ser levado a fazer constatações desse tipo, mas também não vejo outra alternativa a não ser achar que é isso mesmo. Me parece que se configura aí um caso de Casa Grande \& Senzala, um negro que não se assume, um negro que não sabe o seu lugar. Eu acho que estas simplificações, frases deste tipo, são necessárias, automáticas. Eu gostaria muito que não fosse assim, que se pudesse encontrar uma complexidade maior, até inexplicável, deste fenômeno todo. Mas o que fica mesmo, só o que nos resta, a opção que nos resta para entender o episódio todo é que realmente o tal exercício do preconceito racial, por um lado, e do preconceito social por um outro. ${ }^{609}$

Outro episódio, também ocorrido durante a candidatura de Gil, oferece-nos indícios a respeito de estereótipos a que ele esteve exposto. O então presidente do PMDB da Bahia, deputado Luiz Leal, teria comentado, segundo Gil, que "a Bahia não aceita homem de brinco". Tal recusa teria como motivação "um preconceito sexual muitoforte". ${ }^{610}$ Tais considerações levam-nos a novamente evocar as reflexões de Bhabha sobre as representações estereotípicas e o modo como operam uma noção passiva e unívoca de conexão entre a imagem - estética e política - do alvo estereotípico e a recepção do espectador. Essa luta de representações foi essencial para travar a candidatura de Gil.

Quando assumiu o cargo de vereador, Gil pautou suas ações políticas principalmente por questões ligadas ao meio ambiente. Ele logo foi eleito presidente da Comissão do Meio Ambiente da Câmara Legislativa de Salvador. Sua pretensão era que as câmaras de todo o país fossem a base de execução de um projeto criado e divulgado por ele, o Movimento OndAzul. ${ }^{611}$ É ele que nos informa sobre isso:

O verde já era elemento de mobilização em torno de questões ecológicas. Mas o azul não, as águas ainda não propriamente. Então, criamos a fundação com foco específico nas águas: mares, lagos, rios, lençóis freáticos. Os quatro anos na Câmara Municipal tiveram esse viés ecológico e o início do trabalho da OndAzul se deu com a associação a outros movimentos, como o da Fundação Mata Atlântica e do Instituto Socioambiental. Havia uma rede brasileira e Internacional - ligada a projetos na

\footnotetext{
${ }^{609}$ SUZUKY, Matinas. Gil seguirá..., op. cit.

${ }^{610}$ Ibid.

${ }^{611}$ GL quer preservação do litoral brasileiro. Folha de S. Paulo,12 mar. 1989.
} 
Itália, na Suíça, nos EUA. Isso tudo antes da conferência internacional Rio 92. Meu mandato foi até 1992. ${ }^{612}$

Em 1991, a questão do meio ambiente figurava entre as principais preocupações de Gil:

Trata-se da questão ecológica, cujo foco de interesse não está mais restrito à Amazônia. Hoje cresce a preocupação com a ecologia humana, ou seja, a questão do extermínio, da pobreza, da morte de crianças. Na Europa fui procurado por George Harrison e por Jim Capaldi, que estão, assim como eu, interessados em desenvolver um trabalho voltado para essas questões. ${ }^{613}$

De acordo com Eliane Costa, durante o tempo em que exerceu o cargo de vereador, a partir de março de 1989, foi criada a Comissão de Defesa do Meio Ambiente, que Gil passou a presidir, integrando também os conselhos consultivos da Fundação Mata Virgem e da Fundação Alerta Brasil Pantanal. Ainda de acordo com Costa, após as turnês americana e europeia do álbum O eterno deus Mu dança, em junho de 1989, Gil retornou aos Estados Unidos, meses depois, em busca de fundos, junto ao Banco Interamericano de Desenvolvimento e ao Banco Mundial, para projetos ambientais em Salvador. Em maio de 1990, foi convidado pelo Smithsonian Institute para debater, em Washington, políticas ambientais para a América Latina. Três meses depois, representou oficialmente a Câmara Municipal de Salvador no Congresso Mundial de Governos Locais para um Futuro Sustentável, promovido pelo UNEP, o programa de meio ambiente da Organização das Nações Unidas (ONU), em Nova York. No ano seguinte, fez show com Tom Jobim, Caetano, Sting e Elton John no Carnegie Hall, em Nova York, para levantar recursos para a Fundação Mata Virgem. ${ }^{614}$

Em 1991, Gil seria o organizador de um congresso internacional tematizando o Encontro das Águas, a ser realizado em São Paulo, para tratar da preservação dos recursos hídricos do planeta. Na oportunidade Gil comentou: "estamos numa fase em que a política não deve mais ser dirigida para tomar o poder, mas para criar novos poderes". 615

\footnotetext{
${ }^{612}$ ZAPPA, Regina. Gilberto bem de perto, op. cit., p. 216.

613 CA VERSAN, Luiz. Gil faz show no Rio com muitos planos. Folha de S. Paulo, 21 ago. 1991.

${ }^{614}$ COSTA, Eliane Sacramento. Com quantos 'gigabytes 'se faz uma jangada, um barco que veleje: o Ministério da Cultura, na gestão Gilberto Gil, diante do cenário das redes e tecnologias digitais. Mestrado profissional em bens culturais e projetos sociais. Fundação Getúlio Vargas, Rio de Janeiro, 2011, p. 35.

${ }^{615}$ GONÇALVES, Marcos. Gil participa e prepara encontro em São Paulo. Folha de S. Paulo, 9 mar. 1991.
} 
Pouco tempo após deixar o cargo, Gil explicou porque abandonou a carreira política: "Não demonstrei talento para as funções. Era surpreendentemente me ver tão calado, tão inibido. Acho que a cidadania coletiva inibia a cidadania individual". ${ }^{16}$

Vale ressaltar que não há, no discurso político de Gil, durante o tempo de sua experiência política em Salvador, que se estende de 1987 até 1992, através da análise das fontes referentes a esse período, a escolha por defender determinados grupos sociais ou culturais. Não houve o desejo de construir uma identidade monolítica, que privilegiasse a negritude mais que outras ações culturais, mas sim uma postura de respeito às diferenças. Foi possível perceber através das diferentes fontes que se referem a essa época que a preocupação ecológica ocupou grande parte das ações políticas de Gil nesse período.

\section{- Pierre Verger: mensageiro entre dois mundos}

Eu sou um idiota racionalista francês. Isso tem uma coisa despoetizante horrível. ${ }^{617}$

O documentário Pierre Verger: mensageiro entre dois mundos ${ }^{618}$ foi gravado em 1996 e lançado em 1998, portanto, em um momento em que Gil já não era mais vereador. Não faz parte de nenhuma ação política, mas é de grande importância para refletirmos sobre as africanidades construídas por Gil.

Assim a Fundação Pierre Verger o descreve em texto à disposição no site da instituição:

Pierre Edouard Léopold Verger (1902-1996) foi um fotógrafo, etnólogo, antropólogo e pesquisador francês que produziu uma obra escrita de referência sobre as culturas afro-baiana e diaspóricas, voltando seu olhar de pesquisador para os aspectos religiosos do candomblé e tornando-os seu principal foco de interesse. (...) Os negros, em imensa maioria na cidade, monopolizavam a sua atenção. Além de personagens das suas

\footnotetext{
${ }^{616}$ LEDESMA, Vilmar. Gil acústico. Revista Áudio News, ano 3, n. 28, ago. 1994. Disponível em: <www.jobim.org> Acesso em: 21 fev. 2016.

${ }^{617}$ Trecho de entrevista de Pierre Fatumbi Verger para Gilberto Gil, presente em: HOLANDA, Luiz Buarque de. (Direção). Pierre Fatumbi Verger, mensageiro entre dois mundos. Vídeo. Apresentação e narração: Gilberto Gil. Direção de fotografia: César Charlone. Roteiro: Marcos Bernstein. Trilha sonora: Naná Vasconcelos. Consultoria: Milton Guran. Edição: João Henrique Ribeiro, Vicente Kubrusly. Som: Valéria Ferro. Conspiração Filmes/Gege Produções/GNT Globosat. Documentário em 35 mm, 80 min., 1998. ${ }^{618}$ Ibid.
} 
fotos, tornaram-se seus amigos, cujas vidas Verger foi buscando conhecer com detalhes. Quando descobriu o candomblé, acreditou ter encontrado a fonte da vitalidade do povo baiano e se tornou um estudioso do culto aos orixás. Esse interesse pela religiosidade de origem africana the rendeu uma bolsa para estudar rituais na África, para onde partiu em 1948. (...). ${ }^{619}$

Esse estudioso da negritude baiana é aqui o nosso fio condutor para compreendermos ainda mais as africanidades construídas por Gil ao longo de sua trajetória. A partir de 1946, quando se fixou em Salvador, Verger já apontava sua Rolleiflex para pessoas de cores não anêmicas, na fala do próprio Verger. Em 1948, passou a fazer constantes viagens ao continente africano, especialmente Nigéria e Benim, em busca de captar através de fotografias e vivência a cultura religiosa do candomblé, somando ao todo 17 anos na África. Esse francês que devotou grande parte de sua vida à busca por aprofundar seu conhecimento sobre a cultura iorubana é o personagem principal do documentário narrado e produzido por Gilberto Gil.

O documentário é aqui analisado como uma espécie de iniciação ao universo dos orixás, não apenas pelo olhar de Verger, mas do próprio Gil, que percorreu os caminhos trilhados por Verger na França, na Bahia e no Benim. Pelas lentes de Verger, através de sua experiência etnográfica e vida nômade, Gil apresenta a África para os espectadores, mas também experimenta vivenciar vários momentos de ligação com aspectos da cultura africana e afro-baiana, sobretudo pelo filtro do candomblé.

Nossa intenção aqui é analisar o documentário através dos contínuos contatos que o pesquisador francês realizou entre Brasil e África, como uma espécie de narrativa da história do Atlântico negro. Neste tópico investigaremos formas de representação das africanidades, especialmente da cultura iorubá, e seus aspectos religiosos, interessandonos indagar o papel da África e seu consequente diálogo com a cultura brasileira e especialmente a baiana, bem como o papel de Verger e posteriormente de Gil nessa construção. O que buscamos é cotejar representações mobilizadas no audiovisual através da identificação de Gil com Verger. O recorte temático nos permitiu elucidar pontos significativos sobre a questão que percorre toda a tese, a construção de africanidades na obra e trajetória de Gil, especialmente nesse momento em que o artista percorre esses dois mundos, elucidando ainda mais as trocas culturais desse Atlântico negro.

619 Disponível em: 〈http://www. pierreverger.org/br/pierre-fatumbi-verger/biografia/biografia.html〉. Acesso em: 9 mar. 2016. 
Resultado da pesquisa realizada pelo diretor Lula Buarque e pelo roteirista Marcos Bernstein, que estiveram na África, na França e na Bahia em busca da trajetória do fotógrafo e etnógrafo francês Pierre Verger, o documentário contou com a consultoria científica do antropólogo e fotógrafo Milton Guran. É uma coprodução da Conspiração Filmes $^{620}$, Globosat/GNT-Net/Sky ${ }^{621}$ e Gege Produções. ${ }^{622} \mathrm{O}$ filme foi realizado com recursos dos coprodutores e de incentivos culturais aportados através do programa Fazcultura do Estado da Bahia pela Copene - Petroquímica do Nordeste S.A. ${ }^{623}$

Assim como o francês Pierre Verger foi o mensageiro entre o Brasil e a África, Gil, guiando-se pelo caminho percorrido anteriormente por Verger, fez as vezes de um mensageiro atual que percorreu esses dois mundos na tentativa de melhor compreender esse diálogo. Gil conduz a narrativa do filme, percorrendo a ponte criada por Verger entre a cultura negra da Bahia e da África, iniciada em 1948. ${ }^{624}$ Assim como Verger seguiu sua busca por compreender a conexão da Bahia, principalmente, com a cultura iorubana da África Ocidental, Gil seguiu Verger. Caminhos entrecruzados, mensageiros de histórias do Atlântico negro.

O fotógrafo e etnógrafo Pierre Verger, como conta o documentário, chegou à Bahia em 1946 e lá ficou até sua morte, em 1996, data da realização do documentário. Verger morreu no dia seguinte à sua última entrevista para Gil, que presenciou em

\footnotetext{
${ }^{620}$ A Conspiração Filmes é uma as sociação de produtores e diretores de cinema, TV e publicidade co m o grupo Icatu. Oferece produção, pós-produção e criação de conteúdo para Cinema, Publicidade, TV, Branded Content, Digital e Art+Music. Disponível em: $\langle$ http://www.conspiracao.com.br/\#/diretores/15/bio〉. Acesso em: 15 mar. 2016.

${ }^{621}$ OCanal GNT da Globosat é especializado em documentários nacionais e internacionais. Através de sua política de co-produções é um dos principais fomentadores da produção independente de TV no Brasil. canal. Disponível em: <http://www.sky.com.br/servicos/Guiadatv/CanalDetalhe.aspx?qChave=319> Acesso em: 15 mar. 2016.

${ }^{622}$ A Gege Produções é a empresa produtora responsável por todos os eventos artísticos - shows, turnês, discos, editora musical, internet, selo Geleia Geral etc. - e pelas produções audiovisuais de Gilberto Gil. Disponível em: <http://gege.com.br/a-empresa>Acesso em: 16 mar. 2016.

${ }^{623}$ Disponível em: <http://www.conspiracao.com.br/\#/diretores/15/bio>. Acesso em: 15 mar. 2016.

${ }^{624} \mathrm{Em} 1932$ Verger iniciou suas viagens pelo mundo, sua primeira viagem foi ao Taiti, depois EUA, Japão, China, Itália, Espanha, Argentina, Peru e outras localidades, tendo sempre como enfoque a fotografia. Verger depois de se encantarcom os mistérios e o charme da cidade de Salvador e especialmente seduzido pelo grande número de descendentes africanos e sua influência na vida cotidiana do lugar, decidiu se fixar na cidade em 1946. Nessa época grande parte da intelectualidade e dos artistas em Salvador frequentavam os terreiros de candomblé e através dess as amizades Verger chegou ao Apô Afonjá e se tornou amigo íntimo de Mãe Senhora. As constantes conversas coma ialorixá e as fotografias do mundo do candomblé passaram a ser tema de Verger, que decidiu aprofundar-se cada vez mais nesse conhecimento. Verger já havia visitado o continente africano antes de 1948, mas é a partir dessa data que seu enfoque passa a ser o mundo da religiosidade africana.
} 
Benim um ritual de passagem dedicado a Verger, uma espécie de "velório" espiritual, momento de grande emoção do documentário. Durante quase meio século transitando pelo Atlântico, Verger vivenciou o candomblé baiano e o africano, tendo sua cabeça consagrada a Xangô por Mãe Senhora no Axé Opô Afonjá. Na primeira vez em que foi à África, levou um colar vermelho e branco confeccionado por Mãe Senhora, que lhe permitiria falar em seu nome. Na África, Verger tornou-se um iniciado no Ifá, ${ }^{625}$ passando a ser chamado de Fatumbi.

A relação das africanidades experimentadas na Bahia e sua ligação com a Nação Kêtu do Benim deram a tônica do documentário, que apontou constantemente para o diálogo cultural entre esses dois mundos, cheios de semelhanças e permanências culturais, que foram ao longo de todo o documentário expressadas através das fotos tiradas por Verger, postas em contato com as imagens capturadas pelo documentário. A equipe que idealizou o filme demonstrou em inúmeras cenas que as fotografias de Verger ainda em muito se assemelhavam com os costumes atuais da região do Benim.

Gil em vários momentos apareceu com o diário de campo de Verger, além de buscar encontrar pessoas com quem Verger estabeleceu contatos nessas experiências. A equipe analisou o trabalho de Verger através de sua obra acadêmica e sua técnica fotográfica. Todo o tom investigativo do trabalho de Verger é ressaltado no documentário, que contou com a ajuda de historiadores, do escritor Jorge Amado, amigos e conhecidos de Verger, além do povo de santo com que Verger conviveu.

A primeira parada de Gil na África foi em Kêto, atual Benim, onde Verger realizou grande parte de sua pesquisa. Juntamente com Gil e sua equipe, vamos acessando e conhecendo alguns ritos, e, principalmente, quem foi Verger em meio ao povo do antigo Dahomey. Mais do que aquele que fotografava tudo, Verger foi citado como alguém que conhecia o seu lugar no ritual. De acordo com o próprio Verger, sua ação nesses locais e perante a religiosidade africana processou-se da seguinte maneira:

A coisa não me interessava, é por isso que consegui. Porque na vida quando você está com uma dama se você corre atrás dela ela lhe deixa. Se você olha para o outro lado é ela quem corre atrás de você. Com este conhecimento é a mesma coisa. ${ }^{626}$

\footnotetext{
${ }^{625}$ Um jogo de adivinhações, correspondente aos búzios no Brasil.

${ }^{626}$ Entrevista de Verger à Gil para o documentário.
} 
Essa atitude mais passiva do que ativa, uma espécie de observação não participante, foi a mesma adotada por Gil e pela equipe do documentário. Cenas longas e carregadas de simbolismos e significados são acessadas pela observação, e não pelo questionamento constante. Em outro momento da entrevista de Gil com Verger, esse afirmou:

$\mathrm{Na}$ África vivi entre eles sem nunca perguntar qualquer coisa. Convivi com a gente como seria uma coisa natural. Sabia me comportar e não perguntava - Por que você faz isso? - Onde você mostra a sua ignorância. Em geral, você pergunta coisas que não têm significado nenhum. Tem muitas coisas que fazemos e não sabemos por quê. ${ }^{627}$

A câmera joga a todo momento com o mistério, que é ainda reforçado pela trilha sonora. ${ }^{628}$ As imagens constantemente dão destaque à pele negra. As imagens captadas pela equipe, somadas às constantes aparições de fotografias de Verger, nos remetem constantemente ao culto dos orixás.

O documentário empenha-se em desvendar se Verger de fato acreditava na religiosidade que tanto pesquisou, apesar de o próprio revelar sua descrença:

Para mim não é incorporação. Para mim é uma manifestação da verdadeira natureza da gente. Uma possibilidade de esquecer todas as coisas que não têm nada que ver com você. Fica a pessoa como era antes de aprender essas estupidezas de nacionalidades e outros comportamentos. Gil: O sr. já teve esse "esquecimento" do orixá? - Infelizmente não! Porque sou um idiota de francês racionalista. A mim não me contam histórias, eu não sou um idiota que acredita nessas coisas. É uma coisa "despoetizante", horrível. Eu sofri muito, gostaria muito de me deixar ir.

Verger referiu-se à identidade como aquilo que se manifesta no ordinário da cultura ou no próprio indivíduo, e que é formado a partir do contato com o outro. Ele considerava a religião do candomblé como o ponto de encontro entre a cultura africana e a baiana, e, assim sendo, acreditava que através da religiosidade do candomblé a própria identidade se manifestava. Verger criou uma ponte de ligação entre as duas identidades, a baiana e a africana, tornando-se um mensageiro entre esses dois mundos. Esse encargo

\footnotetext{
${ }^{627}$ Entrevista de Verger à Gil para o documentário.

${ }^{628}$ Produzida por Naná Vasconcelos.
} 
pode ser analisado no próprio documentário como um todo, mas também em sua pesquisa e subsequentemente em seus livros. ${ }^{629}$

Quando Verger viajava da África para a Bahia ou da Bahia para África, sempre trazia ou levava cartas, recados e presentes. Há um exemplo, citado no documentário, em que Mãe Senhora recebeu um título de uma entidade do candomblé da África por intermédio de Verger. Ele foi um mensageiro que uniu esses dois mundos, através de suas identidades culturais semelhantes, a religião.

Em busca de pistas que nos auxiliassem a melhor compreender a ligação de Gil com a criação desse documentário, o jornal Folha de S. Paulo nos informa que:

O documentário é, segundo Leonardo Monteiro de Barros, diretor-executivo da Conspiração Filmes, reflexo do crescimento das TVs por assinatura no Brasil e da necessidade de formar coproduções para manter a programação dos canais pagos. A Conspiração, o canal por assinatura GNT e a Gege Produções Artísticas investiram juntos $\mathrm{R} \$ 650$ mil no filme. ${ }^{630}$

Nessa mesma reportagem, Gil foi entrevistado e comentou que se fez de Verger "num ato de serviência e reconhecimento" para que os iorubás prestassem homenagens àquele que se tornou mensageiro e tradutor entre o Brasil e a África. Gil disse ter saído "mais próximo, mas ainda muito distante de adquirir a compreensão que Verger obteve sobra a cultura iorubá". E também que: "ele era um iniciado, eu não sou. Não atingi nem um terço da intensidade e da profundidade com que ele tratou das questões da cultura negra". E completou:

Ainda que não intencionalmente, foi um momento de iniciação para mim. Sem que eu me desse conta, fiz uma aproximação radical com o mundo mais profundo da religiosidade, que nada tem a ver com a frugalidade racional a que as religiões do Ocidente nos obrigaram. ${ }^{631}$

É interessante salientar que quando Gil lançou seu manifesto negro, em 1976, há tempos Verger já era Fatumbi. Enquanto Verger mergulhava profundamente no mundo das africanidades desde 1948, Gil passou a acessar esse mundo nos idos dos anos 1970, em Londres. Outro aspecto importante a ser destacado é que, enquanto Verger dedicou parte da sua vida a compreender o diálogo existente entre a cultura negra baiana e sua

\footnotetext{
${ }^{629}$ Para maiores informações, acessar <http://www.pierreverger.org/br/pierre-fatumb i-verger/suaobra/bibliografia-detalhada/livros-e-artigos.html $>$.

${ }^{630}$ LEE, Anna. Verger. Folha de S. Paulo, 10 set. 1998.

${ }^{631}$ Ibid.
} 
ancestralidade iorubana, Gil interessava-se pelo multiculturalismo, pelas africanidades da América negra, o reggae, o rock, pelo universo pop, o mundo da política, da tecnologia. Mas as africanidades também figuravam entre os interesses de Gil, como é possível perceber novamente através da participação dele na elaboração desse documentário, que adentrou o universo da cultura africana de matriz iorubá.

Percorrer os trajetos de Verger possibilitou a Gil conhecer ainda mais o mundo das africanidades, da cultura negra baiana e sua conexão com a África. A identificação de Gil com Verger, forjada em torno do diálogo da cultura africana e sua continuidade no Brasil, possibilitou a Gil experimentar, através especialmente do candomblé, a cultura africana, seus códigos e linguagens. Gil, ao ser o narrador e ajudar a produzir o documentário, percorrendo o caminho de Verger, estava também em busca de compreender a cultura iorubana e sua conexão com a cultura negra da Bahia; estava mais uma vez reforçando sua ponte com a África, com o mundo das africanidades, do Atlântico negro. Gilberto Gil, nesse documentário, tece novamente um fio que liga a Bahia a uma África que ele tenta demonstrar não só para o mundo, mas principalmente para os brasileiros e para si mesmo.

\section{- O Ministério da Cultura}

Entre 2003 e 2008, paralelamente ${ }^{632}$ à carreira de músico, Gilberto Gil ocupou o posto de Ministro da Cultura. Mais uma vez as vocações política e artística se encontram, agora na esfera federal e sob a égide da hegemonia política do PT, iniciada em 2003 com a chegada de Luiz Inácio Lula da Silva ao poder. Nossa intenção é contextualizar a ascensão de Gil ao Ministério da Cultura (MinC). Primeiramente, traçaremos um breve histórico das políticas culturais no Brasil, que são determinantes para a compreensão dos desafios e das possibilidades enfrentadas por Gil à frente do MinC, e posteriormente nos embrenharemos por uma análise mais detida sobre algumas ações e discursos de Gil como ministro.

\footnotetext{
${ }^{632}$ Gil combinou com Lula que diminuiria sua produção artística e que só faria shows nos momentos em que estivesse de férias. Constantemente submetia ao Conselho de ética suas intenções de realizar shows ou outras atividades artísticas.
} 
Essa investigação debruçou-se sobre as seguintes fontes: quatro periódicos ${ }^{633} \mathrm{de}$ grande circulação do país que noticiaram as experiências de Gil no MinC de 2003 a 2008; o livro ${ }^{634}$ lançado pelo próprio Gil, juntamente com Juca Ferreira, com discursos proferidos nos anos do ministério; e trabalhos acadêmicos que abordaram esse momento político de Gil. A intenção foi entrecruzar essas fontes para então compreendermos através dessas diferentes séries discursivas a maneira como Gil exerceu seu ministério e como questões relacionadas às africanidades e a negritude figuraram entre as suas políticas culturais.

Ao analisar todo o acervo desses periódicos, referentes aos anos de 2003 a 2008, foi possível perceber que as políticas culturais de Gil tomaram o direcionamento da pluralidade, da descentralização da cultura anteriormente demarcada pela centralização no eixo Rio-São Paulo, a criação dos Pontos de Cultura ${ }^{635}$, questionamentos quanto aos creativecommons, além da ênfase em questões até então pouco valorizadas no cenário cultural brasileiro, como, por exemplo, tornar o samba patrimônio imaterial da humanidade. ${ }^{636}$ Dentre as temáticas que configuraram o gerenciamento do MinC na gestão de Gil, estavam questões referentes ao melhoramento dos museus, regulamentação da mídia, disseminação do acesso à cultura de maneira mais igualitária, além de propiciar protagonismo a agentes até então silenciados no quadro cultural do país. Depois de enfrentar algumas turbulências ${ }^{637}$ no início de seu mandato, a criação dos Pontos de Cultura e suas constantes viagens internacionais the geraram uma espécie de imagem de embaixador da cultura brasileira.

Inúmeras edições desses periódicos indicaram que o ministro sempre dava 'canjas' artísticas ao fim dos eventos de que participava como ministro, demonstrando

\footnotetext{
${ }^{633}$ Acervo digital das revistas Istoé, Veja, Época e o jornal Folha de S. Paulo, buscando compreender as tensões, os enfoques e os impasses de sua gestão como ministro.

${ }^{634}$ GIL, Gilberto; FERREIRA, Juca. Cultura pela palavra:coletânea de artigos, discursos e entrevistas dos ministros da Cultura 2003/2010. Rio de Janeiro: Versal, 2013.

${ }^{635}$ Para um detalhamento desse projeto, ver a palestra proferida por Gil sobre Políticas Culturais no Brasil na Universidade de Columbia. Nova York, 21 de fevereiro de 2005. In: GIL, Gilberto. Cultura pela palavra..., op. cit., p. 323.

${ }^{636}$ Vale ressaltar que essa ação foi realizada conjuntamente com outros agentes de políticas públicas, antropólogos, etnomusicólogos e os próprios sambadores do Recôncavo. Para maiores informações ver: SANDRONI, Carlos. Samba de roda, patrimônio imaterial da humanidade. Estudos Avançados, São Paulo, v. 24, n. 69, p. 373-388, jan. 2010. Disponível em: <http://www.revistas.usp.br/eav/article/view/10531> Acesso em: 19 jun. 2016.

${ }^{637}$ Principalmente a demissão de Roberto Pinho, secretário de Desenvolvimento de Programas e Projetos Culturais, exonerado do cargo depois de denúncias referentes à irregularidades no termo de parceria entre o Minc e o Instituto Brasil Cultural (Ibrac) e os problemas com a Ancinav, uma vez que no início de seu mandato Gil propôs a criação de um marco regulatório referente a demandas e propostas do setor audiovisual no país.
} 
assim que o exercício do poder jamais suprimiu o lado artístico. Foi o próprio Gil quem nos deu testemunho sobre esse entrelaçamento da poética com a política experimentados durante o comando no ministério:

Havia música, eu gostava de cantar, dançar e brincar com os agentes culturais dos lugares por onde passava. Então, mantive o que chamei de caráter 'ornamental' da profissão em relação ao trabalho de ministro. A música ornamentava aquele período de atividade ministerial de forma muito interessante, estabelecendo a não interrupção da minha relação com a música. ${ }^{638}$

Quanto à escolha do governo Lula para a pasta da Cultura, assim noticiou a revista Istoé:

$\mathrm{Na}$ aparentemente pacífica pasta da Cultura, os conflitos já começaram com a recusa do ministro Gilberto Gil em participar de algumas reuniões com os setores do PT, que desde 1989 se dedicam à formulação de projetos para o setor. Gil manifesta resistência em aceitar nomeações do PT para cargos. Em seu ministério, como em todos os demais, a escassez de verbas se desenha como o maior obstáculo a uma gestão de sucesso. ${ }^{639}$

Essa notícia nos dá indícios de que Gil chega ao ministério disposto a inovar. Ele era representante do PV e não chegou ao ministério disposto a aceitar imposições do PT. Para assessorá-lo, acabou montando uma equipe de pessoas bastante próximas a ele: sua secretária pessoal era sua filha e produtora Maria Gil; Juca Ferreira, seu secretário executivo e posteriormente seu sucessor; Roberto Pinho, amigo de infância e padrinho de Preta Gil; Antônio Risério e Hermano Vianna.

Ao ocupar o cargo de Ministro da Cultura, Gil viu-se diante de desafios históricos à primeira vista intransponíveis: como dar relevância a um ministério cujo orçamento era um dos mais baixos da máquina pública federal? Que lugar deveria ocupar a cultura na sociedade brasileira do século XXI? Como os investimentos em cultura poderiam se traduzir em desenvolvimento econômico e na produção de justiça social? As transformações pelas quais passou o setor cultural no Brasil, com políticas marcadas por idas e vindas, ajudam-nos a discutir melhor a atuação de Gil no comando do MinC.

\footnotetext{
${ }^{638}$ GIL, Gilberto; OLIVEIRA, Ana de. Disposições amoráveis, op. cit., p. 113.

${ }^{639}$ FILHO, Aziz. A hora da ação: Time de Lula é heterogêneo e tem imagem de competência, mas terá de fazer milagres com recursos escassos. Istoé, 8 jan. 2003.
} 
Afinal, tratar sobre políticas públicas para a cultura é falar sobre um campo relativamente recente na história, e que sempre passou por descontinuidades e percalços. ${ }^{640} \mathrm{~A}$ produção cultural como elemento de intervenção e articulação do Estado só passou a ser fato a partir dos anos 1930, no Brasil e no mundo. Um marco importante no Brasil foi a criação da Secretaria do Patrimônio Histórico e Artístico Nacional (SPHAN), em 1937, mais tarde transformada em instituto, e que buscou intervir diretamente na preservação do patrimônio material brasileiro. Também foram criados nessa época o Instituto Nacional de Cinema Educativo (INCE), o Instituto Nacional do Livro (INL) e o Conselho Nacional de Cultura (CNC). A radiodifusão passa a ser fortemente regulamentada pelo Estado, o que demonstra o reconhecimento por parte do governo Vargas de que era possível conquistar corações e mentes da população através da amplitude garantida por esse meio de comunicação, além, é claro, de acompanhar e controlar a produção de conteúdo, em um contexto de supressão das liberdades políticas que marcou o Estado Novo (1937-1945). ${ }^{641}$

Outro momento em que o Estado procurou intervir mais fortemente na cultura foi na ditadura civil-militar. Em 1966, o presidente Castelo Branco criou o Conselho Federal de Cultura, formado por 24 membros, todos indicados pelo presidente, e imbuído da missão de elaborar planos de cultura que deveriam vigorar em todo o país. Segundo Lia Calabre, alguns planos foram apresentados ao governo, mas nenhum deles foi efetivamente colocado em prática. ${ }^{642}$ Em 1970 foi criado o Departamento de Assuntos Culturais (DAC), submetido ao Ministério da Educação. Sucessivamente foram criadas outras instituições de âmbito nacional, como a Fundação Nacional de Arte (Funarte), o Conselho Nacional de Cinema, o Conselho Nacional de Direito Autoral e, em 1980, a Fundação Pró-Memória. Ao Estado, caberiam o fomento e a articulação do setor cultural. A maior participação do Estado durante a ditadura não se resumiu à instância federal. Houve também um maior engajamento das secretarias de estados e municípios. ${ }^{643}$

\footnotetext{
${ }^{640}$ CALABRE, Lia. Políticas culturais no Brasil: balanço e perspectivas, in: Anais do III Enecult Encontro de Estudos Multidisciplinares em Cultura. Salvador, 23 a 25 maio 2007. Disponívelem: <http://w w w.guiacultural.unicam p.br/sites/default/files/calabre_l_politicas_culturais_no_brasil_balanco_ e_perspectivas.pdf $\geq$ Acesso em: 19 jun. 2016, pp. 1-3.

${ }_{641}^{6}$ Ibid., pp. 3-5.

${ }^{642}$ Ibid., pp. 4-5.

${ }^{643}$ Ibid., p. 6.
} 
Em 1985, o então presidente José Sarney criou o Ministério da Cultura. Apesar de representar um importante avanço simbólico e administrativo, a prática do ministér io foi marcada pela descontinuidade - três pessoas ocuparam a direção do ministério em intervalo de tempo reduzido - e por verbas diminutas. O MinC conseguiu aprovar a Lei Sarney, em 1986, numa tentativa de atrair financiamento do setor privado, mas foi possível obter desse setor apenas parcos recursos, enquanto os investimentos estatais em cultura se restringiram a muito pouco. ${ }^{644}$

Tal descaso com a cultura culminou com o fechamento do MinC, em 1991, pelo presidente Fernando Collor de Melo. Naquele mesmo ano, foi instituída a Lei Rouanet, que pretendia potencializar os investimentos privados em cultura por meio de mecanis mo de renúncia fiscal. Na prática, a Lei Rouanet passou a representar a primazia do setor privado e a utilização de dinheiro público para promover a imagem das corporações. ${ }^{645}$

O MinC foi recriado em 1993 pelo presidente Itamar Franco. Na era FHC (19952002), em que o ministério ficou sob a direção de Francisco Weffort, o que marca o setor é a política do Estado mínimo, com o enxugamento dos investimentos estatais em cultura (e em setores como educação e saúde) e a primazia da iniciativa privada. Segundo Lia Calabre, houve alterações na Lei Rouanet que "ampliaram um mecanismo de exceção, $o$ do abatimento de $100 \%$ do capital investido pelo patrocinador ${ }^{\prime \prime 646}$. Criou-se uma enorme concentração na aplicação de recursos na área da cultura, com destaque para as capitais do Sudeste (especialmente Rio e São Paulo), e sob a mão das grandes empresas. O MinC cumprira, naquele período, basicamente a função de analisar e aprovar projetos que seriam financiados via Lei Rouanet.

No âmbito internacional, a hegemonia neoliberal dos anos 1980 e 1990 reduziu a importância da Unesco, órgão multilateral vinculado à ONU e criado em 1946 para buscar garantir a paz mediante a educação, a cultura, a ciência e as comunicações. Os EUA e a Inglaterra deixaram de ser membros da Unesco em meados da década de 1980 - no auge dos governos de Ronald Reagan (EUA) e Margareth Thatcher (Inglaterra). A potência europeia só retornou ao bloco multilateral em 1997, e os EUA, em 2003. Nesse período,

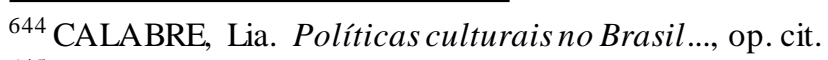

${ }^{645}$ Ibid.

${ }^{646}$ Ibid., p. 8.
} 
vingou a ideia de que a cultura é uma mercadoria como outra qualquer, e que deveria ser regulada pelo próprio mercado ${ }^{647}$.

No final dos anos 1990 e início dos 2000, a Unesco vai se firmando como lugar alternativo de discussão sobre o papel da cultura. É aí que se opera com o conceito de diversidade cultural ${ }^{648}$, em referência aos diversos modos de ser e pensar presentes nas sociedades contemporâneas. Nessa moldura, a cultura está longe de ser algo univocamente ligado aos estados nacionais, e passa a ser compreendida como uma dimensão que perpassa a dimensão cotidiana da vida social, e que é, portanto, direito de todos os cidadãos. Esse direito deveria ser garantido e propiciado pelo Estado contra a ameaça das grandes corporações e da possibilidade de supressão da diferença. ${ }^{649}$

A Conferência Intergovernamental sobre Políticas Culturais para o Desenvolvimento, realizada pela Unesco em 1998, colocou em perspectiva a emergência de questões como essas: "a integralidade e a transversalidade da cultura e da política cultural; a política cultural como dado central da política de desenvolvimento (sustentável) e o patrimônio imaterial/intangível". ${ }^{650}$ A estruturação de políticas culturais passou a ser vista como algo fundamental para o próprio desenvolvimento sustentável das nações. A relação entre cultura e nação foi então deslocada de seu teor identitário cristalizado para a ideia de desenvolvimentismo operado e articulado pela cultura. Segundo Rubim, é preciso "assinalar e desenvolver o papel estratégico da cultura na construção elou consolidação do nacional", num "horizonte de afirmação das nações" em que "a conformação da identidade nacional, operada pelo acionamento da cultura, fundamenta sua centralidade e legitima as políticas culturais naquela conjuntura". ${ }^{651}$

É possível dizer, então, que Gil encontrou grandes desafios no sentido de poder construir uma política cultural nacional. O ministro precisou lidar com uma agenda bastante distinta da que predominou no Brasil ao longo do século XX. Até meados dos anos 1970, compreendia-se a cultura como algo inerente à unidade nacional, a uma identidade unívoca, essencialista. Essa noção foi sendo questionada mundialmente a

\footnotetext{
${ }^{647}$ RUBIM, Antonio Albino Canelas. Panorama das políticas culturais no mundo. In: RUBIM, A. A. C; ROCHA, R. Políticas culturais. Salvador: Ed. UFBA, 2012, pp. 13-27, pp. 22-23.

648 Ibid., p. 23.

649 Ibid., p. 25.

650 Ibid., p. 20.

651 Ibid., p. 23.
} 
partir de 1968, com os movimentos estudantis de Paris. Passou a vingar, então, a noção de "culturas", no plural, a ideia de democratização da produção cultural, a ampliação do acesso dos mais pobres às instituições culturais e o conceito de diversidade cultural. ${ }^{652}$

Nos anos 2000, já predominava a noção da cultura como um fenômeno dotado de diversidade e representativo de diferentes setores da sociedade. A ideia de hibridização cultural proposta por Canclini buscou responder criticamente à noção de que a cultura deveria ser compreendida de forma hierárquica, dividida em culta, popular e massiva. ${ }^{653}$ Essa ideia vai ao encontro de nossa abordagem sobre a produção cultural de Gil e do modo como ele entrelaçou diversas sonoridades, estéticas e tradições do universo musical, criando uma nova síntese, uma obra híbrida - nem culta, nem popular, nem massiva.

No que diz respeito à concretude das ações do serviço público, Gil precisou lidar com as descontinuidades das políticas culturais no Brasil. A tradição do Estado mínimo imperava até 2002, e não se tinha até então um setor cultural basicamente estruturado. Foi preciso criar novas secretarias e novas instituições. Segundo Lia Calabre, era preciso romper com a tradição de ver a cultura como acontecimento episódico e restrito a eventos, e passar a privilegiar o esforço continuado, a formação e especialização de agentes culturais, bem como fortalecer a burocracia estatal de modo a criar condições de regulamentar o setor da cultura. ${ }^{654}$ Passou-se a se privilegiar, então, uma "visão de cultura como força social de interesse coletivo, que não pode ficar dependente das disposições do mercado". 655

Como veremos a partir do discurso do próprio Gil, valorizou-se, em sua gestão, o conceito de diversidade cultural, a qual, enquanto um valor supremo a nortear as ações do MinC, deveria ser garantido aos cidadãos através do processo de democratização cultural. Era preciso ampliar os canais de participação democrática e incluir a sociedade civil nas decisões do MinC. Calabre critica o modelo de uma política de pulverização de recursos, dando o exemplo do Programa de Ação Cultural (PAC) na década de 1970, o

\footnotetext{
652 RUBIM, Antonio Albino Canelas. Panorama das políticas culturais no mundo..., op. cit., pp. 18-20.

${ }^{653}$ CALABRE, Lia. Políticas públicas no Brasil..., op. cit., p. 11.

654 Ibid., p. 12.

655 Ibid., p. 14.
} 
qual, apesar de cobrir quase toda a extensão do território nacional, resumiu-se a ações eventuais e episódicas sem integração entre si. ${ }^{656}$ De acordo com a autora:

Em termos gerais podemos dizer que os primeiros quatro anos de gestãodo Ministro Gil foram de construção real de um Ministério da Cultura. Desde a criação em 1985, o órgão passou por uma série de crises e processos de descontinuidade. A gestão do Ministro Weffort (oito anos) foi acompanhada por uma política de Estado mínimo, o que para um ministério que mal havia sido recriado trouxe enormes dificuldades operacionais. Ao terminar tal gestão, o MinC tinha como principal atividade aprovar os processos que seriam financiados através da Lei de Incentivo à Cultura. ${ }^{657}$

Duas questões centrais compõem a pauta das políticas culturais nos anos 2000: diversidade cultural e economia da cultura. ${ }^{658}$ Calabre apresenta pontos que considera essenciais para o entendimento da problemática das políticas culturais naquele momento e ainda na atualidade, os quais sintetizamos a seguir: a "defesa da diversidade como elemento fundamental para a continuação da existência das próprias sociedades", contra a "globalização uniformizadora" e a falta de diálogo entre os grupos sociais; ${ }^{659}$ a necessidade de regulamentação dos produtos culturais por parte do Estado, na tentativa de inibir a intervenção mercadológica "devastadora"; ${ }^{660}$ uma maior abertura para o intercâmbio cultural internacional, de forma autônoma, e não submissa ou baseada na dependência cultural; o tratamento das manifestações culturais como parte do patrimônio de um povo, contra o conceito tradicional de nacionalidade; a importância da integração das ações de maneira interministerial, de modo a combater o insulamento das ações culturais no âmbito do governo; e o reconhecimento da centralidade dos meios de comunicação corporativos e da posição ocupada por eles na atualidade. ${ }^{661}$

Por fim, a autora defende a tese de que Gil buscou "colocar a cultura dentro da agenda política do governo", fazendo com que esse setor deixasse de ter efeito meramente decorativo. E reflete sobre a necessidade de se implementar ações efetivas e duradouras, para que tais políticas tenham garantia de continuidade nas próximas décadas: “O Estado não deve ser um produtor de cultura, mas pode e deve ter a função de democratizar as

\footnotetext{
${ }^{656}$ CALABRE, Lia. Políticas públicas no Brasil..., op. cit., p. 13.

${ }^{657}$ Ibid., pp. 10-11.

658 Ibid., p. 14.

659 Loc. cit.

${ }^{660}$ Ibid.,p. 15.

${ }^{661}$ Ibid., p. 16.
} 
áreas da produção, distribuição e consumo. Cultura é fator de desenvolvimento."662

É importante frisar que o objetivo, até aqui, não foi analisar exaustivamente o histórico das políticas culturais antes de Gil, mas pontuar questões fundamentais para a construção de inteligibilidade a respeito da ação do compositor-ministro e de seu horizonte de expectativas. A seguir, o foco de análise se volta para as reflexões de Gil a respeito de sua experiência no Ministério da Cultura.

\section{- Um ministro entre muitas culturas}

Em discurso proferido em 2003, assim Gil definiu como seria o novo MinC:

Com as mudanças necessárias para a configuração plena de uma política cultural do governo Lula, tendo por base um projeto brasileiro de civilização, o MinC - um novo MinC, será mais exato dizer - poderá cumprir a sua parte no projeto de reconstrução da dignidade de nosso povo, através da inclusão sociocultural, e no processo de afirmação do Brasil na cena planetária, através da veiculação internacional de nossas "visões de mundo", expressando-se em bens e serviços culturais. Assim, a cultura assumirá, de fato, uma dimensão estratégica no caminho da nação que desejamos construir. ${ }^{663}$

Em 2004, em uma aula magna na Facamp, Gil dimensiona seu arcabouço sobre concepção cultural, abordando que cultura é ao mesmo tempo ponto de partida e chegada das dimensões do desenvolvimento humano:

Falo aqui da cultura não apenas como o conjunto das expressões artísticas, mas como todo patrimônio material e simbólico das sociedades, grupos sociais e indivíduos, e suas múltiplas expressões; da cultura como simbologia, como cidadania e como economia. ${ }^{664}$

\footnotetext{
${ }^{662}$ Ibid., p. 17. Lia Calabre é coordenadora do setor de pesquisa sobre políticas culturais da Casa de Rui Barbosa, vinculada ao Minis tério da Cultura. Percebe-se, no campo de atuação da Casa de Rui e no discurso de Calabre, uma sintonia com o discurso de Gil e de sua equipe, de modo que é possíveldizer que a análise da autora e as ações e discursos de Gil se entrelaçam no contexto do MinC. Ressaltamos, ainda, que o texto é de 2007 - foi escrito durante o período em que Gil ocupou o ministério.

${ }^{663}$ Abertura do Seminário Cultura XXI. Fortaleza, 19 de março de 2003. In: GIL, Gilberto; FERREIRA, Juca, op. cit., p.243.

${ }^{664}$ Aula Magna na Facamp. Campinas, 9 de agosto de 2004. GIL, Gilberto; FERREIRA, Juca, op. cit., p. 292.
} 
Estão presentes no discurso de Gil, citados acima, duas ideias fundamentais elencadas por Lia Calabre: a importância da economia da cultura e o setor cultural como algo imprescindível para o desenvolvimento econômico das nações.

O Livro Disposições amoráveis, de Gil e Ana de Oliveira, de 2015, contou com a participação de inúmeros entrevistadores, dentre eles Lula, Fernando Henrique Cardoso e Marina Silva, tendo como principal intuito partilhar os pensamentos de Gil, referentes a assuntos como ciência, espiritualidade, questões raciais e cidadania global, dentre outros, com seus entrevistadores e leitores. Quando indagado por Ana de Oliveira sobre a possibilidade de o mundo político atender a todas as demandas sociais, assim Gil elaborou suas convicções:

\begin{abstract}
Não dá para atender a todos, o tempo todo. É preciso ter visão da oportunidade, do momento. $\mathrm{O}$ que se deve privilegiar em determinado instante. Quais têm sido os papéis históricos dos governos nos vários períodos da nação brasileira. O que tivemos de superar. A superação dos resíduos da escravidão no Brasil, por exemplo, o problema da desigualdade no caso dos negros, no caso das mulheres, dos homossexuais, etc. Enfim, o bom governo é o que está disposto a fazer os atendimentos diferenciados, a olhar as diferenças como estão estabelecidas e a agir em função dessas diferenças. (...)E fazer o atendimento dife re nciado em relação às dife renças. ${ }^{665}$ [ grifos meus]
\end{abstract}

A passagem acima indica a disposição de Gil em construir um novo sentido político para a cultura: não mais a "Cultura", com inicial maiúscula e no singular, mas sim "culturas", no sentido de privilegiar os diversos grupos subalternos formadores da nação - "no caso dos negros, no caso das mulheres, dos homossexuais etc." Em outra passagem, Gil afirmou que se lembrava bem de sua intenção "de levar a mensagem brasileira ao mundo como força cultural". ${ }^{666}$ E que os maiores eixos de sua política estavam afinados com a "retomada do diálogo com os índios e com setores históricos da vida dos negros no Brasil". 667

Dentre as situações consideradas por Gil como de maior tensão em tempos de ministério estavam:

Momentos em que discutimos mais acirradamente com o mundo das comunicações e da mídia pela necessidade de maior regulamentação nesta área, contra o pensamento de total

\footnotetext{
665 GIL, Gilberto; OLIVEIRA, Ana de. Disposições amoráveis, op. cit., p. 117.

666 Ibid., p. 136.

667 Ibid., p. 137.
} 
autorregulação a que o mundo das comunicações adere, quase como ideologia. ${ }^{668}$

Quando questionado por Lula sobre o porquê de ter aceitado o cargo de ministro, Gil acaba nos dando indícios de seu olhar a respeito da cultura como elemento da política e de seu caráter redentor - principalmente para as classes subalternas - e progressista/emancipacionista:

Poder participar de um governo como foi o seu, que demonstrava claro comprometimento com o desenvolvimento e a emancipação de camadas historicamente pauperizadas do país, um govemo de compromisso com essa dimensão redentora, uma coisa de pagar dívidas e redimir velhos pecados sociais, era um estímulo enorme para alguém como eu - e foi essa a razão básica de ter topado a parada. Foram anos interessantíssimos, exatamente porque essa era a marca principal. Fazer para o povo, para as camadas cada vez maiores da sociedade brasileira e para os lugares mais remotos. Levar benefícios que, tradicionalmente, as grandes cidades obtêm às partes longínquas do país. Tudo era uma motivação enorme; e, como o senhor disse, o convívio com pessoas comprometidas com isso nas várias instâncias de governo, não só no nosso governo federal, mas também nos estados e municípios, as pessoas minimamente comprometidas com o ideário redencionista. ${ }^{669}$

A perspectiva adotada por Gil no Ministério da Cultura colide diretamente com o ideário construído em outros momentos da história do Brasil. O intervencionismo do Estado na cultura é visto agora como instrumento de democratização da produção e do acesso de classes e grupos sociais anteriormente não amparados por políticas públicas. É possível dizer que o MinC de Gil é tão "intervencionista" quanto as políticas culturais de Vargas e da ditadura civil-militar, mas opera com outra finalidade, sob outra perspectiva. O Estado deveria centralizar seus esforços para descentralizar a cultura.

Ainda frisando sua concepção emancipadora e progressista de política cultural, Gil discursou sobre potencializar não apenas as forças produtivas, como propagado pelo marxismo, mas também “do próprio indivíduo, de sua inteligência, de sua criatividade, de sua sensibilidade, de suas capacidades e de suas possibilidades de vida em

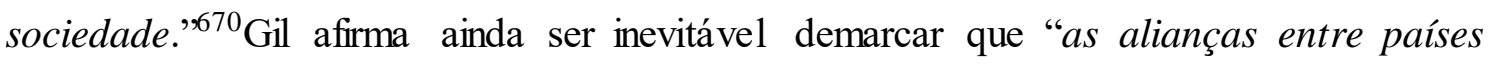
pobres e em desenvolvimento constituem um aspecto importantíssimo nas estratégias para o incremento das indústrias criativas". ${ }^{671}$ Essa consideração está em sintonia com

\footnotetext{
668 Ibid., p. 132.

${ }^{669}$ Ibid., pp.131-132.

670 Ibid., p. 294.

671 Ibid., p. 293.
} 
um dos pontos apresentados por Lia Calabre sobre a problemática das políticas cultura is na atualidade: fazer emergir novas conexões internacionais tendo a cultura como ponto fundamental, não se submetendo a outras potências, mas criando laços com outros países em desenvolvimento. Na visão de Gil,

O principal motor das alianças, e também o limite na negociação de contrapartidas, é o da proteção e da promoção da diversidade cultural, através da qual o diferencial dos povos se manifesta, diferencial vital para o desenvolvimento, e os projetos de nação se harmonizam com a globalização. ${ }^{672}$

Outro discurso de Gil, professado em 2005, ainda como ministro, demonstra que a centralidade das políticas culturais estava no seu horizonte de expectativas:

Retomar o papel constitucional de órgão reformulador, executor e articulador de uma política cultural para o país; completar a reforma administrativa e a capacitação institucional para operar a política; obter os recursos indispensáveis à implementação da política. Estamos dando passos objetivos para enfrentar esses desafios. Quero que esta seja a gestão que construiu o Sistema Nacional de Cultura, que deu ao MinC referenciais e ferramentas para atuar no campo da economia da cultura, que estabeleceu, em tempos democráticos, um conjunto de políticas públicas de cultura, e que realizou o mais abrangente programa de inclusão cultural deste país, em parceria com os estados e municípios, dando vez e lugar a todas as manifestações culturais, em especial às culturas populares, indígenas e afrodescendentes ${ }^{673}$ [grifos meus]

A passagem acima condensa de modo exemplar os principais objetivos de Gil como ministro e os desafios colocados sobre sua ação política. Além da economia da cultura, vista como motor de desenvolvimento nacional, está presente também a ideia de democracia cultural, capaz de garantir os direitos à cultura dos povos indígenas e dos filhos da diáspora africana, entre outros.

Antonio Rubim, estudioso das políticas culturais no Brasil, fez na década passada um balanço dos desafios e das diretrizes do ministério de Gil. Rubim sublinha a "abertura conceitual" operada por Gil e o abandono de uma visão autoritária de cultura, visando a uma democratização das políticas culturais. Segundo Rubim,

A intensa opção por construir políticas públicas em debate com a sociedade emerge como outra marca da gestão Gil. (...) O

\footnotetext{
${ }^{672}$ GIL, Gilberto; OLIVEIRA, Ana de. Disposições amoráveis, op. cit, p. 294.

${ }^{673}$ Discurso de Gilberto Gil na abertura do Seminário Internacional de Políticas Públicas de Cultura na Uerj - Universidade do Estado do Rio de Janeiro. Rio de Janeiro, 9 de maio de 2005. In: GIL, Gilberto; FERREIRA, Juca. Cultura pela palavra..., op. cit., p. 361.
} 
desafio de construir políticas de cultura em um ambiente democrático não é enfrentado de qualquer modo, mas por meio do acionamento da sociedade civil e dos agentes culturais na conformação de políticas públicas e democráticas de cultura. ${ }^{674}$

A ênfase nas diferenças, na democratização, na diversidade - versus a unidade e o universalismo - é a tônica da ação de Gil à frente do MinC, entre 2003 e 2008. Nesse sentido, interroga-se sobre as semelhanças entre a política cultural implementada por Gil e os valores do tropicalismo, já analisados no capítulo 1, entre os quais destacamos a abertura para o novo - a modernidade - em consonância com a tradição, além do reconhecimento da multiplicidade cultural possibilitada pelo amálgama das informações nacionais e internacionais. Vejamos como a questão do tropicalismo se articula com as africanidades constantemente (re)construídas por Gil, num constante entrelaçamento entre arte e política.

\section{9 - A renascença africana}

"O Brasil ainda tem vergonha dos seus indígenas e tem dificuldade de internalizar a cultura africana. A africanidade é parte da constituição do que somos como país, mas isso ainda é secundarizado". ${ }^{675}$

Essa frase, enunciada por Juca Ferreira em 2014, num seminário de estudiosos do setor cultural, aponta os problemas enfrentados pelo Ministério da Cultura na construção de políticas públicas capazes de contemplar a cultura produzida pelos afrodescendentes. $\mathrm{Na}$ mesma ocasião, Ferreira acrescentou que haveria ainda uma grande força conservadora atuando contra essa possibilidade, mas que na gestão dele e de Gil teria sido possível ampliar "a consciência do direito cultural", através dos Pontos de Cultura e dos editais lançados pelo MinC. O balanço crítico feito por Ferreira é o ponto de partida para compreendermos de que maneira as africanidades tecidas por Gil se vinculam a sua atuação como ministro, entrelaçando as dimensões da política e da arte.

\footnotetext{
${ }^{674}$ RUBIM, Antonio Albino Canelas. Políticas culturais do governo Lula/Gil: desafios e enfrentamentos. Intercom - Revista Brasileira de Ciências da Comunicação, São Paulo, v. 31, n. 1, p. 183-203, jan./jun. 2008, p. 196.

${ }^{675}$ Juca Ferreira Apud LOPES, Nilton. Gestores debatem política cultural no Brasil. Enecult, Salvador, 28 ago. 2014. Disponível em: <http://www.cult.ufba.br/enecult/gestores-debatem-politica-cultural-nobrasil/> Acesso em: 20 jun. 2016.
} 
Em 2008, último ano de sua gestão à frente do MinC, em artigo publicado no jornal $O$ Globo por ocasião de sua participação como convidado de honra do comitê organizador do III Festival de Artes Negras, Gil nos dá muitos indícios para refletirmos sobre a comunicação e o intercâmbio cultural entre os países da diáspora negra. No artigo, Gil aborda a mensagem de Bob Marley como aquela que revelou como a cultura de origem africana não desempenhou a prática da segregação, mas a da inclusão que girou em torno de um sentimento de agregação e identificação, enfatizando o reggae como veículo de uma "verdadeira filosofia de vida, baseada na harmonia, na paz e na tolerância". ${ }^{676}$

Sobre as histórias do Atlântico Negro, Gilroy nos elucida que:

Podemos encontrar prazer nesta história de resistência, mas, mais polemicamente, acho que deveríamos também estar preparados para lê-la política e filosoficamente nos momentos em que ela incorporou e manifestou críticas ao mundo tal como é. ${ }^{677}$

Nesse momento, as africanidades são novamente vivenciadas e experimentadas por Gil, que escolhe Bob Marley e sua música como símbolos não apenas de filosofia de vida, mas também de conduta política. No mesmo artigo, Gil afirmou ainda: "tenho buscado traduzir em ações o que considero um grande legado político de Marley para o mundo e para o Brasil. Um legado político que não se traduz facilmente nos códigos da própria politica”. ${ }^{678} \mathrm{E}$, assim, Gil anunciou a possibilidade de um intercâmbio cultural entre os países da diáspora negra:

\begin{abstract}
A mensagem do reggae é de autonomia e autodeterminação. Suas músicas sugerem a busca de uma cidadania política e estética plena. Sua leitura de nossas sociedades me parece ser a de um processo de libertação mais profundo que o permitido hoje pelas esferas econômica e política. Marley canta e pratica os direitos culturais emergentes de multidão de seres humanos e, em alguma medida, demanda a ousadia de um projeto de sociedade feito de ascensão social, igualdade e direitos sociais ampliados e renovados. ${ }^{679}$ [grifos meus $]$
\end{abstract}

\footnotetext{
${ }^{676}$ GIL, Gilberto. A mensagem de Bob Marley. O Globo, 18 mar. 2008. In: GIL, Gilberto; FERREIRA, Juca. Cultura pela palavra..., op. cit., p. 40.

${ }^{677}$ GILROY, Paul. O atlântico negro..., op. cit., p. 13.

${ }^{678}$ GIL, Gilberto. A mensagem de Bob Marley..., op. cit., p. 41.

679 Ibid., p. 41.
} 
O reggae e Marley são interpretados por Gil como representantes das insurgentes culturas negras da América, e fazem menção a um sentimento de desterritorialização, mas também sobre o self, a semelhança e a solidariedade. ${ }^{680}$

Em 2003, ainda durante o período em que Gil presidiu o MinC, o jornal Folha de S. Paulo informa-nos sobre políticas culturais defendidas e adotadas por ele, as quais tiveram como foco a cultura da diáspora. Dentre as primeiras notícias de Gil no MinC, o jornal mencionou a participação do ministro no festival paulistano Agosto Negro:

O grupo propõe formar uma comissão com cinco de seus membros e um representante do $\mathrm{MinC}$, que ajudaria a definir projetos federais de disseminação do hip hop como veículo de inclusão sociocultural e racial. ${ }^{681}$

Alguns dias depois do encontro, o jornal noticiou que Gil propôs aos membros do hip hop um encontro com repentistas nordestinos, e pregou "o respeito a cada uma das muitas correntes, sem fundamentalismos, sem hegemonias, sem que cada corrente queira ser a dona da verdade". ${ }^{682}$

Numa coluna intitulada "Black is beautiful", assim a enviada especial a Maputo descreveu a participação de Gil na equipe do Presidente Lula, em visita àquele País:

Num caso à parte, Gilberto Gil (Cultura) tem sido a alegria da comitiva. Além de conhecer razoavelmente a África e sua história recente, o ministro tem dado "canjas" em jantares e solenidades. Ontem Lula brincou: "Eu nem peço mais pra ele. Ele já levanta e sai cantando. Nem pede mais o violão". ${ }^{683}$

Em outra nota, Gil é novamente elogiado por sua performance na África:

Se há um consenso na comitiva presidencial à África, ele se chama Gilberto Gil, o compositor, cantor e ministro da Cultura, que deu "canja" para presidentes e parecia à vontade, apesar do cansaço. "Eu me sinto em casa aqui, me sinto na Bahia", disse ele mais de uma vez, contando que conhece a África desde os anos 80 e improvisando aulas sobre o continente para os jornalistas. "O Gil arrasou, muitas vezes ele é mais famoso e conhecido do que o próprio Lula", relatou Marco Aurélio Garcia, assessor especial de Lula. Segundo ele, "Gil enfrentou filas de fãs", inclusive o encontro de Lula com intelectuais, na quartafeira. "Todo mundo queria falar com ele, pedir

\footnotetext{
${ }^{680}$ GILROY, Paul. O Atlântico negro..., op. cit., p. 20.

${ }^{681}$ SANCHES, Pedro Alexandre. Festival quer rimar hip hop com política. Folhade S. Paulo,1 ago. 2003.

${ }^{682}$ SANCHES, Pedro Alexandre. Gil propõe intercâmbio entre rappers e repentistas.Folha de S. Paulo, 4 ago. 2003.

${ }^{683}$ CANTANHÊDE, Eliane. Benedita é "negrona bonita". Folha de S. Paulo, 6 nov. 2003.
} 
autógrafo". Lula elogiou seguidamente seu ministro da Cultura, que dançou com grupos locais em Moçambique e na Namíbia. Também cantou ao ar livre na inauguração da primeira embaixada brasileira em São Tomé e Príncipe e em recepções para os presidentes José Eduardo Santos, de Angola, e Joaquim Chissano, de Moçambique. ${ }^{684}$ [grifos meus]

Várias vezes as danças de Gil foram noticiadas, fotografadas e expostas na Folha, não somente as da viagem à África, mas ao lado de Antônio Nóbrega na entrega do prêmio da Ordem do Mérito Cultural. ${ }^{685}$

Em 2005, a Folha anunciou a criação da canção/hino "La Renaissance Africaine", composta pelo ministro, por ocasião do Festival de Dacar. A composição do hino foi proposta a Gil pela organização do evento. Assim Gil se referiu à composição: "Eles pediram para que eu fizesse a letra. Eu fiz a letra. A música, estou dando de quebra, para eles avaliarem se serve, se querem ou não querem. ${ }^{9686}$

A música é outro importante dado para compreendermos o fio que enreda Gil e o continente africano:

L'homme plein de dignité

Sa nature, sesdieux,

Son histoire et l'au de là

L'hommeet son paysageaimé

Tout estlàdevantsesyeux

Tout dedans le baouba

La renaissance africaine

La renaissance africaine

Et sa puissance

La renaissance africaine

La renaissance africaine

Avec sa dance

C'estl'afriqueliberté

C'estl'afrique et sesidées

De sagesse et de vigueur

C'estl'afriqueetsa mission

Clé pour la vrai construction

Du monde civilizé

${ }^{684}$ CANTANHÊDE, Eliane. Comitiva avalia que minis tro 'arrasou'. Folha de S. Paulo, 8 nov. 2003. ${ }^{685}$ ARANTES, Silvana. Lula aceita cultura do possível. Folha de S. Paulo, 20 dez. 2003.

${ }^{686}$ TORRES, Sérgio. Gil compõe 'hino' para festival de Dacar. Folha de S. Paulo, 12 maio 2005. 
Son peuple, son territoire

Quis'étendent en diaspora

Jusqu'àlafin de la terre

En Europe, en Amerique

C'esttoujourl'espritd'afrique

La nouveautéquiprospère

Ses enfants, sesgensmusclés

Ses femmes d'outrebeauté

Unebeauté noir-nuit

Continent le plus agé

Les vieux temps nous ontlaissé

Sa mythologie, savie ${ }^{687}$

A África entoada por Gil em "Renaissance africaine" escapa às representações hegemônicas estabelecidas historicamente pelo Ocidente e (re)constrói poeticamente a imagem de um continente-berço dos ideais de liberdade, beleza, força, sabedoria e vitalidade. A canção opera por inversão, atribuindo aos africanos certos valores associados à Europa. $\mathrm{O}$ renascimento africano associa a dança ao espírito, a mitologia à sabedoria, a beleza à negritude. Nesse sentido, podemos dizer que "Renaissance africaine" é o ponto alto das africanidades de Gil - quando a identidade transatlântica, mestiça e moderna do compositor vai ao encontro de um olhar diferenciado sobre a história africana, estabelecendo um elo conciliatório entre continentes que a ação dos homens tratou de separar ao longo de séculos. Afinal, "esta é a África e a sua missão/a verdadeira chave para a construção/civilizar o mundo". A diáspora, aqui, é vista como dispositivo civilizatório. Eis aí a inversão: a África não é objeto de ação civilizatória do Outro; ela é também capaz de civilizar o Outro (europeu, americano).

Tal visão está em consonância com o ideário de um renascimento africano, produzido no contexto da cooperação entre nações, no bojo de iniciativas como a União Africana, fundada em 2002, e do Festival Mundial de Artes Negras (FESMAN). Vale enfatizar que, até 2009, só houvera duas edições do FESMAN: a primeira, em 1966, em

\footnotetext{
687،La Renaissance Africaine” (Gilberto Gil, 2005)Tradução: O renascimento africano e seu poder, com sua dança/É a liberdade africana/ É a África e sua ideia /De sabedoria e vigor/É a África e sua missão/ Chave para a verdadeira construção/ Do mundo civilizado/ Seu povo, seu território/ Que se estende em dispersão/Até o fim da Terra/ Na Europa, na América/ É sempre o espírito da África/ A novidade que prospera/Suas crianças, suas pessoas musculosas/ Suas mulheres de outra beleza/ Uma beleza preto - noite/ Continente mais velho/ Os velhos tempos nos deixaram/ Sua mitologia, sua vida.
} 
Dacar (Senegal) e a segunda, em 1977, em Lagos (Nigéria). Em ambas, a participação do Brasil foi discreta. A terceira edição, de 2009, noticiada pela Revista de História da Biblioteca Nacional, ocorreu em Salvador, e teve a participação de Gilberto Gil, que na época já não era mais ministro da Cultura. ${ }^{688}$

"Renaissance africaine" transpira uma visão libertária e democrática sobre a África - libertária porque desagrega as africanidades do senso comum ocidental, e democrática porque ajuda a desconstruir a tábua de valores do etnocentrismo. África e Europa - e a América enquanto destino diaspórico - encontram-se aqui em igualdade. A semântica por trás da canção possui relação com a ação política de Gil, seu ideal de democratização cultural e a dignidade proporcionada às culturas que não partilham de certa visão aristocrática de arte. Essa preocupação gerou uma ação central por parte do MinC: os Pontos de Cultura.

\section{- Ministro tropicalista}

O programa Cultura Viva, criado em 2004, constitui o principal elemento da política cultural do MinC sob a gestão de Gil. É dividido em quatro linhas de ação: Pontos de Cultura, Escola Viva e Ação Griô Nacional. No entanto, os Pontos de Cultura constituem a ação prioritária do Cultura Viva, pois articulam as três outras linhas. ${ }^{689}$

Trata-se, de acordo com João Guerreiro, da constituição, da certificação e do reconhecimento de centros comunitários de produção cultural financiados pelo MinC, em reconhecimento às lutas políticas destes grupos. Os projetos são selecionados por edital público, com o objetivo de articular atividades já existentes nas comunidades. O objetivo principal é de territorializar essas ações. ${ }^{690}$

É o próprio Gil que nos informa sobre os Pontos de Cultura, em um discurso realizado em novembro de 2004, em Belo Horizonte, no Primeiro Encontro Nacional de Pontos de Cultura:

\footnotetext{
${ }^{688}$ BELISÁRIO, Adriano. Renascimento africano. Revista de História, Rio de Janeiro, 2 jun. 2009. Disponível em: <http://www.revistadehistoria.com.br/secao/reportagem/renascimento-africano> Acesso em: 22 set. 2016.

${ }^{689}$ GUERREIRO, João. Política cultural de inserção social? In: BARBOSA, Frederico; CALABRE, Lia (orgs.). Pontos de cultura: olhares sobre o programa Cultura Viva. Brasília: IPEA, 2011, p. 179-193. ${ }^{690}$ Ibid., p. 187-8.
} 
Este programa revela o quanto do que se chama "realidade" é apenas uma versão da história. Há manifestações de resistências, beleza guerreira e afirmação de respeito que não saem nos jornais, revistas, rádios ou TVs. Estes Pontos de Cultura são realidades que agora se mostram e se cruzam com a força autêntica da cultura feita por quem a vive como esta teia. ${ }^{691}$

O público-alvo prioritário do Cultura Viva, como registrou o site do MinC, incluiu populações de baixa renda, habitantes de áreas com precária oferta de serviços públicos, tanto nos grandes centros urbanos como nos pequenos municípios; adolescentes e jovens adultos em situação de vulnerabilidade social; estudantes da rede básica de ensino público; professores e coordenadores pedagógicos da educação básica; habitantes de regiões e municípios com grande relevância para a preservação do patrimônio histórico, cultural e ambiental brasileiro; comunidades indígenas, rurais e remanescentes de quilombos; agentes culturais, artistas e produtores, pesquisadores, acadêmicos e militantes sociais que desenvolvem ações de combate à exclusão social e cultural. ${ }^{692}$

Para conectar os Pontos de Cultura entre si, criou-se uma rede, chamada de Teia. Já a Ação Griô Nacional buscou conectar os Pontos de Cultura às escolas. O objetivo era articular a educação formal e a produção cultural, em especial a das classes subalternas, inclusive transformando algumas escolas em Pontos de Cultura. Aliás, a Ação Griô é fruto de uma parceria entre governo e sociedade civil, nos moldes da descentralização e da horizontalidade propostos pelo ministério de Gil.

A Associação Grãos de Luz e Griô, uma instituição sem fins lucrativos de Lençóis (BA), foi selecionada em 2004 como Ponto de Cultura do programa Cultura Viva. A associação foi convidada pelo MinC a criar e coordenar um programa de âmbito nacional baseado em sua experiência local. Em decisão conjunta, Griô e o MinC optaram pelo modelo de gestão compartilhada. O ponto principal da metodologia Griô é a integração entre a tradição oral e os processos escolares formais, em pedagogia a ser desenvolvida

\footnotetext{
${ }^{691}$ Ibid., p. 62.

${ }^{692}$ COSTA, Eliane Sacramento. Com quantos 'gigabytes 'se faz uma jangada, um barco que veleje: o Ministério da Cultura, na gestão Gilberto Gil, diante do cenário das redes e tecnologias digitais. Mestrado profissional em bens culturais e projetos sociais. Fundação Getúlio Vargas, Rio de Janeiro, 2011, p. 153.
} 
de forma lúdica e por meio de linguagens diversas, como teatro, fotografia, filmagem, dança e educação ambiental. ${ }^{693}$

A palavra vem do idioma francês, griot. Os griôs têm origem no Mali, noroeste da África, e possuíam “diversas funções sociais, como genealogistas, músicos, poetas e contadores de história, atuando em rituais sociais de nascimento, aliança matrimonial, cerimônias de casamento e funerais". ${ }^{694}$ A missão da Ação Griô Nacional seria "fortalecer a ancestralidade e a identidade do povo brasileiro por meio do reconhecimento do lugar político sociocultural e econômico de griôs e mestres de tradição oral na educação". Por ancestralidade, entende-se a longevidade por meio da qual tradições e costumes, muitos sem registro escrito, se desenvolvem no interior de uma comunidade, e a importância cultural decorrente dela. ${ }^{695}$

De acordo com Guerreiro, recebem o certificado de Griô todos os Pontos de Cultura 'que têm mestres e aprendizes 'contadores de histórias', artesanatos, representantes da cultura afro-brasileira e demais atores sociais que adquiriram, reelaboram e repassam conhecimentos de antepassados" ${ }^{696}$ Durante o governo Lula, eles recebiam bolsa mensal de um salário mínimo, no período de um ano, para divulgar a tradição oral no país. Em análise publicada em 2011, Guerreiro afirmou que a capilaridade do projeto ainda era bem pequena, tendo em conta as dimensões nacionais. Além disso, muitas das ações previstas no programa Cultura Viva não saíram do papel, devido à escassez de verbas e à falta de articulação entre cultura e educação, à qual se tentou criar alguma integração. ${ }^{697}$ Segundo o autor, "o efeito multiplicador das ações é visível, mas os números estão muito aquém do desejo do governo e da sociedade civil e das demandas da parcela excluída socioculturalmente". ${ }^{998}$

Os Pontos de Cultura, e de forma menos abrangente a Ação Griô, ocorreram graças a uma mudança paradigmática fundamental no interior do MinC. O conceito de cultura na gestão de Gil alargou-se, permitindo ao ministério, a partir desse momento, não se restringir apenas à cultura culta, ou erudita; pelo contrário, passou a advogar a

\footnotetext{
${ }^{693}$ LOPES, Juliana. Ação Griô: uma proposta de política nacional. In: BARBOSA, Frederico; CALABRE, Lia (orgs.). Pontos de cultura: olhares sobre o programa Cultura Viva. Brasília: IPEA, 2011, pp. 139-154, p. 142. 
diversidade das culturas populares contemporâneas. Eliane Costa afirma que os Pontos de Cultura não seguiram um modelo único de atividades ou funcionamento. O que tinham em comum era a gestão compartilhada entre poder público e a comunidade e a presença de um estúdio digital multimídia:

Os Pontos de Cultura são a ação central, se baseiam em três pilares conceituais - autonomia, protagonismo e empoderamento -, que se relacionam, respectivamente, às três já mencionadas dimensões da cultura, na visão proposta pelo MinC: a simbólica, a cidadã e a econômica. ${ }^{699}$

A expansão do conceito de cultura passou a ser empregada especialmente como instrumento de luta contra a exclusão social. Através do do-in antropológico, Gil assim definiu sua política de ação:

Então o do-in antropológico é isso: vamos estimular certos pontos da vida cultural brasileira que estão amortecidos, que estão abandonados, que não são considerados como polos energéticos, etc. E aí, volto a dizer, volto a falar: o protagonismo popular, os setores populares, a criatividade, a imensa criatividade das massas brasileiras. Enfim, que de uma certa forma é ignorada porque estamos ligados a essa produção e consumo de base euro-americana. ${ }^{700}$

E que experiência de políticas públicas no Brasil teria fundamentado a ação de Gil? João Guerreiro lança a hipótese de que, em linhas gerais, a experiência de Marilena Chauí à frente da Secretaria de Cultura do município de São Paulo, na gestão de Luíza Erundina (1989-1992), foi ressignificada por Gil e Juca Ferreira. Ambas guardam semelhanças inequívocas, e esses são alguns dos pontos que fundamentam a hipótese de Guerreiro: a) a incorporação de membros da sociedade civil na elaboração das políticas culturais; b) a certificação de expressões culturais fora do circuito mercadológico; e c) a compreensão da cultura como atividade social e, portanto, elemento gerador de renda e trabalho. ${ }^{701}$

Em texto de 1995, no qual apresenta um balanço de sua experiência como secretária de Cultura de São Paulo, Chauí discute o papel do Estado nas políticas culturais, diferenciando duas linhas distintas de ação: o dirigismo centralizador - hegemônico no Estado Novo (1937-1945) - e o papel de articulação entre os sujeitos. Para ela, é preciso

\footnotetext{
${ }^{699}$ COSTA, Eliane Sacramento. Com quantos 'gigabytes'..., op. cit., p. 61.

${ }^{700}$ CAMPOS, Paulo Mariano Eulálio. Estetizar a política e politizar a estética: as tensões entre arte e práxis político-social na obra e na ação política de Gilberto Gil. Dis sertação de mestrado defendida na Faculdade de Educação da Universidade Federal de Minas Gerais, Belo Horizonte, 2012, p. 104.

701 GUERREIRO, João, op. cit., pp. 190-191.
} 
“diferenciar entre estadismo cultural (cultura oficial) e dimensão pública da cultura (o Estado estimula a criação cultural da sociedade)". ${ }^{702}$

Eis, portanto, a diferença fundamental entre a proposta de Chauí - e que faz parte também do programa do ministro Gil - e o estatismo cultural do passado. O Estado deve ser um operador capaz de estimular e propiciar a criação pelos sujeitos culturais: os cidadãos passam a se reconhecer como sujeitos de sua própria história, sem uma tute la paternalista. Essa concepção deveria garantir os direitos de acesso e fruição dos bens culturais, "por meio de serviços públicos de cultura", e à criação cultural, "entendendo cultura como trabalho da sensibilidade e da imaginação na criação das obras de arte e como trabalho da inteligência e da reflexão na criação das obras de pensamento". ${ }^{703}$

Ao problematizar a atuação de Gil em cargos públicos no todo de sua trajetória, é pertinente que se questione de que modo suas concepções políticas e artísticas se entrelaçam. Nesse sentido, a pesquisa de Paulo Mariano Eulálio Campos ${ }^{704}$ abordou a trajetória de Gil na tentativa de compreender a imbricação entre arte e política. Analisando algumas canções, ${ }^{705}$ consideradas pelo autor como uma espécie de registro do ativis mo sociopolítico de Gil, Campos também entrevistou o ex-minis tro e ex-secretário executivo do Ministério da Cultura Juca Ferreira e o idealizador dos Pontos de Cultura, Célio Turino. Campos buscou compreender como a música ${ }^{706} \mathrm{e}$ as intervenções sociopolíticas de Gilberto Gil contribuíram para a emancipação dos sujeitos e para a vida democrática do país.

Campos prestou-se a refletir sobre o espaço de produção artístico-cultural em relação às intervenções políticas de Gil. Dentre os questionamentos dirigidos aos

\footnotetext{
${ }^{702}$ CHAUÍ, Marilena. Cultura política e política cultural. Estudos avançados, São Paulo, Instituto de Estudos Avançados, Universidade de São Paulo, v. 9, n. 23, pp. 71-84, 1995, p. 82.

${ }^{703}$ Ibid., p. 82.

${ }^{704}$ CAMPOS, Paulo Mariano Eulálio. Estetizar a política..., op. cit.

${ }^{705}$ Essas músicas fazem parte do repertório de um show realizado por Gil em 1973 na USP, em motivo de protesto pela morte de um estudante de Geologia. São elas: Oriente, Cálice (parceria com Chico Buarque), Expresso 2222, Procissão, Domingo no parque e Filhos de Gandhy.

${ }^{706} \mathrm{O}$ autor propõe um conceito de música que abarque tanto o processo histórico de humanização quanto a formação de nossas subjetividades, afirmando que: "Devemos abordá-la como uma das formas marginalizadas de produção de saber que tem ganhado relevância atualmente, entendendo -a como uma experiência de formação humana para além do espaço escolar, capaz não só de dar voz como também de emancipar os indivíduos. Dito de outro modo, a música deve ser encarada como experiência estética deformação que se realiza como potência de saber nas práticas e processos sociais nos quais é produzida, circula, é consumida e fruída como obra de arte, enfim, no caleidoscópio cultural da sociedade contemporânea”. CAMPOS, Paulo Mariano Eulálio. Estetizar a política e politizar a estética..., op. cit., p. 69.
} 
entrevistados, preocupou-se em saber se de alguma maneira as práticas levadas à frente no ministério foram um desdobramento de propostas relacionadas ao tropicalismo, uma vez que o autor considera o movimento como a primeira grande experiência política de Gil, que acabou por repercutir, de acordo com Campos, em toda a sua produção posterior.

Sobre a possível existência de uma "gestão tropicalista", assim Campos a ela se referencia:

\begin{abstract}
A permanência desse movimento na gestão política do Ministério se faz notar nos seguintes traços: abertura para a pluralidade; visão não eurocêntrica da cultura; ao mesmo tempo abertura para as possibilidades trazidas pelas novas descobertas; possibilidades de trocas culturais com os países hegemônicos do capitalismo. (...) Mas são aspectos também bastante claros nas políticas públicas, implantadas pelo ministério, por exemplo: através do incentivo ao uso das novas tecnologias, como ocorreu nos Pontos de Cultura. (...) Portanto, a abertura para a diversidade incluía tanto a cultura nacional quanto o cosmopolitismo, além da valorização da diversidade cultural das minorias. Eis os principais traços tropicalistas do Ministério da Cultura sob a gestão de Gil. ${ }^{707}$
\end{abstract}

Em entrevista a Campos, assim Gil faz referência ao tropicalismo em sua gestão:

(...) Enfim, esse despertar por um gosto, pelo Brasil e os vários brasis, pelo mundo e os vários mundos, a África, a importância da África, a importância dos negros americanos, e a importância, enfim, das minorias. Tudo isso tinha sido objeto de cultivo do plantio tropicalista. Isso evidentemente vai para o ministério. Até porque esse ideário tropicalista, desse ponto de vista sociopolítico, é uma coisa que caminha com o desenvolvimento do Brasil desde o tropicalismo até o governo Lula. ${ }^{708}$

Dentre as novas políticas redistributivas, demarcadas essencialmente pela descentralização geográfica e o incentivo ao protagonismo social, Campos cita os Pontos de Cultura idealizados por Célio Turino, baseados no conceito de gestão compartilhada:

(...) ao inverter as prioridades, colocando como atores principais os movimentos sociais, os Pontos de Cultura operam uma verdadeira transformação na maneira como os grupos artísticos

\footnotetext{
${ }^{707}$ CAMPOS, Paulo Mariano Eulálio. Estetizar a política e politizar a estética..., op. cit., p. 88.

${ }^{708}$ Entrevista com Gilberto Gil concedida a Paulo Mariano Eulálio Campos, em 24 jun. 2012. In: Ibid., p. 88.
} 
excluídos da dinâmica do acesso ao financiamento cultural lidam com o Estado. ${ }^{709}$

De acordo com Campos, um projeto de formação emancipada de sujeitos sociais pode estar presente em políticas públicas cuja filosofia contemple claramente tal dimensão, como, por exemplo, os Pontos de Cultura. A emancipação pode estar também presente na própria postura artística que se reflete em outros campos, segundo o autor, como no tropicalismo. Campos enfatiza e defende uma postura tropicalista como sinônimo de abertura para o novo, para a dimensão cosmopolita da sociedade atual e para a luta contra a noção restritiva de cultura. Afirma ainda que Gilberto Gil, através de sua música, contribuiu para a sublimação de demandas internas e também para a reflexão social, para a construção de nova ordem - se não pós-moderna, no sentido que adquiriu no debate filosófico do século XX, pelo menos utópico, na medida em que desacreditava os valores dominantes.

\section{- Ministro da diáspora}

O mundo das africanidades foi acessado, ao longo da trajetória de Gil, de diferentes maneiras, e concebido no leito de cada experiência. Essas maneiras são contextuais e se ressignificaram a cada nova abordagem, mas possuem entre si o eixo do multiculturalismo. Se em algumas situações a África é acessada através de essencialismos, em outras é vista como ponto de partida de negros que reconfiguraram sua cultura na nova vida nas Américas.

Através de sua atuação no MinC, foi possível perceber uma espécie de luta atual pela descolonização cultural do país e por inserir o Brasil no diálogo com o mundo. Tal luta possui paralelos com sua atuação política de Salvador, entre fins da década de 1980 e início dos anos 1990, e sua tentativa de revalidar, sob um novo paradigma político e cultural, o processo da abolição no Brasil. Atuando no sentido de eliminar as desigualdades e de assegurar a grupos historicamente marginalizados as necessárias condições de produção de bens culturais- para além da mera fruição -, não houve a intenção de privilegiar, por meio de suas políticas culturais, algum segmento específico,

${ }^{709}$ Ibid., p. 104. 
mas sim todo um grupo de pessoas anteriormente marginalizadas no cenário social brasileiro, e dentre eles também os filhos da diáspora.

Assim, procuramos entrelaçar o contínuo processo de construção de africanidades em Gilberto Gil com aspectos gerais de sua trajetória política, a partir dos anos 1980. A relação entre a poética e a política ajuda-nos a pensar de que forma o artista trouxe a África para a sua atuação à frente de órgãos públicos - da Fundação Gregório de Mattos ao Ministério da Cultura. Da mesma forma, a análise de aspectos da produção musical de Gil no período nos ajuda a elucidar a sua relação com a questão. Na contramão de uma narrativa produtora da ilusão biográfica, termo criado por Pierre Bourdieu, ${ }^{710}$ a análise do período procurou demonstrar a ausência de um "caminho lógico" entre a "descoberta" de sua africanidade, em Londres nos anos 1970, e a existência de uma suposta coerência política capaz de estabelecer com o passado um traço retilíneo e óbvio, produzindo no presente uma atuação política baseada em uma causa única. A questão da diáspora esteve presente ao longo da trajetória política do artista, convivendo com outras questões de igual importância na contemporaneidade, como o meio ambiente, a cultura digital e a democratização dos bens culturais. A ação política de Gil é permeada pela pluriculturalidade e pela heterogeneidade observadas por Maffesoli em seu olhar sobre as sociedades contemporâneas.

${ }^{710}$ BORDIEU, Pierre. A ilusão biográfica. Usos e abusos da história oral, v. 8, pp. 183-191, 1996. 


\section{Considerações finais}

Ao longo da tese, foi possível apreender muitas das nuances da trajetória de Gil, e compreender como esse artista se tornou um "ícone" da MPB e da cultura brasileira. Gil foi peça chave do movimento tropicalista, no fim dos anos 1960, o qual problematizou questões referentes ao cenário artístico-musical do país e o grande peso dado aos aspectos nacionalistas, intencionando explorar a possibilidade de universalização da produção cultural. Após o tropicalismo, Gil experimentou e reinventou-se num exílio forçado, abrindo-se a novas tendências, mercados e públicos. Em 1977, lançou seu manifes to negro $^{711}$, engajou-se constantemente na vida política do país, e exerceu, a partir da década seguinte, mais de um cargo político. Assim sendo, ao acompanharmos o fio da trajetória percorrida, foi possível perceber as muitas facetas experimentadas pelo artista e seu diálogo com os diferentes contextos que abrigaram suas práticas e foram por elas informados.

Buscamos estabelecer, na multiplicidade e na complexidade de sua atuação, tanto artística quanto política, questões referentes à construção de africanidades. Tal problemática permitiu a construção de múltiplas veredas. Foi possível conhecer melhor a trajetória, traçada por Gil, desde os remotos tempos em sua tão celebrada Ituaçu; suas primeiras experiências profissionais; e o retorno do exilio, demarcado fortemente pelo desejo de melhor conhecer a cultura do próprio país. Foi possível explorar sonoridades criadas em tão diversas temporalidades, e conhecer suas ações políticas foi também adentrar num universo marcado pela pluralidade. Se a busca que norteou a pesquisa se centrava em compreender as africanidades construídas pelo artista, o que se fez notar foi bem mais uma multiplicidade de tempos, sensibilidades, memórias e negritudes.

Na infância, o menino Gil cresceu cercado pelos mimos da avó em Ituaçu e das tias em Salvador. A musicalidade que permeava seu mundo naquele momento era as das bandas da cidade e das rádios, e seu ídolo maior era Luiz Gonzaga, o rei do baião. O violão e a bossa nova demarcaram sua adolescência. Por meio da análise de fontes, foi possível perceber que questões referentes ao mundo da negritude ainda não faziam parte dos questionamentos da família Gil. A mudança para São Paulo, em 1965, demarcou a

\footnotetext{
711 Álbum Refavela (Warner Music, 1977).
} 
guinada profissional de Gil rumo a carreira de músico. Foi tempo de participar dos festivais e da turbulenta Tropicália.

As experiências da prisão no Brasil e do exilio londrino foram tempos de ressignificação para Gil, como pessoa e como artista. Seu retorno foi fortemente marcado pelo desejo de melhor conhecer a cultura brasileira. Mas esse conhecimento seria processado ao longo de toda a sua trajetória, e não pode ser enquadrado através de signos que englobam apenas o caráter da tradição. Gil sempre foi adepto do universo pop e das hibridações. Os essencialismos culturais, mais especialmente os musicais, nunca foram sua bandeira. Não apenas a questão da negritude figurou como tema de suas inquietações pessoais, ou mesmo políticas; o meio ambiente; a democratização do acesso à cultura e à tecnologia; o esoterismo - muitas foram as suas paixões, pulsões gregárias e demandas.

O convívio londrino com o universo do rock, e também com a música jamaicana, incentivou Gil a trocar o violão pela guitarra. Seu retorno ao Brasil culminou em sua participação no afoxé Filhos de Gandhy, que muito nos informou sobre sua conexão com o mundo das africanidades. A África conectada através dessa filiação é o local que se faz representar pela Bahia através da dança, do canto e do ritmo ijexá. Essa agremiação cultural reelabora a cada carnaval a tradição africana, fundindo-a com tradições indianas. Não há alusão à pureza, mas sim o alinhamento à construção de uma realidade miscigenada, pautando-se pela cura do sofrimento na busca pela paz. Essas escolhas estiveram em sintonia com aquelas adotadas por Gil ao longo de toda sua trajetória.

As africanidades encontradas na trajetória de Gil estiveram relacionadas a uma gama variada de símbolos, processados em diferentes temporalidades. Se muitas vezes ela fez ecoar denúncias sobre o racismo, outras vezes questionou a permanência da escravidão no Brasil. Por muitas vezes, exaltou a Bahia e seus orixás, o reggae e os ideais de Marley, numa complexidade discursiva e sonora que privilegiou dois desejos principais: superar as injustiças sócio raciais e exaltar a diversidade negra do Brasil e das Américas. Gil deu muita visibilidade ao mundo da negritude, tanto pela autoidentificação, quanto pela utilização de símbolos negros transatlânticos, promovendo sempre os ideais da igualdade e da diversidade cultural.

A perspectiva adotada por Gilroy, ao considerar que as identidades negras se constituem no trânsito África-Europa-América, pode ser percebida particularmente no caminho traçado por Gil no que tangencia a construção de sua negritude. Na trilogia ${ }^{712}$ de discos lançada na década de 1970, as rotas abertas por Gilroy possibilitaram-nos pensar a 
cultura atlântica negra acessada por Gil. A identidade negra mescla sua ancestralidade africana através de Logunedé e de Xangô, exalta e celebra sua negritude baiana através dos Filhos de Gandhy e do Ilê Aiyê, e faz contundentes críticas não apenas ao racismo, mas também à desigualdade a que estão sujeitos os negros brasileiros. É importante ressaltar, no entanto, que nessa trilogia as traduções culturais de Gil não se processaram através de uma leitura que contrapôs tradição e modernidade. Sua produção privilegiou o sincretis mo de diferentes códigos musicais e símbolos de negritude com outros do mundo branco, sem sobrevalorizar nenhum deles.

Se as primeiras canções de Gil foram demarcadas pelos pressupostos estéticos da MPB embasados no nacional-popular, na época posterior, a do tropicalismo, suas canções passaram e divulgar um teor mais crítico. ${ }^{713} \mathrm{Se}$ as canções referentes à negritude da década de $1970{ }^{714}$ são fortemente demarcadas pelo caráter de denúncia e descontentamento referentes ao racismo brasileiro, em $2005^{715}$ a África entoada por Gil tematiza as questões raciais de maneira mais conciliatória. Aspectos como esses só puderam ser apreendidos graças ao recorte aqui abordado. As mutações observadas nos mostram o desenvolvimento da questão das africanidades acessadas por Gil, bem como o fato de elas terem sido ressignificadas ao longo de sua trajetória.

Segundo Gilroy, a diáspora favoreceu a formação de um circuito comunicativo que extrapolou as fronteiras étnicas do Estado-nação, permitindo às populações dispersas conversar, interagir e efetuar trocas culturais. Sua alusão ao mar e à vida marítima, presente não apenas no título de sua obra, mas ao longo de toda sua narrativa, indica a ideia de contaminação, mistura, movimento. Tais aspectos são coerentes com a perspectiva de análise que situa o mundo do Atlântico Negro em uma rede entrelaçada entre o local e o global, onde o navio representa "um sistema vivo, microcultural $e$ micropolítico em movimento que coloca em circulação, ideias, ativistas, artefatos culturais e politicos".716

\footnotetext{
$\overline{712}$ Refazenda (Warner Music, 1975), Refavela(Warner Music, 1977) e Realce (Warner Music, 1979).

713 Como, por exemplo, a canção de Gil composta em parceria com Capinam "Miserere Nobis" do álbum Tropicália ou Panis ET circencis (Philips, 1968).

${ }^{714}$ Como, por exemplo, a canção "Refavela" (Gilberto Gil, 1977).

715 "La Renaissance africaine", composta em 2005 pelo ministro, por ocasião do Festival de Dacar e gravada posteriormente no LP Banda larga cordel (Geleia Geral/ Warner, 2008).

${ }^{716}$ BHABHA, Homi K. O local da cultura. Belo Horizonte: Ed. UFMG, 1998, p.38.
} 
Gil é, aqui, o agente que navegou nesse atlântico e reprocessou ideais como a democracia racial e a mensagem política e a sonoridade de Bob Marley. O artista filiou-se ao miscigenado afoxé filhos de Gandhy, enveredou-se muitas vezes pelo mundo do rock, mas não privilegiou nessa mistura apenas elementos de matriz africana. Em seu barco havia espaço para muitos ideais e sonoridades. Em seu barco havia muito espaço para a diversidade. As representações das africanidades engendradas por Gil e exploradas ao longo da tese apontam bem mais para a abertura de reflexões do que encerram a temática em conclusões assertivas. Gilroy conceituou diáspora como aquilo que liberta o indivíduo de uma trajetória linear e de uma identidade prisioneira do território e/ou da origem étnico racial. Isso nos possibilitou também indagar a trajetória de Gil e suas diásporas, bem como as traduções por Gil edificadas, aqui compreendidas como facilitadoras, ou mesmo propulsoras de um elemento emancipador. Ele buscou libertar-se de amarras e lutar pela desconstrução de identidades baseadas somente em critérios "raciais" e "nacionais". Almejou libertar os indivíduos para que suas identidades fossem construídas de acordo com sua própria trajetória e desejo. Tanto a diáspora, quanto as constantes traduções realizadas por Gil, são situações que the permitiram escapar dos atalhos essencialistas forjadores de uma unidade, os quais, na maioria das vezes, revelam bem mais concepções autoritárias do que libertárias. Gil foi bem mais tropicalista que nacionalista; hibridizou, bem mais que defendeu ideais de pureza; mesclou, bem mais do que demarcou.

As africanidades não são somente um recorte político-identitário, mas precisam antes de mais nada se fazer reconhecer; têm que existir primeiramente nas subjetividades de quem as reconhece e de quem as pratica ou discursa em nome delas. Essas africanidades se fazem existir através de investimentos afetivos, emocionais e imaginários. Sua elaboração passa pela produção de subjetividades que não apenas a reconhecem, mas a incorporam como verdade externa ao ser, respondendo e significando ao próprio ser. $\mathrm{O}$ intuito foi perceber a construção de africanidades na obra e na trajetória de Gil, explorando os diálogos musicais por ele acessados, bem como os muitos lugares ocupados nessa construção. Foi possível perceber que o artista-político dialogou com variadas vertentes musicais, mesclando ijexás, baiões, reggae e rock'n'roll, e assimilou uma fusão de aspectos locais e internacionais, sempre com sotaque pop. Sua musicalidade hibridizou diferentes discursos sonoros, sem se deixar representar unicamente por nenhum deles. 
Através de seus discursos poético-musicais e políticos, dá-se a ver, também, o inquieto sonhador: suas subjetividades, ideologias, desejos, medos e pensamentos. São os sons, os sentidos e as ações práticas de sua política, embasada no aspecto da diversidade, o que nos possibilitou conhecer as diferentes percepções sobre tempos e sentidos.

As ações políticas de Gil, especialmente seu projeto de formação emancipada de sujeitos sociais, podem ser interpretadas através de uma postura tropicalista, especialmente pelo fato de intencionar constantemente a abertura para o novo, mas especialmente para a luta contra uma noção restritiva de cultura. Em suma, o mundo das africanidades foi sendo aos poucos processado na trajetória do artista e político Gil de variados modos, e confeccionado diferentemente em cada experiência. Essas maneiras são contextuais e ressignificaram-se a cada nova abordagem, mas possuem entre si os valores do multiculturalismo e do desapego às tradições.

Foi possível perceber que o transito de códigos e referenciais, e, nesse caso, especialmente os musicais, na obra e trajetória de Gil são fortemente demarcados pelo elemento da transnacionalidade, possibilitada via Atlântico negro. A afinidade de Gil com o mundo da negritude não se deu inicialmente no âmbito familiar, nem nos primeiros trabalhos musicais. Assim, podemos ressaltar que o ato contínuo de transitar e explorar novos lugares e significados culturais, foi um fator importante para o constante (re)processamento da identidade do artista.

Compreender a trajetória de Gil, e o modo como se fizeram ecoar traços de africanidades, exigiu um impulso centrado na pós-modernidade. Foi preciso colocar em jogo questões sempre demarcadas por forças de submissão, mas que através do discurso do artista passaram a ser ressignificadas através da criatividade e da emancipação. Tanto as canções quanto as ações políticas de Gil foram processadas para além de simples e fáceis demarcações de apenas um tipo de negritude.

Para encerrar a discussão, não posso deixar de voltar ao ponto inicial desta tese, que é o seu próprio título: O negro é a soma de todas as cores. Ele nos remete claramente ao complexo mundo das relações raciais e ressalta a impossibilidade de tratá-lo como algo fixo e imutável. Nesta tese, a cultura negra global tem sido compreendida a partir da metáfora do Atlântico negro, que representa um espaço de trocas transnacionais, conectando todos os sujeitos da diáspora negra. Assumimos essa mesma metáfora como ponto de partida para nossa reflexão. Se é pelo Atlântico negro que circulam conteúdos 
compartilhados pela comunidade negra mundial, tais como ideias e práticas relacionadas com a religião, a música, a literatura e as formas de organização, então podemos afirmar que a trajetória experimentada por Gil se alimentou dessas múltiplas dimensões. ${ }^{717}$

Os mistérios que tentei desvendar em relação à África acessada por Gil, elemento esse que está sempre temperando muitas de suas composições, foram ao longo da pesquisa sendo aos poucos desnudados. Não foi um caminho simples, como nunca é fácil nenhum dos caminhos trilhados. A África aí encontrada mostrou-se multifacetada. Ela por ora é mãe, e em outros momentos é tida como um lugar capaz de civilizar o resto do mundo. $\mathrm{O}$ impulso foi a busca por compreensão dos lugares que habitamos, dos significados que inventamos, das representações do Outro e de nós mesmos. A busca não para aqui, ela apenas começou. Afinal, "mistério sempre há de pintar por aî". 718

${ }^{717}$ O negro é a soma de todas as cores. Texto da capa do LP Gilberto Gil (Universal, 1968) Gil "psicografado" por Rogério Duarte: "Eu sempre estivenu. Na Academia de Acordeão Regina tocando La Cumparsita, eu estava nu. Eu só sabia que estava nu, e ao lado ficava o camarim cheio de roupas coloridas, roupas de astronauta, pirata, guerrilheiro. E eu, do mais pobre da minha nudez, queria vestir todas. Todas, para não trair minha nudez. Mas eles gostam de uniformes, admitiriam até a minha nudez, contanto que depois pudessem me esfolar e estender a minha pele no meio da praça como se fosse uma bandeira, um guarda-chuva contra o amor, contra os Beatles, contra os Mutantes. Não há guarda-chuva contra Caetano Veloso, Guilherme Araújo, Rogério Duarte, Rogério Duprat, Dirceu, Torquato Neto, Gilberto Gil, co ntra o câncer, contra a nudez. Eu sempre estive nu. Minha nudez Raios X varava os zuartes, as camisas listradas. E esta vida não está sopa e eu pergunto: com que roupa eu vou pro samba que você me convidou? Qual a fantasia que eles vão me pedir que eu vis ta para tolerar meu corpo nu? Vou andar até explodir colorido. O negro é a soma de todas as cores. A nudez é a soma de todas as roupas". <www.gilbertogil.co m>. Acessado em 15 out. 2016.

718 “Esotérico"(Gilberto Gil, 1976). In: Rennó, p. 181. 


\section{Corpus documental}

\section{Revistas e Jornais}

\section{A Tarde}

CERQUEIRA, José. A transa cultural da periferia baiana. 21 jan. 1982.

COLUNA política. [Acervo Tom Jobim]. 08 jan. 1987.

DEPOIS da posse, Gil toma banho de...[Acervo Tom Jobim]. 08 jan. 1987.

\section{Bravo}

ANTENORE, Armando. Eu não existiria sem Gonzagão. Dez. 2012.

\section{Época}

ARANHA, Ana. Show de intenções. 04 set. 2006.

PARDELLAS, Sérgio. Aquele abraço... 06 ago.2008.

SIMÕES, Jaci. O presidente pediu, eu fico. 28 jan.

2008.

Istoé

FILHO, Aziz. A hora da ação: Time de Lula é heterogêneo e tem imagem de competência, mas terá de fazer milagres com recursos escassos. 08 jan. 2003.

\section{Jornal da Bahia}

FERREIRA, Jurandir. Teatro em foco: Caetano e Gil no TCA. 12 jul.1969. 


\section{Jornal do Brasil}

DOIS anos de Bossa com sucesso. 28 maio 1967.

HUNGRIA, Júlio. [Nota sem título]. 15 jan. 1972.

MARIA, Cleusa. Um artista no poder. 04 jan. 1987.

ADÁRIO, Paulo. Eu quero o poder. 21 fev. 1988.

\section{Jornal da Tarde}

GIL espera tranquilo outra vaia. 4 out. 1967.

\section{Folha de São Paulo}

GUIMARÃES, Fernando P. Gilberto Gil em Nova York. 13 out. 1971.

GILBERTO Gil com novos "ingredientes”. 21 jan. 1972.

ARTE negra em Lagos. 28 nov. 1976.

CAMBARÁ, Isa. Gil, um show antes de ver a África. 17 dez. 1976.

BRANCO, Ivo. África, negro, Refavela: Gil. 05 jul. 1977.

JARY, Cardoso. Mautner. 17 jul. 1977.

SOARES, Dirceu. GIL FAZ carnaval para agradar no exterior. 13 out 1978.

JARY, Cardoso e PAZ, Maria. Gilberto Gil com o pé na estrada.01 jul. 1979.

FONTOURA, Marilia. O negro descobre o seu lugar. 30 set. 1979.

TÉRCIO, Jason. Uma escola sem plumas ou paetês. 17 fev. 1980.

CAMBARA, Isa. Cliff e Gil, com a mesma emoção. 23 maio 1980.

ALMEIDA, Miguel. A negritude como realce brasileiro. 29 mar. 1981.

CAMBARA, Isa. A crise de Gil não existe mais. 17 ago. 1982.

ALMEIDA, Miguel. A tristeza e rebeldia do amado Gilberto Gil. 18 set. 1982.

GONÇALVES, Marcos Augusto. Nacionais em nível internacional. 15 jan. 1985. 
FORGANES, Rosely. O antirracismo de Gil na França. 03 jul. 1986.

GILBERTO Gil toma posse hoje.07 jan. 1987.

LO PRETE, Renata. Gil leva Lina de volta à Bahia.12 jan. 1987.

GIL leva planos a Furtado. 05 fev. 1987.

GIL é recebido por Sarney. 14 abril 1987.

GRILLO, Cristina. Gil lança projeto cultural e novo LP. 19

fev.1987. CALADO, Carlos. Gil. 12 mar.1987.

GILBERTO Gil relança em São Paulo o projeto "Figa Brasil”. 17 mar. 1987.

NEGROS refutam 13 de maio e exigem dia de Zumbi. 13 jan. 1988.

RISÉRIO, Antonio. Zelberto Zel é acusado de ser caricatura "racista". 21 abr. 1988.

LIVRO vetado de Gil prega liberdade mestiça. 28 maio 1988.

SUZUKY, Matinas. Gil seguirá na política e diz que Waldir Pires vetou sua candidatura. 08 ago. 1988.

Gil quer preservação do litoral brasileiro. 12 mar. 1989.

CAVERSAN, Luiz. Gil faz show no Rio com muitos planos. 21 ago. 1991.

GONÇALVES, Marcos. Gil participa e prepara encontro em São Paulo. 09 mar. 1991 LEE, Anna. Verger. 10 set. 1998.

MOVIMENTOS negros reagem à gafe de Lula. 8 nov. 2003.

SANCHES, Pedro Alexandre. Festival quer rimar hip hop com política. 01 ago. 2003.

SANCHES, Pedro Alexandre. Gil propõe intercâmbio entre rappers e repentistas. 04 ago. 2003.

CANTANHEDE, Eliane. Benedita é negrona bonita. 06 nov. 2003.

CANTANHEDE, Eliane. Comitiva avalia que ministro 'arrasou.' 08 nov. 2003. 
ARANTES, Silvana. Lula aceita cultura do possível. 20 dez. 2003.

DE TERNO e gravata, Gil vai as escolas de samba. 14 dez. 2004.

TORRES, Sérgio. Gil compõe ‘hino’ para festival de Dacar. 12 maio 2005.

EVANGELISTA, Ronaldo. Geleia geral. 10 jan. 2007.

ARANTES, Silvana. Entrevista com Gilberto Gil. 10 nov. 2007.

\section{O Globo}

BAIANA, Ana Maria. A paz doméstica de Gilberto Gil. 10 jul. 1977, GILBERTO, Gil. A mensagem de Bob Marley. 18 de março de 2008.

\section{O Bondinho}

ALMEIDA, Hamilton. O sonho acabou, Gil está sabendo de tudo. 16 fev. 1972

\section{Pasquim}

LARA, Odete. Gil fala a Odete Lara. 15 out. 1969.

GIL, Gilberto. Recuso + aceito = receito. 25 ago. 1970.

MAUTNER, Jorge. O demiurgo. 10 jun. 1970.

\section{Revista Áudio News}

LEDESMA, Vilmar. Gil acústico. Ano 3, n²8, ago.1994.

\section{Tribuna da Bahia}

"TRAGO o que o povo quer, um novo sonho". 24 abril 1988.

Veja

EXISTE algo de concreto nos baianos. 13 nov. 1968. 
SEGURA este samba, não deixa cair. 1 jan. 1969.

O SOM e a imagem de Gal. 17 jul. 1970.

UM NOVO som: o afro-Gil. 21 mar. 1971.

KUCINSKI, Bernardo. As experiências e a volta de Gilberto Gil. 19 jan. 1972.

LANCELLOTTI, Silvio. Quero apenas cantar. 1 maio 1974.

EIS A dupla. 09 abr. 1975.

SOUZA, Tárik. Inadiável prazer. 09 abr. 1975.

BAR, Décio e ECHEVERRIA, Regina. Eu quero é mel. 10 jan. 1979.

SOUZA, Okky. De passaporte novo. 31 out. 1983.

AZEVEDO, Eliane. Os jovens querem MPB. 8 set. 1993.

MARTINS, Sérgio e OYAMA Thais. Eu Grito Sim. 21 jul. 2004.

FIM do carnaval. 6 ago. 2008

\section{Vídeos}

- DOCES bárbaros. Direção: Jom Tob Azulay. Produção artística: Guilherme Araújo. Rio de Janeiro: Biscoito Fino, 1978.

- $\quad$ FILHOS de Gandhy. Direção Lula Buarque de Hollanda, 2000.

- LA PASSIONsereine. Direção: Ariel de Bigault. Produção: Feeling Productions/TF1/PI Production. Participação: Centre Nacional de La Cinematographie ET di Ministère dês Affaires Etrangères. Apresentação: Grande Othelo, 1987.

- $\quad$ O DEMIURGO. Produção: Jorge Mautner. Londres, 1970.

- O FILHO do Holocausto. Produção: Canal Brasil. Direção e roteiro: Heitor D'Alincourt e Pedro Bial. Rio de Janeiro: Canal Brasil, 2012.

- O POETA e o esfomeado - Gilberto Gil e Jorge Mautner, 1987. Postado por Mautner no youtube. Gravado no Palácio das Convenções do Anhembi São Paulo.

- PIERRE FATUMBI Verger: mensageiro entre dois mundos. Direção: Lula 
Buarque de Hollanda. Apresentação e narração: Gilberto Gil. Direção de fotografia: César Charlone. Roteiro: Marcos Bernstein. Trilha sonora: Naná Vasconcelos. Consultoria: Milton Guran. Conspiração Filmes/Gege Produções/GNT Globosat, 1998.

- TEMPO REI. Documentário dirigido por Lula Buarque de Hollanda, Andrucha Waddington e Breno Silveira. Produção: Gege Produções/Ravina Produções. Rio de Janeiro: Conspiração Filmes, 1996.

- TROPICÁlIA. Direção: Marcelo Machado. Rio de Janeiro: Bossa Nova Filmes, 2012.

- $\quad$ UMA NOITE em 67. TERRA, R.; CALIL, R. Documentário. Videofilmes, 2010.

- VIVA SÃO João! Direção: Andrucha Waddington. Produção: Gege Produções. Roteiro: Emilio Domingos e Andrucha Waddington. Rio de Janeiro: Conspiração Filmes, 2001.

\section{Entrevistas}

- JORGE BEN. Programa Roda Viva, TV Cultura, 1995.

- $\quad$ CAETANO VElOSO. Programa Roda Viva, TV Cultura, 1996.

- $\quad$ GILBERTO GIL. Programa Roda Viva, TV Cultura, 1999.

- $\quad$ GILBERTO GIL. Programa Ensaio, TV Cultura, 2005.

- Programa MOSAICOS: a arte de Jorge Ben. TV Cultura, 2008.

- Entrevista de Gil à Eliane Costa, 18 de maio de 2010. In: COSTA, Eliane Sacramento. "Com quantos gigabytes se faz uma jangada, um barco que veleje": o Ministério da Cultura, na gestão Gilberto Gil, diante do cenário das redes e tecnologias digitais. Mestrado profissional em bens culturais e projetos sociais. Fundação Getúlio Vargas, Rio de Janeiro, 2011.

- $\quad$ GILBERTO, GIL. Programa O som do vinil. Canal Brasil (2011).

- SÉRIE MPB \& Jazz 2012 - Gilberto Gil: Gil e Caetano falam sobre Londres.<https://www.youtube.com/watch?v=NettqMeY2BE> 
- Depoimento do cantor e compositor Gilberto Gil ao Museu da Imagem e do Som do Rio de Janeiro para a série "Depoimentos para a Posteridade", realizado em 6 de junho de 2012 .

- Imbatível ao extremo: assim é Jorge Ben Jor. Apresentado pela Rádio Batuta do Instituto Moreira Sales. Produção: Adriana Maciel, Heloísa Tapajós e Paulo da Costa e Silva, 2012.

- Programa Sem Censura, publicado no YouTube pela TV Brasil em 09 de maio de 2012.

- Entrevista com Gilberto Gil concedida a Paulo Mariano Eulálio Campos, em 24/06/2012. In: CAMPOS, Paulo M. E. Estetizar a política e politizar a estética: As tensões entre arte e práxis político-social na obra e na ação política de Gilberto Gil. 2012. Dissertação (Mestrado em Educação) - Faculdade de Educação da Universidade Federal de Minas Gerais, 2012.

\section{Referências das imagens}

\section{Capítulo 2}

Figura 32 - Capa do disco Gil Jorge Ogum Xangô, 1975. Capa: Aldo Luiz e Rogério Duarte. Foto: João Castrioto.

Figura 2 - Encarte do álbum Gil Jorge Ogum Xangô, 1975.

Figura 3 - Capa do disco Refazenda, 1975. Capa: Aldo Luiz e Rogério Duarte. Foto: João Castrioto.

Figura 4 - Encarte do disco Refazenda, 1975.

Figura 5- Capa do disco Refavela, 1977. Capa: Aldo Luis. Arte final: Jorge Vianna.

Figura 6 - Encarte do disco Refavela, 1977.

Figura 7 - Capa do disco Realce, 1979. Coordenação de capa: Claudio Carvalho. Fotos Gil: Norman Seef. Fotos estúdio: Daniel Rodrigues. Design capa: Noguchi.

Figura 8 - Encarte do disco Realce, 1975. 
Figura 9 - Foto de 1966. Autor: Roberto Santana. Fonte: Acervo Gilberto Gil Instituto Antonio Carlos Jobim.

Figura 10 - Foto de 1996. Festival Internacional da Canção. Autor: não identificado. Fonte: Acervo Gilberto Gil Instituto Antonio Carlos Jobim.

Figura 11 - Foto de 1966. Gilberto Gil e Wanda Sá, no Rio de Janeiro. Autor: não identificado. Fonte: Acervo Gilberto Gil Instituto Antonio Carlos Jobim.

Figura 12 - Foto de 1967. Gil e Os Mutantes apresentando a música Domingo no parque. Autor: não identificado. Fonte: Acervo Gilberto Gil Instituto Antonio Carlos Jobim.

Figura 13 - Foto de 1971. Gil e Gal em turnê pela França. Autor: não identificado. Fonte: Acervo Gilberto Gil Instituto Antonio Carlos Jobim.

Figura 14 - Foto do início da década de 70. Gil com Caetano em Londres. Autor: não identificado. Fonte: Acervo Gilberto Gil Instituto Antonio Carlos Jobim.

Figura 15 - Foto de 1972. Gil em Londres. Autor: não identificado. Fonte: Acervo Gilberto Gil Instituto Antonio Carlos Jobim.

\section{Discografia}

- Louvação (Universal, 1967)

- Gilberto Gil (Universal, 1968)

- Tropicália ou Panis ET circencis (Universal, 1968)

- Gilberto Gil (Universal, 1969)

- $\quad$ Gilberto Gil (Universal, 1971)

- Barra 69 Gil e Caetano ao vivo na Bahia Teatro Castro Alves (Universal, 1969)

- $\quad$ Gil Jorge Ogum Xangô (Universal, 1975

- Refazenda (Warner Music, 1975)

- Doces bárbaros (Universal, 1976)

- Refavela (Warner Music, 1977)

- $\quad$ Realce (Warner Music, 1979)

- A gente precisa ver o luar (Warner Music, 1981)

- Um banda Um (Warner Music, 1982)

- Extra (Warner Music,1983)

- Raça humana (Warner Music, 1984)

- $\quad$ Tropicália 2 (Universal, 1993) 
- Banda larga cordel (Geleia Geral/ Warner, 2008)

\section{Sites consultados}

www.acervo.folha.uol.com.br

www.dicionariompb.com.br

www.discosdobrasil.com.br

www.caetanoveloso.com.br

www.chicoanysio.com

www.conspiracao.com.br

www.gege.com.br

www.gilbertogil.com.br

www.istoe.com.br/edicoes/

www.memoriamusical.com.br

www.pierreverger.org

www.planfletosdanovaera.com.br

www.portal.jobim.org/pt/acervos-digitais/gilbertogil

www.revistaepoca.globo.com/ed icoes-anteriores

www.veja.abril.com.br/complemento/acervodigital

www.youtube.com 


\section{Bibliografia}

ABREU, Martha e SOIHET, Rachel. Ensino de História: conceitos, temáticas e metodologias. Rio de Janeiro, Casa da Palavra; FAPERJ, 2003.

ANDERSON, Benedict. Nação e consciência nacional. São Paulo: Ática, 1989.

Comunidades imaginadas: reflexões sobre a origem e a difusão do nacionalismo. - São Paulo: Companhia das Letras, 2008.

ALBERTI, Verena. Manual de história oral. Rio de Janeiro: Ed. FGV, 2004.

ALBUQUERQUE, Durval Muniz. O engenho anti-moderno: a invenção do Nordeste e outras artes. Campinas: Unicamp (tese de doutoramento), 1994.

ANDRADE, Oswald. Manifesto Pau-Brasil. In: ANDRADE, O. Obras completas. Rio de Janeiro: Civilização Brasileira, 1972.

APPIAH, Kwame Anthony. Na casa de meu pai. Rio de Janeiro: Contraponto, 1997.

ARENDT, Hannah. Entre o passado e o futuro. 6. Ed. - São Paulo: Perspectiva, 2007.

BACELAR, Jeferson. A hierarquia das raças: negros e brancos em Salvador. Rio de Janeiro: Pallas, 2001.

BARSILINI, Leandro. A inserção da bateria na música popular brasileira: aspectos musicais e representações estéticas. ArtCultura, Uberlândia, v. 14, n. 24, p.33-46, 2012.

BAY, Eduardo Kolody. Sobre atabaques, máquinas de costura distorcidas e macumbeiro s picarescos. In: BRITO, Eleonora Zicari Costa de; PACHECO, Mateus de Andrade; ROSA, Rafael (orgs). Sinfonia em prosa: diálogos da história com a música. São Paulo: Intermeios, 2013.

BENJAMIN, Walter. Magia e técnica, arte e política: ensaios sobre literatura e história da cultura. 3. ed. São Paulo: Brasiliense, 1987.

BERMAN, Marshall. Tudo o que é sólido desmancha no ar: a aventura da modernidade. São Paulo: Companhia das Letras, 1988.

BHABHA, Homi K. O local da cultura. - Belo Horizonte: Ed. UFMG, 1998, BLACKING, John. How music is man? Seattle: University of Washington Press, 1955.

BOSI, Ecléa. O tempo vivo da memória: ensaios de psicologia social. $2^{\text {a }}$ ed., São Paulo: Ateliê Editorial, 2003.

BOURDIEU, Pierre. A ilusão biográfica. In: AMADO, Janaína; MORAES, Marieta de (Org.). Usos \& Abusos da história oral. Rio de Janeiro: Editora da Fundação Getúlio Vargas, 1996. 
. A economia das trocas linguísticas: o que falar quer dizer. $2^{\mathrm{a}}$ ed., São Paulo: Editora da Universidade de São Paulo, 1998.

BRANCO, Edwar de Alencar Castelo. Todos os dias de Paupéria: Torquato Neto e a invenção da tropicália. São Paulo: Annablume, 2005.

Eu não tenho nada a ver com a linha evolutiva da Música Popular Brasileira. Música, história e cotidiano sob o susto da pósmodernidade brasileira. In: BRITO, Eleonora Zicari Costa de; PACHECO, Mateus de Andrade; ROSA, Rafael (orgs.). Sinfonia em Prosa. Diálogos da história com a música. São Paulo: Intermeios, 2013.

BRITO, Eleonora Zicari Costa de. A música popular brasileira nos conturbados anos de chumbo: entre o engajamento e o desbunde. Projeto História (PUC-SP), n. 43, 2011.

.História, historiografia e representações. In:

KUYUMJIAN, Márcia; MELLO, Thereza Negrão de (orgs.). Os espaços da história cultural. Brasilia: Paralelo 15, 2008.

História e música: tecendo memórias, compondo identidades. In: Textos de História, vol. 15, n1/2, 2007, p. 2124- 215. Disponível em: http //www.red.unb.br/index.php/textos/article/view/968/635.

BRITO, Marcelo Gustavo Costa. Do chumbo ao ouro: Jorge Ben e o místico como resistência à modernidade. In: Eleonora Zicari Costa de Brito; Mateus de Andrade Pacheco; Rafael Rosa (Orgs.). Sinfonia em prosa: diálogos da história com a música. São Paulo: Intermeios, 2013.

BRUGGER, Silvia Maria Jardim. "O povo é tudo!": Uma análise da carreira e obra da cantora Clara Nunes. In III Simpósio Nacional de História Cultural-Mundo da Imagem: Do Texto ao Visual. Florianópolis, 2006. (Anais eletrônicos).

. (org.) O canto mestiço de Clara Nunes. São João del-Rei: UFSJ, 2008.

BURKE, Peter. O que é história cultural? Rio de Janeiro: Jorge Zahar Ed., 2005.

CALABRE, Lia. A era do rádio. Rio de Janeiro: Jorge Zahar Editor, 2004.

Políticas culturais no Brasil: balanço e perspectivas, in: Anais do III Enecult - Encontro de Estudos Multidisciplinares em Cultura. Salvador, 23 a 25 maio $2007 . \quad$ Disponível em: http//www.guiacultural.unicamp.br/sites/default/files/calabre_1_pol iticas_culturais_no_brasil_balanco_e_perspectivas.pdf.

CALADO, Carlos. Tropicália: a história de uma revolução musical. São Paulo: Ed. 34, 1997.

CAMPOS, Augusto de. Balanço da bossa e outras bossas. $4^{\mathrm{a}}$ ed. São Paulo: Perspectiva, 1986.

CAMPOS, Paulo M. E. Estetizar a política e politizar a estética: As tensões entre arte e práxis político-social na obra e na ação política de Gilberto Gil. 2012. Dissertação 
(Mestrado em Educação) - Faculdade de Educação da Universidade Federal de Minas Gerais, 2012.

CANCLINI, Néstor. Culturas Híbridas: Estratégias para entrar e sair da modernidade. SP, EDUSP, 1998.

CARVALHO, José Murilo. Brasil: Nações imaginadas. In: CARVALHO, José Murilo. Pontos e bordados: escritos de história e política. Belo Horizonte: UFMG: 1998.

CARVALHO, José Jorge. A tradição musical Iorubá no Brasil: um cristal que se oculta e se revela. In: TUGNY, Rosângela, QUEIROZ, Ruben Caixeta (orgs.). Músicas africanas e indígenas no Brasil. Belo Horizonte: Editora UFMG, 2006.

CARVALHO, Pedro Henrique Varoni. A vozque canta na voz que fala. Tese, Programa de Pós graduação em Linguistica, Universidade Federal de São Carlos, 2013.

CATROGA, Fernando. Memória e História. In: PESAVENTO, Sandra Jatahy. Fronteiras do Milênio. Porto Alegre: Ed. Universidade/UFRGS, 2001.

CERTEAU, Michel de. A invenção do cotidiano: artes de fazer. $11^{\mathrm{a}}$ ed., São Paulo: Editora Vozes, 2005.

CHARTIER, Roger. A História Cultural. Lisboa: Difel, 1990.

À beira da falésia: a história entre a incerteza e inquietude. Ed. Universidade. UFRGS, 2002.

COELHO, Frederico. A formação de um tropicalista: um breve estudo da coluna "Música popular", de Torquato Neto. Estudos Históricos, Rio de Janeiro, FGV, n 30, 2002.

COHN, Sergio (org.). Gilberto Gil-Encontros. Rio de Janeiro: Beco do Azougue, 2007.

CONTIER, Arnaldo. Música no Brasil: História e interdisciplinaridade. In: História em debate. Atas do XVI Simpósio Nacional de História, ANPUH/CNPQ, Rio de Janeiro, 1991, p. 151-189.

Edu Lobo e Carlos Lyra: O Nacional e o Popular na Canção de Protesto (Os Anos 60). Rev. Bras. Hist., vol. 18, n. 35, São Paulo, 1998.

COSTA, Eliane Sacramento. "Com quantos gigabytes se faz uma jangada, um barco que veleje": o Ministério da Cultura, na gestão Gilberto Gil, diante do cenário das redes e tecnologias digitais. Mestrado profissional em bens culturais e projetos sociais. Fundação Getúlio Vargas, Rio de Janeiro, 2011.

COSTA E SILVA, Alberto. Um Rio Chamado Atlântico. A África no Brasil e o Brasil na África. Rio de Janeiro: Nova Fronteira, 2003.

São Paulo: Penguin, 2012.

.Imagens da África: da Antiguidade ao Século XIX. 1 ed. - 
CYNTRÃO, Sylvia Helena (org). A forma da festa-tropicalismo: a explosão e seus estilhaços. Brasilia: Editora Universidade de Brasilia; São Paulo: Imprensa Oficial do Estado, 2000.

D'ADESKY, Jacques. Pluralismo Étnico e multiculturalismo: Racismo e Antirracis mos no Brasil. Rio de Janeiro: Pallas, 2001.

DAMATTA, Roberto. O que faz o Brasil, Brasil? 12a ed. Rio de Janeiro: Rocco, 2001.

DEL PRIORE, Mary e VENÂNCIO, Renato. Ancestrais. Uma introdução à história da África Atlântica. Rio de Janeiro: Editora Campus, 2004.

DREYFUS, Dominique. Vida do Viajante: A Saga de Luiz Gonzaga. 3a ed. São Paulo: Ed. 34, 1996.

FANON, Frantz. Pele Negra, Máscaras Brancas. Rio de Janeiro: Fator, 1983.

FANTINI, Débora. O nacional-popular na obra de Elis Regina (1961-1974)Dissertação de mestrado. Universidade Federal de São João Del Rei, 2011.

FAVARETTO, Celso Fernando, 1941. Tropicália - Alegoria, Alegria. São Paulo: Ateliê Editorial, 1996.

FERREIRA, Jorge \& DELGADO, Lucila de Almeida Neves (orgs). O Brasil republicano: o tempo da ditadura, regime militar e movimentos sociais em fins do século XX. Rio de Janeiro: Civilização Brasileira, 2003.

FONTENELES, Bené. Giluminoso: a pó. Ética do Ser. Brasilia: Editora Universidade de Brasilia; São Paulo: SESC, 1999. Gil 60: todas as contas. Rio de Janeiro: Gege Edições, 2002.

FREITAS, Joseania. O carnaval afro-brasileiro em Salvador: patrimônio da cultura brasileira. Texto originalmente apresentado em conferência na Universidade do Norte, em Barranquilha (Colômbia) em 26/02/2004, publicado em espanhol na Revista brasileira do Caribe, vol.8.

FREYRE, Gilberto. Casa grande \& Senzala: formação da família brasileira sob o regime da economia patriarcal. 29.ed. - Rio de janeiro: Record, 1994.

. \& FERREIRA, Juca. Cultura pela palavra: coletânea de artigos, discursos e entrevistas dos ministros da Cultura 2003-2010. Rio de Janeiro: Versal, 2013.

GILROY, Paul. O Atlântico negro: modernidade e dupla consciência. 2. ed. São Paulo: Editora 34; Rio de Janeiro: Universidade Cândido Mendes, Centro de Estudos AfroAsiáticos, 2012.

GINZBURG, Carlo. O Queijo e os Vermes: o cotidiano e as ideias de um moleiro perseguido pela Inquisição. São Paulo: Cia. das Letras, 1987. 
- Mitos, emblemas, sinais: morfologia e história. São

Paulo: Companhia das Letras, 1989.

- O fio $e$ os rastros: verdadeiro, falso, fictício. São Paulo:

Companhia das Letras, 2007.

GÓES, Fred. Gilberto Gil - seleção de textos, notas, estudos biográfico, histórico e crítico e exercícios. São Paulo: Abril Educação, 1982.

GUERREIRO, Goli. A trama dos tambores: a música afro-pop de Salvador. São Paulo: Ed. 34, 2000.

HALL, Stuart. Da diáspora: identidades e mediações culturais. 1.ed. Atualizada. Belo Horizonte: Editora UFMG, 2009.

. Identidade cultural e diáspora. Revista do Patrimônio Histórico e Artístico Nacional, n. 24, Iphan, Rio de Janeiro, Graphos, 1996,

.A identidade cultural na pós-modernidade. Rio de Janeiro: DPA, 2001.

HOBSBAWN, Eric. Nações e nacionalismos desde 1780. RJ: Paz e Terra, 1990.

Letras, 1995. . Era dos Extremos: o breve século XX. 1914-1991. São Paulo: Cia. das

JAMESON, F. Pós-Modernismo: a lógica cultural do capitalismo tardio. São Paulo: Ática, 1996.

JODELET, Denise. As Representações Sociais. Rio de Janeiro: UERJ, 2001.

KOSELLECK, Reinhart. Futuro passado: contribuições à semântica dos tempos históricos. Rio de Janeiro: Contraponto/Ed. PUC-Rio, 2006.

LARA, Silvia Hunold. História cultural e história social. Revista Diálogos, UEM, , p. 2532, 1997.

LE GOFF, Jacques. História e memória. 5. ed. Campinas, São Paulo: Editora da UNICAMP, 2003.

LOPES, Cássia. Gilberto Gil: a poética e a política do corpo. São Paulo: Perspectiva, 2012.

LOPES, Nilton. Gestores debatem política cultural no Brasil. Enecult, Salvador, 28 ago. 2014. Disponível em: <http//www.cult.ufba.br/enecult/gestores-debatem-politicacultural-no-brasil/>.

MACIEL, Luis Carlos. Geração em transe. Memórias do tempo do Tropicalismo. Rio de Janeiro: Nova Fronteira, 1996.

MAFFESOLI, Michel. A transfiguração do político: a tribalização do mundo. Porto Alegre: Sulina, 1997. 
MAIO, Marcos Chor; SANTOS, Ricardo Ventura. (orgs.) Raça como questão: história, ciência e identidade no brasil. Rio de Janeiro: Editora Fiocruz, 2010.

MARTINS, Leda Maria. Afrografias da memória: o Reinado do Rosário no Jatobá. São Paulo: Perspectiva; Belo Horizonte: Mazza Edições, 1997.

MAUTNER, Jorge. Fundamentos do Kaos. São Paulo: Nova Stella Editorial, 1985.

MAZZOLA, Marco. Ouvindo estrelas [autobiografia]. São Paulo: Editora Planeta do Brasil, 2007.

MBEMBE, Achille. As Formas Africanas de Auto-Inscrição. Revista Estudos AfroAsiáticos, ano 23, n. 1, 2001.

MELLO, Maria Thereza Negrão de. Nas terras do sol: Brasil e Cuba nas representações de Glauber Rocha. In: CABRERA, Olga; ALMEIDA, Jaime (Orgs). Caribe, sintonias e dissonâncias. Goiânia: CECAB, 2004.

MELLO, Zuza Homem de. A era dos festivais: uma parábola. São Paulo: Ed. 34, 2003.

MORELLI, Rita C. L. Indústria Fonográfica: um estudo antropológico. Campinas: Ed. UNICAMP, 1991.

MOTA, Nelson. Noites Tropicais: Solos, improvisos e memórias musicais. Rio de Janeiro: Editora Objetiva, 2000.

MUNDIMBE, Valentin. The Idea of Africa. Bloomington; Indianapolis: Indiana University Press, 1994.

NAPOLITANO, Marcos. Seguindo a canção: engajamento político e indústria cultural na MPB (1959-1969). São Paulo: Annablume/Fapesp, 2001.

. História \& Música. História Cultural da música popular brasileira. Belo Horizonte: Autêntica, 2002.

São Paulo: Contexto, 2004.

Cultura Brasileira: utopias e massificação (1950/1980). 2. ed. . A síncope das ideias: a questão da tradição na música popular brasileira.1. ed. São Paulo: Editora Fundação Perseu Abramo, 2007.

; e VILLAÇA, Mariana. Tropicalismo: As Relíquias do Brasil em debate. Revista Brasileira de História, vol. 18, n 35, São Paulo, 1998.

NAVES, Santuza Cambraia; COELHO, Frederico e BACAL, Tatiana (orgs). A MPB em discussão: entrevistas. Belo Horizonte: Editora UFMG, 2006.

OLIVA, Anderson Ribeiro. Diálogos entre as representações dos africanos no imaginário Ocidental e o ensino da História da África no Mundo Atlântico (1990- 2005). 2007. Tese de doutorado em História. Universidade de Brasilia, 2007.

OLIVEIRA, Ana. Disposições amoráveis. São Paulo: Iyá Omin, 2015. 
OLIVEIRA, Laiana Lannes. Entre a Miscigenação e a Multiracialização: Brasileiros negros ou Negros Brasileiros? O desafio do movimento negro brasileiro no período de valorização nacionalista (1930-1950) - A Frente Negra Brasileira e o Teatro Experimental do Negro. 2008. Tese de doutorado em História. Universidade Federal Fluminense, Niterói, 2008.

ONFRAY, Michel. Teoria da viagem, poética da geografia. Porto Alegre: L\&PM, 2009.

ORLANDI, Eni Pulccinelli. Analise de discurso. Princípios e procedimentos. Campinas: Pontes, 1999.

ORTIZ, Renato. Cultura Brasileira e identidade nacional. São Paulo: Editora Brasiliense, 1994.

$$
\text { A Moderna Tradição Brasileira: Cultura Brasileira e }
$$

Indústria Cultural. São Paulo: Brasiliense, 1988.

PANTOJA, Selma. Nzinga Mbandi: mulher, guerra e escravidão. Brasilia: Thesaurus, 2000.

PARANHOS, Adalberto. A música popular e a dança dos sentidos: distintas faces do mesmo. Revista ArtCultura, Uberlândia, Ed. UFU, 2004.

- Novas Bossas e Velhos Argumentos (Tradição e

contemporaneidade na MPB). História e perspectiva, n 3 . Uberlândia: Universidade Federal de Uberlândia, 1990.

PEREIRA, Amílcar A. $O$ mundo negro: a constituição do movimento negro contemporâneo no Brasil (1970-1995).2010. Tese (Doutorado em História): UFF, 2010.

PESAVENTO, Sandra Jatahy. História \& História Cultural. Belo Horizonte: Autêntica, 2003.

POLLAK, Michel. Memória, Esquecimento, Silêncio. Estudos Históricos, Vol. 2. n.3. Rio de Janeiro, 1989.

de Janeiro, 1992.

. Memória e identidade social. Estudos Históricos, Vol. 5, n. 10, Rio

PRANDI, Reginaldo. Mitologia dos Orixás. São Paulo: Companhia das Letras, 2001.

QUEIROZ, Martha Rosa F. Onde cultura é política: Movimento Negro, Afoxés e Maracatus no carnaval do Recife (1979-1995). 2010. Tese (Doutorado em História), UnB, 2010.

REIS, Alexandre. Eu quero ver quando Zumbi chegar: Negritude, política e relações raciais na obra de Jorge Bem $(1963,1976)$. 2014. Dissertação (Mestrado em História): CCHS/UFF, 2014.

RENNÓ, Carlos (org.) Gilberto Gil todas as letras. São Paulo: Companhia das Letras, 1996. 
REVEL, Jacques. Microanálise e construção do social. In: REVEL, Jacques (org.). Jogos de escalas. Rio de Janeiro: FGV, 1998.

RIBEIRO, Solano. Prepare seu coração. São Paulo: Geração Editorial, 2002.

RIDENTI, Marcelo. Em busca do povo brasileiro: Artistas da Revolução do CPC à era da TV Record. São Paulo: Ed. Record, 2000.

Paulo: Editora Unesp, 2010.

Brasilidade revolucionária: um século de cultura e política. São . Artistas e intelectuais no Brasil pós-1960. Tempo Social, São Paulo, v. 17, n. 1, p. 95. Disponível em http//www.scielo.br/pdf/ts/v17n1/v17n1a03.pdf.

Cultura e política: os anos 1960-1970 e sua herança. In: FERREIRA, Jorge; DELGADO, Lucília de Almeida Neves (orgs.). O Brasil republicano, Vol. IV: O tempo da ditadura: regime militar e movimentos sociais em fins do século XX. Rio de Janeiro: Civilização Brasileira, 2003.

RISÉRIO, Antônio. Carnaval Ijexá: notas sobre afoxés e blocos do novo carnaval afrobaiano. Salvador, Corrupio, 1981.

. Gilberto Gil Expresso 2222. Salvador: Corrupio, 1982.

; e GIL, Gilberto. O poético e o político: e outros escritos. Rio de

Janeiro: Paz e Terra, 1988.

O solo da sanfona: contextos do rei do baião. Revista USP, n. 35, São

Paulo, 1990.

.Uma história da Cidade da Bahia. Rio de Janeiro: Versal, 2004.

. A utopia brasileira e os movimentos negros. 2. ed. São Paulo: Editora

34, 2012.

ROLLEMBERG, Denise. Exilio. Refazendo identidades. Revista da Associação

Brasileira de História Oral, Rio de Janeiro, v. 2, p. 39-73, 1999.

Memórias no exilio, memórias do exílio. In: FERREIRA, Jorge;

REIS, Daniel Aarão. (Orgs.). As Esquerdas no Brasil. Revolução e democracia(1964...).

Vol. 3. Rio de Janeiro: Civilização Brasileira, 2007.

RUBIM, Antonio Albino Canelas. Panorama das políticas culturais no mundo. In: RUBIM, A. A. C; ROCHA, R. Políticas culturais. Salvador: EdUFBA, 2012.

RUTHERFORD, Jonathan. O terceiro espaço: uma entrevista com Homi Bhabha. Revista do Patrimônio Histórico e Artístico Nacional, n. 24, Brasília, 1996.

SAHLINS, Marshall. Ilhas de história. Rio de Janeiro: Zahar, 1982.

SANDRONI, Carlos. Feitiço decente: transformações do samba no Rio de Janeiro, 19171933. Rio de Janeiro: Jorge Zahar Ed.: Ed. UFRJ, 2001. 
. Samba de Roda, patrimônio imaterial da humanidade. Estudos avançados [online]. 2010, vol.24, n. 69, p.373-388.

SANSONE, Livio; SANTOS, Jocélio (orgs).Ritmos em trânsito: sócio-antropologia da música baiana.São Paulo: Dynamis Editorial; Salvador, BA: Programa A cor da Bahia e Projeto S.A.M.B.A., 1997.

Os objetos da identidade negra: consumo, mercantilização, globalização e a criação de culturas negras no Brasil. Mana vol.6, n.1. Rio de Janeiro, abril 2000.

Negritude sem etnicidade: o local e o global nas relações e na produção negra no Brasil. Tradução: Vera Ribeiro. Salvador: Edufba; Pallas, 2003.

SANTOS, Boaventura. Um discurso sobre as ciências. Porto (Portugal): Edições Afrontamento, 1987.

SARAIVA, José Flávio Sombra. O Lugar da África. Brasîlia: EdUnB, 1996.

SCHWARCZ, Lilia Moritz. O espetáculo das raças: cientistas, instituições e questão racial no Brasil - 1870-1930. São Paulo: Companhia das Letras, 1993.

. Nem preto nem branco, muito pelo contrário: cor e raça na sociabilidade brasileira. 1. ed. São Paulo: Claro Enigma, 2012.

SEEGER, Anthony. In NYERS, Helen. Ethnomusicoly. An introduction. Londres: The MacMillan Press, 1992.

SEVERIANO, Jairo; MELlO, Zuza Homem de. A canção no tempo - 85 anos de música brasileira. São Paulo: 34 Letras, 1997.

SILVA, Alberto Moby Ribeiro da. Sinal fechado: a música brasileira sob censura (193445/1969-78). 2. ed. Rio de Janeiro: Apicuri, 2008.

SLENES, Robert W. Malungu, ngoma vem!: África coberta e descoberta do Brasil. Revista USP, São Paulo, n. 12, 1992.

SOARES, Astréia. Outras Conversas sobre os jeitos do Brasil: O Nacionalismo na Música Popular. SP, Annablume / FUMEC, 2002.

SOUZA, Leidiane Lopes. "Transformando o tédio em melodia": Subjetivação do político, juventude e tradição em Cazuza. Década de 80. Dissertação de mestrado em História. Universidade de Brasîlia, 2012.

SOUZA, Marina de Mello e. África e Brasil africano. 2. ed. São Paulo: Ática, 2007.

STRATTON, Jon. When music migrates: crossing British and European racial faultlines, 1945-2010. Farnham: Ashgate, 2014.

TINHORÃO, José Ramos. Música Popular: um tema em debate. São Paulo: Ed. 34, 1997. 
THOMPSON, E. P. A miséria da teoria ou um planetário de erros. Londres: The Merlin Press, 1978.

VELOSO, Caetano. Verdade tropical. São Paulo: Cia. das Letras, 1997.

VIANNA, Hermano. O mistério do samba. Rio de Janeiro: Ed. UFRJ-Jorge Zahar Ed., 1994.

ZAPPA, Regina. Gilberto bem perto. 1. ed. Rio de Janeiro: Nova Fronteira, 2013. 